\title{
Phase II Archaeological Investigations at Lackland Air Force Base, San Antonio, Texas
}

Brett A. Houk

Department of Anthropology, Texas Tech University

David L. Nickels

Follow this and additional works at: https://scholarworks.sfasu.edu/ita

Part of the American Material Culture Commons, Archaeological Anthropology Commons, Environmental Studies Commons, Other American Studies Commons, Other Arts and Humanities Commons, Other History of Art, Architecture, and Archaeology Commons, and the United States History Commons

Tell us how this article helped you.

This Article is brought to you for free and open access by the Center for Regional Heritage Research at SFA ScholarWorks. It has been accepted for inclusion in Index of Texas Archaeology: Open Access Gray Literature from the Lone Star State by an authorized editor of SFA ScholarWorks. For more information, please contact cdsscholarworks@sfasu.edu. 
Phase II Archaeological Investigations at Lackland Air Force Base, San Antonio, Texas

\section{Creative Commons License}

(c) (1) (9)

This work is licensed under a Creative Commons Attribution-NonCommercial 4.0 International License 


\title{
Phase II Archaeological Investigations at Lackland Air Force Base, San Antonio, Texas
}

\author{
Brett A. Houk and David L. Nickels
}

with contributions by C. Britt Bousman, Anne A. Fox, Barbara A. Meissner, Lee C. Nordt, Andrew A. Scease, and Steve A. Tomka

\author{
Produced under contract number 1443-CA-8601-96-004, \\ funded by the Air Education and Training Command, U.S. Air Force \\ through the National Park Service, \\ Western Archeological and Conservation Center, Tucson
}

Ccopyright

Center for Archaeological Research

The University of Texas at San Antonio

Archaeological Survey Report, No. 264 
The following information is provided in accordance with the General Rules of Practice and Procedure, Chapter 41.11 (Investigative Reports), Texas Antiquities Committee:

1. Type of investigation: Testing

2. Project name: Lackland Testing

3. County: Bexar

4. Principal investigator: Robert J. Hard and C. Britt Bousman

5. Name and location of sponsoring agency: National Park Service, Western Archeological and Conservation Center, Tucson 85705

6. Texas Antiquities Permit No.: n/a

7. Published by the Center for Archaeological Research, The University of Texas at San Antonio, 6900 N. Loop 1604 W., San Antonio, Texas 78249-0658, 1997

A list of publications offered by the Center for Archaeological Research is available. Call (210) 458-4378; write to the Center for Archaeological Research, The University of Texas at San Antonio, 6900 N. Loop 1604 W., San Antonio, Texas 78249-0658; e-mail to car@lonestar.utsa.edu; or visit CAR's web site at http://www.csbs.utsa.edu/research/car. 


\begin{tabular}{|c|c|c|c|c|c|}
\hline \multicolumn{4}{|c|}{ REPORT DOCUMENTATION PAGE } & & $\begin{array}{l}\text { Form Approved } \\
\text { OMB No. 0704-0188 }\end{array}$ \\
\hline \multicolumn{6}{|c|}{ 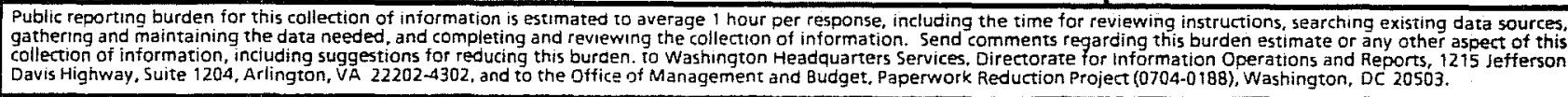 } \\
\hline \multicolumn{2}{|c|}{ 1. AGENCY USE ONLY (Leave blank) } & $\begin{array}{r}\text { 2. REPORT DATE } \\
1997\end{array}$ & \multicolumn{3}{|c|}{$\begin{array}{l}\text { 3. REPORT TYPE AND DATES COVERED } \\
\text { Final Report; } 7-8-96 \text { to } 12-20-97\end{array}$} \\
\hline \multirow{2}{*}{\multicolumn{4}{|c|}{$\begin{array}{l}\text { 4. TITLE AND SUBTITLE } \\
\text { Phase II Archaeological Investigations at Lackland Air Force Base, San An- } \\
\text { tonio, Texas }\end{array}$}} & \multirow{4}{*}{\multicolumn{2}{|c|}{$\begin{array}{r}\text { 5. FUNDING NUMBERS } \\
\text { 1443-CA-8601-96-004 }\end{array}$}} \\
\hline & & & & & \\
\hline \multirow{2}{*}{\multicolumn{4}{|c|}{$\begin{array}{l}\text { 6. AUTHOR(S) } \\
\text { Brett A. Houk and David L. Nickels }\end{array}$}} & & \\
\hline & & & & & \\
\hline \multicolumn{4}{|c|}{$\begin{array}{l}\text { 7. PERFORMING ORGANIZATION NAME(S) AND ADDRESS(ES) } \\
\text { Center for Archaeological Research } \\
\text { The University of Texas at San Antonio } \\
6900 \text { North Loop } 1604 \text { West } \\
\text { San Antonio, Texas } 78249\end{array}$} & \multicolumn{2}{|c|}{$\begin{array}{l}\text { 8. PERFORMING ORGANIZATION } \\
\text { REPORT NUMBER } \\
\text { Archaeological Survey Report, } \\
\text { No. } 264\end{array}$} \\
\hline \multicolumn{4}{|c|}{$\begin{array}{l}\text { 9. SPONSORING / MONITORING AGENCY NAME(S) AND ADDRESS(ES) } \\
\text { National Park Service } \\
\text { Western Archeological and Conservation Center } \\
\text { 1415 N. 6th Avenue } \\
\text { Tucson, Arizona } 85705\end{array}$} & \multicolumn{2}{|c|}{$\begin{array}{l}\text { 10. SPONSORING/MONITORING } \\
\text { AGENCY REPORT NUMBER }\end{array}$} \\
\hline \multicolumn{6}{|l|}{ 11. SUPPLEMENTARY NOTES } \\
\hline \multicolumn{4}{|c|}{ 12a. DISTRIBUTION/AVAILABILITY STATEMENT } & \multicolumn{2}{|c|}{ 12b. DISTRIBUTION CODE } \\
\hline \multicolumn{6}{|c|}{ 13. ABSTRACT (Maximum 200 words) } \\
\hline \multicolumn{6}{|c|}{$\begin{array}{l}\text { The Center for Archaeological Research (CAR) of The University of Texas at San Antonio (UTSA) conducted } \\
\text { significance testing at eight prehistoric archaeological sites at Lackland Air Force Base Medina Annex in } \\
\text { Bexar County, Texas, for the Department of the Air Force under Sections } 106 \text { and } 110 \text { of the National Historic } \\
\text { Preservation Act. The Air Force had selected two areas of Medina Annex for possible impact associated with } \\
\text { the construction of on-base housing. Alternate } 1 \text {, the Medina Annex Housing Area, includes sites } 41 \mathrm{BX} 1088 \text {, } \\
41 \mathrm{BX} 1090 \text { and } 41 \mathrm{BX} 1091 \text {. Alternate } 2 \text {, the Medina Dog Training Area, includes sites } 41 \mathrm{BX} 1070,41 \mathrm{BX} 1102 \text {, } \\
41 \mathrm{BX} 1103 \text {, and } 41 \mathrm{BX} 1114 \text {. Site } 41 \mathrm{BX} 1076 \text { is located outside of the impact areas and was tested under Section } \\
\text { 110. A previously unrecorded site, } 41 \mathrm{BX} 1208 \text {, was located during the course of the testing project in Alternate } \\
\text { 2. The site, a small lithic scatter, was inspected and mapped. }\end{array}$} \\
\hline \multicolumn{6}{|c|}{$\begin{array}{l}\text { Based on the results of the testing at the Medina Annex, CAR recommends to WACC that two sites- } 41 \mathrm{BX} 1102 \\
\text { and } 41 \mathrm{BX} 1103 \text { - are eligible for NRHP designation. CAR recommends that the testing project has exhausted } \\
\text { the research potential of the remaining sites which are all recommended as ineligible for NRHP nomination. }\end{array}$} \\
\hline \multirow{2}{*}{\multicolumn{5}{|c|}{$\begin{array}{l}\text { 14. SUBJECT TERMS } \\
\text { Archaeology, testing phase, prehistoric, geoarchaeology, Section } 106 \text {, Section } 110\end{array}$}} & $\begin{array}{l}\text { 15. NUMBER OF PAGES } \\
258\end{array}$ \\
\hline & & & & & 16. PRICE CODE \\
\hline $\begin{array}{l}\text { 17. SECURITY CLASSIFICATION } \\
\text { OF REPORT } \\
\text { Unclassified }\end{array}$ & $\begin{array}{ll}18.5 \\
\text { Unc }\end{array}$ & $\begin{array}{l}\text { ECURITY CLASSIFICATION } \\
\text { ITHS PAGE } \\
\text { assified }\end{array}$ & $\begin{array}{l}\text { 19. SECURITY CLASSIFIC } \\
\text { OF ABSTRACT } \\
\text { Unclassified }\end{array}$ & ATION & $\begin{array}{l}\text { 20. LIMITATION OF ABSTRACT } \\
\text { UL }\end{array}$ \\
\hline
\end{tabular}





\section{Abstract}

The Center for Archaeological Research (CAR) of The University of Texas at San Antonio (UTSA) conducted significance testing at eight prehistoric archaeological sites at Lackland Air Force Base Medina Annex in Bexar County, Texas, for the Department of the Air Force under Sections 106 and 110 of the National Historic Preservation Act. The Air Force had selected two areas of Medina Annex for possible impact associated with the construction of on-base housing. Alternate 1, the Medina Annex Housing Area, includes sites 41BX1088, 41BX1090 and 41BX1091. Alternate 2, the Medina Dog Training Area, includes sites 41BX1070, 41BX1102, 41BX1103, and 41BX1114. Site 41BX1076 is located outside of the impact areas and was tested under Section 110. A previously unrecorded site, 41BX1208, was located during the course of the testing project in Alternate 2. The site, a small lithic scatter, was inspected and mapped.

Based on the results of the testing at the Medina Annex, CAR recommends to WACC that two sites-41BX1102 and 41BX1103 - are eligible for NRHP designation. CAR recommends that the testing project has exhausted the research potential of the remaining sites-41BX1070, 41BX1076, 41BX1088, 41BX1090, 41BX1091, and 41BX1114-which are all recommended as ineligible for NRHP nomination. CAR therefore recommends that construction should be allowed to proceed in the Medina Annex Housing Area (Alternate 1) because it will have no adverse effect on significant cultural resources. 


\section{Contents}

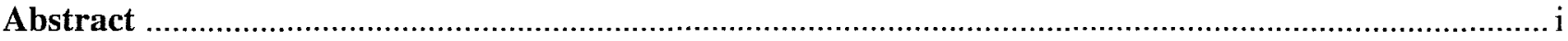

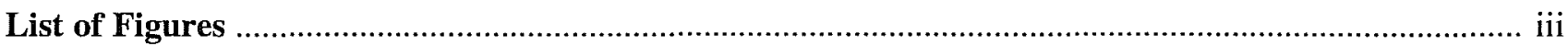

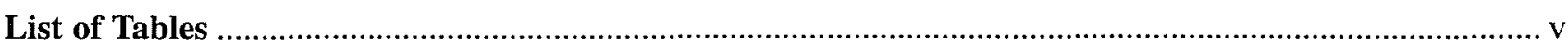

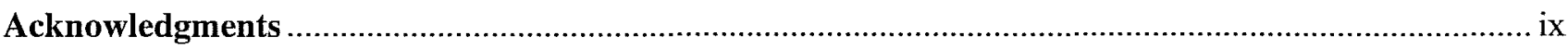

Chapter 1: Introduction

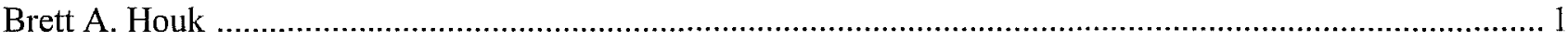

Chapter 2: Research Design and Methods

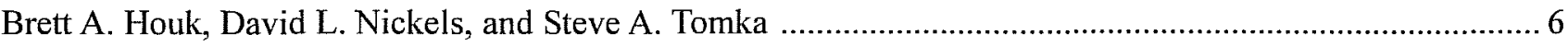

Chapter 3: Environmental and Cultural Setting

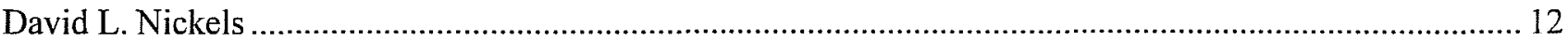

Chapter 4: Geoarchaeology of Lackland Air Force Base

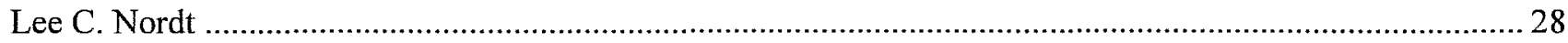

Chapter 5: Results of Archaeological Investigations

Brett A. Houk, David L. Nickels, Lee C. Nordt, and C. Britt Bousman ................................................... 39

Chapter 6: Analysis and Research Issues

Brett A. Houk, C. Britt Bousman, David L. Nickels, and Steve D. Tomka .......................................... 103

Chapter 7: Recommendations

Brett A. Houk, C. Britt Bousman, and David L. Nickels ................................................................. 147

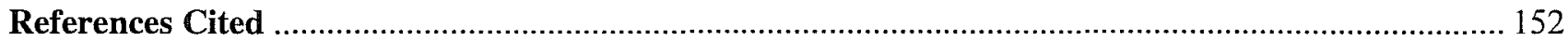

Appendix A: Soil-Stratigraphic Descriptions

Lee C. Nordt

Appendix B: Artifact Analysis

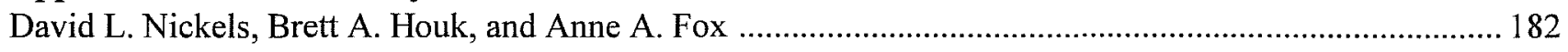

Appendix C: Vertebrate Faunal Remains

Barbara A. Meissner

Appendix D: Documentation of A Newly Discovered Site in the Uplands, 41BX1208

David L. Nickels

Appendix E: Lackland Sewer Line Proposed Right-of-way

David L. Nickels and Andrew A. Scease

Appendix F: Results of Radiocarbon Analyses

Brett A. Houk

Appendix G: Evaluating Field Methods

Brett A. Houk 


\section{Figures}

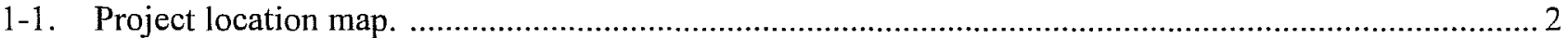

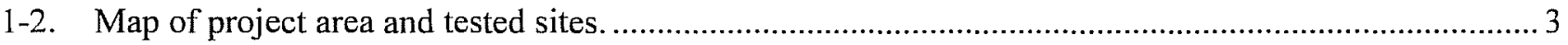

4-1. Geomorphic map of the eastern half of Lackland Air Force Base Medina Annex.............................. 30

4-2. Schematic stratigraphic cross section of Medio Creek in the middle part of the project area in the

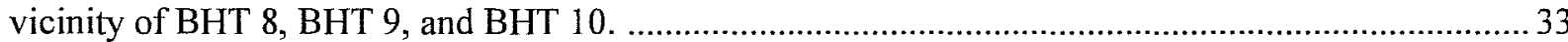

4-3. Schematic stratigraphic cross section of Medio Creek in the vicinity of 41BX1070 .....................34

4-4. Schematic stratigraphic cross section of Medio Creek in the vicinity of 41BX1102 and 41BX1103... 34

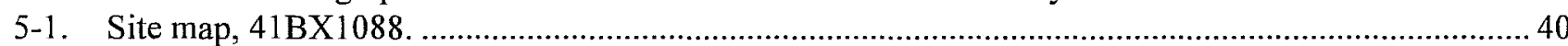

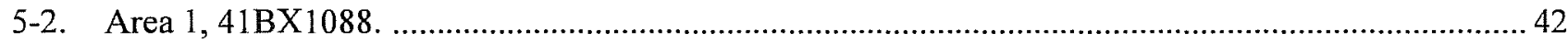

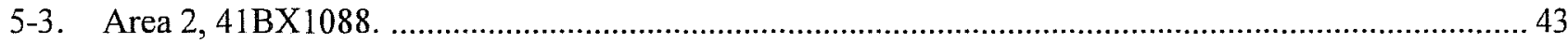

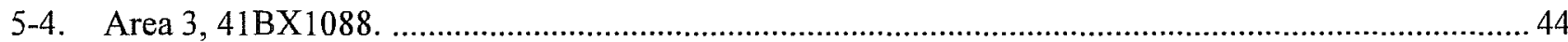

5-5. Profile of south wall of TU N1156 E1038 at 41BX1088, Area 1............................................... 45

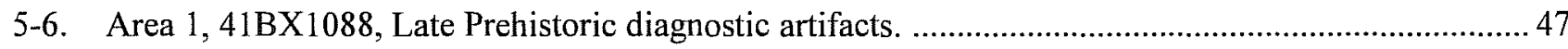

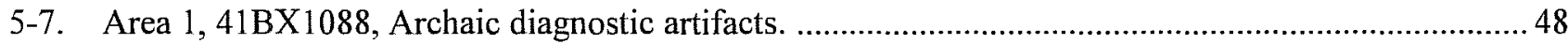

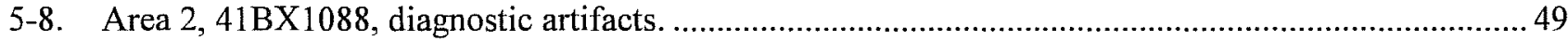

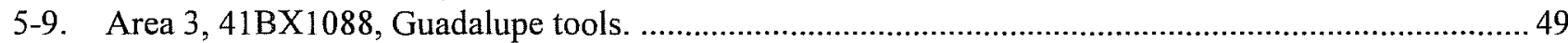

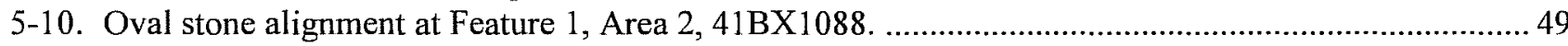

5-11. One of the curvilinear stone alignments at Feature 1, Area 2, 41BX1088. ...................................51

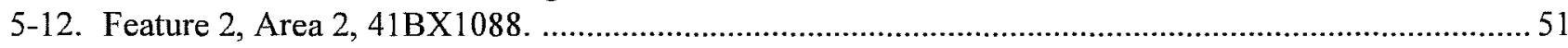

5-13. Debitage by level, TU N1056 E1038, 41BX1088, Area 1. ...................................................... 51

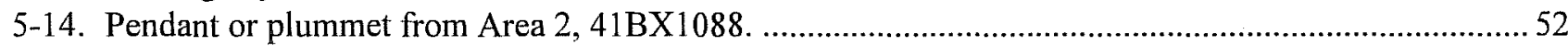

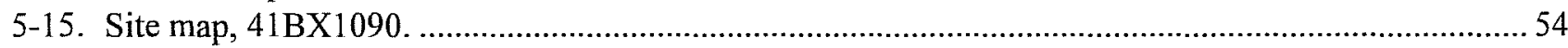

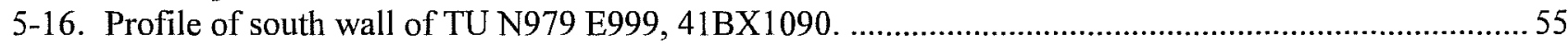

$5-17$. Distribution of debitage in surface collection area at 41BX1090 .............................................. 56

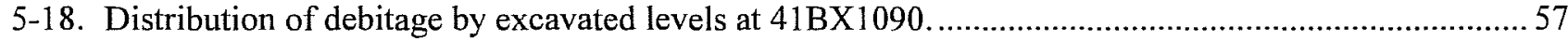

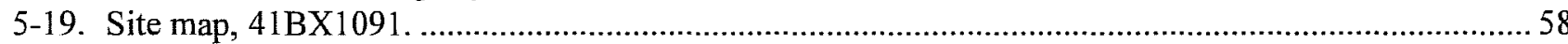

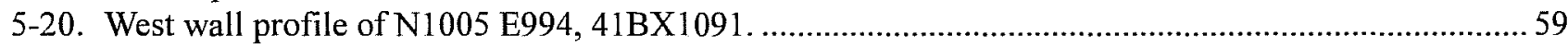

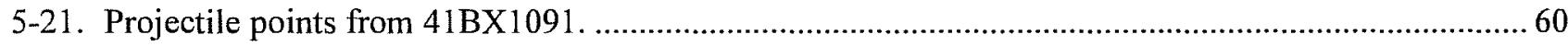

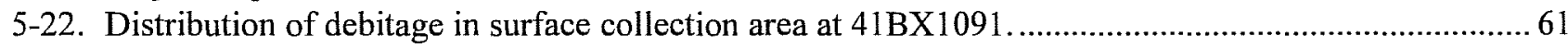

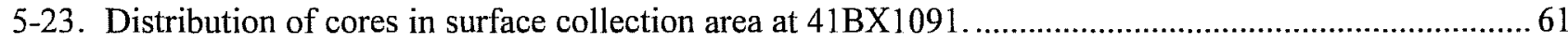

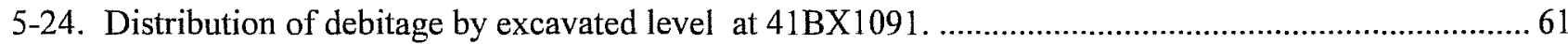

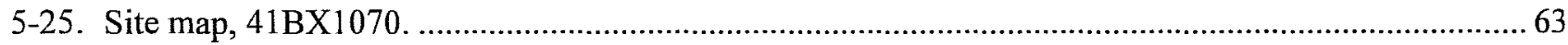

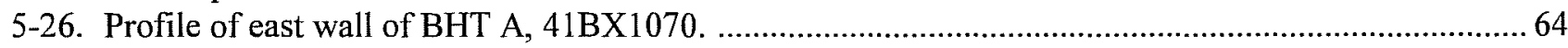

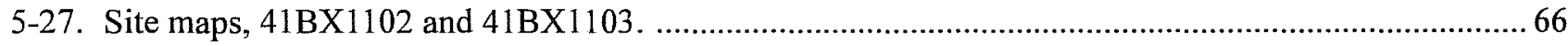

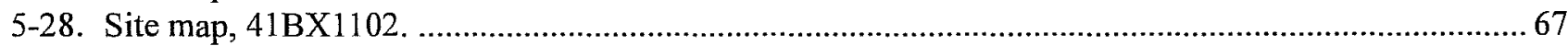

5-29. Geomorphic map of Medio Creek in the vicinity of 41BX1102 and 41BX1103...........................69

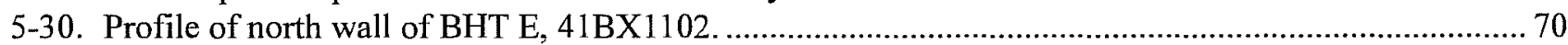

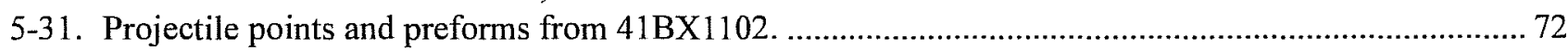

5-32. Distribution of debitage in surface collection area at 41BX1102 ............................................. 73

5-33. Distribution of projectile points in surface collection area at $41 \mathrm{BX} 1102$. ................................... 73

5-34. Distribution of non-debitage chipped stone artifacts in surface collection area at $41 \mathrm{BX} 1102 . \ldots \ldots \ldots . . . .73$

5-35. Distribution of debitage by excavated levels for TU N1000 E1005 and TU N1005 E1015

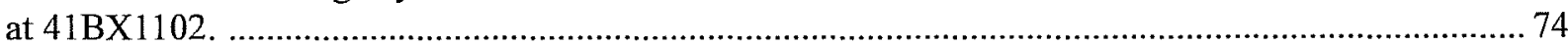

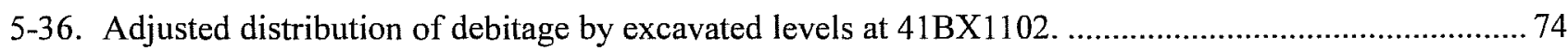

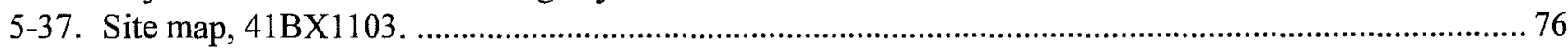

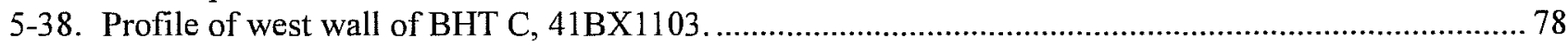




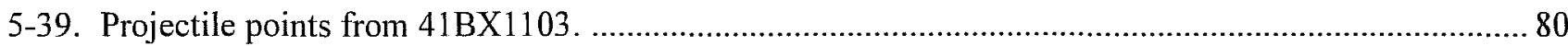

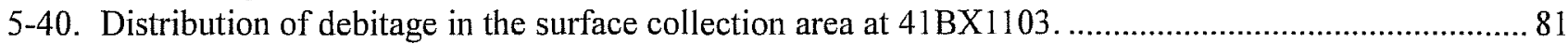

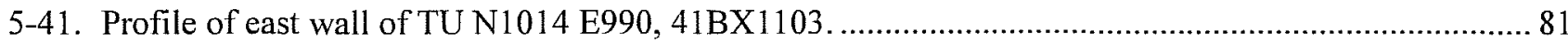

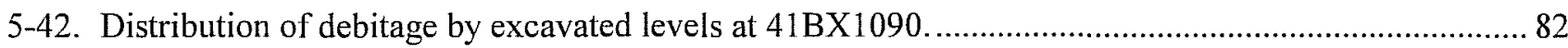

5-43. Plan map, Level 3 of TU N1014 E990, 41BX1103. ................................................................82

5-44. Schematic stratigraphic cross section of the Uplands and an unnamed tributary in the

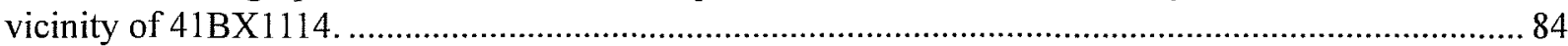

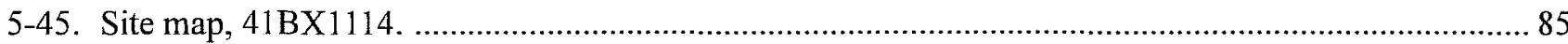

5-46. Profile of north wall of TU N1039 E993, 41BX1114 ............................................................ 87

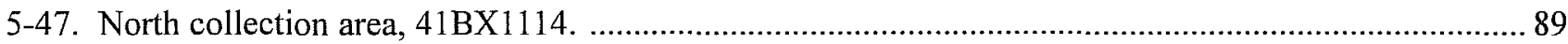

5-48. Projectile points from north surface collection area, 41BX1114 .......................................... 90

5-49. Distribution of debitage in north collection area at 41BX1114 ................................................90

5-50. Distribution of non-debitage chipped stone artifacts in north surface collection area at $41 \mathrm{BX} 1114 . \ldots 91$

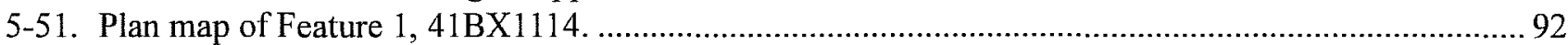

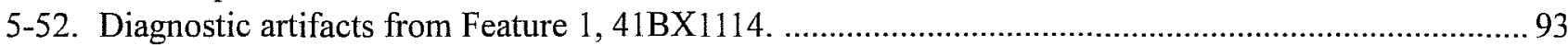

5-53. Photograph of indurated calcium carbonate layer at $20 \mathrm{~cm}$ below surface in TU N1030 E995,

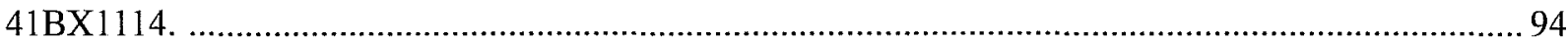

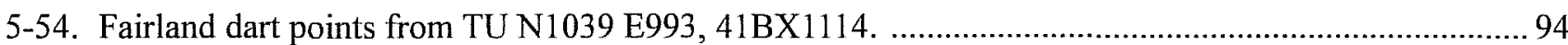

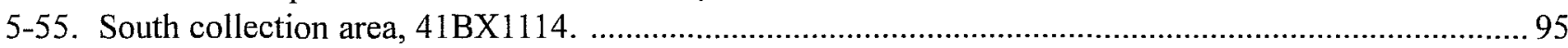

5-56. Distribution of debitage in south surface collection area at $41 \mathrm{BX} 1114$....................................96

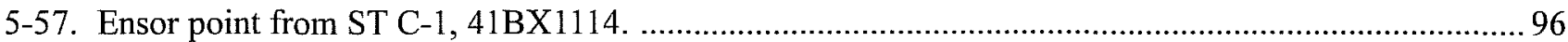

5-58. Debitage counts by excavated level at TUs N817 E1082 and N829 E1075, 41BX1114..................97

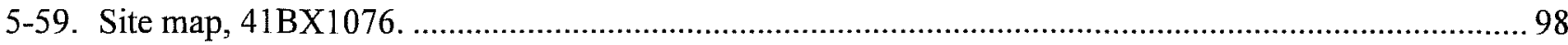

5-60. Proximal perforator fragment from 41BX1076. ................................................................. 100

5-61. Distribution of debitage in surface collection area at 41BX1076............................................. 100

5-62. Distribution of non-debitage chipped stone artifacts in surface collection area at 41BX1076. ......... 101

5-63. Distribution of debitage by excavated level at 41BX1076....................................................... 101

5-64. Photograph of Feature 1 in TU 994 E1002, Level 1, and adjacent area at 41BX1076.................... 102

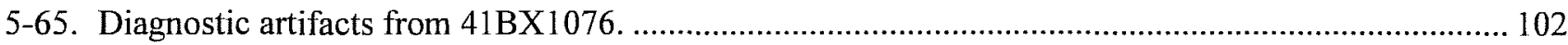

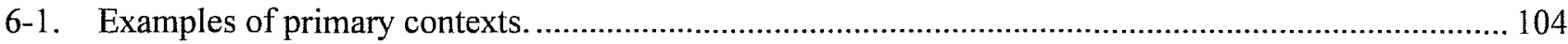

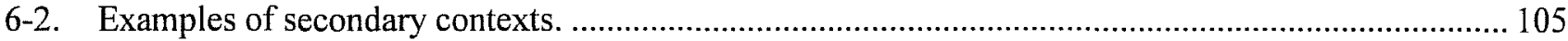

6-3. Comparison of percentage of tertiary flakes in large flake category versus percentage of tertiary flakes in small flake category by site. ....................................................................... 112

6-4. Distribution of tertiary flakes by excavated level at 41BX1103.............................................. 134

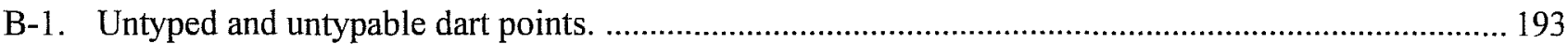

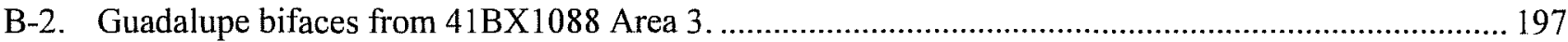

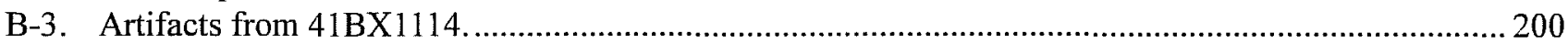

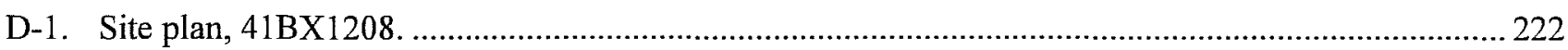

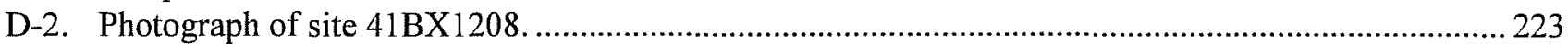

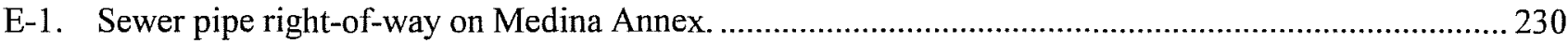

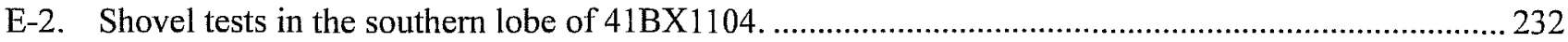

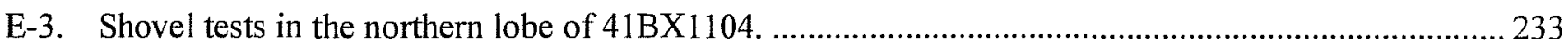

G-1. Debitage counts in Level 1 of excavation block at Feature 1, 41BX1114 …............................ 242 


\section{Tables}

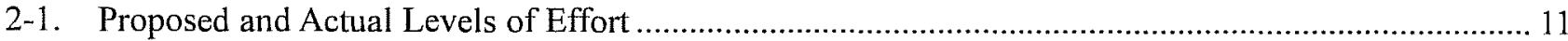

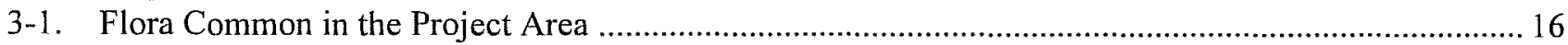

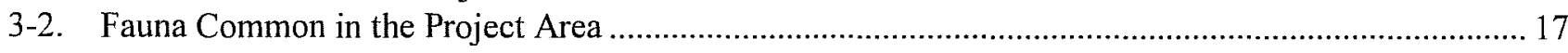

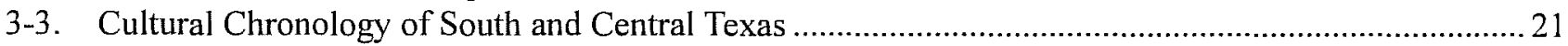

4-1. Surface and Subsurface Chronology of the Major Stratigraphic Units ................................................. 37

4-2. Relation Between the Surface and Subsurface Stratigraphic Sequence and Preservation

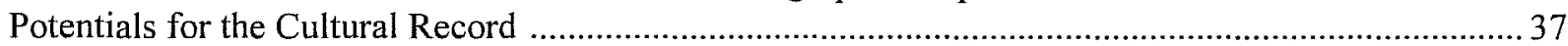

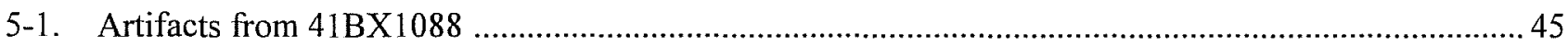

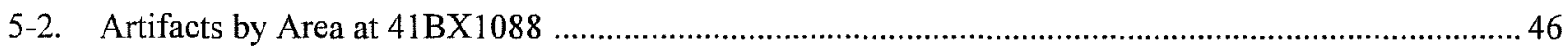

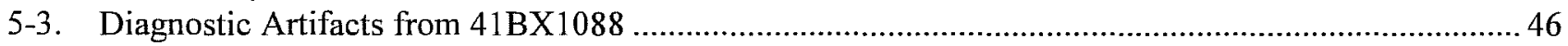

5-4. Percentages of Non-Debitage Chipped Stone Artifacts by Area at 41BX1088 (Surface Only) .............. 51

5-5. Relative Frequencies of Flake Types as Percentages at 41BX1088. ………………........................ 50

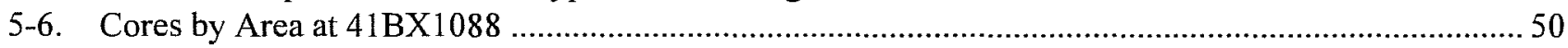

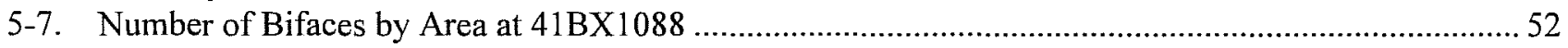

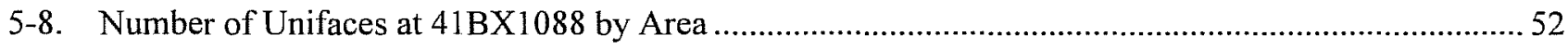

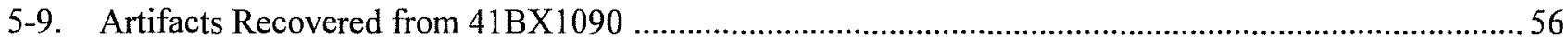

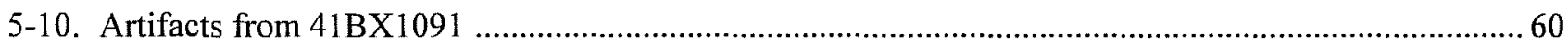

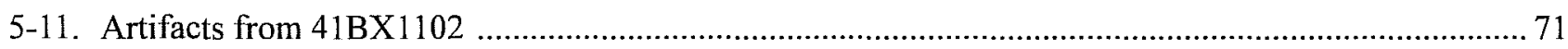

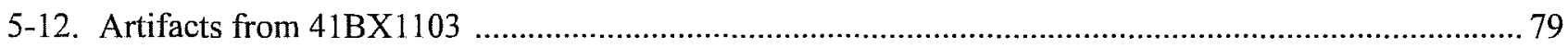

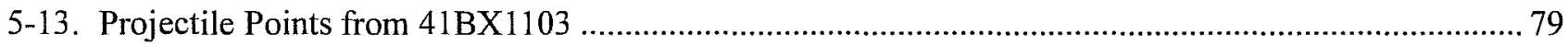

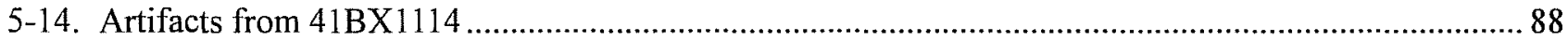

5-15. Radiocarbon Dates from Feature 1, 41BX1114 ....................................................................... 91

5-16. Variation in Artifact Assemblages from North and South Collection Areas at 41BX1114 ….................97

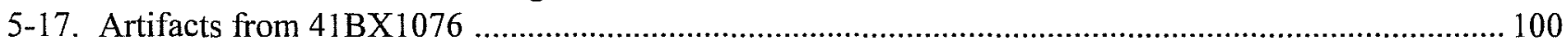

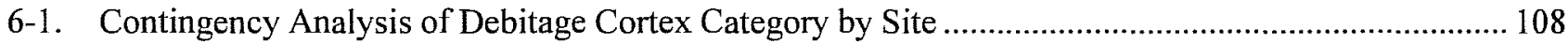

6-2. Contingency Analysis of Debitage Flake Type Category by Site ...................................................... 109

6-3. Contingency Analysis of Debitage Faceting Category by Site ……………………............................ 110

6-4. Mean and Standard Error of Maximum Dimension $(\mathrm{cm})$ of Flakes by Site ………............................ 110

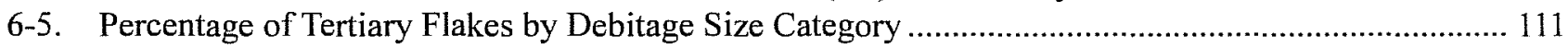

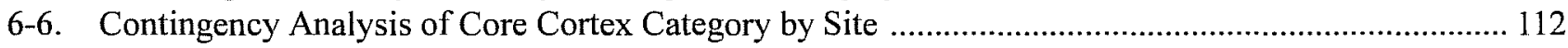

6-7. Contingency Analysis of Core Flake Direction Category by Site ........................................................ 114

6-8. Mean and Standard Error of Flake Scars per Core by Site ................................................................ 114

6-9. Mean and Standard Error of Maximum Dimension (in $\mathrm{cm}$ ) of Cores by Site .................................... 115

6-10. Contingency Analysis of Biface Cortex Category by Site ............................................................... 117

6-11. Contingency Analysis of Biface Blank Type Category by Site …………………………………....... 117

6-12. Contingency Analysis of Biface Stage of Reduction Category by Site ............................................. 119

6-13. Contingency Analysis of Biface Completeness Category by Site ..................................................... 118

6-14. Contingency Analysis of Biface Break Type Category by Site …………………………………........ 120

6-15. Mean and Standard Error of Biface Length (in $\mathrm{mm}$ ) by Site .......................................................... 120

6-16. Mean and Standard Error of Biface Width (in $\mathrm{mm}$ ) by Site .......................................................... 120

6-17. Mean and Standard Error of Biface Thickness (in mm) by Site ....................................................... 121

6-18. Contingency Analysis of Uniface Cortex Category by Site ............................................................ 121

6-19. Contingency Analysis of Uniface Blank Type Category by Site ........................................................ 122

6-20. Contingency Analysis of Uniface Completeness Category by Site ………………………………..... 123

6-21. Contingency Analysis of Uniface Degree of Modification Category by Site ........................................ 124

6-22. Contingency Analysis of Uniface Location of Modification Category by Site .................................... 125 
6-23. Mean and Standard Error of Uniface Maximum Dimension (in $\mathrm{mm}$ ) by Site 125

6-24. Number of Specimens and Percentage of Arrow Point Break Types by Site

6-25. Number of Specimens and Percentage of Dart Point Break Types by Site

6-26. Contingency Analysis of Raw Material Type for Debitage, Cores, Bifaces, Unifaces, and Raw Material at Each Site

6-27. Contingency Analysis of Raw Material Quality for Debitage, Cores, Bifaces, Unifaces, and Raw Material at Each Site

6-28. Average Maximum Dimensions (cm) of Cores and Raw Materials at Each Site

6-29. Average Weights $(\mathrm{g})$ and Maximum Dimensions $(\mathrm{cm})$ of Raw Material at Each Site

6-30. Artifact Counts by Site

6-31. Contingency Analysis of Number of Artifacts by Category at Each Site

7-1. Context of Deposits and Potential for Each Site to Address Research Issues ..................................... 147

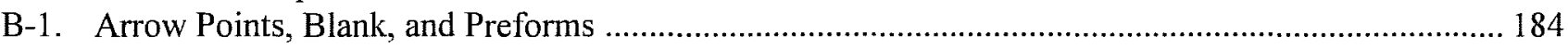

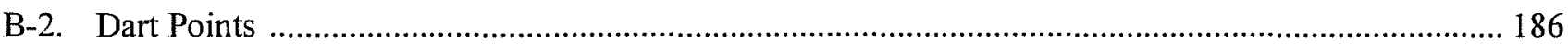

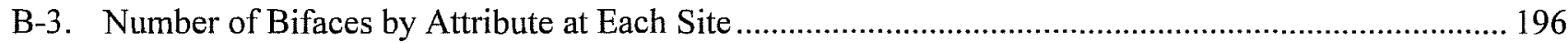

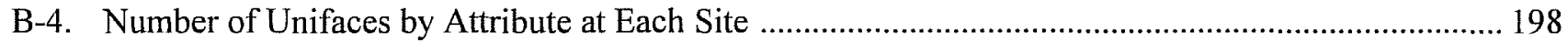

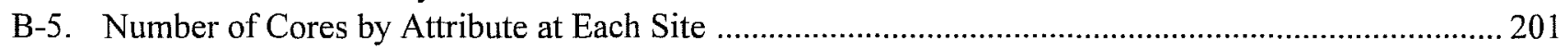

B-6. Number of Complete Flakes by Attribute at Each Site ................................................................... 202

B-7. Ground and Battered Stone Artifacts ...................................................................................... 205

B-8. Size Measurements and Degree of Wear for Hammerstones .......................................................... 205

B-9. Size Measurements and Degree of Wear for Manos ....................................................................... 206

B-10. Size Measurements and Location of Wear for Other Ground-stone Artifacts ......................................2206

B-11. Attributes of Leon Plain Ceramic Sherds Recovered During Lackland Testing Project ....................... 207

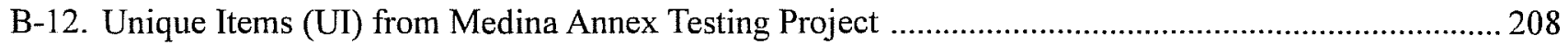

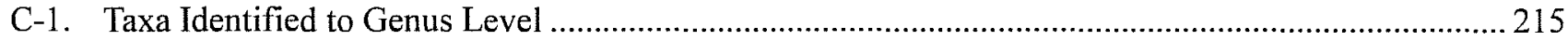

C-2. Provenienced Faunal Remains from Phase II Excavations ............................................................... 216

E-1. Artifacts Recovered from the Sewer Right-of-way Shovel Tests ...................................................... 231 


\section{Management Summary}

The Center for Archaeological Research (CAR) of The University of Texas at San Antonio (UTSA) conducted significance testing at eight prehistoric archaeological sites at Lackland Air Force Base Medina Annex in Bexar County, Texas. The investigations were sponsored by the Department of the Air Force and were conducted under cooperative agreement number 1443-CA-8601-96-004. The Western Archeological and Conservation Center (WACC) at the National Park Service (NPS) acted as the lead federal agency during the project. Fieldwork began on July 8, 1996, and was completed on October 14, 1996. Robert J. Hard was the principal investigator and C. Britt Bousman served as co-principal investigator. Brett A. Houk, the project archaeologist, directed the daily field and laboratory operations.

Because the testing project was sponsored by a federal agency, it falls under the purview of the National Historic Preservation Act (NHPA) of 1966 (and subsequent amendments) which requires that the Advisory Council on Historic Preservation (ACHP) be allowed to comment on cultural resources that are present in an area to be affected by federal actions, funds, or permitting. The enabling regulations of the ACHP are described in 36 CFR 800. Sites within such impact areas must be evaluated as to their significance and for their potential eligibility for nomination to the National Register of Historic Places (NRHP). Seven sites (41BX1070, 41BX1088, 41BX1090, 41BX1091, 41BX1102, 41BX1103, and 41BX1114) were tested under Section 106 of the NHPA and one site (41BX1076), which is located outside of the impact area, was tested under Section 110. Because the project took place entirely on federal property and no state lands were involved, a Texas Antiquities Committee permit was not required, but the State Historical Preservation Officer (SHPO) at the Texas Historical Commission Department of Antiquities Protection (THCDAP) was consulted at all stages of the investigations.

The archaeological testing conducted by CAR was designed to comply with accepted archaeological methods as defined in the United States Department of the Interior's Standards and Guidelines (National Park Service 1983) and the performance standards of the Council of Texas Archeologists (Council of Texas Archeologists [CTA] 1987). Additionally, the project's principal investigators, project archaeologist, and field supervisory personnel exceeded the minimum standards prescribed by the Department of the Interior (NPS 1983) and the CTA (1987). The goals of the project were to 1 ) assess the nature and chronological affiliation of cultural materials, 2) assess the integrity of surface and subsurface deposits, 3) identify pertinent research domains and develop historic contexts or place the resources within previously defined historic contexts if possible, and 4) prepare recommendations of eligibility for each site being investigated.

The Air Force had selected two areas of Medina Annex for possible impact associated with the construction of on-base housing. Alternate 1, the Medina Annex Housing Area, includes sites 41BX1090 and 41BX1091. Alternate 2, the Medina Dog Training Area, includes sites 41BX1070, 41BX1102, 41BX1103, and 41BX1114. The nature of the specific impact to each site was not defined because the final development plans are to be based partially on the results of the testing. Possible impacts include the construction of streets, houses, power lines, fences, and underground pipelines. Prior to beginning the fieldwork, four sites that were originally scheduled to be investigated were declared to be insignificant and ineligible for NRHP listing by the THCDAP. These were 41BX1078 and 41BX1089 in Alternate 1, and 41BX1105 and 41BX1106 in Alternate 2. Each of these sites is described as a small lithic quarry (Nickels et al. 1997).

A previously unrecorded site, 41BX1208, was located during the course of the testing project. The site was inspected and mapped. It is a small lithic scatter similar to others in the impact area. Based on the same criteria used to exclude 41BX1078, 41BX1089, 41BX1105, and 41BX1106 from testing, CAR recommends that $41 \mathrm{BX} 1208$ is not eligible for NRHP listing. 
Based on the results of the project, CAR recommends to WACC that the following tested sites are insignificant and therefore ineligible for nomination to the NRHP: 41BX1070, 41BX1088, 41BX1090, 41BX1091, and 41BX1114. Furthermore, CAR recommends to WACC that the following sites are significant, based on Criterion D as described in the NPS regulations (36 CFR 60): 41BX1102 and 41BX1103. Based on these assessments, CAR recommends that the Air Force be allowed to proceed with construction in Alternate 1, the Medina Annex Housing Expansion area. 


\section{Acknowledgments}

For an undertaking of the scope of the Phase II archaeological testing at Lackland Air Force Base Medina Annex to be successful, the cooperation of a great many individuals and organizations is required. The project staff at the Center for Archaeological Research (CAR) wishes to thank the Commander and staff at Lackland for allowing access to Medina Annex. The cooperation of the staff at the Dog Training Area was especially appreciated since our activities often disrupted their routine. Mr. Gabriel Gonzales, Community Planner for the 37th Civil Engineering Squadron, provided our crews with maps and information about the base that without which our task would have been impossible. The National Park Service (NPS) staff at Western Archeological and Conservation Center (WACC), particularly Dr. Greg Fox and Mr. Steve De Vore, oversaw the development and implementation of the testing project. Their input and assistance have been invaluable. The Texas Historical Commission, represented first by Mr. Lain Ellis and later by Mr. Miles Miller, has been involved with the project since its inception. The comments from the two project reviewers helped shape the final form of the investigations.

The principal investigator for the project was Dr. Robert J. Hard. The co-principal investigator was Dr. C. Britt Bousman. The fieldwork and report write up were directed by project archaeologist, Dr. Brett A. Houk. The report was written by Brett A. Houk, C. Britt Bousman, and David Nickels with contributions from Lee Nordt, Anne Fox, and Barbara Meissner. The technical editor was Marcie Renner. Her skills will be missed at CAR, and we wish her the best in her future endeavors.

The fieldwork was conducted by Brett A. Houk, David Nickels, Ward Bramlett, Jeff Durst, Donna Edmondson, Owen Ford, Jeff Francis, Chris Horrell, Tony Lyle, Bruce Moses, Gloria Murguia, Robert Rector, Ricky Robinson, Andrew Scease, and Kaylee McRae. Dr. Lee Nordt continued the geomorphological study of the base during the project. Mike Fulgham operated the backhoe with exceptional skill on two separate occasions.

The laboratory analysis was conducted by Brett A. Houk, David Nickels, Ricky Robinson, Chris Horrell, Connie Gibson, Tony Lyle, Owen Ford, Barbara Meissner, and Anne Fox. Steve Tomka and C. Britt Bousman provided advice and opinions through out the process. The artifact data was entered into a computer database by Christin Siller. 



\title{
Chapter 1: Introduction
}

\author{
Brett A. Houk
}

\section{Project Description}

This report discusses the results of archaeological testing performed at eight prehistoric sites located at Lackland Air Force Base Medina Annex, Bexar County, Texas, by the Center for Archaeological Research (CAR) of The University of Texas at San Antonio (UTSA) in 1996 (Figure 1-1). The investigated sites were 41BX1070, 41BX1076, 41BX1088, 41BX1090, 41BX1091, 41BX1102, 41BX1103, and 41BX1114. The testing is an element of a proposed development project which will impact two areas of Medina Annex in the near future. One of the two areas will be the location of an on-base housing expansion project for which construction will begin in 1997. Alternate 1, the Medina Annex Housing Area, and Alternate 2, the Medina Annex Dog Training Area (Figure 1-2), both have previously identified cultural resources which required archaeological testing to determine their eligibility for nomination to the National Register of Historic Places (NRHP).

The Western Archeological and Conservation Center (WACC) of the National Park Service (NPS) acted as the agency for oversight management of archaeological compliance-related activities during the duration of the testing. The project was funded by the United States Air Force.

Because the project involves federal funds, federal permitting, and occurs on federal lands, it falls under the purview of the National Historic Preservation Act (NHPA) of 1966 (and subsequent amendments). The NRHP and the Advisory Council for Historic Preservation (ACHP) are both created by the NHPA. Section 106 of the NHPA states that the ACHP must be afforded a chance to comment when any cultural resources eligible for listing on the NRHP are located in an area to be affected by the actions of a federal agency or actions funded or permitted by federal agencies.
Under Section 106 and Section 110 of the NHPA, the protection of cultural resources is related to their eligibility for listing on the NRHP which is in turn dependent on their "significance" as defined by NPS in $36 \mathrm{CFR}$ 60. The National Historic Preservation Act Amendments of 1992 clarified Section 110 and directed federal agencies to establish preservation programs corresponding to their activities and effects on historic properties. Under Section 110, federal agencies may evaluate the significance of cultural resources not currently threatened to assist with the development of preservation planning. At the state level, the State Historic Preservation Officer (SHPO) at the Texas Historical Commission Department of Antiquities Protection (THCDAP) consults with and advises the lead federal agency (WACC/NPS in this case) about the implementation of the Section 106 and Section 110 processes. The federal regulatory process is described in detail in 36 CFR 800.

The purpose of this testing project was to evaluate the eligibility of sites threatened by planned base construction activities. The original scope of the testing included 10 sites: four in Alternate 1, the Housing Expansion Area; four in Alternate 2, the Dog Training Area; and two adjacent to Alternate 2. Prior to testing, however, the WACC recommended to the THCDAP, and the latter agreed, that sites 41BX1078 and 41BX1089 in Alternate 1 and sites 41BX1105 and 41BX1106 in Alternate 2 were ineligible for NRHP listing because they were low-density lithic debris scatters lacking chronological context and integrity. Furthermore, the THCDAP concurred with the WACC's recommendation that the originally proposed level of effort to be employed at 41BX1070, a small site in Alternate 2, be reduced from surface inventory/collection and excavation of two test units to the excavation of a single backhoe trench. As a compromise measure, CAR proposed that sites 41BX1076 and 41BX1088, both of which contained diagnostic artifacts as documented by the Phase I sur- 


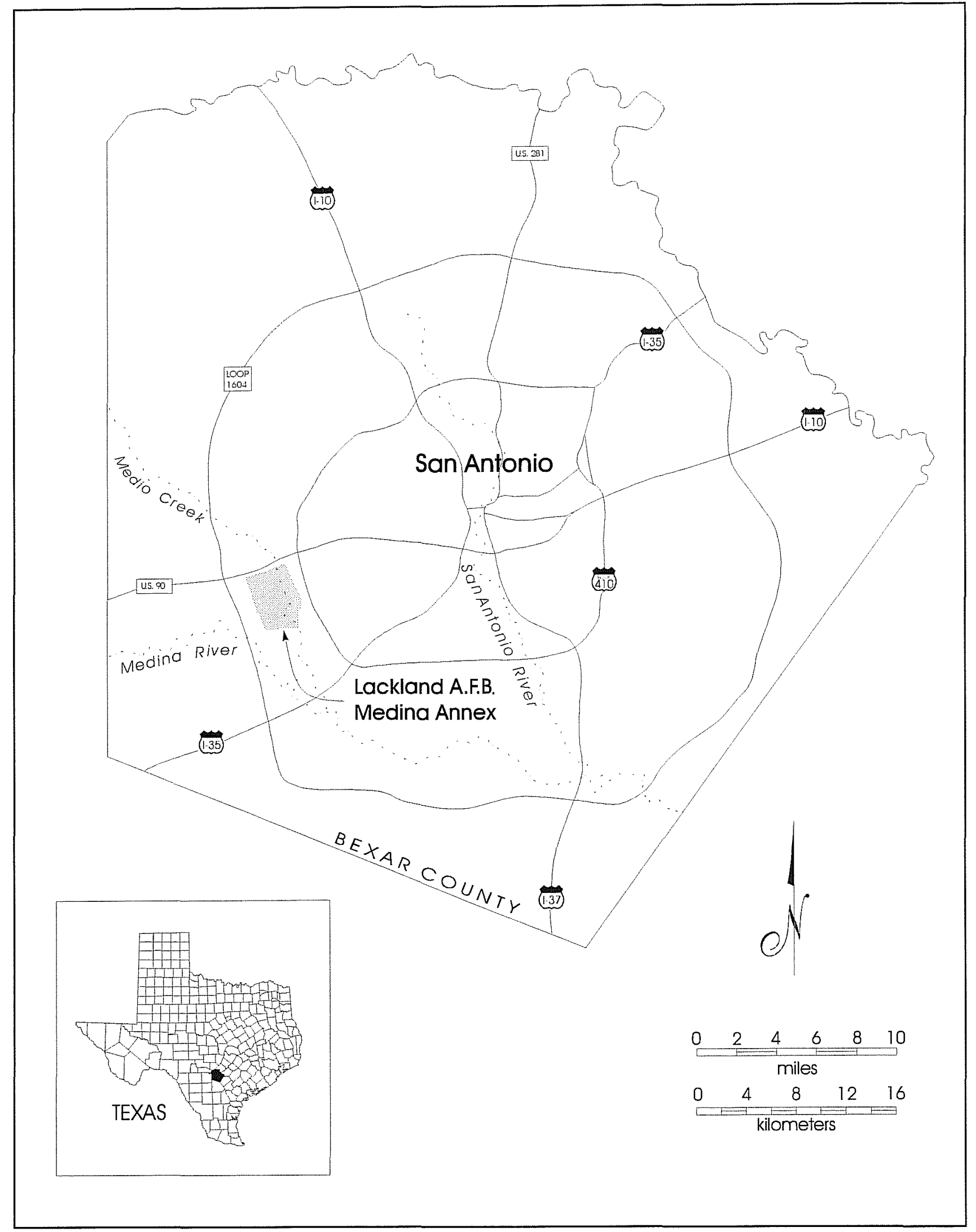

Figure 1-1. Project location map. 
This page has been

redacted because it

contains restricted

information. 
vey of the base (Nickels et al. 1997), be added to the testing project. The THCDAP and WACC concurred with this recommendation. $41 \mathrm{BX} 1088$ was tested under Section 106 because it is adjacent to Alternate 1 and may be indirectly impacted by construction activities. 41BX1076 is outside of the impact areas and was therefore tested under Section 110. Sites 41BX1102 and 41BX1103 are located outside of Alternate 2, but were recommended for Section 106 testing because of the possibility of indirect impacts associated with construction and use.

In summary, the goal of the investigations at the eight sites at Lackland AFB was to evaluate their significance according to Criterion D of the NHPA as defined by NPS in 36 CFR 60. Basically, the significance of a site under Criterion D, and therefore its eligibility for listing on the NRHP, is based on its having yielded information important in history or prehistory or on its having potential to yield such information in the future. Testing at seven of the sites-41BX1070, 41BX1088, 41BX1090, 41BX1091, 41BX1102, 41BX1103, and 41BX1114—was required by Section 106 of the NHPA. The remaining site, $41 \mathrm{BX} 1076$, is located outside of Alternate 1 and Alternate 2 in an area not currently selected for impact. The archaeological testing at this site was conducted under Section 110 of the NHPA.

Fieldwork began on July 8, 1996, and continued until October 14, 1996. Robert J. Hard served as principal investigator and C. Britt Bousman acted as co-principal investigator. Daily field operations were directed by the project archaeologist, Brett A. Houk, who was assisted by David Nickels. Crew sizes varied from two to nine. CAR staff members who worked on the project included Ward Bramlett, Jeff Durst, Donna Edmondson, Owen Ford, Jeff Francis, Chris Horrell, Tony Lyle, Bruce Moses, Gloria Murguia, Robert Rector, Ricky Robinson, Andrew Scease, and Kaylee A. McRae. Field activities at the eight tested sites included extensive brush clearing, site mapping, surface collecting (excluding 41BX1070), shovel testing (excluding 41BX1070, 41BX1076, and 41BX1088), and excavating $1-\mathrm{x}-1-\mathrm{m}$ test units (excluding 41BX1070). Backhoe trenches were excavated at 41BX1070, 41BX1102, 41BX1103, and 41BX1114.
The archaeological investigations were accompanied by the continuation of geomorphological studies originally initiated during the 1994-1995 survey project. Lee C. Nordt of Baylor University served as the consulting project geomorphologist.

Laboratory analysis of the collected prehistoric artifacts and raw material was performed by Brett A. Houk, David Nickels, Ricky Robinson, Chris Horrell, Tony Lyle, and Owen Ford, with frequent assistance by Steve Tomka and C. Britt Bousman. Barbara Meissner examined the faunal assemblage, and Anne Fox was consulted about the few Historic artifacts recovered during testing. The attribute data was entered into a computer database by Christin Siller. The artifacts, records, and other materials recovered or generated during the fieldwork and subsequent laboratory analysis are curated at CAR.

During the course of the testing project, CAR archaeologists located a previously unrecorded site in Alternate 2. This site was mapped and inspected. It is a small lithic scatter, and based on the criteria used to exclude 41BX1078, 41BX1089, 41BX1105, and $41 \mathrm{BX} 1106$ from testing, CAR recommends that $41 \mathrm{BX} 1208$ is similarly insignificant and therefore not eligible for NRHP designation.

\section{Report Organization}

Chapter 2 discusses the field methodology employed during the testing project. The archaeological and environmental background for the project area are discussed in Chapter 3. Chapter 4 is a project area overview of the geomorphological investigations which were initiated during the survey of the base and continued during the testing at Medina Annex. The results of the archaeological testing are discussed for each site in Chapter 5. The data presented in Chapter 5 and the accompanying appendices are used in Chapter 6 to identify pertinent research issues identified during the testing. Specific recommendations about the eligibility of each site for NRHP nomination are presented in Chapter 7.

Supporting data are included in seven appendixes to the report. Appendix A is a list of geomorphic trench 
and unit descriptions. Appendix B discusses the analytical procedures used to characterize the artifacts recovered during the testing project, presents the raw attribute data for each artifact category, and includes descriptions of individual artifacts where appropriate. The results of the analysis of the faunal material recovered during the testing project are discussed in Appendix C. Appendix D is a copy of the archaeological site form for the newly recorded 41BX1208. Appendix E presents the results of shovel testing and monitoring performed for the construction of a sewer trench line on Medina Annex. The results of the analysis of three radiocarbon samples by Beta Analytic, Inc. are presented in Appendix F. Appendix G includes an evaluation of the field methods used during the project and recommended guidelines for mitigation plans for sites determined to be eligible for NRHP nomination. 


\title{
Chapter 2: Research Design and Methods
}

\author{
Brett A. Houk, David L. Nickels, and Steve A. Tomka
}

\section{Research Design}

The Department of the Air Force initiated a Section 110 inventory of portions of Lackland Air Force Base in Bexar County, Texas, to identify cultural resources on the Main Base and Medina Annex. CAR performed an intensive survey of Lackland in 1994 and 1995, identifying 74 archaeological sites at the base (Nickels et al. 1997). The Air Force has planned future development in two areas of that original survey: the Medina Annex Housing Area and the Medina Annex Dog Training Area. CAR identified 10 prehistoric sites in those two areas and recommended testing them to assess their significance.

As discussed in Chapter 1, of the 10 sites associated with the Medina Annex Housing Expansion Area (Alternate 1) and the Medina Annex Dog Training Area (Alternate 2), four were determined to be ineligible for NRHP nomination by the THCDAP prior to testing. One site which is adjacent to Alternate 1, $41 \mathrm{BX} 1088$, was added to the project under Section 106 compliance, and a second site, 41BX1076, located outside of the impact areas, was added under Section 110 compliance by the Air Force based on a recommendation by CAR to WACC and THCDAP. The Phase I survey investigations at these sites, it was postulated that the six upland sites represented lithic procurement localities and that the two terrace sites were multifunctional camp sites with a strong lithic procurement aspect (Nickels et al. 1997).

The Phase II work at these eight sites had two general goals: (1) to establish the contribution of upland lithic procurement sites to understanding regional prehistory; and (2) to define the potential for buried deposits at the two terrace sites. Lithic procurement sites are one of the most common site types found throughout the state, particularly in upland settings. Activities conducted at these sites represent the first stages of lithic raw material procurement (Collins 1975;
Hester 1975). The procurement strategies (e.g., embedded, logistical, indirect) and techniques (e.g., expedient, extraction, quarrying), in turn, reflect the overall organization of land use (Andrefsky 1991, 1994; Bamforth 1990; Camilli 1988; Newman 1994; Odell 1994). Finally, the overall availability of raw materials in the economically exploited landscape, and the diversity and quality of these raw materials, in turn, affects tool design characteristics (Andrefsky 1994; Myers 1989; Torrence 1989), curation, recycling, and retooling behavior (Bouldurian et al. 1986; Gramly 1980; McAnany 1988). Considering the crucial stage that lithic procurement activities represent in the manufacture, use, and discard of stone tools, it is important to learn as much as possible from the lithic procurement sites found at Lackland AFB.

Archaeological work has been conducted in south Texas for over three decades. However, due to the scarcity of deeply stratified sites, most regional chronologies have relied on schemes borrowed from neighboring areas of the state (e.g., Lower Pecos and Central Texas; see Hester 1995). The lack of a regionspecific chronological framework has emphasized the need to find archaeological sites with buried deposits. The investigation of buried cultural deposits in terrace contexts at Lackland AFB continues this search.

While these broad concerns guided the recommendation for work at the eight sites found in the Medina Annex Housing and Dog Training Areas, the Phase II testing project was designed to accomplish four very specific goals derived from and associated with these general research concerns. These specific goals were to: (1) assess the nature and temporal origin of the cultural materials, (2) evaluate the integrity of the surface and subsurface deposits, (3) identify pertinent research domains which can be used to develop historic context statements or to place the resources within established historic contexts if possible, and (4) prepare recommendations of eligibility for NRHP listing 
for each site tested (CAR 1996; Fox 1996). Eligibility was to be determined by applying Criterion D of the NHPA as defined by NPS in 36 CFR 60 .

Based on laboratory analysis of the recovered materials and data, this report identifies important research issues at Medina Annex and makes formal recommendations about the significance of each tested site. These research issues are a first step in developing historic contexts which may be used to guide future Section 106 and Section 110 projects at the base.

Given the initial assumption, based on the results of the Phase I work, that six of the sites are lithic procurement loci and the other two are multifunctional camps, a series of expectations was developed regarding the composition of the assemblages and characteristics of the lithic technology to be observed at these sites. These expectations were to guide the artifact recovery strategies employed at each site and the subsequent data analyses.

It was assumed that the two most likely lithic procurement strategies employed in the project area would have been logistical and embedded procurement (Binford 1980; Haury 1994). Both of these are direct strategies, as opposed to indirect (i.e., exchange or trade). Logistical procurement involves the sending out of small task groups with the specific purpose of obtaining raw materials. Such a strategy would be employed when gearing up for periods of intensive tool use and the anticipation of high tool failure and repair or replacement needs. A logistical strategy may also be employed by groups provisioning trade and exchange networks with raw materials. Logistical raw material procurement would result in sites with high densities of debitage representing the quantities of materials removed and the degree of reduction of the materials (e.g., late reduction-stage blanks and preforms and prepared cores). Embedded procurement, on the other hand, would involves the acquisition of raw materials incidentally to basic subsistence tasks. The raw materials obtained are reduced to facilitate transportation, particularly since other resources are also being transported back to residential camps. When transportation is not possible, caches may be established until a return to the area is made at a future time. The quantities of materials procured would correlate with im- mediate needs, and the degree of material reduction may depend on the distance of the source from the residential site. Each individual visit to the procurement locality contributes relatively little material to the site assemblage, although repeated visits over time could significantly increase the quantity of materials and site size. When suitable outcrops of raw materials are encountered, groups may move there just as they move to other productive resource patches. The length of stay at such sites depends on the quantity of edible resources available within the daily foraging radius of the procurement locality.

Given these lithic procurement strategies, the lithic procurement sites were expected to exhibit the following characteristics:

1. A lithic assemblage characterized by few artifact categories or functional tool types;

2. An artifact assemblage dominated by debitage, cores, and bifaces; small numbers of other tools types (e.g., expedient scrapers, choppers, and usebroken projectile points) may also be present if retooling also occurred within the context of material restocking;

3. Cores may range from tested to exhausted specimens, with the first type dominant in the case of poor-quality raw materials and the latter being more common in sites containing good-quality resources;

4. Bifaces should contain primarily early-stage specimens discarded due to manufacture failures (e.g., manufacture broken and unfinished); the occurrence of manufacture-broken middle- to late-stage specimens may be indicative of high transportation costs;

5. The lithic debitage assemblage should be comprised of early-stage and core/platform preparation debitage (e.g., large biface manufacture flakes with cortex, and small secondary and tertiary flakes); the presence of large quantities of late-stage debitage may be indicative of concern with transportation costs. 
Residential camp sites were assumed to have the following lithic assemblage characteristics:

1. A lithic assemblage characterized by a variety of artifact categories or functional tool types;

2. An artifact assemblage dominated by processing and maintenance-related tool categories (e.g., scrapers [unifaces], knives [bifaces], perforators, and use-broken projectile points);

3. Cores should be dominated by well-prepared, moderately reduced to exhausted specimens;

4. Bifaces should contain primarily late-reductionstage manufacture-broken specimens and discarded use-broken fragments;

5. The lithic debitage assemblage should be dominated by late-reduction-stage and core/platform preparation debitage (e.g., biface thinning flakes, and small tertiary flakes derived from platform preparation and artifact rejuvenation).

\section{Methodology}

The investigations performed by CAR included archival background research, brush clearing at the selected sites, shovel and backhoe testing, surface collecting artifacts and raw material, excavating $1-\mathrm{x}-1-\mathrm{m}$ test units, site mapping, and laboratory analysis of the collected artifacts. The fieldwork was carried out between July 8, 1996, and October 14, 1996, by crews ranging in size from two to nine members.

\section{Preliminary Project Preparation}

The CAR staff conducted an intensive literature search of records, published reports, articles, and unpublished manuscripts to determine the extent of previous archaeological investigations performed in the survey area and the surrounding region. Most of this information was available at the Texas Archaeological Research Laboratory (TARL) at The University of Texas at Austin and at CAR. Historic records of the base were obtained from archival resources (maps, photographs, etc.) on file at Lackland AFB.

\section{Field Methods}

The field methods employed during the Lackland Phase II project were based on a work plan submitted by CAR (1996) to the WACC, on a set of protocols outlined by Fox (1996) of WACC, and on subsequent discussions between CAR and WACC.

Two types of investigations were implemented during the testing project: surface collection and subsurface excavations. The field and laboratory protocols developed prior to the fieldwork guided the type and number of excavation and collection units placed at six of the sites (Fox 1996). These protocols were applied in a consistent manner to $41 \mathrm{BX} 1076$ and 41BX1088, the two sites added to the project after fieldwork had commenced. Surface collection blocks, referred to as characterization units (CUs) as defined by Fox (1996), were a standard 5-x-5-m square. Excavation units included shovel tests (STs), 1-x-1-m test units (TUs), and backhoe trenches (BHTs). Prior to fieldwork, the THCDAP recommended that the eligibility determination for $41 \mathrm{BX} 1070$ be based on only one backhoe trench, therefore no surface collecting or shovel testing was performed at that site.

\section{Site Clearing}

Surface visibility at all sites was extremely low due to dense vegetation. Because the field protocols required intensive surface collection of large areas (400 to 1,200 $\mathrm{m}^{2}$ ) of the sites, the overlying vegetation had to be cleared by hand. Brush clearing teams consisting of two to four crew members used a gas-powered chainsaw and Weedeater, loppers, and machetes to remove obscuring bushes, grasses, and weeds. Because surface visibility was extremely limited and site boundaries were difficult to define, brush-clearing crews normally cleared a greater area than was required for sampling. This was necessary to make informed decisions on which areas of the site offered the most potential for providing information, and to avoid areas that were either heavily disturbed or were judged lim- 
ited in research potential. Brush was carried and piled along the cleared outer edges, leaving only leaf litter and woody debris.

\section{Gridding and Surface Collecting}

A metric grid, incorporating the datum established during the previous survey project (Nickels et al. 1997), was established at each site using either a transit or a total station with a data collector. Five-meter squares were staked to create CUs for controlling the provenience of surface-collected materials. Remaining organic debris was then carefully raked into piles using lawn rakes, causing minimal disturbance to the surface. The piled debris was then shoveled into buckets and sifted through $1 / 4$-inch wire mesh. With organic debris removed, surface visibility was excellent. Crew members carefully removed the remaining cultural materials visible on the surface. All materials were collected and bagged by $\mathrm{CU}$ provenience for analysis in the laboratory. Formal chert tools, ground stone, and temporally diagnostic artifacts were point provenienced and bagged separately.

The southwestern one square meter of each $\mathrm{CU}$ was delineated, and unmodified raw materials greater than $2.5 \mathrm{~cm}$ in length were collected for analysis. Each raw material sample was counted and weighed in the field, given a bag number, and collected for further examination in the laboratory.

Occasionally, artifacts were found beyond the limits of the surface collection area. If these were tools or otherwise unique, they were collected as isolated finds (IF) and their provenience was noted. The IF designation, therefore, is simply an indication of the method of artifact recovery. It is not part of a separate artifact $\log$ as was the case with the survey of the base where isolated artifacts were numbered sequentially and were not associated with sites (Nickels et al. 1997).

\section{Shovel Testing}

Shovel tests were excavated at 41BX1090, 41BX1091, 41BX1102, 41BX1103, and 41BX1114. Depending on site size, from 6 to 88 tests were excavated to de- fine site boundaries and determine the depth of buried cultural material. All tests were approximately 30 $\mathrm{cm}$ in diameter, and levels were removed in arbitrary $10-\mathrm{cm}$ increments to a depth of at least $30 \mathrm{~cm}$ at upland sites and $40 \mathrm{~cm}$ at sites on alluvial terraces. All sediments were screened through $1 / 4$-inch wire mesh. Occasionally, additional levels were removed if artifacts were encountered throughout the deposit and if the potential for subsurface cultural strata was believed to be high.

Notes were made on a standardized form regarding sediment texture, consistency, structure, and color, as well as gravel size and frequency, and artifact content. Artifacts removed from subsurface contexts were bagged and recorded. Special samples, such as faunal and charred plant remains, were bagged and recorded on a separate form.

\section{Unit Excavations}

With the exception of $41 \mathrm{BX} 1070$, from one to 15 $1-x-1-m$ units were excavated at each site. Based on the field protocols, normally two or three units per site were adequate to test each site; however, additional units could be opened at the discretion of the project archaeologist after reviewing the preliminary results of the initial units. For example, the large size of 41BX1114 and the presence of a suspected cultural feature resulted in the placement of 15 TUs at that site.

During surface collecting activities, notes were made concerning areas of the site containing artifact and fire-cracked rock concentrations and point-plotted diagnostics. Those notes were compared to the results obtained from shovel testing and recording activities during the 1995 survey (Nickels et al. 1997) to assist in the placement of TUs in areas that offered the greatest potential for encountering buried deposits.

Each unit was located on the established site grid and identified by the provenience of its southwest corner. All collection bags and forms were labeled accordingly. Two crew members were assigned to each unit. A unit datum was established $10 \mathrm{~cm}$ above the surface, adjacent to the highest corner. Excavation was 
conducted primarily with trowels, although occasionally picks and shovels were used in sterile, packed sediments. When possible, excavations levels conformed to natural stratigraphy, but were limited to 10 $\mathrm{cm}$ in thickness if a natural break was not encountered first. Seventy-five percent of the excavated material was passed through $1 / 4$-inch screen. The remaining 25 percent was screened through $1 / 8$-inch mesh to allow for recovery of a sample of materials which would have passed through the larger screen size.

A sediment sample of at least two liters was collected from the southwest corner of every level for flotation analysis. Based on the results of the analysis of samples collected at 41BX1114 and the geoarchaeological assessment of the age of the upland deposits, the samples from the other upland sites were not floated. The provenience of the samples and results of the flotation analysis are included in Chapter 5. Pollen samples were collected in sealed plastic bags in and around features or from soils that appeared to be organically enriched by human occupation. Charcoal samples were also wrapped in aluminum foil. Macrobotanical remains were collected with a clean trowel and placed in vials. All samples were labeled by provenience and assigned a unique sample number by site.

\section{Backhoe Trenching}

Backhoe trenches were excavated at $41 \mathrm{BX} 1070$, 41BX1102, 41BX1103, and 41BX1114 to address unresolved geoarchaeological issues. The initial seven trenches were excavated to a depth of between 1.5 and $2.5 \mathrm{~m}$ using a 28 -inch backhoe bucket. Trenches were typically four to five meters in length. Each trench was examined by the project geomorphologist. Twenty-five to 50 gallons of excavated matrix from each trench were screened through $1 / 4$-inch mesh to recover artifact samples.

Based on the geomorphological assessment (Nordt, Chapter 4 this volume) that $41 \mathrm{BX} 1102$ had the potential to contain buried Early Archaic deposits, a backhoe with a toothless bucket was used to excavate eight additional trenches at that site. These trenches were scraped in thin layers (ca. three centimeters thick) to search for intact burned rock features or other cultural material. This method of trenching was not employed at other sites.

\section{A Note on Unit Designations}

Collection Units and 1-x-1-m TUs are all designated by their southwest corner's grid coordinate. At sites where a grid was established first, shovel tests are also designated by grid coordinates. At several sites, however, shovel testing was initiated prior to the establishment of the site's grid. These units were designated according to their placement on pace and compass transects, and to avoid the confusion of assigning new numbers to these units, their original field designations were retained. Backhoe trenches were labeled by the project geomorphologist. Trenches excavated during the survey phase of the project were numbered sequentially, those excavated during the testing project were lettered sequentially to avoid confusion.

\section{Site Mapping}

All sites were mapped using a Sokkia total station with a data collector to depict site boundaries, locations of unit data, shovel tests, original survey dogleash sample units, point-plotted artifacts, features, areas of high artifact density, and physical features on the landscape. Each site datum was then related to Lackland Air Force Base Engineer survey points. Using the total station allowed for greater accuracy and speed in mapping.

\section{Level of Effort}

The actual number of excavation units, surface collection blocks, shovel tests, and backhoe trenches varied from the minimum level of effort outlined prior to fieldwork (e.g., CAR 1996; Fox 1996). Table 2-1 presents the proposed level of effort and the actual amount of work performed for each site tested. For sites 41BX1076 and 41BX1088, the investigations represent an attempt to approximate the level of effort employed at comparable sites and were not based on the original research design as these sites were added to the project after fieldwork began. 
Table 2-1. Proposed and Actual Levels of Effort

\begin{tabular}{|c|c|c|c|c|c|c|c|c|}
\hline \multirow{2}{*}{ Site } & \multicolumn{4}{|c|}{ Proposed Level of Effort } & \multicolumn{4}{c|}{ Actual Level of Effort } \\
\cline { 2 - 10 } & $\begin{array}{c}\text { Surface } \\
\text { Coll. }\left(\mathrm{m}^{2}\right)\end{array}$ & $\begin{array}{c}\text { Shovel } \\
\text { Tests }\end{array}$ & $\begin{array}{c}\text { Test } \\
\text { Units }\end{array}$ & $\begin{array}{c}\text { Backhoe } \\
\text { Trenches }\end{array}$ & $\begin{array}{c}\text { Surface } \\
\text { Coll. }\left(\mathrm{m}^{2}\right)\end{array}$ & $\begin{array}{c}\text { Shovel } \\
\text { Tests }\end{array}$ & $\begin{array}{c}\text { Test } \\
\text { Units }\end{array}$ & $\begin{array}{c}\text { Backhoe } \\
\text { Trenches }\end{array}$ \\
\hline 41BX1070 & 0 & 0 & 0 & 1 & 0 & 0 & 0 & 1 \\
\hline $41 \mathrm{BX} 1076$ & $\mathrm{n} / \mathrm{a}$ & $\mathrm{n} / \mathrm{a}$ & $\mathrm{n} / \mathrm{a}$ & $\mathrm{n} / \mathrm{a}$ & 400 & 0 & 3 & 0 \\
\hline 41BX1088 & $\mathrm{n} / \mathrm{a}$ & $\mathrm{n} / \mathrm{a}$ & $\mathrm{n} / \mathrm{a}$ & $\mathrm{n} / \mathrm{a}$ & 1,200 & 0 & 3 & 0 \\
\hline 41BX1090 & 750 & 4 & 2 & 0 & 525 & 6 & 2 & 0 \\
\hline 41BX1091 & 540 & 4 & 2 & 0 & 800 & 17 & 2 & 0 \\
\hline 41BX1102 & 1,050 & 4 & 4 & 0 & 800 & 21 & 3 & 9 \\
\hline 41BX1103 & 700 & 4 & 2 & 0 & 800 & 42 & 5 & 3 \\
\hline 41BX1114 & 500 & 4 & 2 & 0 & 1,200 & 88 & 13 & 2 \\
\hline Totals & $\mathbf{3 , 5 4 0}$ & $\mathbf{2 0}$ & $\mathbf{1 2}$ & $\mathbf{1}$ & $\mathbf{5 , 7 2 5}$ & $\mathbf{1 7 4}$ & $\mathbf{3 1}$ & $\mathbf{1 5}$ \\
\hline
\end{tabular}

\section{Laboratory Methods}

Artifacts and samples were brought to the laboratory at the end of each day in the field. Once there, each sample's provenience was verified. Samples were then placed in appropriate containers before being moved to a special storage area to await analysis. Artifacts were washed by laboratory personnel using water and toothbrushes. Once the artifacts were washed, they were allowed to air dry on mesh racks before being transferred to cardboard flats for temporary storage. These flats were placed on shelves and organized by site. Throughout this process the provenience information was kept with the materials.

Once the fieldwork was completed and all the artifacts had been processed, CAR laboratory personnel catalogued the artifacts according to the system described in Appendix B. Once the cataloguing process was complete, Brett A. Houk, David Nickels, and Ricky Robinson analyzed the artifacts, coding certain attributes for each category of material. Appendix B provides a detailed discussion of the attribute analysis.

Unusual or temporally diagnostic artifacts were assigned Unique Item (UI) numbers sequentially for each site. Each UI is listed or discussed in Appendix B. 


\title{
Chapter 3: Environmental and Cultural Setting
}

\author{
David L. Nickels
}

\section{Introduction}

This chapter provides a synopsis of environmental and archaeological background information for what can be termed a Lackland subregion. Essentially, information was gathered from within an arbitrary $120-\mathrm{km}$ radius around Lackland Air Force Base which encompasses the northern fringe of the South Texas plains, a western portion of the Gulf Coastal Plain, the southeastern edge of the Edwards Plateau, and the southern tips of the Post Oak Belt and the Blackland Prairie. (Figure 3-1). The concept of the arbitrary boundary is meant to focus on the Lackland area, but not to exclude significant information that may lie peripheral to the Lackland subregion. Therefore, if an important and pertinent environmental study or archaeological excavation took place beyond the subregion, it has been included.

\section{Environmental Summary}

\section{Modern Environment}

\section{Physiographic Provinces}

Three major landform regions divide the Lackland subregion: the Balcones Escarpment of the Edwards Plateau, the Blackland Prairie, and the South Texas Plain (also known as the Rio Grande Plain). The Edwards Plateau, with elevations reaching $686 \mathrm{~m}$ $(2,250 \mathrm{ft})$ above mean sea level (amsl) in northern Gillespie County (Allison et al. 1975:76), is a hilly region, gradually sloping to the southeast, and ending in the escarpment running across the middle of the subregion. The rugged southern end of the plateau in the study area is incised by numerous southeasterly flowing rivers such as the Colorado, Guadalupe, San Antonio, Medina, Frio and Nueces, and their tributary creeks including the Cibolo, Leon, Salado, Culebra, Helotes, Medio, and Long Hollow.
The Balcones Escarpment is a fault zone, curving through the center of the study area, consisting of blocky limestone, chalk, shale, and marl. The escarpment slopes to the southeast from about $305 \mathrm{~m}$ $(1,000 \mathrm{ft})$ to $213 \mathrm{~m}(700 \mathrm{ft})$ amsl (Taylor et al. 1991:119). South of the escarpment lies the Blackland Prairie, a rolling and well-dissected plain representing the southern extension of the true prairie running through the center of the country. The South Texas Plain is the western extension of the Gulf Coastal Plain. It is a nearly level to rolling plain that is moderately dissected by major river drainages through its northern half and by numerous intermittent creeks and the Bordas Escarpment in the south.

Lackland Air Force Base and Medina Annex, comprising 2,752 acres and 3,972 acres respectively, are located in southwestern San Antonio in Bexar County (Figure 1-1) at the base of the Balcones Escarpment's junction with the South Texas Plain (Dalbey 1993:22). The project area is on the edge of the Nueces-Guadalupe Plain, a biogeographical subarea of the South Texas Plains. Adjoining the Nueces-Guadalupe Plain to the east is the Gulf Coastal Plain, and beyond is the Gulf of Mexico, approximately $224 \mathrm{~km}$ to the east. Twenty-five kilometers to the north, plains give way to an abrupt rise-the Balcones Escarpment and prominent Edwards Plateau. The Balcones Escarpment serves as a geographical division between the Central Texas archaeological region to the north and the South Texas region to the south (Black 1989a:39-41).

\section{Climate}

The arid climate of the Nueces-Guadalupe Plain changes to subhumid closer to the Gulf Coastal Plain (Hester 1981). The project area has a modified subtropical climate, with cool winters and hot summers, primarily influenced by the low elevations and the Gulf of Mexico. Daytime humidity ranges from 50 to 80 percent throughout the year, while clear skies prevail 
This page has been

redacted because it

contains restricted

information. 
over 70 percent of the summer and 50 percent in winter. The coldest month is January (average temperature: $62.3^{\circ} \mathrm{F}$ ), and the hottest month is August (average temperature: $94.2^{\circ} \mathrm{F}$ ). Rainfall averages 27.89 inches (Taylor et al. 1991:118, Table 11), but a great deal of variation exists from year to year, with 52.28 inches recorded in 1973 and 10.11 in recorded in 1917 (McGraw and Hindes 1987:37). The average seasonal rainfall distribution is: spring - 7.99 inches, summer 7.4 inches, fall - 7.36 inches, and winter -5.14 inches The growing season averages 275 days south of the Balcones Escarpment, between March 1 and December 1. Light snowfalls occur every three or four years (Taylor et al. 1991:118-121, Table 11).

\section{Biotic Resources}

Although recent Pleistocene data suggest that juniper has been on the Edwards Plateau and in the region for at least the last 10,000 years, overgrazing by livestock and restricting range fires in modern times have allowed juniper to overtake much of the plateau (Buechner 1944:703-704; Van Auken 1993:199-210). According to Van Auken (1988:45), the most characteristic flora include juniper (Juniperus ashei), plateau live oak (Quercus fusiformis), Texas persimmon (Diospyros texana), and agarita (Berberis trifoliata). In the western part of the region, mesquite (Prosopis glandulosa) and live oak (Quercus virginiana) are the dominant woody species (Blair 1950:112).

The floral species just below the escarpment are the same as those on the Edwards Plateau, with the addition of numerous riparian species in the river and creek bottoms (Van Auken 1988:55). The most economically important of these are nut trees, including oak, walnut, and pecan (Dalbey 1993:22). An intertwined diversity in biotic resources existing along the escarpment provides an ecotone which would have allowed humans to harvest a seasonal banquet of plants and animals (Collins 1995:366). Hall (1995:633-647) suggests a strong spatial relationship among prehistoric cemeteries and the distribution of nut-bearing species, particularly live oak and pecan (Carya illinoensis) trees, and prickly pear tunas. He infers such a relationship is a result of groups being seasonally tethered to rich food resources.
The Blackland Prairie was once dominated by tallgrass species such as little bluestem (Schizachyrium scoparium), big bluestem (Andropogon gerardii), Indiangrass (Sorghum linnaeanum), tall dropseed (Sporobolus asper), and silveus dropseed (Sporobolus silveanus). Much of this vegetation has been replaced by common invader species including mesquite, and huisache (Acacia smallii). Oaks, elms (Ulmus), cottonwoods (Populus), and native pecan are common along drainages (Gould 1975:11).

The original vegetation of the South Texas Plain was open grasslands mixed with brushy chaparral. Oaks, pecan, and ash were common along streams. Due in part to overgrazing and the exclusion of fire, the invasion of woody species has changed the vegetation into the "Texas brush country" dominated by mesquite, acacia, spiny hackberry (Celtis laevigata), whitebrush (Aloysia ligustrina), and others (Diamond et al. 1987:203-221; Gould 1975:12). Black (1989a:40) describes the Nueces-Guadalupe Plain subarea of the South Texas Plain as "areas of grass and thorny brush savannah" dissected by "narrow bands of riparian (streamside) vegetation" which Hester (1981) suggests are high-density resource areas. Studies along the San Antonio, Guadalupe, Frio, Sabinal, and Nueces rivers (Ford and Van Auken 1982; Van Auken and Bush 1988; Wood and Wood 1988, 1989) suggest that flooding and modern climate have significantly redistributed riparian native vegetation.

The area around Lackland AFB is an ecotone incorporating an interface of diverse ecological communities (Johnson 1967:73). These include Juniper-OakMesquite Savanna, Blackland Prairie, Oak-Hickory forest, and Mesquite-Chaparral Savanna. Stahle and Cleaveland (1995:55) suggest that the diversity in forest mottes was created from microenvironments existing in the late glacial period (ca. 15,000 B.P.). Blair (1950:112) notes that the joining of three biotic provinces occurs in Bexar County: the Texan (eastern half of the county), the Balconian (the Edwards Plateau and Balcones Escarpment), and the Tamaulipan (southwestern county, South Texas Plain).

The geographic location of the project area, essentially on the periphery of these three biotic provinces, provides a dynamic setting for a greater diversity in 
riverine, uplands, and xeric vegetation and fauna. Two ecological settings dominate the project area landscape within the ecotone: uplands and creek zones. Descriptions of the project area prior to 1900 reveal that the uplands were once dominated by tall grasses, with occasional stands of brush and mesquite (Inglis 1964).

Descriptions of plant life by early observers (16751722) who left written records of the area around Lackland AFB suggest that mesquite and other thorny scrub were present in scattered mottes, while the land south of the base and just across the Medina River was open grasslands with little or no brush (Inglis 1964:Plate 1). Later observers documented the change on the South Texas Plain from grassland/scrub grassland mosaic to the domination of thorny brush (Inglis 1964:Plates 1-3). By 1900 the Lackland area was described as "dense brush or chaparral" (Inglis 1964:Plate 3). Likely causes for this change in plant communities (with no discernible changes in climate) are a combination of overgrazing and human interference with natural range fires (Black 1989a:15)

Historic alterations to the primary landscape include plowing, overgrazing, stream rechannelization, controlled burning, and the introduction of deep wells. These have undoubtedly caused lower water tables and have concurrently altered the plant and animal communities. Many springs feeding the streams emanating from the Balcones Fault are now either dry or do not discharge sufficient flows to reach the Lackland area before evaporating or seeping into the sandy soils upstream of the base (Brune 1981:75). Leon Creek briefly passes through Lackland's Main Base, while Medio Creek and Long Hollow drain Medina Annex. Although both Leon and Medio creeks are currently flowing, they are supplemented upstream by artificial means.

Even with the significant environmental changes experienced by the area over the past 12 millennia, the rich diversity of contemporary flora and fauna is remarkable. Today over 200 native species of plants and a wide variety of fish, reptiles, and mammals thrive within the riverine and uplands of the project area (Cleveland and McLain 1992:1-5, 26-28). Such diversity is characteristic of ecotonal settings. Table
3-1 lists the most common flora observed within the project area.

Table 3-2 is a list of common fauna living within the project area. Cleveland and McLain (1992:Tables XXI) identified numerous small rodents and 95 species of birds. The most common fish is the bluegill (Lepomis macrochirus), a species introduced from the eastern United States (Cleveland and McLain 1992:26).

\section{Geology}

During the Upper Cretaceous period, approximately 78 million years ago (Judson and Kauffman 1990:150), Navarro Group limestones and marls began forming and now make up the bedrock underlying the project area. Fluviatile terrace deposits formed in the Late Pleistocene approximately 15,000 years ago in the Main Base area. Low terrace deposits adjacent to Leon Creek began forming later during the Middle Holocene, approximately 6,000 years ago, and are still developing today. Plio-Pleistocene Uvalde Gravels cover the uplands of Medina Annex. Upper Cretaceous Marlbrook Marl is exposed in some areas of Long Hollow, while the terraces along Medio Creek consist of Holocene and perhaps Pleistocene alluvial deposits (Barnes 1983).

\section{Soils}

Houston Black clays and gravelly clays of varying slopes cover the uplands and some creek terraces. This series is generally dark gray to black in color, and calcareous with a blocky structure that tends to crack and shift with episodes of wetting and drying. Archaeological investigations are hampered by these dynamics because of the possibility that artifacts are displaced to deeper sediments if cracking occurs (Hester 1980).

Alluvial soils of the Trinity, Frio, Venus, and Patrick series lie in the modern floodplain and basin areas of Leon and Medio creeks and Long Hollow. They are deep, calcareous, clayey loams associated with bottom lands and terraces (Taylor et al. 1991:18-34). 
Table 3-1. Flora Common in the Project Area

\begin{tabular}{|l|l|l|}
\hline Ecological Setting & Common Name & \multicolumn{1}{|c|}{ Scientific Name } \\
\hline creek & bog rush & Juncus texanus \\
\hline creek & cattails & Typha angustiflora \\
\hline creek & greenbriar & Smilax bona-nox \\
\hline creek & pecan & Carya illinoinensis \\
\hline creek & poison ivy & Rhus toxicodendron \\
\hline creek & river walnut & Juglans microcarpa \\
\hline creek & yaupon & Ilex vomitoria \\
\hline creek/upland & coastal live oak & Quercus virginiana \\
\hline creek/upland & hackberry & Celtis laevigata \\
\hline creek/upland & honey mesquite & Prosopis glandulosa \\
\hline creek/upland & huisache & Acacia smallii \\
\hline upland & agarita & Berberis trifoliolata \\
\hline upland & blackbrush acacia & Acacia rigidula \\
\hline upland & buckthorn & Rhamnus caroliniana \\
\hline upland & catclaw & Acacia greggii \\
\hline upland & guayacan & Guaiacum ang ustifolium \\
\hline upland & horse crippler & Echinocactus texensis \\
\hline upland & javelina bush & Condalia ericoides \\
\hline upland & lace cactus & Echinocereus reichenbachi \\
\hline upland & lime prickly ash & Zanthroxylum fagara \\
\hline upland & snakewood & Colubrina texensis \\
\hline upland & tasajillo & Opuntia leptocaulis \\
\hline upland & Texas persimmon & Diospyros texana \\
\hline upland & Texas prickly pear & Opuntia lindheimeri \\
\hline upland & trecul yucca & Yucca treculeana \\
\hline upland & Acacia neovernicosa \\
\hline upland & Aloysia ligustrina \\
\hline
\end{tabular}

\section{Lithic Resources}

Beyond the project area, rich sources of chert crop out in the Edwards Plateau region. Nodules and cobbles of good quality are commonly found eroding out of the limestone on the plateau itself, and in creekbed gravels originating in the plateau (Black and McGraw 1985). Rich deposits of lag Uvalde gravels quite commonly cap upland areas south of the plateau (Byrd 1971). Lackland lies at the south edge of the Uvalde gravel distribution as mapped by Barnes (1983). Within the project area, Houston Black gravelly clays found on the uplands have fist-size or larger chert cobbles in varying quantities. Extensive exposures of chert gravels are common along the slopes of Long Hollow. Large and small quarry sites abound in the project area, indicating that the gravel exposures were heavily exploited by prehistoric inhabitants. Thus, these groups were not required to travel to the Edwards Plateau for lithic raw materials.

Rich biodiversity created by an ecotonal setting, a constant water supply, and prolific raw material sources persist in the project area. Yet, some variables of the modern environment, specifically climate and biotic resources, have not been constant through time. 
Table 3-2. Fauna Common in the Project Area

\begin{tabular}{|l|l|}
\hline \multicolumn{1}{|c|}{ Common Name } & \multicolumn{1}{c|}{ Scientific Name } \\
\hline opossum & Didelphis virg in iana \\
\hline raccoon & Procyon lotor \\
\hline guano bat (freetailed bat) & Tadarida mexicana \\
\hline nine-banded armadillo & Dasypus novemcinctus \\
\hline gray fox & Urocyon cinereoargenteus \\
\hline eastern cottontail & Sylvilagus floridanus \\
\hline jackrabbit & Lepus californicus \\
\hline striped skunk & Mephitis mephitis \\
\hline collared peccary (javelina) & Pecari tajacu \\
\hline white-tailed deer & Odocoileus virginianus \\
\hline fox squirrel & Sciuris niger \\
\hline bobcat & Lynx rufus \\
\hline kingsnake & Lampropeltis sp. \\
\hline diamond-backed rattlesnake & Crotalus atrox \\
\hline Texas patch-nosed snake & Salvadora grahamiae \\
\hline
\end{tabular}

\section{Paleoenvironment}

In order to understand past human behavior, we must know something of the environment in which prehistoric groups contended for resources. Paleoenvironmental studies provide broadly applicable schemes on climatic and vegetation shifts that have occurred over the past 18,000 years. After the last glacial episode around 18,000 B.P., Texas and northern Mexico were much wetter and colder than today (Bryant and Holloway 1985:50). The South Texas Plain was a mosaic of woodlands and scrub grasslands (Bryant and Holloway 1985:56). Between 20,000 B.P. and 14,000 B.P., pollen samples show that forests (pinyon-juniper woodlands in the Trans-Pecos area of west Texas and spruce-fir woodlands in central Texas) began to be replaced by spreading habitats of grass and scrub species, presumably because of increasingly warmer and drier conditions (Bryant and Holloway 1985:51-52). In the South Texas Plains, scrub grasslands began to dominate at the same time (Bryant and Holloway 1985:56).

In central Texas, pollen spectra from Boriack Bog suggest a shift from grasslands before 16,500 B.P. to woodlands until 12,500 B.P. in a moist and cool climate (Bousman 1994:79). The same spectra reveal a decline in spruce (probably cold-adapted) pollen by
15,000 B.P., indicating a trend towards a warmer climate. Bousman's (1992) oxygen isotope evidence from south Texas compliments the bog pollen data, and suggests early warming by 15,000 B.P.

In south Texas, low resolutions of noble gases within the Carrizo aquifer in Atascosa and McMullen counties indicate that between 12,000 and 17,000 years ago temperatures were $5.2^{\circ} \mathrm{C}$ cooler than today (Stahle and Cleaveland 1995:52-53). Corroborating evidence of white spruce pollen found in Boriak Bog suggesting a mean temperature of about $5.5^{\circ} \mathrm{C}$ lower (Holloway and Bryant 1984; Stahle and Cleaveland 1995). Nordt et al.'s (1994:80) analysis of $\mathrm{C}_{3}-\mathrm{C}_{4}$ plant ratios based on ${ }^{13} \mathrm{C}$ values of organic carbon from the Applewhite project shows two shifts occurring in vegetation and climate during the Late Pleistocene. An increase in $\mathrm{C}_{4}$ grasses (and temperature) is indicated for the thousand year intervals of 14,000 to 13,000 B.P. and 11,000 to 10,000 B.P.

These indicators disagree with beetle fossils from pond sediments in north Texas (Elias 1994) that suggest a much cooler (less $10^{\circ} \mathrm{C}$ ) than modern average climate between 14,200 and 13,500 B.P. From Hall's Cave in the Edwards Plateau, and much closer to the project area, Toomey et al. (1993) argue that summer temperatures in the Late Pleistocene were $6^{\circ} \mathrm{C}$ cooler than 
present averages, and that by 13,000 B.P. the wetter interval became warm and more arid. Between 12,500 and 11,800 B.P., the Boriack Bog data indicate that a drier episode stimulated a brief shift to grasslands, again collaborated by oxygen-isotope ratios showing a cooler setting in south Texas (Bousman 1992, 1994:80). The Hall's Cave record indicates a wetter interval around 11,000 B.P. (Toomey and Stafford 1994).

\section{Early Holocene}

Pollen samples from the Llano Estacado and the dry caves of the Trans-Pecos region prompted Bryant and Shafer (1977:15-19) to suggest a trend of gradual warming and drying throughout the Holocene (after about 10,000 B.P.). Others, including Aten (1979), Gunn and Mahula (1977), and MacNeish (1958:199), use data from Oklahoma, east Texas, and the Sierra de Tamaulipas in Mexico to propose a more variable change from the colder, wetter Pleistocene to the modern climate.

More than 15 years ago, innovative research in opal phytolith analysis from archaeological sites on the Coastal Plain of south Texas (Robinson 1979) also showed that, at least since the Early Holocene, climatic change has been highly variable. Fluctuations in the Holocene trend are also suggested by Bousman (1994), again based on the Boriack Bog data from central Texas. Toward the Pleistocene-Holocene boundary around 10,000 B.P., arboreal species in the Boriack Bog spectra show a return of woodlands up to 9500 B.P., followed by a predominance of grasses. Woodlands that had been reestablished by 8750 B.P. were again replaced by grasslands by 7500 B.P. (Bousman 1994:80). Although poorly dated, Robinson (1979:109) associated his oldest phytolith sample with Late Paleoindian and suggested an age of about 8000 B.P. The predominance of tall grass species, white oak phytoliths, a generally high frequency of other tree species (unidentifiable), and generally small size of the grass phytoliths combined to indicate a wet environment.

Although traces of information obtained from studies $12 \mathrm{~km}$ south on the Medina River suggest the climate was cooler and wetter between 10,000 and 6,000 years ago (cf. Thoms et al. 1996), there is a significant gap in the paleoenvironmental record of Lackland AFB. In the absence of well-designed and adequately funded testing projects, we can only speculate how the environment may have affected prehistoric human subsistence and settlement patterns.

\section{Middle Holocene}

The continuous decline of the woodlands in the Early Holocene was briefly checked around 6000 B.P., but resumed its slide until 5,000 B.P. when arboreal pollen slowly increased with the appearance of a wetter climate (Bousman 1994:80). This Mid-Holocene arid period indicated at Boriack Bog agrees with data presented by Nordt et al. (1994) from the Applewhite project near San Antonio, where a dry period for roughly the same time frame (6000 to 4800 B.P.) is indicated. Humphrey and Ferring (1994) discovered the same arid episode in north central Texas, but with greater duration ( 6500 to 4000 B.P.), agreeing with the revised interpretation from Hall's Cave that gives an episode between 7000 and 2500 B.P. (Toomey and Stafford 1994). A later occurrence between 5000 and 2500 B.P. is reported by Johnson and Goode (1994). The opal phytolith records from the Wilson-Leonard site in central Texas (Fredlund 1994) and two sites on Coleto Creek in south Texas (Robinson 1979:111) agree with increasing aridity in the Middle Holocene, indicated by spreading grasslands around 4400 B.P. and ca. 4500 B.P., respectively. However, a sample from slightly higher in the Coleto Creek strata with roughly the same age argues for a quickly appearing, yet brief wet episode (Robinson's Sample 4, 1979:111), followed by a sample indicating a return to an arid climate up to ca. 2750 B.P.

Phytolith analyses of sediments from the Choke Canyon project (Robinson 1982:597-610) add to the claim of considerable climatic variability. Between 5300 and 4300 B.P., Robinson (1982:598) infers a cool, mesic climatic regime that shifts to a more arid period and then returns to conditions both cooler and wetter than today's by 3250 B.P. 


\section{Late Holocene}

Varied indicators for a fluctuating climate in the Late Holocene continue, but do not necessarily agree. Nordt et al. (1994) suggest a warm and dry episode between 3000 and 1500 B.P. based on deposits from San Antonio. Toomey and Stafford (1994) see a wet period appearing about 2500 B.P. at Hall's Cave. Their observations agree with those of Robinson (1979:112). Ricklis's (1994) study of oyster growth patterns on the Texas Gulf coast tentatively implies a shift to a cooler climate at ca. 3000 B.P., emerging out of a much warmer Middle Holocene. The Gulf Coast data tend to agree with the Choke Canyon analysis that points to mesic conditions, similar to today's, by 2450 B.P. (Robinson 1982:598-599). Afterwards, a shift to more xeric conditions occurred by 1000 B.P., but Robinson suggests that they may have been more mesic than modern conditions. The predominance of short grass species nicely agrees with large quantities of bison remains documented in archaeological context at Choke Canyon (Robinson 1982: 599). Grass species in the Weakly Bog pollen spectra indicate drying episodes at 1600 to 1500 B.P. and 500 to 400 B.P. (Bousman 1994:80).

\section{Archaeological Background}

\section{Previous Research}

Large-scale surveys covering thousands of acres along the eastern edge of the Edwards Plateau, the Balcones Escarpment, and the South Texas Plain have been highly effective in discovering archaeological sites. Seventy-two sites were recorded on 5,600 acres at Camp Bullis in northern Bexar County (Gerstle et al. 1978). The survey covered the watersheds of upper Cibolo Creek, Ranger Creek, and upper Salado Creek. Thirty-four sites were recorded during a 2,500-acre survey of the East and West Elm Creek branches of the upper Salado Creek in the Encino Park area of northern Bexar County. Those sites contained Paleoindian through Late Archaic components (McGraw et al. 1977:10-29). Thirty-one prehistoric sites dating from the Paleoindian through Late Prehistoric periods were found during a 604-acre survey of the upper Cibolo in southern Kendall County (Bass and Hester
1975:9-24; Kelly and Hester 1976:29). Paul McGuff recorded 28 prehistoric sites along Leon Creek in northern Bexar County in 1970 and 1971 (site reports on file at CAR). An intensive survey of approximately 38,000 acres in the late 1970 s and early 1980 s by archaeologists from UTSA, Texas A\&M, and Texas Tech along the Frio River in Live Oak and McMullen counties documented over 400 sites (CAR, Choke Canyon Series). An earlier large scale survey in Atascosa and McMullen counties located 85 sites (Shafer and Baxter 1975).

Closer to Lackland, Medio Creek has been surveyed both north and south of Lackland AFB, resulting in the location of 15 prehistoric sites (McGraw 1977). In 1987, CAR surveyed 3,539 acres and documented 52 sites along the Medina River for a cultural assessment of the area to be affected by the proposed Applewhite Reservoir (McGraw and Hindes 1987). The findings indicate many archaeological sites are located within the areas where the Olmos, Salado, Leon, and Medio creeks converge with the Medina River. A survey south of Medina Annex at the Covel Gardens landfill revealed one prehistoric site on a terrace of Medio Creek (Potter 1990:2-4).

A few of the more significant sites in the Lackland subregion have been intensively tested or investigated (Figure 3-1). The Richard Beene site (41BX831) is located on the Medina River, in the Applewhite Reservoir project area, $12 \mathrm{~km}$ south of Medina Annex. The site was excavated in 1991, and tested further in 1995. The site is deeply buried in the first terrace above the Medina. Its well-defined stratigraphy yielded artifacts and fauna representing a continuous occupation from the Paleoindian through Late Prehistoric periods (Thoms 1992:17-26; Thoms et al. 1996). The Panther Springs Creek site (41BX228), on the Salado Creek drainage, $20 \mathrm{~km}$ north of the project area, was tested in 1979 (Black and McGraw 1985), and then again in 1992. Early Archaic through Late Prehistoric components were defined by diagnostic stone tools (Potter and Black 1995a:23-54). Tested heavily in $1995,41 \mathrm{BX} 47$ is a buried, intact Paleoindian through Middle Archaic campsite on the terraces of Leon Creek, $25 \mathrm{~km}$ north of Lackland (Tennis 1996; Tennis and Hard 1995). Although not well published, Pavo Real (41BX52), in the Leon Creek floodplain at Loop 
1604, is a Clovis and Folsom lithic workshop (Henderson 1980).

Research by the Texas Archeological Research Laboratory (TARL) at The University of Texas at Austin has resulted in a comprehensive assessment of the area to be impacted by the proposed Wurzbach Parkway in San Antonio. This includes the Walker Ranch Historic District on Panther Springs Creek, as well as other sites in the upper-middle Salado Creek watershed. The approach taken by TARL has been innovative and thorough. This is exemplified by the work at the Higgins site (41BX184), and the manner in which the Wurzbach research is being reported. The beginning of what promises to be a series of modules present the conceptual framework (Potter et al. 1995) and testing results from several prehistoric sites (Potter and Black 1995a). The first module proposes two historic contexts and offers an intermediate framework in the absence of a regional planning document (Black and Potter 1995:45-51).

The Wurzbach research also presents the modern theoretical approach best suited for local prehistoric research: hunter-gatherer mobility and subsistence in an ecological context. Since Bexar County represents a transitional zone between two biotic provinces, with geomorphically and geographically changing land forms, different resources are available in each area. The potential for diverse site function across the county is high. The study of archaeological sites in the watershed areas of Salado Creek (Katz 1987; Quigg 1988), Leon Creek (Henderson 1980; Espey, Huston and Associates 1989), and Olmos Creek (Stothert 1989) helps in the total assessment of site distribution along watercourses.

\section{Cultural Chronology}

\section{Prehistoric Chronology}

Several scholars have offered sound but differing arguments for cultural chronologies for central Texas. Using the earlier works of Suhm (1960), Johnson et al. (1962) and Sorrow et al. (1967) as a springboard, Weir (1976) and Prewitt $(1981,1985)$ sorted through the archaeological data from central Texas and estab- lished a chronology defined by phases. Though some of their data have been criticized as unreliable and their phases challenged as actual patterns, chronological markers, and intervals (e.g. Collins 1995; Johnson 1987), they energized fellow colleagues to investigate empirical methods for inferring cultural behavior. Black (1989a, 1989b) synthesized the data of high validity available at the time and offered a synthesis of prehistoric intervals which were widely accepted. Collins (1995) reviewed the archaeological and palynological evidence for central Texas and offered new approximate dates for human occupation from the Paleoindian through Historic periods.

Refining a cultural chronology for south Texas is much more problematic, due to the compressed nature of the archeological record and limited excavations conducted in the region (Hester 1995:433). Hall et al. (1982:463; 1986:393-406) analyzed radiocarbon dates and artifact assemblages from Choke Canyon sites in western Live Oak and eastern McMullen counties to establish a chronology peculiar to that area. Black (1989c:39-62) synthesized available data from south Texas and offered a chronology similar to that of Hall et al. (1982). Both chronologies were considered by Turner and Hester (1993), who offer slightly different chronological periods based on evidence found more recently in south Texas. Supported by data retrieved from Loma Sandia in Live Oak County, Black (1995:31-44) updated his south Texas chronology, again confirming that of Hall et al. (1982). Also considering Hall's scheme, Hester (1995:433) acknowledges the paucity of information that exists for south Texas and offers only a general framework for prehistoric periods particular to the region. The dates in Table 3-3 and the following discussion are primarily derived from Black (1995), Collins (1995), and Hester (1995). A brief discussion of the Transitional Archaic as defined by Turner and Hester (1993) and Hester (1995) is also presented. All dates are approximate and given as years before present (B.P.), i.e., before 1950 .

\section{Pre-Clovis}

Although humans may have inhabited the project area before 11,500 B.P, solid evidence does not support their existence. The argument that artifacts recovered 
Table 3-3. Cultural Chronology of South and Central Texas

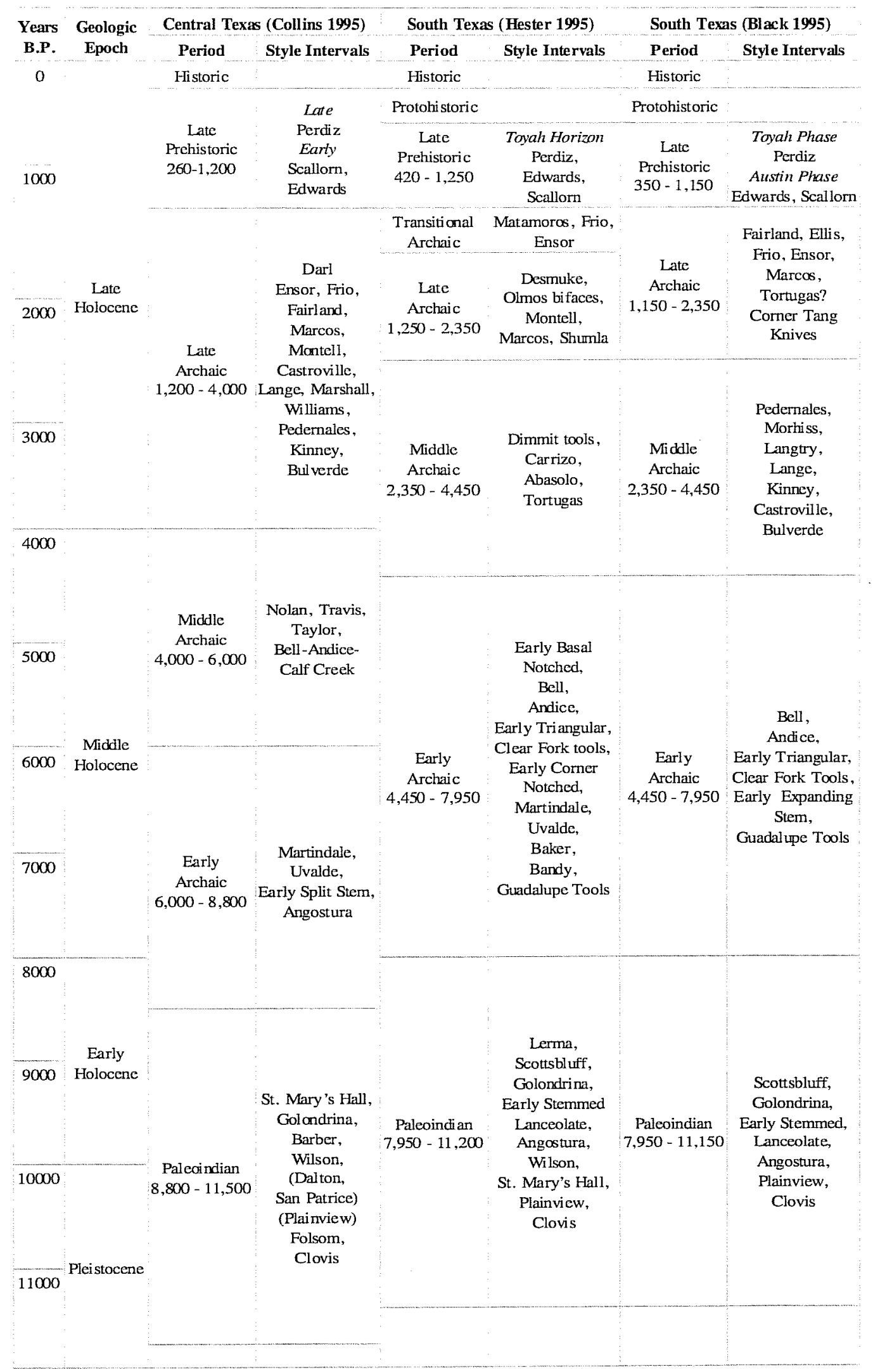


from Levi Rockshelter in Travis County are older than Paleoindian (Alexander 1983:133-145) is not supported by clustered radiocarbon dates, or by distinct artifact and extinct fauna assemblages within welldefined stratigraphy (Collins 1995:380-381). Although human behavior is inferred on stone artifacts from Friesenhahn Cave (Krieger 1964) and mammoth bones at the Waco Site (J. Fox et al. 1992:51-73), all are problematic for the same reasons given for Levi Rockshelter. Although several skulls of "pre-sapien ancestry" with "low sloping foreheads, a pronounced supra-orbital torus, and a marked postorbital construction" were found in Hitzfelder Cave in northeast Bexar County, no radiocarbon dates are available to substantiate their surmised antiquity (Givens 1968a:219). The Middle Archaic points found with the burials suggest the skeletons are more likely 5,000 to 6,000 years old (Givens 1968a:219). As Collins (1995:380-381) offers, eroded landforms are not likely to yield solid stratigraphic proof of human occupation earlier than late Pleistocene, and if we do find earlier occupations on stable landforms, what comprises the signature of a Pre-Clovis culture?

\section{Paleoindian}

This phase spans the period estimated at between ca. 11,500 to 8800 B.P. in central Texas (Collins 1995:381383 ) and between 11,200 to 7,950 B.P in South Texas (Hester 1995:433-436), although a few claims to older sites exist (Alexander 1963, 1983; Fox et al. 1992; Givens 1968a, 1968b; Krieger 1964). The Paleoindian period began toward the close of the Pleistocene. Diagnostic artifacts include Clovis and Folsom projectile points. Certainly the wide distribution of Clovis-type points across most of North America and even into Central America suggests a wide dispersal of the people who made them (Kelly 1993; Wenke 1990:201). Within Texas's political boundaries, Meltzer and Bever (1995:47-81) have documented the presence of 406 Clovis points in 128 of 254 counties. Forty-three of these points were found within the 23 counties overlain by our prescribed Lackland subregion. Other artifacts associated with the Clovis culture include bifaces and prismatic blades, engraved stones, bone and ivory points, stone bolas, ochre, and shaft straighteners.
In general the Paleoindian adaptation has been considered to be one of small bands of nomadic, big-game hunters following herds of Late Pleistocene fauna, including mammoth, mastodons, bison, camel, and horse, across North America (Black 1989a). More recently, emphasis has been placed on the wide diversity of plants and animals used for subsistence by these early Americans (Black 1989a; Hester 1983), such as turtles and tortoises, alligators, mice, badgers, and raccoons (Collins 1995:381), although they undoubtedly hunted the large animals as well (Dibble and Lorraine 1968). Known Clovis sites include killsites, quarries, caches, open campsites, ritual sites, and burials (Collins 1995:381-383; Hester 1995:433-436). A Folsom interval follows the Clovis. Folsom artifacts are fairly common in central and south Texas; however, no camp sites or killsites have been found south of Pavo Real (41BX52) in Bexar County (Hester 1995:434-435).

Most Paleoindian finds in central and south Texas have consisted of surface lithic scatters on upland terraces and ridges (Black 1989b:25, 1989c:48). A few Paleoindian components have been discovered in deeply buried in alluvium. These include the Berclair Terrace site (Sellards 1940), the Berger Bluff site (Brown 1987), Kincaid Rockshelter (Collins et al. 1989), the Wilson-Leonard site (Collins et al. 1993), and at recent excavations of the Richard Beene site (Thoms et al. 1996). Collins (1995:Table 2) recognizes three sites that have high-integrity Paleoindian components resting on stable landforms: Kincaid Rockshelter, Horn Shelter, and Wilson-Leonard (Figure 3-1). Many Paleoindian points have been recovered from surface contexts in Bexar and nearby counties (Chandler and Hindes 1993; Hester 1968a, 1968b; Howard 1974; Meltzer and Bever 1995). A late Paleoindian component with apparent high integrity has also been reported at the St. Mary's Hall site in Bexar County (Hester 1990:14-17, 1995:435).

As the warming marking the transition from Pleistocene to Holocene climates began to take effect in Texas, prehistoric inhabitants adapted with changes in life-style. This climatic shift is also marked by the decline and extinction of mammoth, mastodon, horse, camel, and giant bison (Bison antiquus). With the pos- 
sible exception of the Berclair Terrace site (Sellards 1940), archaeological evidence suggests that after 8000 B.P., large gregarious game animals were either extinct or otherwise extricated from Texas. Human hunters were forced to concentrate on deer, antelope, and other medium-size or smaller game. Changes in the subsistence base required technological shifts that mark the beginning of a new cultural period known as the Archaic.

\section{Early Archaic}

Collins (1995:383) dates the Early Archaic from 8800 to 6000 B.P. in central Texas, with three divisions based on projectile point types, while Hester (1995:436-438) identifies the Early Archaic with Early Corner Notched and Early Basal Notched dart points roughly dating between 7950 and 4450 B.P. The extinction of large herds of megafauna and the changing climate at the beginning of the Holocene stimulated a behavioral change by the prehistoric inhabitants of South Texas (McKinney 1981). While the basic hunter-gatherer adaptation probably remained intact, an economic shift away from big game hunting was necessary. In general, more intensive exploitation of local resources in central Texas - such as deer, fish, and plant bulbs - is indicated by greater densities of ground-stone artifacts, fire-cracked rock cooking features, and more specialized tools such as Clear Fork gouges and Guadalupe bifaces (Turner and Hester 1993: 246,256). Weir (1976) speculates that Early Archaic groups were small and highly mobile, an inference from the fact that Early Archaic sites are thinly distributed and that diagnostic types are seen across a wide area, including most of Texas and northern Mexico. Story (1985) believes that population densities were low during this period, and that groups consisted of related individuals in small bands with "few constraints on their mobility" (Story 1985:39). Their economy was based on diffuse utilization of a wide range of resources, especially such year-round resources as prickly pear and lechugilla, as well as rodents, rabbits, and deer (Story 1985:38). Sites near the study area with components from this period include 41BX47 (Tennis and Hard 1995; Tennis 1996), Richard Beene (Thoms et al. 1996), and several located on Camp Bullis in northern Bexar County (Gerstle et al. 1978) and at Choke
Canyon (Hall et al. 1986). Collins (1995:Table 2) recognizes six sites within or near the Lackland subregion that have high integrity Early Archaic components resting on stable landforms: Loeve, $\mathrm{Ri}-$ chard Beene, Sleeper, Jetta Court, Youngsport, Pearl Wheat (Figure 3-1).

\section{Middle Archaic}

Collins (1995:383) defines this intermediate interval of the Archaic as lasting from about 6,000 to 4,000 B.P. in central Texas, but Hester (1995:438-441) opines that the period between 4450 and 2350 B.P. more correctly reflects the Middle Archaic in south Texas. The Middle Archaic appears to have been a time of increased population, based on the large number of sites from this period in south and central Texas (Story 1985:40; Weir 1976:125, 128). The reasons for this increase are not known, but the amelioration of a very dry period (Altithermal) during the Early Archaic is often seen as the prime mover (Sollberger and Hester 1972:338; Story 1985:40). On the South Texas Plains, exploitation of widely scattered, year-round resources such as prickly pear continued (Campbell and Campbell 1981:13-15), as did hunting deer and rabbit. However, a shift to concentrated, seasonal nut harvests in the riverine environments of the Balcones Escarpment seems to have occurred (Black 1989a). Weir (1976) believes that an expansion of oak on the Edwards Plateau and Balcones Escarpment led to intensive plant gathering and acorn processing. He also believes that the widely scattered bands prevalent in the Early Archaic now began to coalesce, at least during the acorngathering season, into larger groups who shared the intensive work of gathering and processing the acorn harvest (Weir 1976:126). Many researchers believe burned rock middens result from these endeavors (Creel 1986; Prewitt 1991; Weir 1976). Other investigators doubt burned rock middens are the results of acorn processing (Black et al. 1993; Goode 1991; Rector 1993), but the exact processes which formed these sites are still a matter of controversy (Black 1989b:28; Black et al. 1997; Hester 1991).

The common presence of deer remains in burned rock middens encourages the view that deer processing took place at burned rock midden sites (Black and McGraw 
1985:278; Weir 1976:125). Bison bone is encountered in archaeological sites in central and south Texas, at least occasionally, during all but the earliest part of the Middle Archaic (Dillehay 1974). There has been a tendency to equate presence of burned rock middens with absence of bison (Prewitt 1981); however, examinations of several recent faunal reports show that after about 4500 B.P. bison and burned rock middens are contemporaneous, though not at the same sites, at least in the southern Edwards Plateau and northern South Texas Plain (Meissner 1993). Collins (1995:Table 2) recognizes only one site in central Texas that has a high integrity Middle Archaic component resting on a stable landform: Landslide (Figure 3-1).

\section{Late Archaic}

Collins (1995:384) dates the final interval of the Archaic in central Texas to approximately 4000 to 800 B.P. Hester believes the Late Archaic in south Texas may better be defined as between 2350 to 1250 B.P. Some researchers believe populations increased all throughout the Late Archaic (Prewitt 1985), while others feel populations remained the same or fell during this period (Black 1989b:30). Prewitt (1981:8081 ) asserts that the accumulation of burned rock middens nearly ceased during the course of this period; however, excavations at the Blue Hole site (Mueggenborg 1994:1-74) in Uvalde County, the Honey Creek midden at 41MS32 (Black et al. 1997), and at the Mingo site (Houk and Lohse 1993:193-248) in Bandera County provide evidence that large cooking features up to $15 \mathrm{~m}$ in diameter were still very much in use (see also Black et al. 1997). Subsistence is assumed to have become less specialized and focused on acorns, in favor of a broad spectrum subsistence base (Black 1989b:30). By about 1450 B.P., bison had again disappeared (Dillehay 1974).

The proliferation of distinguishable human cemeteries has been attributed to this period, with the earliest occurrences dating to the south Texas Middle Archaic (Hester 1995:439-440). At Loma Sandia, these date between ca. 2550 and 2750 B.P. (Taylor and Highley $1995)$. Story (1985:44-45) believes the presence of cemeteries at sites such as Ernest Witte (Hall 1981), Hitzfelder Cave (Givens 1968b), and Olmos Dam (Lukowski 1988) indicates that Late Archaic populations in central and south Texas were increasing and becoming more territorial.

Although inhabitants of the South Texas Plain near Brownsville and Rockport had begun to make pottery by about 1750 B.P., the northern part of the plain was still "pre-ceramic" until 1,000 years later (Story 1985:45-47). Late Archaic points tend to be much smaller than Middle Archaic points. The most common are Ensor and Frio types (Turner and Hester 1993:114,122), both of which are short, triangular points with side notches. The Frio point also has a notched base (Turner and Hester 1993:122). Collins (1995:Table 2) recognizes three sites within central Texas with high-integrity Late Archaic components resting on stable landforms: Anthon, Loeve Fox, and 41GT91 (Figure 3-1).

\section{Transitional Archaic}

A late subperiod or interval of the Late Archaic is frequently referred to as the Terminal Archaic or Transitional Archaic. Weir (1976) defines the Terminal Archaic as $1650-1150$ B.P., while Turner and Hester (1993) cite data placing the Transitional Archaic as 2250-1250 B.P. Although Hester may lump current data into a Late Archaic period, he cautions that more evidence will likely result in what may be termed as a "Terminal Archaic" period during the latter part of the Late Archaic in south Texas. This Terminal Archaic period is represented by diagnostics such as Ensor, Frio, and Matamoras points which appear to overlap the Late Archaic and Late Prehistoric periods (Hester 1995:442). Weir (1976) believes this marked a transition period to localized area sites, a disappearance of burned rock middens and bison, and a reappearance of highly mobile hunters and gatherers. Others (Black and McGraw 1985; Peter 1982; Skelton 1977) argue that in some locations burned rock middens did not disappear and sites were more intensely occupied during the Transitional Archaic period. 
Late Prehistoric

Collins (1995:385) recognizes that the commonly used date of 1200 B.P. for the end of the Archaic and beginning of the Late Prehistoric in central Texas is arbitrary, and Hester (1995:442) acknowledges the problematic issue of selected tools appearing at both Late Archaic and Late Prehistoric sites. A series of distinctive traits marks the shift from the Archaic to the Late Prehistoric period, including the technological shift to the bow and arrow and the introduction of pottery to central Texas and the northern South Texas Plain (Black 1989b:32; Story 1985:45-47). Most researchers agree the early Late Prehistoric period was a time of population decrease (Black 1989b:32). Though small burned rock middens associated with Scallorn and Edwards points have been found (Goode 1991:71; Houk and Lohse 1993:193-248), they are rare. Settlement shifts into rockshelters such as Scorpion Cave in Medina County (Highley et al. 1978) and Classen Rockshelter in northern Bexar County (Fox and Fox 1967) have been noted (Shafer 1977; Skinner 1981). Cemeteries from this period often reveal evidence of conflict (Black 1989b:32). For example, an excavation of a burial just north of San Antonio (41BX952) revealed an Edwards point between two lumbar vertebra (Meissner 1991). Sites from the Austin phase include Quinta Medina (Guderjan et al. 1992,1993) and Panther Springs Creek, 41BX228 (Black and McGraw 1985). Collins (1995:Table 2) recognizes eight central Texas sites with high integrity Late Prehistoric components resting on stable landforms: Loeve Fox, Frisch Auf, Smith, Rush, Mustang Branch, Rocky Branch B, and Currie (Figure 3-1).

Beginning rather abruptly at about 650 B.P., a shift in technology occurred. This phase is characterized by the introduction of blade technology, the first ceramics in central Texas (bone-tempered plainwares), the appearance of Perdiz arrow points, and alternately beveled bifaces (Black 1989b:32; Huebner 1991:346). Prewitt (1985) and Black (1989b) suggest this technology encroached from north-central Texas. Patterson (1988), however, notes the Perdiz point was first seen in southeast Texas by about 1350 B.P., and was introduced to the west some $600-700$ years later. Hester $(1995: 444)$ recognizes this phase as the "best docu- mented Late Prehistoric pattern" throughout south Texas, with dates ranging between ca. $650 / 700$ to $300 /$ 350 B.P. (corresponding to Hester's A.D. $1250 / 1300$ to $1600 / 1650)$.

Steele and Assad (1986) argue for the occurrence of a distinct change in diet between the Late Archaic and the Late Prehistoric components in two sites in Choke Canyon Reservoir in south Texas. Analysis of the number of identified specimens (NISP) shows a marked increase in artiodactyl elements present during the late Late Prehistoric, an increase largely due to the addition of bison to the menu (Steele and Assad 1986:468). Huebner (1991) suggests that the sudden return of bison to south and central Texas resulted from a more xeric climate in the plains north of Texas, and increased grassiness in the Cross-Timbers and Post Oak Savannah in north central Texas, forming a "bison corridor" into the South Texas Plain along the eastern edge of the Edwards Plateau (Huebner 1991:354-355). Sites from this period frequently have associated bison (Black 1986; Black and McGraw 1985; Henderson 1978; Hulbert 1985; Prewitt 1974).

The only archaeological evidence that domesticated plants were ever introduced in south or central Texas is a single corncob found in Late Prehistoric context in Timmeron Rock Shelter (Harris 1985). This single cob is not enough to postulate there was ever a significant presence of maize in the area. Only the arrival of the Spanish brought significant cultivars to south and central Texas.

\section{Historic Period}

The end of the Late Prehistoric and beginning of the Historic period in both central and south Texas should be characterized by written accounts of European contact with indigenous groups. Collins (1995:386-387) offers that the Historic period then begins ca. 260 B.P. in central Texas. However in south Texas Hester (1995:450-451) agrees with Adkins and Adkins (1982:242) when he suggests that the indigenous groups may have been affected by European influence but we are only able to observe the materials in the archaeological record because the written accounts 
simply are not available. He would rather label this largely unknown period as the "Protohistoric."

The cultural context for the historic groups in the study area is largely conditioned by the presence of outside ethnic groups and regional power struggles. The numerous small groups of Native Americans encountered by the early explorers and later Spanish intrusions are addressed in many sources (Campbell 1983; Campbell and Campbell 1985; Hester 1989; John 1975; Newcomb 1961; Swanton 1952). The various later intrusive groups, such as Tonkawa, Lipan Apache, and Comanche, are also described by numerous researchers (Ewers 1969; Hester 1989; Jones 1969; Kelley 1971; Newcomb 1961, 1993; Sjoberg 1953a, 1953b).

At the beginning of the seventeenth century, many south Texas Indian groups were being pushed northward by continual Spanish expansion. By the mid-seventeenth century, a new pressure on the Indians indigenous to the area began to come from the north: a nomadic group, the Apache, had practiced limited agriculture, but changed to a more Plains-style of bison hunting once they acquired horses from the Spaniards (Campbell and Campbell 1985:27). Later, the Apaches were to be displaced by another group of nomadic, bison-hunting Indians - the Comanchesfrom the high-lands of central Texas (Campbell 1991:111).

A combination of migration, demoralization, innergroup conflict, disease, and death due to warfare fragmented the native Indian groups, and forced continual mixing and remixing among them (Bolton 1915; Campbell 1975, 1991:345; León et al. 1961). Most of the native languages have been lost, although recent attempts at reconstruction are enlightening (e.g. Johnson 1994a; Johnson and Campbell 1992). The establishment and relocation of Spanish Catholic missions along the San Antonio River in the late 1600s and early 1700 s induced many groups to seek the relative comfort and protection offered by a sedentary and peaceful coexistence (Campbell and Campbell 1985; Chipman 1992; de la Teja 1988; Habig 1968a, 1968b; Inglis 1964). Although fear of the invading Apache and Comanche pressured many of the Indians to seek the protection of missions, they were now exposed to the exploitation of the Spanish (Campbell 1975:2, 1991:346-347).

In the autumn of 1785 , a treaty with the Comanches signaled the opening of a period of peaceful coexistence in which Comanches brought hides, meat, and tallow to the area to trade for goods and services not available elsewhere, such as blacksmithing and gun repair (Poyo and Hinojosa 1991:125-126). The few Comanche who entered the missions were apparently women and children who were captured during punitive raids by Spanish soldiers (Campbell and Campbell 1985:26).

Apaches continued to range over the area between San Antonio and Laredo until the early $1800 \mathrm{~s}$, pushed southward by the invading Comanche who had moved into the Hill Country of central Texas (Campbell and Campbell 1985:27). Weary of warfare with the Comanche, a few Apache began seeking asylum in the missions (McGraw and Hindes 1987:367; West 1904:50). However, few landowners dared to live on their outlying lands until about 1840 , when a treaty with the Apaches brought peace for a while (de la Teja 1988:167).

In addition to the threat of attack by Native Americans who were defending their right to the land, early settlers were caught in the middle of political strife which resulted in warfare. Many battles ensued involving Spanish Royalist and Mexican soldiers, and Texan revolutionaries. One such battle, the Battle of the Medina, occurred a few miles south of Lackland on August 18, 1813, between revolutionary forces and Spanish Royalist forces. Known as the Green Flag Rebellion, a force of 1,400 men entered Texas from the neutral ground west of the Sabine River and swept through Texas to San Antonio, declaring Texas an independent republic. General José Álvarez de Toledo $y$ Dubois led the invading forces against General Joaquin de Arredondo and his Spanish Royalist army. Although not determined archaeologically, what began as a running gun battle is believed to have culminated in a standoff approximately 32 kilometers south of San Antonio in a sandy oak motte called "el encinal de Medina" between the Medina and Atascosa rivers. For revolutionary forces, this was bloodiest and most costly battle ever fought over Texas indepen- 
dence, including the battles at the Alamo and San Jacinto; over 1,300 revolutionaries were killed, while only 55 Royalists were lost (Thonhoff 1985; Tyler 1996:601-602).

As Texas became an independent republic in 1836 , and a state in 1845, army incursions from Mexico, the United States, and northern Texas continued to cause political strife and disruption of economic development (Fehrenbach 1978). The political environment of the early government is addressed by Espey, Huston and Associates (1989).

The newly formed government of Texas gave land grants that were large, consisting of around 5,000 acres for each property, and Spanish cattle ranching became prevalent south and southeast of San Antonio (Jackson 1986). However, the political turmoil that permeated early Texas caused the near-complete European desertion of San Antonio following the Mexican War for Independence (Fehrenbach 1968).

Around 1840, settlers from Germany and Alsace-Lorraine and from other regions of the United States began to flood into San Antonio. Many of the Germans moved into the Hill Country to the north, settling into communities such as Boerne, and raised sheep or cattle (Freeman 1994:5-9). As the sheep and cattle markets emerged in the $1880 \mathrm{~s}$, ranchers and farmers settled south and west of San Antonio (Flanagan 1974; Lehmann 1969; Nickels et al. 1997). The introduction of twentieth-century technologies such as mills and improved methods of production have shaped the area as it exists today (Fox et al. 1989; Tyler 1996). 


\section{Chapter 4: Geoarchaeology of Lackland Air Force Base}

\section{Lee C. Nordt}

\section{Introduction}

The goals of the geoarchaeological investigation for Phase II cultural resource testing at Lackland Air Force Base were to: (1) refine the previously constructed geomorphic map; (2) further identify and describe the major stratigraphic units; (3) refine the relative and absolute temporal ordering of the stratigraphic units; and (4) infer how the age and environment of deposition of the stratigraphic units influence prehistoric preservation potentials, especially at those sites assessed as part of the testing phase.

\section{Study Area}

The project area can be broadly divided into two geologic groups. Alluvial landforms and deposits are associated with Medio Creek, whereas the uplands consist of surrounding hillslopes associated with bedrock or colluvium. As mapped by Barnes (1983), the principal stratigraphic units in the uplands are the Upper Taylor Marl and Uvalde Gravel. The Upper Taylor Marl consists mainly of brownish gray montmorillonitic clays. These sediments were deposited in a marine environment during the Cretaceous. The Uvalde Gravel is mapped on the interfluve on the western flank of the Medio Creek valley. It is comprised of a veneer of caliche-cemented and loosely aggregated siliceous cobbles. The environment of deposition was fluvial, which represents the earliest evidence of stream aggradation in the area. The time of deposition is estimated to be Pliocene to early Pleistocene.

Most soil delineations in the uplands are mapped as part of the Houston Black series (Taylor et al. 1991). All map units have a surface scatter of Uvalde Gravel, with occasional subsurface pockets of pebbles and cobbles. These soils are dark and clayey with high shrink-swell activity. During geoarchaeological inves- tigations, widespread colluvial deposits were identified within the Houston Black map units in the uplands. Colluvial soils differed in that they had loamy textures and numerous pebbles and cobbles throughout.

Medio Creek is a low-order tributary of the Medina River. The modern Medio Creek channel contains meanders with both high and low radii of curvature. The larger meander loops were either inherited from a previous flow regime or created by structural control of the underlying limestone. The Medio Creek drainage basin begins in the eastern part of Medina County, flows through the project area at about its midpoint, and finally empties into the Medina River in southwest Bexar County. The drainage basin covers primarily upper Cretaceous limestones and chalks both within and outside of the project area (Barnes 1983). Within the project area, the alluvial valley of Medio Creek is mapped as modern flood plain deposits in the upper half and as Pleistocene terrace deposits in the lower half (Barnes 1983). Geoarchaeological investigations revealed a more complex alluvial sequence than previously mapped along Medio Creek.

Soils on alluvial landforms of Medio Creek are mapped principally as the Houston Black series (terrace phase), Lewisville series, Trinity series, and Frio series (Taylor et al. 1991). These soils are clayey, with occasional accumulations of calcium carbonate filaments and nodules in the subsoil.

\section{Methods}

A geomorphic map was constructed for the project area using field observations, the Soil Survey of Bexar County, Texas (Taylor et al. 1991), the San Antonio Sheet of the Geologic Atlas of Texas (Barnes 1983), and the Department of Air Force topographic maps (1992, copies on file at CAR). Construction of the 
geomorphic map relied considerably on relative elevations above the modern low-water channel of Medio Creek.

Soil-stratigraphic descriptions were written from 18 backhoe trenches (BHT) and seven archaeological test units (TU) following standards and procedures of the Soil Survey Division Staff (1993) and Folk (1980). Field observations, but not formal descriptions, were conducted at two additional test units. In total, test units from eight archaeological sites were observed. Four stratigraphic cross sections were constructed from the stratigraphy revealed in the backhoe trenches.

Stratigraphic units were identified as unconformably bound packages of sediment. Buried unconformities were marked by erosional contacts. Surface unconformities consisted of the landforms uplands, terraces, and flood plains.

Five bulk soil humate samples were collected for carbon-14 assay. Analysis was performed by Beta Analytic, Inc., reported in years before present (B.P.), and corrected for variations in carbon-13. Ages of diagnostic artifacts were estimated using the cultural chronology of Turner and Hester (1993).

\section{Geomorphology and Stratigraphy}

\section{Uplands}

The Upland geomorphic surface in the project area includes all landforms bordering the alluvial deposits adjacent to Medio Creek (Figure 4-1). The Uplands consist of a series of connecting hillslopes, many of which have formed from erosion or colluvial deposition. Based on field observations, topographic analysis, and soil-stratigraphic descriptions from backhoe trenches and archaeological test units, the Uplands were divided into three landscape elements: High $(\mathrm{H})$, Intermediate (I), and Low (L) surfaces (Figure 4-1). These surfaces differ in time of formation, slope gradient, soil development, and associated deposits. Most of these surfaces were mapped as part of the Uvalde Gravel by Barnes (1983).

\section{High Surface}

The High surface $(\mathrm{H})$ in the Uplands is situated above an elevation of $213 \mathrm{~m}$ amsl in the southern part of the project area and above $226 \mathrm{~m}$ amsl in the northern part (Figure 4-1). The High surface forms the highest elevations in the project area, having remained above migrating channel knickpoints initiated during stream entrenchment in the late Quaternary. The landscape is gently rolling and relatively stable.

Test Units N969 E999 and N1030 E997 at site $41 \mathrm{BX} 1088$ represent the stratigraphy associated with the High surface (Figure 4-1). Here, soils developed directly into Cretaceous marls and clays. They have black, very dark gray, dark grayish brown, and olive brown clayey profiles with subsoils enriched in calcium carbonate nodules and slickensides (Appendix A). Chert cobbles are scattered across the surface and occasionally occur in isolated pockets within the soils. It appears that the Uvalde Gravel was never very thick across the High surface, or that it was subsequently eroded during more recent episodes of landscape development. However, the degree of subsoil calcium carbonate development (Blum and Valastro 1994), indicates that the soils have been relatively stable since the late Pleistocene. This is consistent with the discovery of Early Archaic artifacts on the surface.

\section{Intermediate Surface}

The Intermediate surface (I) in the Uplands is situated between an elevation of 198 and $210 \mathrm{~m}$ amsl in the southern part of the project area and between 213 and $226 \mathrm{~m}$ amsl in the northern part (Figure 4-1). This surface occurs on hillslopes with gradients ranging from 3 to 10 percent. These hillslopes grade down to either the T2 terrace or the T1 flood terrace of Medio Creek. This suggests the slopes formed in equilibrium with Medio Creek when it was constructing flood plains at the level of

the $\mathrm{T} 2$ terrace during the late Pleistocene, or the T1 flood terrace during the early to middle Holocene. In some areas, the Intermediate surface appears to record a complex history of landscape evolution represented by two or more geomorphic surfaces. 

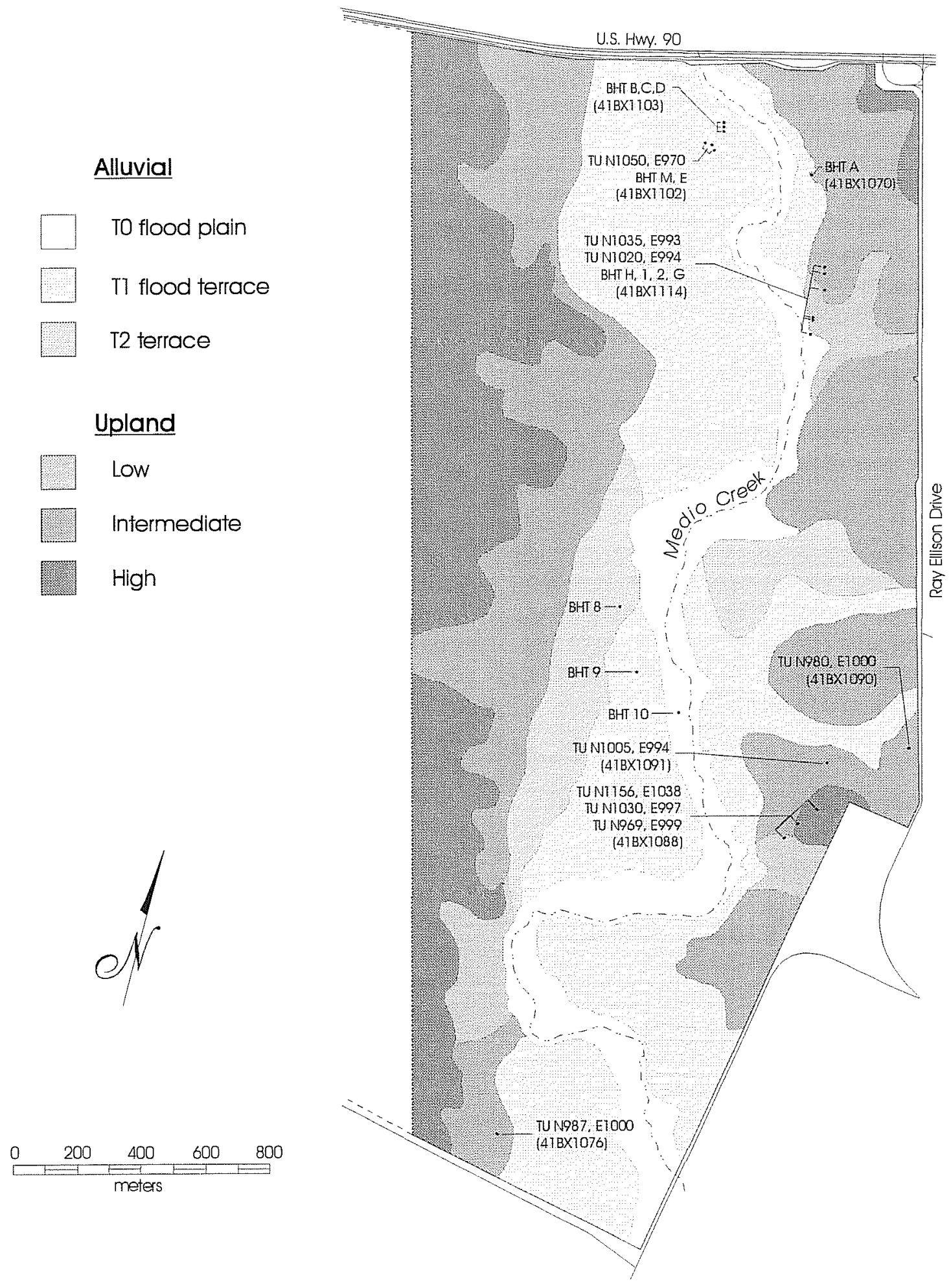

Figure 4-1. Geomorphic map of the eastern half of Lackland Air Force Base Medina Annex. 
The stratigraphy associated with the Intermediate surface is shown in TUs N1035 E993 and N1020 E994, and BHT G at 41BX1114; N979 E999 at 41BX1090; N1005 E994 (no description) at 41BX1091; N987 E1000 (no description) at 41BX1076; and BHT A at $41 B X 1070$ (Figure 4-1). These deposits typically consist of an abundance of matrix-supported pebbles and cobbles having pedogenic calcium carbonate rinds (Appendix A). The carbonate rinds occur on all gravels and at all depths, inconsistent with pedogenic functions related to depth of leaching and calcium carbonate accumulation. As a result, these pebbles and cobbles appear to be inherited from transported Uvalde Gravel. The associated fine-earth sediments are mainly black, very dark gray, dark grayish brown, and olive brown clay loams with minor accumulations of calcium carbonate nodules in the subsoil. In sum, these areas appear to represent a veneer of colluvium derived from Uvalde Gravel situated on the margins of the High surface. Minimal pedogenesis also supports an early to middle Holocene age for deposition in most areas. The exception occurs at TU N1020 E994 at 41BX1114, where soil decalcification indicates a Pleistocene age for colluvial deposition. Older remnants of the Intermediate surface probably also occur where slopes grade down to the T2 terrace.

\section{Low Surface}

The Low surface $(\mathrm{L})$ is not as widespread as the other two. It occurs as hillslopes at similar elevations as the Intermediate surface. However, the Low surface is steeper and typically grades down to the T0 flood plain surface of Medio Creek (Figure 4-1). This indicates that the slopes formed during the middle to late Holocene from impingement of the modern Medio Creek channel, and associated tributaries and gullies, into the Intermediate surface.

As a consequence of erosion of colluvial deposits from the Intermediate surface, soils associated with the Low surface have developed directly into Cretaceous clays. In contrast, Uvalde Gravel veneers the surface or upper part of these soils in some areas. Soils of the Low surface were exposed in TUN969 E999 at 41BX1088 Area 3, and BHT 1 and BHT 2 at 41 BX1114 (Figure 4-1). These soils consist of black, very dark gray, ol- ive, and olive brown clays, with few slickensides and calcium carbonate nodules in the subsoils. Scattered Uvalde Gravels occur on the surface and are diffusely distributed in the upper part of these soils. Stratigraphic position and minimal soil development support a late Holocene age for these slopes, as determined by geomorphic principles.

\section{Summary of Uplands}

The Uplands within the project area record a complex history of landscape development. Three Upland landscape elements and associated deposits and soils were recognized. The High surface is the highest, oldest, and most stable of the three landscape elements. Deep clayey soils with well-developed calcium carbonate subsoils have formed. This surface may relate to the original Uvalde Gravel in elevation; however, it appears to have been eroded sometime after deposition during the Pleistocene.

The Intermediate Upland surface apparently formed in response to one or more episodes of landscape dissection sometime between the late Pleistocene, when the T2 terrace was forming, and early to middle Holocene when the $\mathrm{T} 1$ flood terrace was forming. Widespread colluviation occurred at this time as Uvalde Gravel was reworked and transported to lower landscape positions. Consequently, colluvial soils of the Intermediate surface contain an abundance of matrixsupported cobbles and pebbles with relict calcium carbonate rinds.

The Low surface represents the last episode of landscape development in the Uplands. This surface is the steepest and most unstable of the three landscape elements. The Low surface formed in response to late Holocene channel erosion into the Intermediate surface. Soils have since developed directly into exposed Cretaceous clays and exhibit minimal development.

\section{Medio Creek}

Three late Quaternary alluvial landforms were mapped in the project area adjacent to Medio Creek: the T2 terrace, the T1 flood terrace, and the T0 modern flood- 
plain (Figure 4-1). In addition, four late Quaternary alluvial stratigraphic units associated with the landforms were recognized along Medio Creek. From oldest to youngest, they are: Unit I, Unit II, Unit III, and Unit IV.

\section{Terrace 2 (T2)}

The T2 terrace is the highest and oldest alluvial landform mapped bordering Medio Creek. This terrace occurs on both sides of the Medio Creek valley at an elevation of 7 to $8 \mathrm{~m}$ above the modern low-water channel (Figure 4-1). The T2 terrace is gently rolling and not subjected to flooding. The Houston Black clay terrace, 0 to 1 percent slopes, and the Houston Black gravely clay, 1 to 3 percent slopes, are mapped on the this terrace (Taylor et al. 1991). Houston Black has minor accumulations of calcium carbonate nodules in the subsoil.

\section{Terrace 1 (T1)}

The T1 flood terrace (T1) - situated 3 to $5 \mathrm{~m}$ above the modern low-water channel of Medio Creek (Figure 4-1)-is the most extensively mapped alluvial landform in the project area. This flood terrace is as much as $1.5 \mathrm{~km}$ wide and may flood for brief periods during low frequency, high intensity rainstorms. For the most part, $\mathrm{T} 1$ is confined to the modern meander belt and local tributaries. An exception occurs west of sites 41BX1102 and 41BX1103 where an extensive area of $\mathrm{T} 1$ is mapped outside of the modern meander belt (Figure 4-1). Consequently, further fieldwork may show that $\mathrm{T} 1$ should be subdivided into an older and slightly higher T1 terrace along the outer valley margin, and a younger and slightly lower $\mathrm{T} 1$ terrace within the modern meander belt. The T1 flood terrace is mapped as the Lewisville silty clay 0 to 1 percent slopes, the Houston Black clay terrace 0 to 1 percent slopes, and the Houston Black gravely clay 1 to 3 percent slopes (Taylor et al. 1991). Lewisville soils have minor accumulations of calcium carbonate filaments in the subsoil. Geoarchaeological investigations revealed that soils with these properties are actually of minor extent on the T1 flood terrace.

\section{Terrace 0 (T0)}

The actively aggrading modern flood plain of Medio Creek is mapped as T0 (Figure 4-1). This surface is situated within the innermost part of large meanders and as narrow surfaces along straight channel segments 2 to $2.5 \mathrm{~m}$ above the modern low-water channel. As mapped here, the T0 flood plain is at least two times wider than the flood plain as mapped in the local soil survey (Taylor et al. 1991). The frequency of flood inundation is probably annual. The Trinity and Frio soils, frequently flooded, are mapped in this setting. These soils are clayey throughout and exhibit weak profile development. Geoarchaeological investigations revealed that soils in the $\mathrm{T} 0$ flood plain are much more stratified than as mapped by Taylor et al. (1991).

\section{Unit I}

Based on stratigraphic position and degree of soil development, the oldest alluvial unit in the project area is associated with the T2 terrace of Medio Creek. This alluvium is designated as Unit I as shown in BHT 8 (Figures 4-1 and 4-2). Unit I has been pedogenically weathered to a black silty clay loam surface horizon over a subsoil consisting of very dark grayish brown to brownish yellow silty clays (Appendix A). Slickensides and calcium carbonate nodules have also developed in the subsoil. The grain-size of Unit $I$ as exposed in BHT 8 appears to represent a fine-grained flood basin facies.

A clay increase with depth, decalcification of the surface horizon, and calcium carbonate accumulation in the subsoil, indicates significant weathering of Unit I. Based on the oldest carbon-14 age from the Holocene valley fill of Medio Creek, Unit I is older than approximately 5000 B.P. However, Nordt and Hallmark (1990) observed a decalcified surface horizon in an alluvial soil in central Texas that dated to approximately 15,000 B.P. This suggests that deposition of Unit I and construction of the T2 terrace along Medio Creek may have terminated near 15,000 B.P. 


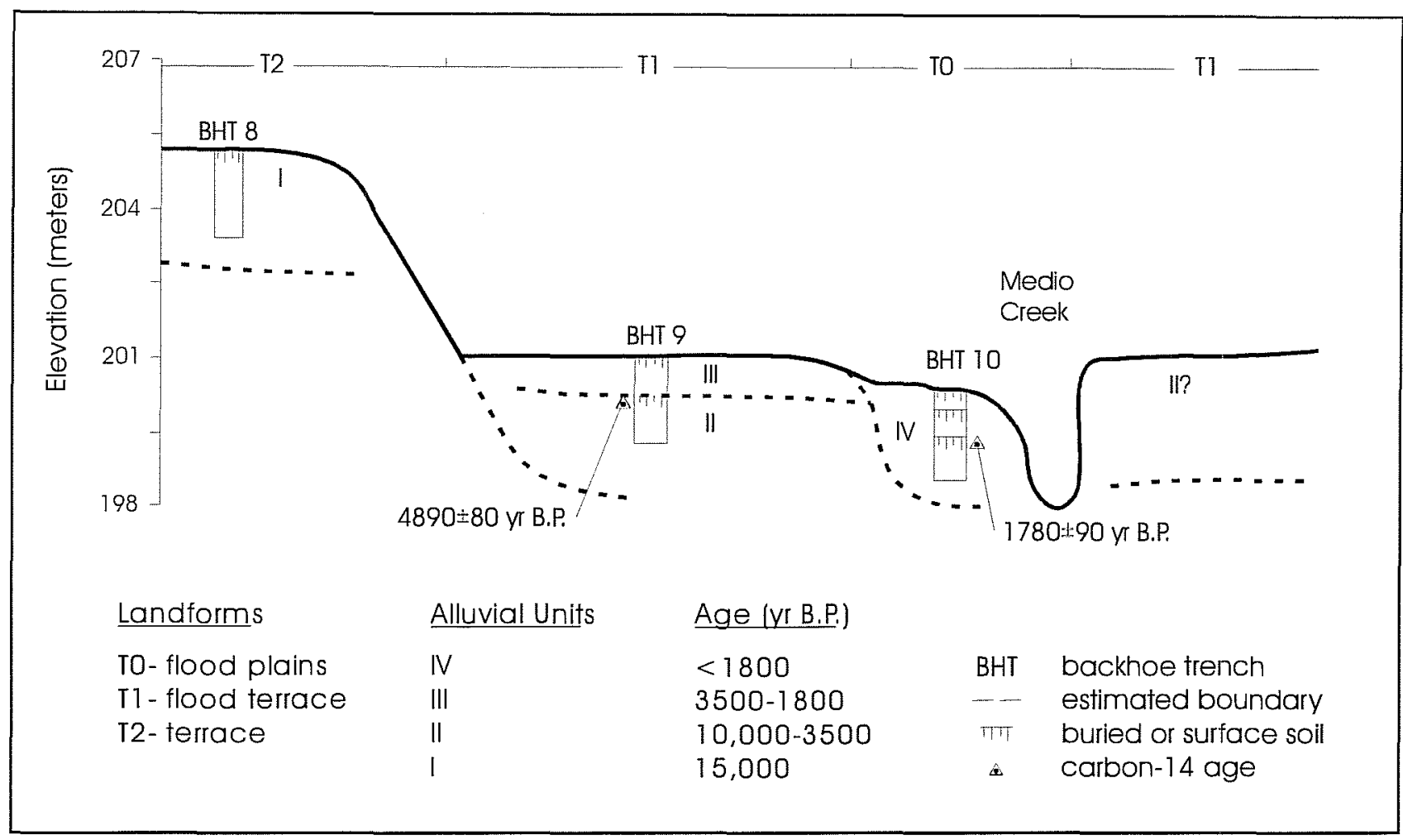

Figure 4-2. Schematic stratigraphic cross section of Medio Creek in the middle part of the project area in the vicinity of BHT 8, BHT 9, and BHT 10.

\section{Unit II}

The three remaining alluvial units occur within the Holocene valley of Medio Creek. The oldest of these deposits is Unit $\Pi$, which is associated with the $T 1$ flood terrace based on exposures provided by BHT 9 , BHT 7, BHT C, BHT D, BHT E, BHT I, and TU N1050 E970 at 41BX1103 (Figures 4-1-4-4). Unit II forms the constructional $\mathrm{T} 1$ flood terrace surface in the vicinity of BHT 7 and BHT E. In BHT 7 (Figure 4-3), there was an abundance of pebbles and cobbles throughout (Appendix A). These deposits have been weathered to black to dark grayish brown silty clay loam surface horizons over yellowish brown subsoils having calcium carbonate pendants on the bottoms of pebbles and cobbles. As indicated by the grain size and grain-supported pebbles and cobbles, BHT 7 exposes a channel facies of Unit II.

In BHT E (Figure 4-4), Unit II has been weathered to a very dark gray silty clay loam surface horizon over a very dark gray to brown silty clay loam subsoil with few to common slickensides and calcium carbonate nodules (Appendix A). Only few matrix-supported pebbles occur throughout. Grain-size distribution indicates that the area around BHT E represents a flood basin facies of Unit II.

Unit II was also exposed in the lower part of BHT 9, BHT C, and BHT D where it has been truncated and buried by recent alluvium (Figures 4-2 and 4-1). In these areas, Unit II was pedogenically altered to yellowish brown to grayish brown clay loams with calcium carbonate filaments and nodules in the subsoils (Appendix A). Few matrix-supported pebbles were scattered throughout. According to stratigraphic position, grain-size distribution, and degree of carbonate development, this unit is correlated to the flood basin facies of Unit II.

Several lines of evidence constrain the timing of deposition of Unit II. In Unit II as exposed in BHT 9, a carbon-14 age of $4890 \pm 80$ B.P. (Beta-90719) was obtained from a bulk humate sample collected at a depth of 120 to $130 \mathrm{~cm}$ (Figure 4-2). In Unit II as exposed in BHT C, a carbon-14 age of $3620 \pm 70$ B.P. (Beta-96366) 


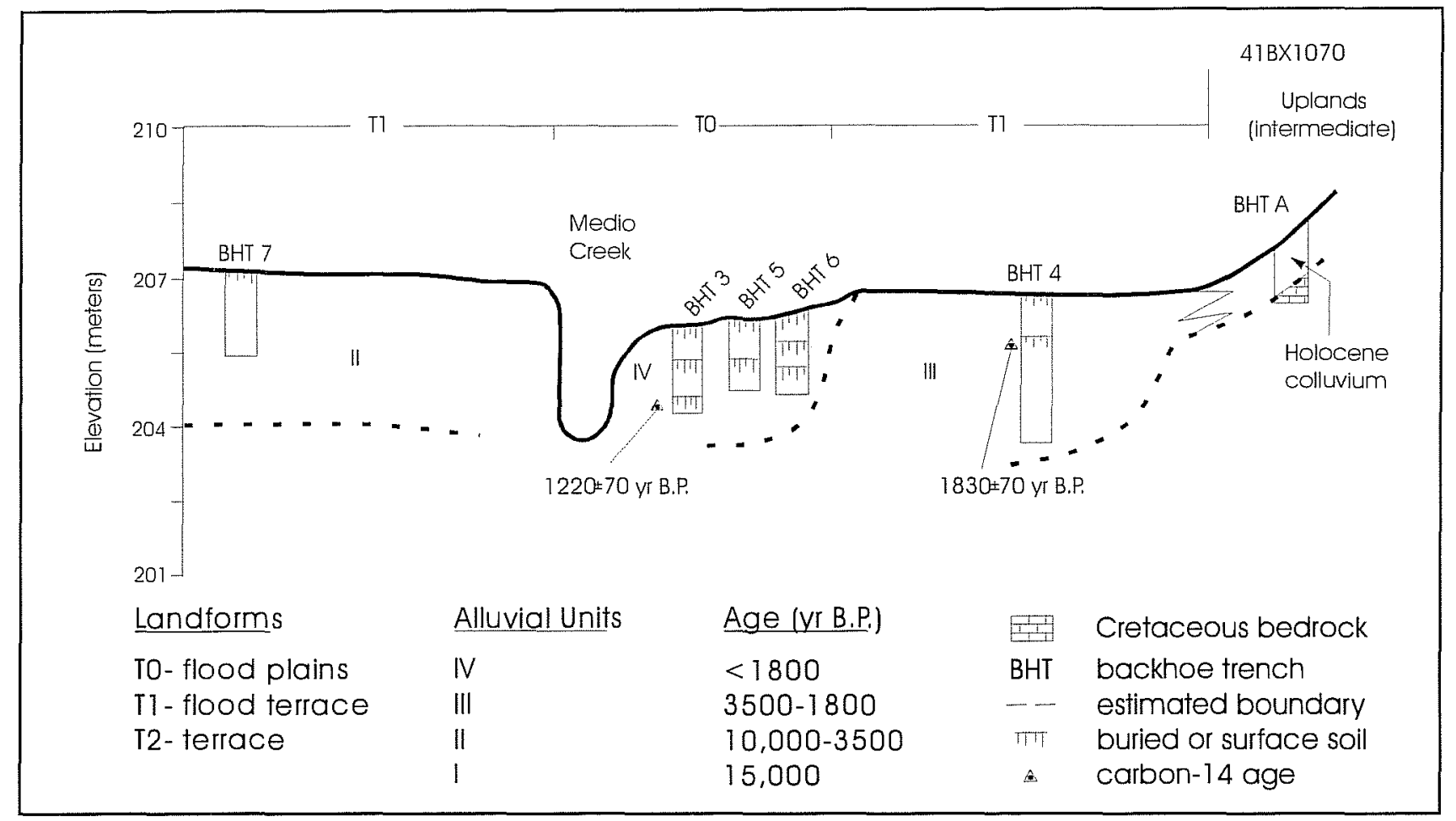

Figure 4-3. Schematic stratigraphic cross section of Medio Creek in the vicinity of $41 B X 1070$.

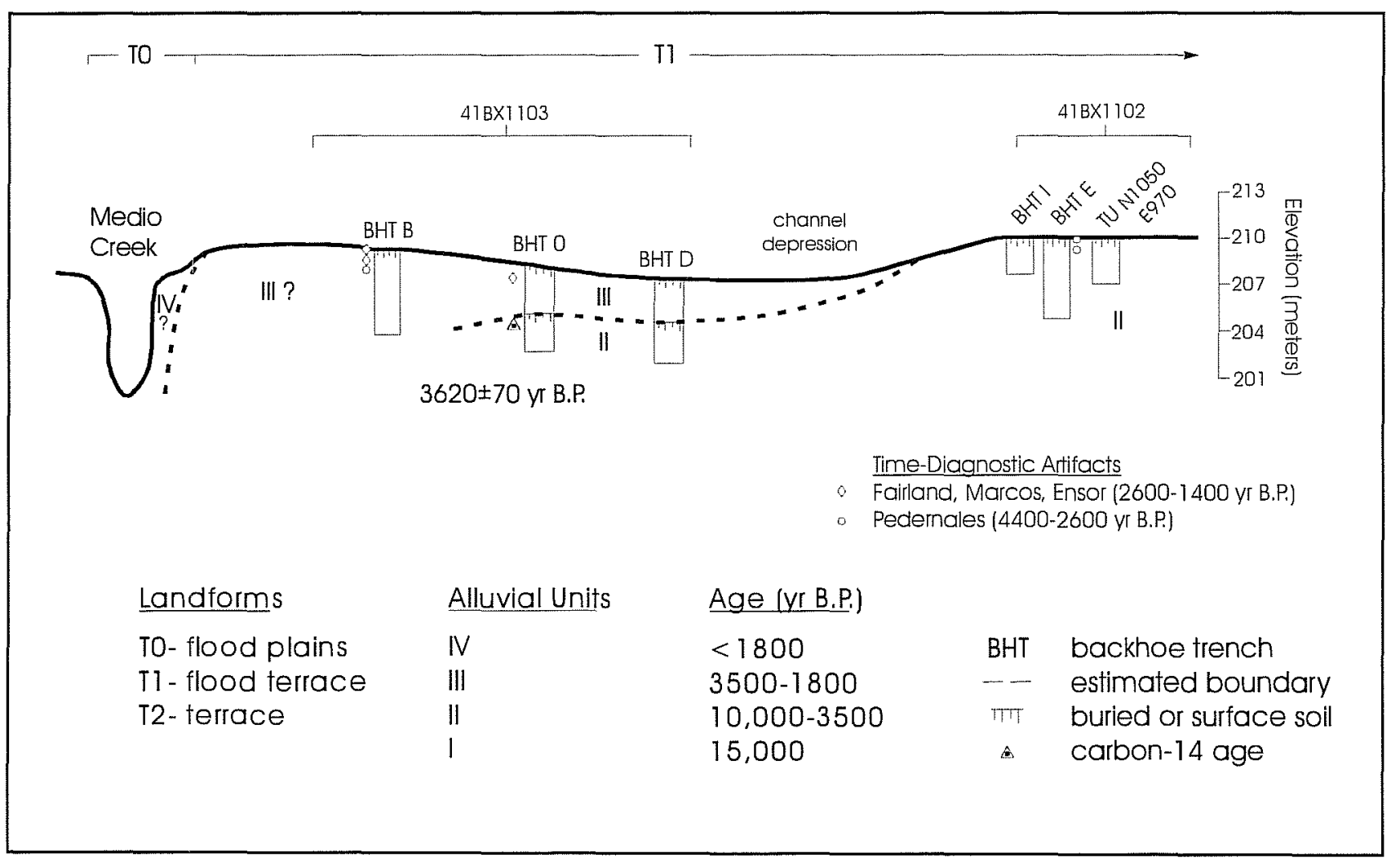

Figure 4-4. Schematic stratigraphic cross section of Medio Creek in the vicinity of $41 B X 1102$ and $41 B X 1103$. 
was obtained from bulk humates collected at a depth of 118 to $128 \mathrm{~cm}$ (Figure 4-4). Near BHT E, surficial time-diagnostic artifacts indicate that deposition of Unit II terminated between 4400 to 2600 B.P. (Figure 4-4). In sum, these ages indicate that Unit II deposition began in the early to middle Holocene and terminated sometime between 5000 and 3500 B.P. An episode of pedogenesis then proceeded up until no later than 1800 B.P. in the vicinity of BHT C, BHT D, and BHT 9 when Unit II was truncated and buried by Unit III channel deposits. Pedogenesis has continued up until the present near BHT 7 and BHT E where Unit II has not been truncated and thus forms the constructional T1 flood terrace.

\section{Unit III}

The youngest deposit associated with the T1 flood terrace was Unit III. This unit was exposed in BHT 9, BHT 4, BHT B, BHT C, and BHT D (Figures 4-14-4). Unit III forms the constructional surface of the T1 flood terrace within the modern meander belt.

In BHT 9, BHT B, BHT C, and BHT D, Unit III unconformably buries Unit II (Figures 4-2 and 4-4). Here, Unit III consists of a fining-upward sequence from basal channel pebbles and cobbles to clay loams with few matrix-supported pebbles (Appendix A). The surface horizons are very dark gray, with dark grayish brown to very dark grayish brown subsoils. The subsoils also have few to common calcium carbonate pendants on gravel bottoms. In BHT 4 (Figure 4-3), Unit III exhibits a thick basal channel facies consisting mainly of well-sorted pebbles that conformably grade up into a weakly developed buried soil consisting of grayish brown to light brownish gray clay loams (Appendix A). The presence of shale clasts in the buried soil suggests minimal pedogenesis before burial by Unit III sediments with few matrix-supported pebbles. These upper deposits form the T1 flood terrace surface, which has been pedogenically altered to very dark gray to black surface layers over a very dark gray subsurface layer.

Unit III marks a shift to coarse-grained channel deposition possibly in response to increased flood magnitudes. In contrast, Unit II was dominated by localized channel deposits connected by thick fine-grained flood basin facies.

The timing of deposition of Unit III is constrained by one bulk humate carbon-14 age, time-diagnostic artifacts, and temporal bracketing by Unit II and Unit IV. Carbon-14 ages from Unit II and Unit IV confine deposition of Unit III to between $3620 \pm 70$ B.P. (Figure 4-4, BHT C) and $1780 \pm 90$ B.P. (Beta-90720) (Figure 4-2, BHT 10). Consistent with stratigraphic bracketing, a carbon-14 age of $1830 \pm 70$ B.P. (Beta-90718) was obtained from the buried soil in BHT 4 of Unit III (Figure 4-3). Furthermore, artifacts from the upper part of BHT B and BHT C indicate that deposition of Unit III terminated sometime between 2600 B.P. and 1400 B.P. (Figure 4-4). This is also consistent with the carbon-14 age of 1830 B.P. from BHT 4 in Unit III. In sum, Unit III was apparently deposited between approximately 3500 and 1800 B.P. The T1 flood terrace has since remained relatively stable except for brief periods of inundation from high magnitude floods.

\section{Unit IV}

Unit IV was the youngest alluvial unit of Medio Creek recognized in the project area. It is associated with the T0 flood plain within the narrow modern meander belt. Apparently the Unit IV channel down cut at the current topographic contact between $\mathrm{T} 1$ and $\mathrm{T} 0$. Unit IV deposition and construction of T0 subsequently proceeded at a slightly lower elevation as the channel migrated away from the erosional scarp to its present position.

Unit IV was exposed in BHT 10, BHT 3, BHT 5, BHT 6, and BHT F (Figures 4-1, 4-2, 4-3, and 4.5). The stratigraphy of Unit IV is more complex than that of the other alluvial units. Several punctuating intervals of landscape stability and soil formation occurred during deposition. This complexity is reflected in the presence of several stacked packages of sediment that fine upward from basal pebbles and cobbles to black and very dark grayish brown silty clay and silty clay loams (Appendix A). The upper fine-grained sediments of each sediment package were altered to an A horizon, which subsequently became buried. This sedimentological sequence indicates continued shifts in flood 
magnitude and frequency not evident in the older stratigraphic units. A veneer of loamy historic alluvium appears to bury Unit IV within the confines of the TO floodplain in some areas. However, because of its limited extent and thickness, the historic alluvium was not formally recognized.

The youngest carbon-14 age from Unit III demonstrates that deposition of Unit IV began sometime after 1830 B.P. (Figures 4-3). Bulk humate carbon-14 ages obtained from the lower of two buried A horizons in BHT 10 and BHT 3 were $1780 \pm 90$ B.P. (Figure 4-2) and $1220 \pm 70$ B.P. (Beta-90717) (Figure 4-3), respectively. These ages demonstrate that Unit IV deposition was initiated after 1800 B.P. and has continued up until Historic times.

\section{Regional Correlation}

The ages of the alluvial landforms and stratigraphic units along Medio Creek generally correlate with other late Quaternary alluvial stratigraphic sequences in central Texas. Blum and Valastro $(1989,1994)$, along the Pedernales and Colorado rivers, and Nordt (1992), along Cowhouse Creek, identified a late Pleistocene terrace dating to between 14,000 to 20,000 B.P. This terrace appears to correlate with the T2 terrace and its associated Unit I deposit in the project area.

Nordt $(1992,1995)$ dated an early Holocene finegrained alluvial unit to between 8000 and 4500 B.P. along several low-order tributaries in central Texas. Blum and Valastro $(1989,1994)$ identified an early Holocene alluvial unit along the Pedernales and Colorado rivers dating to between approximately 10,000 and 5000 B.P. It appears that part of the T1 flood terrace and all of Unit $\Pi$ along Medio Creek correlates with these stream systems for the early to middle Holocene.

Unit III of the T1 flood terrace of Medio Creek generally correlates with late Holocene alluvial units identified along the Pedernales River (Blum and Valastro 1989), Colorado River (Blum and Valastro 1994), and numerous low-order streams in central Texas (Nordt 1992, 1994). These deposits dated to between approximately 4000 and 600 B.P. As with Unit III along Me- dio Creek, these stream networks also displayed an increase in coarse-grained sediment load.

Modern alluvial units along other central Texas streams were deposited during the last 1,000 years (Blum and Valastro 1989, 1994; Nordt 1992, 1995). This is inconsistent with the timing of deposition of Unit IV of Medio Creek, which began shortly after 1800 B.P.

\section{Summary and Conclusions}

This section provides a summary of the geologic stratigraphic sequence and associated potential archaeological distributions in the project area. The summary discussion is divided into two sections: Stratigraphy (Table 4-1) and Geoarchaeology (Table 4-2).

\section{Stratigraphy}

The stratigraphic setting in the project area can be divided geomorphically into uplands and alluvium, and associated surface and subsurface ages (Table 4-1). The Uplands are subdivided into three landscape elements. The High surface is relatively stable, has deep soils, and occurs on the margins of the project area at the highest elevations (Figure 4-1). This surface is Pleistocene in age; however, the associated deposits are Cretaceous (Table 4-1).

The Intermediate surface was constructed by deposition of coarse-grained colluvial deposits. Deposition probably began at the Pleistocene to Holocene boundary in response to widespread channel downcutting (Table 4-1). This surface grades down to both the T2 terrace and $\mathrm{T} 1$ flood terrace of Medio Creek. The channel downcutting episode was probably accompanied by drier climatic conditions, which together initiated widespread erosion on the margins of the High surface and subsequent colluviation on the Intermediate surface.

The Low surface is principally erosional, having formed in the late Holocene in response to channel and gully impingement into the Intermediate surface 
Table 4-1. Surface and Subsurface Chronology of the Major Stratigraphic Units

\begin{tabular}{|c|c|c|c|}
\hline \multirow{2}{*}{\multicolumn{2}{|c|}{ Stratigraphy }} & \multicolumn{2}{|c|}{ Chronology } \\
\hline & & Surface & Subsurface \\
\hline \multirow{3}{*}{$\frac{\mathscr{E}}{\stackrel{E}{D}}$} & High & Pleistocene & Cretaceous \\
\hline & Intermediate & Pleistocene-mid Holocene & Pleistocene-mid Holocene \\
\hline & Low & late Holocene & Cretaceous \\
\hline \multirow{4}{*}{$\underset{z}{\stackrel{\Xi}{\Xi}}$} & T2-Unit I & Pleistocene & Pleistocene \\
\hline & T1-Unit II & mid Holocene & early-mid Holocene \\
\hline & T1-Unit III & late Holocene & late Holocene \\
\hline & T0-Unit IV & modern & late Holocene-modern \\
\hline
\end{tabular}

Table 4-2. Relation Between the Surface and Subsurface Stratigraphic Sequence and Preservation Potentials for the Cultural Record

\begin{tabular}{|c|c|c|c|c|c|c|c|c|c|c|c|}
\hline \multirow{3}{*}{ Period } & \multicolumn{11}{|c|}{ Stratigraphic Chronology } \\
\hline & \multicolumn{6}{|c|}{ Surface } & \multicolumn{5}{|c|}{ Subsurface Units } \\
\hline & $\begin{array}{c}\text { Upland } \\
\text { (H) }\end{array}$ & $\begin{array}{l}\text { Upland } \\
\text { (I) }\end{array}$ & $\begin{array}{l}\text { Upland } \\
\text { (L) }\end{array}$ & $\mathbf{T} 2$ & T1 & T0 & I & II & III & IV & $\begin{array}{c}\text { Colluvium } \\
\text { (I) }\end{array}$ \\
\hline Paleoindian & 慗 & & & 慗 & & & & & & & \\
\hline Early Archaic & 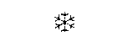 & 楱 & & 箱家 & & & & 骠 & & & 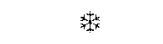 \\
\hline Middle Archaic & 楼 & 橉 & & 䊩 & 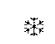 & & & 棵 & 嗦 & & 哧 \\
\hline Late Archaic & 楼 & 装 & & 慗 & 蒌 & & & & 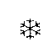 & & \\
\hline $\begin{array}{l}\text { Transitional } \\
\text { Archaic-Historic }\end{array}$ & 䋛 & 荤 & 橉 & 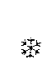 & 菻 & 菻 & & & & 来体 & \\
\hline
\end{tabular}

(Table 4-1). Erosion subsequently exposed Cretaceous sediments into which shallow soils have formed. The Low surface is the least extensive of the three surfaces mapped in the project area (Figure 4-1).

The late Quaternary history of Medio Creek is recorded in three alluvial landforms and four associated alluvial deposits (Table 4-1). Deposition of Unit $I$ and construction of the T2 terrace occurred in the late Pleistocene. Deposition appears to have been largely by a fine-grained meander belt. An episode of channel trenching occurred across the Pleistocene to Holocene boundary. Following downcutting, Unit II was deposited and the T1 flood terrace constructed in the early to middle Holocene. Depositional facies include both channel and flood basins, with the latter being more widespread. Unit III was deposited during the late Holocene. During this time, Unit III channel gravels truncated and buried Unit $\Pi$ principally within the modern meander belt of Medio Creek. In some areas, Unit III consists of a thick alluvial fill, whereas Unit II was completely truncated. The last major episode of channel downcutting along Medio Creek occurred in the late Holocene shortly after 2000 B.P. Deposition of Unit IV and construction of the modern T0 flood plain followed. The T0 flood 
plain is confined to a narrow zone bordering the modern Medio Creek channel. Unit IV records alternating high- and low-magnitude floods.

\section{Geoarchaeology}

Based on the Quaternary landscape history of the project area, general inferences can be made for preservation potentials of the surface and subsurface cultural record (Table 4-2). Paleoindian sites will be largely confined to the High Upland surface and to the T2 terrace of Medio Creek. Subsurface preservation will be minimal because of the paucity of sediments dating to this time period.

The Early Archaic record may be distributed across the High and Intermediate surfaces in the Uplands and the T2 terrace in the alluvial valley of Medio Creek. Preservation in the subsurface will be limited to Unit $\Pi$ and upland colluvium associated with the Intermediate surface. Preservation of the Middle Archaic should occur on the High and Intermediate surfaces in the Uplands and on the T2 terrace and T1 flood terrace in the alluvial valley (Table 4-2). The Middle Archaic may be buried within parts of Unit II, in most of Unit III, and in colluvium associated with the Intermediate surface. However, preservation in primary contexts in Unit III and in colluvium may be limited because of the predominance of coarse-grained channel and gully facies.

The Late Archaic record may be distributed across all landforms except the Low Upland surface and T0 (Table 4-2). In the subsurface, it will be preserved mainly in Unit III. However, as stated above, potential for preservation in primary contexts may be low. The Transitional Archaic to Historic record may be preserved on all landforms, but buried only in Unit IV. Frequent high-magnitude floods may have limited preservation in primary contexts. The geologic record in the project area biases preservation of surface sites to the Transitional Archaic to present (Table 4-2). Furthermore, as landform age increases, there is greater potential for preservation of palimpsests of sites spanning numerous cultural time periods. Sites dating to all cultural divisions except Paleoindian have a reasonable potential for subsurface preservation.
However, there will be a slight bias towards subsurface preservation of the Early Archaic because environments of deposition associated with other Holocene deposits were not as favorable for preservation in primary contexts. 


\title{
Chapter 5: Results of Archaeological Investigations
}

\author{
Brett A. Houk, David L. Nickels, Lee C. Nordt, and C. Britt Bousnan
}

\section{Introduction}

Eight prehistoric archaeological sites at Lackland Air Force Base Medina Annex were tested to assess their eligibility for listing on the National Register of Historic Places (NRHP) in compliance with Sections 106 and 110 of the National Historic Preservation Act (NHPA). Two of the sites, 41BX1102 and 41BX1103, are situated in terraces adjacent to Medio Creek. The remaining six sites, 41BX1070, 41BX1076, 41BX1088, 41BX1090, 41BX1091, and 41BX1114, are located in the surrounding uplands. Sites 41BX1076 and 41BX1088 are located outside of the primary and secondary impact areas and were investigated in accordance with Section 110 of the NHPA.

For each of the tested sites, this chapter describes the site's setting, reviews the previous investigations, outlines the level of effort employed during testing, and describes the results of the testing as they relate to site size, depth, stratigraphy, and material culture. This discussion is organized into three sections: Medina Annex Housing Area (Alternate 1), Medina Annex Dog Training Area (Alternate 2), and sites outside the impact areas. Formal recommendations about significance for each site are given in Chapter 6 .

\section{Medina Annex Housing Area (Alternate 1)}

\section{Site $41 B X 1088$}

\section{Site Setting}

Site 41BX1088 occurs on the Upland surface in the southeast part of the project area. This large site covers approximately $166,000 \mathrm{~m}^{2}$ (41 acres) and is to the east of Medio Creek (Figure 5-1). It ranges in elevation from approximately $222.5 \mathrm{~m}$ amsl at its highest point to $198 \mathrm{~m}$ amsl sloping toward Medio Creek, 120 $\mathrm{m}$ to the west. The upper elevations are relatively flat, and judging from the densities of fire-cracked rock, informal and formal tools, and occasional pieces of ground stone, these are the areas with the most intensive occupations. Steep slopes toward the south and west portions of the site are littered with evidence of early stage reduction such as cores and quarry blanks. Raw materials in the form of Uvalde gravels are present across the entire site but occur more heavily along its western slope and along both sides of an intermittent east-west drainage that dissects its southern end. Dense upland vegetation includes mesquite, persimmon, hackberry, agarita, assorted cacti, and herbaceous weeds and grasses.

Most of the impacts to $41 \mathrm{BX} 1088$ have been from erosion: the most severe is a deep gully cutting through the center of the site. The Air Force has cleared several intersecting, grass-covered roads and fire breaks through the site. The piling of debris along the sides of these roads suggests mechanical clearing resulted in the destruction of the upper 10 to $20 \mathrm{~cm}$ of the site within these impact areas. Despite these disturbances, huge areas remain virtually undisturbed because the site is so large.

\section{Previous Investigations}

During the initial survey, CAR field crews excavated two shovel tests and inventoried three 5-m radius dogleashes. One shovel test was sterile, but the other contained artifacts in the upper $30 \mathrm{~cm}$. The dogleashes, all of which were placed in the north half of the site where artifact concentrations were greatest, contained 38,42 , and 109 artifacts, respectively. The collection of artifacts from the site included two Guadalupe tools, one Pedernales point, and one Lange point (Nickels et al. 1997). 


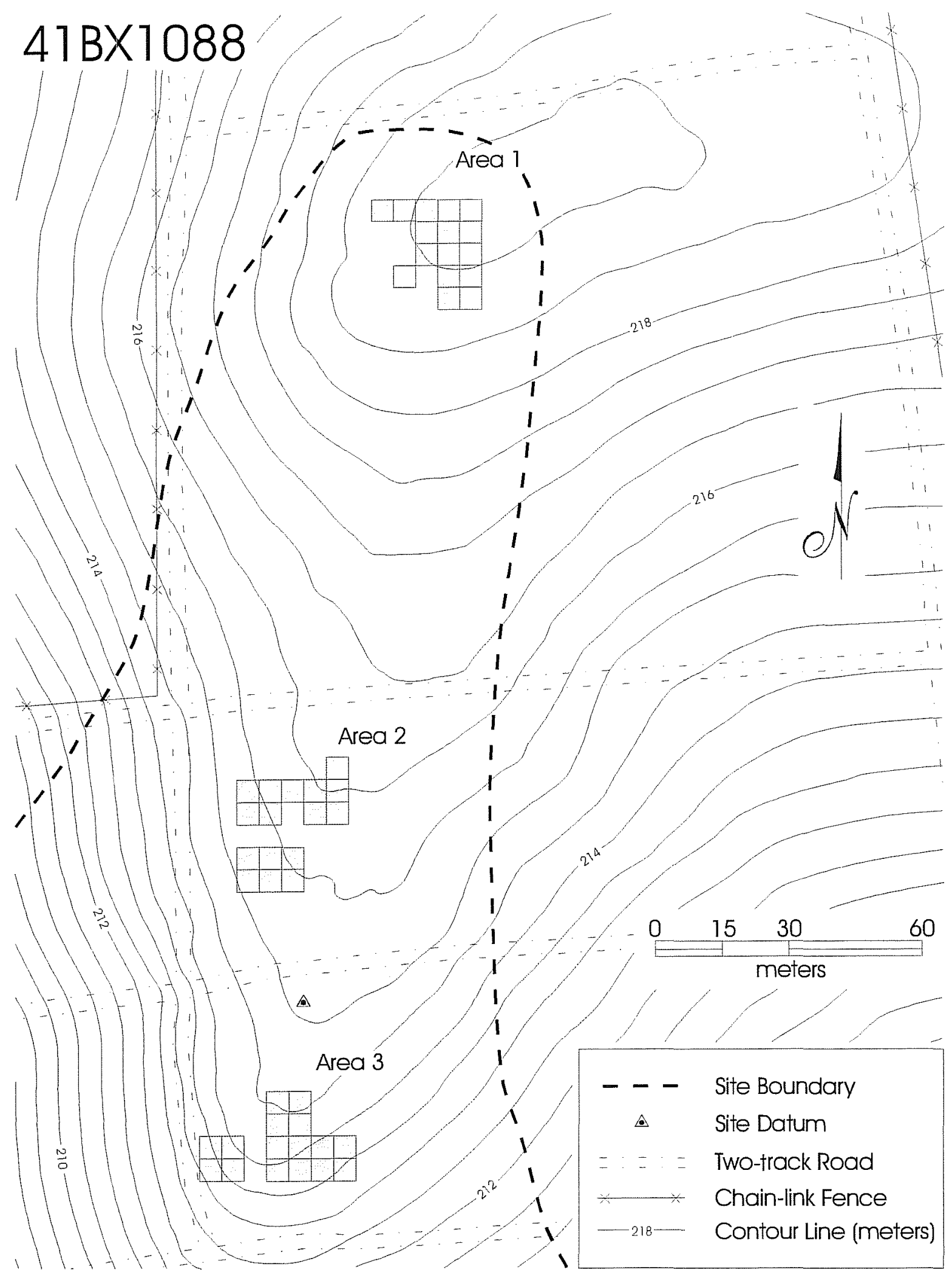

Figure 5-1. Site map, 41BX1088. Collection areas are represented by shading (TUs not shown). 


\section{Level of Effort}

Because $41 \mathrm{BX} 1088$ is such a large site, the testing methodology was modified slightly. Three separate collection areas, each corresponding to the approximate location of one of the survey dogleashes, were staked and investigated. Within each area (designated Area 1 to 3 from north to south), sixteen 5-x-5-m CUs were collected, and one $1-\mathrm{x}-1-\mathrm{m}$ test unit was excavated (Figures 5-2-5-4). The actual site boundaries were not remapped, but the three tested areas were mapped together using a total station. No shovel tests or backhoe trenches were excavated at the site.

\section{Site Size and Depth}

The testing project did not attempt to relocate the site boundaries, so the survey estimate of $166,000 \mathrm{~m}^{2}$ has not been revised (e.g. Nickels et al. 1997). At each of the three areas, the test units were excavated to 100 $\mathrm{cm}$ below the surface (bs). In each case, artifacts were present in every level, although the quantity diminished dramatically below $20 \mathrm{~cm}$ in depth.

\section{Testing Results}

\section{Geoarchaeological Assessment}

This site was divided into three areas. TU N1156 E1038 was excavated in Area 1 approximately 26 m above the modern low-water channel (Figure 5-5). TU N1030 E997 was excavated in Area 2 about $21 \mathrm{~m}$ above the modern low-water channel, and TU N969 E999 was excavated in Area 3 about $21 \mathrm{~m}$ above the modern low-water channel.

The soils in all areas of site $41 \mathrm{BX} 1088$ have high clay content and shrink-swell properties (Appendix A). Only few matrix-supported pebbles occur throughout most profiles. An occasional pocket of pebbles within the soil probably originated from mixing of surface Uvalde Gravel lag along biological channels or from falling into surface desiccation cracks. TUs N1156 E1038 at Area 1 and TUN1030 E997 at Area 2 occur on the High Upland surface. These soils have thick dark profiles with significant subsurface accumulations of calcium carbonate (Figure 5-5). This degree of soil development is consistent with a Pleistocene age. TU N969 999 at Area 3 is situated on an erosional remnant of the Low Upland surface. The soils here are thinner and lighter colored, having more similarities to the underlying Cretaceous bedrock.

The sediments in all three areas of site 41BX1088 are probably Cretaceous in age and have little potential for containing buried cultural materials in a primary context. Cretaceous age shark teeth recovered from TU N969 E999 at Area 3 in Levels 4, 5, 6, 9, and 10 apparently support the hypothesis that these upland soils are developing in situ out of the underlying bedrock. However, because of surface cracking, artifacts could become incorporated at depth in the soils. Following the proposed model of landscape evolution for the Uplands (Chapter 3), sites on the High surface could span the entire known prehistoric cultural record in central Texas. However, because of more recent surface erosion, sites on the Low surface should be Transitional Archaic or younger.

Archaeological Investigations

The investigations at $41 \mathrm{BX} 1088$ identified two features and recovered 8,154 artifacts, including 6,649 pieces of debitage, 338 bifaces, 132 unifaces, 1008 cores, 17 projectile points, one mano, one stone pendant, two Leon Plain sherds, and two hammerstones (Table 5-1). The archaeological testing at 41BX1088 revealed distinctly different artifact assemblages from each of the three areas examined. Rather than discussing each area separately, the results of the investigations are summarized by comparing the three assemblages (Table 5-2). This discussion is divided into comparisons of diagnostic artifacts, features, surface artifact counts and distributions, subsurface testing, and the nature of the artifact assemblages.

\section{Diagnostic Artifacts}

Sixteen diagnostic artifacts, two untyped projectile points, one arrow point blank, and one dart point blank were recovered at $41 \mathrm{BX} 1088$. These artifacts are summarized in Table 5-3. All these artifacts were recovered from the surface of the site in Areas 1 and 2 with 


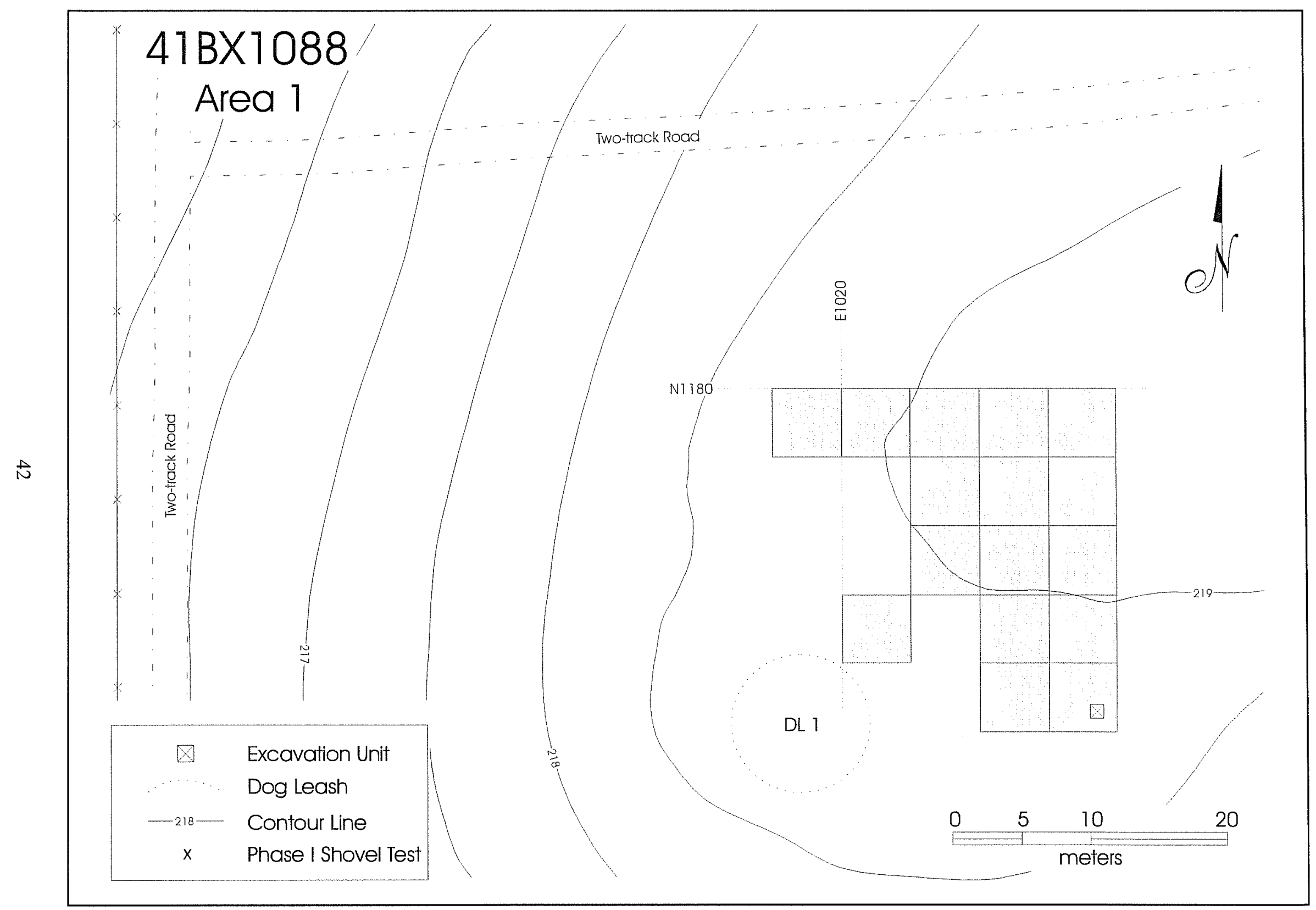

Figure 5-2. Area 1, 41BX1088. Collection areas are represented by shading. 


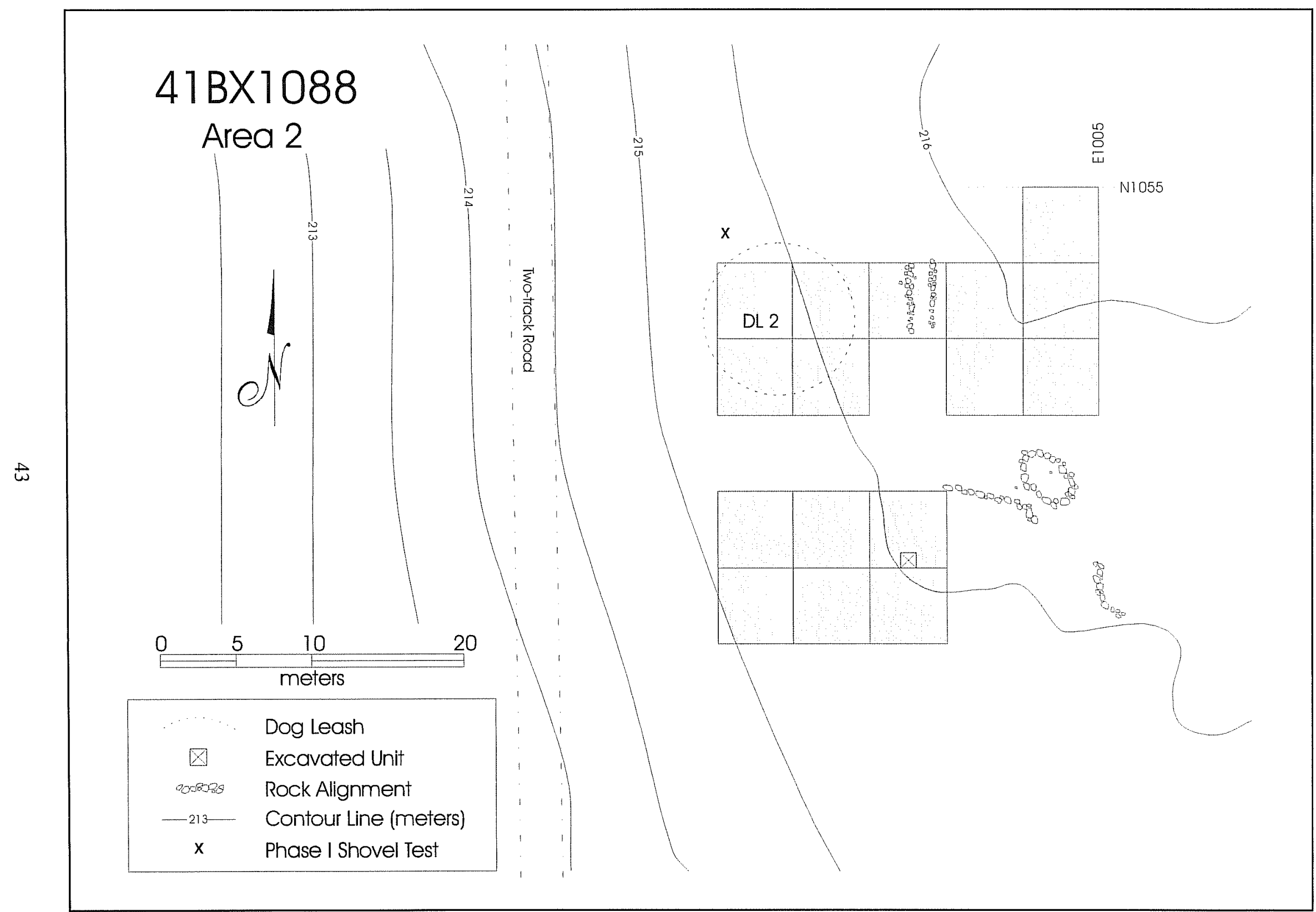

Figure 5-3. Area 2, 41BX1088. Collection areas are represented by shading. 


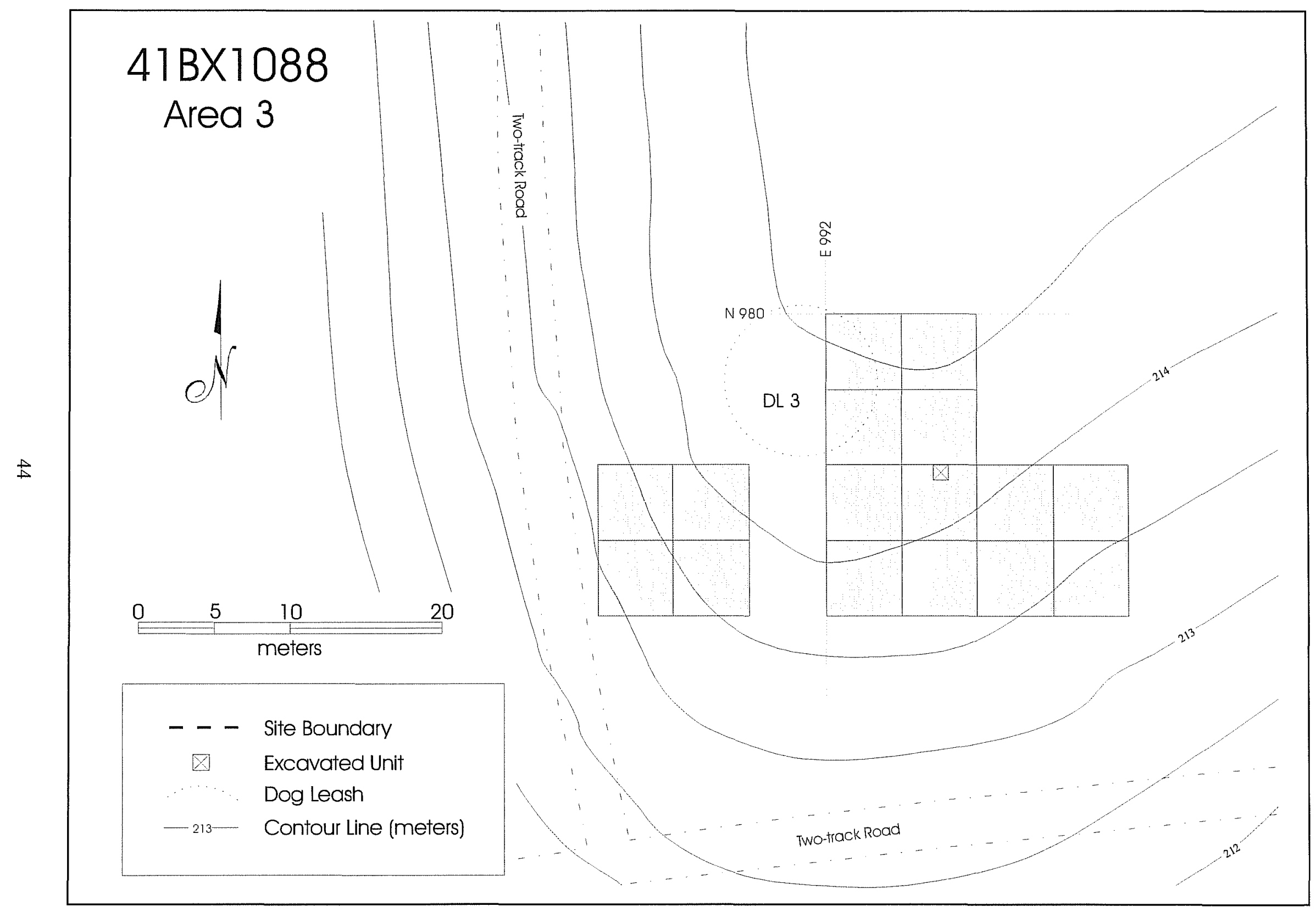

Figure 5-4. Area 3, 41BX1088. Collection areas are represented by shading. 


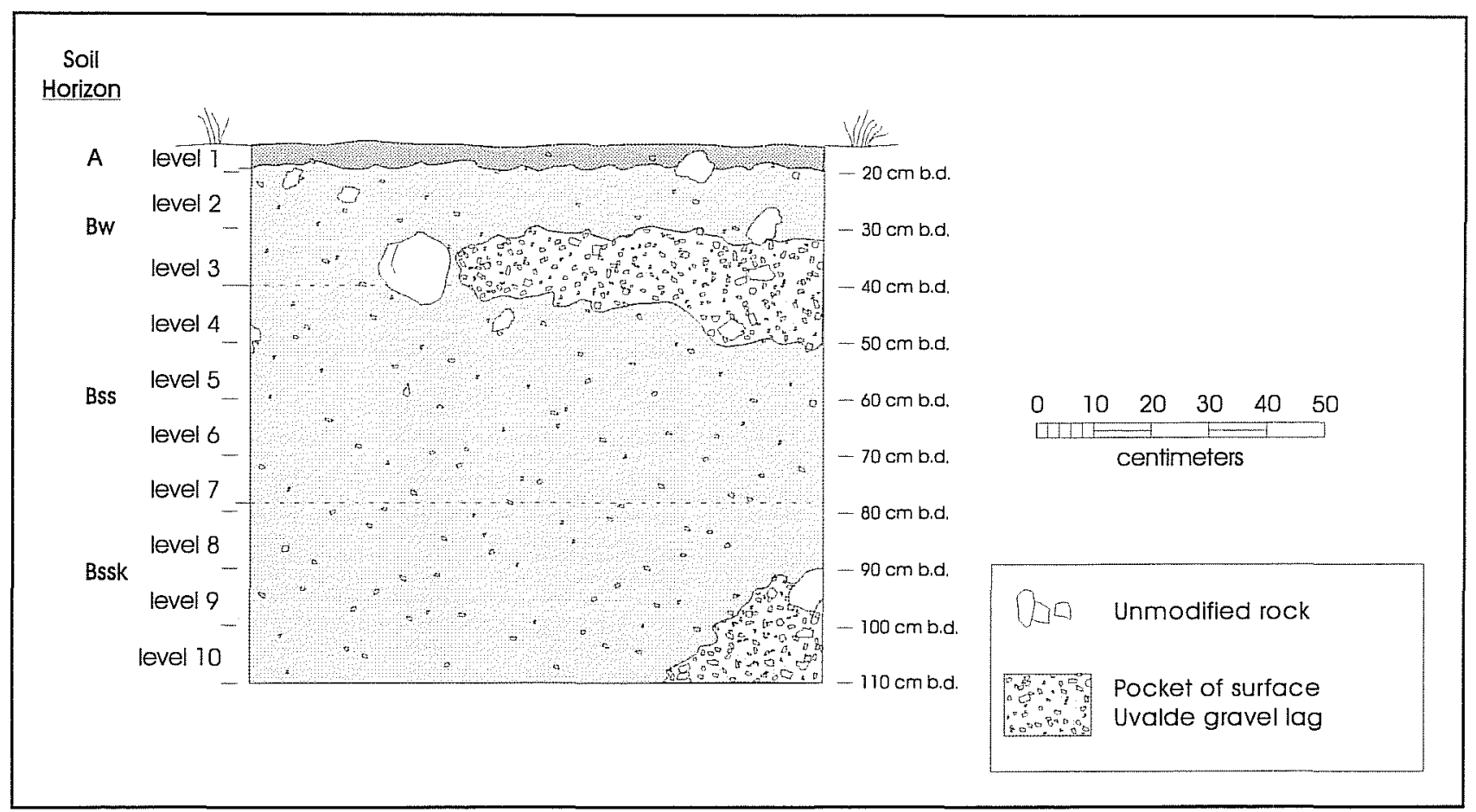

Figure 5-5. Profile of south wall of TU N1156 E1038 at 41BX1088, Area 1

the exception of one untyped dart point which was found in the first excavation level of TU N1156 E1038 at Area 1. Of the diagnostic artifacts, all except the Pedernales point from Area 1 and the two Guadalupe tools (one unifacial and one bifacial) from Area 3 date to either the Transitional Archaic or Late Prehistoric time periods. The diagnostic artifacts are illustrated in Figures 5-6 to 5-9.

Table 5-1. Artifacts from 41BX1088

\begin{tabular}{|l|r|r|r|r|}
\hline \multicolumn{1}{|c|}{ Artifact Type } & Surface & TUs & IF & Total \\
\hline Debitage & 6269 & 380 & 0 & 6649 \\
\hline Bifaces & 329 & 1 & 9 & 339 \\
\hline Unifaces & 127 & 4 & 1 & 132 \\
\hline Cores & 990 & 16 & 4 & 1010 \\
\hline Projectile Points & 16 & 1 & 0 & 17 \\
\hline Ceramic Sherds & 1 & 0 & 1 & 2 \\
\hline Pendant/plummet & 1 & 0 & 0 & 1 \\
\hline Hammerstones & 2 & 0 & 0 & 2 \\
\hline Manos & 1 & 0 & 0 & 1 \\
\hline Total & $\mathbf{3 1 4 0}$ & $\mathbf{1 5 5}$ & $\mathbf{1 2}$ & $\mathbf{8 1 5 4}$ \\
\hline
\end{tabular}

\section{Features}

At Area 2, two features were documented during the testing project. Both features are located on the surface of the site and consist of alignments formed by large stones (Figure 5-3). Feature 1 consists of an oval stone alignment (Figure 5-10) and two adjacent curvilinear stone alignments (Figure 5-11). The oval part of the feature measures approximately $2.5 \times 3.5 \mathrm{~m}$. The alignment is approximately $25 \mathrm{~cm}$ wide and is formed by a single course of stones. One curvilinear section is located one meter southwest of the stone circle and is approximately $5.75 \mathrm{~m}$ long. It is also constructed of a single course of stones, approximately $25 \mathrm{~m}$ wide. The second curvilinear section was discovered in the southeast corner of the cleared area and apparently extends beyond the limits of the clearing. It may be a second oval shaped arrangement of stones. Feature 2 is located $14 \mathrm{~m}$ north of Feature 1 (Figure 5-12). It consists of two parallel stone alignments, three meters long, formed by single courses of stone approximately $35 \mathrm{~cm}$ wide.

Feature 1 has been disturbed by modern dumping of broken cinder blocks. Although the alignments may be Historic in age, no records of any Historic occupa- 
Table 5-2. Artifacts by Area at 41BX1088

\begin{tabular}{|l|r|r|r|r|}
\hline \multicolumn{1}{|c|}{ Artifact Type } & Area 1 & Area 2 & Area 3 & Total \\
\hline Debitage & 3374 & 1275 & 2000 & 6649 \\
\hline Bifaces & 111 & 62 & 166 & 339 \\
\hline Unifaces & 56 & 11 & 65 & 132 \\
\hline Cores & 276 & 122 & 612 & 1010 \\
\hline Projectile Points & 15 & 2 & 0 & 17 \\
\hline Ceramic Sherds & 2 & 0 & 0 & 2 \\
\hline Pendant/plummet & 0 & 1 & 0 & 1 \\
\hline Hammerstones & 0 & 1 & 1 & 2 \\
\hline Manos & 1 & 0 & 0 & 1 \\
\hline Total & $\mathbf{3 8 3 5}$ & $\mathbf{1 4 7 4}$ & $\mathbf{2 8 4 4}$ & $\mathbf{8 1 5 3}$ \\
\hline
\end{tabular}

Table 5-3. Diagnostic Artifacts from 41BX1088

\begin{tabular}{|c|c|c|c|}
\hline Area & Artifact Type & $\#$ & Time Period \\
\hline \multirow[t]{14}{*}{1} & Leon Plain body sherd & 1 & Late Prehistoric (late) \\
\hline & Leon Plain rim sherd & 1 & Late Prehistoric (late) \\
\hline & Perdiz arrow point & 1 & Late Prehistoric (late) \\
\hline & Perdiz preform & 1 & Late Prehistoric (late) \\
\hline & Scallorn arrow point & 2 & Late Prehistoric (early) \\
\hline & Edwards arrow point & 1 & Late Prehistoric (early) \\
\hline & Arrow point blank & 1 & Late Prehistoric \\
\hline & Fairland dart point & 1 & Transitional Archaic \\
\hline & Frio dart point & 2 & Transitional Archaic \\
\hline & Ensor dart point & 1 & Transitional Archaic \\
\hline & Darl dart point & 1 & Transitional Archaic \\
\hline & Pedernales dart point & 1 & Middle Archaic \\
\hline & Untyped dart point & 2 & Unknown \\
\hline & Dart point blank & 1 & Unknown \\
\hline \multirow[t]{2}{*}{2} & Perdiz preform & 1 & Late Prehistoric (late) \\
\hline & Fairland dart point & 1 & Transitional Archaic \\
\hline 3 & Guadalupe tool & 2 & Early Archaic (?) \\
\hline
\end{tabular}

tion for this area of the base was found during the survey-level archival research (Nickels et al. 1997).

\section{Surface Collections}

The intensive surface collecting of $16 \mathrm{CUs}$ at each of the three areas of $41 \mathrm{BX} 1088$ recovered 7,733 chipped stone artifacts, the majority ( 81 percent) of which were debitage. The greatest number of chipped stone artifacts was recovered from Area 1. Area 2, located approximately midway between Areas 1 and 3, contained considerably fewer chipped stone artifacts than the other two.

Differences in the surface collections from the three areas are apparent in the frequencies of non-debitage chipped-stone artifacts. In each of the three areas, the most common non-debitage artifact was cores, but the number of cores as a percentage of the total non-debitage artifacts from Area 3 was approximately 10 to 12 percent higher than at Areas 1 and 2 . The assemblage from Area 2 had an unusually high percentage of bifaces when compared to Areas 1 and 3 . Area 1 had considerably more projectile points than the other two collection blocks (Table 5-4).

\section{Excavation Units}

One $1-x-1-m$ test unit was excavated at each of the three areas at $41 \mathrm{BX} 1088$. No features were encountered in any of the units. The greatest quantity of debitage was recovered from TU N1156 E1038 at Area 1 (Figure 5-5). This unit was located within the CU from which the two Leon Plain ceramic sherds had been recovered. Figure 5-13 shows the dramatic decrease in debitage with depth in this unit. One untyped dart point - the only projectile point from 41BX1088 - was found in Level 1 of this unit, $6 \mathrm{~cm}$ bs.

At the other two areas, the amount of debitage was considerably lower than at Area 1, but material was present intermittently as deep as $90 \mathrm{~cm}$ bs at Area 3. The geoarchaeological assessment of the site indicates that the sediments are Cretaceous or older, meaning that any material encountered at depth is in a secondary context.

Twenty-six flotation samples were collected during the excavations; one from each excavated level per unit. Based on the geoarchaeological assessment of the site and the results of the analysis of samples from 41BX1114, another upland site, the samples from $41 \mathrm{BX} 1088$ were not analyzed. 


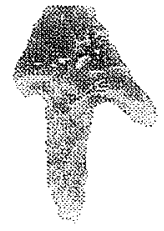

a

(UI 7)

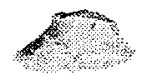

d

(U) 14)

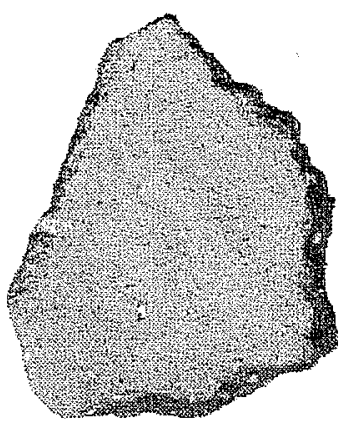

9

(UI 17)

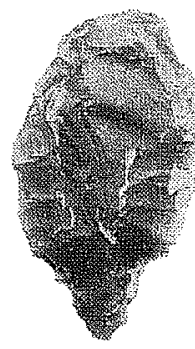

b

(UI 3)

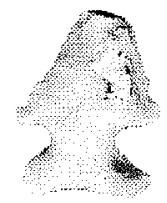

e

(UI 4)

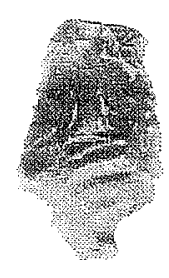

c

(U1 10)

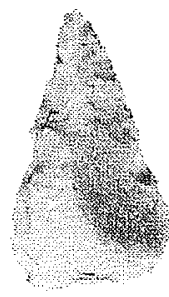

(UI 9)

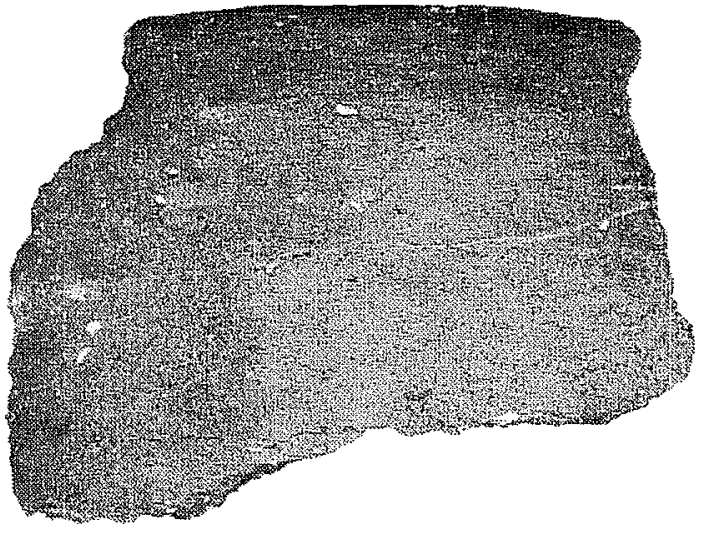

h

(U1 16)

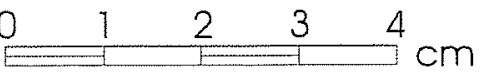

Figure 5-6. Area 1, 41BX1088, Late Prehistoric diagnostic artifacts. a: Perdiz; b: Perdiz preform; c, d: Scallorn; e: Edwards; f: Arrow point blank; g, h: Leon Plain sherds.

Artifact Assemblages

A comparison of the artifact assemblages from each of the areas reveals some interesting variations. In the debitage category (Table 5-5), the most common flake type is platform/core preparation at all three areas, but the relative frequency of this type is 11 percent higher at Area 3 than at the other two areas. Conversely, biface manufacturing flakes and biface thin- 


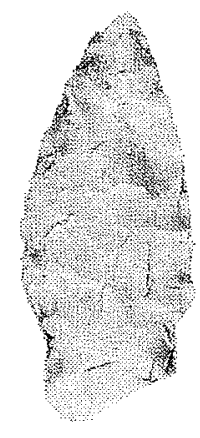

a

(UI 8)

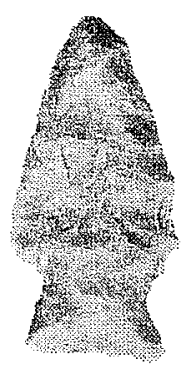

b

(UI 12)

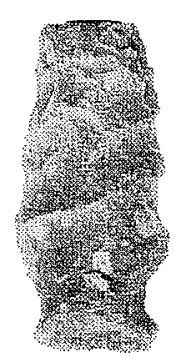

C

(UI 2)

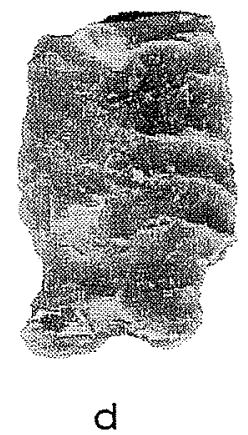

(UI 5)

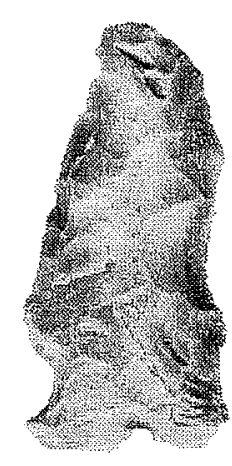

$e$

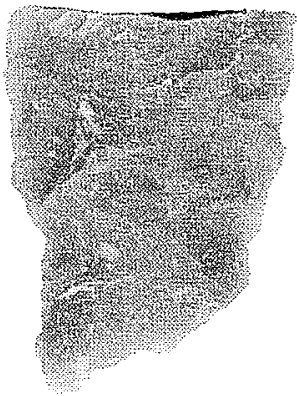

f

(U1 11)

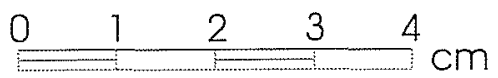

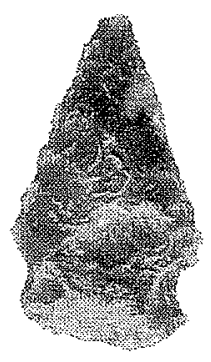

$g$

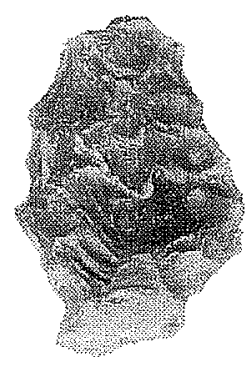

h

(UI 1)

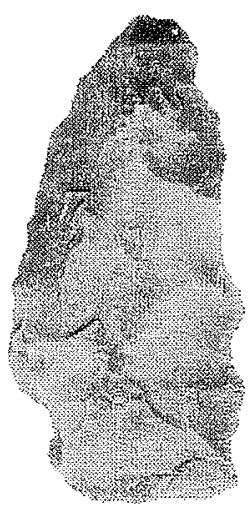

i

(UI 15)

Figure 5-7. Area 1, 41BX1088, Archaic diagnostic artifacts. a: Darl; b: Edgewood; c: Ensor; d, e: Frio; f: Pedernales; g, h; untyped dart points; i: dart point blank. 


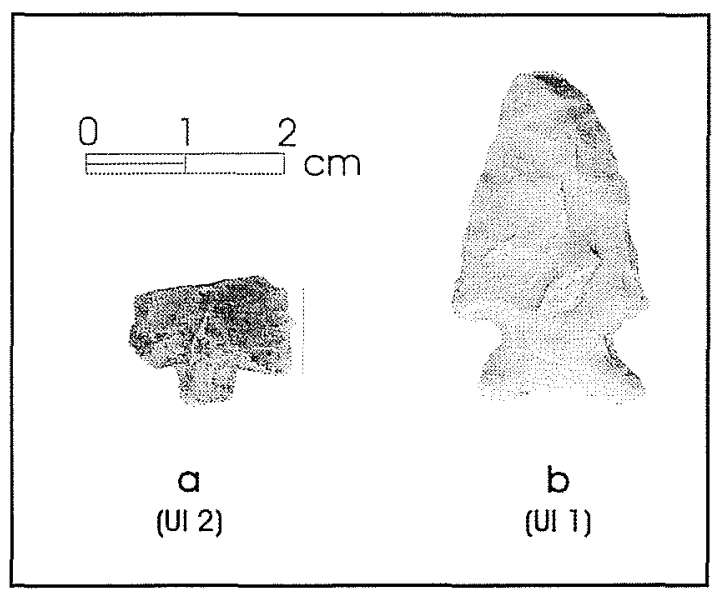

Figure 5-8. Area 2, 41BX1088, diagnostic artifacts. a: Perdiz preform; b: Fairland.

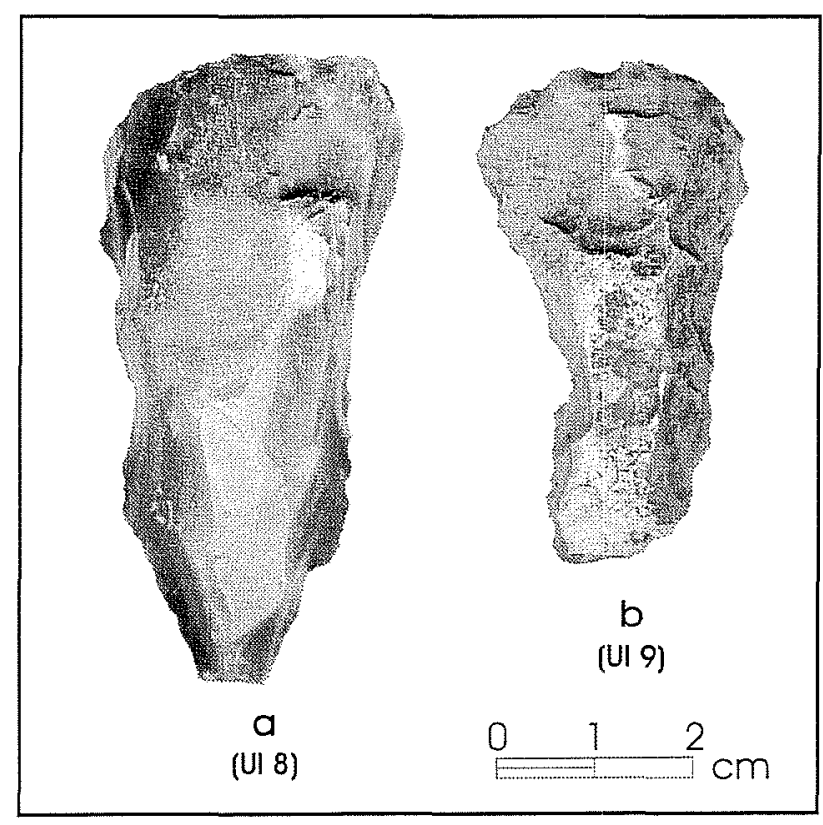

Figure 5-9. Area 3, 41BX1088, Guadalupe tools.

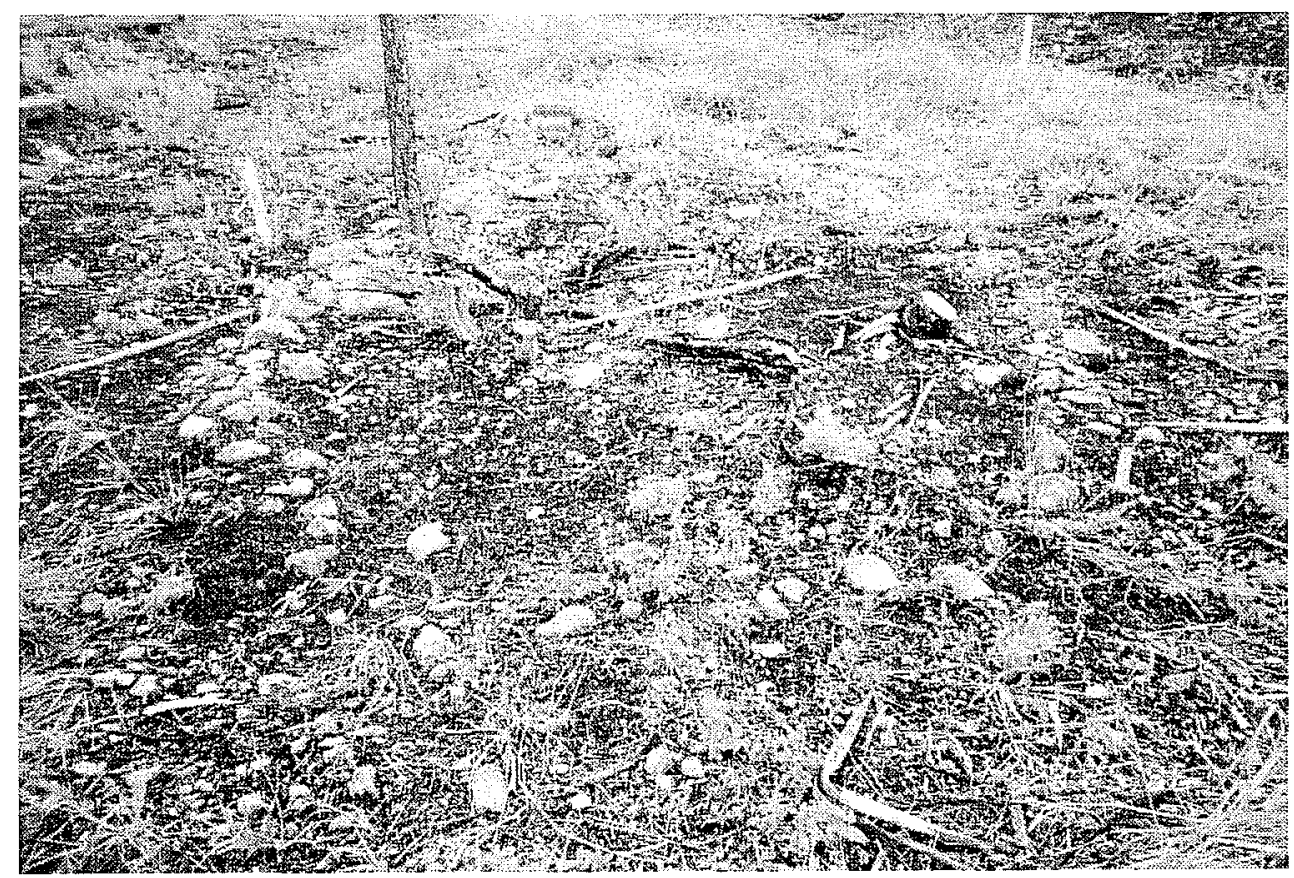

Figure 5-10. Oval stone alignment at Feature 1, Area 2, 41 BX1088. 


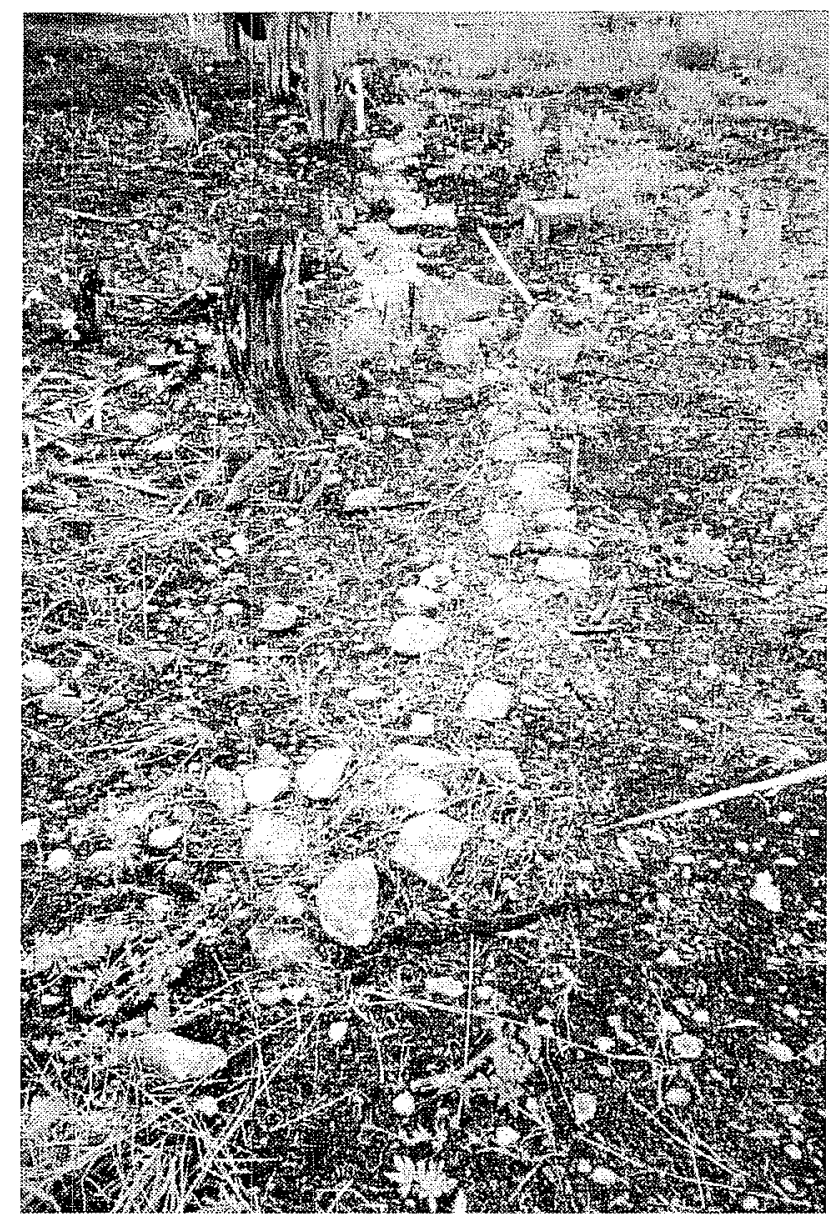

Figure 5-11. One of the curvilinear stone alignments at Feature 1, Area 2, $41 B X 1088$.

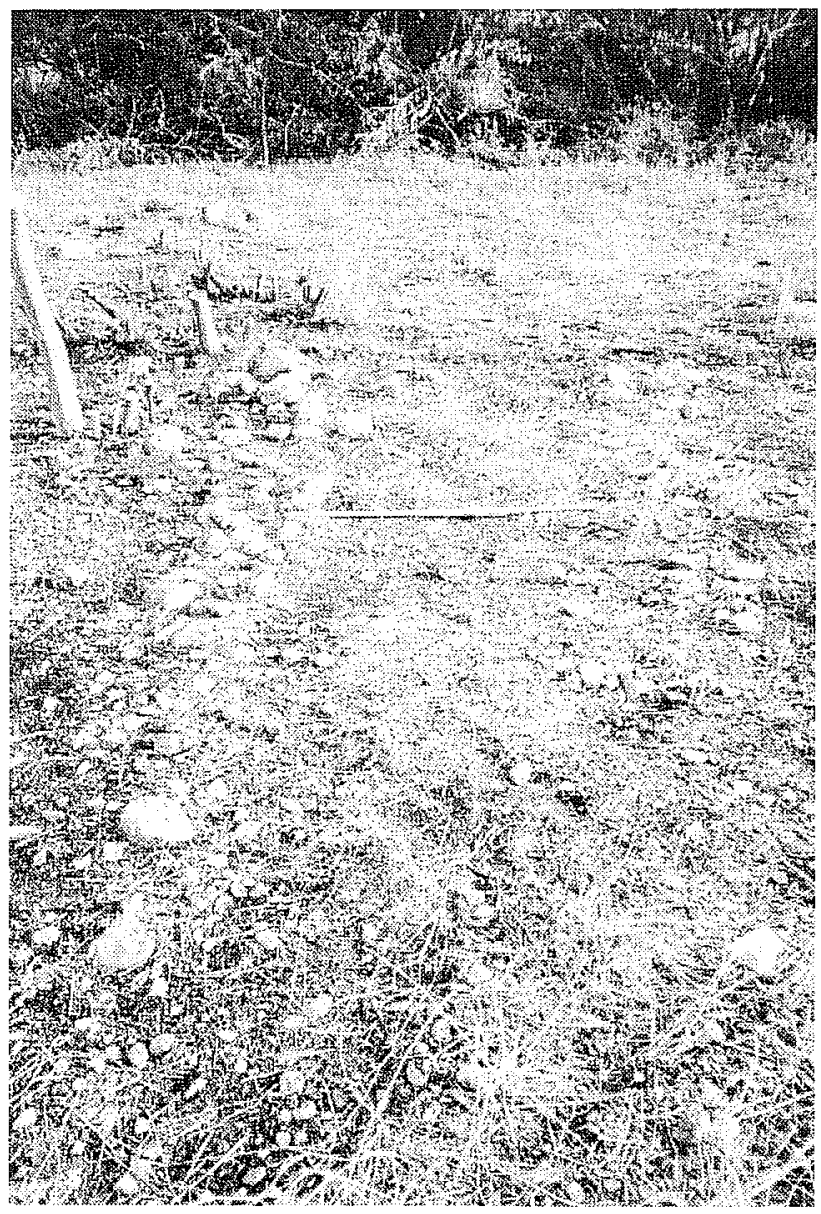

Figure 5-12. Feature 2, Area 2, $41 B X 1088$.

Table 5-4. Percentages of Non-Debitage Chipped Stone Artifacts by Area at 41BX1088 (Surface Only)

\begin{tabular}{|l|r|r|r|r|}
\hline \multicolumn{1}{|c|}{ Artifact Type } & \multicolumn{1}{c|}{ Area 1 } & Area 2 & \multicolumn{1}{c|}{ Area 3 } & Total \\
\hline Cores & 59.5 & 62.1 & 72.9 & 67.4 \\
\hline Bifaces & 24.4 & 31.0 & 19.3 & 22.4 \\
\hline Unifaces & 12.5 & 4.6 & 7.5 & 8.7 \\
\hline Projectile Points & 3.1 & 1.0 & 0.0 & 1.0 \\
\hline
\end{tabular}




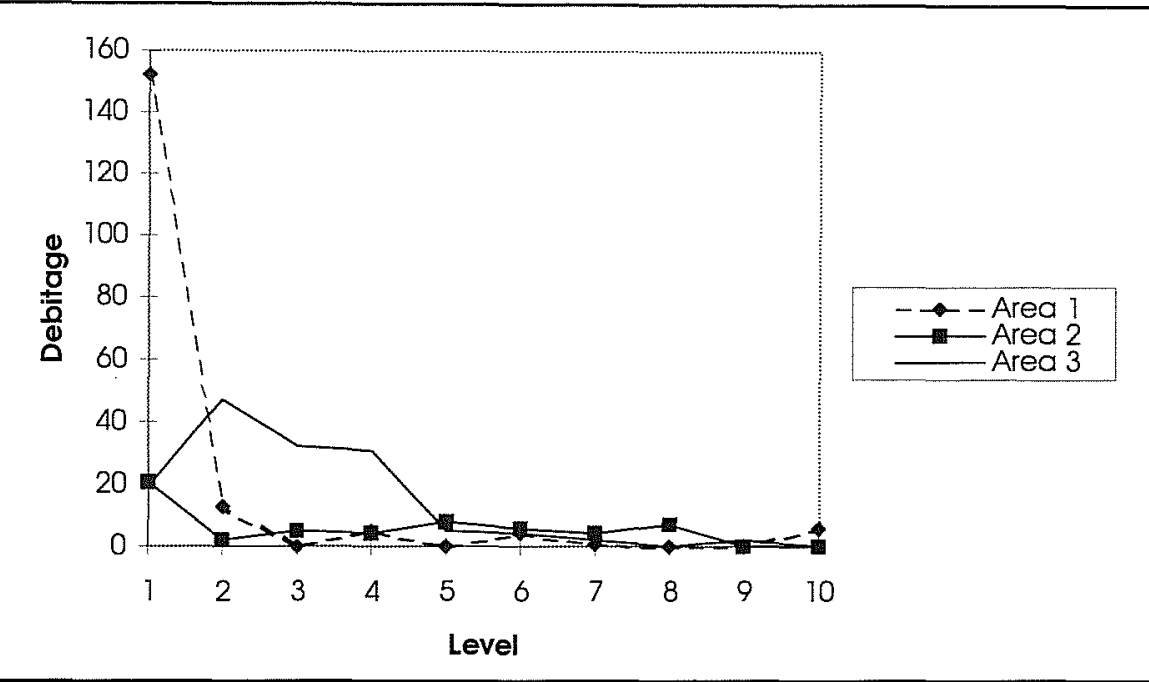

Figure 5-13. Debitage by level, TUN1056 E1038, 41BX1088, Area 1. age number of flakes scars per core is 4.7 with a median value of 3. At Area 2, where the number of cores was comparatively low $(\mathrm{n}=122)$, the average number of flake scars per core is 5.6 with a median of 4 . At Area 1 where the greatest amount of debitage was recovered, the average number of flake scars per core is 6.4 with a median of 5 . The split-cobble technology originally recognized at $41 \mathrm{BX} 1091$ is present in the $41 \mathrm{BX} 1088$ assemblage, as well. Twenty-seven split cobble cores were found at ning/resharpening occur more frequently in the assemblages from Areas 1 and 2 than from Area 3.

A comparison of the cores (Table 5-6) collected at each area shows that at Area 3, where cores account for 73 percent of the non-debitage artifacts, the aver-
Area 3 compared to four at Area 1 and none at Area 2.

A total of 339 bifaces was collected at 41BX1088; 111 from Area 1, 62 from Area 2, and 166 from Area 3 (Table 5-7). While 79 percent of these are early stage bifaces, there are some important differences.

Table 5-5. Relative Frequencies of Flake Types as Percentages at 41BX1088.

\begin{tabular}{|c|c|c|c|c|}
\hline Flake Type & Area 1 & Area 2 & Area 3 & Total \\
\hline Biface manufacturing & 17.1 & 19.4 & 7.4 & 14.7 \\
\hline Biface thin nin $\mathrm{g} / \mathrm{resharpening}$ & 2.0 & 2.2 & 0.6 & 1.6 \\
\hline Unif ace M anufacture/resharpening & 0.8 & 1.5 & 0.2 & 0.8 \\
\hline Blade & 1.4 & 0.3 & 0.2 & 0.8 \\
\hline Platform/core preparation & 73.1 & 73.4 & 84.8 & 76.7 \\
\hline Notching & 0.0 & 0.5 & 0.0 & 0.1 \\
\hline Sequence & 0.4 & 0.0 & 0.2 & 0.2 \\
\hline In determinate & 5.3 & 2.7 & 6.6 & 5.1 \\
\hline Total & 100.0 & 100.0 & 100.0 & 100.0 \\
\hline
\end{tabular}

Table 5-6. Cores by Area at 41BX1088

\begin{tabular}{|c|c|c|c|c|c|c|c|c|c|c|}
\hline \multirow{3}{*}{ Category } & \multicolumn{3}{|c|}{ Area 1} & \multicolumn{3}{|c|}{ Area 2} & \multicolumn{3}{|c|}{ Area 3} & \multirow{3}{*}{ Total } \\
\hline & \multirow[t]{2}{*}{$\#$} & \multicolumn{2}{|c|}{$\begin{array}{c}\text { Flake Scars } \\
\# / c o r e\end{array}$} & \multirow[t]{2}{*}{$\#$} & \multicolumn{2}{|c|}{$\begin{array}{c}\text { Flake Scars } \\
\# / \text { core }\end{array}$} & \multirow[t]{2}{*}{ \# } & \multicolumn{2}{|c|}{$\begin{array}{c}\text { Flake Scars } \\
\# / \text { core }\end{array}$} & \\
\hline & & avg. & median & & avg. & median & & avg. & median & \\
\hline Total number of cores & 276 & & & 122 & & & 612 & & & 1010 \\
\hline Number of analyzed cores & 143 & 6.4 & 5 & 61 & 5.6 & 4 & 309 & 4.7 & 3 & 513 \\
\hline
\end{tabular}


Table 5-7. Number of Bifaces at 41BX1088 by Area

\begin{tabular}{|l|r|r|r|r|}
\hline \multicolumn{1}{|c|}{ Reduction } & Area 1 & Area 2 & Area 3 & Total \\
\hline Early & 68 & 47 & 153 & 268 \\
\hline Middle & 37 & 11 & 10 & 58 \\
\hline Late & 5 & 4 & 3 & 12 \\
\hline Indeterminate & 1 & 0 & 0 & 1 \\
\hline Total & $\mathbf{1 1 1}$ & $\mathbf{6 2}$ & $\mathbf{1 6 6}$ & $\mathbf{3 3 9}$ \\
\hline
\end{tabular}

Sixty-five percent of these bifaces are complete. A single Guadalupe biface (UI 8) was found at Area 3.

The unifaces at $41 \mathrm{BX} 1088$ were divided unevenly across the three areas (Table 5-8). Interestingly, Area 3 had the greatest number of formally modified unifaces and of unifaces in general. One of the four formally modified unifaces from Area 3 was a unifacial Guadalupe tool (UI 9). As with other sites in the testing project, minimally retouched unifaces account for the greatest percentage of the sample.

Table 5-8. Number of Unifaces at 41BX1088 by Area

\begin{tabular}{|c|c|c|c|c|}
\hline Degree of Retouch & Area 1 & Area 2 & Area 3 & Total \\
\hline Expedient & 12 & 3 & 18 & 33 \\
\hline Minimal & 43 & 7 & 43 & 93 \\
\hline Formal & 1 & 1 & 4 & 6 \\
\hline Total & 56 & 11 & 65 & 132 \\
\hline
\end{tabular}

Ground- and battered-stone artifacts were recovered from all three areas of 41BX1088. At Area 1, a chert mano (UI 25) was collected from the surface. A small chert pendant or plummet (UI 4) was collected at Area 2 (Figure 5-14, described in Appendix B). This small pebble is covered entire cortex, but the interior chert is visible through the single hole drilled through the artifact. Finally, a hammerstone (UI 3) was collected at Area 3.

\section{Discussion}

The testing at 41BX1088 examined a fraction of the total site (less than one percent of the total surface

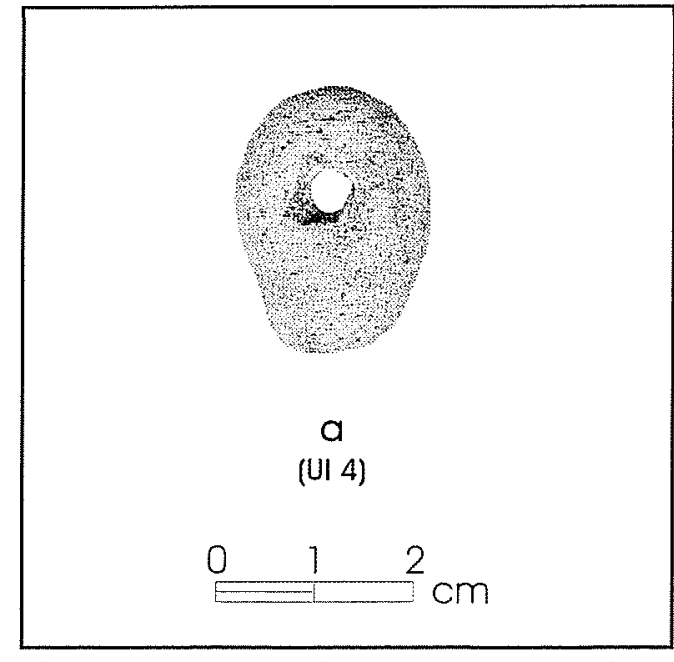

Figure 5-14. Pendant or plummet from Area 2, $41 B X 1088$.

area). The limited investigations, however, recovered 16 diagnostic artifacts including two Leon Plain sherds, six arrow points (including blanks and preforms), eight dart points (including one blank), and two Guadalupe tools. With the exception of the two Guadalupe tools and a Pedernales point, the diagnostic projectile points and the two sherds date to the Transitional Archaic and/or Late Prehistoric time periods.

The stone alignments, Features 1 and 2, documented at Area 2 are the only features recognized at 41BX1088. Unfortunately, their function and temporal association are unknown. It is likely that they are Historic, but a Prehistoric origin can not necessarily be dismissed.

Site $41 \mathrm{BX} 1088$ has not been seriously affected by artificial impacts. The integrity of the surface is, therefore, fairly good, although material has most likely been displaced to some degree by bioturbation and erosion. The surface of those areas cleared as fire breaks and access roads has been impacted by bulldozing. Because the majority of the material at the site appears to be concentrated in the upper $10 \mathrm{~cm}$, these impact areas have essentially been destroyed. However, this accounts for a small percentage of the total site. The geoarchaeological model proposed by Nordt suggests that the surface material at Areas 1 and 2 at $41 \mathrm{BX} 1088$ could span the entire known prehistoric cultural record in central Texas, but that the material at Area 3, which is situated on a remnant of 
the Low Upland surface, should be Transitional Archaic or younger.

The geoarchaeological assessment indicates that the sediments at the site are probably Cretaceous in age and have little potential for containing buried cultural materials in a primary context. The material encountered in the excavation units presumably has worked downward through bioturbation and desiccation cracking.

In general, the artifact assemblage at $41 \mathrm{BX} 1088$ is comparable to those at $41 \mathrm{BX} 1076,41 \mathrm{BX} 1090$, $41 \mathrm{BX} 1091$, and 41BX1114 in that it is composed of chipped stone debris and artifacts indicative of lithic testing and procuring and early stage reduction. This is evidenced by the high frequencies of core/platform preparation flakes, early stage bifaces, and cores, and in the low average number of flake scars per core.

When the three separate areas are considered individually, however, intrasite variation in artifact assemblages becomes apparent, even though the areas are within $300 \mathrm{~m}$ of one another. For example, at Areas 1 and 2, the chipped stone assemblage contains a higher percentage of debitage, projectile points, and middle stage reduction bifaces, and a lower frequency of cores than the assemblage at Area 3. Area 2, though similar to Area 1 in some respects, was characterized by a much lower artifact density than the other two. The average number of artifacts per square meter was 9.15 at Area 1,3.53 at Area 2, and 6.80 at Area 3. The only features encountered at the site, however, are located at Area 2, although their cultural context has not been established. Finally, the greatest amount of firecracked limestone and the only Leon Plain ceramics were found at Area 1.

\section{Site 41BX1090}

\section{Site Setting}

41BX1090 (Figure 5-15) is a small site indicated on the surface by a sparse surface scatter of lithic debris and fire-cracked rock (chert and limestone). The site is situated on the Intermediate Upland surface, about $14 \mathrm{~m}$ above the modern low-water channel of Medio
Creek and is adjacent to a local tributary having Holocene alluvium. The surface is covered with dense grasses, weeds, whitebrush, agarita, and assorted cacti under a canopy of mesquite, persimmon, and hackberry.

The site is located along the boundary of Medina Annex within $15 \mathrm{~m}$ of Ray Ellison Boulevard. A cleared, grass-covered access road passes between the northeast edge of the site and Ray Ellison Boulevard. The construction of this road and an adjacent chainlink fence could have resulted in the disturbance or destruction of a portion of the site. The south end of the site is subjected to surface runoff and sheet erosion during heavy rains as water is channeled from the residential streets associated with Ray Ellison Boulevard onto the downslope location of 41BX1090. Although the site was characterized as being only slightly disturbed during the initial survey (Nickels et al. 1997), the amount of burned chert and macroscopic pieces of charcoal visible on the surface suggests that the area may have been recently subjected to burning.

\section{Previous Investigations}

While recording and mapping this site in 1995, CAR staff observed a concentration of artifacts near the center of the site along with scattered fire-cracked rock, suggesting more intensive use of that area. A shovel test was dug to a depth of $30 \mathrm{~cm}$ revealing no cultural material below the surface. An inventory of artifacts from a 5-m radius dogleash placed at the site located a total of 10 flakes, cores, and informal tools. An inventory of the remaining surface artifacts included 62 lithic artifacts and nine fire-cracked rock fragments. No diagnostic artifacts were encountered (Nickels et al. 1997).

\section{Level of Effort}

The investigations at $41 \mathrm{BX} 1090$ included site mapping, surface collecting, shovel testing, and excavating test units. Site boundaries were determined by the surface scatter of cultural material and six shovel tests. As the site covered less than $1,500 \mathrm{~m}^{2}$, the established protocols recommended that the entire site surface be 


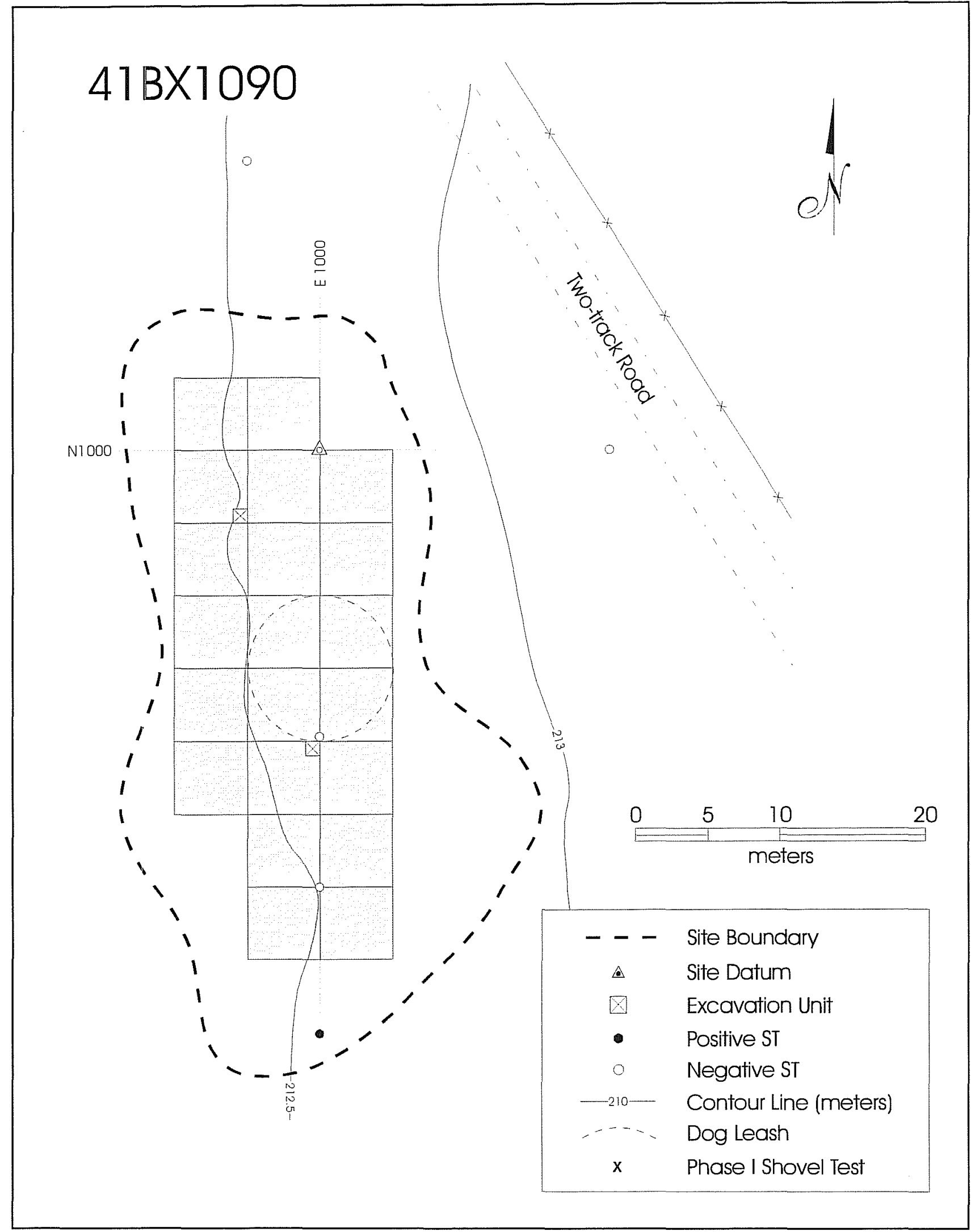

Figure 5-15. Site map, 41BX1090. Collection are represented by shading. 
inventoried/collected (Fox 1996). The project archaeologist, in consultation with the principal investigators, had decided to employ a consistent, $5-x-5-m, C U$ size at each site. This approach was problematic because in order to collect 100 percent of the surface of a small site, a much larger area had to be cleared to establish the CUs across the site. This necessitated a compromise since brush clearing proved to be a very time-consuming task. At 41BX1090, approximately 100 percent of the site was cleared, but the south end of the site which was disturbed by sheet erosion was eliminated from the collection area. The remaining cleared area accommodated 21 CUs, covering $525 \mathrm{~m}^{2}$. Six shovel tests were excavated to define site boundaries. Two 1-x-1-m test units were placed at N979 E999 and N995 E994.

\section{Site Size and Depth}

Based on the extent of the surface scatter of cultural material and the data from the six shovel tests, $41 \mathrm{BX} 1090$ covers an area of $1,040 \mathrm{~m}^{2}$. This is 139 percent larger than initial survey assessment of 750 $\mathrm{m}^{2}$. Cultural material was recovered to a depth of approximately $80 \mathrm{~cm}$ bs in TUN979 E999, although the density of material was decreased significantly below the upper $10 \mathrm{~cm}$.

\section{Testing Results}

\section{Geoarchaeological Assessment}

No backhoe trenches were excavated at $41 \mathrm{BX} 1090$, but a brief soil-stratigraphic description was written from TU N979 E999 (Figure 5-16). The sediments were very dark grayish brown and clayey, with few matrix-supported pebbles throughout (Appendix A). Common calcium carbonate nodules began at a depth of $60 \mathrm{~cm}$ in the bottom of the test unit. The surface of this deposit grades downslope into an upland alluvial valley correlative with the $\mathrm{T} 1$ flood terrace on the east side of Medio Creek. This stratigraphic relationship, coupled with appreciable calcium carbonate accumulation, indicates that the valley fill and adjacent upland sediments at $41 \mathrm{BX} 1090$ correlate with alluvial Unit II of Medio Creek. It follows that these deposits are early to middle Holocene in age. Consequently, there is potential for finding buried artifacts within this valley fill and the Intermediate surface in this area. However, because of the shrink-swell character of

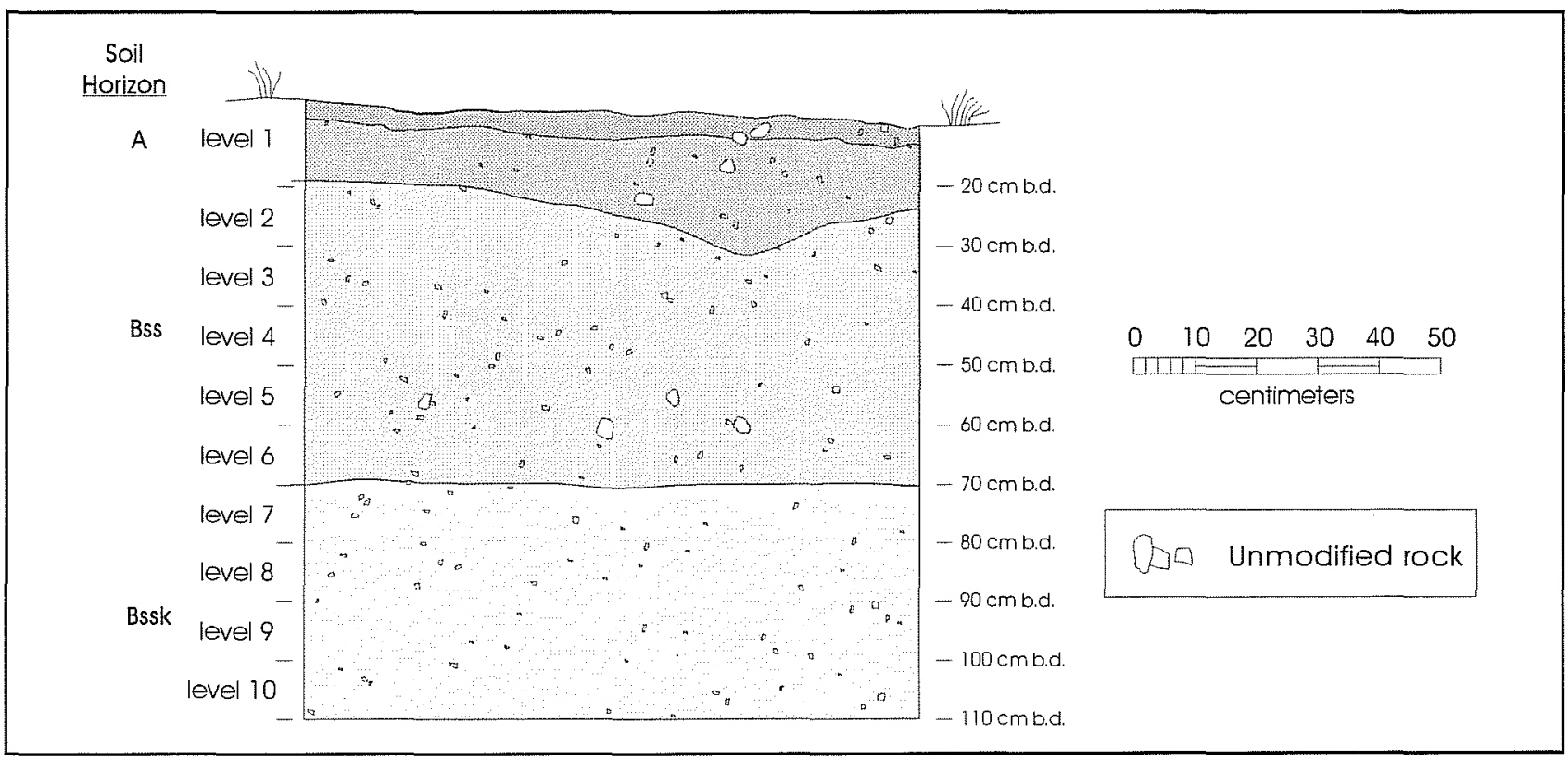

Figure 5-16. Profile of south wall of TU N979 E999, 41BX1090. 
these clayey sediments, contextual integrity of cultural materials could be compromised.

\section{Archaeological Investigations}

The testing at 41BX1090 did not locate any features or diagnostic artifacts despite an intensive surface collection of over 50 percent of the total site surface area. While the site is covered in fractured chert cobbles, much of this material is fire-cracked, presumably the result of modern burning.

A collection of 351 chipped stone artifacts was recovered from 41BX1090, the majority (58 percent) of which was debitage (Table 5-9). Cores were the second largest artifact class with 133 specimens accounting for 38 percent of the total assemblage. The other chipped stone artifacts were 10 early stage bifaces, 1 expedient uniface, 3 minimally retouched flakes, and 1 formal uniface. One battered stone artifact (UI 1), classified as a hammerstone, was collected at the site.

The majority of the material was recovered from the 21 CUs placed over the intact area of the site. The surface collection accounted for 170 pieces ( 84 percent of the total) of debitage, all 10 bifaces, 122 cores ( 92 percent of total), 4 of 5 unifaces, and the one hammerstone. In general, the frequency of debitage was highest in the northwest corner of the site (Figure 5-17), but there is a rough circular pattern of CUs with higher debitage counts surrounding CUs with low debitage counts at the north end of the collection area. The 10 bifaces, all of which were early stage reduction and nine of which were complete, were recovered from the north half of the collection area, but no more than two were recovered
Table 5-9. Artifacts Recovered from 41BX1090

\begin{tabular}{|c|c|c|c|c|}
\hline Artifact Type & Surface & TUs & STs & Total \\
\hline Debitage & 170 & 29 & 4 & 203 \\
\hline Bifaces & 10 & 0 & 0 & 10 \\
\hline Unifaces & 3 & 1 & 1 & 5 \\
\hline Cores & 122 & 6 & 5 & 133 \\
\hline Hammerstones & 1 & 0 & 0 & 1 \\
\hline Total & 306 & 36 & 10 & 352 \\
\hline
\end{tabular}

from one 5-x-5-m unit. Generally, the cores followed a similar distribution with the majority of the specimens being recovered from the north half of the collection area. Forty-six chipped stone artifacts were recovered from the two test units and six shovel tests excavated at $41 \mathrm{BX} 1090$. This small assemblage was composed of 33 flakes, 2 unifaces, and 11 cores. Subsurface investigations in the two $1-\mathrm{x}-1-\mathrm{m}$ test units demonstrated that artifact density decreased with depth between 0 and $50 \mathrm{~cm}$ below the surface ( $\mathrm{cm} \mathrm{bs}$ ) (Figure 5-18). In each unit, the number of artifacts increased slightly between 50 and $70 \mathrm{~cm}$ bs, but in each case, the sample size is no greater than four artifacts per excavated level. Cretaceous age sharks teeth was noted in several of the excavated levels.

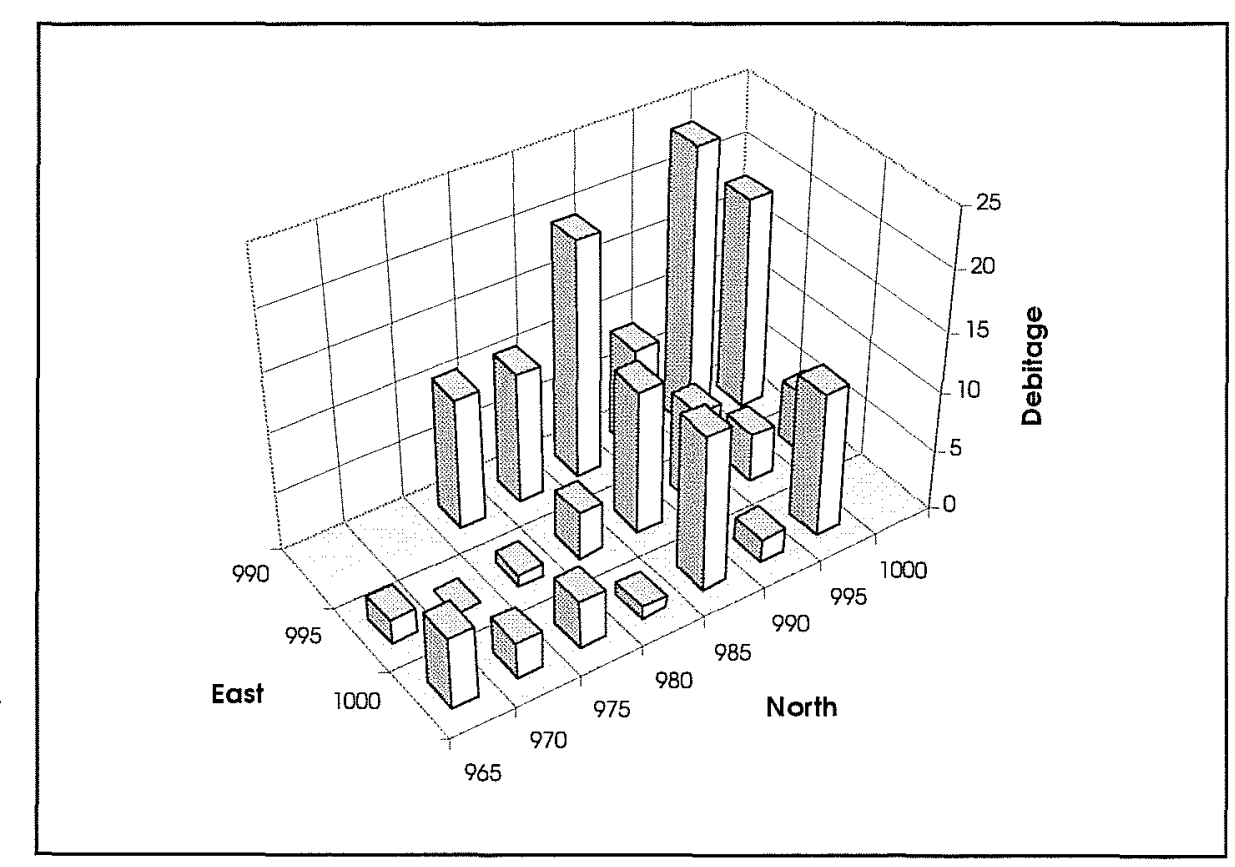

Figure 5-17. Distribution of debitage in surface collection area at 
Seventeen flotation samples were collected during the excavations at 41BX1090; one from each excavated level of each unit. Based on the geoarchaeological assessment of the site and the results of the analysis of samples from 41BX1114, another upland site, the samples were not analyzed.

\section{Discussion}

No diagnostic artifacts were found at 41BX1090 during either the survey (Nickels et al. 1997) or the testing investigations. The testing investigations did not encounter any features. We were unable to determine the temporal origin of the material at 41BX1090.

\section{Site 41BX1091}

\section{Site Setting}

Site 41BX1091 is situated on a hillside of the Intermediate Upland surface, $12 \mathrm{~m}$ above the modern lowwater channel of Medio Creek. 41BX1091 (Figure 5-19) is composed of a scatter of lithic debris and firecracked rock where chert gravels have outcropped across the slope of the site. The hillside setting supports dense grasses, agarita, assorted cacti, and an immature growth of mesquite trees. The location offers visibility for miles in all directions, including the broad and flat terraces adjacent to Medio Creek, $550 \mathrm{~m}$ to the west.

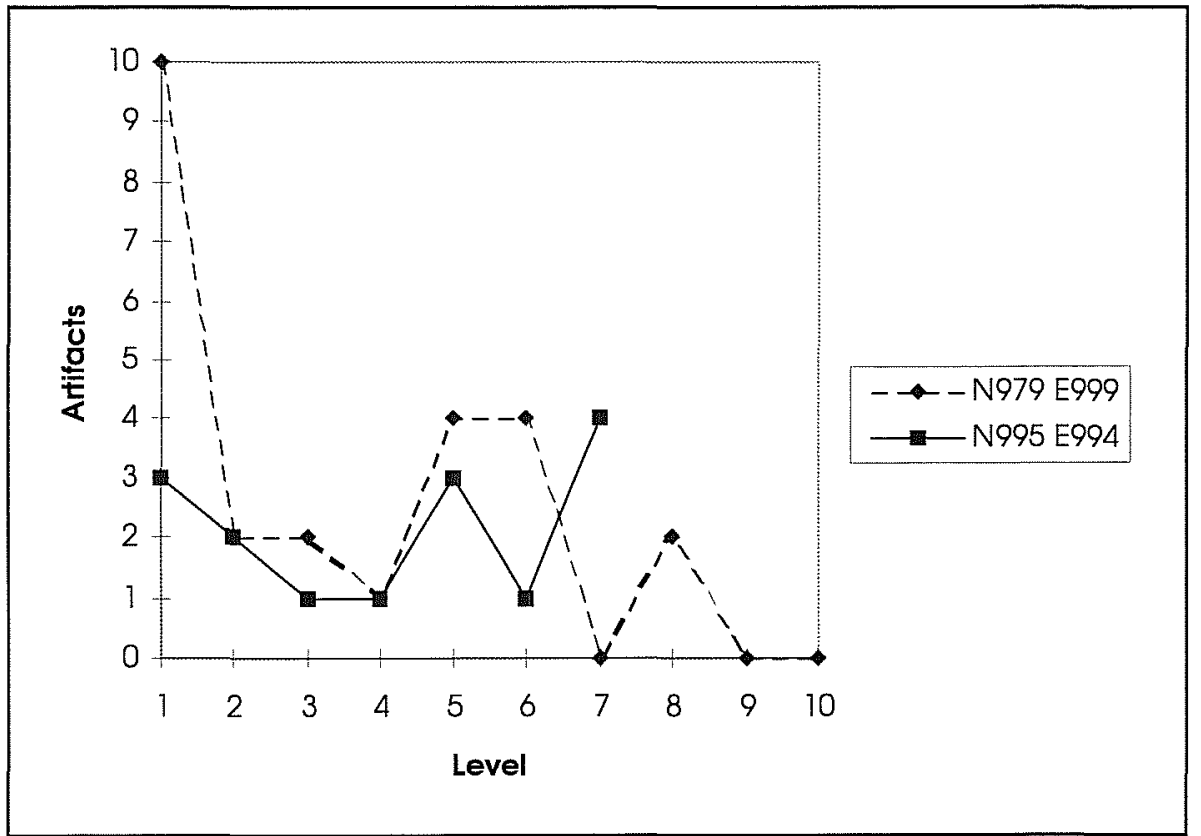

The site appears to be have been disturbed by a variety of impacts. There is evidence of artificial terracing of the hill slope, and the trees around the site are uniformly young suggesting that the area may have been completely cleared as recently as 10 to 15 years ago. A two-track road passes through the center of the site, indicating additional mechanical disturbance of the surface. The north and east boundaries of the site are now defined by areas of heavy disturbance delineated by two intersecting chain-link fences.

Figure 5-18. Distribution of debitage by excavated levels at 41BX1090.

The integrity of the surface deposits has been severely compromised by modern impacts and burning. The burning is evidenced by macroscopic pieces of charcoal and fire-cracked chert cobbles. Additionally, the subsurface deposits lack integrity due to the shrinkswell nature of the clayey sediments and the high probability of vertical movement of cultural material down the profile through desiccation cracks. The increase in subsurface material in each TU between 50 to $70 \mathrm{~cm}$ bs could be evidence for a buried component, but the artifact counts are extremely low.

\section{Previous Investigations}

While recording and mapping this site in 1995, CAR survey crews excavated one shovel test, inventoried one 5-m radius dogleash, and made a separate inventory of the surface artifacts across the site (Nickels et al. 1997). The shovel test was excavated to a depth of $30 \mathrm{~cm}$ and revealed no cultural material below the surface. The dogleash area contained 20 chipped stone artifacts, including one crude biface, eight cores, and 11 pieces of debitage. The inventory of artifacts outside the dogleash contained 18 chipped stone artifacts 


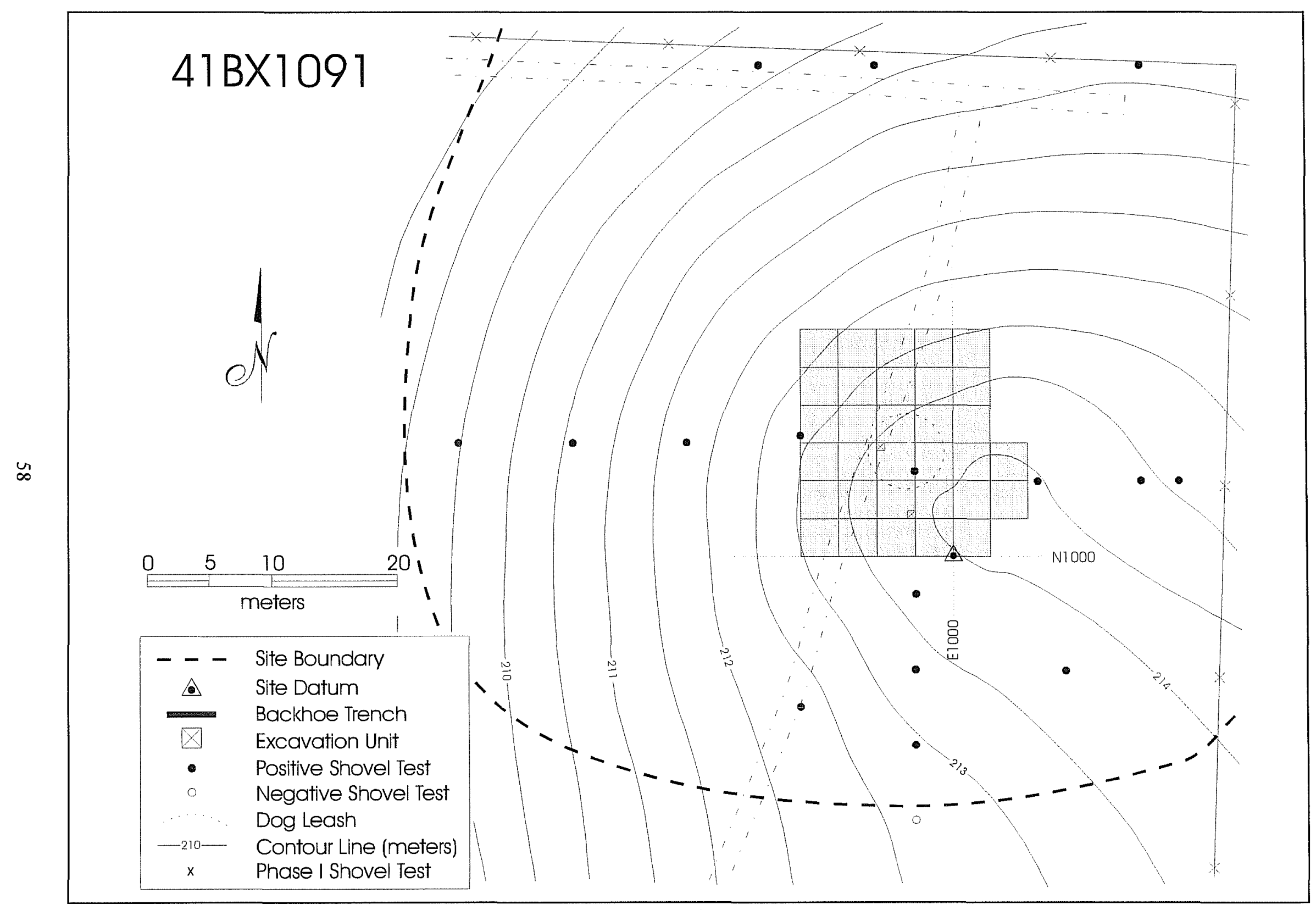

Figure 5-19. Site map, 41BX1091. Collection areas are represented by shading. 
and no fire-cracked rock fragments (Nickels et al. 1997).

\section{Level of Effort}

The investigations at 41BX1091 included site mapping, surface collecting, shovel testing, and excavating test units. Site boundaries were determined by surface scatter of cultural material, shovel test data, and the limits of disturbed areas north and east of the site. Approximately $1,000 \mathrm{~m}^{2}$ of brush were cleared to allow for the placement of $32 \mathrm{CUs}\left(800 \mathrm{~m}^{2}\right)$ in the area of the greatest artifact concentrations. Seventeen shovel tests were excavated to determine site depth and extent. Two test units were excavated within the boundaries of the CUs. No backhoe trenching was performed at the site, but the project geomorphologist examined the two test units.

\section{Site Size and Depth}

The survey crew that originally recorded 41BX1091 estimated the size of the site to be $540 \mathrm{~m}^{2}$ (Nickels et al. 1997), but with the vegetation cleared the testing project determined that the part of the site remaining intact covers at least $9,500 \mathrm{~m}^{2}$. While most of the site is characterized by very low artifact density, a concentrated area corresponding approximately to the originally recorded site boundaries covers $400 \mathrm{~m}^{2}$. Cultural material appears to be eroding downslope to the west, making it difficult to determine the extent of the site in that direction. The western boundary has been drawn somewhat arbitrarily based on a decrease in surface artifact density.

Cultural material was encountered to a depth of $52 \mathrm{~cm}$ bs in one shovel test (N1016 E980). In TU N1005 E994, artifacts were found as deep as $40 \mathrm{~cm}$; below that depth the deposits became culturally sterile.

\section{Testing Results}

\section{Geoarchaeological Assessment}

Sediments observed in TUN1005 E994 were very dark grayish brown, with numerous matrix-supported pebbles down to a depth of $50 \mathrm{~cm}$ (Figure 5-20). Relict calcium carbonate rinds completely encased many of the pebbles, regardless of depth. Matrix-supported pebbles, relict calcium carbonate rinds, and stratigraphic position suggest that sediments in the area were colluvially derived Uvalde Gravels on the edge
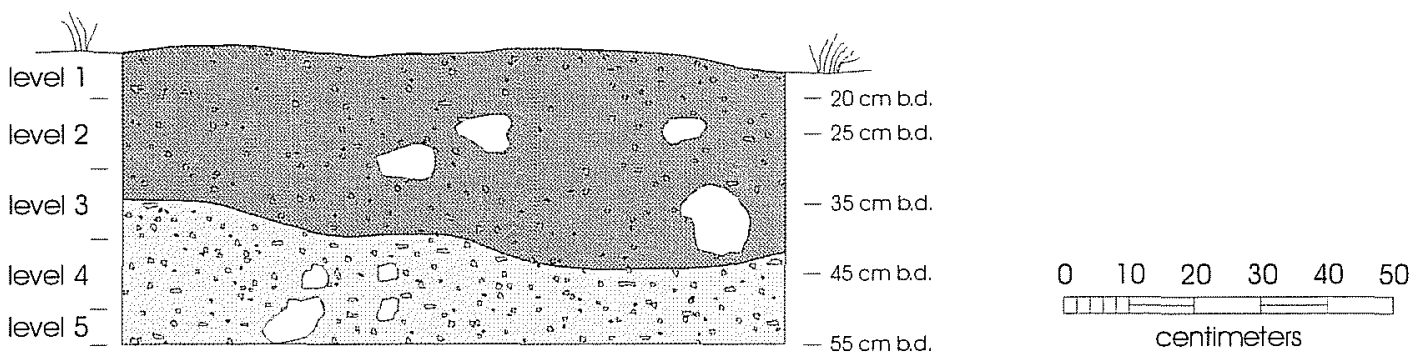

$$
\begin{aligned}
& \text { UJa Unmodified rock } \\
& \text { Dark grayish-brown soil matrix with } 20 \% \text { gravels. } \\
& \square \text { Light yellowish-brown soil matrix with } 80 \% \text { gravels. }
\end{aligned}
$$

Figure 5-20. West wall profile of N1005 E994, 41BX1091. 
of the adjacent High Upland surface near 41BX1088. The degree of pedogenesis indicates an early to middle Holocene age for deposition at 41BX1091, similar to that in BHT G at site 41BX1114. Considering a Holocene age, the area around site 41BX1091 has potential for site burial, but perhaps not in a primary context because of the environment of deposition.

\section{Archaeological Investigations}

The testing at 41BX1091 did not locate any features, but two diagnostic artifacts were recovered (Figure 5-21). The first, a Scallorn point (UI 2), was found during the surface collecting of the 32 CUs at the site,

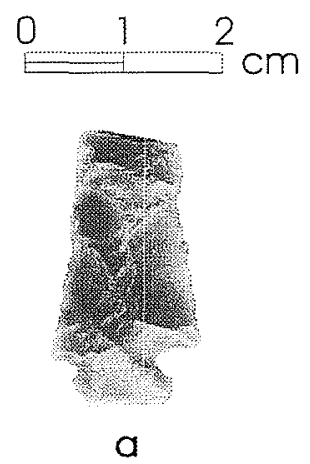

(UI 2)

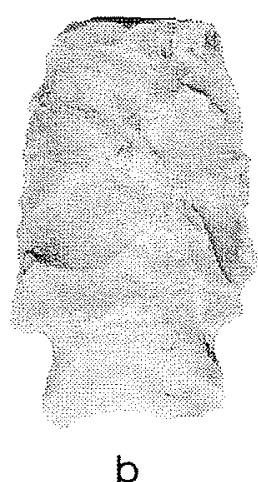

(UI I)
Figure 5-21. Projectile points from 41BX1091. a: Scallorn point (UI 2); b: Fairland point (UI 1).

and the second, a Fairland point (UI 1), was encountered in Level 2 of TUN1014 E990. Both points were proximal fragments apparently broken through use.

A total of 2,844 prehistoric artifacts was recovered from 41BX1091 (Table 5-10), the majority $(n=2,388$, 90 percent) of which was debitage. Cores accounted for the second largest artifact class with 409 specimens accounting for 14 percent of the total assemblage. The other chipped stone artifacts were 25 early stage bifaces, 4 expedient unifaces, 13 minimally retouched flakes, and 2 formal unifaces.
Table 5-10. Artifacts from 41BX1091

\begin{tabular}{|l|r|r|r|r|}
\hline \multicolumn{1}{|c|}{ Artifact Type } & Surface & TUs & S Ts & Total \\
\hline Debitage & 1906 & 350 & 132 & 2388 \\
\hline Bifaces & 23 & 2 & 0 & 25 \\
\hline Unifaces & 17 & 2 & 0 & 19 \\
\hline Cores & 386 & 13 & 10 & 409 \\
\hline Projectile Points & 1 & 1 & 0 & 2 \\
\hline Ground stone & 0 & 1 & 0 & 1 \\
\hline \multicolumn{1}{r|}{ Total } & $\mathbf{2 3 3 3}$ & $\mathbf{3 6 9}$ & $\mathbf{1 4 2}$ & $\mathbf{2 8 4 4}$ \\
\hline
\end{tabular}

The majority of the material was recovered from the 32 CUs placed at the site. The surface collection accounted for 1,906 pieces ( 80 percent of the total) of debitage, 23 of the 25 bifaces, 386 cores (94 percent of total), and 17 of 19 unifaces. The material was markedly concentrated in the south half of the collection area. This is best reflected in the distributions of debitage (Figure 5-22) and cores (Figure 5-23) across the sampled portion of the site.

The two $1-\mathrm{x}-1-\mathrm{m}$ units and 17 shovel tests accounted for 742 pieces of debitage, 2 bifaces, 23 cores, 2 unifaces, and 1 piece of ground stone. No features were encountered in either excavated test unit. The quantities of debitage recovered from the first level of each unit mirror the surface distribution of debitage across the collection area. In TUN1005 E994, 188 pieces of debitage were collected from the first excavated level as opposed to 38 from the first level of TU N1014 E990. The amount of debitage decreased dramatically with depth in N1005 E994 (Figure 5-24). The single piece of ground stone (UI 3) was recovered from Level 4 of TU N1014 E990. It is a chert cobble with extensive, but unevenly distributed, polish on its faces. In each unit, excavations were terminated between 45 and $55 \mathrm{~cm}$ bs in a culturally sterile layer of matrixsupported gravels.

Ten flotation samples were collected during the excavations at 41BX1091; one from each excavated level of both units. Based on the geoarchaeological assessment of the site and the results of the analysis of samples from 41BX1114, another upland site, the samples from 41BX1091 were not analyzed. 


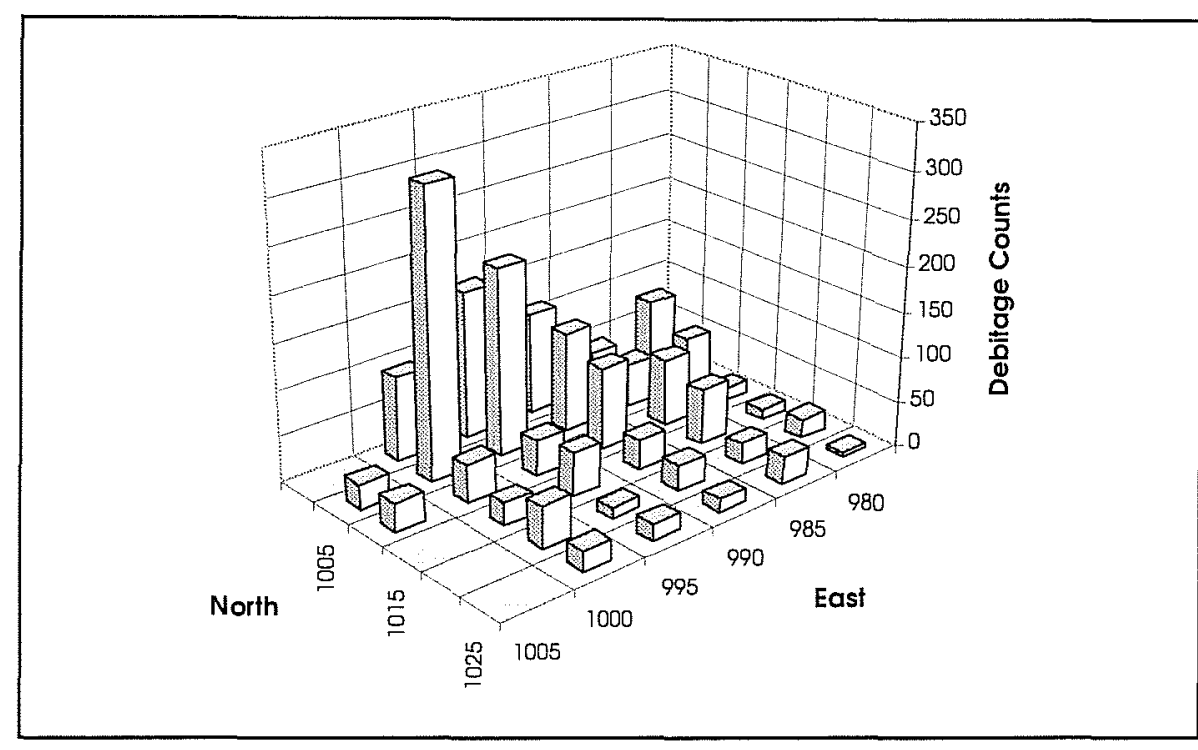

Figure 5-22. Distribution of debitage in surface collection area at $41 B X 1091$.

Figure 5-23. Distribution of cores in surface collection area at $41 B \times 1091$.
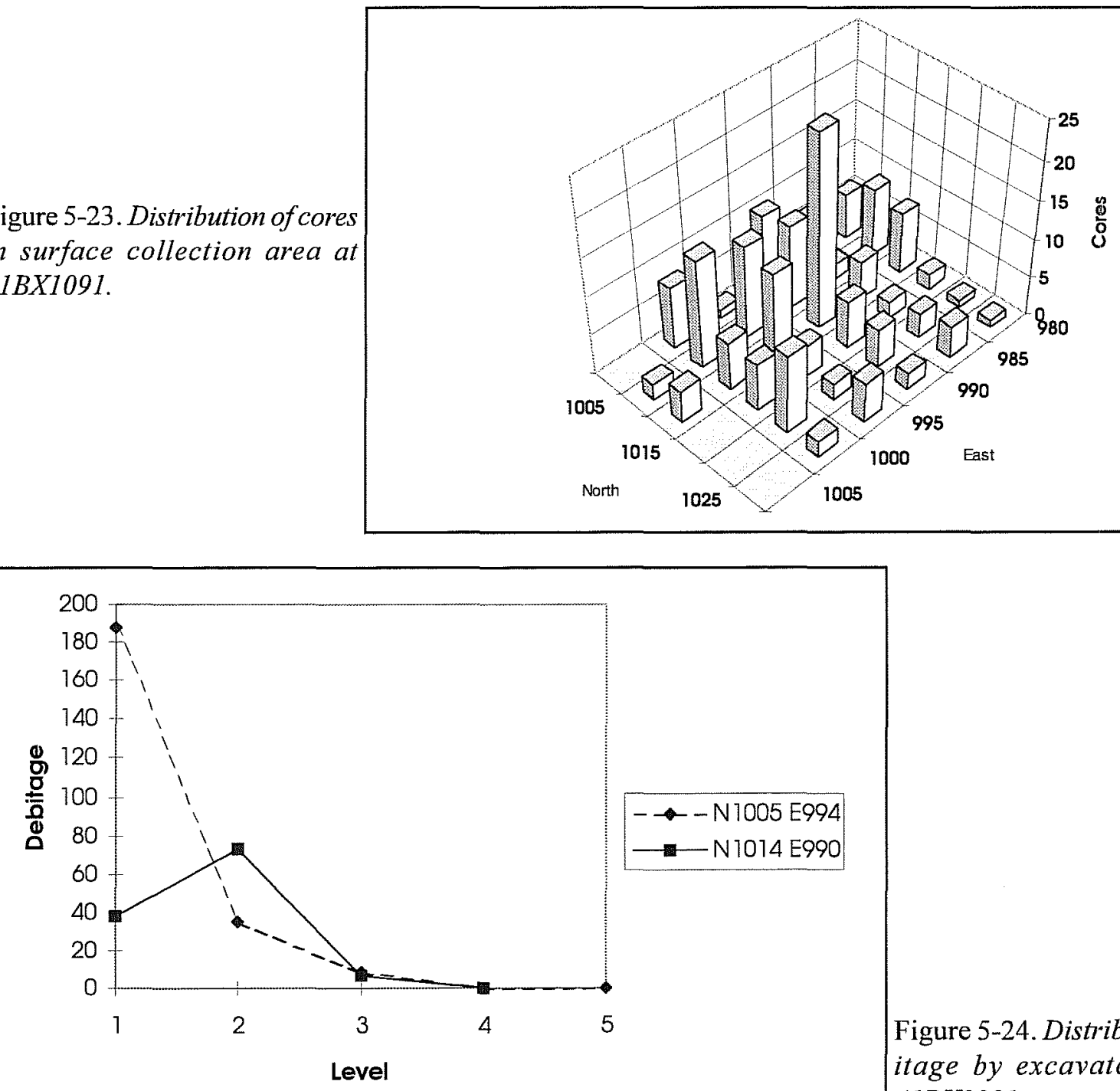

Figure 5-24. Distribution of debitage by excavated level at $41 B X 1091$. 


\section{Discussion}

The two diagnostic artifacts recovered at 41BX1091, a Fairland point and a Scallorn point, date to the Transitional Archaic and Late Prehistoric, respectively. No other dateable materials or diagnostic artifacts were recovered. The surface integrity at $41 \mathrm{BX} 1091$ has apparently been diminished due to previous brush clearing activities, possible terracing of the hill slope, and the presence of a two-track road through the center of the site.

While cultural material, including the Fairland point, was recovered within the subsurface gravels from both TUs, the possibility of encountering buried deposits in primary contexts is low based on the geoarchaeological assessment of the site. The dramatic decrease in debitage with depth implies that 41BX1091 is a surface site with material working its way downward by falling into desiccation cracks or being transported by bioturbation.

\section{Medina Annex Dog Training Area (Alternate 2)}

\section{Site 41BX1070}

\section{Site Setting}

$41 \mathrm{BX} 1070$ is a small site (Figure 5-25) marked by a light surface scatter of lithic debris, located on the Intermediate Upland surface near the contact point between the uplands and the T1 flood terrace of Medio Creek, $200 \mathrm{~m}$ to the southwest. There is an intermittent drainage approximately $25 \mathrm{~m}$ to the north of the site. Dense grasses, agarita, and assorted cacti are present under a sparse scatter of mature mesquite and hackberry trees. The site is located in an active military dog training area, but was not believed to have been subjected to much artificial disturbance at the time of its initial discovery (Nickels et al. 1997). Rutted tracks from a small four-wheeled vehicle that were not present when the site was originally recorded mark an area of severe, but shallow, impact. The site is located on a slope and is presumably subjected to downslope erosion.

\section{Previous Investigations}

41BX1070 was first located during the 1994-1995 CAR survey of Lackland Air Force Base (Nickels et al. 1997). While recording and mapping this site in 1995, CAR staff observed only eight artifacts across the entire surface, five of which were cores. No temporally diagnostic artifacts were found at the site. The one shovel test excavated at the site did not reveal any subsurface cultural material (Nickels et al. 1997).

\section{Level of Effort}

Based on the recommendation of the THC project reviewer, the scope of work at $41 \mathrm{BX} 1070$ was reduced from a proposed surface inventory/assessment and excavation of two test units to the excavation of a single backhoe trench. Therefore, the site was mapped using the total station, and BHT A was excavated to a depth of approximately $112 \mathrm{~cm}$ below surface. The trench was examined by the project geomorphologist, and a 50-gallon sample of backdirt (from the upper $25 \mathrm{~cm}$ of the deposit) was screened through $1 / 4$-inch mesh to characterize the artifact assemblage at the site.

\section{Site Size and Depth}

The site was believed to cover a $300-\mathrm{m}^{2}$ area based on the survey assessment (Nickels et al. 1997), but the extent of the scattered debitage, cores, and tested cobbles mapped during the testing project indicate that the site is approximately $2,650 \mathrm{~m}^{2}$ in area. A few chert flakes were visible in the trench profile, but were confined to the upper $10-15 \mathrm{~cm}$ of the trench.

\section{Testing Results}

\section{Geoarchaeological Assessment}

In BHT A (Figure 5-26), $108 \mathrm{~cm}$ of colluvium buried Cretaceous bedrock (Appendix A). The colluvium consisted of very dark grayish brown and very dark gray clay loams and clays with matrix-supported pebbles and cobbles. Minimal pedogenesis and gra- 


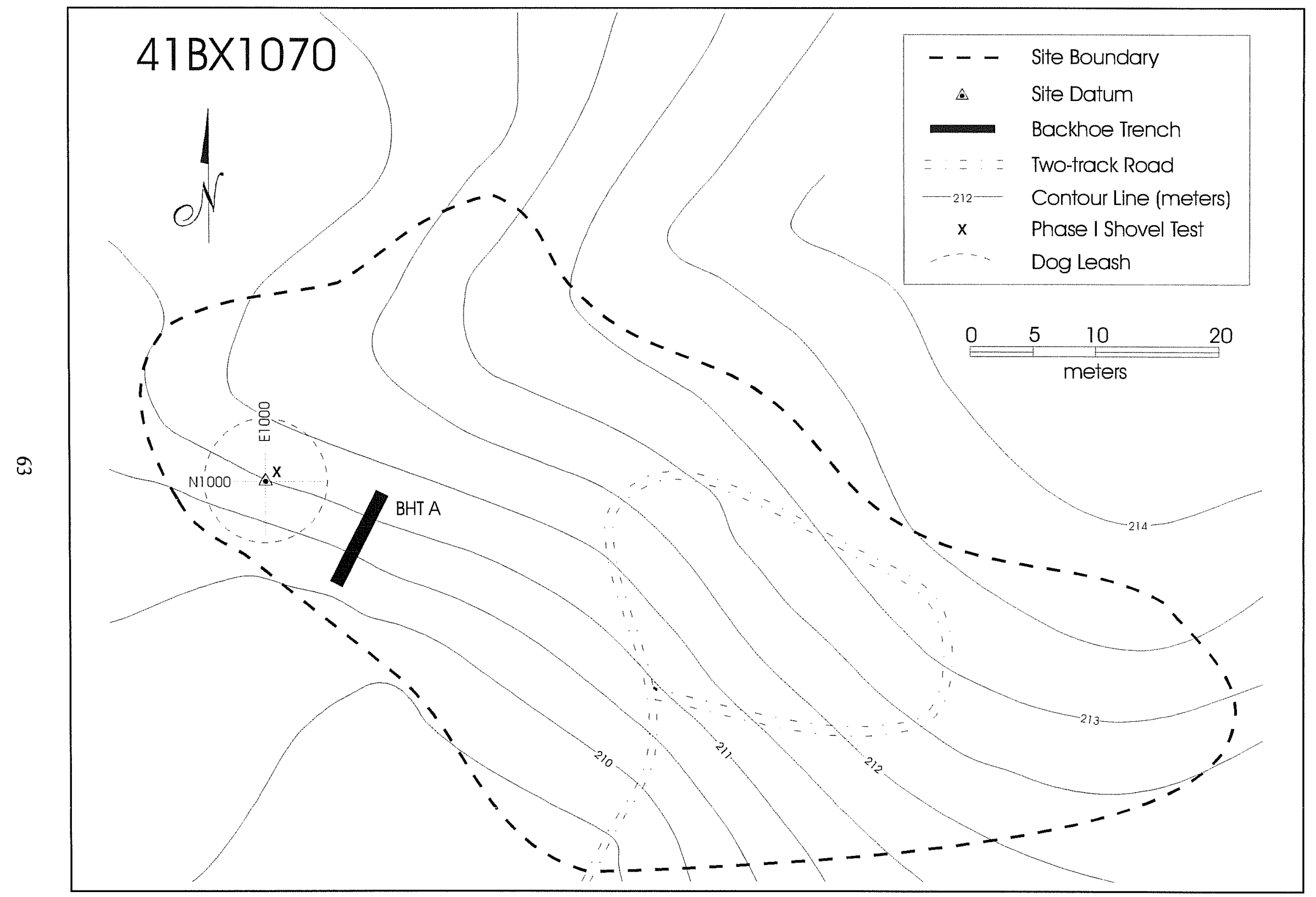

Figure 5-25. Site map, 41BX1070. 


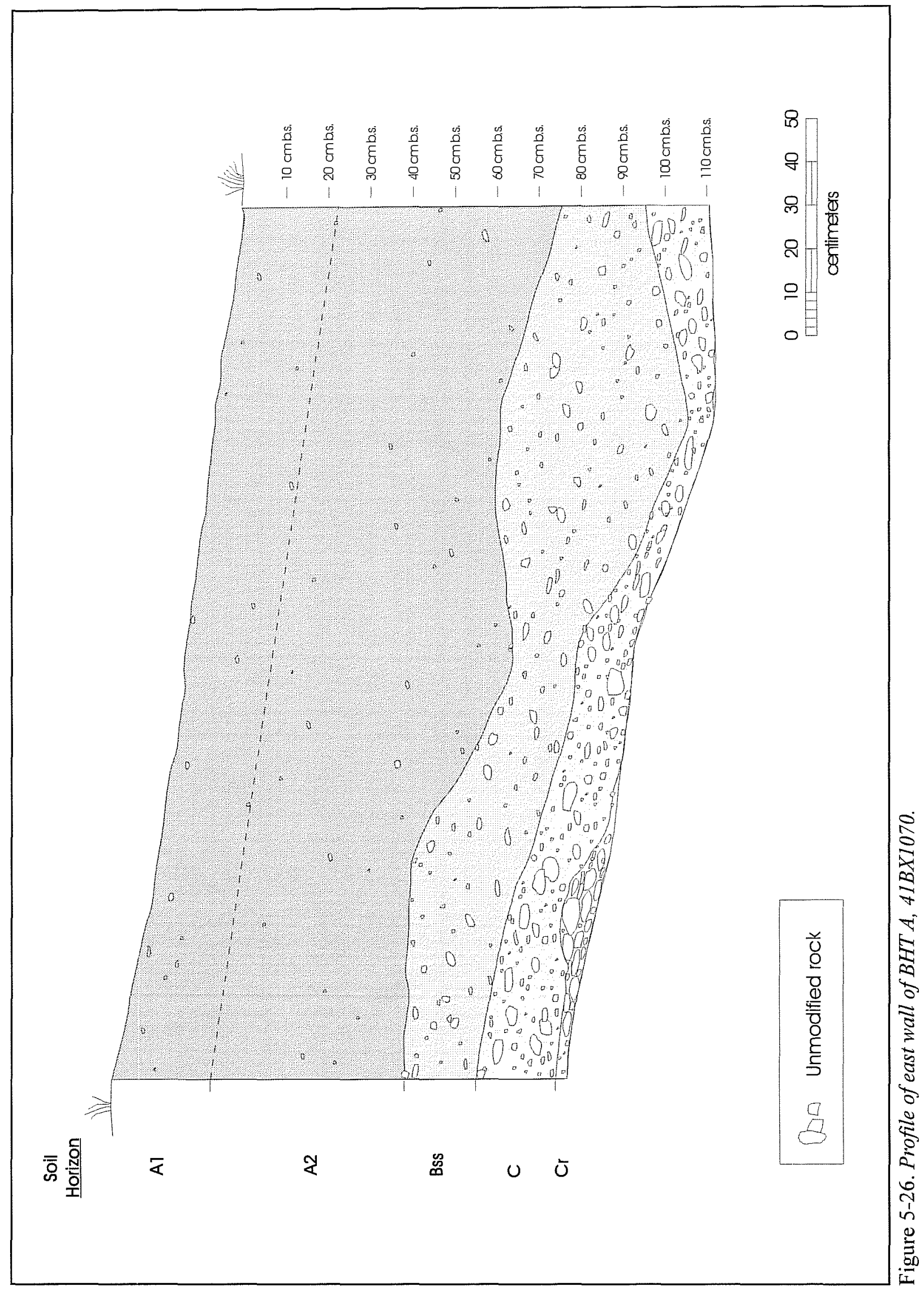


dation of the surface down to the T1 flood terrace suggest a Holocene age for this deposit. Consequently, there could be buried artifacts at site 41BX1070. However, a colluvial depositional environment with matrix-supported pebbles and cobbles may mitigate against site preservation in primary contexts. Surface components of the site will probably be no older than Middle Archaic.

\section{Archaeological Investigations}

The extent of the artifact scatter on the surface was mapped during the 1996 testing, but neither a collection nor an inventory was made of the materials present. The scatter consisted of tested cobbles, cores, and early stage reduction flakes. No projectile points, bifaces, unifaces, or cultural features were found during the inspection of the surface. BHT A, the only excavation unit placed at the site, did not encounter any buried features.

From the 50 gallons of backdirt which were screened, four incomplete flakes, one complete flake, and one core were recovered. No bifaces, unifaces, or projectile points were recovered from the trench walls or the screened sample.

\section{Discussion}

The limited data available from the survey and testing investigations performed at $41 \mathrm{BX} 1070$ suggest that the site was used as a location from which to procure and at which to test naturally occurring chert cobbles. The surface scatter of chert cobbles and artifacts terminates abruptly at the base of the slope where the Intermediate Upland surface is buried by the younger T1 flood terrace of Medio Creek. Because the scope of work limited the investigations to a single backhoe trench, the T1 terrace was not investigated. Therefore, the possibility of buried deposits below the contact line between the terrace and the Intermediate Upland surface can not be dismissed. Unfortunately, the lack of diagnostic artifacts and dateable features make it currently impossible to determine the time frame during which the site was visited by prehistoric groups, although the geomorphology of the site suggests that the surface components are Middle Archaic or younger. With respect to the integrity of surface and subsurface deposits on the Intermediate Upland surface, the geoarchaeological assessment of the site indicates that there is little chance for encountering buried deposits in primary contexts given the environment of colluvial deposition. Furthermore, the possible temporal range for surface materials is Middle Archaic to Historic, suggesting that the likelihood of finding isolable components with chronological integrity is low.

\section{Site 41BX1102}

\section{Site Setting}

Site $41 \mathrm{BX} 1102$ is situated on the T1 flood terrace adjacent to the elongated channel depression identified at site 41BX1103 (Figures 5-27; see Chapter 4). The western half of the site has been cleared for use as a military dog training area. Heavy grasses in that area are mowed regularly. Vegetation on the eastern half of the site consists of grasses and leaf litter under a closed canopy of mesquite, persimmon, and hackberry. Raw materials in the form of chert cobbles are present on the surface in the relatively undisturbed eastern half of the site.

The site has been subjected to several artificial impacts. The most extensively impacted area is the clearing where military dogs are walked each morning before their training exercises. Prior to the creation of this cleared area, the entire site was presumably covered in mesquite, persimmon, and hackberry trees. Piles of soil around the margin of the cleared area suggest that the trees and undergrowth were removed by mechanical means which would have disturbed the surface and upper level of subsurface deposits. The area is regularly subjected to vehicle traffic, although this impact presumably has little effect since it is confined to the already-disturbed areas of the site.

Other artificial impacts to the site were also documented during the testing project. A drainage ditch was excavated between the site and the dog kennels to the southwest. While the date of the construction of this feature is not known, it is probably related to 
This page has been

redacted because it

contains restricted

information. 
the development of the base. A small concrete slab and associated debris (including auto parts and oil cans) in the overgrown east end of the site suggest that the area was used to service vehicles sometime between 1950 and 1970. Finally, segments of the natural, elongated channel depression separating 41BX1102 from 41BX1103 were used as a concrete and sheet rock dumping area.

Animal burrowing is presumably a major natural source of disturbance. Desiccation cracks and vegetation growth also occur across the site, and could result in the vertical transportation of artifacts from the surface.

\section{Previous Investigations}

While originally recording the site in 1995, CAR archaeologists found a Pedernales point on the surface at the east end of the site (Nickels et al. 1997). Other cultural material observed on the surface included flakes, cores, and fire-cracked rock. Investigations at the site included two shovel tests and three 5-m radius dogleashes, all located within the eastern half of the site (Figure 5-28). One shovel test revealed artifacts to $20 \mathrm{~cm}$ bs. This was followed by a sterile zone, after which cultural debris was again recovered at $50-60 \mathrm{~cm}$ bs. An inventory of all artifacts within the three dogleashes suggested that late-stage reduction activities occurred at 41BX1102 (Nickels et al. 1997).

\section{Level of Effort}

The testing investigations at $41 \mathrm{BX} 1102$ included site mapping, surface collecting, shovel testing, backhoe trenching, and excavating test units. Site boundaries were determined by surface scatter of cultural material, shovel test data, and the locations of disturbed areas south and west of the site. Approximately $1,500 \mathrm{~m}^{2}$ of brush was cleared to allow for the placement of 32 CUs $\left(800 \mathrm{~m}^{2}\right)$ in the largely undisturbed, wooded area of the site (Figures 5-27 and 5-28). Twenty-one shovel tests were excavated to determine site depth and extent. Two TUs, N1000 E1005 and N1005 E1015, were excavated within the boundaries of the CUs. A third TU, N1050 E970, was excavated in the disturbed cleared area at the west side of the site.

Nine backhoe trenches were excavated at 41BX1102 in two stages of investigations. First, BHT E was excavated during the current geomorphological study of the project area. Based on Nordt's conclusion that the site had the potential to contained buried Early Archaic deposits (see below), eight additional trenches were excavated across the site. This second phase of trenching used a backhoe with a smooth bucket to remove shallow layers of soil, concentrating on the older parts of Unit II where Early Archaic deposits had the potential to be encountered. One of these trenches, BHT M, was later described by Nordt during a second trip to the project area.

\section{Site Size and Depth}

The part of 41BX1102 remaining intact (assuming some of the site was destroyed during the construction of the ditch to the southwest) covers approximately $13,975 \mathrm{~m}^{2}$. This is over 13 times the originally estimated site size. Were it not for a narrow corridor devoid of artifacts, 41BX1102 would join 41BX1103 to the northwest (Figure 5-27).

Although artifact counts were generally low, cultural material was recovered in each excavated level of the three test units. The maximum depth tested was $100 \mathrm{~cm} \mathrm{bs}$, but the geoarchaeological assessment of the site indicates that a potential for buried archaeological materials in a primary context below this depth exists. However, no such deep archaeological components were encountered during backhoe trenching.

\section{Testing Results}

\section{Geoarchaeological Assessment}

BHT E (Figure 5-29 and Figure 5-30), BHT M, and TU N1050 E970 were examined in this area. In these units, Unit II deposits were exposed, five meters above the modern low-water channel of Medio Creek. An erosional scarp connects the occupation surface of site $41 \mathrm{BX} 1102$ to the elongated channel northeast of 


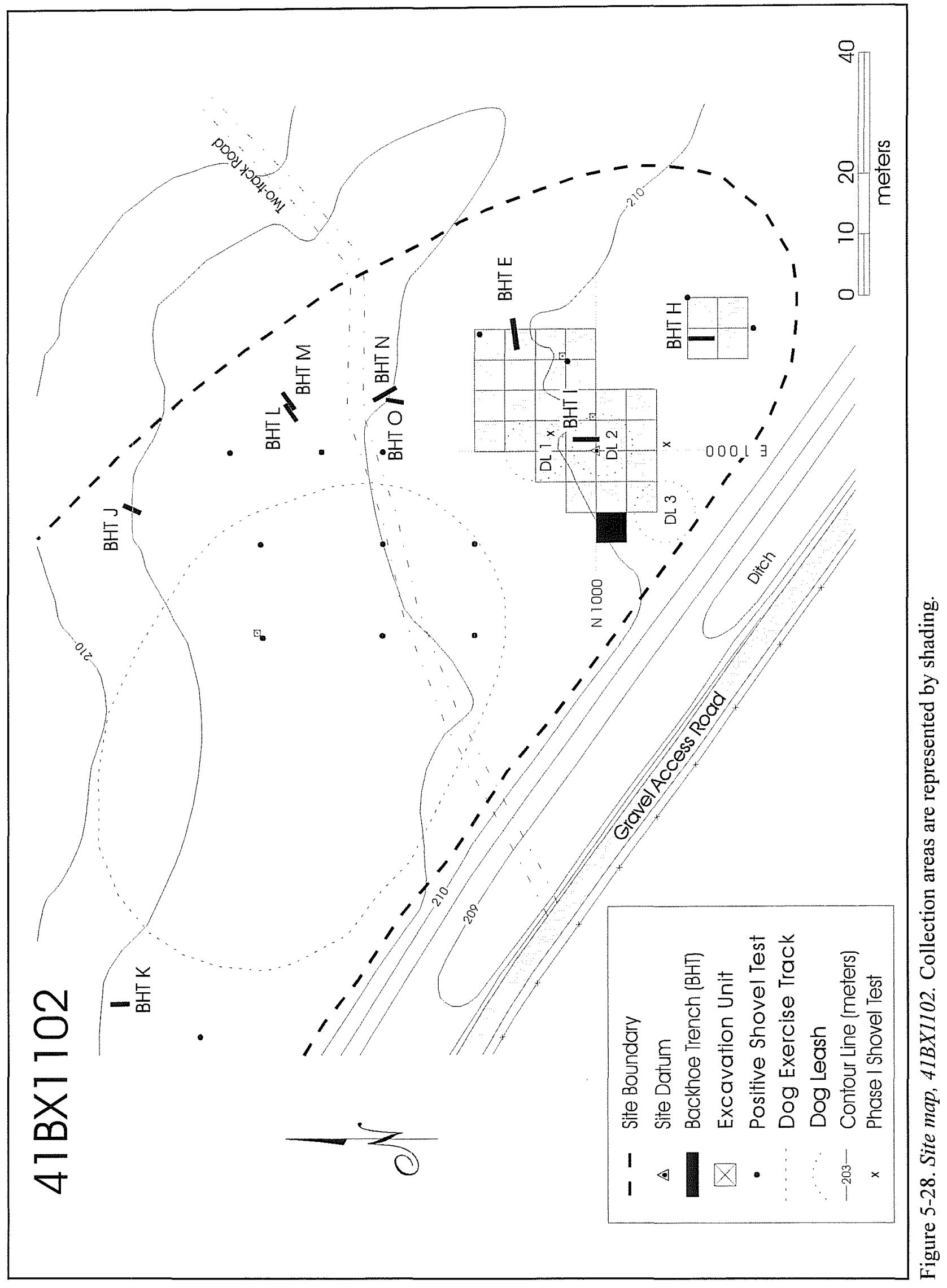


This page has been

redacted because it

contains restricted

information. 


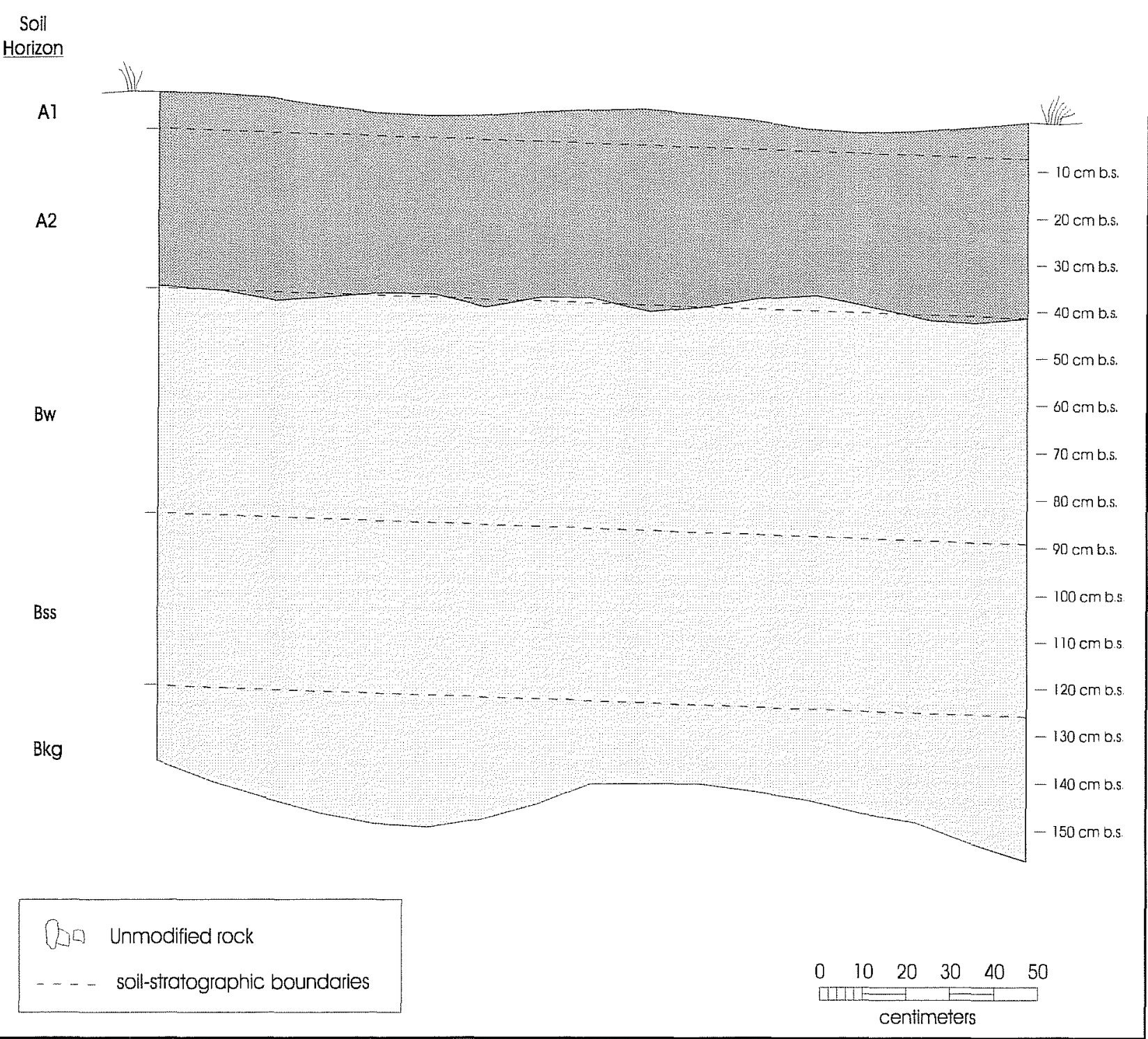

Figure 5-30. Profile of north wall of BHT E, 41BX1102.

BHT E (Figure 5-27). The scarp and Unit II sediments appear to have been eroded by the unnamed tributary or Medio Creek at the same time that the Unit III gravel bar was deposited at 41BX1103 (discussed below). Fine-grained sediments with few matrix-supported pebbles (Appendix A) indicate deposition in a flood basin facies by a low-order stream subjected to occasional high-magnitude and perhaps flashy channel discharge. Occasional large magnitude floods probably deposited the pebbles, with flood recession depositing the fine-grained matrix particles. In contrast, a greater abundance of gravels in BHT M may represent a remnant of a channel facies of Unit II. Signifi- cant calcium carbonate accumulation in the subsoil suggests an age similar to the sediments exposed in BHT E.

Time-diagnostic artifacts discovered at 41BX1102 were generally confined to the surface and ranged in age from 4400 to 2600 B.P. (see discussion below). One dart point was discovered in a vertical position at a depth of approximately $50 \mathrm{~cm}$, but along with historic glass, suggesting mixing by biological activity or from materials falling into desiccation cracks. Because Unit II deposition terminated by 3500 B.P., surface cultural components could range from Middle 
Archaic to Historic in age. Based solely on environment of deposition, the probability of finding buried components in a primary context is high at $41 \mathrm{BX} 1102$.

\section{Archaeological Investigations}

Testing at $41 \mathrm{BX} 1102$ recovered 12 projectile points (Figure 5-31). Seven are Pedernales points and two are Pedernales preforms. The remaining three dart points are untypable. With the exception of one Pedernales point, all the projectile points were found on the surface of the site. No other diagnostic artifacts were encountered during the testing. Additionally, no features were noted at the site.

The testing recovered a total of 2,042 pieces of chipped stone (Table 5-11). The bulk of this assemblage is debitage, with 1,753 total pieces. The other artifacts recovered included 78 bifaces, 50 unifaces, and 149 cores. A ground stone mano was also recovered from the site.

The majority ( 68 percent) of this material was recovered during the surface collecting phase of investigations. This included 1,127 pieces of debitage, 67 bifaces, 44 unifaces, 139 cores, and the mano. The distribution of debitage varies across the site (Figure 5-32). The largest quantity of debitage from a single $\mathrm{CU}$ was 90 pieces, recovered at N1010 E1005 in the north half of the collection area.

This variation in artifact distribution densities is mirrored in the distribution of projectile points (Figure 5-33). Other non-debitage artifacts, however, were more concentrated in CUs in the center of the collec- tion area (Figure 5-34). No isolable clusters of artifacts were recognized during the surface collection, nor were any recognizable burned rock features present. Although burned rock was present in most units, it was generally found in low densities.

Two test units were located within the surface collection area, and a third was excavated in the cleared dog training area. While the excavations did not encounter any subsurface features, a Pedernales point was recovered at $51 \mathrm{~cm}$ bs in Level 6 of N1005 E1015. This was the only diagnostic artifact found during the subsurface testing.

Even though no features were encountered, the distribution of debitage by excavated level reveals an important pattern (Figure 5-35). Debitage counts within the two excavation units (N1000 E1005 and N1005 E1015) located within the collection area in the undisturbed eastern part of the site decrease between Levels 1 and 3, before increasing dramatically in Levels 4 and 5 . In each case, the amount of debitage in Level 5 is more than twice as high as in Level 1. Debitage counts decrease in Level 6 of each unit before rebounding in Level 7, after which point they decrease once again. This suggests that $41 \mathrm{BX} 1102$ has a surface component that is separate from two buried components at ca. $50 \mathrm{~cm}$ and $70 \mathrm{~cm}$ below original ground surface.

Upon initial comparison, the data from N1050 E970, the test unit placed in the cleared area northwest of the collection units, do not seem to match this trend. If, however, it is assumed that approximately $10 \mathrm{~cm}$ of material was removed from this part of the site during mechanical brush clearing of the dog training area,

Table 5-11. Artifacts from 41BX1102

\begin{tabular}{|l|r|r|r|r|r|r|}
\hline \multicolumn{1}{|c|}{ Artifact Type } & Surface & TUs & STs & BHTs & IF & Total \\
\hline Debitage & 1127 & 341 & 166 & 119 & 0 & 1753 \\
\hline Bifaces & 67 & 2 & 1 & 7 & 1 & 78 \\
\hline Unifaces & 44 & 1 & 1 & 4 & 0 & 50 \\
\hline Cores & 139 & 2 & 0 & 8 & 0 & 149 \\
\hline Projectile Points & 11 & 1 & 0 & 0 & 0 & 12 \\
\hline Manos Total & 1 & 0 & 0 & 0 & 0 & 1 \\
\hline \multicolumn{1}{|r|}{} & $\mathbf{1 3 8 9}$ & $\mathbf{3 4 7}$ & $\mathbf{1 6 8}$ & $\mathbf{1 3 8}$ & $\mathbf{1}$ & $\mathbf{2 0 4 3}$ \\
\hline
\end{tabular}




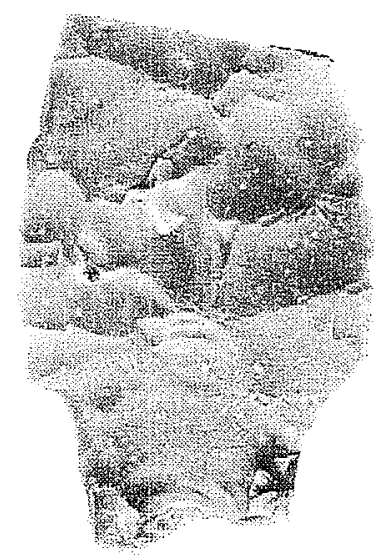

a

(UI 3)

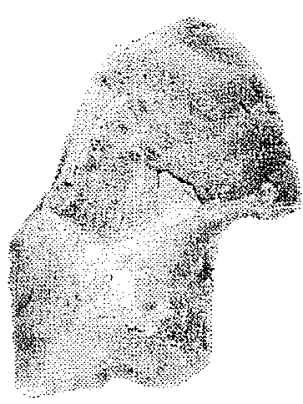

e

(U1 11)

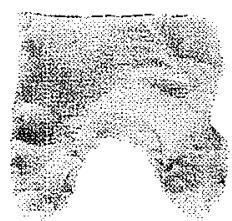

i

(U1 7)

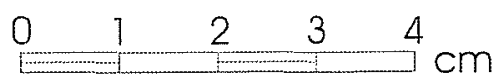

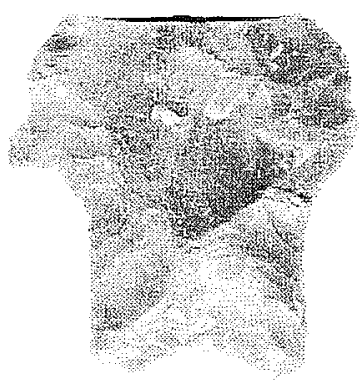

C

(UI 9)

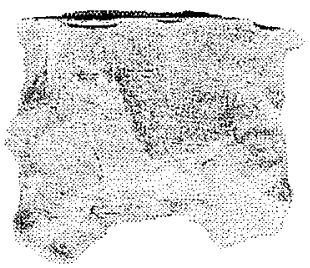

$g$

(UI 8)

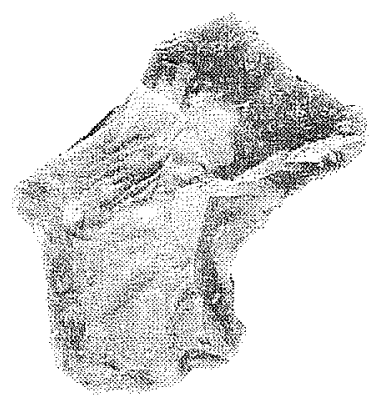

k

(UI 2)

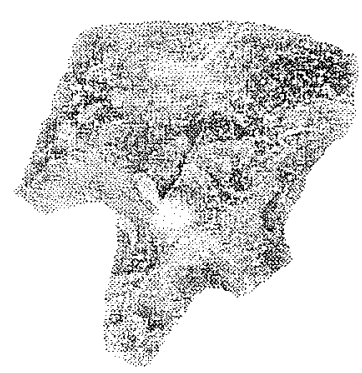

d

(UI 5)

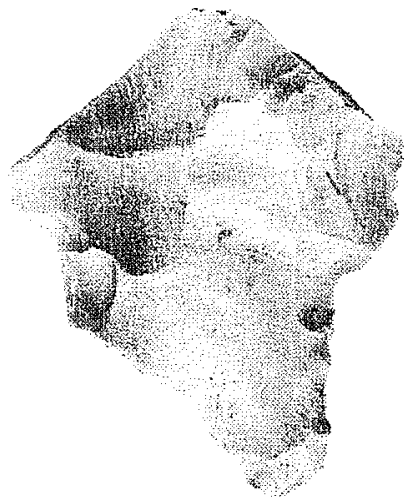

h

(UI 4)

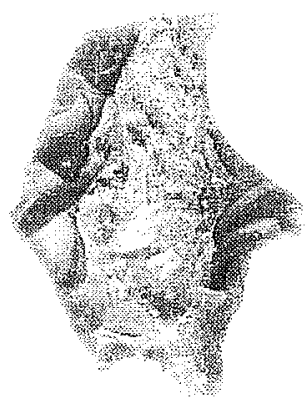

1

(UI 6)

Figure 5-31. Projectile points and preforms from 41BX1102. a-g: Pedernales points; $\mathrm{h}$, i: Pedernales preforms; $\mathrm{j}-\mathrm{l}$ : untypable dart point fragments.

it is possible to adjust the N1050 E970 data so that Level 1 is considered equivalent to Level 2 at the other units (Figure 5-36). When this operation is performed, all three units demonstrate similar patterns of debitage distribution with depth. 


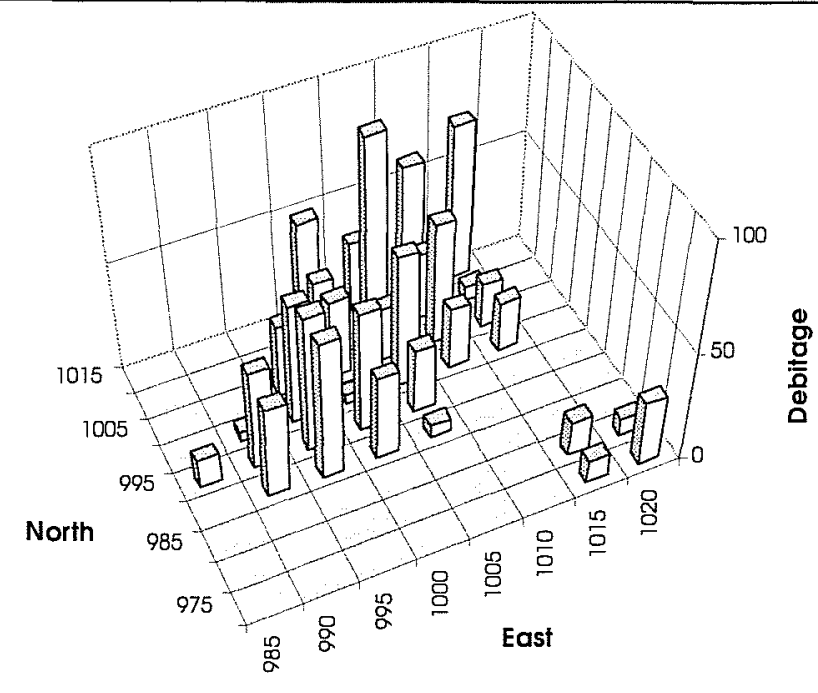

Figure 5-32. Distribution of debitage in surface collection area at $41 B X 1102$.

Figure 5-33. Distribution of projectile points in surface collection area at $41 B X 1102$.
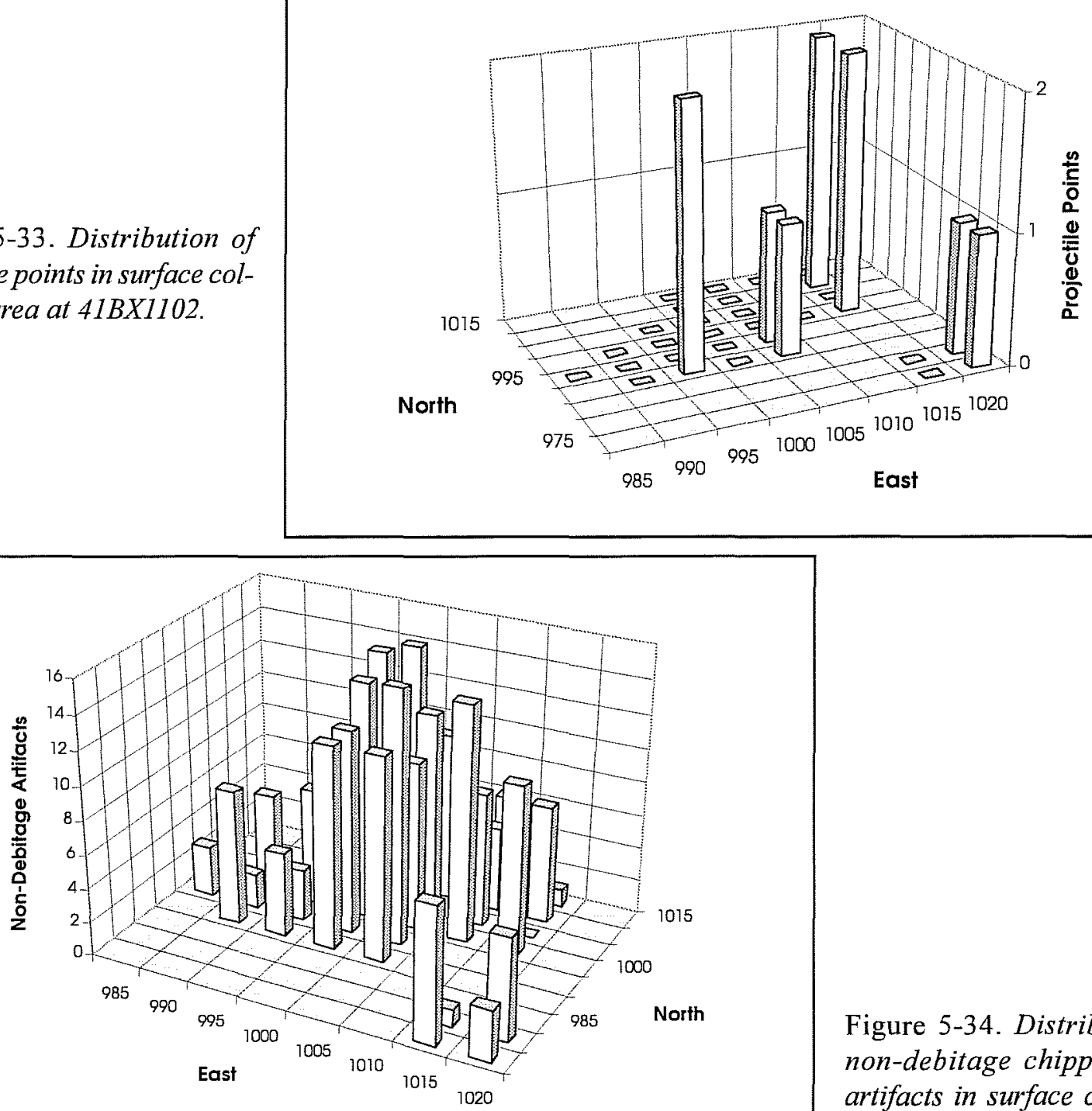

Figure 5-34. Distribution of non-debitage chipped stone artifacts in surface collection area at $41 B X 1102$. 


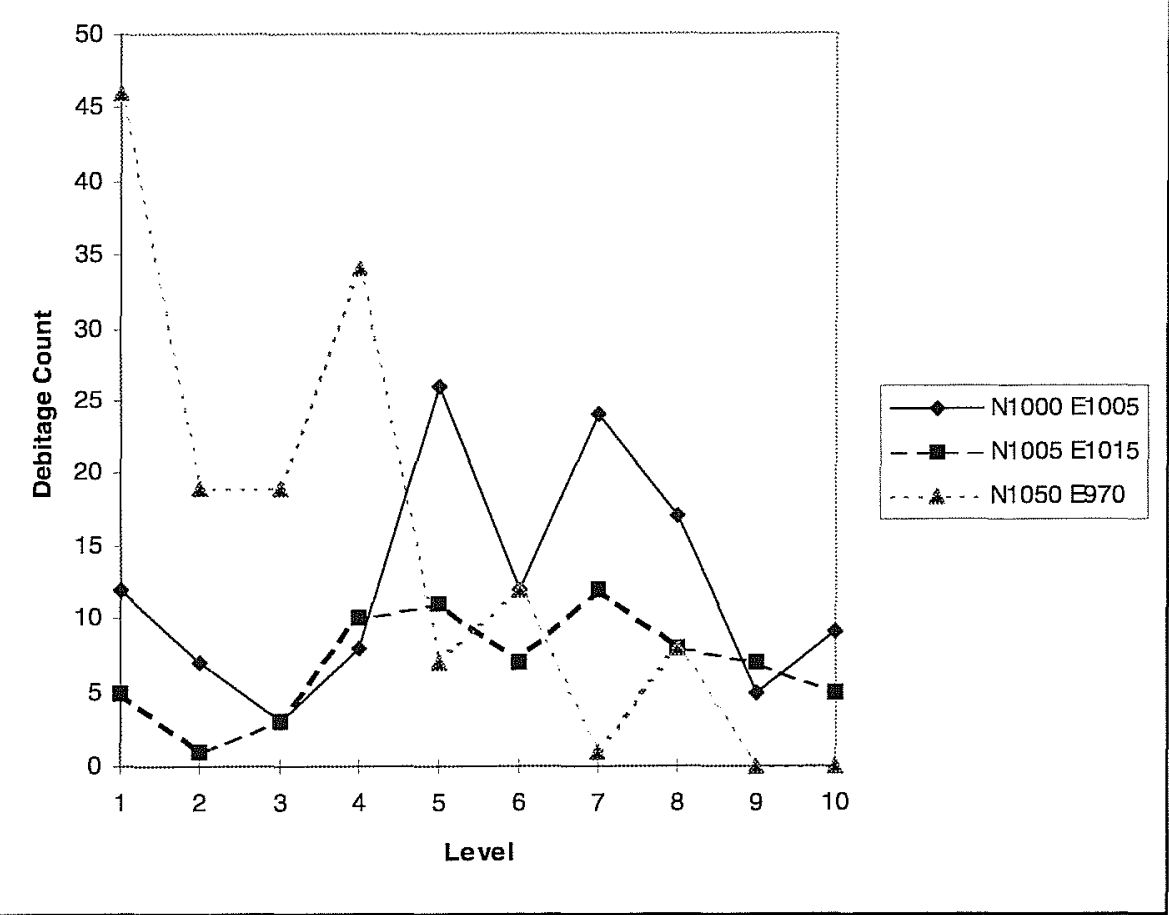

Figure 5-35. Distribution of debitage by excavated levels for TUN1000 E1005 and TUN1005 E1015 at 41BX1102.

The primary concern over the integrity of the subsurface deposits at $41 \mathrm{BX} 1102$ is based on the presence of modern broken glass fragments at depth in TU N1000 E1005 and TU N1005

E1015. These pieces of glass, though low in number, indicate that material from the surface of the site is moving downward through vertical desiccation cracks. Such cracking was observed during the testing project which occurred during an extended drought. Glass was encountered as deep as Level 7 in TU N1000 E1005. However, at other sites with apparent vertical movement of material, such as $41 \mathrm{BX} 1088$ discussed above, the decrease in debitage with depth is fairly dramatic and continuous. The clear increase in debitage counts in Levels 4, 5, and 7 at 41BX1102 implies that mate- rial was previously buried at depth.

Twenty flotation samples were collected at 41BX1102; one from each excavated level of N1000 E1005 and N1005 E1015. Each of these samples was processed at CAR and scanned for macrobotanical remains. Neither the light nor heavy fractions of these 20 samples were found to contain macrobotanical remains.

\section{Discussion}

During the survey and testing projects, eight Pedernales points and two Pedernales preforms were recovered at $41 \mathrm{BX} 1102$, all from the eastern part of the site. The remaining three projectile points were untypable and are therefore not temporally diagnostic. No features were encountered on the surface or during subsurface testing.

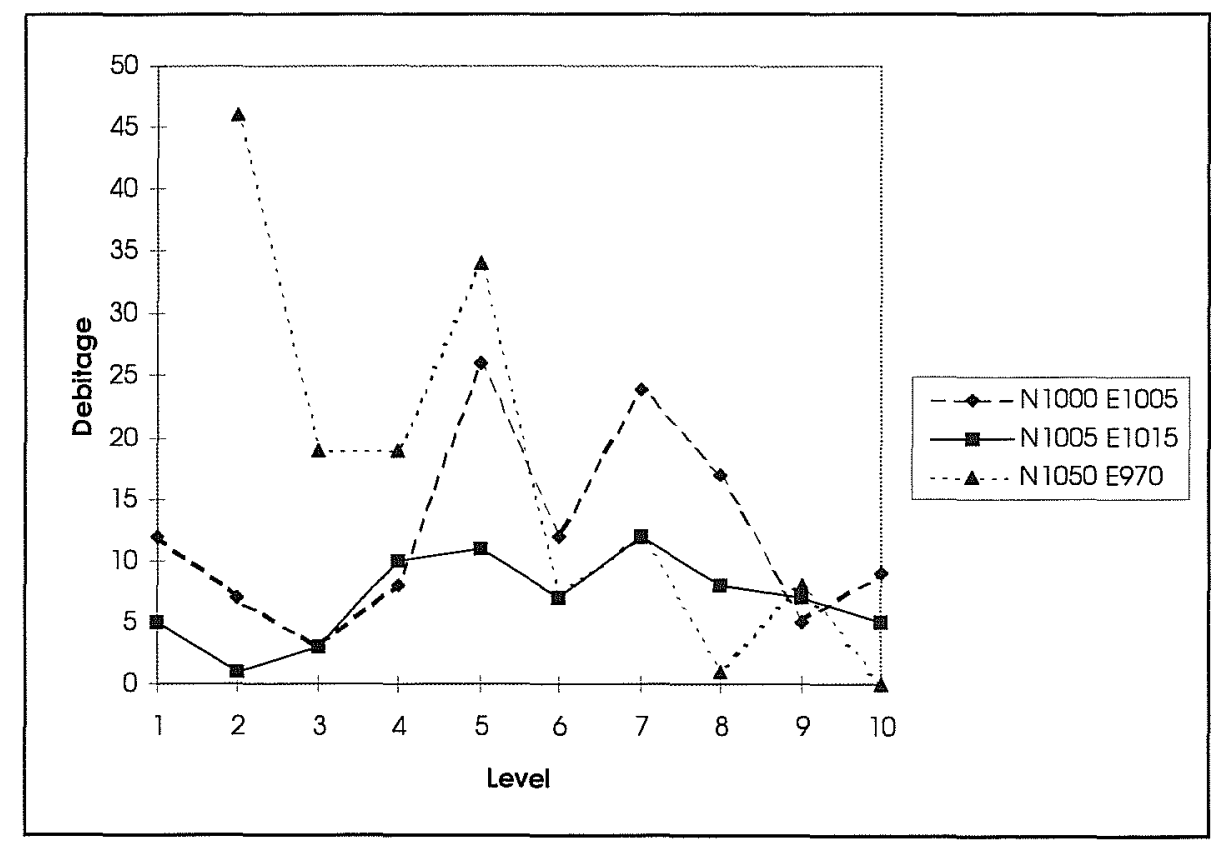

Figure 5-36. Adjusted distribution of debitage by excavated levels at 
The integrity of the surface of a large percentage of the site's total area has been seriously compromised in the area cleared for dog training by the military. Bulldozing of the surface presumably removed the upper $10 \mathrm{~cm}$ of the site in this area. Based on the high debitage counts from the first excavated level at TU N1050 E970 which was located in the center of this area, this part of the site may have contained the greatest quantities of cultural material before it was disturbed. The surface integrity of the area southeast of the clearing, however, has been less severely impacted. Other than some minor artificial disturbances, this part of the site has been impacted by natural forces such as desiccation cracking and bioturbation to the same extent as the rest of the base. Chronologically, the surface material appears to be from a single component as indicated by the presence of Pedernales points and preforms at the exclusion of any other diagnostic artifacts.

Although it is clear that some vertical movement of material has taken place at the site, the distribution of debitage by excavated level suggests that 41BX1102 has at least one buried component between 50 and $70 \mathrm{~cm}$ bs. Two components, indicated by higher artifact counts at 50 and $70 \mathrm{~cm}$ bs are possible, but unconfirmed. The presence of a Pedernales point at $51 \mathrm{~cm}$ bs in TUN1005 E1015 indicates that the component may date to the Middle Archaic. This specimen, however, is heavily patinated and may have been mixed with lower materials by falling into a desiccation crack. It appears that 41BX1102 offers intact and potentially isolable subsurface deposits which have been contaminated to a small degree with material from the surface. From a geomorphological perspective, $41 \mathrm{BX} 1102$ offers the best potential of the eight tested sites for containing intact subsurface deposits based on the environment of deposition.

\section{Site 41BX1103}

\section{Site Setting}

Site 41BX1103 (Figures 5-27, 5-29, and 5-37) is situated on the $\mathrm{T} 1$ flood terrace of Medio Creek in the northern part of the project area. Artifacts have been found within and on a gravel bar adjacent to an elon- gated channel depression about 4.5 to $5 \mathrm{~m}$ above the modern low-water channel of Medio Creek. The channel depression emanates from the Intermediate Upland surface to the west. Consequently, the gravel bar and associated sediments may have been deposited near the confluence of Medio Creek and a small unnamed tributary (elongated channel depression). Vegetation at the site consists of dense grasses under a canopy of mesquite, persimmon, and hackberry.

$41 \mathrm{BX} 1103$ is located in the dog training area, but the part of the site which was intensively investigated during the testing project is largely unaffected by military training activities. Other areas of the site, however, have been adversely impacted to varying degrees by base development. A gravel road encircles the site on three sides, marking the tentative boundaries of the intact part of the site. Depressions and mounds of debris apparently related to road construction activities indicate that portions of the site adjacent to the road have also been seriously disturbed. A large pit and adjacent backdirt pile in the west half of the site mark another area of severe impact of unknown date.

\section{Previous Investigations}

The 1995 survey of the site included an inventory of one $5-\mathrm{m}$ radius dogleash and the excavation of one shovel test (Figure 5-37). An Edgewood point and a thin biface were collected from the surface within four meters of the dogleash. The shovel test, located between the dogleash and Edgewood point, produced a continuum of chipped stone artifacts to a depth of $80 \mathrm{~cm}$ bs. Fire-cracked limestone was also present near the surface and again from 50 to $70 \mathrm{~cm}$, along with burned bone, indicating the possibility of buried hearth features. Soils from the subsurface test suggested gentle flooding episodes sealed the cultural deposits in situ (Nickels et al. 1997).

\section{Level of Effort}

During the testing at $41 \mathrm{BX} 1103, \mathrm{CAR}$ field crews cleared approximately $1,600 \mathrm{~m}^{2}$ of brush, collected 32 CUs $\left(800 \mathrm{~m}^{2}\right)$, excavated 42 shovel tests to determine site boundaries, and excavated five $1-x-1-m$ test 
This page has been

redacted because it

contains restricted

information. 
units. Additionally, three backhoe trenches were excavated to examine the unique stratigraphy related to the site's depositional environment. Because $41 \mathrm{BX} 1103$ is spatially very close to $41 \mathrm{BX} 1102$, the two sites were mapped together using the total station, but a separate grid was established at each site to maintain horizontal control.

\section{Site Size and Depth}

The estimated size of $41 \mathrm{BX} 1103$ is $13,115 \mathrm{~m}^{2}$. This area includes the intact areas of the site and is largely based on the location of modern impact areas which have made determining the actual site boundaries impossible. The southeast boundary is the exception to this situation as it was located based on the limits of surface artifact distribution and shovel tests. Vertically, cultural material was recovered throughout the excavated levels to a depth of $100 \mathrm{~cm}$ bs in an apparent gravel bar (Unit III). The possibility exists for the burial of early to middle Holocene remains within the truncated Unit II at the site which was encountered below the gravel bar.

\section{Testing Results}

\section{Geoarchaeological Assessment}

Three backhoe trenches, B, C (Figure 5-38), and D, were excavated at site 41BX1103. All of BHT B and the upper parts of BHTs C and D exposed Unit III sediments. These sediments exhibited an abundance of poorly sorted and matrix-supported pebbles in both the gravel bar setting and upper part of the channel depression where Unit III buries Unit II (Appendix A). Deposition of Unit III appears to have been by a low-order stream subjected to high-magnitude floods.

The lower parts of BHTs C and D in the channel depression exposed Unit II sediments. These sediments were part of a fine-grained flood basin facies containing a few matrix-supported pebbles. Prior to erosion and subsequent burial of Unit II by Unit III sediments, a period of soil genesis ensued that is now recognized as a buried soil. This buried soil consists of a thick Bk horizon with calcium carbonate filaments and nod- ules and moderate to strong structure in the upper Unit II sediments.

A carbon-14 age of $3620 \pm 70$ B.P. (Beta-96366; see Appendix D) was obtained from the buried soil in the upper part of Unit II in the channel depression (BHT C). This places deposition of Unit II in this area to the early to middle Holocene. Because the overlying Unit III deposits laterally grade into the gravel bar at BHT B, deposition of the gravel bar must have ensued shortly after 3620 B.P. Since 3620 B.P., Medio Creek has been slowly migrating away from the site toward the northeast. Minimal calcium carbonate development in the form of thin pendants on gravel bottoms, supports a late Holocene age for termination of gravel bar deposition, the beginning of modern soil genesis, and neo-landscape stability. Furthermore, diagnostic artifacts from the site, all within a depth of $50 \mathrm{~cm}$, range from Middle Archaic to Transitional Archaic.

Based on carbon-14 dating, time-diagnostic artifacts, and association with Unit III sediments, the occupation at site 41BX1103 could have occurred no earlier than approximately 3600 B.P. Occupation then extended until at least 1400 B.P. based on the presence of near-surface diagnostic artifacts. With landscape stabilization, cultural components would have become compressed on the T1 surface of the gravel bar and adjacent channel depression. Fire-cracked rock was encountered in BHT B within a depth of $40 \mathrm{~cm}$. These rocks were typically larger and more angular than the surrounding fluvial pebbles. These observations suggest that while the fire-cracked rock may not have been in a primary context, they probably originated from within the gravel bar setting. It appears that the gravel bar was the prehistoric campsite, with occupational components losing their contextual integrity by scouring of subsequent flood events. Matrix-supported pebbles in the upper part of the gravel bar indicate that with each initial flood surge, coarse fragments were deposited. This was followed by void infilling with fine-grained sediments during flood recession.

Prehistoric preservation potentials in a primary context in the gravel bar setting at site 41BX1103 appear to be low. Cultural materials were disturbed from their primary contexts by flood waters, but only to the ex- 


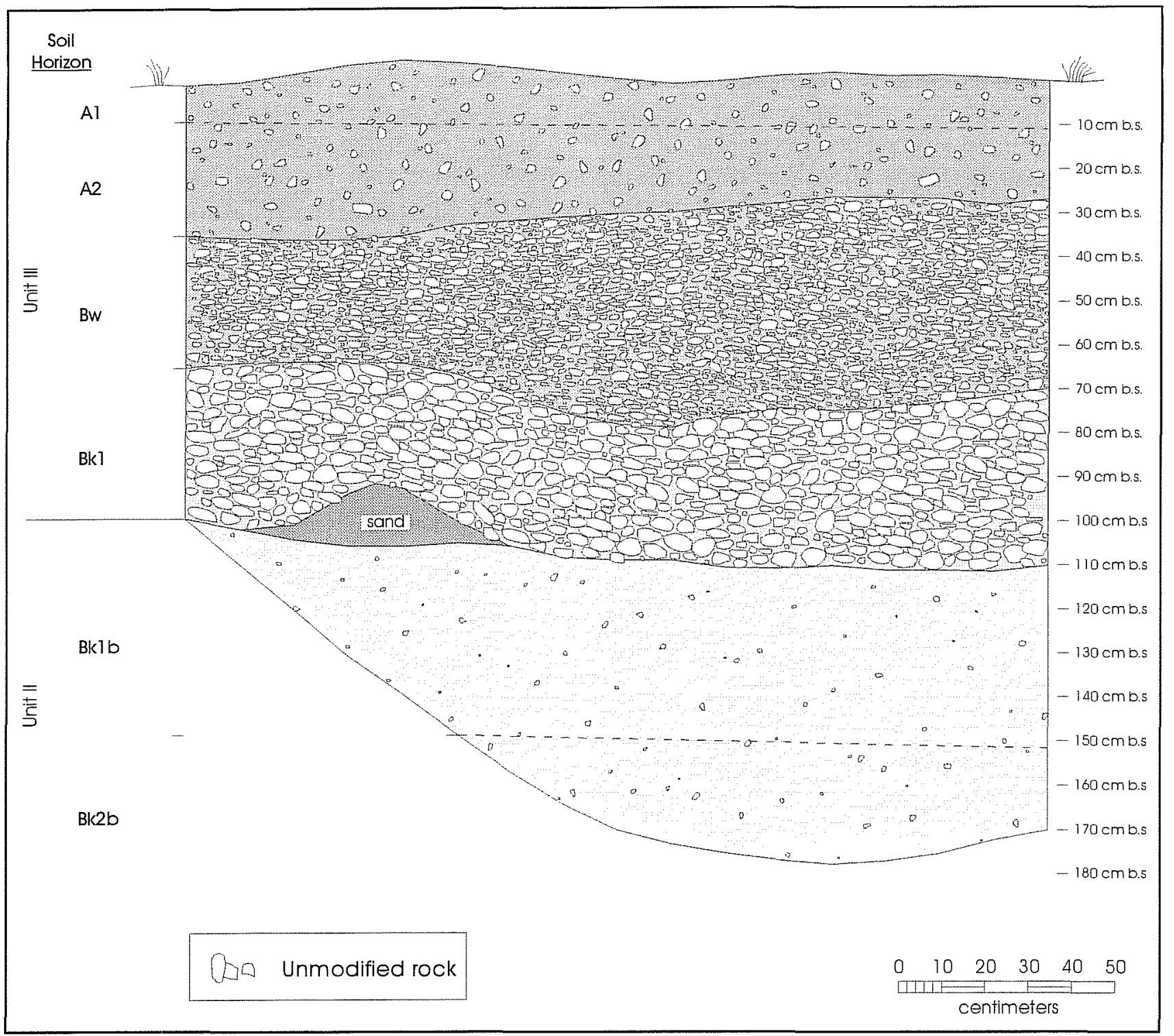

Figure 5-38. Profile of west wall of BHT C, $41 B X 1103$.

tent that the materials remained within the gravel bar setting where occupation occurred. However, the intensity of cultural occupation appears great enough that some components may approximate a primary context. The probability of encountering features in a primary context in the Unit II paleosol is higher.

\section{Archaeological Investigations}

The testing at 41BX1103 did not discover any intact features, but it did recover 6,854 chipped stone artifacts, the most recovered at any site (Table 5-12). This total includes 11 dart points, nine of which could be assigned to established types (Table 5-13, Figure 5-39). The points span the Middle Archaic through the Transitional Archaic. The other chipped stone artifacts consist of 6,503 pieces of debitage, 116 bifaces, 173 unifaces, and 51 cores. Unexpectedly, several historic artifacts were also found at the site, including items of ceramic, glass, and metal. The historic artifacts are described in Appendix B.

As with the survey investigations at 41BX1103 which recovered faunal material in shovel tests (Nickels et al. 1997), Phase II testing encountered faunal remains in several units. The analysis of the 33 fragments of 
Table 5-12. Artifacts from 41BX1103

\begin{tabular}{|l|r|r|r|r|r|r|}
\hline \multicolumn{1}{|c|}{ Artifact Type } & Surface & TUs & STs & BHTs & IF & Total \\
\hline Debitage & 1844 & 3467 & 901 & 290 & 1 & 6503 \\
\hline Bifaces & 59 & 24 & 10 & 22 & 1 & 116 \\
\hline Unif aces & 138 & 23 & 5 & 7 & 0 & 173 \\
\hline Cores & 33 & 10 & 2 & 6 & 0 & 51 \\
\hline Projectile Points & 6 & 2 & 0 & 3 & 0 & 11 \\
\hline Hammerstones & 1 & 0 & 0 & 0 & 0 & 1 \\
\hline \multicolumn{1}{|r|}{ Total } & $\mathbf{2 0 8 1}$ & $\mathbf{3 5 2 6}$ & $\mathbf{9 1 8}$ & $\mathbf{3 2 8}$ & $\mathbf{2}$ & $\mathbf{6 8 5 5}$ \\
\hline
\end{tabular}

bone is presented in Appendix D. The only identified animal species in the assemblage was Odocoileus virginanus (white-tailed deer), found in one surface collection unit, one shovel test, one backhoe trench, and one test unit. Three fragments representing one or two charred phalanges, were found as deep as 60 to $70 \mathrm{~cm}$ bs in ST N975 E985. Other bone fragments had indications of having been chopped, cut, or burned (Appendix D).

Table 5-13. Projectile Points from 41BX1103

\begin{tabular}{|l|l|l|}
\hline Dart Point Type & $\#$ & \multicolumn{1}{c|}{ Time Period } \\
\hline Edgew ood & 1 & Transitional Archaic \\
\hline Ensor & 1 & Transitional Archaic \\
\hline Fairland & 3 & Transitional Archaic \\
\hline Frio & 1 & Transitional Archaic \\
\hline Marcos & 1 & Late Archaic \\
\hline Pedernales & 2 & Middle Archaic \\
\hline Untyped & 2 & Unknown \\
\hline
\end{tabular}

The artifact assemblage from 41BX1103 is one of two tested sites to have fewer artifacts from the surface collection than from the test excavations. The $32 \mathrm{CUs}$ recovered only 30 percent of the total artifacts. This included 1,844 flakes, 59 bifaces, 138 unifaces, 33 cores, and 6 projectile points. The one hammerstone found at the site also was recovered from the surface. The distribution of debitage (Figure 5-40) across the collection area does not show any clear trends, although there are several CUs with comparatively low debitage counts including N985 E985, N990 E985, N1015 E985, and N1015 E990. Each of these units had less than 25 pieces of debitage while the average for the collected area was 60 pieces per CU.

During the surface collection of 41BX1103, CAR archaeologists did not recognize any distinct concentrations or recognizable cluster of artifacts. Additionally, no burned-rock features were identified although burned rock was present in most collection units in relatively low quantities.

Four out of six projectile points found on the surface of the site could be assigned to previously established types. These types-Edgewood, Ensor, Fairland, and Frio-are all Transitional Archaic in age.

The subsurface testing at $41 \mathrm{BX} 1103$ consisted of three backhoe trenches, 5 test units, and 42 shovel tests. These units accounted for approximately 70 percent of the artifacts recovered from the site. This included 4,758 pieces of debitage, 56 bifaces, 35 unifaces, and 18 cores. Of the eight sites tested, the subsurface deposits at $41 \mathrm{BX} 1103$ are unique in that they represent a gravel bar which formed after 3620 B.P. based on the geoarchaeological assessment of the three backhoe trenches.

The excavations of the test units confirmed that the density of gravel and the average size of the gravel increased with depth. Furthermore, it was possible to terminate some of the excavation levels at natural stratigraphic changes. For example, Level 1 was ended at a depth of between 3 and $7 \mathrm{~cm}$ at the point where the thin layer of very dark gray clay loam with 5 percent gravels came into contact with an underlying 


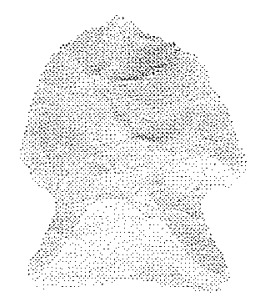

$a$

(U) 8 )

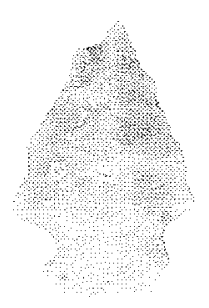

$b$

(UI $b$ )

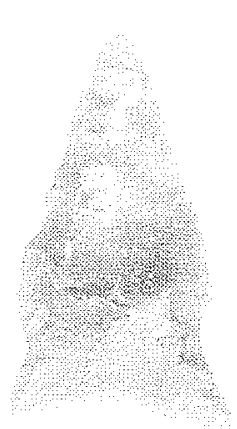

$c$

(UII)

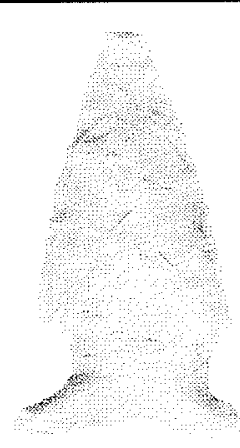

d

(U) 2)

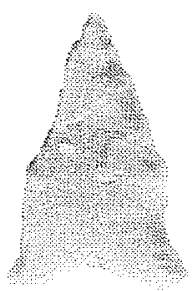

e

(u)

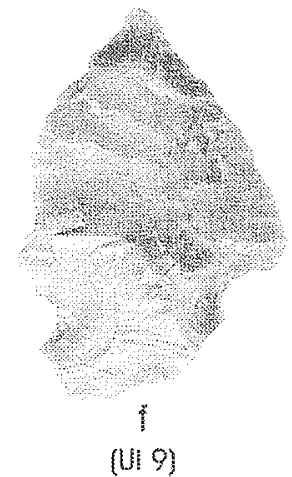

4 $\mathrm{cm}$

(4) 11)

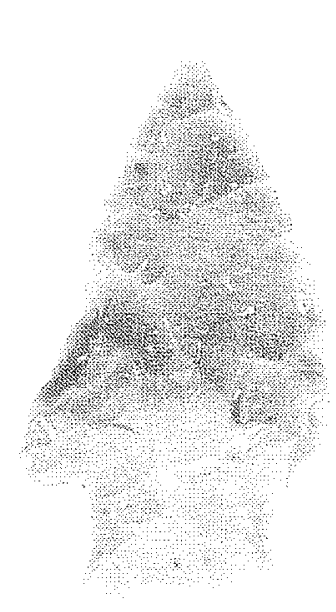

i

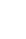

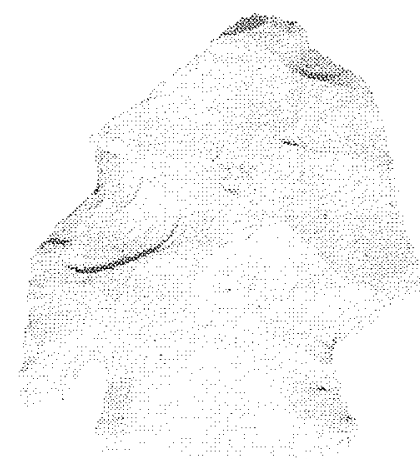

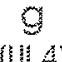

(U1 4$)$

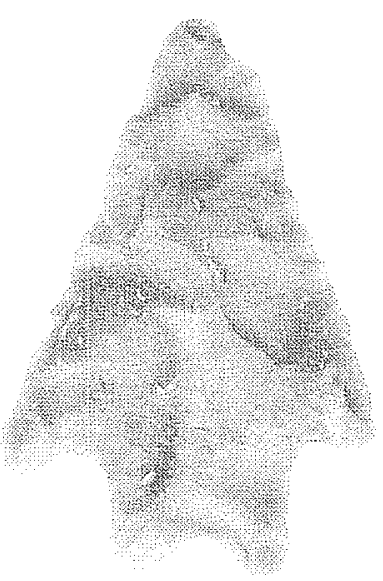

h

(u) 10$)$

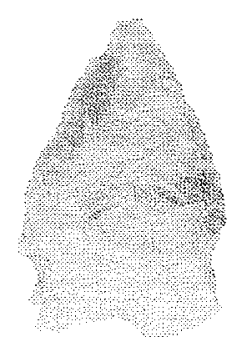

i

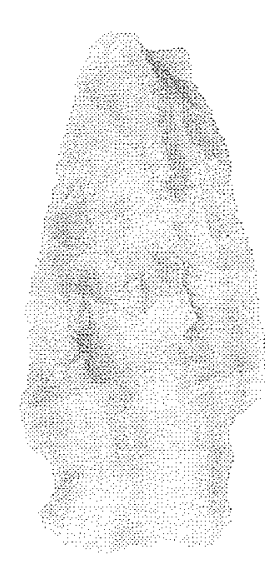

k

(U) 5$)$

Figure 5-39. Projectile points from 41BX1103. a: Edgewood; b: Ensor; c-e: Fairland; f: Frio; g: Marcos; $\mathrm{h}, \mathrm{i}$ : Pedernales; j, k: untyped dart points.

black clay loam supporting 25 percent gravels (Figure 5-41). Similarly, Level 5 was terminated at a thickness of $8 \mathrm{~cm}$ when it was determined that the sediment had changed to a very dark gray clay loam with 50 percent matrix- and grain-supported gravels that were poorly sorted. Above this depth, the gravels were generally well sorted. All of these excavated levels were located in Unit III deposits as discussed in the geoarchaeological description above. 


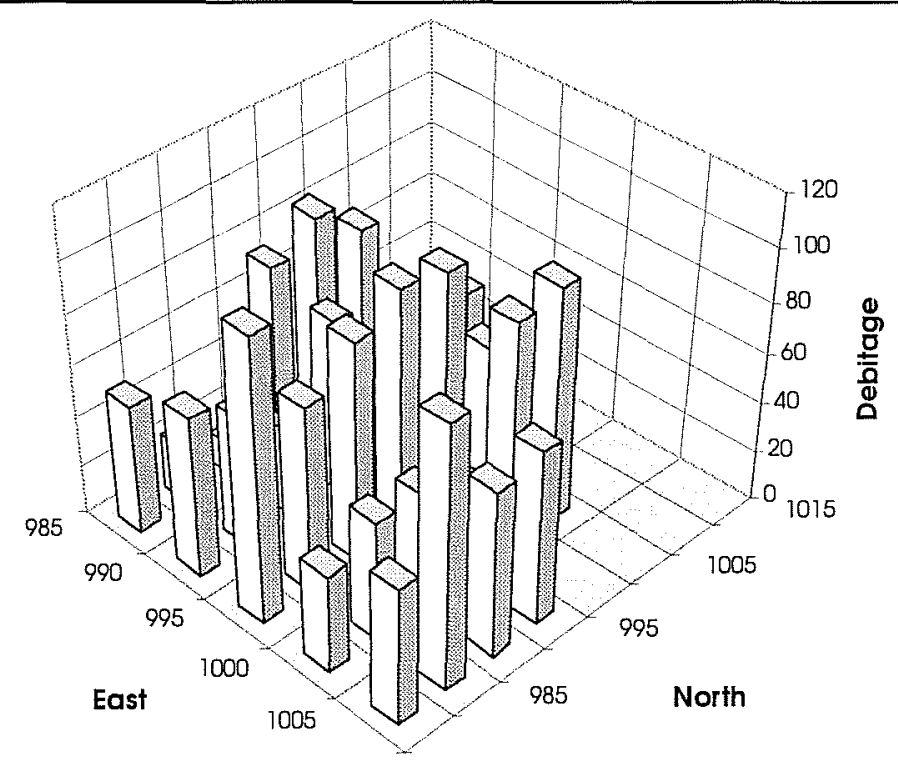

Figure 5-40. Distribution of debitage in the surface collection area at $41 B X 1103$.

The distribution of debitage by excavated level indicates that in all five units, the density of debitage in Level 2 was greater than in Level 1 (Figure 5-42). The density counts also demonstrate dramatic differences between levels within the same units and between the same level in different units, suggesting spatial variation in cultural material concentrations across the site at different levels.
Burned rock was present in all excavation levels, although the quantities varied greatly. The largest concentration was noted in TUN1014 E990 at the base of Level 3 (Figure 5-43). Twenty-one archaeomagnetic sample were drilled from in situ rocks in the five test units. Unfortunately, funds were not available for their analysis. The samples are curated for possible future investigations.

A Fairland dart point (UI 2; Figure 5-39d) was recovered from N999 E1003 in Level 3. The only other projectile point recovered from a test unit was a Pedernales point (UI 11; Figure 5-39i) from N980 E1002.3, Level 5. Three dart points were recovered from backhoe trench backdirt. Although their exact vertical provenience could not be determined, all three were excavated from the upper $50 \mathrm{~cm}$ of the deposits. These included a Fairland (UI 1), a Marcos (UI 4), and a Pedernales (UI 10).

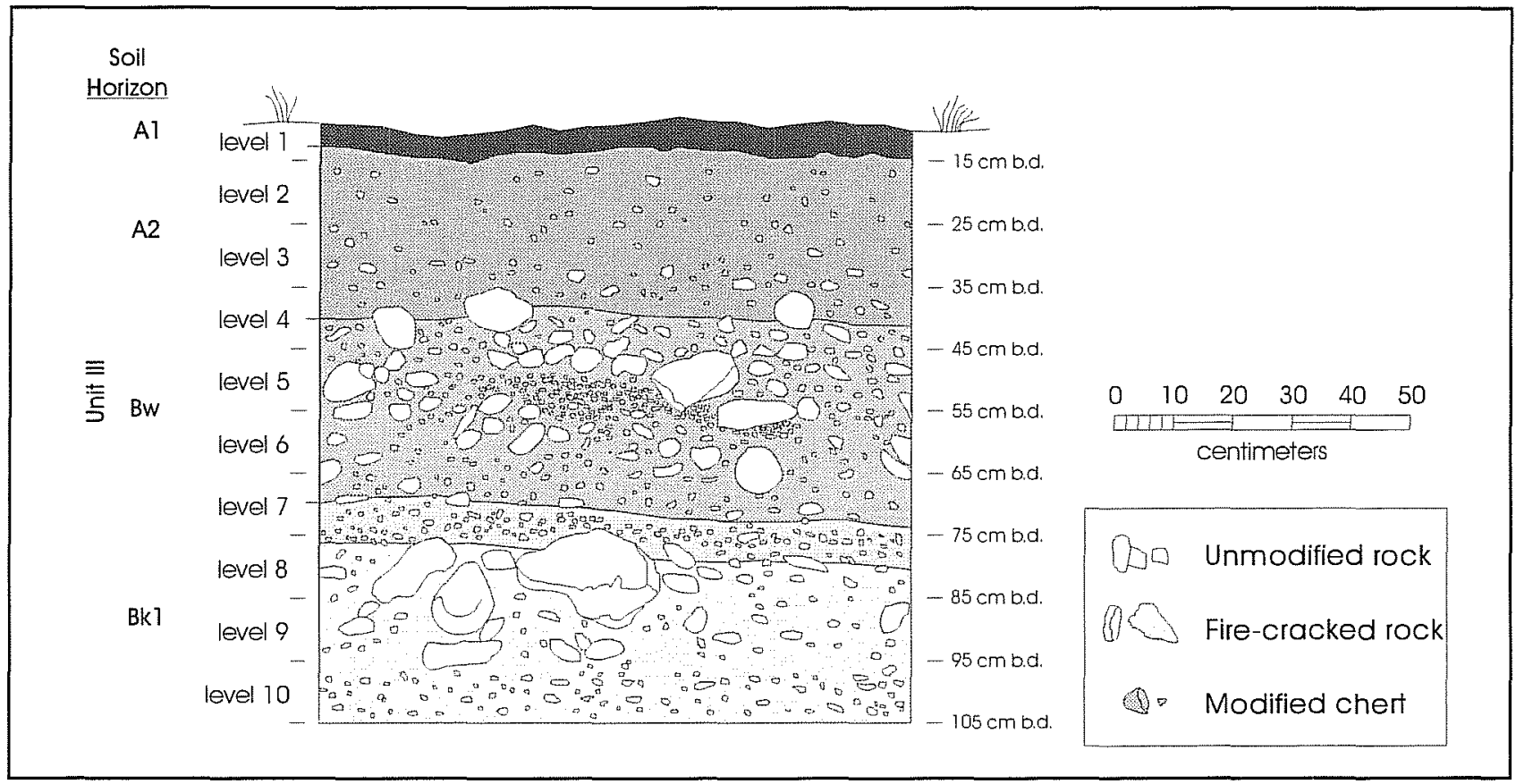

Figure 5-41. Profile of east wall of TU N1014 E990, $41 B X 1103$. 


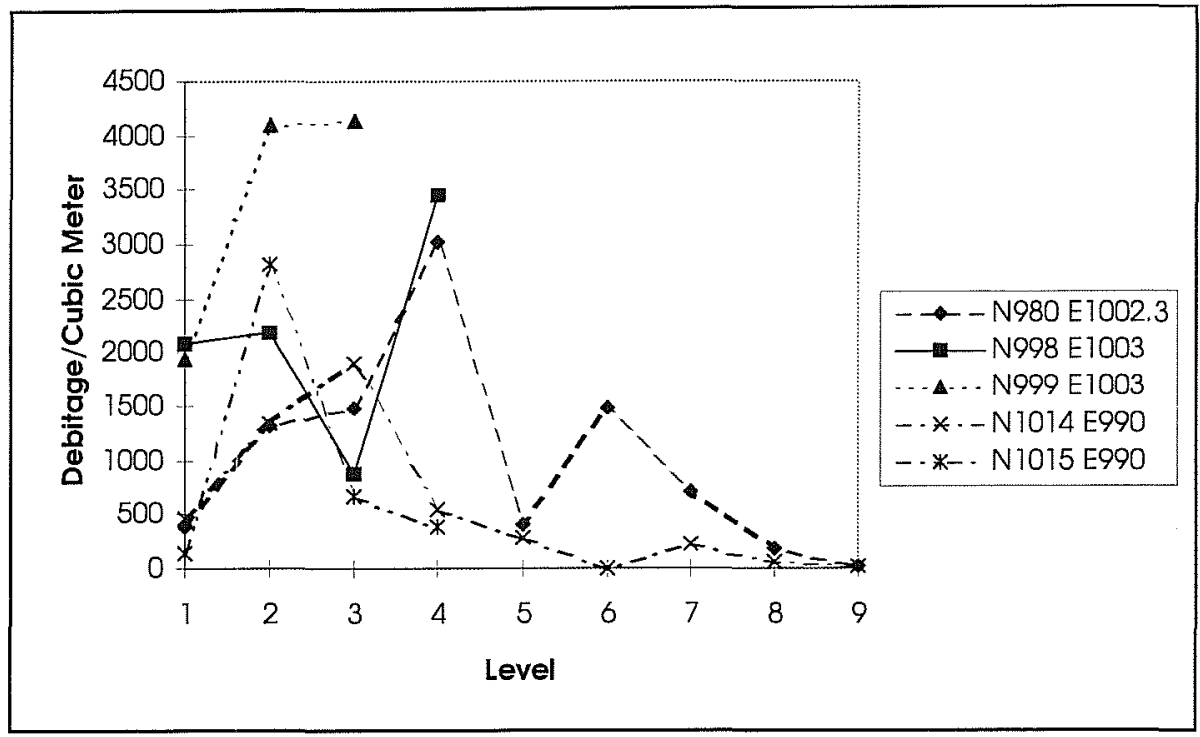

Figure 5-42. Distribution of debitage by excavated levels at $41 B X 1090$. age which was coded as absent, present, or indeterminate. The criteria for assessing stream damage was whether or not the flake scar ridges, not artifact edges, appeared to be battered, smoothed, or rounded. Of the analyzed specimens (complete flakes, cores, bifaces, and unifaces) recovered from subsurface contexts, 15 showed conclusive evidence of stream damage, 14 were characterized as indeterminate, and 839 lacked any indication of having stream damage as defined above. The conclusion from this study is that the majority The degree to which material at 41BX1103 had been displaced or transported by water movement was a concern that had to be addressed in order to evaluate the site's subsurface integrity. The geoarchaeological assessment indicated that the potential for preservation of cultural material in primary context was low. During laboratory analysis, each artifact from 41BX1103 was examined for evidence of stream dam- of material at 41BX1103 has not been stream transported any significant distance.

Twenty-three flotation samples were collected at 41BX1103; one from each excavated level of each $1-x-1-m$ unit at the site. Each of these samples was processed at CAR and scanned for macrobotanical remains. Neither the light nor heavy fractions of these

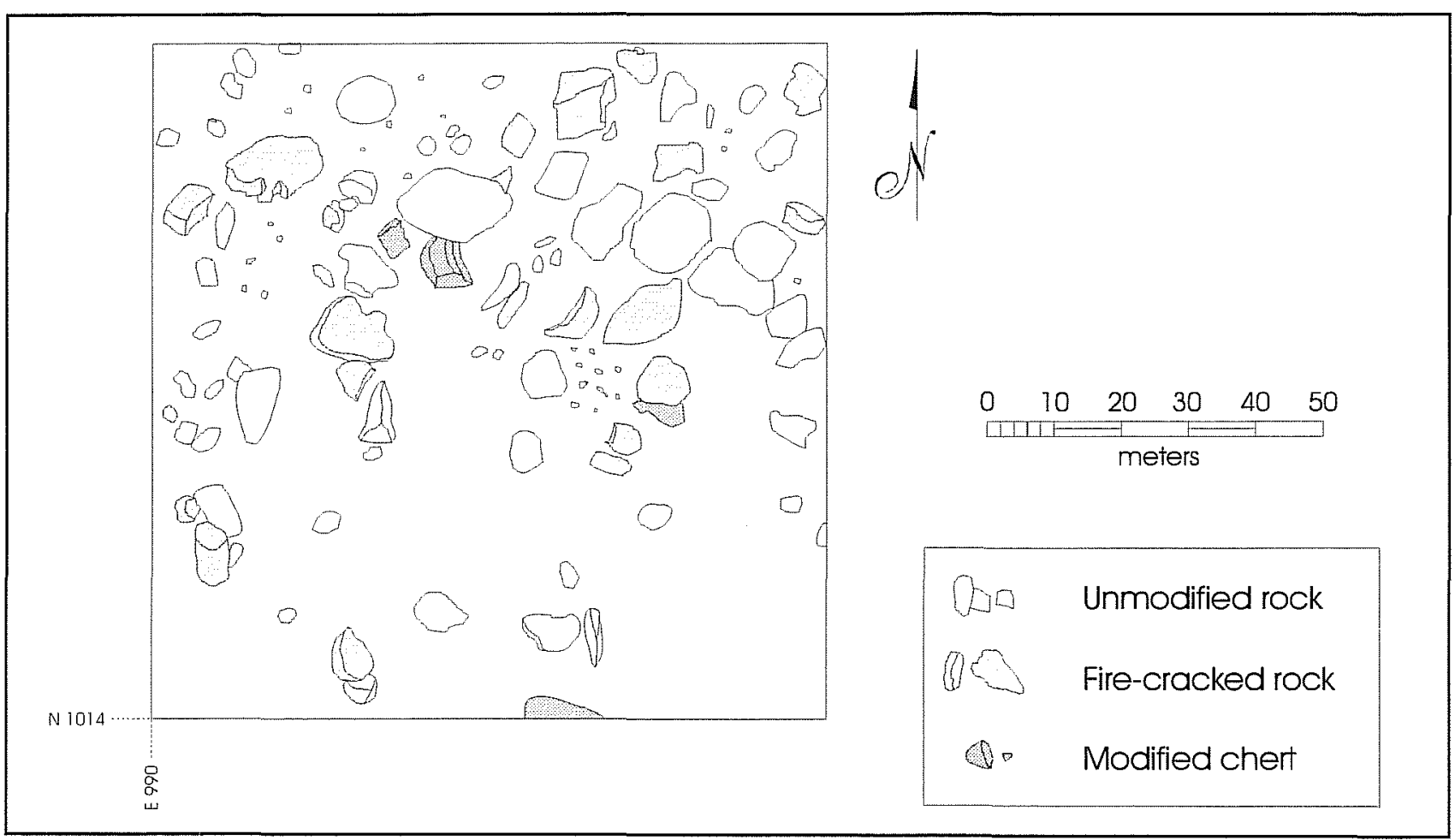

Figure 5-43. Plan map, Level 3 of TUN1014 E990, $41 B X 1103$. 
samples were found to contain macrobotanical remains.

\section{Discussion}

The testing investigations discovered that 41BX1103 is much larger than originally believed. The north and west site boundaries are arbitrarily based on the location of major artificial impacts. The area within the proposed site boundaries has not been adversely impacted by base activities. It is subject to natural impacts including bioturbation, erosion, and possibly flooding.

During the survey and testing projects, seven projectile points were recovered from the surface of the site. The specimens which can be assigned to previously established types are all Transitional Archaic in age. The geoarchaeological assessment of the site suggests that once the landscape stabilized, the components on the surface would have begun to become compressed. The presence of exclusively Transitional Archaic dart points on the surface, however, may indicate that a single component is represented by the surface assemblage. Therefore, the integrity of the surface in the undisturbed areas is considered good because the compression of a single temporal component will not result in the formation of a palimpsest. The few historic artifacts on the surface are not associated with any structures or foundations and may be the result of historic dumping activities. They do not represent a serious impact to the integrity of the prehistoric surface component.

Site 41BX 1103 is unique in its physical setting in that the site formed on an actively accreting gravel bar. The integrity of the deposits is therefore suspect from a geoarchaeological viewpoint. The artifact analysis, however, does not indicate substantial stream damage to the flake scare ridges. Only 15 of 839 (or less than 2 percent) subsurface artifacts clearly had evidence of stream damage. Additionally, the presence of faunal material within the gravel bar setting suggests that the degree of transportation of cultural material was minimal. The data from the test units suggest that the subsurface deposits may be chronologically stratified and that individual components may be isolable at various depths. The Transitional Archaic component may extend as deep as $25-30 \mathrm{~cm}$ bs based on the Fairland dart point (UI 2) from Level 3 of N999 E1003.

The geoarchaeological assessment of the deepest levels of the gravel bar indicates that, in sediments which are composed of 60 percent or greater grain-supported gravels, the likelihood of encountering intact cultural deposits is very low due to the velocity of water required to deposit the river gravels. Above this depth ( 0 to approximately $45 \mathrm{~cm}$ bs) the materials have the potential to be in situ or to approximate a primary context even though minimal horizontal displacement may have occurred. In the truncated Unit II below the gravel bar, there is potential for Early to Middle Holocene age deposits, although the testing investigations did not encounter any archaeological materials in these deposits.

In summary, the subsurface integrity of $41 \mathrm{BX} 1103$ is considered good in that the site contains stratified deposits ranging in age from the Middle Archaic to Transitional Archaic periods. The cultural materials may be minimally displaced horizontally in the upper $45 \mathrm{~cm}$ of the deposit, but retain their primary vertical context and are therefore significant.

\section{Site 41BX1114}

\section{Site Setting}

Site 41BX1114 is situated on the Intermediate Upland surface approximately 9 to $18 \mathrm{~m}$ above the modern low-water channel of Medio Creek (Figure 5-44). The site has surface and shallow subsurface components in the sediment veneer that drapes three landscape positions: a high flat ridge on the north side, a hillside in the middle part, and an erosional knoll in the south part nearest an unnamed tributary. The site is oriented on a north-south axis, conforming to the natural topographic outline of the upland surface. Its close proximity to Medio Creek, located $150 \mathrm{~m}$ to the west, and high elevation, $221 \mathrm{~m}$ amsl, afford an ideal location offering visibility for miles in all directions. Extensive outcrops of chert cobbles and fossils are exposed along its steep western edge, with chert and 


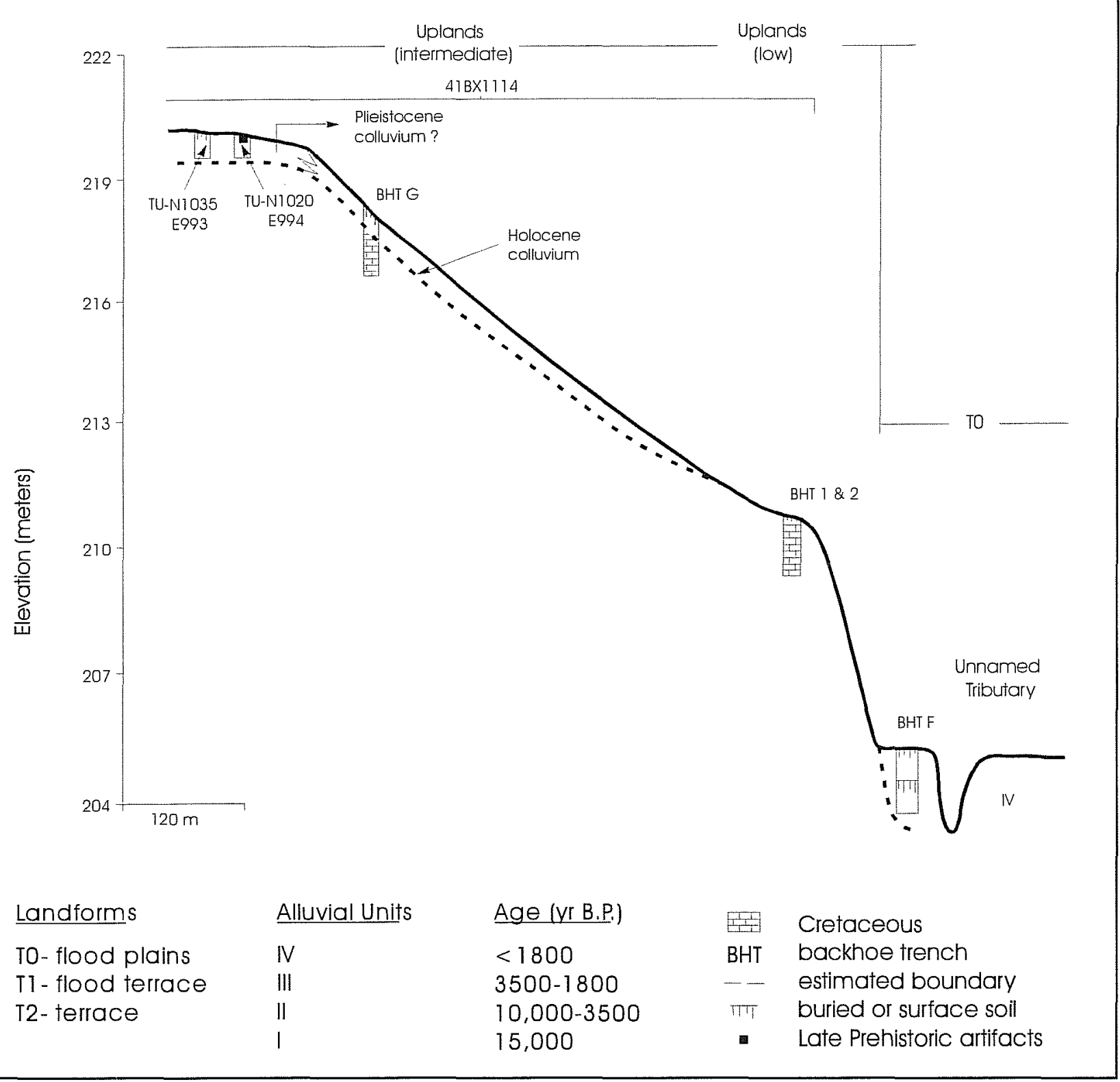

Figure 5-44. Schematic stratigraphic cross section of the uplands and an unnamed tributary near 41 BX1114.

limestone outcrops along the top of the hill. Vegetation includes mesquite, whitebrush, agarita, persimmon, yucca, and dense herbaceous weeds and grasses.

The site has been subjected to several types of impact associated with military dog training in the area. Two roads intersect approximately in the center of the site (Figure 5-45). It is possible that gravel has been dumped on portions of these roads to improve traction during wet weather. The middle of the site-the hill and interfluve slope-has been cleared of most vegetation and is covered in grass that is mowed regu- larly. Large sections of the site, however, remain largely undisturbed by military activities. This undisturbed area includes the areas of greatest artifact concentration where the majority of the testing effort was concentrated on the crest (see below).

\section{Previous Investigations}

While recording the site during the survey of the base, CAR archaeologists excavated two shovel tests and inventoried two 5-m radius dogleashes. One shovel 


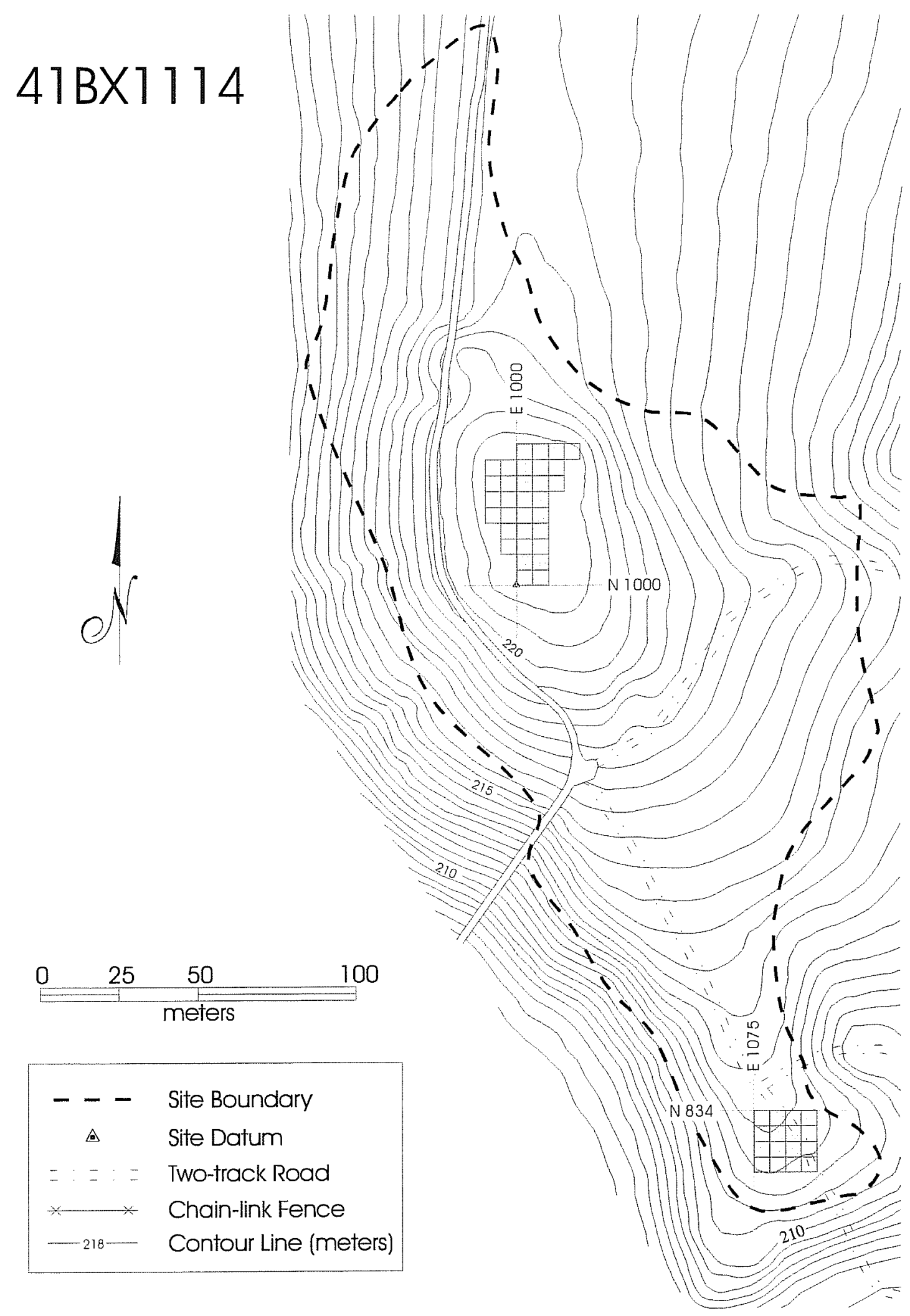

Figure 5-45. Site map, 41BX1114. Collection areas are represented by shading. Backhoe trenches, test units, and shovel tests are not shown. 
test was negative, but the other yielded flakes as deep as $30 \mathrm{~cm}$ below the surface. The two dogleashes placed on the northwest corner of the site contained 11 and 24 artifacts, respectively. A Guadalupe biface was found on the surface near the intersection of the gravel roads in the middle of the site (Nickels et al. 1997).

\section{Level of Effort}

Site 41BX1114 was more intensively investigated than any other site during the testing project. This was because of its large size and the discovery of what was initially interpreted to be an intact feature at the north end of the site. Site boundaries were originally determined by the excavation of 88 shovel tests. Approximately $1,600 \mathrm{~m}^{2}$ of dense brush were cleared to allow for the placement of two collection areas. The first, located at the north end of the site in the area of the highest artifact densities, included 32 5-x-5-m CUs covering $800 \mathrm{~m}^{2}$. The second included $16 \mathrm{CU}$ placed at the south end of the site in the vicinity of ST C-1, from which an Ensor point was recovered. Two $1-\mathrm{x}-1-\mathrm{m}$ test units were excavated in the south end, and 11 more were placed at the north end. The majority of these were centered around the location of the suspected feature. Two backhoe trenches, one at the south edge of the site and one at the juncture of the hill slope and the high flat ridge at the north end, were excavated to allow for a more detailed geoarchaeological assessment of the site. This data was used to supplement the information gathered from two geomorphological trenches excavated at the site during the survey of the base (Nickels et al. 1997).

\section{Site Size and Depth}

During testing, CAR archaeologists plotted the site boundaries based on the results of the intensive shovel testing and on the extent of the surface scatter of artifacts. The resulting area covers $29,775 \mathrm{~m}^{2}$.

Testing recovered subsurface cultural material from as deep as $80 \mathrm{~cm}$ below the surface in TUN1039 E993. The majority of material from test units and shovel tests was encountered in the upper $30 \mathrm{~cm}$ of the site. The geoarchaeological assessment of the site, how- ever, suggests that the only potential for buried deposits at the north end of the site, the location of TU N1035 E993, is through turbation (see below).

\section{Testing Results}

\section{Geoarchaeological Assessment}

In the north side of the site, an indurated calcium carbonate zone was identified in TU N1039 E993 (Figure 5-46) at a depth of $35 \mathrm{~cm}$ (Appendix A). Caliche horizons exhibiting indurated properties commonly require millions of years of pedogenesis to form (Machette 1985). At TU N1020 E994 the soil was more deeply weathered, oxidized, and completely decalcified (Appendix A). Substantial downward translocation has also enriched the subsoil in clay. The indurated calcium carbonate zone probably occurs at the bottom of this test unit.

Because profile decalcification in soils developed from calcareous parent material takes tens of thousands of years (Nordt and Hallmark 1990), the deeply weathered soil at TU N1020 E994 must be too old to contain buried cultural materials. Consequently, remnants of Pleistocene-age colluvium must exist in parts of the Intermediate surface. However, the origin and age of the calcareous and cobbly sediments above the indurated zone in the vicinity of TU N1039 E993 are problematic. It would require many meters of decalcified topsoil to develop the indurated subsoil caliche horizon identified in this test unit. Because sediments above the indurated zone are thin and calcareous, they may not be chronologically related to the caliche zone. The sediments overlying the undulatory subsurface caliche zone at site $41 \mathrm{BX} 1114$ may have originated from: 1) deposition of alluvium related to early flood plain construction of Medio Creek; 2) gully knickpoints migrating into the uplands that were subsequently filled with colluvium derived locally from the Uvalde Gravel or early Medio Creek alluvium; 3) reworking of Uvalde Gravel or early Medio Creek alluvium in situ by intense biological activity and vertical mixing; or 4) colluvium deposited from the super adjacent High Upland surface to the south. Eolian sedimentation has not been documented in the area and is therefore not a likely depositional possibility. 


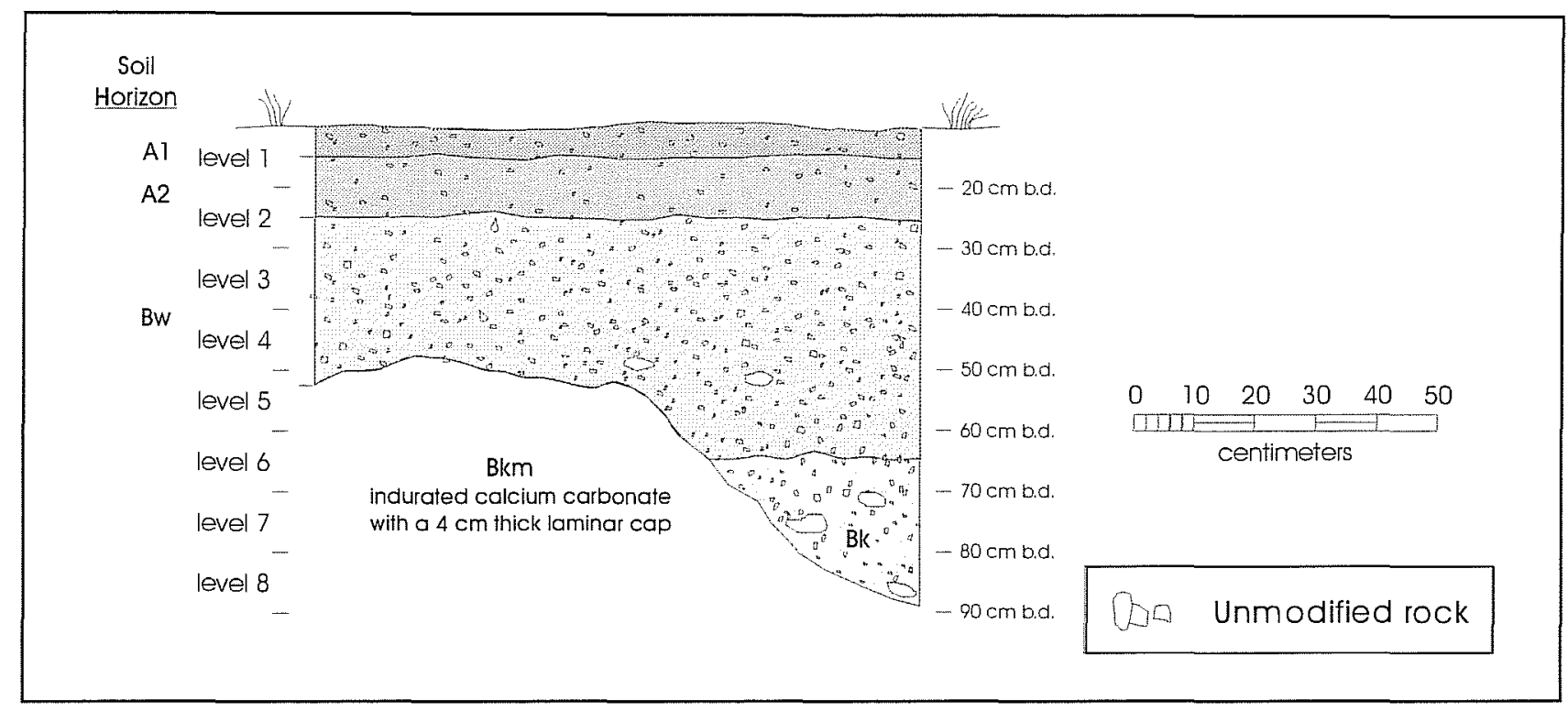

Figure 5-46. Profile of north wall of TUN1039 E993, 41BX1114.

Because of stratigraphic position, if sediments overlying the caliche horizon were deposited as Medio Creek alluvium, it would have occurred prior to the arrival of prehistoric people (hypothesis 1). The absence of surface topographic scars suggests that gully activity never occurred in the area, or that it occurred so long ago that there is now no visible surficial evidence (hypothesis 2). Intense biological activity could have inhibited soil development and weathering in some areas across the site, even though the sediments are very old (hypothesis 3). Following hypotheses 1 , 2 , and 3 , there is little possibility of subsurface preservation of prehistoric sites in a primary context. Colluviation from the High Upland surface to the south could have occurred in the Holocene during the formation of the Intermediate surface (hypothesis 4); thus, there is potential for localized preservation of buried features.

What was originally believed to be an intact feature was discovered in TU N1020 E994 at a depth of approximately 5 to $15 \mathrm{~cm}$. The first three hypothesis listed above all point to the possibility that the deposits in this part of site $41 \mathrm{BX} 1114$ are too old to contain buried cultural materials in a primary context. If the age of the sediments pre-dated human occupation, the cultural materials at depth at the site must have been: 1) surface features that were subsequently worked into the soil by biological activity (secondary context); or 2) buried at a shallow depth in a primary context by biological activity, such as with mounding or treethrow. In contrast, if the sediments were deposited in the early to middle Holocene it is possible that this feature was buried in a primary context by colluvium. However, the north side of the site is on a plateau topographically above the rest of the Intermediate surface. Thus, even a colluvial event probably would have preceded human occupation.

BHT $\mathrm{G}$ was also excavated in 41BX1114, but on the sideslope adjacent to TUs N1035 E993 and N1020 E994. In this area, there were $66 \mathrm{~cm}$ of colluvium containing mostly matrix-supported pebbles and cobbles that increased in abundance with depth (Appendix A). This layer unconformably buried Cretaceous clays. In the downslope part of BHT G, the basal gravel bed decreased in thickness. Furthermore, many of the cobbles in the colluvial layer were completely coated with calcium carbonate rinds (relict soil carbonate), regardless of depth. These observations suggest that the pebbles and cobbles were washed down the hillside as colluvium from the higher topographic area in the vicinity of the previously described test units. Minimal pedogenesis in the colluvium indicates that it may be early to middle Holocene in age. Furthermore, based on stratigraphic position, this landscape element is younger than that at TU N1035 E993 and at TU N1020 E994. No cultural materials were observed in BHT G; however, if they occur, they probably will be preserved in a secondary context. Based 
on estimated time of deposition, surface features could range in age from the Middle Archaic to present.

The colluvial hillside in the vicinity of BHT G grades down to the area just upslope from BHT 1 and BHT 2 which were excavated during the original survey of the base (Nickels et al. 1997). This area is within the Low Upland surface that was eroded in the late Holocene by lateral channel migration of Medio Creek and associated tributaries into the Intermediate surface. Consequently, the soils exposed in these backhoe trenches formed entirely in Cretaceous clays (Appendix A). Apparently the upper hill slope colluvium did not emanate very far down the slope, or if so, it was subsequently eroded and washed down the next lower hillside grading down to the $\mathrm{T} 1$ flood terrace. Consequently, there is little potential for discovering buried cultural materials in site 41BX1114 below the downslope extension of Holocene colluvium. If the geomorphic surface was cut in the late Holocene, surface features will be Transitional Archaic or younger.

\section{Archaeological Investigations}

The investigations at 41BX1114 located one possible feature which was designated Feature 1 and seven projectile points. A collection of 5,062 chipped stone artifacts was recovered from the site (Table 5-14). This included 4,454 pieces of debitage, 98 bifaces, 183 unifaces, 320 cores, and 7 projectile points. One ground stone tool (UI 7) and 86 fragments of animal bone were also collected at the site. The assemblage from 41BX1114 was the second largest collected during the testing project. The ground- stone artifact is described in Appendix B and the faunal remains are discussed in detail in Appendix D. Approximately 52 percent of the material was recovered from the subsurface testing, and the remaining 48 percent was collected from the 48 CUs.

\section{North Collection Area}

Because the two areas of investigation at $41 \mathrm{BX} 1114$ are located on different landforms and are separated by over $175 \mathrm{~m}$ of horizontal distance, they will be discussed separately and the results compared. The north collection area contained $32 \mathrm{CUs}$, twice as many as the south area (Figure 5-47). The materials recovered from the surface included 1,634 pieces of debitage, 55 bifaces, 118 cores, 140 unifaces, and two untyped and one untypable projectile points (Figure 5-48).

The distribution of debitage across the north collection area indicates a concentration of material near the west edge, extending into the center of the area (Figure 5-49). This concentration is reflected in the distribution of non-debitage chipped stone artifacts (Figure 5-50). Of the CUs in the north collection area, the second highest debitage count, the second highest biface count, the highest core count, and the highest uniface count are from CU N1020 E990, located at the west edge of the collection area. This area corresponds to the location of the intensively excavated area around Feature 1 which is discussed in detail below.

Initially, CAR archaeologists excavated five 1-x-1-m test units in the north collection area. The discovery of Feature 1 in N1020 E990 prompted the excavation

Table 5-14. Artifacts from 41BX1114

\begin{tabular}{|l|r|r|r|r|r|r|}
\hline \multicolumn{1}{|c|}{ Artifact Type } & Surface & TUs & STs & BHTs & IF & Total \\
\hline Debitage & 1885 & 2338 & 227 & 4 & 0 & 4454 \\
\hline Bifaces & 72 & 21 & 4 & 0 & 1 & 98 \\
\hline Unifaces & 154 & 19 & 6 & 0 & 4 & 183 \\
\hline Cores & 257 & 53 & 10 & 0 & 0 & 320 \\
\hline Projectile Points & 3 & 3 & 1 & 0 & 0 & 7 \\
\hline Ceramic Sherds & 0 & 8 & 0 & 0 & 0 & 8 \\
\hline Misc. Ground stone & 1 & 0 & 0 & 0 & 0 & 1 \\
\hline Total & $\mathbf{2 3 7 2}$ & $\mathbf{2 4 4 2}$ & $\mathbf{2 4 8}$ & $\mathbf{4}$ & $\mathbf{5}$ & $\mathbf{5 0 7 1}$ \\
\hline
\end{tabular}




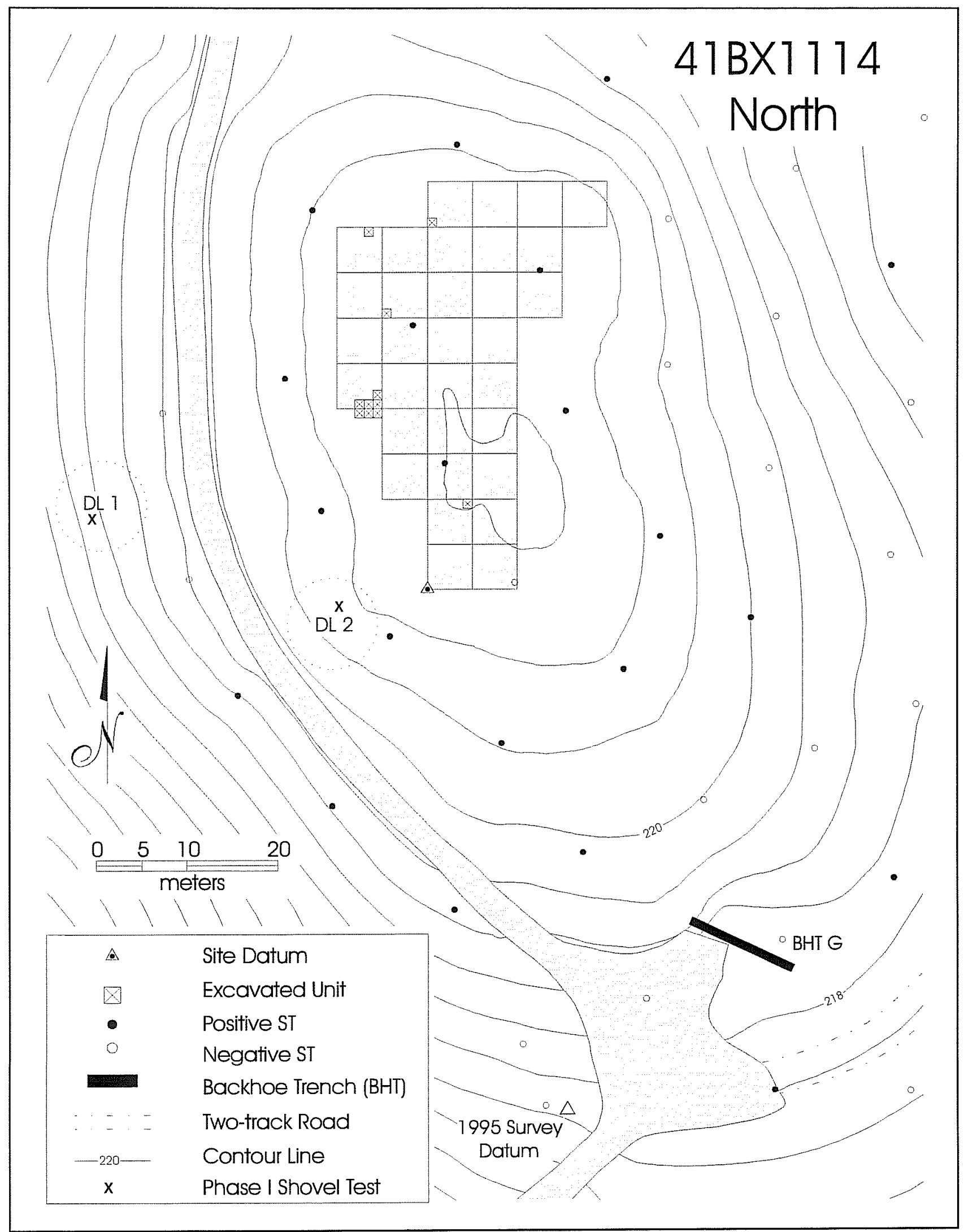

Figure 5-47. North collection area, 41BX1114. 


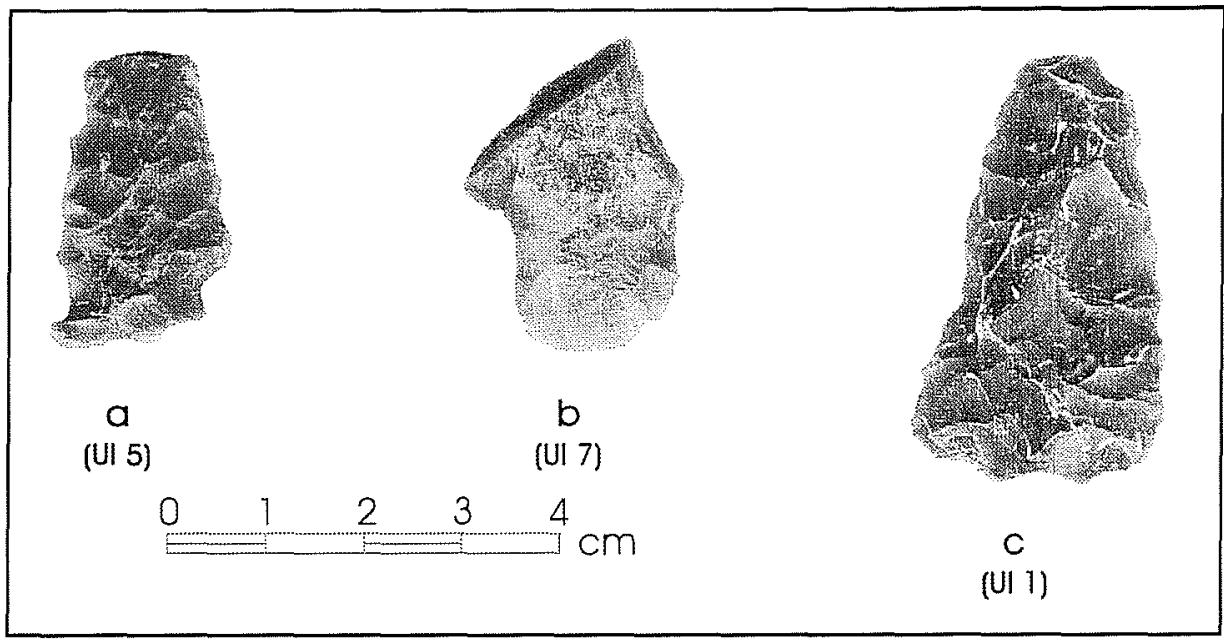

Figure 5-48. Projectile points from north surface collection area, 41BX1114. a, b: untyped dart point; c: untypable dart point. density for this volume equals 918 pieces $/ \mathrm{m}^{3}$. Debitage densities by excavated level, however, demonstrate an overall decrease with depth from 1,401 pieces $/ \mathrm{m}^{3}$ in Level 1 to 1,078 pieces $/ \mathrm{m}^{3}$ in Level 2. Densities in Level 3 plummeted to 65 pieces $/ \mathrm{m}^{3}$, and no debitage was recovered from Levels 4 and 5.

Two samples of charcoal and a sample of bone from Feature 1 were submitted to Beta Analytic for radiocarbon dat- of six additional test units (Figure 5-51). The block of seven $1-x-1-m$ units was partially located within the 5-x-5-m CUN1020 E990 which had the highest overall artifact density. Feature 1, which was originally believed to be an intact hearth, yielded large quantities of charcoal, ashy soil, burned chert, and burned limestone. The faunal material recovered from the block of units included 79 bone fragments, some of which are Odocoileus virginianus, and others of which are from a cow/ bison-sized animal (Appendix $C$ ). The expanded excavations recovered eight sherds of Leon Plain ceramics and a Scallorn point (Brangus variety) from the upper $10 \mathrm{~cm}$ of sediment (Figure 5-52).

The other artifacts recovered from the seven test units included 1,560 pieces of debitage, 58 cores, 15 bifaces, and 17 unifaces. While the depth to which each unit was excavated varied, the deepest unit was terminated at $50 \mathrm{~cm}$ bs at the indurated calcium carbonate zone. The total excavated volume for the seven units equaled $1.7 \mathrm{~m}^{3}$. The debitage ing (Appendix D). The two charcoal samples underwent standard radiometric analysis while the bone sample underwent Accelerated Mass Spectrometer (AMS) dating. The results are listed in Table 5-15 and Appendix D. The radiocarbon dates indicate that the bone and the charcoal post-date the prehistoric mate-

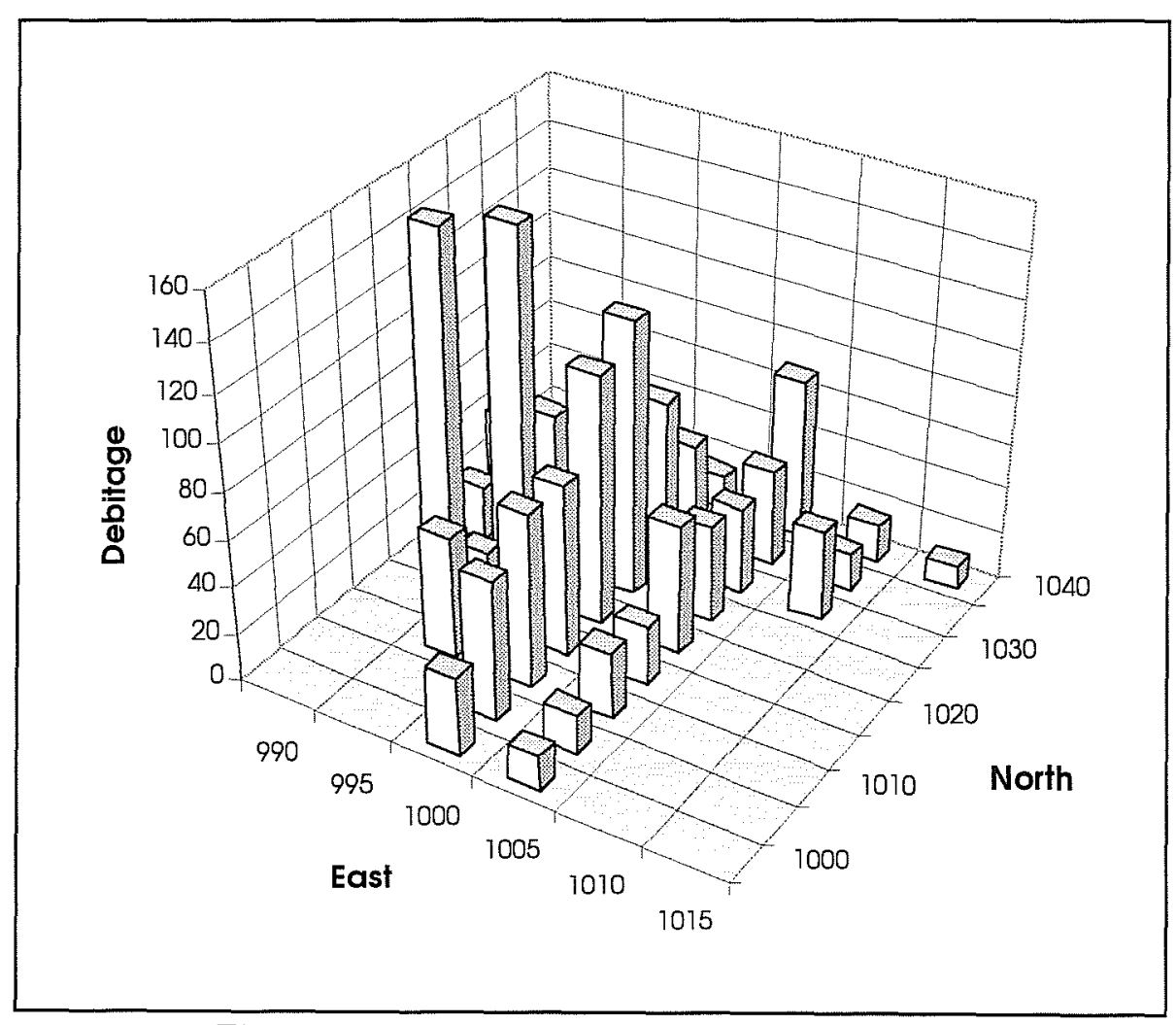

Figure 5-49. Distribution of debitage in north collection area at $41 B X 1114$. 


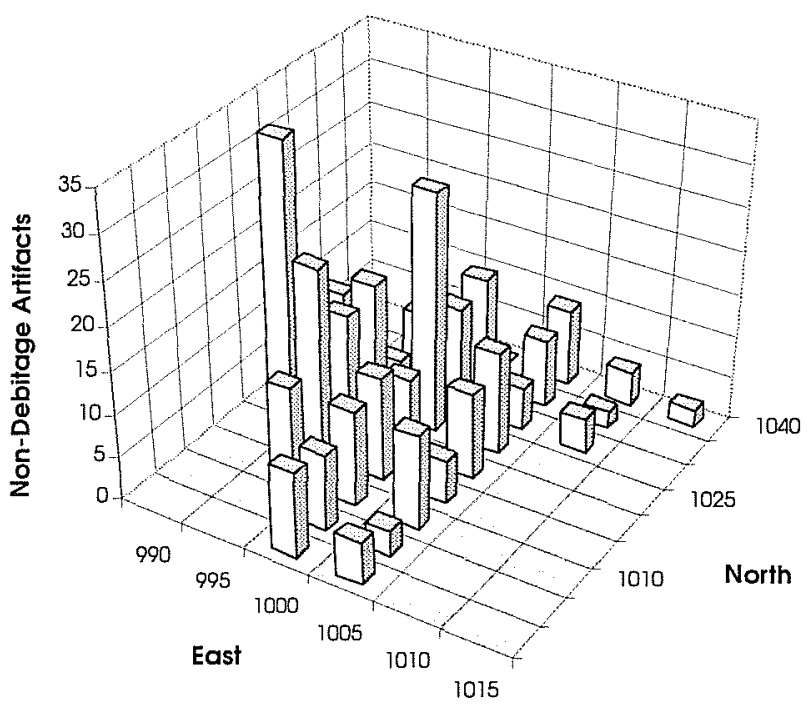

Figure 5-50. Distribution of non-debitage chipped stone artifacts in north surface collection area at 41BX1114.

rial, presuming a range of ca. 1250 B.P. to 180 B.P. (A.D. 700 to 1770) based on earliest date for Scallorn points (Hester 1995) and the latest date for Leon Plain (Pertulla et al. 1995:195). The bone contained "bomb carbon" and is therefore younger than 50 years old. The two charcoal dates are in the nonlinear portion of the calibration curve and accurate age estimates are not possible. The association of Leon Plain ceramics, a Scallorn arrow point, and numerous other prehistoric artifacts with the modern charcoal and bone was simply incidental.

The expanded excavations, which resulted from the original interpretation that the assemblage represented an intact feature, provide important data about site formation processes and artifact densities. The fact that modern bone was buried up to $15 \mathrm{~cm}$ below the surface is testimony to the ability of turbation pro- cesses to rapidly transport surficial material downward. The continuous drop in debitage densities with depth support the interpretation that $41 \mathrm{BX} 1114$ is a surface site with material continuously being reworked by turbation.

If the geoarchaeological assessment that $41 \mathrm{BX} 1114$ is located on a surface that is too old to contain buried deposits in a primary context is correct, then any material encountered below the surface has been transported there through postdepositional processes. The small block excavation, however, demonstrates that the majority of material is concentrated between the surface and a depth of $20 \mathrm{~cm}$ below the surface. Secondly, the quantity of artifacts recovered indicates that the block excavation technique may be a useful approach to investigating such upland sites, particularly if movement of material is limited to a maximum of $20 \mathrm{~cm}$ of vertical displacement.

The other excavated test units in the north collection area demonstrated similar decreases in debitage counts below the second excavated level. Importantly, these units exposed the indurated calcium carbonate zone, discussed above, at widely varying depths. For example, this zone was encountered at approximately $20 \mathrm{~cm}$ below the surface in TU N1030 E995 (Figure 5-53) and at 35 to $70 \mathrm{~cm}$ in TU N1039 E993 (Figure 5-46) where it was very irregular. Two Fairland dart points recovered from TU N1039 E993 apparently

Table 5-15. Radiocarbon dates from Feature 1, 41BX1114

\begin{tabular}{|c|c|c|c|c|}
\hline Sample \# & Type & Measured $C^{1 / 4}$ Age & $C^{13} / C^{12}$ Ratio & Conventional $\mathrm{C}^{\mathrm{n} \pi}$ Age \\
\hline Beta-098912* & Bone & $110.1 \pm 0.6 \%$ modern & $-26.1 \%$ & $110.3 \pm 0.6 \%$ modern \\
\hline Beta-096367 & Charcoal & $110 \pm 50 \mathrm{BP}$ & $-24.1 \%$ & $120 \pm 50 \mathrm{BP}$ \\
\hline Beta-096368 & Charcoal & $180 \pm 50 \mathrm{BP}$ & $-25.0 \%$ & $180 \pm 50 \mathrm{BP}$ \\
\hline
\end{tabular}

* Report result indicates an age of post 0 B.P. and has been reported as a percent of the modern reference standard. 


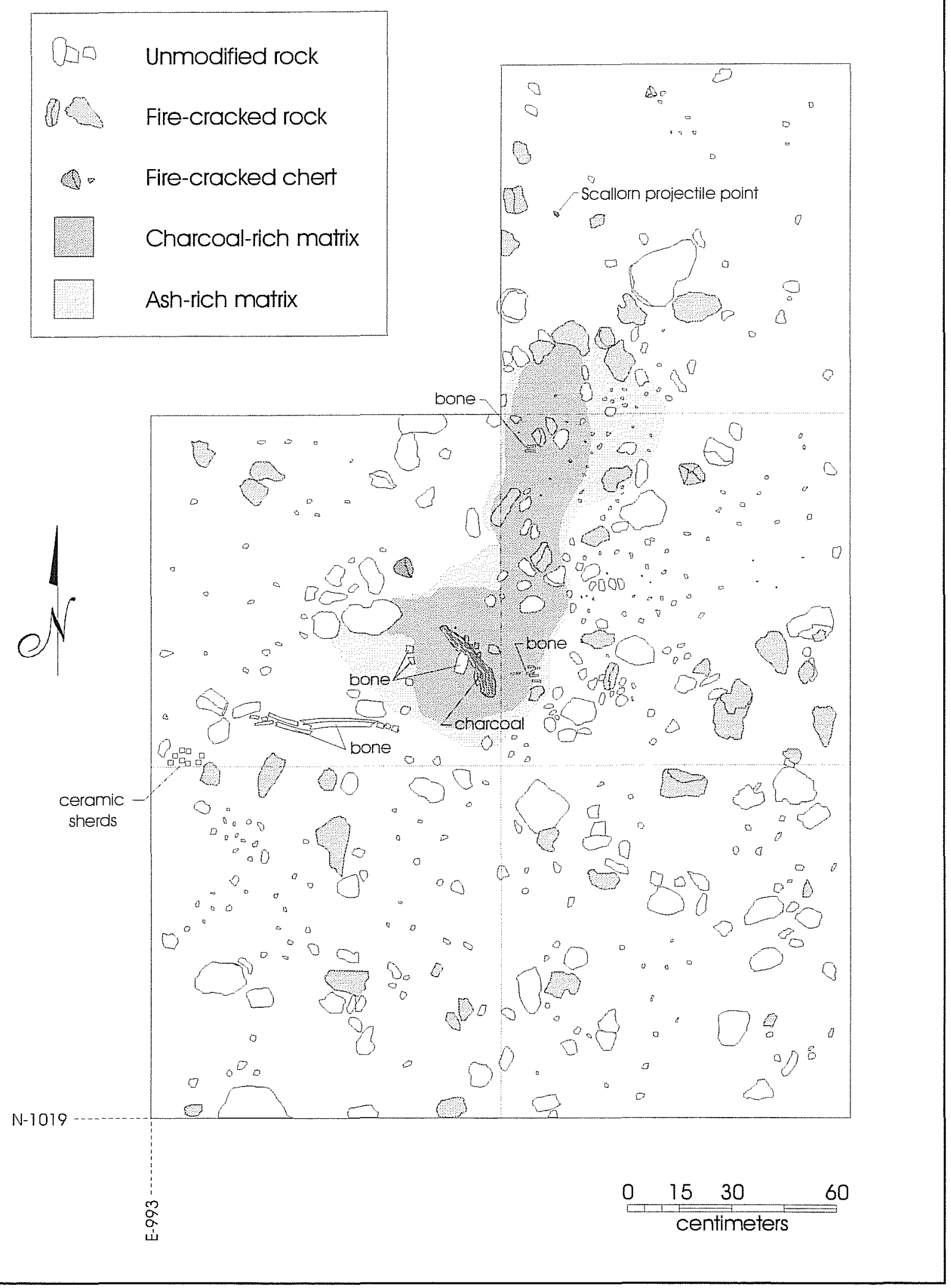

Figure 5-51. Plan map of Feature 1, 41BX1114. TUs N1019 E992 and N1020 E992 not pictured. 


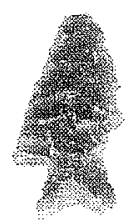

a

(UI 4)

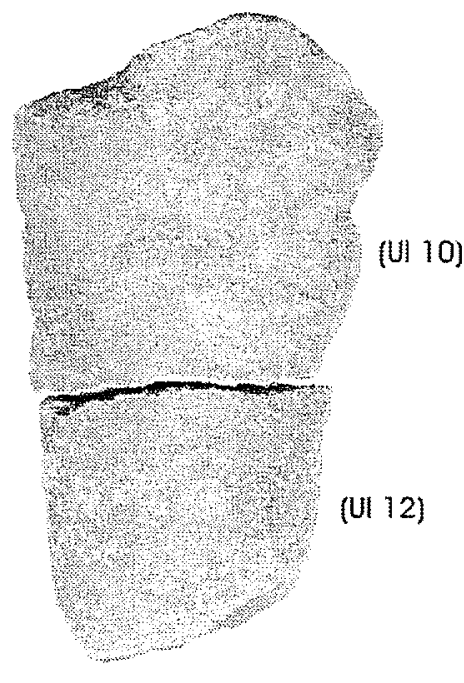

$b$

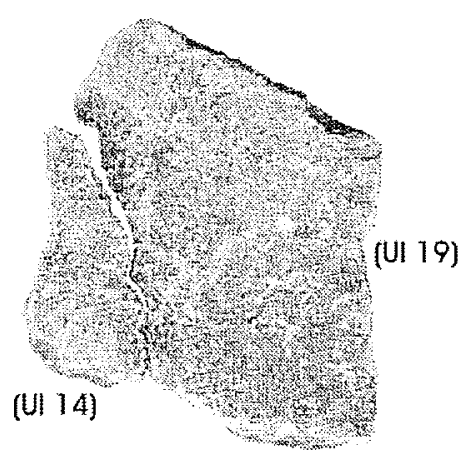

C

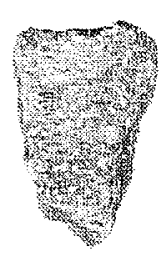

d

(UI 15)

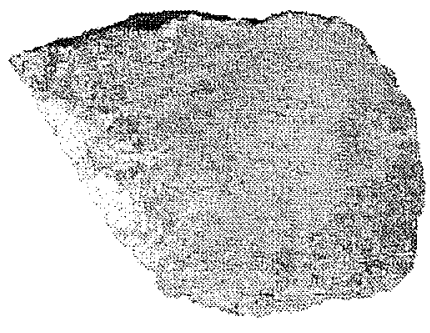

e

(UI 11)

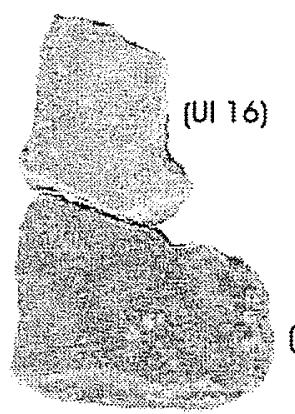

(Ul 13)

$f$

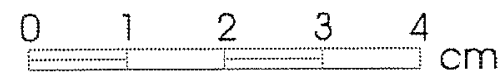

Figure 5-52. Diagnostic artifacts from Feature 1, 41BX1114. a: Scallorn-Brangus arrow point; b-f: Leon Plain sherds.

confirm the vertical movement of material at the site (Figure 5-54). The first was from Level 1 (UI 3) and the second (UI 2) was from Level 5, deep in the pocket formed by the irregular calcium carbonate surface and the walls of the unit. No other diagnostics were recovered from subsurface testing outside of the Feature 1 area.

\section{South Collection Area}

The smaller surface collection area at the south end (Figure 5-55) of the site was characterized by significantly lower artifact counts with material unevenly dispersed across the $400 \mathrm{~m}^{2}$ area (Figure 5-56). The total number of chipped stone artifacts recovered from the south area included 206 pieces of debitage, 109 cores, 11 bifaces, and 11 unifaces. This includes 


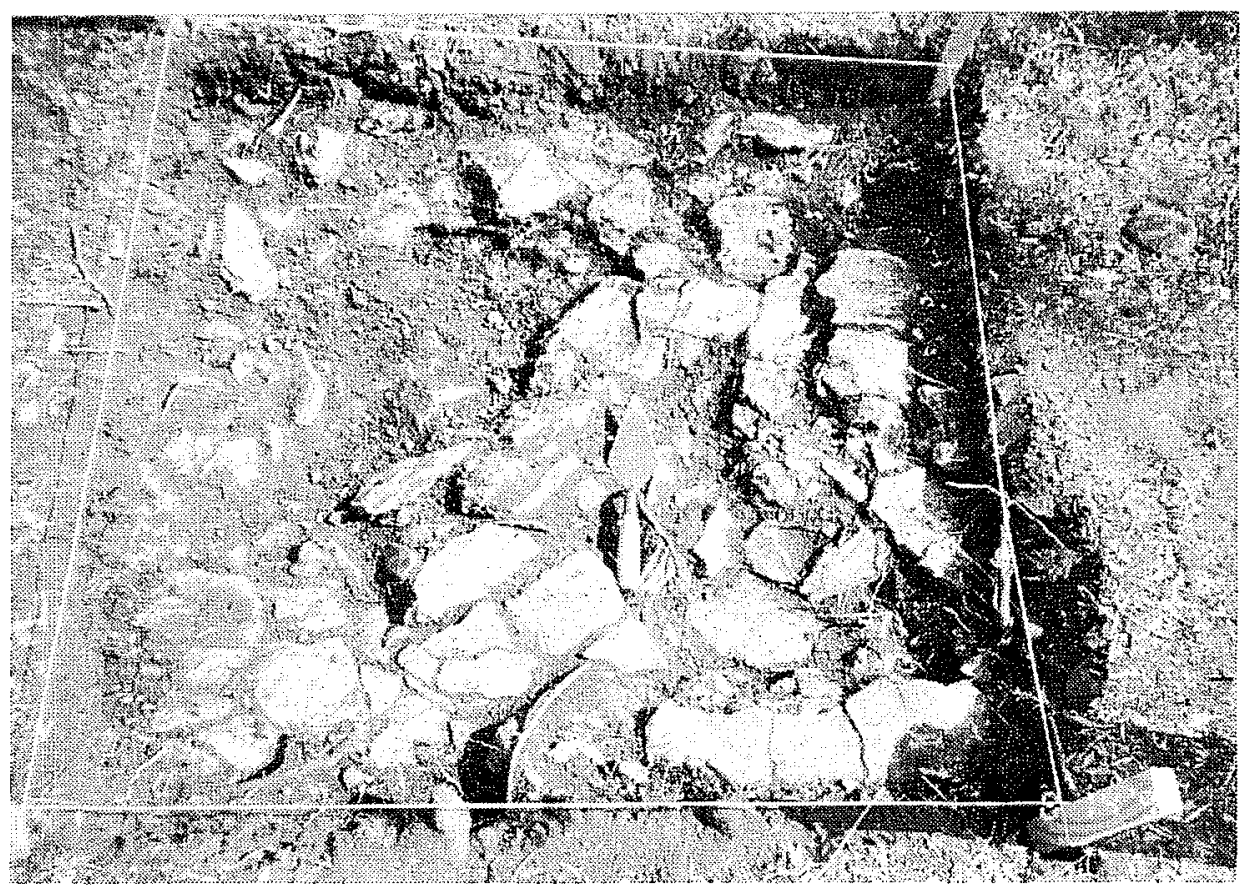

Figure 5-53. Photograph of indurated calcium carbonate layer at $20 \mathrm{~cm}$ bs in TUN1030 E995, 41BX1114.

a possible Guadalupe tool (UI 17) that is small and crudely flaked. The only ground stone artifact, a chert cobble (UI 8) with polish on one face, was recovered from the south collection area. No features were encountered on the surface or during excavations. The only diagnostic artifact (Figure 5-57) recovered during excavations from the south end of the site was an

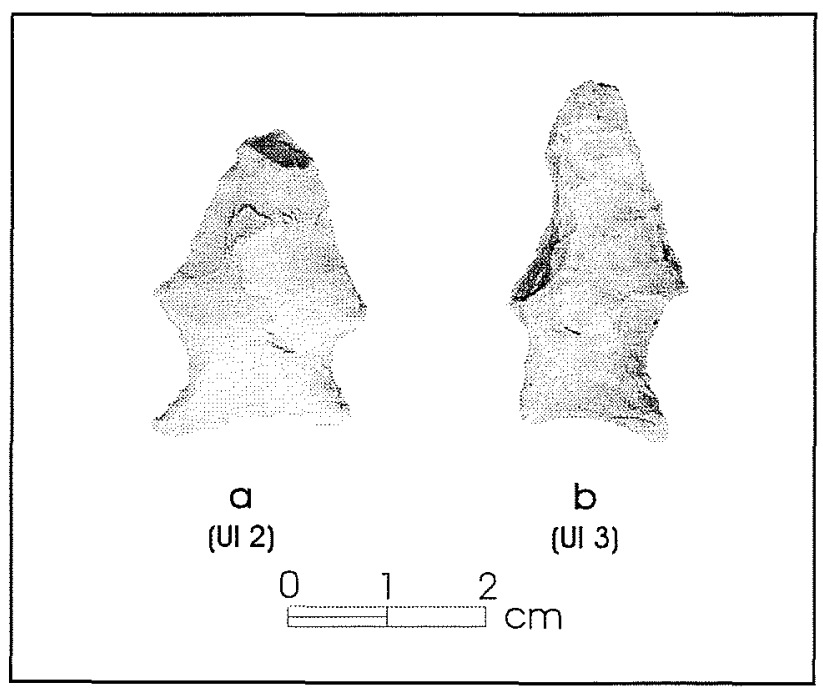

Figure 5-54. Fairland dart points from TU N1039 E993, $41 B X 1114$.
Ensor dart point (UI 6) from ST C-1, located immediately west of the collection area.

The two 1-x-1-m test units excavated in the south end reflect the low artifact counts documented for the surface (Figure 5-58). The geoarchaeological assessment of 41BX1114 indicates there is little chance for finding buried deposits in this section of the site (see discussion above). The generally decreasing debitage counts in TU N817 E1082 and TU N829 E1075 are consistent with material from the surface migrating downward through bioturbation or by falling into desiccation cracks. This material, however, should be Transitional Archaic or younger given the apparent geomorphic history of this intermediate surface.

Fifty-two flotation samples were collected at 41BX1114; one from each excavated level of the $1-\mathrm{x}-1-\mathrm{m}$ units outside of the Feature 1 area and 31 from the block of units around Feature 1. Each of these samples was processed at CAR and scanned for macrobotanical remains. The light and heavy fractions from the Feature 1 area contained abundant charcoal and occasional burned bone fragments. However, the analysis of the radiocarbon samples from this area indicate that charcoal and bone are modern. No macrobotanical remains were found in the fractions from the other samples collected at 41BX1114.

\section{Discussion}

The testing at $41 \mathrm{BX} 1114$ recovered diagnostic artifacts dating to the Transitional Archaic and Late Prehistoric time periods. All the diagnostic material with the exception of an Ensor dart point and the possible Guadalupe biface was recovered at the north end of 


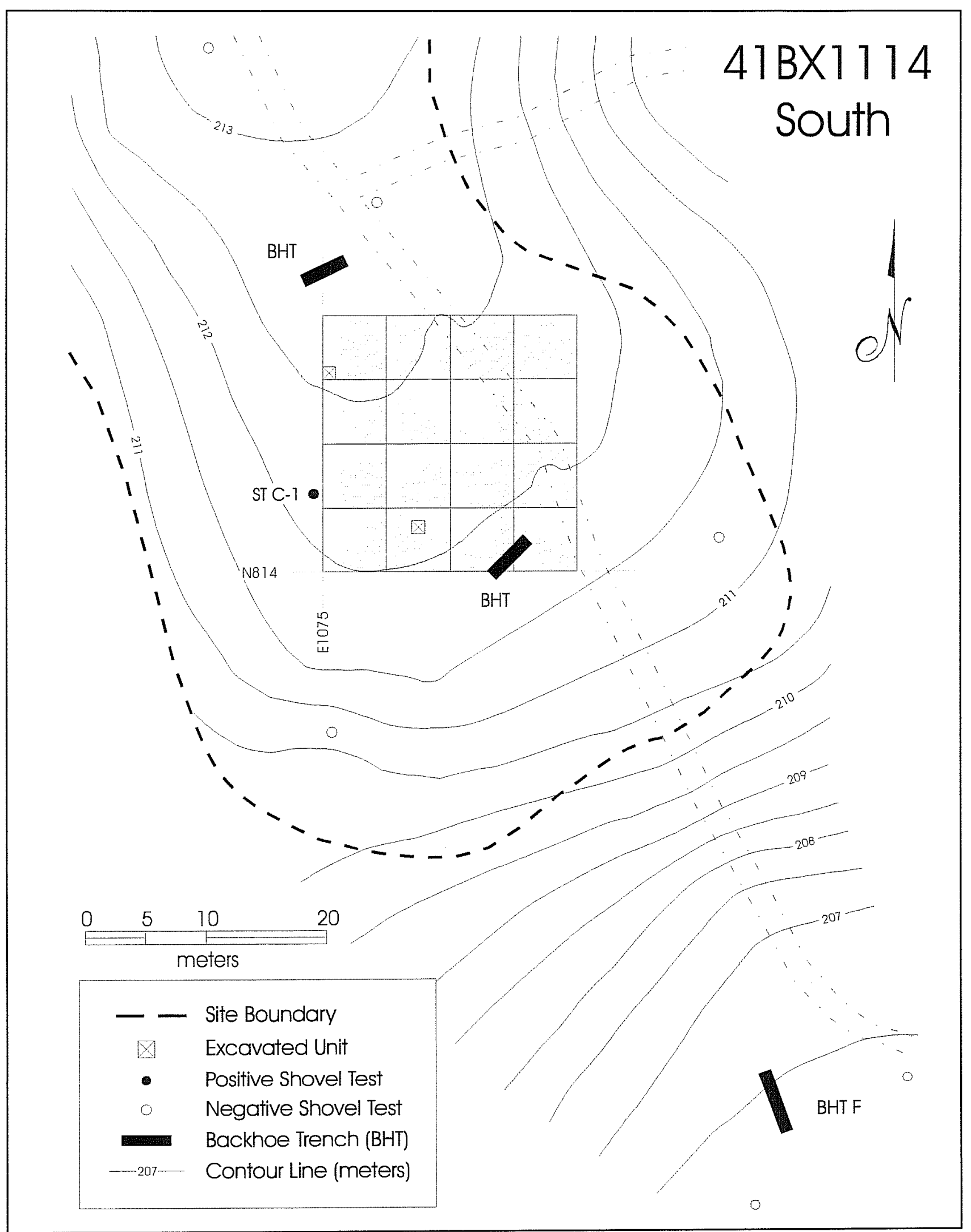

Figure 5-55. South collection area, 41BX1114. 


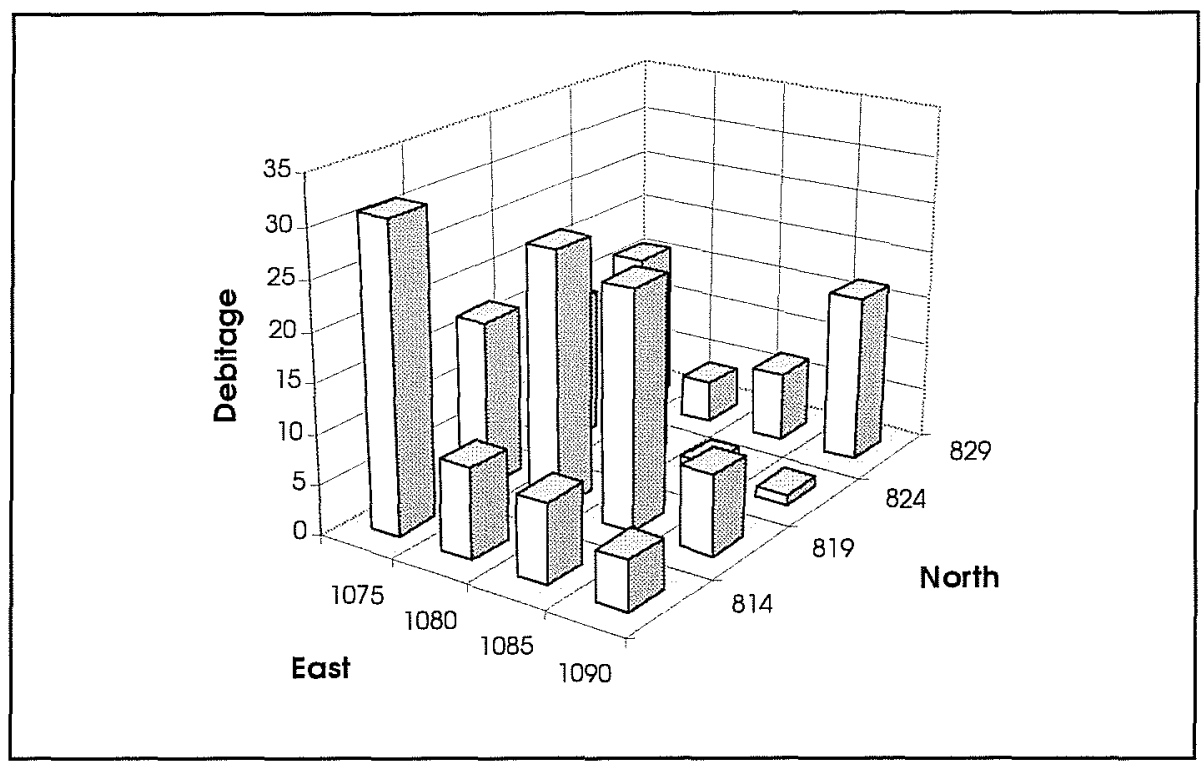

Figure 5-56. Distribution of debitage in south surface collection area at $41 B X 1114$.

the site where the greatest level of effort was expended. Eight Leon Plain ceramic sherds and one Scallorn arrow point were recovered from a $7-\mathrm{m}^{2}$ block of shallowly excavated test units placed to investigate a concentration of charcoal and bone that was designated Feature 1. The three radiocarbon dates from this feature indicate that the Late Prehistoric artifacts were not associated with the bone and charcoal, probably the remnant of a burned stump, which were historic to modern in date.

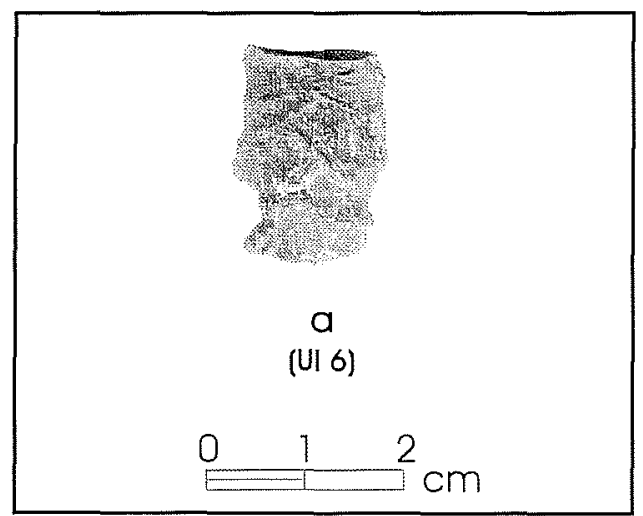

Figure 5-57. Ensor point from $S T C-1$, $41 B X 1114$.
The test excavations confirmed that biological activity is intense at $41 \mathrm{BX} 1114$ and is responsible for the vertical movement of material from the surface to the subsurface. The integrity of the surface deposits has therefore been compromised, but only to the extent that most of the displaced material has been moved down profile $20 \mathrm{~cm}$ or less. There is no chance of encountering buried cultural features or artifacts in a primary context unless they have been buried by a tree throw, some other biological process, or by colluvial deposits. The latter possibility exists for the area between the south and north collection units where material eroding from the hill top may form a colluvial wedge.

The generally shallow soil at 41BX1114 and the large quantity of cultural material, however, suggest that it may be possible to identify distinct clusters of associated artifacts using shallow block excavations. Assuming that $41 \mathrm{BX} 1114$ is a surface site at which the soils are too old to contain buried deposits in a primary context, with the exception of the hill slope area, and given the potential for rapid burial as evidenced by the modern animal bone in Feature 1, the material recovered subsurface is potentially of the same age as the material on the surface. Additionally, the diagnos- 


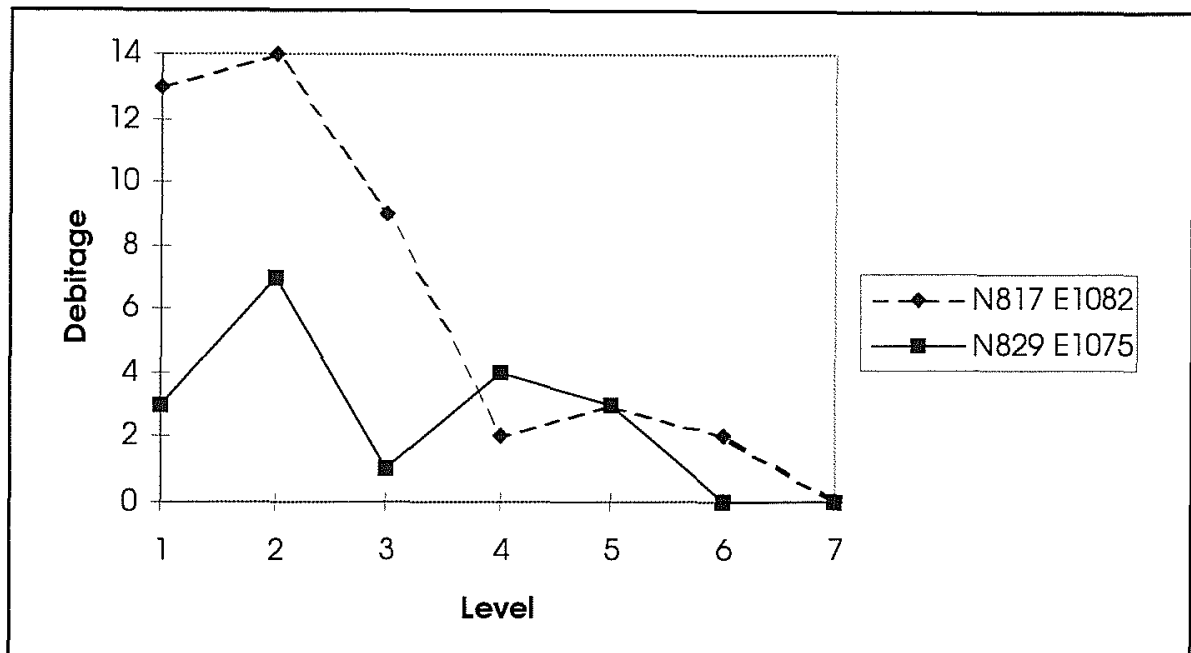

Figure 5-58. Debitage counts by excavated level at TUs N817 E1082 and N829 E1075, 41BX1114.

tics indicate that the site was used most intensively, during the Transitional Archaic and Late Prehistoric.

The two collection areas at the site indicate tremendous intrasite variation in artifact assemblage (Table 5-16), reflecting variation in prehistoric activities. At the south end of the site, raw material was being tested and procured. This is evidenced by the high frequency of cores, the low average number of flake scars per core, and the high frequency of core/platform preparation flakes. At the north end, the artifact assemblage displays greater diversity and is indicative of multiple activities. The average number of flake scars per core is higher, suggesting that material was being reduced further. This is confirmed by the comparatively high frequency (12 percent) of biface manufacture flakes in the north area. Additionally, the frequency of bifaces and unifaces is much higher than in the south.

\section{Sites Outside Impact Areas}

\section{Site 41BX1076}

\section{Site Setting}

Site 41BX1076 (Figure 5-59) is located on the Intermediate Upland surface $12 \mathrm{~m}$ above the modern lowwater channel of Medio Creek, $500 \mathrm{~m}$ to the north. The site is located on a high knoll in the uplands at an elevation of $205 \mathrm{~m}$ amsl. The location offers visibility

Table 5-16. Variation in Artifact Assemblages from North and South Collection Areas at 41BX1114

\begin{tabular}{|l|c|c|}
\hline \multicolumn{1}{|c|}{ Category } & North & South \\
\hline Biface manufacturing flakes as a \% of debitage & 12.0 & 2.0 \\
\hline Cores as a \% of non-debitage artifacts & 44.0 & 83.0 \\
\hline Average flake scars per core & 5.9 & 4.7 \\
\hline Bifaces as a \% of non-debitage artifacts & 18.0 & 9.0 \\
\hline Unifaces as a \% of non-debitage artifacts & 37.0 & 8.0 \\
\hline Debitage density per 5-x-5-m CU & 51.1 & 12.9 \\
\hline
\end{tabular}




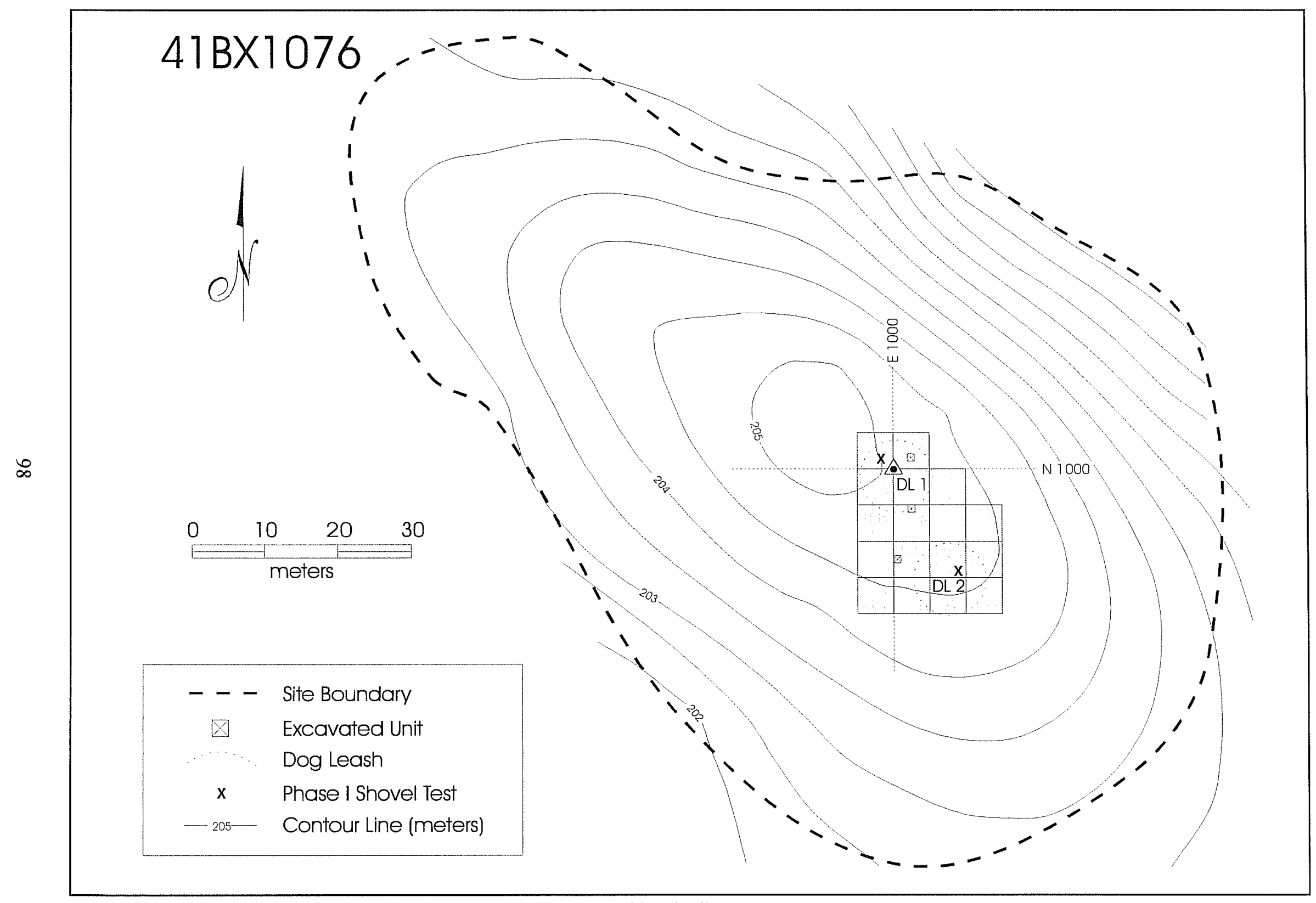

Figure 5-59. Site map, 41BX1076. Collection areas are represented by shading. 
for miles in all directions, including the broad and flat terraces adjacent to Medio Creek. The almost flat surface on the knoll is covered with dense grasses under a canopy of mesquite, persimmon, and hackberry. Raw materials in the form of chert cobbles outcrop on the lip of the knoll and continue downslope for $20-30 \mathrm{~m}$ in all directions.

Site 41BX1076 is located near the boundary of the Medina firing range impact area and has therefore been spared any recent artificial impacts. Because the site is located on a hilltop, material on the surface is subjected to erosion during heavy rains, but bioturbation may be the most active form of impact at the site.

\section{Previous Investigations}

While recording and mapping this site in 1995, CAR staff placed a 5-m radius dogleash placed around a possible hearth feature visible on the surface. The inventory of the unit documented 117 fire-cracked rock fragments and 168 artifacts, including a Scallorn point. A finely worked thin biface found on the south edge of the site served as the center of a second 5-m radius dogleash containing 56 artifacts and 21 fire-cracked rock fragments. A shovel test was excavated to a depth of $50 \mathrm{~cm}$ in each of the dogleash areas. Each test contained artifacts to a depth of $30 \mathrm{~cm}$ bs (Nickels et al. 1997)

\section{Level of Effort}

41BX1076 was the last of the eight sites to be tested. Investigations were limited to the collection of $16 \mathrm{CUs}$ over $400 \mathrm{~m}^{2}$ of the site and the excavation of three 1$\mathrm{x}-1-\mathrm{m}$ test units. The site was mapped using a total station with site boundaries based on the surface distribution of artifacts.

\section{Site Size and Depth}

The size of the site is estimated to be $8,525 \mathrm{~m}^{2}$. This is an increase of 568 percent over the survey estimate of $1,500 \mathrm{~m}^{2}$. Two test units, N987 E1000 and N1001
E1002, were excavated to $50 \mathrm{~cm}$ below surface at which point excavations were terminated. Cultural material was present throughout the deposit, but decreased dramatically in quantity with depth. A third test unit, N994 E1002, was excavated to a depth of 10 $\mathrm{cm}$ bs to expose an irregular accumulation of burned rock, designated Feature 1.

\section{Testing Results}

\section{Geoarchaeological Assessment}

As with site 41BX1091, no formal soil-stratigraphic descriptions were written at this site. However, a cursory description was made from TUN987 E1000. This test unit consisted of $50 \mathrm{~cm}$ of few matrix-supported pebbles in a very dark grayish brown and clayey matrix. An occasional dense pocket of pebbles also occurred to this depth. The landscape at $41 \mathrm{BX} 1076$ evolved in one of two ways. The first possibility is that the area was a Pleistocene alluvial terrace that was subsequently eroded, thus leaving a gravel lag at the site. The problem with this scenario is the gravels look to be Uvalde and, therefore, possibly derived from a superadjacent landscape. The alternate hypothesis is that the gravels and sediments at 41BX1076 are Pleistocene colluvium originating from a higher surface to the southeast. Subsequent landscape dissection could have rounded-off the hilltop, leaving a section of the colluvium intact.

\section{Archaeological Investigations}

The investigations at 41BX1076 located one irregular burned rock feature which was designated Feature 1, one Fairland dart point (UI 1), and one Scallorn arrow point (UI 2). A collection of 4,216 chipped stone artifacts was recovered from the site, including 3,829 pieces of debitage, 104 bifaces, 60 unifaces, and 221 cores (Table 5-17).

The surface collection recovered 75 percent of the total chipped stone assemblage including 2,868 pieces of debitage, 100 bifaces, 59 unifaces, and 192 cores. Both projectile points, a proximal drill or perforator fragment (UI 17) (Figure 5-60), and two hammerstones 
Table 5-17. Artifacts from 41BX1076

\begin{tabular}{|c|c|c|c|c|}
\hline Artifact Type & Surface & TUs & IF & Total \\
\hline Debitage & 2868 & 961 & 0 & 3829 \\
\hline Bifaces & 100 & 3 & 1 & 104 \\
\hline Unifaces & 59 & 1 & 0 & 60 \\
\hline Cores & 192 & 29 & 0 & 221 \\
\hline Projectile Points & 2 & 0 & 0 & 2 \\
\hline Hammerstones & 2 & 2 & 0 & 4 \\
\hline Manos & 0 & 1 & 0 & 1 \\
\hline Grinding Slabs & 0 & 1 & 0 & 1 \\
\hline Total & 3223 & 998 & 1 & 4222 \\
\hline
\end{tabular}

were collected from surface units. The debitage was generally distributed evenly across the collection area (Figure 5-61), but there is a "hole" in the distribution formed by a $\mathrm{CU}$ in the center of the site with a low debitage count surrounded by $\mathrm{CU}$ s with higher counts. The distribution of cores, bifaces, unifaces, and projectile points shows a clear concentration of material in CUN1000 E1000 (Figure 5-62). This 5-x-5-m unit accounted for 21 percent of the non-debitage chipped stone artifacts (including the Scallorn point [UI 2]) recovered at $41 \mathrm{BX} 1076$

Subsurface investigations in three test units recovered 961 pieces of debitage, 3 bifaces, 1 unifaces, 29 cores, one grinding slab (UI 15), one mano (UI 13), and two hammerstones (UI 11 and UI 16). Feature 1 was partially excavated in TUN994 E1002. The other two excavation units (TU N987 E1000 and TU N1001 E1002) encountered burned rock in the upper $10 \mathrm{~cm}$ of the deposits, but in both cases, the burned rock lacked a recognizable pattern or structure. Generally, the amount of debitage dropped significantly between 10 and $20 \mathrm{~cm}$ bs before increasing slightly in Level 3 (Figure 5-63). Material was present in Levels 4 and 5 , but in diminished quantities.

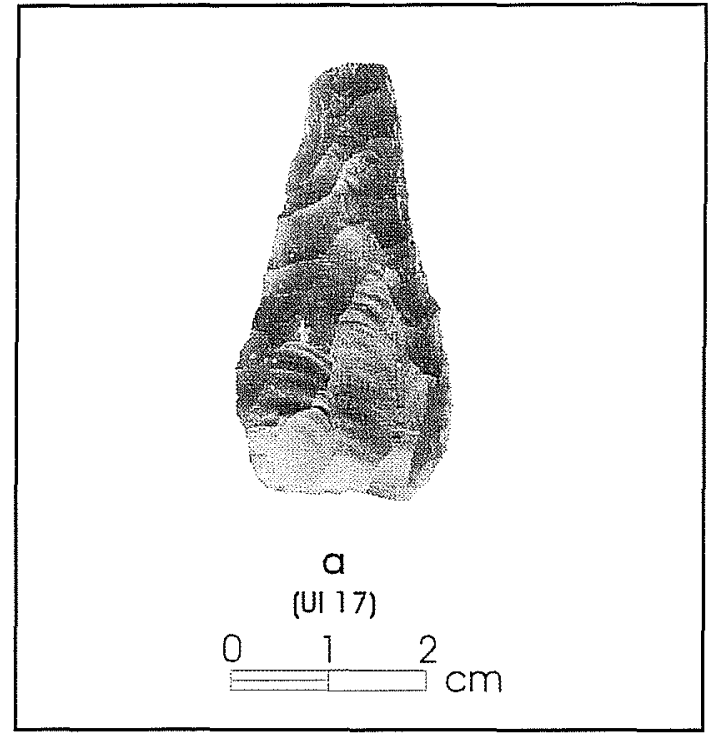

Figure 5-60. Proximal perforator fragment from $41 B X 1076$.

The original CAR survey crew placed a dogleash inventory unit in the approximate location of CUN 1000 E1000, recording high artifact and burned rock densities and recovering a Scallorn point (Nickels et al. 1997:Table G-1). The survey crew postulated that an intact hearth could be present in the dogleash (Nickels et al. 1997), but none was recognized during testing. The area around and including CUN1000 E1000

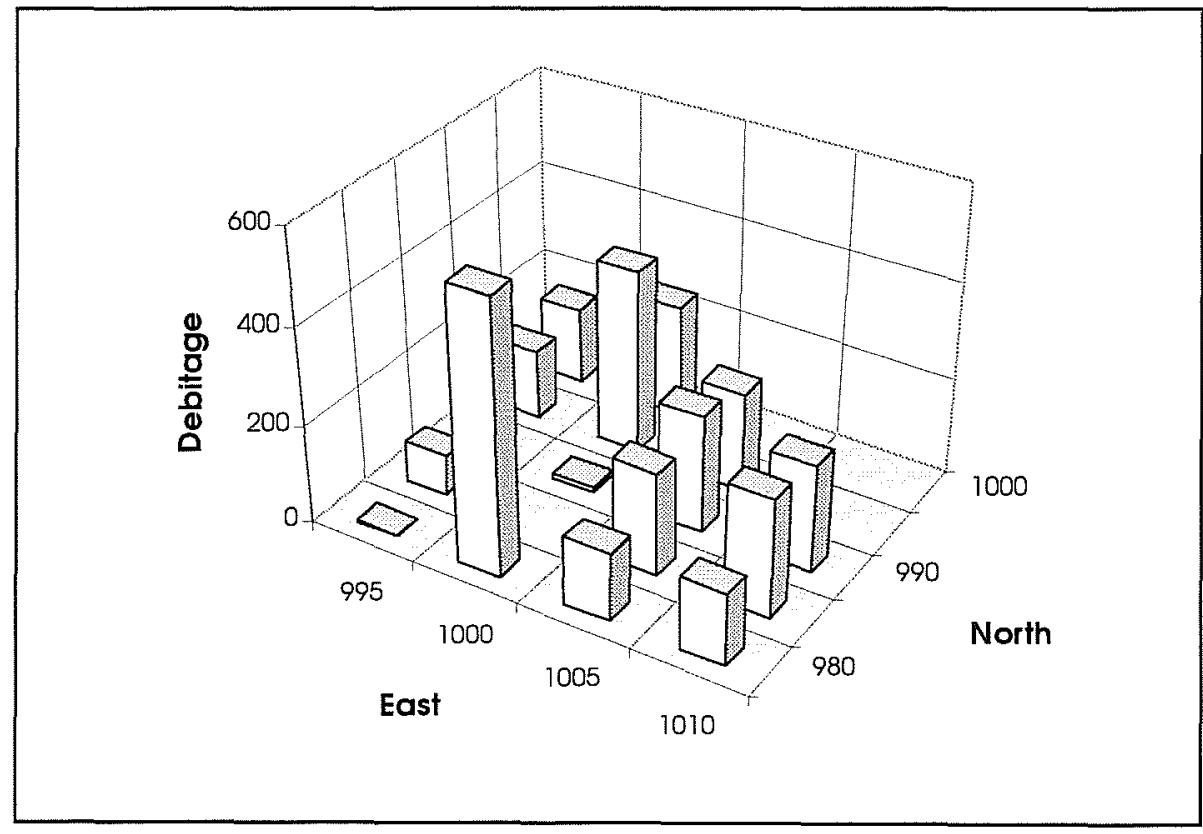

Figure 5-61. Distribution of debitage in surface collection area at $41 B X 1076$. 


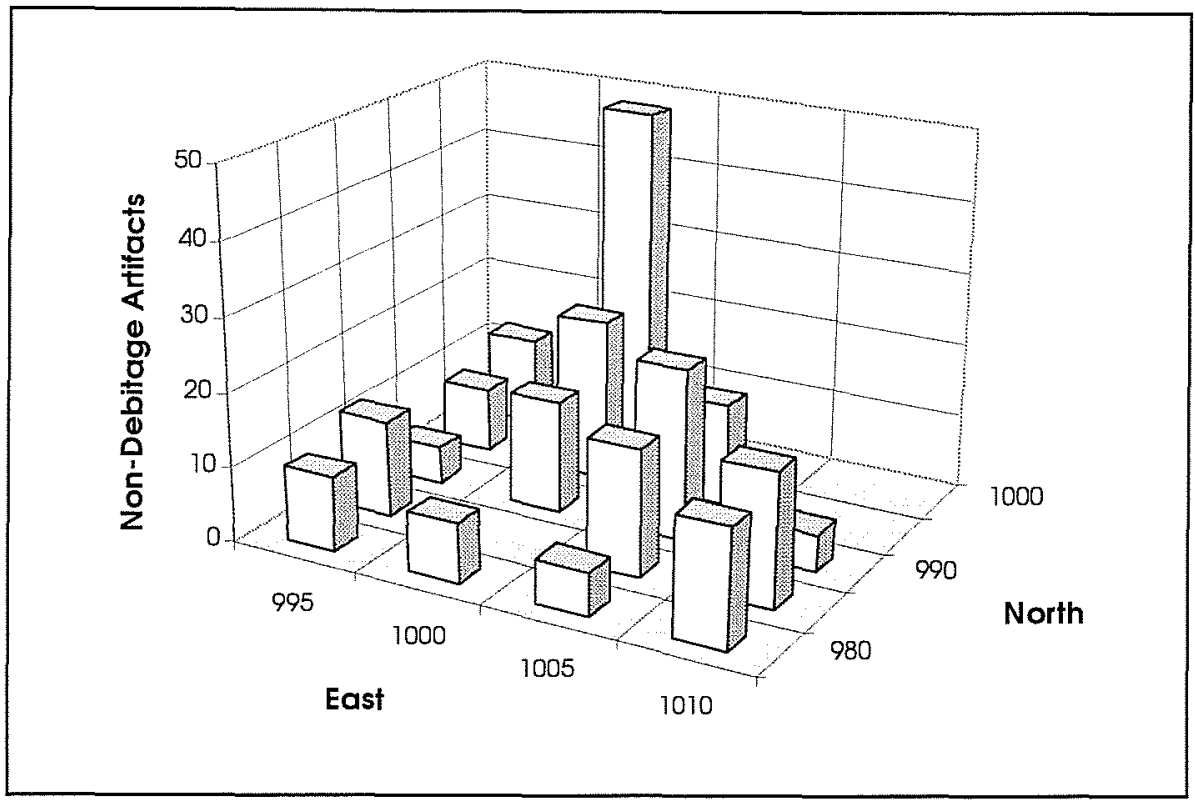

Figure 5-62. Distribution of nondebitage chipped stone artifacts in surface collection area at $41 B X 1076$.

Figure 5-63. Distribution of debitage by excavated level at $41 B X 1076$.

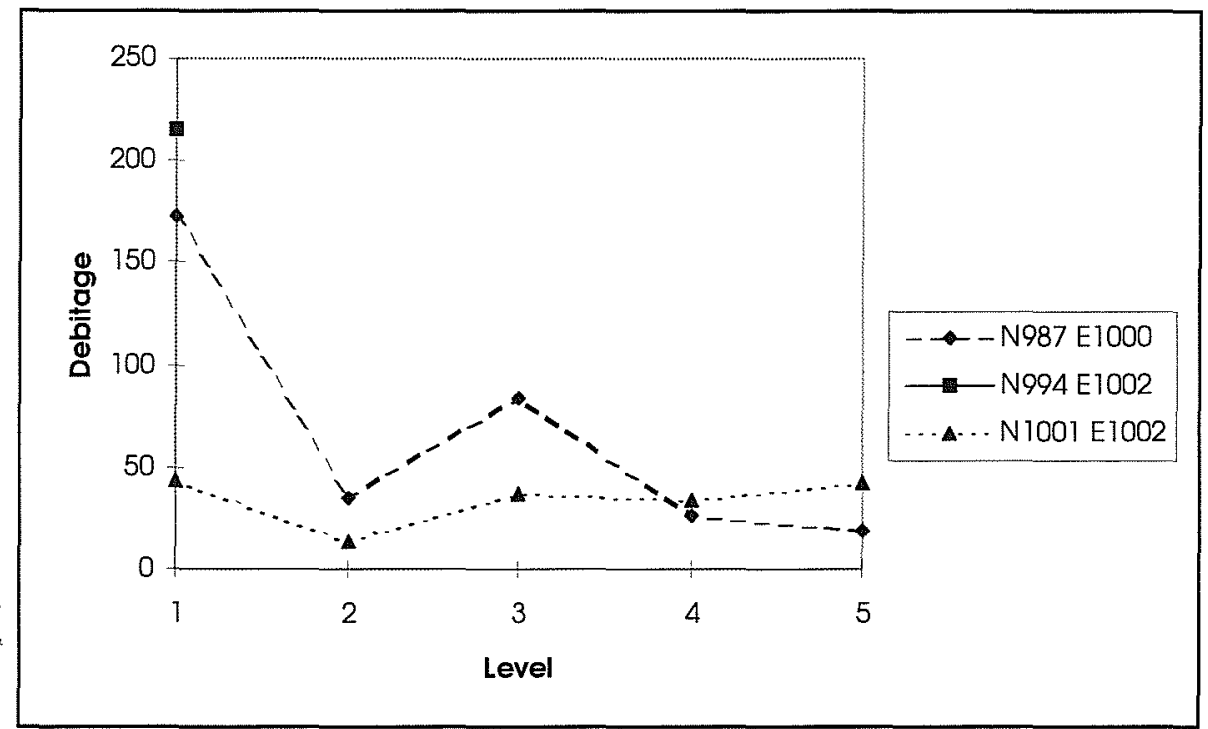

contained a high density of burned rock on the surface but no pattern was clearly discernible.

A cluster of burned rocks exposed in TU N994 E1002 directly south of the CU was designated Feature 1 (Figure 5-64). This loosely grouped feature was composed of burned limestone and fire-cracked chert. The surrounding matrix yielded the greatest quantity of debitage $(n=218)$ recovered from any excavated level at the site. Burned rock was visible on the surface outside the limits of the excavation unit.

Eleven flotation samples were collected during the excavations at 41BX1076; one from each excavated level of each unit. Based on the geoarchaeological assessment of the site and the results of the analysis of samples from 41BX1114, another upland site, the samples were not processed. 


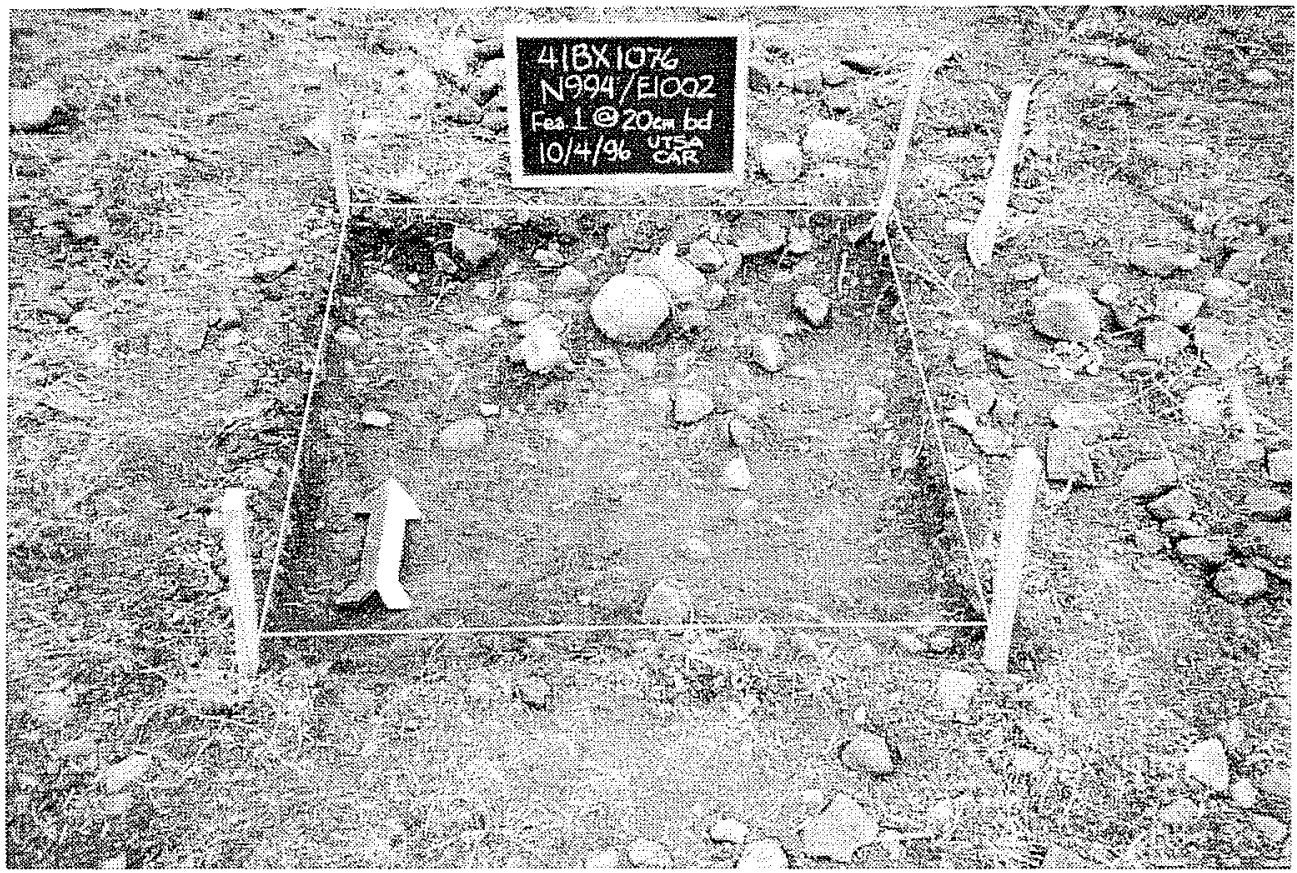

Figure 5-64. Photograph of Feature 1 in TU994 E1002, Level 1, and adjacent area at $41 B X 1076$.

\section{Discussion}

Both the Scallorn and Fairland points recovered at 41BX1076 are proximal fragments, apparently broken through use (Figure 5-65). Combined with the survey data (Nickels et al. 1997), the site has yielded three diagnostic projectile points from the Transitional Archaic and Early Late Prehistoric time periods. No other dateable materials or diagnostic artifacts were recovered.

Site 41BX1076 has not been seriously affected by artificial impacts. The integrity of the surface is, therefore, fairly good, although material has most likely been displaced to some degree by bioturbation and, along the hillsides, by erosion. Of the upland sites which were tested, $41 \mathrm{BX} 1076$ has the most concentrated accumulation of burned limestone, and it is possible that block excavations could recover largely intact features.

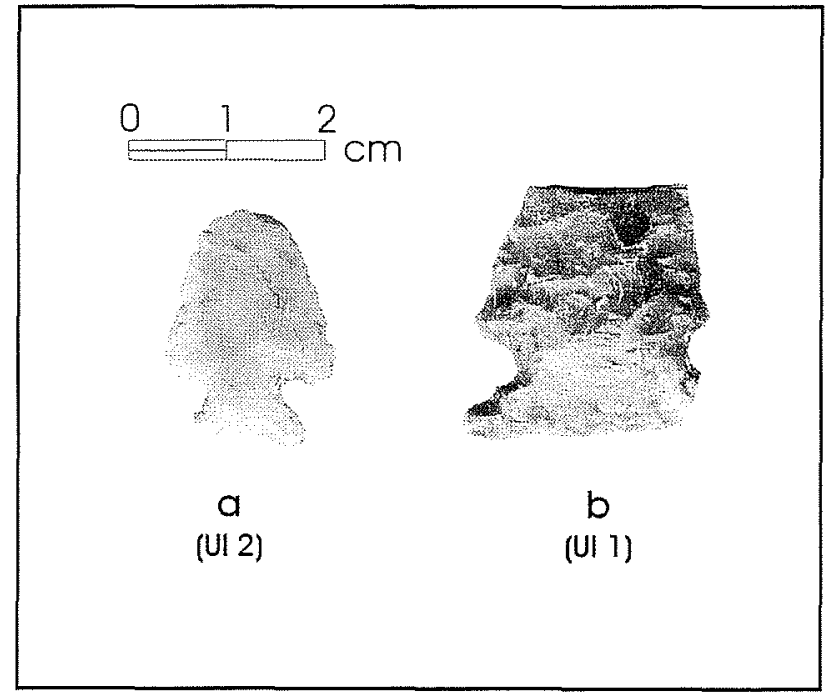

Figure 5-65. Diagnostic artifacts from $41 B X 1076$. a: Scallorn arrow point; b: Fairland dart point. 


\title{
Chapter 6: Analysis and Research Issues
}

\author{
Brett A. Houk, C. Britt Bousman, David L. Nickels, and Steve D. Tomka
}

\section{Introduction}

The archaeological testing at eight prehistoric sites at Medina Annex recovered over 29,700 artifacts from $5,725 \mathrm{~m}^{2}$ of surface collected area and over $30 \mathrm{~m}^{3}$ of excavated subsurface deposits. The temporally diagnostic artifacts span the Early Archaic period to the latter part of the Late Prehistoric, although the majority date to the Transitional Archaic and Late Prehistoric periods. Six of the eight sites were located in the Uplands adjacent to Medio Creek, and two were situated in creek terraces.

This chapter is divided into three major sections. The first section is a discussion of the different geologic contexts of archaeological sites. The second section is an analysis of the data which provides an intersite comparison of the artifact assemblages collected from seven of the sites during the project. $41 \mathrm{BX} 1070$ is excluded from this analysis because of the limited investigations undertaken there. The final section is a discussion of research issues identified during the fieldwork and laboratory analysis associated with the archaeological testing. These research issues are used to make recommendations about the significance of the investigated sites in Chapter 7.

\section{Geological Context of Archaeological Occupations or Sites}

A great deal of recent literature discusses the formation processes involved in the creation of archaeological sites and the post-depositional processes that disturb the context of materials on archaeological sites (Waters 1992; Goldberg, Nash, Petraglia 1992; Johnson and Watson-Stegner 1990). These discussions are usually organized along process dimensions (for good reasons), but another manner of organizing these discussions is by the results produced by the various processes. Below is a brief discussion of the end-products created by various geologic (deposition and erosion), pedogenic (shrinking, swelling, and cracking) and biologic (burrowing, tree fall) processes in terms of archaeological sites, features, and artifacts. The various end-products can be grouped by primary and secondary contexts. Primary contexts include Good Geological Context, Good Surface Context, Surface Palimpsest, and Compressed Stratigraphy (Figure 6-1). Secondary contexts include Turbated Palimpsest, Lag Palimpsest, Mixed Deposit, Redeposited Context, and Reversed Stratigraphy (Figure 6-2). It is entirely possible that individual sites will represent multiple types of context expressed horizontally and vertically and in various combinations.

\section{Primary Geological Context}

Good Geological Context-Archaeological materials are discarded in a geological context that covers the materials by low energy deposits which do not move artifacts or materials in any appreciable manner. In some settings archaeological occupations or components are separated by sterile deposits.

Good Surface Context-Archaeological materials (artifacts and features) from a single occupation or component are discarded on a stable surface. These materials undergo little horizontal or vertical movement, and little or no mixing with materials from other occupations or components.

Compressed Stratigraphy - Archaeological materials are discarded in very slowly accumulating deposits but in correct stratigraphic order, although the physical separation is noticeably less than occurs in other sites with good geological context.

Surface Palimpsest - Artifacts and/or features from multiple occupations or components are discarded on 


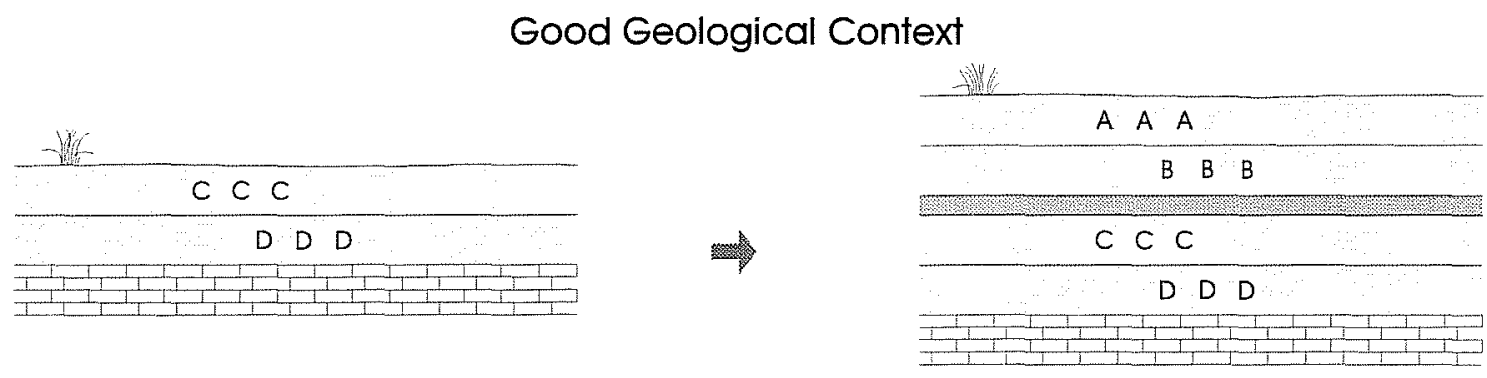

Good Surface Context

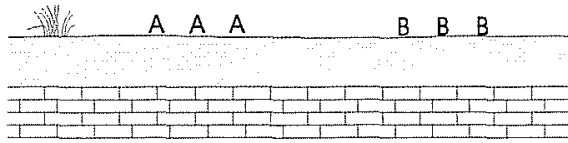

or

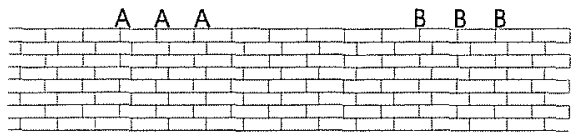

\section{Compressed Stratigraphy}

$y$

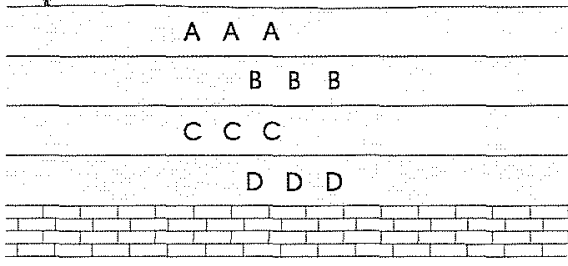

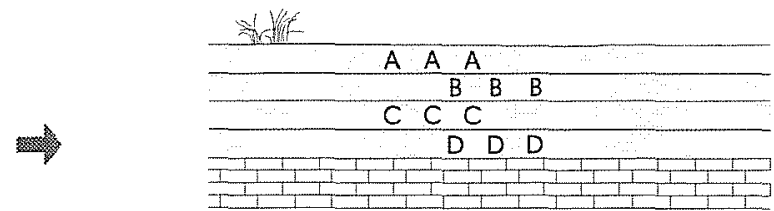

Surface Palimpsest
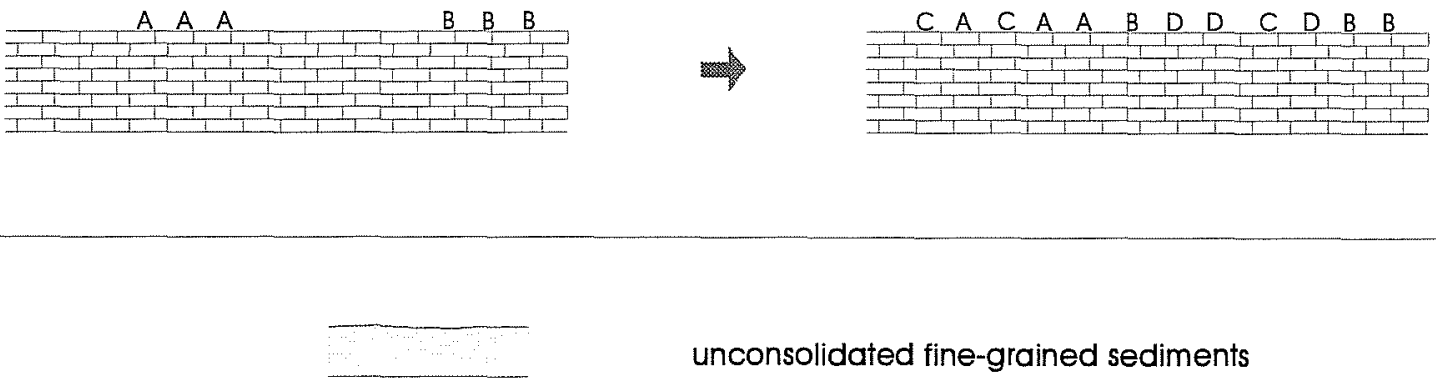

unconsolidated fine-grained sediments

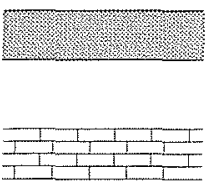

unconsolidated gravels

consolidated sediments or bedrock

Figure 6-1. Examples of primary contexts. 


\section{Turbated Palimpsest}

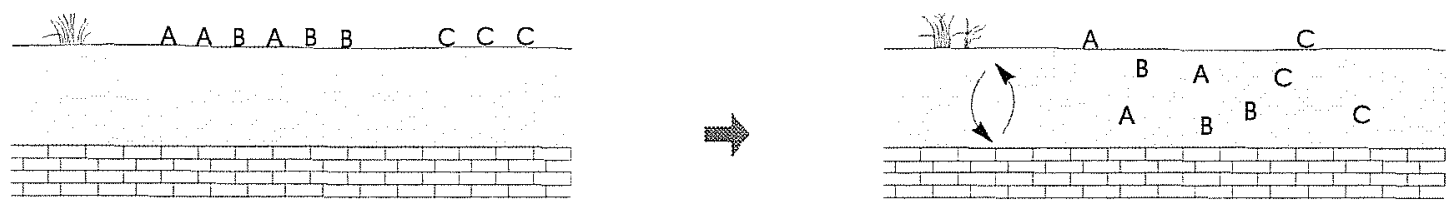

\section{Lag Palimpsest}
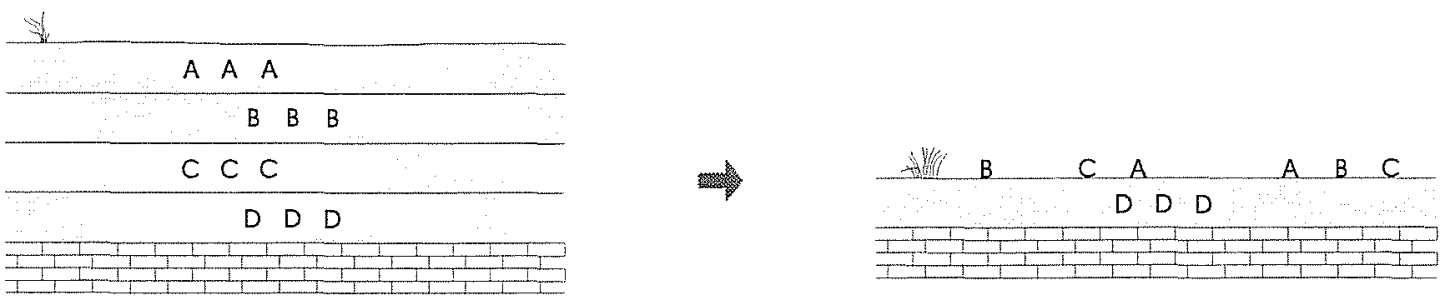

\section{Mixed Context}
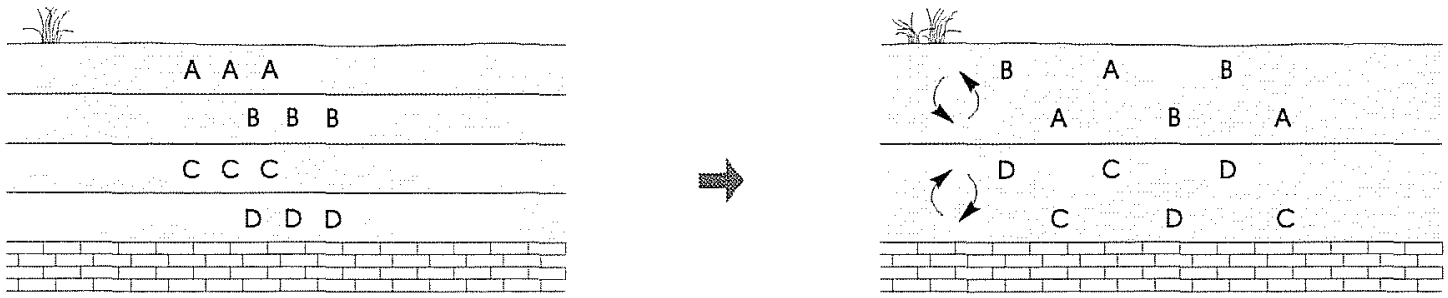

\section{Redeposited Context}
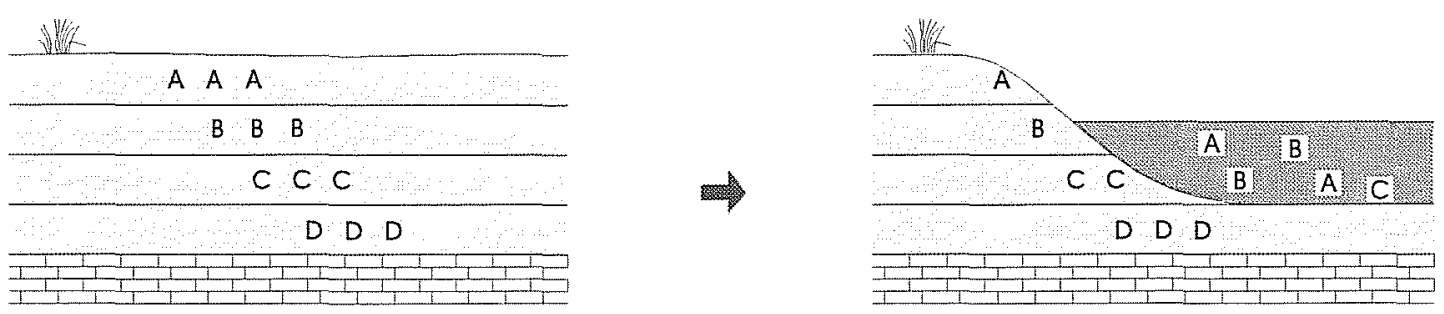

\section{Reversed Stratigraphy}
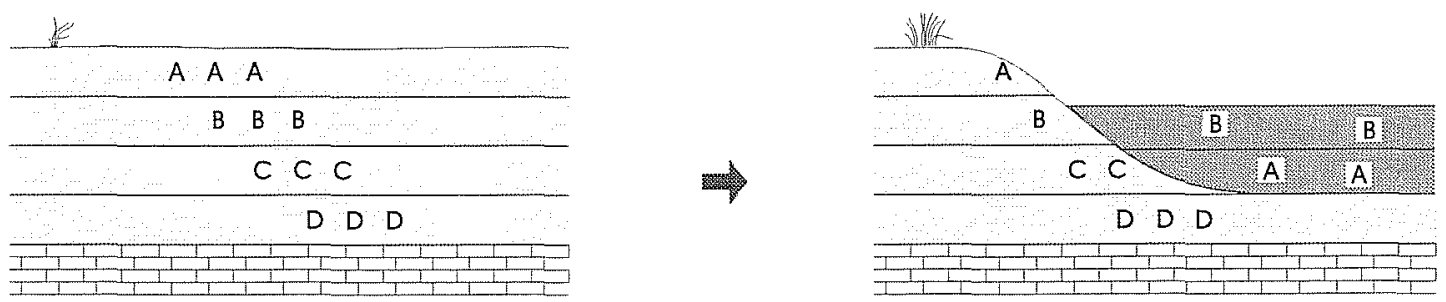

Figure 6-2. Examples of secondary contexts. 
a stable surface (bedrock), and these materials are intermingled on this surface.

\section{Secondary Contexts}

Turbated Palimpsest-Archaeological materials are discarded on a stable surface, however pedo-geological processes and biological activity below and on that surface move artifacts at various rates in multiple directions.

Lag Palimpsest -Archaeological materials discarded in an accumulating depositional environment but later, usually either by wind or water erosion, artifacts from different occupations or components are intermingled on erosional surfaces.

Mixed Deposit-Archaeological materials are discarded in an accumulating depositional environment, but later, through rodent burrowing, tree falls, or other forms of bioturbation or soil processes, materials are vertically mixed.

Redeposited Context-Archaeological materials discarded in an accumulating depositional environment or on a stable surface but by wind or water erosion, artifacts are transported and then redeposited in another sedimentary unit.

Reversed Stratigraphy-Archaeological materials discarded in an accumulating depositional environment or on a stable surface but later, either by wind or water erosion, artifacts are redeposited in another sedimentary unit and in reversed chronological order. Reversed stratigraphy is a subset of materials in redeposited contexts.

\section{Contexts at Lackland}

Many of the sites at Lackland, especially all the sites in the uplands, represent turbated palimpsests. Also present are sites in good geological contexts (41BX1102) and redeposited contexts (41BX1103). One should realize that the definitions between some of these depositional contexts represent a continuum and not singular classes. For example $41 \mathrm{BX} 1103$ is classified as a redeposited context, but an analysis of artifact damage indicates that the lithic artifacts were transported very short distances, if at all. Thus considering the current state of archaeological knowledge in this portion of Bexar County and the temporal resolution offered by the site, 41BX1103 can be considered as a site with at least moderate geological context rather than good geological context, but nevertheless a site with the potential for providing scientifically useful information. Also it is clear that at least one primary context, surface palimpsest, usually does not provide high resolution information. Thus the simple classification of site context into primary or secondary contexts does not offer a simple rationale for determining site significance.

\section{Data Analysis}

The purpose of the tables reproduced below is to allow for a comparison of artifact assemblages between sites based on specific attributes that were examined during the analysis of the material collected during the testing project. Definitions of attribute categories and terms, as well as the methods of analysis, are included in Appendix B of this report.

The statistical manipulation of the data can also be used to evaluate the similarities and differences between upland and floodplain sites. An assumption guiding the testing project was that the upland sites were used primarily as locales from which to procure raw materials and at which to test those raw materials, while the floodplain sites were used for other purposes such as residential camps, hunting camps, or other special activities. The upland sites include 41BX1070, from which the artifact sample is extremely small, 41BX1076, 41BX1088, 41BX1090, 41BX1091, and 41BX1114. The floodplain sites in this study are 41BX1102 and 41BX1103.

The five main chipped stone artifact categories (debitage, cores, bifaces, unifaces, and projectile points) are discussed individually. Contingency table analysis was conducted on most categories to evaluate several of the more important artifact attributes. Because the assemblage from $41 \mathrm{BX} 1070$ contains only one flake and one core, it will not be discussed in this sec- 
tion, although it was included in the analysis. The raw material type and quality of the artifacts was evaluated separately and compared to the type and quality of unmodified raw material available at each site. The contingency table analyses utilize adjusted residuals along with raw counts and appropriate percentages. Adjusted residuals measure the difference between observed and expected values for each cell in the contingency table and convert this difference into a value that has the same distribution as a typical z-score for a normal probability distribution (Haberman 1978; Norusis 1993). Adjusted residuals with a value of equal to or greater than 2, or equal to or less than -2 are considered significant at a 0.05 level of confidence. The results of these comparisons follow the artifact analysis below.

\section{Artifacts}

\section{Debitage}

Contingency table analysis was conducted for the following debitage attributes: cortex, flake type, and platform faceting. The mean and standard deviation for the maximum dimension of complete flakes is also presented. These attributes were chosen for analysis because they are measures of the type and nature of lithic material reduction and tool manufacture. The amount of cortex on a flake is indicative of how early in the reduction process it was removed from the parent material. Flake type provides information on the type of lithic reduction and tool manufacture that took place at a site. Platform faceting is an indication of both reduction stage and type of tool manufacture. The maximum dimension of a flake is related to stage of reduction, reduction strategy, and raw material size.

Before presenting the debitage contingency tables, it is necessary to point out that the debitage from 41BX1091 was analyzed differently than that from other sites. During the attribute analysis, we originally believed that a large percentage of the debitage from the site was artificially created by heavy machinery's crushing the naturally occurring chert cobbles. We later concluded, however, that these flakes and associated cores were the result of cobble splitting. In replication studies, successful attempts to split unmodified cobbles created two large "flakes," neither of which possessed a bulb of percussion. Unsuccessful attempts created distinctive angular flakes like those found in the 41BX1091 assemblage. This cobble-splitting technology is discussed in more detail in Appendix B.

The debitage from 41BX1091 was sorted into split cobble flakes (including complete and proximal specimens), complete flakes, and incomplete flakes. Because no attempt was made to differentiate complete split cobble flakes from proximal fragments, the assemblage is not directly comparable to those from other sites. When treated as a "flake type," the split cobble category is artificially high because it includes proximal fragments in addition to complete flakes. For the other flake type categories, only complete flakes were analyzed.

From the 41BX1091 assemblage, 618 flakes and flake fragments were identified as split cobble flakes out of a total of 2,388 pieces of debitage. The assemblage contained 287 complete flakes, excluding those classified as split cobble flakes. The proximal and complete split cobble flakes were not included in these contingency tables.

\section{Cortex}

The results of the analysis of debitage cortex are presented in Table 6-1. At all sites combined tertiary flakes are the most common (47.2 percent) with secondary flakes almost as common (41.5 percent), and primary flakes still fairly numerous (11.2 percent). This pattern shows that overall initial lithic reduction is prevalent at Lackland, nevertheless important variations occur at specific sites. For example, sites 41BX1088, 41BX1090, and 41BX1091, all upland sites, have greater-than-expected quantities of primary flakes and lower-than-expected quantities of tertiary flakes. The floodplain sites of $41 B \times 1102$ and 41BX1103 have greater-than-expected quantities of tertiary flakes. In general, with the exception of $41 \mathrm{BX} 1070$ which is represented by only one flake, the upland sites have greater-than-expected quantities of primary and/or secondary flakes and/or fewer-thanexpected late-stage tertiary flakes. The opposite is true for the floodplain sites, especially $41 B X 1103$ where 
Table 6-1. Contingency Table Analysis of Debitage Cortex Category by Site

Top value in cell represents artifact count, middle value is row percent, and bottom value represents adjusted residuals.

Percent value in total column represents column percent. Significant $(p \leq 0.05)$ values are shown in bold.

\begin{tabular}{|c|c|c|c|c|c|}
\hline Site & Primary & Secondary & Tertiary & Unknown & Total \\
\hline $41 \mathrm{BX} 1070$ & $\begin{array}{c}0 \\
0.0 \% \\
-0.4 \\
\end{array}$ & $\begin{array}{c}0 \\
0.0 \% \\
-0.8 \\
\end{array}$ & $\begin{array}{c}1 \\
100.0 \% \\
1.1 \\
\end{array}$ & $\begin{array}{c}0 \\
0.0 \% \\
0.0 \\
\end{array}$ & $\begin{array}{c}1 \\
0.0 \%\end{array}$ \\
\hline $41 \mathrm{BX} 1076$ & $\begin{array}{c}104 \\
10.9 \% \\
-0.3\end{array}$ & $\begin{array}{c}433 \\
45.3 \% \\
\mathbf{2 . 6}\end{array}$ & $\begin{array}{c}416 \\
43.6 \% \\
-\mathbf{2 . 5}\end{array}$ & $\begin{array}{c}2 \\
0.2 \% \\
0.7\end{array}$ & $\begin{array}{c}955 \\
16.4 \%\end{array}$ \\
\hline $41 \mathrm{BX} 1088$ & $\begin{array}{c}253 \\
14.8 \% \\
5.7 \\
\end{array}$ & $\begin{array}{c}809 \\
47.4 \% \\
\mathbf{5 . 8} \\
\end{array}$ & $\begin{array}{c}643 \\
37.6 \% \\
\mathbf{- 9 . 4} \\
\end{array}$ & $\begin{array}{l}3 \\
0.2 \% \\
.5 \\
\end{array}$ & $\begin{array}{c}1708 \\
29.4 \%\end{array}$ \\
\hline $41 \mathrm{BX} 1090$ & $\begin{array}{c}18 \\
24.0 \% \\
\mathbf{3 . 6} \\
\end{array}$ & $\begin{array}{c}40 \\
53.3 \% \\
\mathbf{2 . 1} \\
\end{array}$ & $\begin{array}{c}17 \\
22.7 \% \\
-4.3 \\
\end{array}$ & $\begin{array}{c}0 \\
0.0 \% \\
-0.3 \\
\end{array}$ & $\begin{array}{c}75 \\
1.3 \%\end{array}$ \\
\hline $41 \mathrm{BX} 1091$ & $\begin{array}{c}51 \\
17.8 \% \\
\mathbf{3 . 7} \\
\end{array}$ & $\begin{array}{c}130 \\
45.3 \% \\
1.3 \\
\end{array}$ & $\begin{array}{c}106 \\
36.9 \% \\
\mathbf{- 3 . 6} \\
\end{array}$ & $\begin{array}{c}0 \\
0.0 \% \\
-0.6 \\
\end{array}$ & $\begin{array}{r}287 \\
4.9 \%\end{array}$ \\
\hline $41 \mathrm{BX} 1102$ & $\begin{array}{c}17 \\
4.7 \% \\
-4.0 \\
\end{array}$ & $\begin{array}{c}125 \\
34.8 \% \\
-2.7 \\
\end{array}$ & $\begin{array}{c}217 \\
60.4 \% \\
\mathbf{5 . 2} \\
\end{array}$ & $\begin{array}{c}0 \\
0.0 \% \\
-0.7 \\
\end{array}$ & $\begin{array}{r}359 \\
6.2 \%\end{array}$ \\
\hline $41 \mathrm{BX} 1103$ & $\begin{array}{c}37 \\
3.4 \% \\
\mathbf{- 9 . 1}\end{array}$ & $\begin{array}{c}295 \\
26.8 \% \\
\mathbf{- 1 1 . 0} \\
\end{array}$ & $\begin{array}{c}766 \\
69.7 \% \\
\mathbf{1 6 . 6} \\
\end{array}$ & $\begin{array}{c}1 \\
.1 \% \\
-0.5 \\
\end{array}$ & $\begin{array}{c}1099 \\
18.9 \%\end{array}$ \\
\hline $41 \mathrm{BX} 1114$ & $\begin{array}{c}168 \\
12.6 \% \\
1.9 \\
\end{array}$ & $\begin{array}{c}583 \\
43.8 \% \\
1.9 \\
\end{array}$ & $\begin{array}{c}579 \\
43.5 \% \\
\mathbf{- 3 . 1} \\
\end{array}$ & $\begin{array}{c}2 \\
.2 \% \\
.1 \\
\end{array}$ & $\begin{array}{c}1332 \\
22.9 \%\end{array}$ \\
\hline $\begin{array}{c}\text { Column } \\
\text { Total }\end{array}$ & $\begin{array}{c}648 \\
11.1 \%\end{array}$ & $\begin{array}{c}2415 \\
41.5 \%\end{array}$ & $\begin{array}{c}2745 \\
47.2 \%\end{array}$ & $\begin{array}{c}8 \\
0.1 \%\end{array}$ & $\begin{array}{c}5816 \\
100.0 \%\end{array}$ \\
\hline
\end{tabular}

the debitage assemblage is dominated by tertiary flakes.

\section{Flake Type}

The examination of flake types by site (Table 6-2) demonstrates a similar pattern, although important variations are seen. Most of the sites-especially the upland sites of $41 \mathrm{BX} 1088,41 \mathrm{BX} 1090$, and 41BX1114- have high percentages of core/platform flakes. These flakes are typically removed from cores or they represent non-diagnostic removals from other types of artifacts. Core/platform flakes are unusually rare at $41 \mathrm{BX} 1103$. Additionally at $41 \mathrm{BX} 1102$, the debitage assemblage has a higher-than-expected quan- tity of biface manufacture flakes, but a lower-thanexpected quantity of biface thinning flakes. At 41BX1103, the quantities of biface thinning flakes, blades, and uniface flakes are all higher than expected. In addition to rare core/platform preparation flakes, the numbers of sequence flakes are lower than expected for the same site.

As indicated above at the upland sites, there are greater-than-expected numbers of core/platform preparation flakes and also fewer-than-expected biface flakes, the exception to this being 41BX1076. At the latter site, the numbers of biface manufacture flakes and notching flakes are higher than expected. 41BX1088 and 41BX1114 have lower-than-expected quantities of uniface flakes. The only other anomalous adjusted residual is the greater-than-expected 
Table 6-2. Contingency Table Analysis of Debitage Flake Type Category by Site Top value in cell represents artifact count, middle value is row percent, and bottom value represents adjusted residuals. Percent value in total column represents column percent. Significant $(p \leq 0.05)$ values are shown in bold.

\begin{tabular}{|c|c|c|c|c|c|c|c|c|c|}
\hline Site & $\begin{array}{l}\text { Biface } \\
\text { Manuf. }\end{array}$ & $\begin{array}{l}\text { Biface } \\
\text { Thinning }\end{array}$ & Blade & Notch & $\begin{array}{c}\text { Core/ } \\
\text { Platform }\end{array}$ & Sequence & Uniface & Indeterm. & Total \\
\hline $41 \mathrm{BX} 1070$ & $\begin{array}{c}0 \\
0.0 \% \\
-0.4\end{array}$ & $\begin{array}{c}0 \\
0.0 \% \\
-0.3 \\
\end{array}$ & $\begin{array}{c}0 \\
0.0 \% \\
-0.1\end{array}$ & $\begin{array}{c}0 \\
0.0 \% \\
-0.1 \\
\end{array}$ & $\begin{array}{c}0 \\
0.0 \% \\
-1.5 \\
\end{array}$ & $\begin{array}{c}0 \\
0.0 \% \\
-0.1 \\
\end{array}$ & $\begin{array}{c}0 \\
0.0 \% \\
-0.1 \\
\end{array}$ & $\begin{array}{c}1 \\
100.0 \% \\
\mathbf{3 . 7}\end{array}$ & $\begin{array}{c}1 \\
0.0 \%\end{array}$ \\
\hline $41 \mathrm{BX} 1076$ & $\begin{array}{c}183 \\
19.2 \% \\
\mathbf{4 . 0} \\
\end{array}$ & $\begin{array}{c}66 \\
6.9 \% \\
1.2 \\
\end{array}$ & $\begin{array}{c}0 \\
0.0 \% \\
-\mathbf{- 3 . 4}\end{array}$ & $\begin{array}{c}8 \\
0.8 \% \\
2.9 \\
\end{array}$ & $\begin{array}{c}639 \\
66.9 \% \\
-1.5 \\
\end{array}$ & $\begin{array}{c}6 \\
.6 \% \\
2.1 \\
\end{array}$ & $\begin{array}{c}18 \\
1.9 \% \\
0.9 \\
\end{array}$ & $\begin{array}{c}35 \\
3.7 \% \\
-4.3\end{array}$ & $\begin{array}{c}955 \\
16.4 \%\end{array}$ \\
\hline $41 \mathrm{BX} 1088$ & $\begin{array}{c}251 \\
14.7 \% \\
-0.3 \\
\end{array}$ & $\begin{array}{c}28 \\
1.6 \% \\
-9.1 \\
\end{array}$ & $\begin{array}{c}13 \\
.8 \% \\
-1.1 \\
\end{array}$ & $\begin{array}{c}2 \\
0.1 \% \\
-1.9 \\
\end{array}$ & $\begin{array}{c}1310 \\
76.7 \% \\
\mathbf{8 . 2} \\
\end{array}$ & $\begin{array}{c}4 \\
.2 \% \\
-0.5 \\
\end{array}$ & $\begin{array}{c}13 \\
.8 \% \\
-\mathbf{3 . 2} \\
\end{array}$ & $\begin{array}{c}87 \\
5.1 \% \\
\mathbf{- 3 . 4} \\
\end{array}$ & $\begin{array}{c}1708 \\
29.4 \%\end{array}$ \\
\hline $41 \mathrm{BX} 1090$ & $\begin{array}{c}0 \\
0.0 \% \\
-\mathbf{3 . 7} \\
\end{array}$ & $\begin{array}{c}1 \\
1.3 \% \\
-1.7 \\
\end{array}$ & $\begin{array}{c}1 \\
1.3 \% \\
.3 \\
\end{array}$ & $\begin{array}{c}0 \\
0.0 \% \\
-0.5 \\
\end{array}$ & $\begin{array}{c}65 \\
86.7 \% \\
\mathbf{3 . 3} \\
\end{array}$ & $\begin{array}{c}0 \\
0.0 \% \\
-0.5 \\
\end{array}$ & $\begin{array}{c}0 \\
0.0 \% \\
-1.1 \\
\end{array}$ & $\begin{array}{c}8 \\
10.7 \% \\
1.3 \\
\end{array}$ & $\begin{array}{c}75 \\
1.3 \%\end{array}$ \\
\hline $41 \mathrm{BX} 1091$ & $\begin{array}{c}20 \\
7.0 \% \\
-\mathbf{- 3 . 9}\end{array}$ & $\begin{array}{c}9 \\
3.1 \% \\
\mathbf{- 2 . 1}\end{array}$ & $\begin{array}{c}6 \\
2.1 \% \\
2.0\end{array}$ & $\begin{array}{c}3 \\
1.0 \% \\
\mathbf{2 . 1}\end{array}$ & $\begin{array}{c}206 \\
71.8 \% \\
1.0\end{array}$ & $\begin{array}{c}1 \\
.3 \% \\
.2\end{array}$ & $\begin{array}{c}3 \\
1.0 \% \\
-0.7 \\
\end{array}$ & $\begin{array}{c}39 \\
13.6 \% \\
4.6\end{array}$ & $\begin{array}{c}287 \\
4.9 \%\end{array}$ \\
\hline $41 \mathrm{BX} 1102$ & $\begin{array}{c}68 \\
18.9 \% \\
2.2 \\
\end{array}$ & $\begin{array}{c}13 \\
3.6 \% \\
\mathbf{- 2 . 0} \\
\end{array}$ & $\begin{array}{c}4 \\
1.1 \% \\
.3 \\
\end{array}$ & $\begin{array}{c}0 \\
0.0 \% \\
-1.1 \\
\end{array}$ & $\begin{array}{c}246 \\
68.5 \% \\
-0.2 \\
\end{array}$ & $\begin{array}{c}0 \\
0.0 \% \\
-1.1 \\
\end{array}$ & $\begin{array}{c}2 \\
.6 \% \\
-1.6 \\
\end{array}$ & $\begin{array}{c}26 \\
7.2 \% \\
.3 \\
\end{array}$ & $\begin{array}{c}359 \\
6.2 \%\end{array}$ \\
\hline $41 \mathrm{BX} 1103$ & $\begin{array}{c}180 \\
16.4 \% \\
1.5\end{array}$ & $\begin{array}{c}185 \\
16.8 \% \\
\mathbf{1 6 . 6}\end{array}$ & $\begin{array}{c}19 \\
1.7 \% \\
2.8\end{array}$ & $\begin{array}{c}7 \\
0.6 \% \\
1.8 \\
\end{array}$ & $\begin{array}{c}519 \\
47.2 \% \\
\mathbf{- 1 7 . 3}\end{array}$ & $\begin{array}{c}0 \\
0.0 \% \\
\mathbf{- 2 . 0} \\
\end{array}$ & $\begin{array}{c}47 \\
4.3 \% \\
\mathbf{8 . 0} \\
\end{array}$ & $\begin{array}{c}142 \\
12.9 \% \\
\mathbf{8 . 9} \\
\end{array}$ & $\begin{array}{c}1099 \\
18.9 \%\end{array}$ \\
\hline $41 \mathrm{BX} 1114$ & $\begin{array}{c}166 \\
12.5 \% \\
\mathbf{- 2 . 9}\end{array}$ & $\begin{array}{c}51 \\
3.8 \% \\
-\mathbf{3 . 9}\end{array}$ & $\begin{array}{c}14 \\
1.1 \% \\
.3\end{array}$ & $\begin{array}{c}0 \\
0.0 \% \\
-\mathbf{- 2 . 4}\end{array}$ & $\begin{array}{c}1027 \\
77.1 \% \\
7.3\end{array}$ & $\begin{array}{c}6 \\
.5 \% \\
1.2\end{array}$ & $\begin{array}{c}8 \\
.6 \% \\
\mathbf{- 3 . 2}\end{array}$ & $\begin{array}{c}60 \\
4.5 \% \\
\mathbf{- 3 . 9}\end{array}$ & $\begin{array}{c}1332 \\
22.9 \%\end{array}$ \\
\hline $\begin{array}{c}\text { Column } \\
\text { Total }\end{array}$ & $\begin{array}{c}868 \\
14.9 \%\end{array}$ & $\begin{array}{c}353 \\
6.1 \%\end{array}$ & $\begin{array}{c}57 \\
1.0 \%\end{array}$ & $\begin{array}{c}20 \\
0.3 \%\end{array}$ & $\begin{array}{c}4012 \\
69.0 \%\end{array}$ & $\begin{array}{c}17 \\
0.3 \%\end{array}$ & $\begin{array}{c}91 \\
1.6 \%\end{array}$ & $\begin{array}{c}398 \\
6.8 \%\end{array}$ & $\begin{array}{c}5816 \\
100.0 \%\end{array}$ \\
\hline
\end{tabular}

number of blades at 41BX1091. Since blade production characterizes Clovis and Toyah technologies, the high representation of blades is probably a reflection of a Late Prehistoric component at the site.

\section{Faceting}

Platform faceting, which is another indirect measure of reduction stage, loosely follows the same pattern established above with respect to differences between upland and floodplain sites (Table 6-3). There are, however, some unexpected variations in these data. Generally, upland sites have higher-than-expected quantities of corticate platform flakes, while the opposite is true for floodplain sites. 41BX1076 and 41BX1088 have higher-than-expected quantities of double-faceted platform flakes as does the floodplain site of 41BX1102. 41BX1076 unexpectedly has a low frequency of single-facet platform flakes, thereby differing in this attribute from the other upland sites, particularly 41BX1088 and 41BX1090.

The variation in the frequency of double-faceted platforms does not conform to the upland versus flood- 
Table 6-3. Contingency Table Analysis of Debitage Faceting Category by Site Top value in cell represents artifact count, middle value is row percent, and bottom value represents adjusted residuals. Percent value in total column represents column percent. Significant $(\mathrm{p} \leq 0.05)$ values are shown in bold.

\begin{tabular}{|c|c|c|c|c|c|c|}
\hline Site & Single & Double & Multiple & Corticate & Unknown & Total \\
\hline $41 \mathrm{BX} 1070$ & $\begin{array}{c}0 \\
0.0 \% \\
-0.8 \\
\end{array}$ & $\begin{array}{c}0 \\
0.0 \% \\
-0.4\end{array}$ & $\begin{array}{c}1 \\
100.0 \% \\
1.5\end{array}$ & $\begin{array}{c}0 \\
0.0 \% \\
-0.5\end{array}$ & $\begin{array}{c}0 \\
0.0 \% \\
.0\end{array}$ & $\begin{array}{c}1 \\
0.0 \%\end{array}$ \\
\hline 41BX1076 & $\begin{array}{c}332 \\
34.8 \% \\
-2.2 \\
\end{array}$ & $\begin{array}{c}155 \\
16.2 \% \\
\mathbf{3 . 5} \\
\end{array}$ & $\begin{array}{c}275 \\
28.8 \% \\
-1.7 \\
\end{array}$ & $\begin{array}{c}193 \\
20.2 \% \\
1.8 \\
\end{array}$ & $\begin{array}{c}0 \\
0.0 \% \\
-0.6 \\
\end{array}$ & $\begin{array}{c}955 \\
16.4 \%\end{array}$ \\
\hline $41 \mathrm{BX} 1088$ & $\begin{array}{c}689 \\
40.3 \% \\
2.5\end{array}$ & $\begin{array}{c}257 \\
15.0 \% \\
\mathbf{3 . 3}\end{array}$ & $\begin{array}{c}411 \\
24.1 \% \\
-7.5\end{array}$ & $\begin{array}{c}350 \\
20.5 \% \\
\mathbf{3 . 0}\end{array}$ & $\begin{array}{c}1 \\
.1 \% \\
0.6 \\
\end{array}$ & $\begin{array}{c}1708 \\
29.4 \%\end{array}$ \\
\hline $41 \mathrm{BX} 1090$ & $\begin{array}{c}40 \\
53.3 \% \\
\mathbf{2 . 8} \\
\end{array}$ & $\begin{array}{c}5 \\
6.7 \% \\
-1.6 \\
\end{array}$ & $\begin{array}{c}10 \\
13.3 \% \\
-\mathbf{3 . 3} \\
\end{array}$ & $\begin{array}{c}20 \\
26.7 \% \\
1.9 \\
\end{array}$ & $\begin{array}{c}0 \\
0.0 \% \\
-0.2 \\
\end{array}$ & $\begin{array}{c}75 \\
1.3 \%\end{array}$ \\
\hline $41 \mathrm{BX} 1091$ & $\begin{array}{c}112 \\
39.0 \% \\
0.4 \\
\end{array}$ & $\begin{array}{c}25 \\
8.7 \% \\
-2.1 \\
\end{array}$ & $\begin{array}{c}73 \\
25.4 \% \\
-2.1 \\
\end{array}$ & $\begin{array}{c}77 \\
26.8 \% \\
\mathbf{3 . 9} \\
\end{array}$ & $\begin{array}{c}0 \\
0.0 \% \\
-0.3 \\
\end{array}$ & $\begin{array}{c}287 \\
4.9 \%\end{array}$ \\
\hline $41 \mathrm{BX} 1102$ & $\begin{array}{c}122 \\
34.0 \% \\
-1.6 \\
\end{array}$ & $\begin{array}{c}60 \\
16.7 \% \\
\mathbf{2 . 3} \\
\end{array}$ & $\begin{array}{c}123 \\
34.3 \% \\
1.3 \\
\end{array}$ & $\begin{array}{c}54 \\
15.0 \% \\
-1.6 \\
\end{array}$ & $\begin{array}{c}0 \\
0.0 \% \\
-0.4 \\
\end{array}$ & $\begin{array}{r}359 \\
6.2 \%\end{array}$ \\
\hline $41 \mathrm{BX} 1103$ & $\begin{array}{c}397 \\
36.1 \% \\
-1.3 \\
\end{array}$ & $\begin{array}{c}123 \\
11.2 \% \\
-1.8 \\
\end{array}$ & $\begin{array}{c}489 \\
44.5 \% \\
\mathbf{1 0 . 6} \\
\end{array}$ & $\begin{array}{c}90 \\
8.2 \% \\
\mathbf{- 9 . 5}\end{array}$ & $\begin{array}{c}0 \\
0.0 \% \\
-0.7 \\
\end{array}$ & $\begin{array}{c}1099 \\
18.9 \%\end{array}$ \\
\hline $41 \mathrm{BX} 1114$ & $\begin{array}{c}511 \\
38.4 \% \\
0.4 \\
\end{array}$ & $\begin{array}{c}120 \\
9.0 \% \\
-4.7 \\
\end{array}$ & $\begin{array}{c}427 \\
32.1 \% \\
0.9 \\
\end{array}$ & $\begin{array}{c}273 \\
20.5 \% \\
\mathbf{2 . 5} \\
\end{array}$ & $\begin{array}{c}1 \\
.1 \% \\
0.9 \\
\end{array}$ & $\begin{array}{c}1332 \\
22.9 \%\end{array}$ \\
\hline $\begin{array}{c}\text { Column } \\
\text { Total }\end{array}$ & $\begin{array}{c}2203 \\
37.9 \%\end{array}$ & $\begin{array}{c}745 \\
12.8 \%\end{array}$ & $\begin{array}{c}1809 \\
31.1 \%\end{array}$ & $\begin{array}{c}1057 \\
18.2 \%\end{array}$ & $\begin{array}{c}2 \\
0.0 \%\end{array}$ & $\begin{array}{c}5816 \\
100.0 \%\end{array}$ \\
\hline
\end{tabular}

plain pattern established by the other attributes discussed above. 41BX1102, 41BX1076, and 41BX1088 have higher-than-expected quantities of double-faceted flakes while 41BX1091 and 41BX1114 have lower-than-expected quantities. Still, 41BX1103 has higher-than-expected numbers of multiple-faceted flakes, suggesting a greater degree of lithic reduction and perhaps biface production.

\section{Maximum Dimension}

The mean and standard errors for complete flakes from each site are presented in Table 6-4. 41BX1103 has the smallest flakes with the second smallest standard
Table 6-4. Mean and Standard Error of Maximum Dimension $(\mathrm{cm})$ of Flakes by Site

\begin{tabular}{|c|r|r|r|}
\hline \multicolumn{1}{|c|}{ Site } & Mean & \multicolumn{1}{c|}{$\begin{array}{c}\text { Standard } \\
\text { Error }\end{array}$} & Cases \\
\hline $41 \mathrm{BX} 1070$ & 2 & & 1 \\
\hline $41 \mathrm{BX} 1076$ & 4.04 & 0.06 & 955 \\
\hline $41 \mathrm{~B} \times 1088$ & 4.34 & 0.05 & 1708 \\
\hline $41 \mathrm{BX} 1090$ & 5.04 & 0.26 & 75 \\
\hline $41 \mathrm{BX} 1091$ & 4.24 & 0.11 & 287 \\
\hline $41 \mathrm{BX} 1102$ & 4.25 & 0.09 & 359 \\
\hline $41 \mathrm{BX} 1103$ & 3.51 & 0.05 & 1099 \\
\hline $41 \mathrm{BX} 1114$ & 4.23 & 0.05 & 1332 \\
\hline Total & 4.11 & 0.02 & 5816 \\
\hline
\end{tabular}


deviation, excluding 41BX1070's single flake. 41BX1088, with the largest debitage sample, has the highest average maximum flake dimension in the study. Generally flake size declines as a core or biface is reduced, and again these data support the argument that the sites with other indicators of early stage reduction (41BX1088, 41BX1090 and 41BX1091) have larger flakes. Predictably, the site (41BX1103) that consistently shows indicators of late-stage reduction has small flakes.

\section{Cortex Category by Maximum Dimension}

The analysis of cortex category, and in particular the percentage of tertiary flakes, within debitage size classes (e.g., smallest and largest size groups) offers an expedient way of quantifying the nature (e.g., corticate, decorticate, unfinished blank, finished tool) of raw materials reduced on site and the length of the reduction sequences carried out (Hines et al. 1994; Tomka and Fields 1990). Table 6-5 shows the percentage of tertiary debitage in the two smallest (1-10 $\mathrm{mm}$ and $11-20 \mathrm{~mm})$ and largest $(61 \mathrm{~mm},+)$ size groups by site.

Table 6-5. Percentage of Tertiary Flakes by Debitage Size Category

\begin{tabular}{|c|c|c|}
\hline Site & $\begin{array}{c}\text { Small } \\
(\mathbf{1 - 2 0} \mathbf{~ m m})\end{array}$ & $\begin{array}{c}\text { Large } \\
(\mathbf{6 1} \mathbf{~ m m} \text { and up })\end{array}$ \\
\hline $41 \mathrm{BX} 1076$ & $79 \%$ & $6 \%$ \\
\hline $41 \mathrm{BX} 1088$ & $78 \%$ & $10 \%$ \\
\hline $41 \mathrm{BX} 1090$ & $67 \%$ & $6 \%$ \\
\hline $41 \mathrm{BX} 1091$ & $65 \%$ & $6 \%$ \\
\hline $41 \mathrm{BX} 1102$ & $85 \%$ & $26 \%$ \\
\hline $41 \mathrm{BX} 1103$ & $92 \%$ & $27 \%$ \\
\hline $41 \mathrm{BX} 1114$ & $86 \%$ & $7 \%$ \\
\hline
\end{tabular}

In general, the smallest size group contains debitage from platform preparation and tool rejuvenation activities. Platform preparation flakes generated in the process of a biface manufacture should contain relatively large percentages $(70 \%$ or more) of tertiary specimens. Tool rejuvenation should generate even higher percentages of small tertiary debitage. Debitage in the largest size groups represents the early stages of biface manufacture when the parent material is still large. Primary and secondary specimens would be removed from corticate nodules and tertiary specimens would be produced from the reduction of decorticate raw materials such as quarry blanks.

Based on the patterns in Table 6-5, three groups of sites can be defined: (1) 41BX1090 and 41BX1091; (2) 41BX1076, 41BX1088, and 41BX1114; and (3) $41 \mathrm{BX} 1102$ and 41BX1103. These groupings are shown graphically in Figure 6-3.

The pattern exhibited by the first group of sites (41BX1090 and 41BX1091) represents a very short reduction sequence characteristic of lithic procurement sites where little else besides raw material testing and core preparation are conducted. The very small percentages of large tertiary flakes suggests that very few early-stage "quarry blanks" were produced at these sites. The debitage from the second group of sites (41BX1076, 41BX1088, and 41BX1114) is indicative of somewhat longer reduction sequences and/or the possibility that some of the small tertiary flakes have been contributed to the debitage assemblages by rejuvenating curated finished tools on site. The fact that the sites in this group have some of the highest frequencies of bifaces supports the first alternative. Debitage from the third group of sites (41BX1102 and 41BX1103) represents the longest reduction sequences observed. The strong over-representation of biface manufacture flakes at both sites, and the even greater over-representation of biface thinning flakes at 41BX1103 further supports this interpretation. It is also likely that some proportion of the small tertiary debitage derives from the rejuvenation of worn or broken artifacts brought into the site or perhaps, the manufacture of artifacts from small tertiary flake blanks.

Overall, the debitage collections from the eight sites represent relatively short reduction sequences that appear to have been truncated during the early stage of reduction. The longest reduction sequences are those found in the debitage from the two multifunctional terrace sites, 41BX1102 and 41BX1103. None of the debitage collections reflect the importation of large quantities of raw materials into the site and their further "staged" reduction while at these sites. On the contrary, the debitage assemblages appear to reflect the attempts by site inhabitants to produce raw 


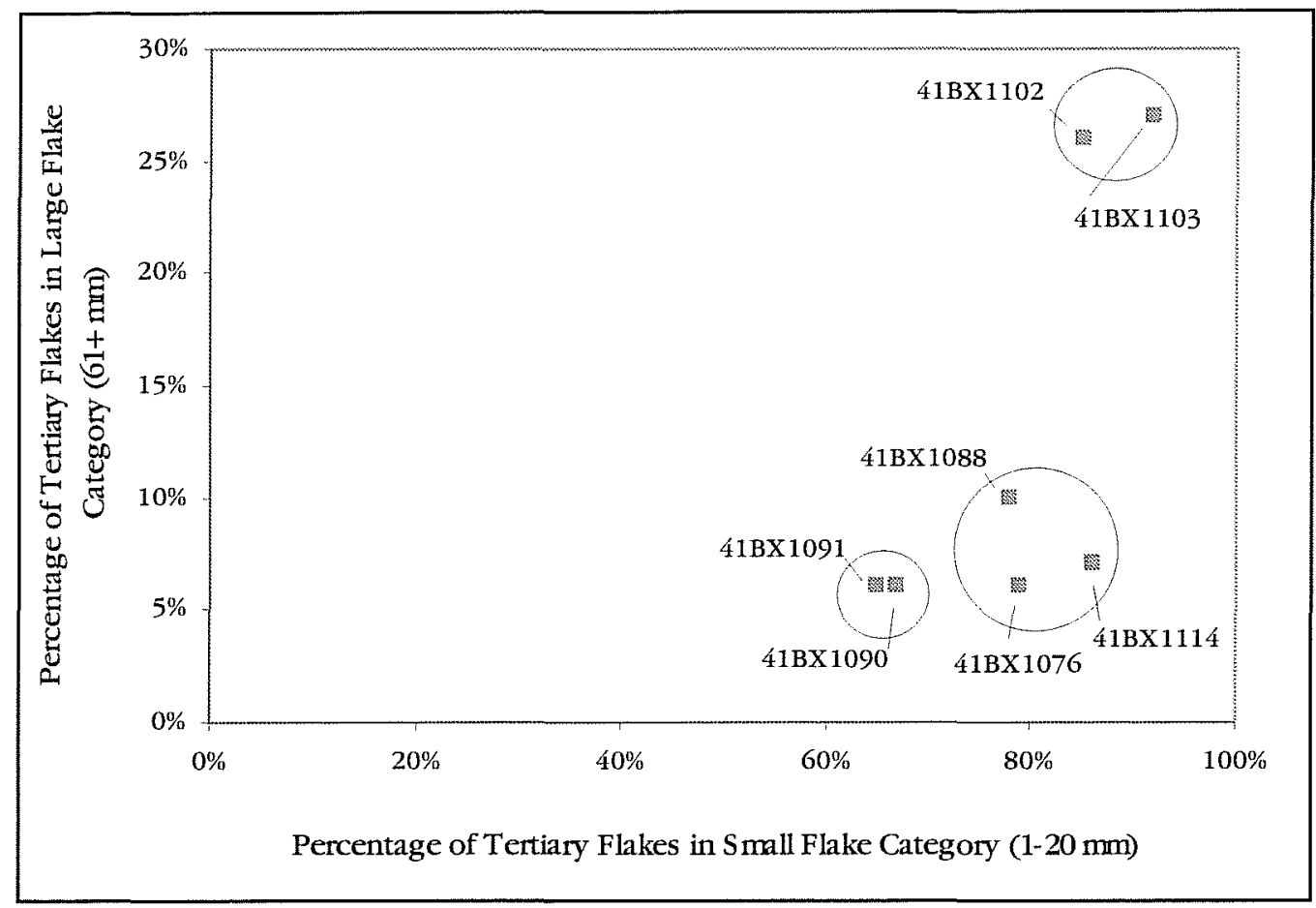

Figure 6-3. Comparison of percentage of tertiary flakes in large flake category versus percentage of tertiary flakes in small flake category by site.

material blanks for export to other localities rather than the manufacture of finished bifacial artifacts for onsite use.

\section{Cores}

Contingency table analysis was conducted for the debitage attributes of cortex and flake direction. Means and standard deviations for the maximum dimension of complete cores and the number of flake scars per core are also presented. The amount of cortex remaining on a core is related to the degree of reduction of the parent material. The direction of flake scars is indicative of the degree of reduction and the reduction strategy, possibly indicating that a special type of flake was being produced, such as a blade. The maximum dimension of complete cores indicates the degree of reduction and provides a point of comparison to the unmodified raw material at each site. The number of flake scars is directly related to the degree of reduction.

As with the debitage from 41BX1091, a large number of cores resulting from the cobble-splitting technique were recovered. Although "core type" was not an attribute that was coded, the split cobble cores from $41 \mathrm{BX} 1091$ were counted. Of the 216 cores which were analyzed (representing 53 percent of the cores collected), 41 were identified as split cobble cores, accounting for 19 percent of the analyzed assemblage. Split cobble cores were also identified at 41BX1076 ( 2 cores) and 41BX1088 (31 cores).

\section{Cortex}

The analysis of the cortex category for cores is presented in Table 6-6. Sites 41BX1088, 41BX1090, and 41BX1091 have greater-than-expected quantities of cores with 51-99 percent cortex and lower-than-expected quantities of cores with 1-50 percent cortex. Three sites-41BX1102, 41BX1103, and 41BX1114-have greater-than-expected quantities of cores with 1-50 percent cortex. The two floodplain sites have lower-than-expected quantities of cores with 51-99 percent cortex and unusually high frequencies of cores without cortex. The results of the analysis of the cortex for cores from the testing project generally correspond to the patterns observed for the debitage 
attributes in that there are clear differences between the upland and floodplain assemblages. Typically, the upland sites have more cores with more cortex, while the floodplain sites have more cores with less cortex. The exception to this pattern is $41 \mathrm{BX} 1114$ which more closely resembles the floodplain sites.

\section{Flake Direction}

The analysis of the flake direction category does not demonstrate a clear difference between floodplain and upland sites (Table 6-7). Excluding 41BX1070, the only higher-than-expected values are at 41BX1088 and 41BX1091 for multidirectional flake scars; 41BX1114 for unidirectional and bidirectional flake scars; and
41BX1102 and 41BX1103 for indeterminate flake scars. The indeterminate category reflects high frequencies of core fragments for which flake direction could not be determined. Lower-than-expected quantities occur at 41BX1090 for indeterminate flake scar direction; 41BX1091 and 41BX1103 for unidirectional flake scars; and 41BX1114 for multidirectional flake scars.

\section{Number of Flake Scars}

There is a large amount of variation in the mean number of flake scars per core (Table 6-8). At 41BX1103, where the small sample size is probably distorting the results, the mean number of flake scars per core is

Table 6-6. Contingency Table Analysis of Core Cortex Category by Site

Top value in cell represents artifact count, middle value is row percent, and bottom value represents adjusted residuals. Percent value in total column represents column percent. Significant $(\mathrm{p} \leq 0.05)$ values are shown in bold.

\begin{tabular}{|c|c|c|c|c|}
\hline Site & Absent & $1-50 \%$ & $51-99 \%$ & Total \\
\hline $41 \mathrm{BX} 1070$ & $\begin{array}{c}0 \\
0.0 \% \\
-0.2 \\
\end{array}$ & $\begin{array}{c}0 \\
0.0 \% \\
-0.9 \\
\end{array}$ & $\begin{array}{c}1 \\
100.0 \% \\
0.9 \\
\end{array}$ & $\begin{array}{c}1 \\
0.1 \%\end{array}$ \\
\hline $41 \mathrm{BX} 1076$ & $\begin{array}{c}5 \\
4.0 \% \\
0.2 \\
\end{array}$ & $\begin{array}{c}47 \\
37.6 \% \\
-1.3 \\
\end{array}$ & $\begin{array}{c}73 \\
58.4 \% \\
1.2 \\
\end{array}$ & $\begin{array}{r}125 \\
8.6 \%\end{array}$ \\
\hline $41 \mathrm{BX} 1088$ & $\begin{array}{c}21 \\
4.1 \% \\
0.6 \\
\end{array}$ & $\begin{array}{c}200 \\
39.0 \% \\
-2.4 \\
\end{array}$ & $\begin{array}{c}292 \\
56.9 \% \\
\mathbf{2 . 2} \\
\end{array}$ & $\begin{array}{c}513 \\
35.5 \%\end{array}$ \\
\hline $41 \mathrm{BX} 1090$ & $\begin{array}{c}0 \\
0.0 \% \\
-1.7\end{array}$ & $\begin{array}{c}20 \\
27.8 \% \\
-2.7\end{array}$ & $\begin{array}{c}52 \\
72.2 \% \\
\mathbf{3 . 3}\end{array}$ & $\begin{array}{c}72 \\
5.0 \%\end{array}$ \\
\hline $41 \mathrm{BX} 1091$ & $\begin{array}{c}6 \\
2.8 \% \\
-0.8 \\
\end{array}$ & $\begin{array}{c}80 \\
37.0 \% \\
-\mathbf{2 . 0} \\
\end{array}$ & $\begin{array}{c}130 \\
60.2 \% \\
2.3 \\
\end{array}$ & $\begin{array}{c}216 \\
14.9 \%\end{array}$ \\
\hline $41 \mathrm{BX} 1102$ & $\begin{array}{c}10 \\
6.7 \% \\
\mathbf{2 . 1} \\
\end{array}$ & $\begin{array}{c}85 \\
57.0 \% \\
\mathbf{3 . 6} \\
\end{array}$ & $\begin{array}{c}54 \\
36.2 \% \\
-4.3 \\
\end{array}$ & $\begin{array}{c}149 \\
10.3 \%\end{array}$ \\
\hline $41 \mathrm{BX} 1103$ & $\begin{array}{c}7 \\
13.7 \% \\
\mathbf{3 . 9} \\
\end{array}$ & $\begin{array}{c}35 \\
68.6 \% \\
3.7 \\
\end{array}$ & $\begin{array}{c}9 \\
17.6 \% \\
-5.2 \\
\end{array}$ & $\begin{array}{c}51 \\
3.5 \%\end{array}$ \\
\hline $41 \mathrm{BX} 1114$ & $\begin{array}{c}4 \\
1.3 \% \\
\mathbf{- 2 . 6} \\
\end{array}$ & $\begin{array}{c}159 \\
49.7 \% \\
\mathbf{2 . 6}\end{array}$ & $\begin{array}{c}157 \\
49.1 \% \\
-1.6 \\
\end{array}$ & $\begin{array}{c}320 \\
22.1 \%\end{array}$ \\
\hline $\begin{array}{l}\text { Column } \\
\text { Total }\end{array}$ & $\begin{array}{c}53 \\
3.7 \%\end{array}$ & $\begin{array}{c}626 \\
43.3 \%\end{array}$ & $\begin{array}{c}768 \\
53.1 \%\end{array}$ & $\begin{array}{c}1447 \\
100.0 \%\end{array}$ \\
\hline
\end{tabular}


Table 6-7. Contingency Table Analysis of Core Flake Direction Category by Site Top value in cell represents artifact count, middle value is row percent, and bottom value represents adjusted residuals. Percent value in total column represents column percent. Significant $(p \leq 0.05)$ values are shown in bold.

\begin{tabular}{|c|c|c|c|c|c|}
\hline Site & Unidirectional & Bidirectional & $\begin{array}{c}\text { Multi- } \\
\text { Directional }\end{array}$ & Indeterminate & Total \\
\hline $41 \mathrm{BX} 1070$ & $\begin{array}{c}0 \\
0.0 \% \\
-0.6 \\
\end{array}$ & $\begin{array}{c}1 \\
100.0 \% \\
\mathbf{2 . 2} \\
\end{array}$ & $\begin{array}{c}0 \\
0.0 \% \\
-0.8 \\
\end{array}$ & $\begin{array}{c}0 \\
0.0 \% \\
-0.5 \\
\end{array}$ & $\begin{array}{c}1 \\
0.1 \%\end{array}$ \\
\hline 41BX1076 & $\begin{array}{c}34 \\
27.2 \% \\
0.3\end{array}$ & $\begin{array}{c}15 \\
12.0 \% \\
-1.5\end{array}$ & $\begin{array}{c}55 \\
44.0 \% \\
1.7\end{array}$ & $\begin{array}{c}21 \\
16.8 \% \\
-0.9\end{array}$ & $\begin{array}{c}125 \\
8.6 \%\end{array}$ \\
\hline $41 \mathrm{BX} 1088$ & $\begin{array}{c}148 \\
28.8 \% \\
1.7 \\
\end{array}$ & $\begin{array}{c}75 \\
14.6 \% \\
-1.7 \\
\end{array}$ & $\begin{array}{c}212 \\
41.3 \% \\
\mathbf{2 . 4} \\
\end{array}$ & $\begin{array}{c}78 \\
15.2 \% \\
-3.2 \\
\end{array}$ & $\begin{array}{c}513 \\
35.5 \%\end{array}$ \\
\hline $41 \mathrm{BX} 1090$ & $\begin{array}{c}21 \\
29.2 \% \\
0.6 \\
\end{array}$ & $\begin{array}{c}18 \\
25.0 \% \\
1.9 \\
\end{array}$ & $\begin{array}{c}27 \\
37.5 \% \\
0.1 \\
\end{array}$ & $\begin{array}{c}6 \\
8.3 \% \\
-2.5 \\
\end{array}$ & $\begin{array}{c}72 \\
5.0 \%\end{array}$ \\
\hline $41 \mathrm{BX} 1091$ & $\begin{array}{c}41 \\
19.0 \% \\
-\mathbf{2 . 6}\end{array}$ & $\begin{array}{c}34 \\
15.7 \% \\
-0.5\end{array}$ & $\begin{array}{c}103 \\
47.7 \% \\
\mathbf{3 . 5}\end{array}$ & $\begin{array}{c}38 \\
17.6 \% \\
-0.8\end{array}$ & $\begin{array}{c}216 \\
14.9 \%\end{array}$ \\
\hline $41 \mathrm{BX} 1102$ & $\begin{array}{c}32 \\
21.5 \% \\
-1.4 \\
\end{array}$ & $\begin{array}{c}27 \\
18.1 \% \\
0.4 \\
\end{array}$ & $\begin{array}{c}45 \\
30.2 \% \\
-1.9 \\
\end{array}$ & $\begin{array}{c}45 \\
30.2 \% \\
3.4 \\
\end{array}$ & $\begin{array}{c}149 \\
10.3 \%\end{array}$ \\
\hline $41 \mathrm{BX} 1103$ & $\begin{array}{c}2 \\
3.9 \% \\
-3.7 \\
\end{array}$ & $\begin{array}{c}7 \\
13.7 \% \\
-0.6 \\
\end{array}$ & $\begin{array}{c}14 \\
27.5 \% \\
-1.5 \\
\end{array}$ & $\begin{array}{c}28 \\
54.9 \% \\
6.4 \\
\end{array}$ & $\begin{array}{c}51 \\
3.5 \%\end{array}$ \\
\hline $41 \mathrm{BX} 1114$ & $\begin{array}{c}101 \\
31.6 \% \\
\mathbf{2 . 5} \\
\end{array}$ & $\begin{array}{c}68 \\
21.3 \% \\
\mathbf{2 . 3} \\
\end{array}$ & $\begin{array}{c}82 \\
25.6 \% \\
-4.8 \\
\end{array}$ & $\begin{array}{c}69 \\
21.6 \% \\
1 \\
\end{array}$ & $\begin{array}{c}320 \\
22.1 \%\end{array}$ \\
\hline $\begin{array}{l}\text { Column } \\
\text { Total }\end{array}$ & $\begin{array}{c}379 \\
26.2 \%\end{array}$ & $\begin{array}{c}245 \\
16.9 \%\end{array}$ & $\begin{array}{c}538 \\
37.2 \%\end{array}$ & $\begin{array}{c}285 \\
19.7 \%\end{array}$ & $\begin{array}{c}1447 \\
100.0 \%\end{array}$ \\
\hline
\end{tabular}

Table 6-8. Mean and Standard Error of Flake Scars per Core by Site

\begin{tabular}{|c|c|c|r|}
\hline Site & Mean & $\begin{array}{c}\text { Standard } \\
\text { Error }\end{array}$ & \multicolumn{1}{c|}{ Cases } \\
\hline $41 \mathrm{BX} 1070$ & 2 & & 104 \\
\hline $41 \mathrm{BX} 1076$ & 5.89 & 0.44 & 435 \\
\hline $41 \mathrm{BX} 1088$ & 5.25 & 0.22 & 66 \\
\hline $41 \mathrm{BX} 1090$ & 3.35 & 0.36 & 179 \\
\hline $41 \mathrm{BX} 1091$ & 4.07 & 0.26 & 105 \\
\hline $41 \mathrm{BX} 1102$ & 6.45 & 0.50 & 22 \\
\hline $41 \mathrm{BX} 1103$ & 10.18 & 1.31 & 249 \\
\hline $41 \mathrm{BX} 1114$ & 5.32 & 0.22 & 1161 \\
\hline Total & 5.23 & 0.13 & \\
\hline
\end{tabular}


10.18 with a standard error of 1.31 . The second highest mean (6.45) is from the other floodplain site of $41 \mathrm{BX} 1102$. Excluding the one core from 41BX1070, the lowest mean number of flake scars (3.35) is from 41BX1090.

\section{Maximum Dimension}

A comparison of the mean of the maximum dimensions of cores from the tested sites indicates very little difference between collections (Table 6-9). Excluding the one core from $41 \mathrm{BX} 1070$, the lowest mean is $7.08 \mathrm{~cm}$ from the 112 measurable cores at $41 \mathrm{BX} 1102$, and the highest is $7.97 \mathrm{~cm}$ from the 261 complete cores at 41BX1114.

Table 6-9. Mean and Standard Error of Maximum Dimension (in $\mathrm{cm}$ ) of Cores by Site

\begin{tabular}{|c|c|c|r|}
\hline Site & Mean & $\begin{array}{c}\text { Standard } \\
\text { Error }\end{array}$ & Cases \\
\hline $41 \mathrm{BX} 1070$ & 7 &. & 1 \\
\hline $41 \mathrm{~B} \times 1076$ & 7.41 & 0.30 & 105 \\
\hline $41 \mathrm{~B} \times 1088$ & 7.63 & 0.11 & 447 \\
\hline $41 \mathrm{BX} 1090$ & 7.37 & 0.23 & 67 \\
\hline $41 \mathrm{BX} 1091$ & 7.76 & 0.20 & 179 \\
\hline $41 \mathrm{~B} \times 1102$ & 7.08 & 0.19 & 112 \\
\hline $41 \mathrm{BX} 1103$ & 7.70 & 0.56 & 23 \\
\hline $41 \mathrm{BX} 1114$ & 7.97 & 0.17 & 261 \\
\hline Total & 7.64 & 0.07 & 1195 \\
\hline
\end{tabular}

\section{Bifaces}

Contingency table analysis was conducted for the following biface attributes: cortex, blank type, reduction stage, completeness, and break type. The means and standard deviations for the maximum length, width, and thickness for measurable bifaces are also presented. Cortex and stage of reduction are indicative of the amount of reduction of the parent material. Blank type is related to stage of reduction, the type of biface being produced, and the biface technology being employed at a site or during a particular time period. Completeness and break type are both related to stage of reduction and/or use. The dimensions for measurable bifaces provide comparisons between col- lections and may reflect reduction or biface technology.

\section{Cortex}

Table 6-10 demonstrates that biface assemblages can be differentiated based on upland and floodplain sites. The bifaces from 41BX1102 and 41BX1103 have greater-than-expected quantities of bifaces without cortex and lower-than-expected quantities of bifaces with 1-50 percent cortex remaining. At upland sites, particularly 41BX1088 and 41BX1091, this pattern is reversed. At 41BX1114, there is a greater-than-expected quantity of bifaces with 51-99 percent cortex. This is the only site at which this occurs.

These patterns indicate that, in general, bifaces from terrace sites have been reduced to a greater degree than specimens found on upland sites. These differences in reduction sequence lengths may be indicative of different final product desired or differences in procurement strategies (e.g., encounter versus embedded procurement or staged reduction across landscapes).

\section{Blank Type}

The analysis of the biface blank category (Table 6-11) reveals that there is no pattern to the data, probably because of the high number of cases classified as indeterminate blank type. $41 \mathrm{BX} 1088$ has a higherthan-expected quantity of bifaces made on flakes, and 41BX1090 and 41BX1091 have higher-than-expected quantities of bifaces made on nodules. Both 41BX1102 and $41 \mathrm{BX} 1114$ have lower-than-expected quantities of bifaces made on flakes, and 41BX1103 has lowerthan-expected quantities of bifaces made on nodules.

The numerical dominance of bifaces made on flake cores or blanks, among those specimens with identifiable types, indicates the use of two biface manufacture trajectories. It is likely that at least some of the flake blank reduction episodes were intended to manufacture projectile points. The reduction of nodular cores may have been intended for the manufacture of either large projectile point types and/or other bifa- 
Table 6-10. Contingency Table Analysis of Biface Cortex Category by Site

Top value in cell represents artifact count, middle value is row percent, and bottom value represents adjusted residuals. Percent value in total column represents column percent. Significant $(p \leq 0.05)$ values are shown in bold.

\begin{tabular}{|c|c|c|c|c|}
\hline Site & Absent & $1-50 \%$ & $51-99 \%$ & Total \\
\hline $41 \mathrm{BX} 1076$ & $\begin{array}{c}46 \\
44.2 \% \\
-0.8\end{array}$ & $\begin{array}{c}56 \\
53.8 \% \\
1.0\end{array}$ & $\begin{array}{c}2 \\
1.9 \% \\
-0.6\end{array}$ & $\begin{array}{c}104 \\
13.5 \%\end{array}$ \\
\hline $41 \mathrm{BX} 1088$ & $\begin{array}{c}147 \\
43.4 \% \\
\mathbf{- 2 . 1}\end{array}$ & $\begin{array}{c}184 \\
54.3 \% \\
2.4\end{array}$ & $\begin{array}{c}8 \\
2.4 \% \\
-0.7\end{array}$ & $\begin{array}{c}339 \\
44.0 \%\end{array}$ \\
\hline $41 \mathrm{BX} 1090$ & $\begin{array}{c}1 \\
10.0 \% \\
\mathbf{- 2 . 4} \\
\end{array}$ & $\begin{array}{c}8 \\
80.0 \% \\
1.9\end{array}$ & $\begin{array}{c}1 \\
10.0 \% \\
1.4 \\
\end{array}$ & $\begin{array}{c}10 \\
1.3 \%\end{array}$ \\
\hline $41 \mathrm{BX} 1091$ & $\begin{array}{c}4 \\
16.0 \% \\
-3.2\end{array}$ & $\begin{array}{c}21 \\
84.0 \% \\
\mathbf{3 . 5}\end{array}$ & $\begin{array}{c}0 \\
0.0 \% \\
-0.9\end{array}$ & $\begin{array}{c}25 \\
3.2 \%\end{array}$ \\
\hline $41 \mathrm{BX} 1102$ & $\begin{array}{c}47 \\
60.3 \% \\
2.3\end{array}$ & $\begin{array}{c}30 \\
38.5 \% \\
-\mathbf{2 . 1}\end{array}$ & $\begin{array}{c}1 \\
1.3 \% \\
-0.9\end{array}$ & $\begin{array}{c}78 \\
10.1 \%\end{array}$ \\
\hline $41 \mathrm{BX} 1103$ & $\begin{array}{c}79 \\
68.1 \% \\
4.8\end{array}$ & $\begin{array}{c}35 \\
30.2 \% \\
-4.5\end{array}$ & $\begin{array}{c}2 \\
1.7 \% \\
-0.8\end{array}$ & $\begin{array}{c}116 \\
15.1 \%\end{array}$ \\
\hline $41 \mathrm{BX} 1114$ & $\begin{array}{c}43 \\
42.9 \% \\
-0.8\end{array}$ & $\begin{array}{c}47 \\
48.0 \% \\
-0.3\end{array}$ & $\begin{array}{c}8 \\
8.2 \% \\
3.4 \\
\end{array}$ & $\begin{array}{c}98 \\
12.7 \%\end{array}$ \\
\hline $\begin{array}{c}\text { Column } \\
\text { Total }\end{array}$ & $\begin{array}{l}367 \\
47.7 \%\end{array}$ & $\begin{array}{l}381 \\
49.5 \%\end{array}$ & $\begin{array}{l}22 \\
2.9 \%\end{array}$ & $\begin{array}{l}770 \\
100.0 \%\end{array}$ \\
\hline
\end{tabular}

cial artifact types. Finally, the occurrence of both reduction trajectories accounts for the large number of both cores and bifaces recovered from these sites.

\section{Stage of Reduction}

When the biface stage of reduction category is analyzed using contingency table analysis, a clear difference between assemblages from upland and floodplain sites is seen (Table 6-12). For example, all the upland sites, except 41BX1114, have greater-than-expected quantities of early stage bifaces and lower-than-expected quantities of middle-stage bifaces. This pattern is reversed for the two floodplain sites. Interestingly, 41BX1114 appears more similar to the two floodplain sites in that it has a lower-than-expected quantity of early stage bifaces. $41 \mathrm{BX} 1114$ is the only site to have a greater-than-expected quantity of latestage bifaces. $41 \mathrm{BX} 1076$ is the only site to have a lower-than-expected quantity of late-stage bifaces.

The numerical predominance of early-stage specimens at the upland sites, in combination with relatively high corticate debitage percentages, indicate relatively short reduction sequences. There appears to have been an emphasis on the production of early- to middle-reduction stage bifacial "quarry blanks" rather than wellthinned bifaces. This pattern, in turn indicates relatively expedient procurement techniques and a lack of concern with transportation costs or to the contrary a high concern with acquiring as much usable raw material as possible. The higher proportions of middleand late-reduction stage bifaces at $41 \mathrm{BX} 1102$ and 41BX1103 indicate longer reduction sequences performed at these sites. These differences between upland and terrace sites may be indicative of different 
Table 6-11. Contingency Table Analysis of Biface Blank Type Category by Site Top value in cell represents artifact count, middle value is row percent, and bottom value represents adjusted residuals. Percent value in total column represents column percent. Significant $(p \leq 0.05)$ values are shown in bold.

\begin{tabular}{|c|c|c|c|c|}
\hline Site & Flake & Nodule & Indeterminate & Total \\
\hline $41 \mathrm{BX} 1076$ & $\begin{array}{c}36 \\
34.6 \% \\
0.5 \\
\end{array}$ & $\begin{array}{c}26 \\
25.0 \% \\
1.4 \\
\end{array}$ & $\begin{array}{c}42 \\
40.4 \% \\
-1.6 \\
\end{array}$ & $\begin{array}{c}104 \\
13.5 \%\end{array}$ \\
\hline $41 \mathrm{BX} 1088$ & $\begin{array}{c}130 \\
38.3 \% \\
\mathbf{3 . 1} \\
\end{array}$ & $\begin{array}{c}76 \\
22.4 \% \\
1.6 \\
\end{array}$ & $\begin{array}{c}133 \\
39.2 \% \\
-4.2 \\
\end{array}$ & $\begin{array}{c}339 \\
44.0 \%\end{array}$ \\
\hline $41 \mathrm{BX} 1090$ & $\begin{array}{c}1 \\
10.0 \% \\
-1.5\end{array}$ & $\begin{array}{c}7 \\
70.0 \% \\
4\end{array}$ & $\begin{array}{c}2 \\
20.0 \% \\
-1.8\end{array}$ & $\begin{array}{c}10 \\
1.3 \%\end{array}$ \\
\hline $41 \mathrm{BX} 1091$ & $\begin{array}{c}4 \\
16.0 \% \\
-1.8 \\
\end{array}$ & $\begin{array}{c}12 \\
48.0 \% \\
\mathbf{3 . 6} \\
\end{array}$ & $\begin{array}{c}9 \\
36.0 \% \\
-1.2 \\
\end{array}$ & $\begin{array}{c}25 \\
3.2 \%\end{array}$ \\
\hline $41 \mathrm{BX} 1102$ & $\begin{array}{c}16 \\
20.5 \% \\
-\mathbf{2 . 4} \\
\end{array}$ & $\begin{array}{c}9 \\
11.5 \% \\
-1.9 \\
\end{array}$ & $\begin{array}{c}53 \\
67.9 \% \\
\mathbf{3 . 8} \\
\end{array}$ & $\begin{array}{c}78 \\
10.1 \%\end{array}$ \\
\hline $41 \mathrm{BX} 1103$ & $\begin{array}{c}42 \\
36.2 \% \\
0.9 \\
\end{array}$ & $\begin{array}{c}6 \\
5.2 \% \\
-4.3 \\
\end{array}$ & $\begin{array}{c}68 \\
58.6 \% \\
\mathbf{2 . 6} \\
\end{array}$ & $\begin{array}{c}116 \\
15.1 \%\end{array}$ \\
\hline $41 \mathrm{BX} 1114$ & $\begin{array}{c}21 \\
21.4 \% \\
\mathbf{- 2 . 5}\end{array}$ & $\begin{array}{c}17 \\
17.3 \% \\
-0.7\end{array}$ & $\begin{array}{c}60 \\
61.2 \% \\
\mathbf{2 . 9}\end{array}$ & $\begin{array}{c}98 \\
12.7 \%\end{array}$ \\
\hline $\begin{array}{c}\text { Column } \\
\text { Total }\end{array}$ & $\begin{array}{c}250 \\
32.5 \%\end{array}$ & $\begin{array}{c}153 \\
19.9 \%\end{array}$ & $\begin{array}{c}367 \\
47.7 \%\end{array}$ & $\begin{array}{c}770 \\
100.0 \%\end{array}$ \\
\hline
\end{tabular}

material procurement strategies, related, in part, to functional differences between site groups.

\section{Completeness}

The analysis of biface completeness also demonstrates differences between the upland and floodplain assemblages (Table 6-13). At 41BX1076 and 41BX1091 there are higher-than-expected quantities of complete bifaces. 41BX1102 and 41BX1103 have lower-thanexpected quantities of complete bifaces. The other categories are not as meaningful, but the floodplain sites do have higher-than-expected quantities of proximal, medial, and/or distal fragments.
The fact that three quarters or more of the bifaces found at upland sites were discarded in a complete state indicates that material flaws such as embedded fracture lines or other manufacture problems were quite common in the raw materials selected for reduction. The smaller proportions of discarded complete bifaces in the terrace site assemblages suggests higher raw material quality among the terrace gravels or the transportation of only high quality raw material or blanks to the floodplain sites. The high percentages of biface fragments may result from higher percentage of specimens in the middle-to late-stages of reduction since material failure may increase with decreased maximum thickness. 
Table 6-12. Contingency Table Analysis of Biface Stage of Reduction Category by Site Top value in cell represents artifact count, middle value is row percent, and bottom value represents adjusted residuals.

Percent value in total column represents column percent. Significant $(p \leq 0.05)$ values are shown in bold.

\begin{tabular}{|c|c|c|c|c|c|}
\hline Site & Early & Middle & Late & Indeterminate & Total \\
\hline $41 \mathrm{BX} 1076$ & $\begin{array}{c}93 \\
89.4 \% \\
4.3\end{array}$ & $\begin{array}{c}9 \\
8.7 \% \\
\mathbf{- 3 . 5}\end{array}$ & $\begin{array}{c}1 \\
1.0 \% \\
-\mathbf{2 . 1}\end{array}$ & $\begin{array}{c}1 \\
1.0 \% \\
-0.5\end{array}$ & $\begin{array}{c}104 \\
13.5 \%\end{array}$ \\
\hline $41 \mathrm{BX} 1088$ & $\begin{array}{c}268 \\
79.1 \% \\
\mathbf{4 . 1}\end{array}$ & $\begin{array}{c}58 \\
17.1 \% \\
\mathbf{- 2 . 8}\end{array}$ & $\begin{array}{c}12 \\
3.5 \% \\
-1.7\end{array}$ & $\begin{array}{c}1 \\
0.3 \% \\
-2.5\end{array}$ & $\begin{array}{c}339 \\
44.0 \%\end{array}$ \\
\hline $41 \mathrm{BX} 1090$ & $\begin{array}{c}10 \\
100.0 \% \\
2\end{array}$ & $\begin{array}{c}0 \\
0.0 \% \\
-1.7\end{array}$ & $\begin{array}{c}0 \\
0.0 \% \\
-0.7 \\
\end{array}$ & $\begin{array}{c}0 \\
0.0 \% \\
-0.4 \\
\end{array}$ & $\begin{array}{c}10 \\
1.3 \%\end{array}$ \\
\hline 41BX1091 & $\begin{array}{c}25 \\
100.0 \% \\
\mathbf{3 . 2} \\
\end{array}$ & $\begin{array}{c}0 \\
0.0 \% \\
-\mathbf{2 . 7} \\
\end{array}$ & $\begin{array}{c}0 \\
0.0 \% \\
-1.2 \\
\end{array}$ & $\begin{array}{c}0 \\
0.0 \% \\
-0.6 \\
\end{array}$ & $\begin{array}{c}25 \\
3.2 \%\end{array}$ \\
\hline $41 \mathrm{BX} 1102$ & $\begin{array}{c}44 \\
56.4 \% \\
\mathbf{- 3 . 1} \\
\end{array}$ & $\begin{array}{c}28 \\
35.9 \% \\
\mathbf{3 . 2} \\
\end{array}$ & $\begin{array}{c}5 \\
6.4 \% \\
0.6 \\
\end{array}$ & $\begin{array}{c}1 \\
1.3 \% \\
-0.2 \\
\end{array}$ & $\begin{array}{c}78 \\
10.1 \%\end{array}$ \\
\hline $41 \mathrm{BX} 1103$ & $\begin{array}{c}52 \\
44.8 \% \\
-6.9\end{array}$ & $\begin{array}{c}48 \\
41.4 \% \\
5.5\end{array}$ & $\begin{array}{c}9 \\
7.8 \% \\
1.4\end{array}$ & $\begin{array}{c}7 \\
6.0 \% \\
4.2\end{array}$ & $\begin{array}{c}116 \\
15.1 \%\end{array}$ \\
\hline $41 \mathrm{BX} 1114$ & $\begin{array}{c}59 \\
60.2 \% \\
-2.7 \\
\end{array}$ & $\begin{array}{c}25 \\
25.5 \% \\
0.9 \\
\end{array}$ & $\begin{array}{c}12 \\
12.2 \% \\
\mathbf{3 . 5} \\
\end{array}$ & $\begin{array}{c}2 \\
2.0 \% \\
0.4 \\
\end{array}$ & $\begin{array}{c}98 \\
12.7 \%\end{array}$ \\
\hline $\begin{array}{c}\text { Column } \\
\text { Total }\end{array}$ & $\begin{array}{c}551 \\
71.6 \%\end{array}$ & $\begin{array}{c}168 \\
21.8 \%\end{array}$ & $\begin{array}{c}39 \\
5.1 \%\end{array}$ & $\begin{array}{c}12 \\
1.6 \%\end{array}$ & $\begin{array}{c}770 \\
100.0 \%\end{array}$ \\
\hline
\end{tabular}

\section{Break Type}

The analysis of the break type category for bifaces is presented in Table 6-14. Of all the sites, only 41BX1103 has a greater-than-expected quantity of use breaks. 41BX1103 and 41BX1114 both have greaterthan-expected quantities of manufacturing breaks. Both floodplain sites and 41BX1114 have lower-thanexpected quantities of post-depositional breaks. For the upland sites, 41BX1076 and 41BX1088 have greater-than-expected quantities of post-depositional breaks, the high percentages may be a reflection of the difficulty in identifying this break type.

The numerical predominance of manufacture-broken specimens at all sites except $41 \mathrm{BX} 1088$, is in line with other observations supporting the emphasis on raw material procurement at the upland sites at Lackland. The over-representation of use-broken specimens at 41BX1103 may be indicative of the residential aspect of this assemblage. The small numbers of use-broken bifaces at other sites may have been introduced within the context of raw material procurement (i.e., the procurement of raw materials for the on-site replacement of broken tools). The high percentage of post-depositionally broken bifaces at $41 \mathrm{BX} 1088$ indicates a heavily impacted and perhaps altered site surface.

\section{Dimensions}

The means and standard deviations for biface length, width, and thickness are presented in Tables 6-15, 
Table 6-13. Contingency Table Analysis of Biface Completeness Category by Site Top value in cell represents artifact count, middle value is row percent, and bottom value represents adjusted residuals. Percent value in total column represents column percent. Significant $(\mathrm{p} \leq 0.05)$ values are shown in bold.

\begin{tabular}{|c|c|c|c|c|c|c|c|c|}
\hline Site & Complete & Proximal & Medial & Distal & Longitudinal & Wedge & Indeterminate & Total \\
\hline $41 \mathrm{BX} 1076$ & $\begin{array}{c}77 \\
74.0 \% \\
\mathbf{3} \\
\end{array}$ & $\begin{array}{c}6 \\
5.8 \% \\
-0.4 \\
\end{array}$ & $\begin{array}{c}2 \\
1.9 \% \\
-1.2 \\
\end{array}$ & $\begin{array}{c}7 \\
6.7 \% \\
-0.7 \\
\end{array}$ & $\begin{array}{c}1 \\
1.0 \% \\
-0.9 \\
\end{array}$ & $\begin{array}{c}0 \\
0.0 \% \\
-1.8 \\
\end{array}$ & $\begin{array}{c}11 \\
10.6 \% \\
-1.4 \\
\end{array}$ & $\begin{array}{c}104 \\
13.5 \%\end{array}$ \\
\hline $41 \mathrm{BX} 1088$ & $\begin{array}{c}219 \\
64.6 \% \\
1.9 \\
\end{array}$ & $\begin{array}{c}20 \\
5.9 \% \\
-0.8 \\
\end{array}$ & $\begin{array}{c}9 \\
2.7 \% \\
-1.9 \\
\end{array}$ & $\begin{array}{c}31 \\
9.1 \% \\
0.6 \\
\end{array}$ & $\begin{array}{c}7 \\
2.1 \% \\
-0.2\end{array}$ & $\begin{array}{c}7 \\
2.1 \% \\
-0.8\end{array}$ & $\begin{array}{c}46 \\
13.6 \% \\
-1 \\
\end{array}$ & $\begin{array}{c}339 \\
44.0 \%\end{array}$ \\
\hline $41 \mathrm{BX} 1090$ & $\begin{array}{c}9 \\
90.0 \% \\
1.9\end{array}$ & $\begin{array}{c}0 \\
0.0 \% \\
-0.9 \\
\end{array}$ & $\begin{array}{c}0 \\
0.0 \% \\
-0.7 \\
\end{array}$ & $\begin{array}{c}0 \\
0.0 \% \\
-1 \\
\end{array}$ & $\begin{array}{c}0 \\
0.0 \% \\
-0.5 \\
\end{array}$ & $\begin{array}{c}0 \\
0.0 \% \\
-0.5 \\
\end{array}$ & $\begin{array}{c}1 \\
10.0 \% \\
-0.5 \\
\end{array}$ & $\begin{array}{c}10 \\
1.3 \%\end{array}$ \\
\hline $41 \mathrm{BX} 1091$ & $\begin{array}{c}23 \\
92.0 \% \\
3.3 \\
\end{array}$ & $\begin{array}{c}0 \\
0.0 \% \\
-1.4 \\
\end{array}$ & $\begin{array}{c}0 \\
0.0 \% \\
-1.1 \\
\end{array}$ & $\begin{array}{c}0 \\
0.0 \% \\
-1.5 \\
\end{array}$ & $\begin{array}{c}1 \\
4.0 \% \\
0.6 \\
\end{array}$ & $\begin{array}{c}1 \\
4.0 \% \\
0.4 \\
\end{array}$ & $\begin{array}{c}0 \\
0.0 \% \\
-2.1 \\
\end{array}$ & $\begin{array}{c}25 \\
3.2 \%\end{array}$ \\
\hline $41 \mathrm{BX} 1102$ & $\begin{array}{c}33 \\
42.3 \% \\
-3.5 \\
\end{array}$ & $\begin{array}{c}2 \\
2.6 \% \\
-1.6 \\
\end{array}$ & $\begin{array}{c}13 \\
16.7 \% \\
5.8 \\
\end{array}$ & $\begin{array}{c}6 \\
7.7 \% \\
-0.3 \\
\end{array}$ & $\begin{array}{c}2 \\
2.6 \% \\
0.2 \\
\end{array}$ & $\begin{array}{c}3 \\
3.8 \% \\
0.7 \\
\end{array}$ & $\begin{array}{c}19 \\
24.4 \% \\
2.4 \\
\end{array}$ & $\begin{array}{c}78 \\
10.1 \%\end{array}$ \\
\hline $41 \mathrm{BX} 1103$ & $\begin{array}{c}42 \\
36.2 \% \\
-\mathbf{5 . 9}\end{array}$ & $\begin{array}{c}18 \\
15.5 \% \\
4.1\end{array}$ & $\begin{array}{c}8 \\
6.9 \% \\
1.6\end{array}$ & $\begin{array}{c}16 \\
13.8 \% \\
2.2\end{array}$ & $\begin{array}{c}5 \\
4.3 \% \\
1.7\end{array}$ & $\begin{array}{c}6 \\
5.2 \% \\
1.9\end{array}$ & $\begin{array}{c}21 \\
18.1 \% \\
1\end{array}$ & $\begin{array}{c}116 \\
15.1 \%\end{array}$ \\
\hline $41 \mathrm{BX} 1114$ & $\begin{array}{c}65 \\
66.3 \% \\
1.2 \\
\end{array}$ & $\begin{array}{c}6 \\
6.1 \% \\
-0.3 \\
\end{array}$ & $\begin{array}{c}0 \\
0.0 \% \\
-2.2 \\
\end{array}$ & $\begin{array}{c}5 \\
5.1 \% \\
-1.3 \\
\end{array}$ & $\begin{array}{c}1 \\
1.0 \% \\
-0.9 \\
\end{array}$ & $\begin{array}{c}3 \\
3.1 \% \\
0.3 \\
\end{array}$ & $\begin{array}{c}18 \\
18.4 \% \\
1 \\
\end{array}$ & $\begin{array}{c}98 \\
12.7 \%\end{array}$ \\
\hline $\begin{array}{c}\text { Column } \\
\text { Total }\end{array}$ & $\begin{array}{c}468 \\
60.8 \%\end{array}$ & $\begin{array}{c}52 \\
6.8 \%\end{array}$ & $\begin{array}{c}32 \\
4.2 \%\end{array}$ & $\begin{array}{c}65 \\
8.4 \%\end{array}$ & $\begin{array}{c}17 \\
2.2 \%\end{array}$ & $\begin{array}{c}20 \\
2.6 \%\end{array}$ & $\begin{array}{c}116 \\
15.1 \%\end{array}$ & $\begin{array}{c}770 \\
100.0 \%\end{array}$ \\
\hline
\end{tabular}

6-16, and 6-17, respectively. The two floodplain sites have the bifaces with lowest average lengths, widths, and thicknesses. 41BX1091 has the highest average biface length; 41BX1076 has the highest average biface width; and 41BX1090 has the highest average biface thickness. This indicates that bifaces are reduced further at floodplain sites.

\section{Unifaces}

Contingency table analysis was conducted for the following uniface attributes: cortex, blank type, completeness, degree of modification, and location of modification. The mean and standard deviation for the maximum dimension, for measurable unifaces are also presented.

\section{Cortex}

In general, there is little variation among the uniface assemblages based on the amount of cortex (Table 6-18). 41BX1103 has a greater-than-expected quantity of unifaces without cortex and a less-than-expected quantity of unifaces with $1-50$ percent cortex. $41 \mathrm{BX} 1088$ has a higher-than-expected quantity of unifaces with $1-50$ percent cortex.

These patterns, in conjunction with the cortex categories among the unmodified debitage, indicate that there was no selection of debitage with specific characteristics in the manufacture of unifaces. That is, raw material reduction strategies were not designed for the production of specific, standardized, flake blanks to be employed as expedient unifacial tools or to be 
Table 6-14. Contingency Table Analysis of Biface Break Type Category by Site Top value in cell represents artifact count, middle value is row percent, and bottom value represents adjusted residuals. Percent value in total column represents column percent. Significant $(p \leq 0.05)$ values are shown in bold.

\begin{tabular}{|c|c|c|c|c|c|c|}
\hline Site & Use & Manufacturing & Bu rning & Post-Depositional & Indeterminate & Total \\
\hline \multirow{3}{*}{$41 \mathrm{BX} 1076$} & 0 & 9 & 1 & 14 & 3 & 27 \\
\hline & $0.0 \%$ & $33.3 \%$ & $3.7 \%$ & $51.9 \%$ & $11.1 \%$ & $8.9 \%$ \\
\hline & -1.3 & -0.8 & -0.3 & 2.2 & -0.7 & \\
\hline \multirow{3}{*}{$41 \mathrm{BX} 1088$} & 3 & 36 & 4 & 67 & 9 & 119 \\
\hline & $2.5 \%$ & $30.3 \%$ & $3.4 \%$ & $56.3 \%$ & $7.6 \%$ & $39.4 \%$ \\
\hline & -1.9 & -3 & -1 & 6.9 & -3.1 & \\
\hline \multirow{3}{*}{$41 \mathrm{BX} 1090$} & 0 & 0 & 0 & 0 & 1 & 1 \\
\hline & $0.0 \%$ & $0.0 \%$ & $0.0 \%$ & $0.0 \%$ & $100.0 \%$ & $0.3 \%$ \\
\hline & -0.2 & -0.8 & -0.2 & -0.7 & 2.3 & \\
\hline \multirow{3}{*}{$41 \mathrm{BX} 1091$} & 0 & 1 & 0 & 0 & 0 & 1 \\
\hline & $0.0 \%$ & $100.0 \%$ & $0.0 \%$ & $0.0 \%$ & $0.0 \%$ & $0.3 \%$ \\
\hline & -0.2 & 1.2 & -0.2 & -0.7 & -0.4 & \\
\hline \multirow{3}{*}{$41 \mathrm{BX} 1102$} & 3 & 19 & 3 & 8 & 12 & 45 \\
\hline & $6.7 \%$ & $42.2 \%$ & $6.7 \%$ & $17.8 \%$ & $26.7 \%$ & $14.9 \%$ \\
\hline & 0.3 & 0.2 & 0.6 & -2.4 & 2.2 & \\
\hline \multirow{3}{*}{$41 \mathrm{BX} 1103$} & 8 & 38 & 7 & 8 & 14 & 75 \\
\hline & $10.7 \%$ & $50.7 \%$ & $9.3 \%$ & $10.7 \%$ & $18.7 \%$ & $24.8 \%$ \\
\hline & 2.2 & 2 & 2 & -4.8 & 0.9 & \\
\hline \multirow{3}{*}{$41 \mathrm{BX} 1114$} & 3 & 20 & 0 & 3 & 8 & 34 \\
\hline & $8.8 \%$ & $58.8 \%$ & $0.0 \%$ & $8.8 \%$ & $23.5 \%$ & $11.3 \%$ \\
\hline & 0.9 & 2.3 & -1.4 & -3.2 & 1.4 & \\
\hline Column & 17 & 123 & 15 & 100 & 47 & 302 \\
\hline Total & $5.6 \%$ & $40.7 \%$ & $5.0 \%$ & $33.1 \%$ & $15.6 \%$ & $100.0 \%$ \\
\hline
\end{tabular}

Table 6-15. Mean and Standard Error of Biface Length (in $\mathrm{mm}$ ) by Site

\begin{tabular}{|c|r|r|r|}
\hline Site & Mean & $\begin{array}{c}\text { Standard } \\
\text { Error }\end{array}$ & Cases \\
\hline $41 \mathrm{BX} 1076$ & 69.78 & 2.49 & 78 \\
\hline $41 \mathrm{BX} 1088$ & 70.50 & 1.55 & 227 \\
\hline $41 \mathrm{BX} 1090$ & 81.44 & 4.25 & 9 \\
\hline $41 \mathrm{BX} 1091$ & 82.75 & 4.19 & 24 \\
\hline $41 \mathrm{BX} 1102$ & 64.77 & 3.05 & 35 \\
\hline $41 \mathrm{BX} 1103$ & 65.93 & 3.35 & 46 \\
\hline $41 \mathrm{BX} 1114$ & 79.41 & 7.43 & 66 \\
\hline Total & 71.56 & 1.39 & 485 \\
\hline
\end{tabular}

Table 6-16. Mean and Standard Error of Biface Width (in $\mathrm{mm}$ ) by Site

\begin{tabular}{|c|c|c|r|}
\hline Site & Mean & $\begin{array}{c}\text { Standard } \\
\text { Error }\end{array}$ & Cases \\
\hline $41 \mathrm{BX} 1076$ & 47.60 & 1.45 & 89 \\
\hline $41 \mathrm{BX} 1088$ & 47.04 & 0.97 & 268 \\
\hline $41 \mathrm{BX} 1090$ & 63.22 & 4.70 & 9 \\
\hline $41 \mathrm{BX} 1091$ & 53.09 & 3.00 & 23 \\
\hline $41 \mathrm{BX} 1102$ & 45.21 & 2.13 & 43 \\
\hline $41 \mathrm{BX} 1103$ & 46.27 & 2.35 & 60 \\
\hline $41 \mathrm{BX} 1114$ & 49.23 & 1.79 & 73 \\
\hline Total & 47.70 & 0.66 & 565 \\
\hline
\end{tabular}


Table 6-17. Mean and Standard Error of Biface Thickness (in mm) by Site

\begin{tabular}{|c|r|c|r|}
\hline Site & Mean & $\begin{array}{c}\text { Standard } \\
\text { Deviation }\end{array}$ & Cases \\
\hline $41 \mathrm{BX} 1076$ & 23.26 & 0.88 & 93 \\
\hline $41 \mathrm{BX} 1088$ & 22.45 & 0.67 & 288 \\
\hline $41 \mathrm{BX} 1090$ & 35.90 & 3.15 & 10 \\
\hline $41 \mathrm{BX} 1091$ & 30.58 & 1.80 & 24 \\
\hline $41 \mathrm{BX} 1102$ & 19.66 & 1.35 & 44 \\
\hline $41 \mathrm{BX} 1103$ & 17.69 & 1.48 & 67 \\
\hline $41 \mathrm{BX} 1114$ & 24.57 & 1.33 & 75 \\
\hline Total & 22.65 & 0.46 & 601 \\
\hline
\end{tabular}

Table 6-18. Contingency Table Analysis of Uniface Cortex Category by Site

Top value in cell represents artifact count, middle value is row percent, and bottom value represents adjusted residuals.

Percent value in total column represents column percent. Significant $(\mathrm{p} \leq 0.05)$ values are shown in bold.

\begin{tabular}{|c|c|c|c|c|}
\hline Site & Absent & $1-50 \%$ & $51-99 \%$ & Total \\
\hline $41 \mathrm{BX} 1076$ & $\begin{array}{c}20 \\
33.3 \% \\
-0.5\end{array}$ & $\begin{array}{c}40 \\
66.7 \% \\
0.9\end{array}$ & $\begin{array}{c}0 \\
0.0 \% \\
-1.3\end{array}$ & $\begin{array}{c}60 \\
9.6 \%\end{array}$ \\
\hline $41 \mathrm{BX} 1088$ & $\begin{array}{c}39 \\
29.5 \% \\
-1.8\end{array}$ & $\begin{array}{c}91 \\
68.9 \% \\
2\end{array}$ & $\begin{array}{l}2 \\
1.5 \% \\
-0.8\end{array}$ & $\begin{array}{c}132 \\
21.2 \%\end{array}$ \\
\hline $41 \mathrm{BX} 1090$ & $\begin{array}{c}1 \\
20.0 \% \\
-0.8\end{array}$ & $\begin{array}{c}4 \\
80.0 \% \\
0.9 \\
\end{array}$ & $\begin{array}{c}0 \\
0.0 \% \\
-0.4 \\
\end{array}$ & $\begin{array}{c}5 \\
0.8 \%\end{array}$ \\
\hline $41 \mathrm{~B} \times 1091$ & $\begin{array}{c}4 \\
21.1 \% \\
-1.4\end{array}$ & $\begin{array}{c}14 \\
73.7 \% \\
1.1\end{array}$ & $\begin{array}{c}1 \\
5.3 \% \\
0.8\end{array}$ & $\begin{array}{c}19 \\
3.1 \%\end{array}$ \\
\hline $41 \mathrm{~B} \times 1102$ & $\begin{array}{c}15 \\
30.0 \% \\
-0.9\end{array}$ & $\begin{array}{c}33 \\
66.0 \% \\
0.7\end{array}$ & $\begin{array}{c}2 \\
4.0 \% \\
0.8\end{array}$ & $\begin{array}{c}50 \\
8.0 \%\end{array}$ \\
\hline $41 \mathrm{~B} \times 1103$ & $\begin{array}{c}88 \\
50.9 \% \\
4.7\end{array}$ & $\begin{array}{c}81 \\
46.8 \% \\
-4.6\end{array}$ & $\begin{array}{c}4 \\
2.3 \% \\
-0.1 \\
\end{array}$ & $\begin{array}{c}173 \\
27.8 \%\end{array}$ \\
\hline $41 \mathrm{BX} 1114$ & $\begin{array}{c}58 \\
31.7 \% \\
-1.5\end{array}$ & $\begin{array}{c}119 \\
65.0 \% \\
1.2\end{array}$ & $\begin{array}{c}6 \\
3.3 \% \\
0.9 \\
\end{array}$ & $\begin{array}{c}183 \\
29.4 \%\end{array}$ \\
\hline $\begin{array}{c}\text { Column } \\
\text { Total }\end{array}$ & $\begin{array}{c}225 \\
36.2 \%\end{array}$ & $\begin{array}{c}382 \\
61.4 \%\end{array}$ & $\begin{array}{c}15 \\
2.4 \%\end{array}$ & $\begin{array}{c}622 \\
100.0 \%\end{array}$ \\
\hline
\end{tabular}


manufactured into formal unifaces (e.g., those found in Late Archaic and Toyah Phase Late Prehistoric sites). Rather, specimens were selected from the bulk debitage derived from the reduction of bifaces and cores.

\section{Blank Type}

Table 6-19 presents the results of the contingency table analysis of uniface blank type. The only unexpected values are at 41BX1091, 41BX1102, and 41BX1103. The 41BX1091 assemblage has a higher-than-expected quantity of unifaces made on blanks other than blades or flakes, and a lower-than-expected quantity of unifaces made on flakes. At 41BX1102 there is a higher-than-expected quantity of unifaces made on blades. At 41BX1103 there is a higher-than-expected quantity of unifaces made on flakes with corresponding lower-than-expected quantities of flakes made on blades or other types of blanks. The scarcity of unifaces made on blades at most sites and the numerical dominance of tools made on flakes again supports the earlier observation regarding the lack of standardization in blank production. In general, blades are considered to be a more standardized form of blank production than flakes.

\section{Completeness}

When analyzed by completeness, the only unexpected values for the unifaces are from $41 \mathrm{BX} 1088$, 41BX1103, and 41BX1114 (Table 6-20). 41BX1088 has a greater-than-expected quantity of longitudinal fragments and a lower-than-expected quantity of medial fragments. At 41BX1103 there are fewer-thanexpected complete unifaces and more-than-expected

Table 6-19. Contingency Table Analysis of Uniface Blank Type Category by Site

Top value in cell represents artifact count, middle value is row percent, and bottom value represents adjusted residuals. Percent value in total column represents column percent. Significant $(\mathrm{p} \leq 0.05)$ values are shown in bold.

\begin{tabular}{|c|c|c|c|c|c|}
\hline Site & Blade & Flake & Other & Indeterminate & Total \\
\hline \multirow{3}{*}{$41 \mathrm{BX} 1076$} & 3 & 57 & 0 & 0 & 60 \\
\hline & $5.0 \%$ & $95.0 \%$ & $0.0 \%$ & $0.0 \%$ & $9.6 \%$ \\
\hline & 0.5 & 0.8 & -1 & -1.2 & \\
\hline \multirow{3}{*}{$41 \mathrm{BX} 1088$} & 3 & 124 & 3 & 2 & 132 \\
\hline & $2.3 \%$ & $93.9 \%$ & $2.3 \%$ & $1.5 \%$ & $21.2 \%$ \\
\hline & -1.1 & 0.8 & 0.7 & -0.6 & \\
\hline \multirow{3}{*}{$41 \mathrm{BX} 1090$} & 0 & 5 & 0 & 0 & 5 \\
\hline & $0.0 \%$ & $100.0 \%$ & $0.0 \%$ & $0.0 \%$ & $0.8 \%$ \\
\hline & -0.4 & 0.6 & -0.3 & -0.3 & \\
\hline \multirow{3}{*}{ 41BX1091 } & 0 & 15 & 3 & 1 & 19 \\
\hline & $0.0 \%$ & $78.9 \%$ & $15.8 \%$ & $5.3 \%$ & $3.1 \%$ \\
\hline & -0.9 & -2.2 & 5 & 0.9 & \\
\hline \multirow{3}{*}{$41 \mathrm{BX} 1102$} & 6 & 43 & 1 & 0 & 50 \\
\hline & $12.0 \%$ & $86.0 \%$ & $2.0 \%$ & $0.0 \%$ & $8.0 \%$ \\
\hline & 3.1 & -1.7 & 0.2 & -1.1 & \\
\hline \multirow{3}{*}{$41 \mathrm{BX} 1103$} & 2 & 167 & 0 & 4 & 173 \\
\hline & $1.2 \%$ & $96.5 \%$ & $0.0 \%$ & $2.3 \%$ & $27.8 \%$ \\
\hline & -2.2 & 2.5 & -2 & 0.1 & \\
\hline \multirow{3}{*}{$41 \mathrm{BX} 1114$} & 10 & 163 & 3 & 7 & 183 \\
\hline & $5.5 \%$ & $89.1 \%$ & $1.6 \%$ & $3.8 \%$ & $29.4 \%$ \\
\hline & 1.3 & -1.9 & 0 & 1.7 & \\
\hline Column & 24 & 574 & 10 & 14 & 622 \\
\hline Total & $3.9 \%$ & $92.3 \%$ & $1.6 \%$ & $2.3 \%$ & $100.0 \%$ \\
\hline
\end{tabular}


medial fragments. Finally, $41 \mathrm{BX} 1114$ has a greaterthan-expected quantity of complete unifaces.

\section{Degree of Modification}

There is very little difference in the degree of modification of unifaces across sites (Table 6-21). 41BX1090 has a greater-than-expected number of formal unifaces, but the sample size is very small. At 41BX1102 there are more expedient unifaces and fewer minimally retouched unifaces than expected.

The fact that minimally retouched unifaces dominate the collections and expedient specimens constitute about a fourth of the assemblages indicates that the majority of the unifaces recovered were made with little work investment to meet immediate on-site needs. The relatively large numbers of unifaces also may not be surprising given higher discard rates among lowlabor investment tools compared to their formal variants. Although formal curated specimens may have been made in quantities and transported off site, the relative scarcity of small debitage mentioned earlier argues against this possibility.

\section{Location of Modification}

Table 6-22 presents the results of the contingency table analysis of the location of modification category for unifaces. At 41BX1088 and 41BX1091 there are morethan-expected unifaces with modification on both lateral edges. The only other unexpected value is the high number of unifaces at 41BX1102 with modification on only one lateral edge.

Table 6-20. Contingency Table Analysis of Uniface Completeness Category by Site

Top value in cell represents artifact count, middle value is row percent, and bottom value represents adjusted residuals.

Percent value in total column represents column percent. Significant $(p \leq 0.05)$ values are shown in bold.

\begin{tabular}{|c|c|c|c|c|c|c|}
\hline Site & Complete & Medial & Distal & Longitudinal & Indeterminate & Total \\
\hline $41 \mathrm{BX} 1076$ & $\begin{array}{c}39 \\
65.0 \% \\
0 \\
\end{array}$ & $\begin{array}{c}4 \\
6.7 \% \\
0.8 \\
\end{array}$ & $\begin{array}{c}7 \\
11.7 \% \\
-0.5 \\
\end{array}$ & $\begin{array}{c}4 \\
6.7 \% \\
0.8 \\
\end{array}$ & $\begin{array}{c}1 \\
1.7 \% \\
0.1 \\
\end{array}$ & $\begin{array}{c}60 \\
9.6 \%\end{array}$ \\
\hline 41BX1088 & $\begin{array}{c}86 \\
65.2 \% \\
0 \\
\end{array}$ & $\begin{array}{c}1 \\
0.8 \% \\
-2.4 \\
\end{array}$ & $\begin{array}{c}19 \\
14.4 \% \\
0.3 \\
\end{array}$ & $\begin{array}{c}11 \\
8.3 \% \\
2.3 \\
\end{array}$ & $\begin{array}{c}2 \\
1.5 \% \\
0.1 \\
\end{array}$ & $\begin{array}{c}132 \\
21.2 \%\end{array}$ \\
\hline $41 \mathrm{BX} 1090$ & $\begin{array}{c}5 \\
100.0 \% \\
1.6 \\
\end{array}$ & $\begin{array}{c}0 \\
0.0 \% \\
-0.5 \\
\end{array}$ & $\begin{array}{c}0 \\
0.0 \% \\
-0.9 \\
\end{array}$ & $\begin{array}{c}0 \\
0.0 \% \\
-0.5 \\
\end{array}$ & $\begin{array}{c}0 \\
0.0 \% \\
-0.3 \\
\end{array}$ & $\begin{array}{c}5 \\
0.8 \%\end{array}$ \\
\hline $41 \mathrm{BX} 1091$ & $\begin{array}{c}16 \\
84.2 \% \\
1.8\end{array}$ & $\begin{array}{c}0 \\
0.0 \% \\
-1\end{array}$ & $\begin{array}{c}0 \\
0.0 \% \\
-1.8\end{array}$ & $\begin{array}{c}1 \\
5.3 \% \\
0.1\end{array}$ & $\begin{array}{c}1 \\
5.3 \% \\
1.4\end{array}$ & $\begin{array}{c}19 \\
3.1 \%\end{array}$ \\
\hline $41 \mathrm{BX} 1102$ & $\begin{array}{c}28 \\
56.0 \% \\
-1.4 \\
\end{array}$ & $\begin{array}{c}3 \\
6.0 \% \\
0.5 \\
\end{array}$ & $\begin{array}{c}8 \\
16.0 \% \\
0.5 \\
\end{array}$ & $\begin{array}{c}0 \\
0.0 \% \\
-1.6 \\
\end{array}$ & $\begin{array}{c}0 \\
0.0 \% \\
-0.9 \\
\end{array}$ & $\begin{array}{c}50 \\
8.0 \%\end{array}$ \\
\hline $41 \mathrm{BX} 1103$ & $\begin{array}{c}97 \\
56.1 \% \\
-\mathbf{3} \\
\end{array}$ & $\begin{array}{c}15 \\
8.7 \% \\
2.9 \\
\end{array}$ & $\begin{array}{c}27 \\
15.6 \% \\
0.9 \\
\end{array}$ & $\begin{array}{c}9 \\
5.2 \% \\
0.4 \\
\end{array}$ & $\begin{array}{c}1 \\
0.6 \% \\
-1.1 \\
\end{array}$ & $\begin{array}{c}173 \\
27.8 \%\end{array}$ \\
\hline $41 \mathrm{~B} \times 1114$ & $\begin{array}{c}135 \\
73.8 \% \\
\mathbf{2 . 9} \\
\end{array}$ & $\begin{array}{c}6 \\
3.3 \% \\
-1.1 \\
\end{array}$ & $\begin{array}{c}24 \\
13.1 \% \\
-0.3 \\
\end{array}$ & $\begin{array}{c}4 \\
2.2 \% \\
-1.9 \\
\end{array}$ & $\begin{array}{c}4 \\
2.2 \% \\
1 \\
\end{array}$ & $\begin{array}{c}183 \\
29.4 \%\end{array}$ \\
\hline $\begin{array}{c}\text { Column } \\
\text { Total }\end{array}$ & $\begin{array}{c}406 \\
65.3 \%\end{array}$ & $\begin{array}{c}29 \\
4.7 \%\end{array}$ & $\begin{array}{c}85 \\
13.7 \%\end{array}$ & $\begin{array}{c}29 \\
4.7 \%\end{array}$ & $\begin{array}{c}9 \\
1.4 \%\end{array}$ & $\begin{array}{c}622 \\
100.0 \%\end{array}$ \\
\hline
\end{tabular}


Table 6-21. Contingency Table Analysis of Uniface Degree of Modification Category by Site Top value in cell represents artifact count, middle value is row percent, and bottom value represents adjusted residuals.

Percent value in total column represents column percent. Significant $(\mathrm{p} \leq 0.05)$ values are shown in bold.

\begin{tabular}{|c|c|c|c|c|}
\hline Site & Expedient & Minimal & Formal & Total \\
\hline \multirow{3}{*}{$41 \mathrm{BX} 1076$} & 17 & 41 & 2 & 60 \\
\hline & $28.3 \%$ & $68.3 \%$ & $3.3 \%$ & $9.6 \%$ \\
\hline & 0.5 & -0.5 & 0 & \\
\hline \multirow{3}{*}{$41 \mathrm{BX} 1088$} & 33 & 93 & 6 & 132 \\
\hline & $25.0 \%$ & $70.5 \%$ & $4.5 \%$ & $21.2 \%$ \\
\hline & -0.2 & -0.2 & 0.8 & \\
\hline \multirow{3}{*}{$41 \mathrm{BX} 1090$} & 1 & 3 & 1 & 5 \\
\hline & $20.0 \%$ & $60.0 \%$ & $20.0 \%$ & $0.8 \%$ \\
\hline & -0.3 & -0.5 & 2.1 & \\
\hline \multirow{3}{*}{ 41BX1091 } & 4 & 13 & 2 & 19 \\
\hline & $21.1 \%$ & $68.4 \%$ & $10.5 \%$ & $3.1 \%$ \\
\hline & -0.5 & -0.3 & 1.8 & \\
\hline \multirow{3}{*}{$41 \mathrm{BX} 1102$} & 21 & 27 & 2 & 50 \\
\hline & $42.0 \%$ & $54.0 \%$ & $4.0 \%$ & $8.0 \%$ \\
\hline & 2.8 & -2.8 & 0.3 & \\
\hline \multirow{3}{*}{$41 \mathrm{BX} 1103$} & 38 & 132 & 3 & 173 \\
\hline & $22.0 \%$ & $76.3 \%$ & $1.7 \%$ & $27.8 \%$ \\
\hline & -1.3 & 1.8 & -1.4 & \\
\hline \multirow{3}{*}{$41 \mathrm{BX} 1114$} & 45 & 133 & 5 & 183 \\
\hline & $24.6 \%$ & $72.7 \%$ & $2.7 \%$ & $29.4 \%$ \\
\hline & -0.4 & 0.6 & -0.6 & \\
\hline Column & 159 & 442 & 21 & 622 \\
\hline Total & $25.6 \%$ & $71.1 \%$ & $3.4 \%$ & $100.0 \%$ \\
\hline
\end{tabular}

\section{Maximum Dimension}

The average maximum dimension and standard deviation for complete unifaces are presented in Table 6-23. The smallest average is from the 41BX1103 assemblage which is represented by 105 complete artifacts. The highest average is from 41BX1090 which is represented by a small sample of five complete unifaces.

\section{Projectile Points}

The detailed attributes of the projectile points recovered during the testing project are presented in Appendix B. The percentages of break types for incomplete arrow points and for incomplete dart points are presented in Tables 6-24 and 6-25, respectively.
Projectile point break type is an indicator of what types of tool processing were taking place at a site.

For both dart points and arrow points, the most common break type is use/resharpening. Only at 41BX1102 and 41BX1103, where there are high frequencies of post-depositional or indeterminate break types, is use/resharpening not the most common form of projectile point breakage.

\section{Raw Material}

\section{Methods of Investigation}

During the surface collecting of the tested sites at Medina Annex, a sample of unmodified raw material 
Table 6-22. Contingency Table Analysis of Uniface Location of Modification Category by Site Top value in cell represents artifact count, middle value is row percent, and bottom value represents adjusted residuals.

Percent value in total column represents column percent. Significant $(\mathrm{p} \leq 0.05)$ values are shown in bold.

\begin{tabular}{|c|c|c|c|c|c|c|c|c|}
\hline Site & Proximal & Distal & Lateral (1) & Lateral (2) & $\begin{array}{l}\text { Lateral } \\
\text { + Distal }\end{array}$ & $\begin{array}{c}\text { Other } \\
\text { Multiple }\end{array}$ & $\begin{array}{l}\text { Indeter- } \\
\text { minate }\end{array}$ & Total \\
\hline \multirow{3}{*}{$41 \mathrm{BX} 1076$} & 3 & 13 & 34 & 5 & 3 & 0 & 2 & 60 \\
\hline & $5.0 \%$ & $21.7 \%$ & $56.7 \%$ & $8.3 \%$ & $5.0 \%$ & $0.0 \%$ & $3.3 \%$ & $9.6 \%$ \\
\hline & 0.3 & -0.1 & 0.6 & 0 & -0.3 & -1.8 & 1 & \\
\hline \multirow{3}{*}{$41 \mathrm{BX} 1088$} & 4 & 35 & 60 & 18 & 5 & 9 & 1 & 132 \\
\hline & $3.0 \%$ & $26.5 \%$ & $45.5 \%$ & $13.6 \%$ & $3.8 \%$ & $6.8 \%$ & $0.8 \%$ & $21.2 \%$ \\
\hline & -0.7 & 1.3 & -1.9 & 2.5 & -1.1 & 1.3 & -1 & \\
\hline \multirow{3}{*}{$41 \mathrm{BX} 1090$} & 0 & 1 & 2 & 0 & 1 & 1 & 0 & 5 \\
\hline & $0.0 \%$ & $20.0 \%$ & $40.0 \%$ & $0.0 \%$ & $20.0 \%$ & $20.0 \%$ & $0.0 \%$ & $0.8 \%$ \\
\hline & -0.5 & -0.1 & -0.6 & -0.7 & 1.4 & 1.6 & -0.3 & \\
\hline \multirow{3}{*}{$41 \mathrm{BX} 1091$} & 1 & 4 & 8 & 4 & 1 & 0 & 1 & 19 \\
\hline & $5.3 \%$ & $21.1 \%$ & $42.1 \%$ & $21.1 \%$ & $5.3 \%$ & $0.0 \%$ & $5.3 \%$ & $3.1 \%$ \\
\hline & 0.2 & -0.1 & -1 & 2 & -0.1 & -1 & 1.2 & \\
\hline \multirow{3}{*}{$41 \mathrm{BX} 1102$} & 4 & 7 & 34 & 2 & 3 & 0 & 0 & 50 \\
\hline & $8.0 \%$ & $14.0 \%$ & $68.0 \%$ & $4.0 \%$ & $6.0 \%$ & $0.0 \%$ & $0.0 \%$ & $8.0 \%$ \\
\hline & 1.4 & -1.5 & 2.2 & -1.2 & 0.1 & -1.6 & -1 & \\
\hline \multirow{3}{*}{$41 \mathrm{BX} 1103$} & 4 & 42 & 85 & 11 & 15 & 12 & 4 & 173 \\
\hline & $2.3 \%$ & $24.3 \%$ & $49.1 \%$ & $6.4 \%$ & $8.7 \%$ & $6.9 \%$ & $2.3 \%$ & $27.8 \%$ \\
\hline & -1.4 & 0.7 & -1.2 & -1.1 & 1.9 & 1.7 & 0.6 & \\
\hline \multirow{3}{*}{$41 \mathrm{BX} 1114$} & 10 & 37 & 106 & 12 & 8 & 7 & 3 & 183 \\
\hline & $5.5 \%$ & $20.2 \%$ & $57.9 \%$ & $6.6 \%$ & $4.4 \%$ & $3.8 \%$ & $1.6 \%$ & $29.4 \%$ \\
\hline & 1 & -0.8 & 1.6 & -1 & -1 & -0.6 & -0.2 & \\
\hline Column & 26 & 139 & 329 & 52 & 36 & 29 & 11 & 622 \\
\hline Total & $4.2 \%$ & $22.3 \%$ & $52.9 \%$ & $8.4 \%$ & $5.8 \%$ & $4.7 \%$ & $1.8 \%$ & $100.0 \%$ \\
\hline
\end{tabular}

Table 6-23. Mean and Standard Error of Uniface Maximum Dimension (in mm) by Site

\begin{tabular}{|c|c|c|r|}
\hline Site & Mean & $\begin{array}{c}\text { Standard } \\
\text { Error }\end{array}$ & Cases \\
\hline $41 \mathrm{BX} 1076$ & 53.02 & 1.83 & 42 \\
\hline $41 \mathrm{BX} 1088$ & 56.42 & 1.91 & 90 \\
\hline $41 \mathrm{BX} 1090$ & 65.00 & 8.15 & 5 \\
\hline $41 \mathrm{BX} 1091$ & 51.75 & 3.16 & 16 \\
\hline $41 \mathrm{BX} 1102$ & 53.14 & 2.77 & 29 \\
\hline $41 \mathrm{BX} 1103$ & 48.01 & 1.49 & 105 \\
\hline $41 \mathrm{BX} 1114$ & 56.65 & 1.50 & 135 \\
\hline Total & 53.76 & 0.81 & 422 \\
\hline
\end{tabular}


Table 6-24. Number of Specimens and Percentage of Arrow Point Break Types by Site

\begin{tabular}{|c|c|c|c|}
\hline$\stackrel{\Xi}{\dot{n}}$ & 总 & 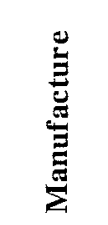 & \\
\hline $41 \mathrm{BX} 1076$ & $\begin{array}{c}1 \\
100 \%\end{array}$ & $\begin{array}{c}0 \\
0 \% \\
\end{array}$ & $\begin{array}{c}0 \\
0 \%\end{array}$ \\
\hline $41 \mathrm{BX} 1088$ & $\begin{array}{c}4 \\
80 \% \\
\end{array}$ & $\begin{array}{c}1 \\
20 \% \\
\end{array}$ & $\begin{array}{c}0 \\
0 \% \\
\end{array}$ \\
\hline $41 \mathrm{BX} 1091$ & $\begin{array}{c}1 \\
100 \% \\
\end{array}$ & $\begin{array}{c}0 \\
0 \% \\
\end{array}$ & $\begin{array}{c}0 \\
0 \%\end{array}$ \\
\hline $41 \mathrm{BX} 1114$ & $\begin{array}{c}1 \\
100 \% \\
\end{array}$ & $\begin{array}{c}0 \\
0 \% \\
\end{array}$ & $\begin{array}{c}0 \\
0 \% \\
\end{array}$ \\
\hline Total & $\begin{array}{c}7 \\
87.5 \%\end{array}$ & $\begin{array}{c}1 \\
12.5 \%\end{array}$ & $\begin{array}{c}0 \\
0 \%\end{array}$ \\
\hline
\end{tabular}

was collected from each site. All the raw material larger than $2.5 \mathrm{~cm}$ in diameter on the surface in the southwest $1 \mathrm{~m}^{2}$ of each $5-\mathrm{x}-5-\mathrm{m}$ collection unit was returned to the laboratory at CAR. Raw materials eligible for the study included chert, chalcedony, quartzite, or any other stone used to make chipped stone artifacts by prehistoric peoples. This excluded limestone, and it was the responsibility of the collector to discriminate based solely on cortex characteristics and weight which rocks were limestone and which were workable raw material. The quantity of material recovered precluded an analysis of the entire collection. The raw material from each site was sampled to provide the greater of 100 pieces of material or 25 percent of the total collected from the site. Each piece of raw material was weighed, measured (maximum dimension to nearest $\mathrm{cm}$ ), and then cracked open using a hammer. The material was then analyzed with respect to composition and quality. A total of 816 pieces was analyzed in this fashion, but this sample was later reduced to 524 pieces once inadvertently collected
Table 6-25. Number of Specimens and Percentage of Dart Point Break Types by Site

\begin{tabular}{|c|c|c|c|c|}
\hline$\stackrel{\Xi}{\check{\omega}}$ & 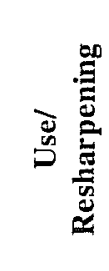 & 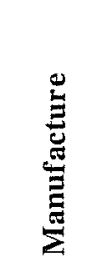 & 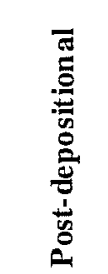 & \\
\hline $41 \mathrm{BX} 1076$ & $\begin{array}{c}1 \\
100 \% \\
\end{array}$ & $\begin{array}{c}0 \\
0 \% \\
\end{array}$ & $\begin{array}{c}0 \\
0 \% \\
\end{array}$ & $\begin{array}{c}0 \\
0 \% \\
\end{array}$ \\
\hline $41 \mathrm{BX} 1088$ & $\begin{array}{c}6 \\
66.7 \% \\
\end{array}$ & $\begin{array}{c}0 \\
0 \% \\
\end{array}$ & $\begin{array}{c}1 \\
11 \% \\
\end{array}$ & $\begin{array}{c}2 \\
22 \% \\
\end{array}$ \\
\hline $41 \mathrm{BX} 1091$ & $\begin{array}{c}1 \\
100 \% \\
\end{array}$ & $\begin{array}{c}0 \\
0 \% \\
\end{array}$ & $\begin{array}{c}0 \\
0 \%\end{array}$ & $\begin{array}{c}0 \\
0 \%\end{array}$ \\
\hline $41 \mathrm{BX} 1102$ & $\begin{array}{c}3 \\
25 \% \\
\end{array}$ & $\begin{array}{c}1 \\
8.3 \% \\
\end{array}$ & $\begin{array}{c}4 \\
33.3 \% \\
\end{array}$ & $\begin{array}{c}4 \\
33.3 \% \\
\end{array}$ \\
\hline $41 \mathrm{BX} 1103$ & $\begin{array}{c}5 \\
50 \% \\
\end{array}$ & $\begin{array}{c}0 \\
0 \% \\
\end{array}$ & $\begin{array}{c}0 \\
0 \% \\
\end{array}$ & $\begin{array}{c}5 \\
50 \% \\
\end{array}$ \\
\hline $41 \mathrm{BX} 1114$ & $\begin{array}{c}4 \\
80 \% \\
\end{array}$ & $\begin{array}{c}0 \\
0 \% \\
\end{array}$ & $\begin{array}{c}1 \\
20 \% \\
\end{array}$ & $\begin{array}{c}0 \\
0 \% \\
\end{array}$ \\
\hline Total & $\begin{array}{c}19 \\
51.4 \%\end{array}$ & $\begin{array}{c}1 \\
2.7 \%\end{array}$ & $\begin{array}{c}6 \\
16.2 \%\end{array}$ & $\begin{array}{c}11 \\
29.7 \%\end{array}$ \\
\hline
\end{tabular}

pieces of limestone and two improperly coded samples were removed from the analysis.

\section{Data Manipulation}

The data gathered during the raw material study are summarized in Table 6-26. The raw material and artifacts from each site have been classified as either chert or other. The other category includes chalcedony, silicified wood, jasper/agate, and quartzite. The first observation made from the study is that each of the tested sites has naturally occurring raw materials. The second trend is that chert represents the most common raw material, accounting for between 98.5 percent and 99.7 percent of the raw material and artifacts collected from each site. The only unexpectedly high or low adjusted residual values are found at 41BX1076 and 41BX1088. At 41BX1088 there is a greater-thanexpected quantity of chert debitage and a lower-thanexpected quantity of debitage made on other material. 
Table 6-26. Contingency Table Analysis of Raw Material Type for Debitage, Cores, Bifaces, Unifaces, and Raw Material at Each Site Top value in cell represents artifact count, middle value is row percent, and bottom value represents adjusted residuals.

Percent value in total column represents column percent. Significant $(\mathrm{p} \leq 0.05)$ values are shown in bold.

\begin{tabular}{|c|c|c|c|c|c|c|c|c|c|c|c|c|c|c|c|}
\hline \multirow{2}{*}{ Class } & \multicolumn{2}{|c|}{ 41BX1076 } & \multicolumn{2}{|c|}{ 41BX1088 } & \multicolumn{2}{|c|}{$41 \mathrm{BX} 1090$} & \multicolumn{2}{|c|}{ 41BX1091 } & \multicolumn{2}{|c|}{$41 \mathrm{BX} 1102$} & \multicolumn{2}{|c|}{$41 \mathrm{BX} 1103$} & \multicolumn{2}{|c|}{$41 \mathrm{BX} 1114$} & \multirow{2}{*}{ Total } \\
\hline & Chert & Other & Chert & Other & Chert & Other & Chert & Other & Chert & Other & Chert & Other & Chert & Other & \\
\hline \multirow{3}{*}{ Debitage } & 935 & 18 & 1705 & 1 & 75 & 0 & 285 & 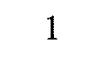 & 356 & 3 & 1089 & 8 & 1325 & 6 & 5807 \\
\hline & $98.1 \%$ & $1.9 \%$ & $99.9 \%$ & $0.1 \%$ & $100.0 \%$ & $0.0 \%$ & $99.7 \%$ & $0.3 \%$ & $99.2 \%$ & $0.8 \%$ & $99.3 \%$ & $0.7 \%$ & $99.5 \%$ & $0.5 \%$ & $61.7 \%$ \\
\hline & -2.2 & 2.2 & 3.1 & -3.1 & 0.8 & -0.8 & 0.4 & -0.4 & -1.0 & 1.0 & -1.0 & 1.0 & -0.1 & 0.1 & \\
\hline \multirow{3}{*}{ Core } & 125 & 0 & 509 & 4 & 72 & 0 & 213 & 2 & 149 & 0 & 51 & 0 & 318 & 2 & 1445 \\
\hline & $100.0 \%$ & $0.0 \%$ & $99.2 \%$ & $0.8 \%$ & $100.0 \%$ & $0.0 \%$ & $99.1 \%$ & $0.9 \%$ & $100.0 \%$ & $0.0 \%$ & $100.0 \%$ & $0.0 \%$ & $99.4 \%$ & $0.6 \%$ & $15.3 \%$ \\
\hline & 1.4 & -1.4 & -1.9 & 1.9 & 0.8 & -0.8 & -1.2 & 1.2 & 1.0 & -1.0 & 0.6 & -0.6 & -0.6 & 0.6 & \\
\hline \multirow{3}{*}{ Biface } & 104 & 0 & 331 & 1 & 10 & 0 & 25 & 0 & 78 & 0 & 116 & 0 & 98 & 0 & 763 \\
\hline & $100.0 \%$ & $0.0 \%$ & $99.7 \%$ & $0.3 \%$ & $100.0 \%$ & $0.0 \%$ & $100.0 \%$ & $0.0 \%$ & $100.0 \%$ & $0.0 \%$ & $100.0 \%$ & $0.0 \%$ & $100.0 \%$ & $0.0 \%$ & $8.1 \%$ \\
\hline & 1.3 & -1.3 & 0.1 & -0.1 & 0.3 & -0.3 & 0.4 & -0.4 & 0.7 & -0.7 & 0.9 & -0.9 & 0.7 & -0.7 & \\
\hline \multirow{3}{*}{ Uniface } & 59 & 0 & 132 & 0 & 5 & 0 & 19 & 0 & 49 & 1 & 172 & 1 & 182 & 1 & 621 \\
\hline & $100.0 \%$ & $0.0 \%$ & 100.0 & $0.0 \%$ & $100.0 \%$ & $0.0 \%$ & $100.0 \%$ & $0.0 \%$ & $98.0 \%$ & $2.0 \%$ & $99.4 \%$ & $0.6 \%$ & $0.5 \%$ & $0.5 \%$ & $6.6 \%$ \\
\hline & 1.0 & -1.0 & 0.7 & -0.7 & 0.2 & -0.2 & 0.3 & -0.3 & -1.4 & 1.4 & 0.1 & -0.1 & -0.2 & 0.2 & \\
\hline \multirow{3}{*}{$\begin{array}{c}\text { Raw } \\
\text { Material }\end{array}$} & 67 & 1 & 239 & 4 & 135 & 2 & 88 & 0 & 82 & 0 & 22 & 0 & 137 & 0 & 777 \\
\hline & $98.5 \%$ & $1.5 \%$ & $98.4 \%$ & $1.6 \%$ & $98.5 \%$ & $1.5 \%$ & $100.0 \%$ & $0.0 \%$ & $100.0 \%$ & $0.0 \%$ & $100.0 \%$ & $0.0 \%$ & $99.5 \%$ & $0.0 \%$ & $8.3 \%$ \\
\hline & 0.0 & 0.0 & -3.6 & 3.6 & -1.5 & 1.5 & 0.7 & -0.7 & 0.7 & -0.7 & 0.4 & -0.4 & -0.2 & -0.8 & \\
\hline Column & 1290 & 19 & 2916 & 10 & 297 & 2 & 630 & 3 & 714 & 4 & 1450 & 9 & 2060 & 9 & 9413 \\
\hline Total & $98.5 \%$ & $1.5 \%$ & $99.7 \%$ & $0.3 \%$ & $99.3 \%$ & $0.7 \%$ & $99.5 \%$ & $0.5 \%$ & $99.4 \%$ & $0.6 \%$ & $99.4 \%$ & $0.6 \%$ & $99.6 \%$ & $0.4 \%$ & $100.0 \%$ \\
\hline
\end{tabular}


There is a higher-than-expected quantity of other material in the raw material collected at $41 \mathrm{BX} 1088$. At 41BX1076, there is a higher-than-expected quantity of debitage made non-chert raw material. The 18 pieces of non-chert debitage are the highest number of non-chert items in any class at any site.

The majority of collected and sampled raw material was classified as coarse-grained. Fine-grained material is uniformly uncommon in the raw material samples from Medina Annex. Even if fine-grained material with inclusions is combined with the finegrained category as has been done in Table 6-27, the frequencies are low. A dramatic reversal of this pattern is seen in the material quality of all chipped stone artifact categories at all of the tested sites (Table 6-27). The overwhelming majority of the debitage, cores, unifaces, and bifaces collected during the project was fine-grained chert, the opposite of the pattern noted in the raw material sample.

For the four artifact categories, the percentage of finegrained material ranges from 70.7 percent in the $41 \mathrm{BX} 1088$ cores to 100 percent in the $41 \mathrm{BX} 1090 \mathrm{bi}-$ faces. For raw material, the highest percentage of finegrained chert is 43.1 percent at $41 \mathrm{BX} 1090$, and the lowest percentage is 26.1 percent at $41 \mathrm{BX} 1091$. At every site except $41 \mathrm{BX} 1103$, the contingency table analysis reveals that there are lower-than-expected quantities of coarse-grained debitage. The reverse is the case for raw material at every site including 41BX1103 where there are higher-than-expected quantities of coarse-grained raw material.

A comparison of the average maximum dimension of fine-grained and coarse-grained raw material with the average maximum dimension of each analyzed core from the seven sites in the study reveals that in all cases except 41BX1076, cores are larger on average than the unmodified raw material (Table 6-28). This is especially significant as most cores are fine-grained and the fine-grained raw materials are usually smaller than the coarse-grained raw materials. A comparison of the average weights and maximum dimensions of raw material reveals that at all sites except 41BX1114 the coarse-grained rocks are larger and heavier than the fine-grained ones (Table 6-29).

\section{Artifact Assemblages by Site}

In Table 6-30 counts for each artifact category are presented by site. However, because of low frequencies of certain artifacts such as hammerstones, ground stone, and ceramics, formal comparisons are difficult with these data. In order to make more formal comparisons of the chipped stone artifacts, they are listed by major category in Table 6-31. The results of the contingency table analysis uses these more limited assemblages. The two most similar sites are 41BX1090 and 41BX1091. Both have higher-than-expected quantities of cores and lower-than-expected quantities of bifaces and unifaces. The other three upland sites, however, deviate to varying degrees from this pattern. $41 \mathrm{BX} 1088$ has more cores and bifaces than expected, and fewer unifaces. At 41BX1076, there are more bifaces than expected. The final upland site, 41BX1114, is unique in that it has fewer-than-expected cores and bifaces, and more than expected unifaces. The two floodplain sites are similar in that each has greaterthan-expected frequencies of bifaces and projectile points, and lower-than-expected frequencies of cores. The number unifaces at 41BX1103 is also unexpectedly high.

\section{Data Analysis Discussion}

The results of the analyses of artifacts and raw materials are summarized for each site in this section. The individual summaries discuss the assemblage level analysis present in Table 6-31 and highlight the unexpectedly high or low values from selected attribute analyses of debitage, bifaces, and cores. Uniface categories proved to be unremarkable in most instances, so are not discussed. Unexpected values from the following attributes, which best reflect lithic reduction strategies, are noted for each site: cortex, flake type, and faceting for debitage; cortex, flake direction, and mean number of flake scars for cores; and cortex, completeness, stage of reduction, and blank type for bifaces. Unexpected results from the comparison of naturally available raw material type and grain size to artifact material and quality are also noted. Because the artifact assemblage from $41 \mathrm{BX} 1070$ is too small to make valid comparisons to those from the other sites, 41BX1070 is not included in this discussion. 
Table 6-27. Contingency Table Analysis of Raw Material Quality for Debitage, Cores, Bifaces, Unifaces, and Raw Material at Each Site Top value in cell represents artifact count, middle value is row percent, and bottom value represents adjusted residuals.

Percent value in total column represents column percent. Significant $(p \leq 0.05)$ values are shown in bold.

\begin{tabular}{|c|c|c|c|c|c|c|c|c|c|c|c|c|c|c|c|}
\hline \multirow{2}{*}{ Class } & \multicolumn{2}{|c|}{ 41BX1076 } & \multicolumn{2}{|c|}{ 41BX1088 } & \multicolumn{2}{|c|}{ 41BX1090 } & \multicolumn{2}{|c|}{ 41BX1091 } & \multicolumn{2}{|c|}{ 41BX1102 } & \multicolumn{2}{|c|}{ 41BX1103 } & \multicolumn{2}{|c|}{ 41BX1114 } & \multirow{2}{*}{ Total } \\
\hline & Coarse & Fine & Coarse & Fine & Coarse & Fine & Coarse & Fine & Coarse & Fine & Coarse & Fine & Coarse & Fine & \\
\hline \multirow{3}{*}{ Debitage } & 146 & 807 & 269 & 1437 & 14 & 61 & 55 & 231 & 50 & 309 & 114 & 983 & 278 & 1053 & 5807 \\
\hline & $15.3 \%$ & $84.7 \%$ & $15.8 \%$ & $84.2 \%$ & $18.7 \%$ & $81.3 \%$ & $19.2 \%$ & $80.8 \%$ & $13.9 \%$ & $86.1 \%$ & $10.4 \%$ & $89.6 \%$ & $20.0 \%$ & $79.1 \%$ & $61.7 \%$ \\
\hline & -3.2 & 3.2 & -6.9 & 6.9 & -3.0 & 3.0 & -5.4 & 5.4 & -4.7 & 4.7 & 0.5 & -0.5 & -2.6 & 2.6 & \\
\hline \multirow{3}{*}{ Core } & 15 & 110 & 74 & 439 & 4 & 68 & 63 & 152 & 23 & 126 & 2 & 49 & 64 & 256 & 1445 \\
\hline & $12.0 \%$ & $88.0 \%$ & $14.4 \%$ & $85.6 \%$ & $5.6 \%$ & $94.4 \%$ & $29.3 \%$ & $70.7 \%$ & $15.4 \%$ & $84.6 \%$ & $3.9 \%$ & $96.1 \%$ & $20.0 \%$ & $80.0 \%$ & $15.3 \%$ \\
\hline & -1.7 & 1.7 & -3.5 & 3.5 & -5.6 & 5.6 & -0.3 & 0.3 & -1.9 & 1.9 & -1.5 & 1.5 & -1.2 & 1.2 & \\
\hline \multirow{3}{*}{ Biface } & 19 & 85 & 66 & 266 & 0 & 10 & 7 & 18 & 12 & 66 & 10 & 106 & 8 & 90 & 763 \\
\hline & $18.3 \%$ & $81.7 \%$ & $19.9 \%$ & $80.1 \%$ & $0.0 \%$ & $100.0 \%$ & $28.0 \%$ & $72.0 \%$ & $15.4 \%$ & $84.6 \%$ & $8.6 \%$ & $91.4 \%$ & $8.2 \%$ & $91.8 \%$ & $8.1 \%$ \\
\hline & 0.3 & -0.3 & -0.1 & 0.1 & -2.2 & 2.2 & -0.2 & 0.2 & -1.3 & 1.3 & -0.6 & 0.6 & -3.5 & 3.5 & \\
\hline \multirow{3}{*}{ Uniface } & 1 & 58 & 19 & 113 & 2 & 3 & 1 & 18 & 5 & 45 & 5 & 168 & 22 & 161 & 621 \\
\hline & $1.7 \%$ & $98.3 \%$ & $14.4 \%$ & $85.6 \%$ & $40.0 \%$ & $60.0 \%$ & $5.3 \%$ & $94.7 \%$ & $10.0 \%$ & $90.0 \%$ & $2.9 \%$ & $97.1 \%$ & $12.0 \%$ & $88.0 \%$ & $6.6 \%$ \\
\hline & -3.2 & 3.2 & -1.7 & 1.7 & 0.3 & -0.3 & -2.4 & 2.4 & -2.0 & 2.0 & -3.4 & 3.4 & -3.6 & 3.6 & \\
\hline \multirow{3}{*}{$\begin{array}{c}\text { Raw } \\
\text { Material }\end{array}$} & 46 & 22 & 160 & 83 & 78 & 59 & 65 & 23 & 61 & 21 & 17 & 5 & 97 & 40 & 777 \\
\hline & $67.6 \%$ & $32.4 \%$ & $65.8 \%$ & $34.2 \%$ & $56.9 \%$ & $43.1 \%$ & $73.9 \%$ & $26.1 \%$ & $74.4 \%$ & $25.6 \%$ & $77.3 \%$ & $22.7 \%$ & $70.8 \%$ & $29.2 \%$ & $8.3 \%$ \\
\hline & 11.3 & -11.3 & 18.6 & -18.6 & 8.2 & -8.2 & 9.6 & -9.6 & 12.6 & -12.6 & 10.5 & -10.5 & 13.9 & -13.9 & \\
\hline Column & 227 & 1082 & 588 & 2338 & 98 & 201 & 191 & 442 & 151 & 567 & 148 & 1311 & 469 & 1600 & 9413 \\
\hline Total & $17.3 \%$ & $82.7 \%$ & $20.1 \%$ & $79.9 \%$ & $32.8 \%$ & $67.2 \%$ & $30.2 \%$ & $69.8 \%$ & $21.0 \%$ & $79.0 \%$ & $10.1 \%$ & $89.9 \%$ & $22.7 \%$ & $77.3 \%$ & $100.0 \%$ \\
\hline
\end{tabular}


Table 6-28. Average Maximum Dimensions (cm) of Cores and Raw Materials at Each Site

\begin{tabular}{|c|c|c|c|c|c|c|c|c|c|}
\hline & \multirow{2}{*}{ Attribute } & \multicolumn{8}{|c|}{ Site $41 B X$} \\
\hline & & 1076 & 1088 & 1090 & 1091 & 1102 & 1103 & 1114 & All \\
\hline \multirow{2}{*}{8} & Cores & 7.0 & 7.6 & 7.4 & 7.8 & 7.1 & 7.7 & 8.0 & 7.6 \\
\hline & Raw Material & 8.1 & 6.7 & 5.9 & 6.2 & 5.6 & 6.7 & 6.5 & 6.5 \\
\hline
\end{tabular}

Table 6-29. Average Weights (g) and Maximum Dimensions (cm) of Raw Material at Each Site

\begin{tabular}{|c|c|c|c|c|c|c|c|c|c|}
\hline \multirow{2}{*}{\multicolumn{2}{|c|}{ Attribute }} & \multicolumn{8}{|c|}{ Site $41 B X$} \\
\hline & & 1076 & 1088 & 1090 & 1091 & 1102 & 1103 & 1114 & Total \\
\hline \multirow{2}{*}{$\frac{E}{\frac{0}{60}}$} & Coarse & 251.0 & 217.5 & 109.5 & 211.6 & 91.6 & 192.3 & 103.9 & 167.0 \\
\hline & Fine & 229.6 & 113.5 & 84.4 & 109.5 & 65.0 & 123.4 & 119.7 & 113.6 \\
\hline \multirow{2}{*}{ 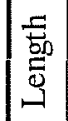 } & Coarse & 8.5 & 7.1 & 6.1 & 6.6 & 5.8 & 7.2 & 6.4 & 6.7 \\
\hline & Fine & 7.7 & 6.1 & 5.6 & 5.4 & 5.2 & 6.6 & 6.7 & 6.1 \\
\hline
\end{tabular}

Table 6-30. Artifact Counts by Site

\begin{tabular}{|c|c|c|c|c|c|c|c|c|c|c|c|}
\hline Site & : & 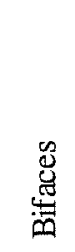 & 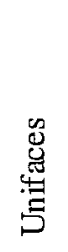 & 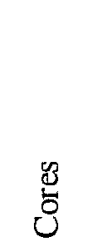 & 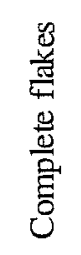 & 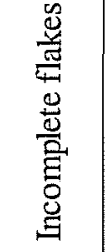 & 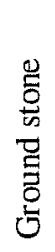 & 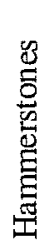 & 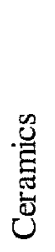 & 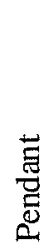 & 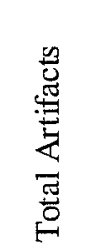 \\
\hline $41 \mathrm{BX} 1070$ & 0 & 0 & 0 & 1 & 1 & 4 & 0 & 0 & 0 & 0 & 5 \\
\hline $41 \mathrm{BX} 1076$ & 2 & 104 & 60 & 221 & 955 & 2874 & 2 & 4 & 0 & 0 & 4222 \\
\hline $41 \mathrm{BX} 1088$ & 17 & 339 & 132 & 1010 & 1708 & 4941 & 1 & 2 & 2 & 1 & 8154 \\
\hline $41 \mathrm{BX} 1090$ & 0 & 10 & 5 & 133 & 75 & 128 & 0 & 1 & 0 & 0 & 352 \\
\hline $41 \mathrm{BX} 1091$ & 2 & 25 & 19 & 409 & 287 & 2101 & 1 & 0 & 0 & 0 & 2844 \\
\hline $41 \mathrm{BX} 1102$ & 12 & 78 & 50 & 149 & 359 & 1394 & 1 & 0 & 0 & 0 & 2043 \\
\hline $41 \mathrm{BX} 1103$ & 11 & 116 & 173 & 51 & 1099 & 5404 & 0 & 1 & 0 & 0 & 6855 \\
\hline $41 \mathrm{BX} 1114$ & 7 & 98 & 183 & 320 & 1332 & 3122 & 0 & 0 & 8 & 0 & 5070 \\
\hline Total & 51 & 770 & 622 & 2294 & 5816 & 19968 & 5 & 8 & 10 & 1 & 29545 \\
\hline
\end{tabular}


Table 6-31. Contingency Table Analysis of Number of Artifacts by Category at Each Site Top value in cell represents artifact count, middle value is row percent, and bottom value represents adjusted residuals. Percent value in total column represents column percent. Significant $(\mathrm{p} \leq 0.05)$ values are shown in bold.

\begin{tabular}{|c|c|c|c|c|}
\hline Site & Cores & Bifaces & $\begin{array}{c}\text { Projectile } \\
\text { Points }\end{array}$ & Unifaces \\
\hline $41 \mathrm{~B} \times 1090$ & $\begin{array}{c}133 \\
89.9 \% \\
\mathbf{7 . 3} \\
\end{array}$ & $\begin{array}{c}10 \\
6.8 \% \\
-4.3 \\
\end{array}$ & $\begin{array}{c}0 \\
0.0 \% \\
-1.5 \\
\end{array}$ & $\begin{array}{c}5 \\
3.4 \% \\
-4.4 \\
\end{array}$ \\
\hline $41 \mathrm{BX} 1091$ & $\begin{array}{c}409 \\
89.9 \% \\
\mathbf{1 3 . 3} \\
\end{array}$ & $\begin{array}{c}25 \\
5.5 \% \\
\mathbf{- 8 . 5} \\
\end{array}$ & $\begin{array}{c}2 \\
0.4 \% \\
-1.8 \\
\end{array}$ & $\begin{array}{c}19 \\
4.2 \% \\
-7.6 \\
\end{array}$ \\
\hline 41BX 1088 & $\begin{array}{c}1010 \\
67.4 \% \\
\mathbf{5 . 7} \\
\end{array}$ & $\begin{array}{c}339 \\
22.6 \% \\
\mathbf{3 . 2} \\
\end{array}$ & $\begin{array}{c}17 \\
1.1 \% \\
-1.0 \\
\end{array}$ & $\begin{array}{r}132 \\
8.8 \% \\
\mathbf{- 1 0 . 5} \\
\end{array}$ \\
\hline $41 \mathrm{BX} 1076$ & $\begin{array}{c}221 \\
57.1 \% \\
-1.8 \\
\end{array}$ & $\begin{array}{c}104 \\
26.9 \% \\
\mathbf{3 . 2} \\
\end{array}$ & $\begin{array}{c}2 \\
0.5 \% \\
-1.5 \\
\end{array}$ & $\begin{array}{c}60 \\
15.5 \% \\
-0.6 \\
\end{array}$ \\
\hline $41 \mathrm{BX} 1114$ & $\begin{array}{c}320 \\
52.6 \% \\
\mathbf{- 4 . 8} \\
\end{array}$ & $\begin{array}{c}98 \\
16.1 \% \\
\mathbf{- 3 . 0} \\
\end{array}$ & $\begin{array}{c}7 \\
1.2 \% \\
-0.5 \\
\end{array}$ & $\begin{array}{c}183 \\
30.1 \% \\
9.7 \\
\end{array}$ \\
\hline $41 \mathrm{BX} 1103$ & $\begin{array}{c}51 \\
14.5 \% \\
\mathbf{- 1 8 . 9} \\
\end{array}$ & $\begin{array}{c}116 \\
33.0 \% \\
\mathbf{6 . 1}\end{array}$ & $\begin{array}{c}11 \\
3.1 \% \\
\mathbf{3 . 0} \\
\end{array}$ & $\begin{array}{c}173 \\
49.3 \% \\
\mathbf{1 7 . 2} \\
\end{array}$ \\
\hline $41 \mathrm{BX} 1102$ & $\begin{array}{c}149 \\
51.6 \% \\
\mathbf{- 3 . 6} \\
\end{array}$ & $\begin{array}{c}78 \\
27.0 \% \\
\mathbf{2 . 8} \\
\end{array}$ & $\begin{array}{c}12 \\
4.2 \% \\
\mathbf{4 . 3} \\
\end{array}$ & $\begin{array}{c}50 \\
17.3 \% \\
0.3 \\
\end{array}$ \\
\hline $\begin{array}{c}\text { Column } \\
\text { Total }\end{array}$ & $\begin{array}{c}2293 \\
61.9 \%\end{array}$ & $\begin{array}{c}770 \\
20.6 \%\end{array}$ & $\begin{array}{c}51 \\
1.4 \%\end{array}$ & $\begin{array}{c}622 \\
16.6 \%\end{array}$ \\
\hline
\end{tabular}

\section{BX1076}

Two components, the Transitional Archaic and the Late Prehistoric, are represented by diagnostic artifacts at $41 \mathrm{BX} 1076$. The site is classified as a turbated palimpsest, similar to $41 \mathrm{BX} 1088$ and $41 \mathrm{BX} 1114$. The landscape evolved either as an eroded Pleistocene terrace or as Pleistocene colluvium from a higher surface. In either case, the site is too old to contain buried deposits in a primary context.

41BX1076 may have a burned rock feature, but its dispersed nature and its geoarchaeological context make a definite determination difficult. There is a concentration of burned rock in one TU on the surface and in the first excavated level.

At an assemblage level, 41BX1076 has a high frequency of bifaces. The debitage has high secondary and low tertiary flakes, high biface manufacturing, notching, and sequence flakes. However, there are no blades at this Transitional Archaic/Late Prehistoric site which lacks Toyah phase artifacts. Cores lack any distinctive patterns other than those noted below in relation to the raw materials. $41 \mathrm{BX} 1076$ has a high number of early stage bifaces and low frequencies of middle and late-stage bifaces, and a high frequency of complete bifaces. When compared to naturally occurring raw materials at the site, debitage present at 41BX1076 
has a high frequency of other (mostly chalcedony) raw materials. A similar comparison of material grain shows that debitage and unifaces made on fine-grained materials occur in greater-than-expected frequencies when compared to naturally occurring raw materials. Unlike all other sites, the naturally occurring raw materials at $41 \mathrm{BX} 1076$ are on average larger than the cores that were recovered from the site.

\section{BX1088}

Four components, the Early Archaic, the Middle Archaic, the Transitional Archaic, and the Late Prehistoric, are represented by diagnostics at $41 \mathrm{BX} 1088$. The Early Archaic diagnostic artifacts are two Guadalupe tools from Area 3. The Middle Archaic is represented by a single Pedernales point recovered from the surface of Area 1. Transitional Archaic and Late Prehistoric diagnostic artifacts are present at Areas 1 and 2. The site is classified as a turbated palimpsest because the geoarchaeological assessment indicates that the soil development is consistent with a Pleistocene age and therefore too old to contain buried deposits in a primary context.

At an assemblage level, 41BX1088 has high frequencies of bifaces and cores, but low frequencies of unifaces. Debitage has high primary and secondary flakes, but low tertiary flakes. In terms of flake types present at the site, there are high frequencies of core/platform preparation flakes and low frequencies of biface thinning and uniface flakes. Single-faceted, double-faceted, and corticate platforms occur in high numbers on the flakes. Cores with a great amount of surface cortex occur in high frequencies, while those with little cortex occur in low numbers. A high number of multidirectional cores is also seen. This is surprising considering the other indicators of early stage lithic reduction. A high number of early stage bifaces and a low number of middle-stage bifaces occur on the site. A large number of these bifaces were made on flakes rather than nodules. Bifaces with cortex occur in expected or higher-than-expected frequencies, but those without cortex are noticeable rare. Raw materials are represent by a low number of agate/ jasper, chalcedony, and quartzite pieces of debitage while the naturally occurring materials have a higher-than-expected number of chalcedony and quartzite pieces. High frequencies of fine-grained debitage and cores are seen, while the natural raw materials has a high frequency of coarse-grained materials. This pattern occurs at most sites. The average size of cores at $41 \mathrm{BX} 1088$ are larger than the average size of raw materials at the site. This is a common pattern at all the remaining sites.

\section{BX1090}

No diagnostic artifacts were recovered at 41BX1090. Because the site is situated on colluvially derived soils dating to the early to middle Holocene, and the artifacts are probably Late Holocene in age, the site is classified as a turbated palimpsest.

At the assemblage level, 41BX1090 has a high number of cores and low frequencies of bifaces and unifaces. Both primary and secondary cortex flakes occur in high frequencies, while tertiary flakes are rare. Associated with these patterns are high frequencies of single-faceted platforms and low frequencies of multifaceted flakes. Core/platform flakes are common and biface manufacturing flakes occur in lower than expected frequencies. Cores at the site with high frequencies of surface cortex are common, and cores with little or no cortex are rare. Bifaces with cortex also occur in greater-than-expected frequencies, but these values are not significant. All the bifaces represent early stage reduction. All artifacts are chert, and other types of raw material were not utilized even though a low frequency of quartzite cobbles does occur at the site. As at other sites, many worked artifacts occur in greater-than-expected frequencies on fine-grained materials.

\section{BX1091}

Two components, the Transitional Archaic and the Late Prehistoric, are represented by diagnostic artifacts at 41BX1091. The soils at the site are colluvially derived Uvalde Gravels dating to the early to middle Holocene. Because the cultural material at the site is Late Holocene, 41BX1091 is classified as a turbated palimpsest. 
The assemblage patterns at 41BX1091 are very similar to those observed at 41BX1090: cores are very common, while bifaces and unifaces occur in lowerthan-expected frequencies. Primary flakes occur in high frequencies, while tertiary flakes are fairly rare. Notching flakes and blades occur in higher-than-expected frequencies even though the actual numbers are not high, but biface manufacturing and thinning flakes occur in low frequencies. Flakes with corticate platforms occur in high frequencies, while flakes with double and multiple facets occur in low frequencies. Cores with more than 50 percent cortex are common and cores with less cortex are not frequent. However, unidirectional cores (indicating very little reduction) are rare and multidirectional cores (suggesting a greater degree of reduction) are common. Most bifaces have low cortex percentages indicating a moderate amount of biface reduction. However, bifaces with no cortex are very rare, suggesting that late-stage biface reduction did not occur or they were removed from the site. At 41BX1091, a large number of bifaces are made on nodules and not flakes. All bifaces are early stage in terms of reduction, and most are complete rather than broken. It appears that the raw materials that were exploited at the site are an accurate representation of the raw materials that were available at the site except for a high number of fine-grained flakes and unifaces. Also the cores are larger than the remaining raw materials.

\section{$41 B \times 1102$}

One temporal component is represented by the nine Pedernales points and preforms at $41 \mathrm{BX} 1102$, although there is apparently a buried component that may predate the Middle Archaic occupation. The geoarchaeological context of the site is classified as a good stratified context because the fine-grained sediments at the site indicate deposition in a flood basin facies by a low-order stream.

41BX1102 is the only site with greater-than-expected numbers of projectile points. Unifaces also occur in greater-than-expected frequencies, but the deviations are not significant. The debitage assemblage is dominated by high frequencies of tertiary flakes and fewerthan-expected numbers of primary and secondary flakes. Biface manufacturing flakes occur in greaterthan-expected frequencies, but surprisingly biface thinning flakes are rare. While cores are the most frequent non-debitage artifact type, most of these have little or no cortex and those with high frequencies of cortex are rare. There is a high average number of flake scars per core, which suggests a fair amount of core reduction at the site. Bifaces without cortex occur in high numbers while those with cortex occur in low frequencies. Early stage bifaces are rare, while middle-stage bifaces are most frequent; few, however, are complete. Utilized and un-utilized show an emphasis on the use and occurrence of cherts, however the naturally occurring raw materials show more coarse-grained cherts than the modified artifacts or the lithic debitage.

\section{BX1103}

Three components are present at 41BX1103, represented by Middle Archaic, Late Archaic, and Transitional Archaic diagnostic artifacts. Although the site is classified as a redeposited context because the Unit III sediments were deposited by a low-order stream subjected to high-magnitude floods, the movement of materials has been minimal. The site approximates a good geoarchaeological context and appears to have stratified components.

At the assemblage level, $41 \mathrm{BX} 1103$ has low frequencies of cores and high frequencies of projectile points, bifaces, and unifaces. Tertiary flakes occur in high frequencies, and primary and secondary flakes are rare. Most flakes are biface thinning flakes, blades, and uniface flakes, while core/platform preparation flakes are rare. This supports an interpretation of late-stage biface production activities and a lack of early stage lithic reduction at this site. Most flakes have multiplefaceted platforms, and few have cortex platforms. While cores are not common, most of these have little or no cortex, and those with high frequencies of cortex are rare. $41 \mathrm{BX} 1103$ cores have the highest average number of flake scars per core and the lowest number of unidirectional cores of any site, suggesting a high degree of core reduction at the site despite the fact that cores are not common. The unexpectedly low number of cores at the site is important considering the problematic nature of the site's geomorphological 
setting. If stream transportation of raw materials was a major factor in the formation of the modified artifact assemblage at 41BX1103, a much higher number of cores would be expected than occurs at the site.

Another attribute of the artifact assemblage from 41BX1103 that supports the conclusion that the assemblage has not been altered by stream transportation is the distribution of tertiary flakes by excavated level (Figure 6-4). In a setting where archaeological materials were being deposited on a gravel bar and then subjected to high velocity flooding, it is expected that the smaller flakes would either be transported by the water away from the site or worked downward into the gravels. This would result in a pattern where the proportion of smaller flakes would be lower in the upper levels of the deposit and higher in the lower levels. The distribution of tertiary flakes by excavated level at 41BX1103, however, does not reflect this pattern. The number of flakes with a maximum dimension of $1 \mathrm{~cm}$ is probably biased by the use of $1 / 4$ inch screens, but the frequency of flakes with a maximum dimension of $2 \mathrm{~cm}$ remains high in levels 1 through 8 .
This consistency in frequency is a pattern expected of a site in good geologic context.

Bifaces are characterized by high frequencies without cortex and low numbers with cortex. There are high numbers of middle-stage bifaces, and low numbers of early stage bifaces. Many of these bifaces are broken. Naturally occurring raw materials and utilized materials show an emphasis on cherts, while the graininess demonstrates a selection for fine-grained materials in all artifact classes. Again cores are larger than the naturally occurring materials suggesting selection based on size.

\section{BX1114}

Two components are clearly represented by Transitional Archaic and Late Prehistoric diagnostic artifacts at 41BX1114, and a third, the Early Archaic, is indicated by a possible Guadalupe biface. The site is an excellent example of a turbated palimpsest. The decalcified soils, which were developed from calcare-

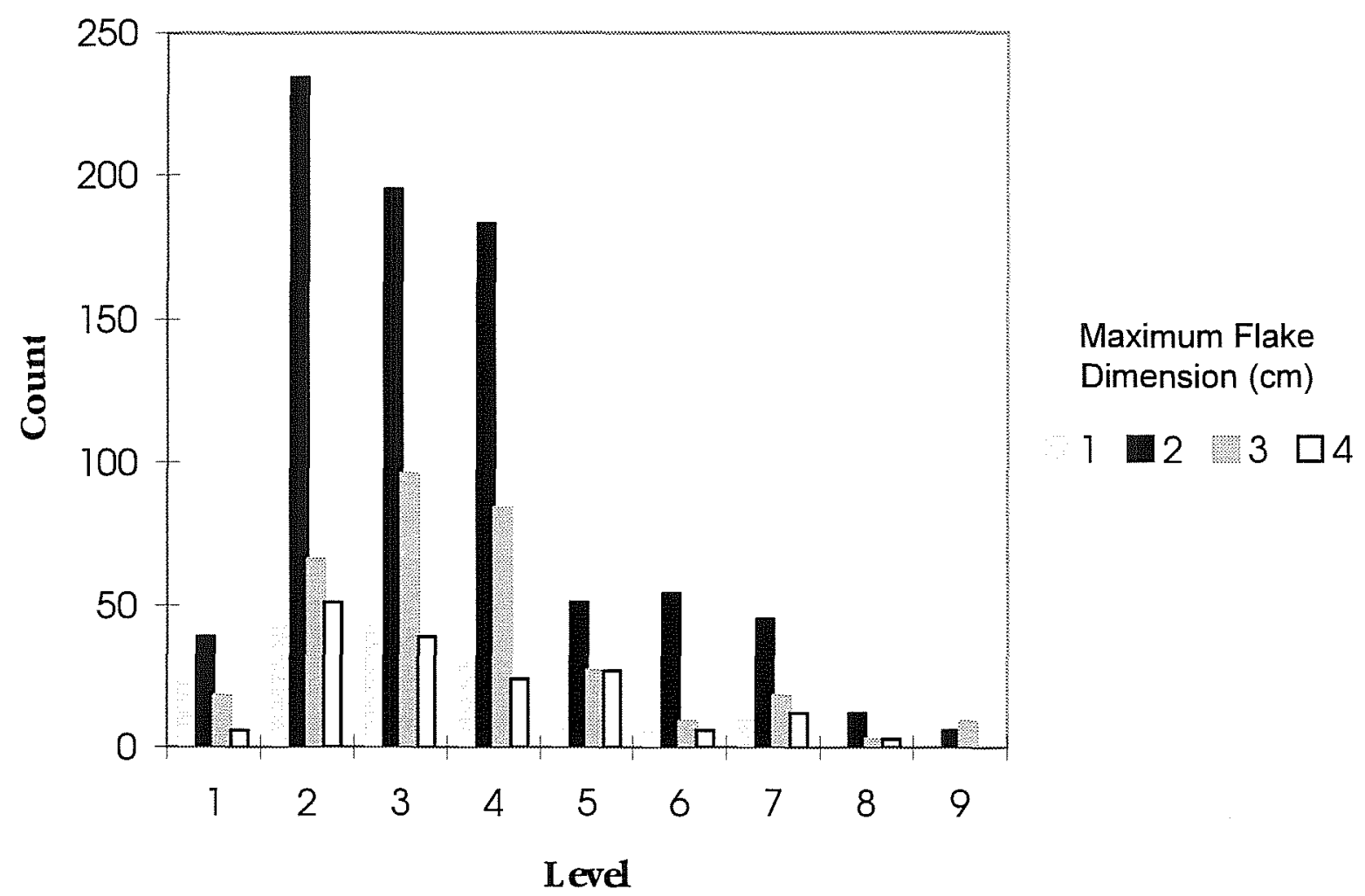

Figure 6-4. Distribution of tertiary flakes by excavated level at $41 B X 1103$. 
ous parent material, take tens of thousands of years to form, and cannot contain buried cultural material in a primary context.

The 41BX1114 assemblage shows an emphasis on unifaces while cores and bifaces occur in low numbers. Debitage cortex indicates that tertiary flakes occur in lower-than-expected numbers. Biface manufacturing, biface thinning, uniface, and notching flakes all occur in low numbers, while core/platform preparation flakes occur in high numbers. Also flakes with cortex platforms occur in high numbers. Cores with some cortex but less than 50 percent occur in high numbers, but cores without cortex are infrequent. There are high numbers of unidirectional and bidirectional cores, but low numbers of multidirectional cores. These patterns suggest the presence of early stage core reduction. Bifaces with high frequencies of cortex also occur in greater-than-expected frequencies. There is also a somewhat high number of late-stage bifaces, although most bifaces are early stage. Most of the broken bifaces appear to have broken during manufacture. Only chert raw materials were discovered as naturally occurring lithic materials at the site, but non-chert flakes, cores, and unifaces were present. This could indicate that lithic materials were transported to the site. In terms of raw material texture, the frequencies of artifacts, debitage and naturally occurring materials strongly suggests the intensive selection for fine-grained materials. This is a consistent pattern that occurs at all sites.

\section{Intersite Patterns}

When individual attributes for different artifact categories are compared, a pattern of upland versus floodplain sites develops. This pattern is maintained when the amounts of different artifact types from each site are compared to one another, but somewhat unexpectedly there is a marked amount of variation within the upland site category. Two sites, 41BX1090 and 41BX1091 most closely resemble the pretesting expectations for upland sites. They have high numbers of cores, and low numbers of bifaces and unifaces. The other upland sites, excluding 41BX1070 from which there is too little data to draw valid comparisons, apparently were either multipurpose sites or their function changed through time. 41BX1088 closely resembles $41 \mathrm{BX} 1090$ and $41 \mathrm{BX} 1091$ except that the unexpectedly high frequency of bifaces is indicative of different types of lithic reduction. Furthermore, the analysis of the $41 \mathrm{BX} 1088$ data obscures the variation within the site. It is likely that Area 1, where Late Prehistoric ceramics were recovered, was used as a campsite as well as a lithic procurement station. 41BX 1076 also has a high frequency of bifaces, but does not follow the upland pattern of high core and low uniface counts. The burned rock present in large quantities on the surface of the site, combined with the deviation from the general upland assemblage pattern, suggests that $41 \mathrm{BX} 1076$ was used as an occupation site. The most deviant upland site is $41 \mathrm{BX} 1114$. It has comparatively low numbers of cores and bifaces, and high numbers of unifaces. It shares characteristics with the upland sites of 41BX1090 and 41BX1091 and the floodplain sites of 41BX1102 and 41BX1103, discussed below. As in Area 1 at 41BX1088, ceramics were recovered from the topographic high point of the site, and it is probable that $41 \mathrm{BX} 1114$ was another upland campsite.

The two floodplain sites both have low numbers of cores, and high numbers of bifaces and projectile points. 41BX1103 also has a high frequency of unifaces. This pattern is believed to reflect more consistent and intensive use of these sites as camps. The type of reduction taking place at each site was middleto late-stage biface and core reduction. Other evidence of camping related activities is present at $41 \mathrm{BX} 1103$ in the faunal material and the large quantity of burned rock.

The data above largely confirm the pretesting assumptions that upland sites included a strong lithic procurement component and that floodplain sites were primarily occupation zones. Lithic procurement, however, also took place, although to a lesser degree, at the floodplain sites as demonstrated by the artifact assemblages, specifically the debitage and cores. This conclusion is indirectly supported by the projectile point data. For both arrow points and dart points, the most frequent type of break was use/resharpening, indicating that projectile point manufacture was not an important activity. Only 2 of the 45 ( 4.4 percent) broken projectile points were clearly broken during manufacture, while $26(57.8 \%)$ were broken during use or resharpening. 
The variation within the upland site category, reflected in the contingency tables presented above dispels the assumption that these sites are homogenous. Furthermore, because the upland sites have all been subjected to essentially the same types of disturbances, particularly with respect to natural forces such as bioturbation and erosion, differential preservation is not indicated as a potential cause of the variation in artifact inventories among upland sites. The variable presence of projectile points, ceramics, burned rock, and evidence for the specialized split-cobble reduction at the upland sites is testimony to the richness of these site types. Additionally, the data indicate that important variations exist spatially in the artifact assemblages within the same site. This is most clearly evidenced at 41BX1088 (Area A versus Area C) and 41BX1114 (north versus south collection area).

\section{Research Issues}

The archaeological testing at Medina Annex has resulted in the identification of several research issues that may provide the basis for the development of historical contexts for Lackland AFB and the surrounding area. In the short term, these research issues act as criteria by which to judge the significance of the tested sites with respect to their eligibility for NRHP designation. Two of these issues are based directly on the results of the testing project, but may be applicable to the surrounding region as well. They are shifts in settlement patterns and patterns of lithic technological organization. The other two-chronology and subsistence - are major gaps in the regional database for south and central Texas (Collins 1995; Hester 1995).

\section{Research Issue 1: Chronology}

Despite decades of research in the Bexar County area, the local cultural chronology remains problematic. Black (1989c) identified chronology as one of the major problems in the South Texas archaeological subregion nearly a decade ago. Since that time, some advances have been made, but major spans of the region's cultural chronology remains poorly defined. Hester (1995:433), in a recent synthesis of south Texas prehistory, notes that the chronology of the area "remains poorly understood" and that researchers still rely on the chronological divisions established by Black (1989c) and Hall et al. (1986) almost a decade ago.

A large problem with refining the chronology of the area is the nature of archaeological record in the region (Black 1989c; Hester 1995). South Texas sites are often surface sites; preservation of organic remains is usually poor; there are few well excavated sites in the region; and "surface mining of all potentially diagnostic lithics by collectors" has stripped many sites of their temporal association (Black 1989c:57). To resolve this issue, Black (1989c) and Hester (1995) state that careful excavation of buried, stratified sites is needed. This is a strategy that can also produce data relevant to the other research issues discussed below. The larger number of excavated and reported stratified sites in central Texas is the primary reason that culture chronology in that area is better defined (Collins 1995).

Even though over the past forty years central Texas archaeology has concentrated primarily on establishing and fine-tuning chronologies, more can be accomplished. In some cases radiocarbon dated material is simply too meager, or not available at all. Therefore we need to think not only in terms of accelerator mass spectrometry dating methods but also other techniques which rely heavily on geological principles (Collins 1995:371).

Chronological understanding in south Texas is still poor, so proposed chronologies should not be accepted without serious scrutiny. The lack of adequate excavations have forced archaeologists to speculate on period occupations based on surface finds and these speculations can easily be in error (see Kelly 1992 versus Collins and Headrick 1992). The problem has been exasperated not only by the geomorphology of the region but also by the activities of avid relic collectors (Black 1995:35, 41). For example, even though they are the most predominant type site in south Texas, establishing temporal affiliations for open occupation sites in south Texas is extremely difficult. Open campsites are most often lying on the surface, representing surface palimpsests, lag palimpsests, and good sur- 
face contexts, and therefore subjected to erosion and intense collection by relic hunters. Projectile points and other diagnostic artifacts are the most attractive and have been collected for years. The collection effort has increased in recent years as a pastime, sport, and for some, a source of income (Hester 1995:429).

Hester (1995:433) acknowledges that the cultural chronology explanation for south Texas is riddled with more questions than answers. While central Texas's chronological record has benefitted from the investigations of a large number of well-stratified sites with many radiocarbon dates, strides in establishing a solid south Texas chronology are hampered by the relative dearth of well-stratified intact sites, and by the lack of intensive excavations at the few good sites that have been discovered (Hester 1995:433).

\section{Pre-Clovis}

A significant gap in the central Texas record that precludes us from identifying pre-Clovis culture is that we don't know what encompasses a pre-Clovis signature. For an acceptable identification of a site of this time period we need to find a site in good geological and archaeological contexts with a radiocarbon-dated intact component stratigraphically underlying Clovis (Collins 1995:381). Sites of this nature have not been found in Texas, much less south Texas.

\section{Paleoindian}

Until we excavate more Paleoindian sites there's very little we can say about their lifeways (Black 1995:42). The presence of isolated Clovis and Folsom points in south Texas suggests occupation of the region during that period, however there is no record of an Early Paleoindian occupation site; Pavo Real (Henderson and Goode 1991) in northwest Bexar County appears to be the only excavated Early Paleoindian site in the region. Only the excavation of an intact Clovis or Folsom kill or camp site can fill this knowledge gap (Hester 1995:434). The Late Paleoindian period in south and central Texas seems to represent a distinct cultural division from the Early Paleoindian occupations. In central Texas ongoing studies at the Wilson-
Leonard site comparing Early and Late Paleoindian cultural materials should help clarify subsistence, technological and settlement patterns between these two Paleoindian periods (Collins 1997). Unfortunately, no site in south Texas provides an avenue for comparison between Early and Late Paleoindian occupations, and little is known in this region besides the data provided by surface finds.

\section{Archaic}

The Archaic is seen as a cultural continuum marked by changes in how humans adapted to the changing climate and landscape. Although we have defined those changes by Early, Middle, and Late periods, we do not fully understand the significance of nor the behavior patterns represented by those changes. Further study is needed on the abruptness or subtlety of changes in cultural material in relation to climatic shifts (Collins 1995:383).

\section{Early Archaic}

Occupations in the Early Archaic are not represented in the archaeological record of south Texas. Also little is known about this period in the immediate region. However, pollen evidence from central Texas (Collins and Bousman 1990; Bousman 1994), and phytolith evidence from south Texas and the coastal plains (Robinson 1979 and 1982) suggest that this was a period of dramatic changes in climate and vegetation. The consistent occurrence of Early Archaic diagnostic artifacts at Lackland AFB suggests a consistent use of Lackland during this period. However, considering the nature of the diagnostic Early Archaic tools (primarily wood working tools such as Clear Fork gouges and Guadalupe bifaces) the use of the Lackland AFB may have been limited to special tasks. Nevertheless, the temporal ages of these diagnostic tools is very poorly documented even though nearby investigations have shown that Early Archaic occupations occur with surprising density in the floodplains of large streams such as Leon Creek (Tennis 1996; Tennis and Hard 1995). Still we know little about when these tools were manufactured, how these peoples 
organized themselves, what they ate, and how large of an area they exploited.

\section{Middle Archaic}

More evidence is needed to confirm the time span during which Tortugas points were used in south Texas. Although Tortugas were commonly found at Loma Sandia, providing the evidence that they were used during the south Texas late Middle Archaic, their temporal span may also surround that period (Hester 1995a:xviii). The 3,000-year span of the south Texas Middle Archaic can at present only be defined in broad general ways. Within the Middle Archaic the chronological use of Pedernales, Kinney, Langtry, and Morhiss is unclear. Point types generally accepted as fitting into the Middle Archaic period most probably overlap with surrounding periods. For example, Bulverde points may fit as well into the Early Archaic, while Castroville and Lange are likely part of the Late Archaic assemblages. The oft misinterpreted Middle Archaic Tortugas point may in fact been used as a knife throughout the whole Archaic. The considerable confusion that surrounds point types synergistically distorts our current perspective on Middle Archaic site quantity and distribution. (Black 1995:43).

\section{Late Archaic}

Although many Late Archaic sites have been dug in central Texas, the Late Archaic Bulverde interval requires solid information that can only be retrieved from newly reported or newly examined sites with intact stratification (Collins 1995:384).

As noted by Johnson and Goode (1994) the archaeological signature representing the Late Archaic appears as a veritable "melting pot" (our term) of cultures. The reasons for this may be a rapidly expanding population (Prewitt 1981; Weir 1976) influenced by eastern North America religious practices (cf. Collins 1995:384-385). Research into these issues creates a continuum of unanswered questions which may best be addressed through pristine site investigations.
The south Texas Late Archaic is better understood than earlier periods because more sites have been excavated and documented for study. Heat-treating chert for easier knapping appears to be common at south Texas sites (Hester 1995:441), but does this practice extend into central Texas where quality fine-grained cherts are found in greater abundance?

Olmos bifaces (gouges?) are associated with Late Archaic sites in south Texas. However, there remains a question as to whether their usage represents a continuum into the Late Prehistoric (Hester 1995:441).

It is unclear what diagnostic artifacts mark the end of the Late Archaic and the beginning of the Late Prehistoric. Hester (1995:442) suggests that after further research we may consider a "terminal Archaic" period during which later Late Archaic points such as Ensor, Frio, Catan, and Matamoros are manifest.

Edwards chert has been found far south of the plateau, but to what extent trade goods were exchanged during the south Texas Late Archaic is unknown (cf. Hester 1995:442).

\section{Late Prehistoric}

The Austin and Toyah horizons of the central Texas Late Prehistoric are fairly well defined, but some issues still need to be addressed. Pottery seems to have come relatively late and agriculture perhaps not at all to the region. Is it because the region was such so lucratively plush with edible plants and animals and fresh water that there was no need for ceramic utilitarian vessels or crops? The temporal spread of pottery technology across south Texas has not been fully assessed (Collins 1995:385-386). Whether the introduction of pottery is associated with Toyah, or is an earlier introduction is an unresolved issue (Hester 1995:443). Fueling research into these issues is the stimulating debate over whether Toyah represents a distinct group (Johnson 1994b) or a spreading technology (Ricklis 1994; cf. Collins 1995: 385-386).

Although the later Toyah horizon of the south Texas Late Prehistoric period is fairly well defined and consistent with central Texas Toyah, dart points such as 
"Ensor, Matamoros, Catan, and Zavala" associated with the later portion of the Late Archaic are found with Late Prehistoric components. The question remains as to whether these points were dart or arrow points, and whether or not they were simply made by earlier groups, to be picked up by later groups and reworked (Hester 1995:443).

The Scallorn and Edwards points that so clearly mark the Austin interval in central Texas are also prevalent in south Texas. However, at this time we are not sure that the two represent comparable cultures because there are no sites thus far investigated in south Texas which clearly manifest Austin interval traits in association with Scallorn and Edwards points. On the contrary, Hall et al. (1986) notes their presence in later radiocarbon dated context at Choke Canyon, while Hester (1995:443) has documented them in association with the later Perdiz point in Zavala County. In addition, Toyah points found in the Starr and Webb counties area deserve a cultural context study (Hester 1995:444).

The broad subject of cultural interaction has equally gross room for study. Exactly what central Texas Toyah traits were adopted or carried into south Texas is unclear, as are the Brownsville complex group traits that may have influenced south Texas culture along the lower Rio Grande. The presence of obsidian, and jade and shell beads in south Texas suggests a Huastecan connection with Mesoamerica during the Late Prehistoric period, but excavated evidence is needed (Hester 1995:446-447).

Whether the Toyah occupations observed in the south Texas Late Prehistoric archaeological record results from population movement or cultural diffusion will never be understood until we determine its origin in either central or north(east) Texas. At the present time, a lack of distinct evidence supporting rapid technological changes in the artifact assemblages supports neither argument. The Toyah issue is further exacerbated by the general lack of site stratification (Black 1995:45).

\section{Protohistoric}

The south Texas Protohistoric is plagued with questions about the effect that European contact and the mission period had upon Native Americans. One issue concerns the movement of bone tempered pottery through south Texas where it is commonly referred to in earlier periods as Leon Plain, but once it is identified in a mission setting it is referred to as Goliad ware; Is it not the same technology? Another mystery that begs further study is why bone-tempered pottery appears early in the archaeological record at Chaparrosa Ranch but by the time the Guerrero missions are established it is not present in either the Ranch sites or the mission sites (Hester 1995:450). Other questions still unanswered for the Protohistoric period are the nature of interaction and movement between mission and non-mission Native Americans and the organization of Native American populations at early missions.

\section{Research Issue 2: Subsistence}

Although Late Pleistocene fauna and lithic artifacts were found in geological association at Berclair Terrace (Sellards 1940), no conclusive evidence exists that Clovis period groups hunted mammoth in south Texas. This hunting adaptation seems likely but only the excavation of an intact mammoth kill site can fill this gap (Hester 1995:434). In addition Folsom subsistence patterns and site types are poorly understood. Although it appears they were bison hunters, "camps, stone-working, and kill sites are all that have been documented, mostly in or near grassland habitats" (Collins 1995:382). At Berger Bluff, hearths contemporary with Folsom occupations elsewhere are associated with a varied fauna that consists entirely of small fauna and microfauna, suggesting collection rather than hunting as the primary subsistence strategy (Brown 1995).

Information on subsistence patterns during the Archaic is limited. Additional data is needed to supplement the sparsely available evidence for deer, fish, small animals, and plant bulbs present in Early Archaic components (Collins 1995:383). The extent to which Middle Archaic hunter-gatherers shifted their subsis- 
tence efforts to coincide with bison seasonal rounds and to exploit other flora and fauna during the Middle Archaic is largely unknown (Collins 1995:384). As with the earlier culturally defined time periods for south Texas, the Middle Archaic sites do not provide well preserved fauna. Until we are fortunate enough to find and carefully excavate a site that allows for a finite fauna analysis, the issue of subsistence during the Middle Archaic will be poorly known (Hester 1995:439).

Although it appears the diet of central Texas' Late Archaic groups consisted mainly of carbohydrates and was therefore less healthy, further analysis of available skeletal remains may shed needed light on the issue (Johnson and Goode 1994:34). Subsistence issues in the south Texas Late Archaic need to address the use of grinding stones and mortars. What were they grinding or pounding - mesquite or acacia beans, or something else? No conclusive evidence for the use of grinding stones has been found (Hester 1995:441). Also no strong evidence exists which can confirm bison hunting activities during the late subperiod of the Late Archaic period on the eastern Edwards Plateau of central Texas. If prehistoric hunters were pursuing buffalo, we should find more Marcos points at kill sites (Johnson and Goode 1994:36).

The conspicuous absence of evidence for farming in central Texas during the Late Archaic and Late Prehistoric periods does not necessarily mean that it did not happen. We may have unable to detect the evidence as yet (Johnson and Goode 1994:41).

Potter et al. (1995) identified prehistoric human adaptation and subsistence as a historic context for sites along the Wurzbach Parkway in north San Antonio. They were concerned about the "interactive relationship between human groups and the physical environment they occupied", including seasonality of occupation and exploitation of resources (Potter et al. 1995:48). Certain site types have higher potential to contribute information to this issue than others. Specifically, sites with good geological context, isolable components, and good faunal or organic preservation have the greatest potential for contributing significantly to the subsistence question (Potter et al. 1995).

\section{Research Issue 3: Patterns of Lithic Technological Organization}

\section{Raw Material Availability and Exploitation}

The disparity between the predominant artifact material and the raw material at the sites at Lackland is enigmatic. In every case there is clear difference in the overall quality of raw material available at each site and the material used for artifacts. The concordance of raw material qualities among the tools and the debitage suggests that the later are the by-products from manufacturing the former. In addition, there is no evidence in the debitage collections indicating that tools and/or cores were brought to the Lackland sites in a partially or fully decorticate form.

Given these observations, how can the discrepancies in raw material quality be explained? At least four hypotheses can be postulated to explain the difference. First, the prehistoric groups in the area were able to assess with some degree of accuracy the nature of the raw material texture without testing the cobble. For this to be possible, there would have to be a visual and/or tactile difference between coarse and finegrained chert nodules, one that was not noted or selected for examination during the analysis of raw material. Second, the larger raw material at the site was of finer grain and was therefore selected first and exhausted, explaining why the average core size is larger than the average raw material size. In the current sample, however, this is not the case. A third hypothesis is that the artifacts encountered at the eight investigated sites, including the cores, were imported from another location. The previous analysis of tertiary flake percentages within small and large debitage has established that the debitage collections represent primarily the early stages of reduction. There is no evidence supporting the hypothesis that finegrained materials were brought into and further reduced at the tested sites. Fourth, the raw material to be tested was first heat treated; thereby modifying the grain size. However, no evidence was observed to suggest that heat treating took place at any of the sites under investigation.

Given the obvious differences between the quality of the raw material currently available at each site and 
the quality of the core and debitage material. An important consideration related to the above data is that tested cobbles, those with one or two flakes removed, were counted as cores. Therefore, the low frequency of coarse-grained raw material includes pieces which were tested and, for whatever reason, rejected. This is significant because it suggests that the original selection process largely excluded coarse-grained raw material before it was tested. This inference supports the hypothesis that the prehistoric groups exploiting the raw material at Lackland were able to assess raw material quality based on exterior features of the parent rock or that the larger material was generally of higher quality. In either case, one conclusion that can be drawn from the data is that the supply of fine-grained chert at the Medina Annex sites was largely exhausted by the prehistoric peoples in the area. It is unlikely, given transportation costs associated with carrying heavy cores, that the majority of the artifacts is composed of imported chert, although this hypothesis should be tested by future research projects in the area.

The observations about raw material quality raise important questions about the methods by which raw materials were chosen for reduction and the intensity of raw material exploitation at the sites in question. The raw material study suggests that either the frequency of fine-grained chert was small before human groups began exploiting it, or that the supply of finegrained chert had been tremendously reduced by human activities. The following questions are proposed avenues of investigation related to this issue:

1. Does the dramatic difference in quality between the unmodified cobbles at a site and the artifacts present at the same site indicate that the artifacts are largely or partially imported?

2. Alternatively, is the low ratio of fine-grained chert to coarse-grained chert in the currently available raw material the result of the exhaustion of the finegrained raw material at these upland sites by the prehistoric populations or a reflection of the natural composition of the parent Uvalde gravels in the area?

3. Is it possible to determine the criteria used by prehistoric groups to select fine-grained raw material based solely on exterior visual and tactile characteristics?

\section{Reduction Strategies}

Results of the analyses of debitage collections and artifact assemblages suggest that the most strongly represented behavior at each of the eight sites is lithic raw material procurement and the manner in which these behaviors are played out on the landscape. The numerous cores and bifaces recovered from all of the Lackland sites suggest that raw material procurement focused on the production of flake blanks and bifacial "quarry blanks". Flake blank production may have been particularly important at 41BX1090, 41BX1091, 41BX1088, and 41BX1114. On the other hand, the production of bifacial "quarry blanks" appears to have been the primary activity at $41 \mathrm{BX} 1102$ and $41 \mathrm{BX} 1103$.

The production of flake blanks from the unidirectional and/or multidirectional reduction of cores is a relatively expedient technique that can be easily embedded within the context of subsistence-related activities. For instance, daily hunting trips which result in the traverse of large portions of the landscape in search of prey provide ideal contexts for the acquisition of raw material when suitable outcrops are encountered. Such acquisition stops may even result in the discard of diagnostic artifacts when use-broken artifacts need to be replaced immediately. The manufacture of small numbers of bifacial "quarry blanks" may also occur particularly if time constraints and transportation costs are not sever enough to encourage the making of latestage bifaces. It is likely that, with the exception of artifacts in Area 1 at 41BX1088, most of the Late Prehistoric arrow points recovered from these sites were discarded within the context of embedded lithic procurement.

The acquisition of raw material in the form of bifacial blanks is initially somewhat more time consuming than flake blank production and may indicate lengthier stays at procurement localities. The discard of use-broken projectile points and the use of large numbers of expedient and minimally retouched unifaces also may be indicative of longer site visits. If this inference is correct, it may indicate that sites such as $41 \mathrm{BX} 1076$, 
Area 1 at 41BX1088, and 41BX1114 were briefly occupied for the expressed purpose of replenishing a depleted tool kit consisting of a variety of functional types. Such site visits would involve overnight stays but raw material procurement sites are expected to have been utilized primarily during transit between more productive resource patches. The recovery of Leon Plain sherds in Area 1 at 41BX1088 and at 41BX1114 indicate lengthier on-site stays implied by the ceramic vessel fragments.

Somewhat longer occupation spans may be expected at raw material outcrops found in the vicinity of settings providing a variety of edible resources (e.g., terrace gravels, valley margins). Site $41 \mathrm{BX} 1102$ and $41 B X 1103$ may represent the remains of raw material procurement within this type of procurement strategy. The difference between these two sites and 41BX1076 and $41 \mathrm{BX} 1088$ is the longer stay at the terrace sites. The longer reduction sequences and the greater variety of artifacts may be primarily due to the more favorable combination of edible foods, surface water, and lithic resources compared to upland settings.

The identification of intensive split cobble lithic reduction at 41BX1091 and limited utilization of this technique at other upland sites with Transitional Archaic and/or Late Prehistoric assemblages suggests that procurement and reduction strategies may have changed through time. The development (or adoption) of this technology, particularly if it is a temporally sensitive trait, may have important implications for subsistence related issues as well in that the intended tools may have been used to process a specific resource.

Although logistical raw material procurement was initially also considered as a likely strategy employed at Lackland sites, no archaeological evidence in support of this strategy was encountered. The patterns of lithic technological organization encountered at these Lackland sites lead to a number of research questions and avenues of future archaeological investigations:

1. Are there lithic procurement localities at Lackland AFB that exemplify a logistically organized raw material procurement system?
2. Do flake blank and "bifacial quarry blank" procurement strategies represent complementary systems as interpreted in this report or do they represent changing strategies through time?

3 . Is the split cobble reduction technique a temporally sensitive technological trait dating to the Transitional Archaic and/or the Late Prehistoric, and what were the intended end products of this technology?

4. How did the exploitation of the upland raw material sources change through time in terms of intensity and reduction strategies?

\section{Research Issue 4: Settlement Patterns}

In order for a site to provide information about how prehistoric groups utilized the landscape, it must contain chronological and functional components in addition to a spatial context. The survey level investigations located numerous sites with diagnostic artifacts, and the testing investigations have provided additional data related to the number and intensity of occupations at several of those sites. Settlement patterns reflect changes or continuity in land-use, population movements, and resource exploitation.

The survey of Medina Annex found that Early and Middle Archaic diagnostic projectile points were more common in terrace settings, while Late and Transitional Archaic diagnostic projectile points occurred slightly more frequently in the uplands (Nickels et al. 1997). This pattern is not due to a geological preservation bias (Nordt, Chapter 4 this volume). The Late Prehistoric sample from the survey is composed of only three arrow points and is therefore not a statistically reliable data set. Of these three, one was from the T1 terrace of Medio Creek, one was from Long Hollow, and the final was from 41BX1076 in the Uplands (Nickels et al. 1997).

The testing investigations at $41 \mathrm{BX} 1102$ and 41BX1103 recovered Middle to Transitional Archaic diagnostics. Neither site contained Late Prehistoric materials, thereby conforming to the pattern noted during the survey project. 


\section{Transitional Archaic and Late Prehistoric Pattern}

An unexpected pattern, the occurrence of Transitional Archaic and Late Prehistoric diagnostic artifacts at upland sites (Table 6-32), emerged from the testing at Medina Annex. In the case of 41BX1076 and 41BX1091, the only diagnostic artifacts were from the Transitional Archaic and Late Prehistoric periods. At 41BX1088 and 41BX1114 other components were represented in the assemblage, though by few artifacts.

These sites are similar to one another in topographic setting: all except 41BX1091 are located on prominent hill tops. At the other three, the densest artifact concentrations and the majority of diagnostic artifacts were located at the highest elevation on the hill. These sites are therefore very similar to one another in terms of artifact assemblage and physical setting. Also, the Late Prehistoric vegetation in this area probably consisted of open grasslands and not heavy brush, thus the hilltop locations may have offered good visibility.

As previously noted, 41BX1076, 41BX1088 Area 1, and the north area of 41BX1114 occupy topographic high points which overlook the Medio Creek flood basin. The fourth site, 41BX1091, is located on a level spot on the $41 \mathrm{BX} 1088$ hill slope, only $200 \mathrm{~m}$ northwest of Area 1. The distances from these sites to Medio Creek and its terraces vary, but in no case are greater than $520 \mathrm{~m}$ (Table 6-33). Today these sites are covered in dense woody thorn scrub growth, but precontact vegetation was different (see Chapter 3). The descriptions of the area suggest that in the uplands mesquite and thorny scrub vegetation were in scattered mottes and grasslands predominated. Thus it is likely that the creek channels and floodplains of the region would have been wooded, the uplands would have been covered in prairie grasses with oaks, mesquite and white thorn forming occasional thickets (Hatch et al. 1990:13). No local paleoenvironmental data provide evidence for vegetation patterns between 2250 and 350 B.P., but a grassland/scrub grassland mosaic is most likely.

The testing data suggest that while lithic procurement and testing was a major activity at each of these sites, other activities were taking place at these hill top locations as well. Burned rock, projectile points, middleand late-stage bifaces, formal unifaces, and ground stone are indicative of multiple activities reflecting intensive use of the locations as campsites as well as lithic procurement stations.

This pattern, which apparently indicates a dramatic increase in the intensity of use and/or occupation of hill top locations, may be related to an increase in the regional population and/or a change in land use and settlement pattern practices during the Transitional Archaic and Late Prehistoric periods. There are conflicting opinions about the population of the area dur-

Table 6-32. Diagnostic Artifacts from Upland Sites at Medina Annex

\begin{tabular}{|c|c|c|c|c|c|}
\hline \multirow{2}{*}{ Site } & \multirow{2}{*}{$\begin{array}{c}\text { Late } \\
\text { Prehistoric }\end{array}$} & \multirow{2}{*}{$\begin{array}{c}\text { Transitional } \\
\text { Archaic }\end{array}$} & \multicolumn{3}{|c|}{ Archaic } \\
\hline & & & Late & Middle & Early \\
\hline $41 B \times 1076$ & $\begin{array}{l}\text { Scallorn (1) } \\
\text { Scallorn }(1)^{*}\end{array}$ & F airland (1) & None & & \\
\hline $41 \mathrm{BX} 1088$ & $\begin{array}{l}\text { Leon Plain sherds (2) } \\
\text { Perdiz (1) } \\
\text { Perdiz preforms (2) } \\
\text { Edwards (1) } \\
\text { Scallorn (2) }\end{array}$ & $\begin{array}{l}\text { Fairland (2) } \\
\text { Frio (2) } \\
\text { Ensor (1) } \\
\text { Darl (1) }\end{array}$ & Lange $(1)^{*}$ & $\begin{array}{l}\text { Pedernales }(1) \\
\text { Pedernales }(1)^{*}\end{array}$ & Guadalupe tools $(2)^{*}$ \\
\hline $41 \mathrm{BX} 1091$ & Scallorn (1) & Fairland (1) & None & & \\
\hline $41 \mathrm{BX} 1114$ & $\begin{array}{l}\text { Leon Plain sherds ( } 8 \text { ) } \\
\text { Scallorn-Brangus (1) }\end{array}$ & $\begin{array}{l}\text { Fairland (2) } \\
\text { Ensor (1) }\end{array}$ & & & $\begin{array}{l}\text { Clear Fork Biface }(1)^{*} \\
\text { Possible Guadalupe tool }\end{array}$ \\
\hline $\begin{array}{c}\text { Total } \\
\text { Diagnostics }\end{array}$ & 20 including 10 sherds & 11 & 1 & 2 & 4 \\
\hline
\end{tabular}

* Recovered during the survey project (Nickels et al. 1997) 
Table 6-33. Distance to Creek Terraces and Channel

\begin{tabular}{|c|c|c|}
\hline Site & $\begin{array}{c}\text { Distance to Creek } \\
\text { Terraces }(\mathbf{m})\end{array}$ & $\begin{array}{c}\text { Distance to Creek } \\
\text { Channel }(\mathbf{m})\end{array}$ \\
\hline $41 \mathrm{BX} 1076$ & 320 & 410 \\
\hline $41 \mathrm{~B} \times 1088$ Area 1 & 275 & 425 \\
\hline $41 \mathrm{BX} 1091$ & 275 & 520 \\
\hline $41 \mathrm{BX} 1114$ & 60 & 150 \\
\hline
\end{tabular}

ing the time periods in question. Johnson and Goode (1994:40) believe populations were increasing while others suggest it was falling (Black 1989b:32). Many scholars agree, however, that the early Late Prehistoric period saw an increase in conflict between groups in the region (e.g. Johnson and Goode 1994; Prewitt 1982). An increase in population and a concurrent increase in competition for resources would seem a likely cause of this phenomena.

Johnson and Goode (1994:37-39) note that there is an increase in cult paraphernalia and practices, best evidenced in burials and cemeteries, at the end of the Archaic. They suggest that many of these traits were influenced by the complex belief system emerging among the Middle Woodland cultures to the east (Johnson and Goode 1994:36). Collins (1995:387) believes that throughout central Texas prehistory, but particularly in the Late Archaic and subsequent Late Prehistoric periods, the populations in the area were not living in isolation and that "culture brokers, travelers, multilingual interpreters, and diplomats" may have been behind the infusion of exotic artifacts and cultural practices. Hester (1995:442) discusses the possibility of increased trade between central and south Texas at the end of the Archaic as well. Increased interaction between groups and the adoption or assimilation of foreign cultural traits may have contributed to regional stress and resulted in the conflict proposed for the early Late Prehistoric.

Whereas in the Early, Middle, and Late Archaic periods, the hill top chert outcrops were visited as lithic procurement sites, increased conflict and intergroup competition may have encouraged the Transitional Archaic and Late Prehistoric inhabitants of the area to use these locations as camps. Their elevated summits would have allowed occupants of these sites to observe game and other groups of humans as they moved through the surrounding upland prairies and nearby creek valleys.

\section{Questions of Chronology and Context}

Related to the issue of the significance of these sites is the degree to which the deposits are temporally mixed or are palimpsests. Turner and Hester (1993) place the Transitional Archaic's beginning ca. 2,250 B.P. (300 B.C.) and its ending at ca. 1,250 B.P. (A.D. 700). The Late Prehistoric continues from this point in time until approximately 350 B.P. (A.D. 1600). The combined time span for these two periods is 1,900 years, suggesting that the sites in question could be palimpsests with dubious research value.

The problem is more complex, however. The transition between the long-lived Archaic and comparatively brief Late Prehistoric periods is one of the more poorly understood aspects of the regional chronology. In south Texas sites, Transitional Archaic dart points "often occur in what are otherwise Late Prehistoric contexts, some even in very late contexts" (Hester 1995:443). For example, Transitional Archaic types including an Ensor point and two Matamoros points were found at 41 LK106 along with Leon Plain ceramics and two arrow points.

In central Texas, the commingling of dart and arrow points has been documented at several sites. At the Mingo site (41BN101), Houk and Lohse (1993:193244) excavated a small burned rock midden containing four Transitional Archaic dart points and numerous Scallorn, Edwards, and Sabinal arrow points. In one excavated level, a Frio dart point was stratigraphically above a Sabinal arrow point, prompting the authors to 
suggest that arrow points and dart points were coeval for a period of time (Houk and Lohse 1993:243). This hypothesis is echoed by others (e.g. Hester 1995:443). Henderson (1990:630) excavated "crude dart-pointlike arrow points in association with Edwards points at the Rainey site (41BN33), a stratified sinkhole three kilometers northwest of the Mingo site. The points described by Henderson (1990:514, 630) closely resemble Fairland or Frio points in outline. Similar artifact assemblages were found by Goode (1991) at the Heard Schoolhouse site (41UV86) and the Honey Creek site (41MS32). At the Blue Hole (41UV159), Mueggenborg (1994) concluded that at least one Ensor/Frio variant occurred almost exclusively with Late Prehistoric arrow points in the upper layers of the site.

If Transitional Archaic dart point styles did overlap with arrow points, then dart points persisted longer and/or arrow points were introduced earlier than commonly believed. Hester (1995:443) suggests that the data from 41 LK106 (e.g. Creel et al. 1979) indicate that small dart points "were made and used as part of the bow and arrow system," rather than "recycled" by Late Prehistoric hunters. Johnson and Goode (1994:40) posit the same possibility. As for the arrow points, the earliest type to appear or be developed in central and south Texas is the Edwards point, generally dated to ca. 1250 B.P. (Johnson and Goode 1994) and/or the Scallorn point, appearing around the same time (Hester 1995). Huebner and Comuzzie (1992) report a Scallorn arrow point from the Blue Bayou site (41VT94) dating between 1400-1300 B.P., while Edwards points at the Rainey site (41BN33) date to ca. 1250-1150 B.P. (Henderson 1990).

To dismiss these upland sites as indecipherably mixed may be based on a premature assumption. The presence of pottery and Perdiz points, commonly accepted markers of the Toyah subperiod of the Late Prehistoric (Black 1989b, 1989c; Collins 1995; Hester 1995; Johnson 1994b; Ricklis 1994), are strong indicators that $41 \mathrm{BX} 1114$ and $41 \mathrm{BX} 1088$ have multiple, late components, but the degree of mixing could be much less than a cursory glance at the regional chronology would suggest because that chronology lacks resolution. These sites are possibly representative of a very important time in Texas prehistory-the transitional period between two lifeways. The change from hunt- ing solely with a spear to hunting with a bow assuredly involved more than a technological change from making dart points to arrow points. This new technology would have involved new hunting strategies, new ways of organizing groups, and new settlement patterns. As surface features, these sites themselves will not be able to resolve the chronological issues, but, until the regional culture history is better defined, the palimpsest nature of some of these sites must be demonstrated because short term, single component sites do exist.

\section{Conclusions}

The testing of eight prehistoric sites at Lackland Air Force Base has generated some important data related to prehistoric use and occupation of the region, resulted in the formulation of four research issues by which to guide future investigations in the region, prompted an assessment of the possible geological contexts for sites, and confirmed some pretesting assumptions while dispelling others. The formal evaluations of the significance of the tested sites and eligibility recommendations are included in the following chapter, but some of the important conclusions generated by the testing and subsequent analyses which resulted in those determinations are summarized below.

The testing project confirmed that the upland and floodplain sites are contextually different. The floodplain sites of 41BX1102 and 41BX1103 have buried components that are apparently stratified. $41 \mathrm{BX} 1102$ has good geological context, while $41 \mathrm{BX} 1103$ approximates a site with good geological context because the stream transportation of materials at the site appears to be very minimal. Each of the upland sites has buried cultural material as well, but because these sites are turbated palimpsests, the subsurface artifacts are in secondary contexts, having been transported by biological activity. These deposits may or may not be mixed, however. Until the regional chronology is refined, the palimpsest nature of these sites must be demonstrated through testing because single component sites exist across the landscape. 
The testing also confirmed that the upland and floodplain sites have different artifact assemblages, reflecting different aspects of the prehistoric land-use patterns. The floodplain sites reflect longer periods of occupation and use as camps, while the upland sites reflect more intensive use as lithic procurement localities. The investigations revealed, however, that there is marked variability among the upland sites and that they are not homogenous. Not only do the artifact assemblages reflect different activities and intensity of use between sites, there is clear evidence for important variation within sites. This latter observation is most clearly seen at $41 \mathrm{BX} 1088$, where the three areas investigated were markedly dissimilar to one another, and at 41BX1114, where the north and south ends of the site reflected different degrees of raw material exploitation and intensity of use.

The unexpected frequency of Transitional Archaic and Late Prehistoric diagnostic projectile points in association with ceramics and/or burned rock at topographic high points at 41BX1076, 41BX1088, and $41 \mathrm{BX} 1114$ suggests an increase in the intensity of use of these locations, perhaps as camps rather than just resource procurement loci, during these periods. What this observation signifies is unclear, but the identification of the pattern will allow future investigations to study more fully this research issue.

Possibly related to the shift in land-use postulated for the Transitional Archaic and Late Prehistoric is the appearance of the split-cobble reduction technique at 41BX1076, 41BX1088, and (most notably) $41 \mathrm{BX} 1091$. The end product of this reduction strategy may have been large unifacial scrapers such as those recovered at 41BX1076 and 41BX1091. While the temporal association of this technique has not been confirmed, it may a diagnostic trait of the Transitional Archaic and/or Late Prehistoric period since splitcobbles and split-cobble failures were found at sites with diagnostic artifact assemblages dominated by arrow points and small dart points.

Unfortunately, the testing project did not recover significant data for addressing the issues of subsistence and chronology. Both floodplain sites, however, have the potential to provide important chronological data because they both apparently contain stratified cul- tural deposits. The testing at 41BX1102 produced exclusively Middle Archaic diagnostics (Pedernales points), but the vertical distribution of material indicates that there is at least one buried component at the site. Despite its unusual context, 41BX1103 contains stratified components with diagnostic artifacts, possible features, and excellent faunal preservation. Even though the flotation samples from the two floodplain sites did not contain any macrobotanical remains, but the unexpectedly good faunal preservation at $41 \mathrm{BX} 1103$ is an important discovery that has the potential to provide subsistence data. 


\section{Chapter 7: Recommendations}

\section{Brett A. Houk, C. Britt Bousman, and David L. Nickels}

\section{Introduction}

The purpose of the Medina Annex testing project was to provide the Department of the Air Force with recommendations as to the eligibility of the tested sites for nomination to the National Register of Historic Places (NRHP). As discussed in Chapters 1 and 2 of this report, eligibility for NRHP listing is based on a site's significance. In the case of prehistoric sites, significance is usually based on Criterion D of the National Historic Preservation Act (NHPA) as defined by the National Park Service in 36 CFR 60. The significance of a site under Criterion $\mathrm{D}$, and therefore its eligibility for listing on the NRHP, is based on its hav- ing yielded information important in history or prehistory or on its having the potential to yield such information in the future. For the eight sites investigated CAR at the Medina Annex, a site's significance is judged by its ability to address one or more of the research issues outlined in Chapter 6 (Table 7-1). An integral component of a site's significance is its geological context. Table 7-1 presents the assessment of the context of each site as determined by Nordt's geoarchaeological assessment, surface collections, and excavation units. This chapter presents CAR's recommendations as to the eligibility of each site for NRHP designation (Table 7-1). This discussion is organized by impact area for management purposes.

Table 7-1. Context of Deposits and Potential for Each Site to Address Research Issues

\begin{tabular}{|c|c|c|c|c|c|c|c|}
\hline \multicolumn{2}{|c|}{$\begin{array}{c}\text { Site } \\
41 \mathrm{BX}\end{array}$} & $\begin{array}{c}\text { Geological } \\
\text { Context }\end{array}$ & Chronology & $\begin{array}{c}\text { Settlement } \\
\text { Patterns }\end{array}$ & \begin{tabular}{l}
\multicolumn{1}{c}{ Lithic } \\
Technological \\
Organization
\end{tabular} & Subsistence & Eligibility \\
\hline \multirow{3}{*}{ 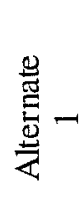 } & 1088 & Turbated Palimpsest & None & Exhausted & Exhausted & None & Not Eligible \\
\hline & 1090 & Turbated Palimpsest & None & None & Exhausted & None & Not Eligible \\
\hline & 1091 & Turbated Palimpsest & None & Moderate & High & None & Not Eligible \\
\hline \multirow{4}{*}{ 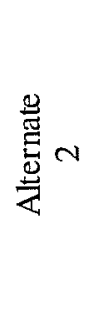 } & 1070 & Turbated Palimpsest & None & None & Low & None & Not Eligible \\
\hline & 1102 & Good Geological Context & High & High & Moderate & Moderate & Eligible \\
\hline & 1103 & Redeposited Context* & High & High & Moderate & High & Eligible \\
\hline & 1114 & Turbated Palimpsest & None & Exhausted & Exhausted & None & Not Eligible \\
\hline$\stackrel{\Xi}{8} \stackrel{0}{8}$ & 1076 & Turbated Palimpsest & None & Exhausted & Exhausted & None & Not Eligible \\
\hline
\end{tabular}

*Redeposited Context, but material has been transported very short distances. Context is therefore moderately good. 


\section{Medina Annex Housing Area (Alternate 1)}

\section{BX1088}

The testing at $41 \mathrm{BX} 1088$ investigated less than one percent of the total site's surface area, but still recovered sixteen diagnostic artifacts. This total includes two Leon Plain sherds, six arrow points (including blanks and preforms), eight dart points (including one blank), and two Guadalupe tools. With the exception of the two Guadalupe tools and a Pedernales point, the diagnostic artifacts date to the Transitional Archaic and/or Late Prehistoric time periods. Two features, problematic stone alignments at Area 2, were documented, but no temporal association for them was established.

In some areas of the site, the surface has been cleared for fire breaks and access, but this accounts for a small percentage of the total site. The geoarchaeological assessment indicates that the sediments at the site represent soils formed on Cretaceous deposits and have little potential for containing buried cultural materials in a primary context as the site is a turbated palimpsest. The material encountered in the excavation units presumably has worked downward through bioturbation and desiccation cracks.

Area 1 at $41 \mathrm{BX} 1088$ has contributed important information relevant to the issue of settlement patterns, specifically the apparent selection of the topographic high point at the site for use or occupation during the Late Prehistoric. Most importantly, the testing at 41BX1088 has identified distinct differences in the artifact assemblages across the site. This suggests that it may be possible to identify temporally or functionally discrete assemblages in certain areas of 41BX 1088 and similar upland sites. With respect to the significance of the site, CAR concludes that the research potential of the three areas investigated during this project has been exhausted. No future archaeological investigations are recommended in these three areas, and they are recommended as ineligible for NRHP nomination.

\section{BX1090}

The intensive testing investigations at $41 \mathrm{BX} 1090 \mathrm{did}$ not locate any diagnostic artifacts or intact cultural features. It is therefore not possible to assign a temporal association to the small amount of cultural material recovered at the site. The presence of macroscopic pieces of charcoal and burned chert cobbles on the surface of the site suggests that the area was recently burned. The geoarchaeological assessment indicates that the site is on or in a colluvially derived soil dating to the early to middle Holocene. Turbation has moved the Late Holocene age cultural material into a buried context. The integrity is therefore considered poor, and the site is a turbated palimpsest. Although artifacts were recovered during subsurface testing, the quantities were low.

Because of the lack of diagnostic artifacts and cultural features, combined with the poor surface and subsurface integrity, the site has no research potential with respect to the issues outlined in Chapter 6. CAR therefore recommends that $41 \mathrm{BX} 1090$ is ineligible for nomination to the NRHP and that no further archaeological investigations are necessary at this location.

\section{BX1091}

At 41BX1091, the archaeological testing recovered two diagnostic projectile points and demonstrated that cultural material was concentrated in the southern part of the collection area. The diagnostic artifacts, a Fairland dart point and a Scallorn arrow point, date to the Transitional Archaic and Late Prehistoric periods, respectively. No intact cultural features were discovered on the surface or in the subsurface units. The soils at the site are colluvially derived Uvalde Gravels dating to the early to middle Holocene. Because the cultural material at the site is Late Holocene, 41BX1091 is classified as a turbated palimpsest.

There is evidence that the site has been subjected to modern, and possibly intensive, disturbance in the form of terracing and brush clearing. The integrity of the surface and shallow subsurface deposits is therefore considered to be poor. 
The site has a high frequency of split cobble cores, flakes, and detritus. While similar items were successfully replicated in the laboratory, it is possible that some of the split cobble artifacts are the result of mechanical crushing associated with the modern alteration of the site.

The site has yielded data suitable to address the settlement patterns research issue discussed in Chapter 6, particularly with respect to the Transitional and Late Prehistoric pattern noted in the data. Additionally, if the split cobbles at the site are of prehistoric origin, $41 \mathrm{BX} 1091$ has provided data applicable to the issue of lithic technological organization. The high degree of disturbance to the site, however, suggest that the data with respect to these two issues has been exhausted by the significance testing. CAR recommends that the site is ineligible for NRHP nomination and that no additional archaeological work be undertaken at $41 \mathrm{BX} 1091$

\section{Medina Annex Dog Training Area (Alternate 2)}

\section{$41 B \times 1070$}

The investigations at $41 \mathrm{BX} 1070$ consisted only of site mapping and excavating one backhoe trench. No diagnostic artifacts were recovered at the site. The limited data available from the survey (e.g. Nickels et al 1997) and the testing investigations suggest that $41 \mathrm{BX} 1070$ was used as a location from which to procure and test naturally occurring chert cobbles. The geoarchaeological assessment of the site indicates that it is a turbated palimpsest on an eroding slope. Furthermore, the possible temporal range for surface materials is Middle Archaic to Historic, suggesting that the likelihood of finding isolable components with chronological integrity is low.

Lacking any diagnostic artifacts and intact cultural features, 41BX1070 cannot address the issues discussed in Chapter 6. CAR recommends that no further work be initiated at $41 \mathrm{BX} 1070$ and that the site is ineligible for NRHP nomination.

\section{BX1102}

During the survey (Nickels et al. 1997) and testing projects, a total of eight Pedernales points and two Pedernales preforms were recovered at $41 \mathrm{BX} 1102$, all from the eastern part of the site. The remaining three projectile points can not be assigned to previously established types and are therefore not temporally diagnostic. No features were encountered on the surface or during subsurface testing.

The integrity of the surface in the area of the site cleared for dog training by the military is poor due to the apparent bulldozing of the upper $10 \mathrm{~cm}$. This part of the site may have contained the greatest quantities of cultural material before it was disturbed based on the high debitage counts in the upper level of TU N1050 E970, located in the center of this area. The surface integrity of the area southeast of the clearing, however, is good, having been spared any serious artificial impacts. Chronologically, the surface material appears to represent a single component as indicated by the presence of Pedernales points and preforms at the exclusion of any other diagnostic artifacts.

The site is contained on and in Holocene alluvial deposits and is classified as a good geological context, although some vertical movement of material has taken place in the subsurface deposits at 41BX1102 as indicated by modern glass encountered at depth. The distribution of debitage by excavated level, however, suggests that $41 \mathrm{BX} 1102$ has at least one buried component. This increase in material, which is marked by higher artifact counts at 50 and $70 \mathrm{~cm}$ bs may actually represent two separate components. The presence of a Pedernales point at $51 \mathrm{~cm}$ bs in TU N1005 E1015 indicates a Middle Archaic date for the uppermost component, if indeed there are two. This heavily patinated specimen, however, may have been mixed with lower materials by falling into a desiccation crack. The general conclusion, however, is that $41 \mathrm{BX} 1102$ offers intact and potentially isolable subsurface deposits which have been contaminated to a small degree with material from the surface. Geomorphologically, 41BX1102 offers the best potential of the eight tested sites for containing intact subsurface deposits based on the environment of deposition. 
The site offers a high research potential for addressing issues of settlement patterns and chronology. The preliminary indications are that $41 \mathrm{BX} 1102$ contains at least one buried component in addition to the Middle Archaic surface assemblage. CAR therefore recommends that 41BX1102 is eligible for NRHP nomination. Any future impacts to the site should require appropriate mitigation of the adverse effects to the cultural resources present at $41 \mathrm{BX} 1102$.

\section{BX1103}

The testing at 41BX1103 recovered diagnostic artifacts dating from the Middle Archaic to the Transitional Archaic, and, although no clearly defined features were located at 41BX1103, the site contains burned rock on the surface and at depth. The site apparently accumulated on an actively accreting gravel bar, but the presence of faunal material at depth and the lack of apparent stream damage to the debitage and other chipped stone artifacts recovered at the site may indicate that the cultural material has not been significantly displaced by stream action. The diagnostic artifacts recovered from the surface all date to the Transitional Archaic. The presence of exclusively Transitional Archaic dart points on the surface and at a depth of approximately $30 \mathrm{~cm}$ bs, indicates that a single component is represented by the surface assemblage and upper levels of the deposit. Therefore, despite the potential for the formation of a palimpsest on the surface after landscape stability had been achieved, the integrity of the surface in the undisturbed areas is considered good because the surface artifacts apparently represent a single temporal component.

Despite the site's unusual physical setting, the data from the test units suggests that the subsurface deposits are stratified and that individual components may be isolable at various depths. Although the site is a redeposited context and the subsurface material in the upper $45 \mathrm{~cm}$ of the site may be displaced or redeposited, the movement has been to such a low degree that the site approximates intact cultural deposits. Below this depth, the frequency and size of the gravels precludes the preservation of intact deposits, but below the gravel bar in the truncated Unit II there is the potential for Early to Middle Holocene age deposits, al- though the testing investigations did not encounter any archaeological materials in these deposits. Because the upper $45 \mathrm{~cm}$ of the deposit may be minimally displaced horizontally and retain their primary vertical context, the subsurface integrity for this part of the site is considered good.

The deposits at 41BX1103 have the potential to address issues of settlement patterns, chronology, and subsistence. Because the site appears to be stratified and contain multiple cultural components, it has a high potential for addressing chronology. Furthermore, the unusually good preservation of faunal material suggests that it may be possible to obtain absolute dates for these cultural components in addition to addressing directly the issue of subsistence. CAR therefore recommends that $41 \mathrm{BX} 1103$ is significant and eligible for NRHP nomination. CAR recommends that future impacts to the site require appropriate mitigative measures.

\section{$41 B \times 1114$}

The testing at $41 \mathrm{BX} 1114$ recovered diagnostic artifacts dating to the Early Archaic, Transitional Archaic, and Late Prehistoric time periods, including eight Leon Plain ceramic sherds. No intact cultural features were encountered. The area originally designated Feature 1 is apparently a fortuitous association of prehistoric artifacts and more recent animal bone and charcoal.

The integrity of the surface deposits has been compromised by biological activity, but only to the extent that material has been moved $20 \mathrm{~cm}$ or less below the surface. Because the site is a turbated palimpsest, there is very little chance of encountering buried cultural features or artifacts in a primary context unless they have been buried by a tree throw or colluvial deposits. The latter possibility exists for the area between the south and north collection units where material eroding from the hill top may form a colluvial wedge

The large amounts of cultural material and the internal variation in debitage densities revealed in the shallow block excavations in the north collection area suggest it may be possible to identify distinct clusters 
of related artifacts despite the vertical displacement of material.

$41 \mathrm{BX} 1114$ has provided information about settlement patterns and lithic technological organization, but the testing project has exhausted the site's research potential with respect to these issues. CAR recommends that 41BX1114 is ineligible for nomination to the NRHP and that no additional research is necessary.

\section{Section 110 Testing}

\section{$41 B \times 1076$}

The combined testing and survey (e.g. Nickels et al. 1997) investigations at $41 \mathrm{BX} 1076$ recovered three diagnostic projectile points: one Transitional Archaic dart point and two Late Prehistoric arrow points. The testing located a concentrated area of burned limestone, designated Feature 1, visible on the surface and extending into the upper $10 \mathrm{~cm}$ of subsurface material. Although major artificial impacts have spared the site, 41BX1076 is on and in a soil forming from a Pleistocene terrace or Pleistocene colluvium which is too old to contain buried cultural material. The site is classified as a turbated palimpsest. Like at the north end of 41BX1114, any material encountered below the surface has presumably been transported there by biological activity or pedogenic processes.

Testing at $41 \mathrm{BX} 1076$ has provided settlement pattern data and additional examples of the split cobble technology, including unifaces manufactured on split cobbles. The testing investigations have exhausted the site's research potential with respect to the issues outlined in Chapter 6. It is CAR's recommendation that 41BX1076 is ineligible for NRHP designation and that no further archaeological investigations be undertaken at the site. 


\section{References Cited}

Adkins, L., and R. A. Adkins

1982 A Thesaurus of British Archaeology. David and Charles, London.

Alexander, H. L.

1963 The Levi Site: A Paleo-Indian Campsite in Central Texas. American Antiquity 28:510-528.

1983 The Pre-Clovis and Clovis Occupations at the Levi Site. In Peopling of the New World, edited by J. E. Ericson, R. E. Taylor, and R. Berger, pp. 133-145. Ballena, Los Altos, California.

Allison, J. E., G. W. Dittmar, and J. L. Hensell

1975 Soil Survey of Gillespie County, Texas. Soil Conservation Service, U.S. Department of Agriculture, Washington, D.C.

Andrefsky, W.

1991 Inferring Trends in Prehistoric Settlement Behavior from Lithic Production Technology in the Southern Plains. North American Archaeology 12:129-144.

1994 The Geological Occurrence of Lithic Material and Stone Tool Production Strategies. Geoarchaeology 9:375-391.

Aten, L. E.

1979 Indians of the Upper Texas Coast: Ethnohistoric and Archaeological Frameworks. Unpublished Ph.D. dissertation. The University of Texas at Austin.

Bamforth, D. B.

1990 Settlement, Raw Material, and Lithic Procurement in the Central Mojave Desert. Journal of Anthropological Archaeology 9:70-104.

Barnes, V. E.

1983 Geologic Atlas of Texas: San Antonio Sheet. Bureau of Economic Geology. The University of Texas at Austin.

Bass F. A., Jr., and T. R. Hester

1975 An Archaeological Survey of the Upper Cibolo Creek Watershed, Central Texas. Archaeological Survey Report, No. 8. Center for Archaeological Research, The University of Texas at San Antonio.

Binford, L. R.

1980 Willow Smoke and Dogs' Tails: Hunter-Gatherer Settlement Systems and Archaeological Site Formation. American Antiquity (45(1):4-20.

Black, S. L.

1986 The Clemente and Herminia Hinojosa Site, 41JW8: A Toyah Horizon Campsite in Southern Texas. Special Report No. 18. Center for Archaeological Research, The University of Texas at San Antonio.

1989a Environmental Setting. In From the Gulf Coast to the Rio Grande: Human Adaptation in the Central, South, and Lower Pecos Texas, edited by T. R. Hester, S. L. Black, D. G. Steele, B. W. Olive, A. A. Fox, K. J. Reinhard, and L. C. Bement, pp. 5-17. Research Series No. 33. Arkansas Archeological Survey, Fayetteville. 
1989b Central Texas Plateau Prairie. In From the Gulf Coast to the Rio Grande: Human Adaptation in Central, South and Lower Pecos Texas, edited by T. R. Hester, S. L. Black, D. G. Steele, B. W. Olive, A. A. Fox, K. J. Reinhard, and L. C. Bement, pp. 17-38. Research Series No. 33. Arkansas Archeological Survey, Fayetteville.

1989c South Texas Plain. In From the Gulf Coast to the Rio Grande: Human Adaptation in the Central, South, and Lower Pecos Texas, edited by T. R. Hester, S. L. Black, D. G. Steele, B. W. Olive, A. A. Fox, K. J. Reinhard, and L. C. Bement, pp. 39-62. Research Series No. 33. Arkansas Archaeological Survey, Fayetteville.

1995 Archaeological and Historical Background. In Archaeological Investigations at the Loma Sandia Site (41LK28): A Prehistoric Campsite in Live Oak County, Texas. 2 volumes. Studies in Archeology No. 20, pp 31-45. Texas Archeological Research Laboratory, The University of Texas at Austin.

Black, S. L., L. W. Ellis, D. G. Creel, and G. T. Goode (editors)

1997 Hot Rock Cooking on the Greater Edwards Plateau: Four Burned Rock Midden Sites in West Central Texas, Two Volumes. Studies in Archaeology 22. Texas Archaeological Research Laboratory, The University of Texas at Austin.

Black, S. L., and A. J. McGraw

1985 The Panther Springs Creek Site: Cultural Change and Continuity in the Upper Salado Creek Drainage, South-Central Texas. Archaeological Survey Report, No. 100. Center for Archaeological Research, The University of Texas at San Antonio.

Black, S. L., K. Jolly, and D. R. Potter

1993 The Higgins Experiment: Field Report. Wurzbach Project Working Papers. Texas Archeological Research Laboratory, The University of Texas at Austin.

Black, S. L., and D. R. Potter

1995 Defining Historic Contexts for Prehistoric Sites along the Wurzbach Parkway. In Archaeology Along the Wurzbach Parkway: Module 1. Introduction, Conceptual Framework, and Contexts of Archaeological Investigations in Bexar County, South-Central Texas, edited by D. R. Potter, S. L. Black, and K. Jolly, pp. 45-51. Studies in Archaeology 17. Texas Archeological Research Laboratory, The University of Texas at Austin.

Blair, W. F.

1950 The Biotic Provinces of Texas. Texas Journal of Science 2(1):93-117.

Blum, M. D., and S. Valastro, Jr.

1989 Response of the Pedernales River of Central Texas to late Holocene climatic change. Annals of the Association of American Geographers 79:435-456.

1994 Late Quaternary sedimentation, lower Colorado River, Gulf Coastal Plain of Texas. Geological Society of America Bulletin 106:1002-1016.

Bolton, H. E.

1915 Texas in the Middle Eighteenth Century: Studies in Spanish Colonial History and Administration. Volume 3, University of California Publications in History. University of California, Berkeley. 
Bouldurian, A. T., G. A. Agogino, P. H. Shelley, and M. Slaughter

1986 Folsom Biface Manufacture, Retooling, and Site Function at the Mitchell Locality of Blackwater Draw. Plains Anthropologist 31:299-310.

Bousman, C. B.

1992 Preliminary Oxygen-Isotope Evidence for Late Pleistocene-Early Holocene Climatic Change. Current Research in the Pleistocene 11:79-81.

1994 The Central Texas Pollen Record: A Reinterpretation. Current Research in the Pleistocene 11:79-81.

Brown, K. M.

1995 Berger Bluff: Early Holocene Foraging Station on the Coleto Creek Floodplain, Texas. Paper presented at the 60th annual meeting of the Society for American Archaeology, Minneapolis.

Cabeza de Vaca, A. N.

1966[1542] Relation of Alvar Nuñez Cabeza de Vaca. Microfilm reprint of 1871 edition, translated by B. Smith. Readex Microprint Corp, New York.

Camilli, E. L.

1988 Lithic Raw Material Selection and Use in the Desert Basins of South-Central New Mexico. The Kiva 5:147-163.

Campbell, T. N.

1975 The Payaya Indians of Southern Texas. Special Publications No. 1. Southern Texas Archaeological Association, San Antonio.

1983 Coahuiltecans and Their Neighbors. In Handbook of North American Indians Volume 10: Southwest, edited by A. Ortiz, pp. 343-358. Smithsonian Institution, Washington, D.C.

1991 Coahuiltecans and Their Neighbors. In Ethnology of the Texas Indians, edited by T. R. Hester. Spanish Borderlands Sourcebooks 7. Garland, New York.

Campbell, T. N., and T. J. Campbell

1981 Historic Indians of the Choke Canyon Reservoir Surrounding Area, Southern Texas. Choke Canyon Series, No. 1. Center for Archaeological Research, The University of Texas at San Antonio.

1985 Indian Groups Associated with Spanish Missions of the San Antonio Missions National Historical Park. Special Report, No. 16. Center for Archaeological Research, The University of Texas at San Antonio.

Center for Archaeological Research

1996 An Archaeological Work Plan for Lackland Air Force Base. Letter report from Center for Archaeological Research, The University of Texas at San Antonio, to Western Archaeological and Conservation Center, National Park Service, Tuscon.

Chandler, C. K., and K. Hindes

1993 Scottsbluff Points from Atascosa, Frio, and McMullen Counties, South-Central Texas. La Tierra 20(1):31-36.

Chipman, D. E.

1992 Spanish Texas, 1519-1821. University of Texas Press, Austin. 
Cleveland, A. G., and D. D. McLain

1992 Habitat Study of the Lackland Air Force Base Medina Annex Flora and Fauna. Report submitted to the U.S. Air Force, Contract No. F4163691PF453. Lackland Air Force Base, San Antonio.

Collins, M. B.

1975 Lithic Technology as a Means of Processual Inference. In Lithic Technology: Making and Using Stone Tools, edited by E. Swanson, pp. 15-34. Academic, New York.

1995 Forty Years of Archeology in Central Texas. Bulletin of the Texas Archeological Society 66:361-400.

Collins, M. B. (editor)

1997 Archaeological Investigations of the Wilson-Leonard Site. Draft manuscript. Texas Archaeological Research Laboratory, The University of Texas at Austin.

Collins, M. B., and C. B. Bousman

1990 Cultural Implications of Late Quaternary Environmental Change in Northeastern Texas. Unpublished manuscript submitted to the Texas Historical Commission.

Collins, M. B., C. B. Bousman, P. Goldberg, P. R. Takac, J. C. Guy, J. L. Lanata, T. W. Stafford, and V. T. Holliday

1993 The Paleoindian Sequence at the Wilson-Leonard Site, Texas. Current Research in the Pleistocene $10: 10-12$.

Collins, M. B., G. L. Evans, T. N. Campbell, M. C. Winans, and C. E. Mears

1989 Clovis Occupation at Kincaid Rockshelter. Current Research in the Pleistocene 6:3-5.

Collins, M. B., and P. J. Headrick

1992 Comments on Kelly's Interpretation of the "Van Autry" Cores. La Tierra 19:4:26-39.

Council of Texas Archeologists

1987 Guidelines for Federal Performance Standards. Council of Texas Archeologists, Austin.

Creel, D. G.

1986 Assessing the Importance of Acorns in Archaic Subsistence: The Distribution of Prehistoric Burned Rock Middens in West Central Texas. Unpublished Ph.D. dissertation. University of Arizona, Tucson.

Creel, D., A. J. McGraw, F. Valdez, Jr., and T. C. Kelly

1979 Excavations at 41LK106, a Prehistoric Occupation Site in Live Oak County, Texas. Archaeological Survey Report, No. 62. Center for Archaeological Research, The University of Texas at San Antonio.

Dalbey, T. S.

1993 An Overview Guide to Historic and Prehistoric Cultural Resources Potential on Lackland Air Force Base as Pertains to the National Historic Preservation Act of 1966, as Amended. U.S. Army Corps of Engineers, Fort Worth District, Fort Worth.

de la Teja, J. F.

1988 Land and Society in 18th Century San Antonio de Bexar, A Community on New Spain's Northern Frontier. Unpublished Ph.D. dissertation. The University of Texas at Austin. 
Diamond, D. D., D. H. Riskind, and S. L. Orzell

1987 A Framework for Plant Community Classification and Conservation in Texas. The Texas Journal of Science 39(3):203-221.

Dibble, D. S., and D. Lorrain

1968 Bonfire Shelter: A Stratified Bison Kill Site, Val Verde County, Texas. Miscellaneous Papers 1. Texas Memorial Museum, Austin.

Dillehay, T.

1974 Late Quaternary Bison Population Changes on the Southern Plains. Plains Anthropologist 19(64):180196.

Elias, S. A.

1994 Insect Fossil Evidence of Late Glacial Environments at the Aubrey Clovis Site, Texas [Abstract]. American Quaternary Association, Programs and Abstracts of the 13th Biennial Meeting, pp 77. University of Minnesota, Minneapolis.

Espey, Huston and Associates, Inc.

1989 Archaeological Investigations of Kelly Air Force Base, Bexar County, Texas. Melissa W. Voellinger, principal investigator. Document No. 890604. Espey, Huston and Associates, Austin.

Ewers, J. C., editor

1969 The Indians of Texas in 1830. Publication series 4745. Smithsonian Institution Press, Washington, D.C.

Fehrenbach, T. R.

1968 Lone Star, A History of Texas and the Texans. Macmillian, Toronto.

1978 The San Antonio Story. Continental Heritage, Tulsa, Oklahoma.

Flanagan, S.

1974 Trailing the Longhorns: A Century Later: Madrona, Austin.

Folk, R. L.

1980 Petrology of Sedimentary Rocks. Hemphill, Austin.

Ford, A. L., and O. W. Van Auken

1982 Distribution of Woody Species in the Guadalupe River Flood Plain in the Edwards Plateau of Texas. Southwestern Naturalist 27:383-392.

Fox, A. A., I. W. Cox, L. Highley, and D. Hafernik

1989 Archaeological and Historical Investigations at the Site of the New Bexar County Justice Center in Downtown San Antonio, Texas. Archaeological Survey Report, No. 184. Center for Archaeological Research, The University of Texas at San Antonio.

Fox, A. A., and D. E. Fox

1967 The Classen Rockshelter, 41BX23. Manuscript on file. Center for Archaeological Research, The University of Texas at San Antonio. 
Fox, G.

1996 Field and Laboratory Protocols: Phase II Testing, Lackland Air Force Base, Bexar County, Texas. Letter from Western Archaeological and Conservation Center, National Park Service, Tuscon to Center for Archaeological Research, The University of Texas at San Antonio.

Fox, J., C. B. Smith, and D. O. Lintz

1992 Herd Bunching at the Waco Mammoth Site: Preliminary Investigations, 1978-1987. In Proboscidean and Paleoindian Interactions, edited by J. W. Fox, C. B. Smith, and K. T. Wilkins, pp 51-73. Baylor University Press, Waco, Texas.

Fredlund, G.

1994 The Phytolith Record at the Wilson-Leonard Site. Program and Abstracts, 52nd Plains Conference, 65th Annual Meeting of the Texas Archaeological Society. Lubbock, Texas.

Freeman, M. D.

1994 Agriculture in Texas: Ranching and Stock Farming on the Eastern Edwards Plateau, 1845-1941. Komatsu/Rangel, Fort Worth.

Gerstle, A., T. C. Kelly, and C. Assad

1978 The Fort Sam Houston Project: An Archaeological and Historical Assessment. Archaeological Survey Report, No. 40. Center for Archaeological Research, The University of Texas at San Antonio.

Givens, R. D.

1968a On the Peopling of America. Current Anthropology 9:219.

1968b A Preliminary Report on Excavations at Hitzfelder Cave. Bulletin of the Texas Archeological Society 38:47-50.

Goode, G. T.

1991 Late Prehistoric Burned Rock Middens in Central Texas. In The Burned Rock Middens of Texas: An Archeological Symposium, edited by T. R. Hester, pp. 71-93. Studies in Archeology 13. Texas Archeological Research Laboratory, The University of Texas at Austin.

Gould, F. W.

1975 Texas Plants-A Checklist and Ecological Summary. Bulletin MP-585:5-14. Texas Agricultural Experimentation Station, College Station.

Gramly, R. M.

1980 Raw Materials Source Areas and "Curated" Tool Assemblages. American Antiquity 45:823-833.

Guderjan, T. H., B. Baker, C. B. Bousman, C. K. Chandler, A. A. Fox, and B. A. Meissner

1992 Prehistoric Settlement in the Medina Valley and the 1991 STAA-ITC Field School. La Tierra 19(2):1428.

Guderjan, T. H., B. A. Meissner, B. Baker, C. K. Chandler, S. Kennedy, D. McReynolds, H. R. Smith, F. Ward, J. Watts, and J. Zapata

1993 The Medina Valley Project and the 1992 STAA-ITC Field School. La Tierra 20(1):12-26. 
Gunn, J., and R. Mahula

1977 Hop Hill: Culture and Climatic Change in Central Texas. Special Report, No. 5. Center for Archaeological Research, The University of Texas at San Antonio.

Haberman, S. J.

1978 Analysis of Qualitative Data. Academic, New York.

Habig, M. A.

1968a San Antonio's Mission San José, State and National Historic Site, 1720-1968. Naylor, San Antonio.

1968b The Alamo Chain of Missions, A History of San Antonio's Five Old Missions. Franciscan Herald, Chicago.

Hall, G. D.

1981 Allens Creek: A Study in the Cultural Prehistory of the Brazos River Valley, Texas. Research Report 61. Texas Archeological Survey, The University of Texas at Austin.

1995 Prehistoric Cemeteries on the Texas Central Texas Coastal Plain: Interpretations and Hypotheses. In Archaeological Investigations at the Loma Sandia Site (41LK28): A Prehistoric Cemetery and Campsite in Live Oak County, Texas. Studies in Archaeology 20. Texas Archaeological Research Laboratory, The University of Texas at Austin.

Hall, G. D., S. L. Black, and C. Graves

1982 Archaeological Investigations at Choke Canyon Reservoir; South Texas: The Phase I Findings. Choke Canyon Series, No. 5. Center for Archaeological Research, The University of Texas at San Antonio.

Hall, G. D., T. R. Hester, and S. L. Black

1986 The Prehistoric Sites at Choke Canyon Reservoir, Southern Texas: Results of the Phase II Archaeological Investigations. Choke Canyon Series, No. 10. Center for Archaeological Research, The University of Texas at San Antonio.

Harris, E. S.

1985 An Archaeological Study of the Timmeron Rockshelter (41HY95), Hays County, South Central Texas. Special Publication 4. Southern Texas Archaeological Association, San Antonio.

Hatch, S. L., K. N. Gandhi, and L. E. Brown

1990 Checklist of the Vascular Plants of Texas. MP-1655. The Texas Agricultural Experiment Station, The Texas A\&M University System, College Station.

Haury, C. E.

1994 Defining Lithic Procurement Terminology. In Lithic Resource Studies: A Sourcebook for Archaeologists, edited by. T. Church, pp. 26-31. Special Publication \#3. Department of Anthropology, University of Tulsa, Oklahoma.

Henderson, $\mathrm{J}$

1978 Faunal Analysis of Site 41BX36, with Data Presented for 41BX377 and 41BX428. In The Fort Sam Houston Project: An Archaeological and Historical Assessment, edited by A. Gerstle, T. C. Kelly, and C. Assad, pp. 229-252. Archaeological Survey Report, No. 40. Center for Archaeological Research, The University of Texas at San Antonio. 
1980 Update on the Texas Highway Department's Excavations at 41BX52 on Leon Creek. Paper presented at a meeting of the Southern Texas Archaeological Association, San Antonio.

1990 Archaeological Investigations at the Rainey Site. Texas Department of Transportation, Austin. Draft. Manuscript on file at Texas Archeological Research Laboratory, Austin.

Henderson, J., and G. Goode

1991 Pavo Real: An Early Paleoindian Site in South-Central Texas. Current Research in the Pleistocene 8:26-28.

Hester, T. R.

1968a Folsom Points from Southwest Texas. Plains Anthropologist 15(50):237-250.

1968b Paleo-Indian Artifacts Along San Miguel Creek: Frio, Atascosa, and McMullen Counties, Texas. Bulletin of the Texas Archeological Society 39:147-162.

1971 Archeological Investigations at the La Jita Site, Uvalde County, Texas. Bulletin of the Texas Archeological Society 45:51-148.

1975 Chipped Stone Industries on the Rio Grande Plain, Texas: Some Preliminary Observation. The Texas Journal of Science XXVI (1-2):213-222.

1978 Background to the Archaeology of Chaparrosa Ranch, Southern Texas. Special Report No. 6. Center for Archaeological Research, The University of Texas at San Antonio.

1981 Tradition and Adversity Among the Prehistoric Hunters and Gatherers of Southern Texas. Plains Anthropologist 26(92):119-128.

1980 A Survey of Paleo-Indian Archaeological Remains Along the Texas Gulf Coast. In Papers on the Archaeology of the Texas Coast, edited by L. Highley and T. R. Hester, pp. 1-12. Special Report, No. 11. Center for Archaeological Research, The University of Texas at San Antonio.

1983 Late Paleo-Indian Occupations at Baker Cave, Southwestern Texas. Bulletin of the Texas Archeological Society 53:101-119.

1989 Historic Native American Populations. In From the Gulf to the Rio Grande: Human Adaptation in Central, South, and Lower Pecos Texas, edited by T. R. Hester, S. L. Black, D. G. Steele, B. W. Olive, A. A. Fox, K. J. Reinhard, and L. C. Bement, pp. 1-4. Research Series 33. Arkansas Archeological Survey, Fayetteville.

1990 Plainview Artifacts at the St. Mary's Hall Site, South Central Texas. Current Research in the Pleistocene 7:14-17.

1995 The Prehistory of South Texas. Bulletin of the Texas Archeological Society 66:427-459.

Hester, T. R. (editor)

1991 The Burned Rock Middens of Texas: An Archeological Symposium. Studies in Archeology 13. Texas Archeological Research Laboratory, The University of Texas at Austin.

Hester, T. R., and T. C. Hill, Jr.

1971 An Initial Study of a Prehistoric Ceramic Tradition in Southern Texas. Plains Anthropologist 16(52):195-203.

Highley, L., C. Graves, and G. Judson

1978 Archeological Investigations at Scorpion Cave (41ME7), Medina County, Texas. Bulletin of the Texas Archeological Society 49:139-194. 
Hines, M. H., S. A. Tomka, and K. W. Kibler

1994 Data Recovery Excavations at the Wind Canyon Site, 41HZ119, Hudspeth County, Texas. Reports of Investigations No. 99. Prewitt and Associate. Austin.

Holloway, R. G., and V. M. Bryant, Jr.

1984 Picea Glauca Pollen from Late-Glacial Deposits in Central Texas. Palynology 8:21-32.

Houk, B. A., and J. C. Lohse

1993 Archeological Investigations at the Mingo Site, Bandera County, Texas. Bulletin of the Texas Archeological Society 61:193-247.

Howard, C. D.

1974 Paleo-Indian Surface Finds in Bexar County. La Tierra 1(4):14-17.

Huebner, J. A.

1991 Late Prehistoric Bison Populations in Central and Southern Texas. Plains Anthropologist 36(137):343358.

Huebner, J. A., and A. G. Comuzzie

1992 The Archeology and Bioarcheology of Blue Bayou: A Late Archaic and Late Prehistoric Mortuary Locality in Victoria County, Texas. Studies in Archeology 9. Texas Archeological Research Laboratory, The University of Texas at Austin.

Hulbert, R. C., Jr.

1985 Vertebrate Faunal Remains. In The Panther Springs Creek Site: Cultural Change and Continuity within the Upper Salado Creek Watershed, South-Central Texas, edited by S. L. Black and A. J. McGraw, pp. 209-215. Archaeological Survey Report, No. 100. Center for Archaeological Research, The University of Texas at San Antonio.

Humphrey, J. D., and C. R. Ferring

1994 Stable Isotopic Evidence for Latest Pleistocene and Holocene Climatic Change in North Central Texas. Quaternary Research 41:200-213.

Inglis, J. M.

1964 A History of Vegetation on the Rio Grande Plain. Bulletin 45. Texas Parks and Wildlife Department, Austin.

Jackson, J.

1986 Los Mesteños: Spanish Ranching in Texas, 1721-1821. Texas A\&M University Press, College Station.

John, E. A. H.

1975 Storms Brewed in Other Men's Worlds: Confrontations of Indians, Spanish and French in the Southwest, 1540-1795. Texas A\&M University Press, College Station.

Johnson, L., Jr.

1967 Toward a Statistical Overview of the Archaic Cultures of Central and Southwestern Texas. Bulletin 12. Texas Memorial Museum, Austin. 
1987 A Plague of Phases. Bulletin of the Texas Archeological Society 57:1-26.

1994a The Reconstructed Crow Terminology of the Titkanwatits, or Tonkawas, with Inferred Social Correlates. Plains Anthropologist (39) 150:377-413.

1994b The Life and Times of Toyah-Culture Folk as Seen from the Buckhollow Encampment, Site 41KM16, of Kimble County, Texas. Office of the State Archeologist Report 38. Texas Department of Transportation and Texas Historical Commission, Austin.

Johnson, L., Jr., and T. N. Campbell

1992 Sanan: Traces of a Previously Unknown Aboriginal Language in Colonial Coahuila and Texas. Plains Anthropologist 37(140):185-212.

Johnson, L., Jr., and G. T. Goode

1994 A New Try at Dating and Characterizing Holocene Climates, as Well as Archeological Periods, on the Eastern Edwards Plateau. Bulletin of the Texas Archeological Society 65:1-51.

Johnson, L., Jr., D. A. Suhm, and C. D. Tunnell

1962 Salvage Archaeology of Canyon Reservoir: The Wunderlich, Footbridge, and Oblate Sites. Bulletin No. 5. Texas Memorial Museum, The University of Texas at Austin.

Johnson, R. L.

1995 Past Cultures and Climates at Jonas Terrace, 41ME29, Medina County, Texas. Report No. 40. Office of the State Archeologist, Texas Historical Commission, Austin.

Jones, W. K.

1969 Notes on the History and Material Culture of the Tonkawa Indians. Smithsonian Contributions to Anthropology 2(5). Smithsonian Institution, Washington, D.C.

Judson, S. and M. E. Kauffman

1990 Physical Geology. Prentice Hall, Englewood Cliffs, New Jersey.

Katz, P. R.

1987 Archaeological Mitigation at 41BX300, Salado Creek Watershed, South-Central Texas.. Archaeological Survey Report, No. 130. Center for Archaeological Research, The University of Texas at San Antonio.

Kelly, D.

1971 Indian Tribes of Texas, edited by D. H. Winfrey. Texian, Waco.

Kelly, T. C.

1992 Two Polyhedral Cores from Comanche Hill, San Antonio, Texas. La Tierra 19:2:29-33.

1993 Preceramic Projectile-Point Typology in Belize. Ancient Mesoamerica 4:205-227.

Kelly, T. C., and T. R. Hester

1976 Archaeological Investigations at Sites in the Upper Cibolo Creek Watershed, Central Texas. Archaeological Survey Report, No. 17. Center for Archaeological Research, The University of Texas at San Antonio. 
Krieger, A. D.

1964 Early Man in the New World. Prehistoric Man in the New World, edited by J. D. Jennings and E. Norbeck, pp 23-81. University of Chicago Press, Chicago.

Lehmann, V. W.

1969 Forgotten Legions. Texas Western, The University of Texas at El Paso.

León, A., J. B. Chapa, and F. S. de Zamora

1961 Historia de Luevo León, con Noticias sobre Cohuila, Tamaulipas, Texas y Nueva México. Estudio Preliminar y Notas de Israel Cavzos Garza. Centrio de Estudios Humanistico. Universidad de Nuevo León, Monterrey.

Lukowski, P. D.

1988 Archaeological Investigations at 41BX1, Bexar County, Texas. Archaeological Survey Report, No. 135. Center for Archaeological Research, The University of Texas at San Antonio.

Machette, M. N.

1985 Calcic Soils of the Southwestern United States. In Soils and Quaternary Geology of the Southwestern United States, edited by D. L. Weide, pp. 1-21. Soc. Am Spec. Pap. 203, Boulder, Colorado.

MacNeish, R. S.

1958 Preliminary Archaeological Investigations in the Sierra de Tamaulipas, Mexico. Transactions of the American Philosophical Society 48(6). American Philosophical Society, Philadelphia.

McAnany, P. A.

1988 The Effects of Lithic Procurement Strategies on Tool Curation and Recycling. Lithic Technology 4:311.

McGraw, A. J.

1977 A Preliminary Archaeological Survey Along The Medio Creek Drainage, Southwestern Bexar County, Texas. Regional Studies, No. 3. Center for Archaeological Research, The University of Texas at San Antonio.

McGraw, A. J., and K. Hindes

1987 Chipped Stone and Adobe: A Cultural Resources Assessment of the Proposed Applewhite Reservoir, Bexar County, Texas. Archeological Survey Report, No. 163. Center for Archeological Research, The University of Texas at San Antonio.

McGraw, A. J., F. Valdez, Jr., and I. W. Cox

1977 Archaeological Survey of Areas Proposed for Modification in the Encino Park Development, Northern Bexar County, Texas. Archaeological Survey Report, No. 39. Center for Archaeological Research, The University of Texas at San Antonio.

McKinney, W. W.

1981 Early Holocene Adaptations in Central and Southern Texas: The Problem of the Paleo-Indian-Archaic Transition. Bulletin of the Texas Archeological Society 52:91-120. 
Mehalchick, G., K. Kleinbach, D. K. Boyd, S. A. Tomka, and K. W. Kibler

1996 National Register Testing of 19 Prehistoric Archeological Sites on Fort Hood, Texas: The 1995 Season. United States Army Fort Hood Archeological Resource Management Series, Research Report No. 37. Prewitt and Associates, Austin.

Meissner, B. A.

1991 Notes on the Excavation of 41BX952. Manuscript on file. Center for Archaeological Research, The University of Texas at San Antonio.

1993 Where the Buffalo Roam: Archaeological Evidence of Bison Populations in South and Central Texas. Manuscript on file. Center for Archaeological Research, The University of Texas at San Antonio.

Meltzer, D. J., and M. R. Bever

1995 Paleoindians of Texas: An Update on the Texas Clovis Fluted Point Survey. Bulletin of the Texas Archeological Society 66:47-81.

Mueggenborg, H. E.

1994 Excavations at the Blue Hole Site, Uvalde County, Texas, 1990. Bulletin of the Texas Archeological Society 62:1-86.

Myers, A.

1989 Reliable and Maintainable Technological Strategies in the Mesolithic of Mainland Britain. In Time, Energy, and Stone Tools, edited by R. Torrence, pp. 78-91. New Directions in Archaeology. Cambridge University Press, Cambridge.

Newman, J. R.

1994 The Effects of Distance on Lithic Material Reduction Technology. Journal of Field Archaeology 21:491501.

Newcomb, W. W., Jr.

1961 The Indians of Texas: From Prehistoric to Modern Times. University of Texas Press, Austin.

1993 The Indians of Texas: From Prehistoric to Modern Times. Second Printing. University of Texas Press, Austin.

Nickels, D. L., D. W. Pease, and C. B. Bousman

1997 Archaeological Survey of Lackland Air Force Base, Bexar County, Texas. Draft manuscript. Archaeological Survey Report, No. 248. Center for Archaeological Research, The University of Texas at San Antonio.

Nordt, L. C.

1992 Archaeological Geology of the Fort Hood Military Reservation, Fort Hood, Texas. United States Army Fort Hood Archaeological Resource Management Series, Research Report Number 25. Texas A\&M University, College Station.

1995 Geoarchaeological Investigations of Henson Creek: A Low-order Tributary in Central Texas. Geoarchaeology 10:205-221. 
Nordt, L. C., T. W. Boutton, J. S. Jacob, and R. Mandel

1994 Late Quaternary Climates of Central Texas Based on the Stable Isotopic Composition of Organic Carbon. Paper presented at the 52nd Plains Conference, 65th Annual Meeting of the Texas Archaeological Society, Lubbock, Texas.

Nordt, L. C., and C. T. Hallmark

1990 Soils-geomorphology Tour Guidebook. Departmental Technical Report 90-7. Department of Soil and Crop Sciences. Texas A\&M University, College Station.

Norusis, M. J.

1993 SPSS for Windows: Base System User's Guide, Release 6.0. SPSS, Chicago.

Odell, G. H.

1994 Prehistoric Hafting and Mobility in the North American Midcontinent: Examples from Illinois. Journal of Anthropological Archaeology 13:51-73.

Patterson, L. W.

1988 Intergroup Conflict in Prehistoric Texas. Houston Archeological Society Journal 90:8-10.

Perttula, T. K., M. R. Miller, R. A. Ricklis, D. J. Prikryl, and C. Lintz

1995 Prehistoric and Historic Aboriginal Ceramics in Texas. Bulletin of the Texas Archeological Society $66: 175-235$.

Peter, D. E.

1982 Alternative Perspectives on Burned Rock Middens. Part V. In Final Draft Report, Archaeological Investigations at the San Gabriel Reservoir Districts, Central Texas, assembled by T. R. Hays, pp. 19.1-19.15. Manuscript on file. Department of Anthropology, Southern Methodist University, Dallas.

Potter, D. R.

1990 Archaeological Survey of the Covel Gardens Landfill Area in San Antonio, Bexar County, Texas. Archaeological Survey Report, No. 202. Center for Archaeological Research, The University of Texas at San Antonio.

Potter, D. R., and S. L. Black

1995a Archeology Along the Wurzbach Parkway: Module 2. Initial Testing and Evaluation of Five Prehistoric Sites in the Upper Salado Watershed, Bexar County, Texas. Studies in Archeology 18. Texas Archeological Research Laboratory, The University of Texas at Austin.

1995b Conceptual Framework. In Archeology Along the Wurzbach Parkway: Module 1. Initial Testing and Evaluation of Five Prehistoric Sites in the Upper Salado Watershed, Bexar County, Texas, edited by D. R. Potter, S. L. Black, and K. Jolly, pp. 19-38. Studies in Archeology 17. Texas Archeological Research Laboratory, The University of Texas at Austin.

Potter, D. R., S. L. Black, and K. Jolly, editors

1995 Archeology Along the Wurzbach Parkway: Module 1. Introduction, Conceptual Framework, and Contexts of Archeological Investigations in Bexar County, South-Central Texas. Studies in Archeology 17. Texas Archeological Research Laboratory, The University of Texas at Austin. 
Poyo, G. E., and G. M. Hinojosa (editors)

1991 Tejano Origins in Eighteenth-Century San Antonio. University of Texas Press, Austin.

Prewitt, E. R.

1974 Archeological Investigations at the Loeve-Fox Site, Williams County, Texas. Research Report 49. Texas Archeological Survey, The University of Texas at Austin.

1981 Cultural Chronology in Central Texas. Bulletin of the Texas Archeological Society 52:65-89.

1982 Archeological Investigations at the Loeve-Fox Site, Williamson County, Texas. Reprints in Archeology, No. 1. Prewitt and Associates, Austin.

1985 From Circleville to Toyah: Comments on Central Texas Chronology. Bulletin of the Texas Archeological Society 54:201-238.

1991 Burned Rock Middens: A Summary of Previous Investigations and Interpretations. In The Burned Rock Middens of Texas: An Archeological Symposium, edited by T. R. Hester, pp. 25-32. Studies in Archeology 13. Texas Archeological Research Laboratory, The University of Texas at Austin.

Quigg, J. M.

1988 Cultural Resources Reconnaissance in Secondary Impact Areas Along Salado Creek at Brooke Army Medical Center, Fort Sam Houston and Camp Bullis, Bexar County, Texas. Technical Reports No. 5. Prewitt and Associates, Austin.

Rector, R. R.

1993 Live Oak Acorn Yield Studies in Relation to Hunter and Gathering Populations in Central Texas. Unpublished Master's thesis on file, Center for Archaeological Research, The University of Texas at San Antonio.

Ricklis, R. A.

1994 Toyah Components: Evidence for Occupation in the Project Area during the Latter Part of the Late Prehistoric. In Archaic and Late Prehistoric Human Ecology in the Middle Onion Creek Valley, Hays County, Texas. Studies in Archeology 19. Texas Archeological Research Laboratory, The University of Texas at Austin.

Robinson, R. L.

1979 Biosilica and Climatic Change at 41GD21 and 41GD21A. In Archaeological Investigations of Two Prehistoric Sites on the Coleto Creek Drainage, Goliad County, Texas, edited by D. E. Fox, pp. 102 113. Archaeological Survey Report, No. 69. Center for Archaeological Research, The University of Texas at San Antonio.

1982 Biosilica Analysis of Three Prehistoric Archaeological Sites in the Choke Canyon Reservoir, Live Oak County, Texas: Preliminary Summary of Climatic Implications. In Archaeological Investigations at Choke Canyon Reservoir, South Texas: The Phase I Findings, edited by G. D. Hall, S. L. Black, and C. Graves, pp. 597-610. Choke Canyon Series, No. 5. Center for Archaeological Research, The University of Texas at San Antonio.

Sellards, E. H.

1940 Pleistocene Artifacts and Associated Fossils from Bee County, Texas. Bulletin of the Geological Society of America 51:1627-1658.

Shafer, H. J.

1970 Notes on Uniface Retouch Technology. American Antiquity 35:480-487. 
1977 Art and Territoriality in the Lower Pecos Region. Plains Anthropologist 22:13-22.

Shafer, H. J. and E. P. Baxter

1975 An Archaeological Survey of the Lignite Project, Atascosa and McMullen Counties, Texas. Anthropology Laboratory Report No. 7. Texas A\&M University, College Station.

Sjoberg, A. F.

1953a The Culture of the Tonkawa, A Texas Indian Tribe. Texas Journal of Science 5(3):280-304.

1953b Lipan Apache Culture in Historical Perspective. Southwestern Journal of Anthropology 9(1):76-98.

Skelton, D. W.

1977 Archeological Investigations at the Fayette Power Project, Fayette County, Texas. Research Report 60. Texas Archeological Survey, The University of Texas at Austin.

Skinner, S. A.

1981 Aboriginal Demographic Changes in Central Texas. Plains Anthropologist 26(92):111-118.

Soil Survey Division Staff

1993 Soil Survey Manual. U.S. Department of Agriculture Handbook Number 18. U.S. Government Printing Press, Washington, D.C.

Sollberger, J., and T. R. Hester

1972 The Strohacker Site: A Review of Pre-Archaic Manifestations in Texas. Plains Anthropologist 17(58):326-344.

Sorrow, W. M., H. J. Shafer, and R. E. Ross

1967 Excavations at Stillhouse Hollow Reservoir. Papers of the Texas Archaeological Salvage Project, No. 11. The University of Texas at Austin.

Stahle, D. W. and M. K. Cleaveland

1995 Texas Paleoclimatic Data from Daily to Millennial Time Scales. In The Changing Climate of Texas: Predictability and Implications for the Future, edited by J. Norwine, J. R. Giardino, G. R. North, and J. B. Valdes, pp. 49-69. GeoBooks, Texas A\&M University, College Station.

Steele, D. G., and C. Assad Hunter

1986 Analysis of Vertebrate Faunal Remains from 41MC222 and 41MC296, McMullen County, Texas. In The Prehistoric Sites at Choke Canyon Reservoir, Southern Texas: Results of Phase II Archaeological Investigations, edited by G. D. Hall, T. R. Hester, and S. L. Black. Choke Canyon Series, No. 10. Center for Archaeological Research, The University of Texas at San Antonio.

Story, D. A.

1985 Adaptive Strategies of Archaic Cultures of the West Gulf Coastal Plain. In Prehistoric Food Production in North America, edited by R. I. Ford, pp. 19-56. Anthropological Papers No. 75. Museum of Anthropology, University of Michigan, Ann Arbor. 
Stothert, K.

1989 The Archaeology and Early History of the Head of the San Antonio River. Special Publication No. 5, Southern Texas Archaeological Association, and Archaeology Series No. 3, Incarnate Word, San Antonio.

Suhm, D. A.

1960 A Review of Central Texas Archaeology. Bulletin of the Texas Archeological Society 28:63-108.

Suhm, D. A., and E. B. Jelks

1962 Handbook of Texas Archeology: Type Descriptions. Special Publications, No. 1, Texas Archeological Society, and Bulletin, No. 4, Texas Memorial Museum, Austin.

Swanton, J. R.

1952 The Indian Tribes of North America. Bulletin 145. Bureau of American Ethnology, Washington, D.C.

Taylor, A. J., and C. L. Highly

1995 Archaeological Investigations at the Loma Sandia Site (41LK28): A Prehistoric Campsite in Live Oak County, Texas. 2 volumes. Studies in Archeology No. 20. Texas Archeological Research Laboratory, The University of Texas at Austin.

Taylor, F. B., R. B. Hailey, and D. L. Richmond

1991 Soil Survey of Bexar County, Texas. Soil Conservation Service, U.S. Department of Agriculture, Washington, D.C.

Tennis, C. L.

1996 Archaic Land Use of Upper Leon Creek Terraces: Archaeological Testing in Northern Bexar County, Texas. Archaeological Survey Report, No. 234. Center for Archaeological Research, The University of Texas at San Antonio.

Tennis, C. L., and R. J. Hard

1995 Archaeological Survey of the Upper Leon Creek Terraces, Bexar County, Texas. Archaeological Survey Report, No. 233. Center for Archaeological Research, The University of Texas at San Antonio.

Thoms, A. V.

1992 Late Pleistocene and Early Holocene Regional Land Use Patterns: A Perspective from the Preliminary Results of Archaeological Studies at the Richard Beene Site, 41BX831, Lower Medina River, South Texas. In Late Cenozoic Alluvial Stratigraphy and Prehistory of the Inner Gulf Coast Plain, SouthCentral Texas. Series No. 4. Lubbock Lake Quaternary Research Center . Lubbock, Texas.

Thoms, A. V., D. D. Keuhn, B. W. Olive, J. E. Dockall, P. A. Clabaugh, and R. D. Mandel

1996 Early and Middle Holocene Occupations at the Richard Beene Site: The 1995 Southern Texas Archaeological Association Field School Project. La Tierra (23)4:1-36.

Thonhoff, R. H.

1985 Forgotten Battlefield of the First Texas Revolution: The Battle of Medina. Eakin, Austin. 
Toomey, R. S., M. D. Blum, and S. Valastro, Jr.

1993 Late Quaternary Climates and Environments of the Edwards Plateau, Texas. Global and Planetary Change 7:299-320.

Tomka, S. A., and R. C. Fields

1990 Chipped Stone Artifacts, 41LN29A and 41LN106. In Investigations at the Charles Cox, Lambs Creek Knoll, and Buffalo Branch Sites, Jewett Mine Project, Leon and Freestone Counties, Texas, Volume 1, edited by R. C. Fields, pp. 141-287. Reports of Investigations No. 70. Prewitt and Associated, Austin, Texas.

Toomey, R. S., and T. W. Stafford, Jr.

1994 Paleoenvironmental and Radiocarbon Study of the Deposits from Hall's Cave, Kerr County, Texas. Paper presented at the 52nd Plains Conference, 65th Annual Meeting of the Texas Archaeological Society. Lubbock, Texas.

Torrence, $\mathrm{R}$.

1989 Re-tooling: Towards a Behavioral Theory of Stone Tools. In Time, Energy, and Stone Tools, edited by R. Torrence, pp. 57-66. New Directions in Archaeology. Cambridge University Press, Cambridge.

Turner, E. S., and T. R. Hester

1993 A Field Guide to Stone Artifacts of Texas Indians. Second Edition. Texas Monthly Field Guide Series. Gulf, Houston.

Tyler, R. (editor)

1996 The New Handbook of Texas. Six volumes. The Texas State Historical Association, Austin.

Van Auken, O. W.

1988 Woody Vegetation of the Southern Escarpment and Plateau. In Edwards Plateau Vegetation: Plant Ecological Studies in Central Texas, edited by B. B. Amos and F. R. Geilbach, pp. 43-55. Baylor University Press, Waco, Texas.

1993 Size Distribution Patterns and Potential Population Change of Some Dominant Woody Species of the Edwards Plateau Region of Texas. The Texas Journal of Science 45(3):199-210.

Van Auken, O. W., and J. K. Bush

1988 Dynamics of Establishment, Growth, and Development of Black Willow and Cottonwood in the San Antonio River Forest. The Texas Journal of Science 40 (3):269-277.

Waters, M. R.

1992 Principles of Geoarchaeology: A North American Perspective. University of Arizona Press, Waco, Texas.

Weir, F.

1976 The Central Texas Archaic. Unpublished Ph.D. dissertation. Department of Anthropology, Washington State University, Pullman.

Wenke, R. J.

1990 Patterns in Prehistory: Humankind's First Three Million Years. 3rd Edition. Oxford University Press, Oxford, England. 
West, E. H. (translator)

1904 A Brief Compendium of the Events Which Have Occurred in the Province of Texas from its Conquest, or Reduction to the Present Day, Written by Antonio Bonilla in 1772. Quarterly of the Texas State Historical Association VIII(1):1-78.

Wood, C. E., and J. K. Wood

1988 Woody Vegetation of the Frio River Riparian Forest, Texas. The Texas Journal of Science 40(3):310 321.

1989 Riparian Forests of the Leona and Sabinal Rivers. The Texas Journal of Science 41(4):395-411. 


\section{Appendix A: Soil-Stratigraphic Descriptions}

\section{Lee C. Nordt}

\section{Uplands}

\section{Test Unit (TU) N969 E999; Site 41BX1088-Area 1}

Upland surface (High); Cretaceous; $26 \mathrm{~m}$ above the modern low-water channel; Uvalde gravel and Early Archaic to Late Prehistoric points on surface; calcareous throughout.

A $\quad 0-22 \mathrm{~cm} \quad$ black (10YR 2/1) clay loam; moderate fine subangular blocky; very hard; $5 \%$ matrixsupported pebbles, 1 to $4 \mathrm{~cm}$ diameter in upper half, moderately well sorted, subrounded; gradual smooth boundary

Bw1 22-43 cm very dark gray (10YR 3/1) clay loam; moderate medium angular blocky; very hard; $1 \%$ matrix-supported pebbles, 1 to $2 \mathrm{~cm}$ diameter; $3 \%$ light yellowish brown $(2.5 \mathrm{Y} 6 / 4)$ biocasts; clear smooth boundary

Bw2 43-61 cm dark grayish brown (2.5Y 4/2) clay loam; weak medium angular blocky; very hard; $15 \%$ very dark gray (10YR 3/1) biocasts; gradual smooth boundary

Bk 61-74 cm grayish brown (2.5Y 5/2) and light yellowish brown (2.5Y 6/4) loam; weak coarse angular blocky; very hard; $15 \%$ soft calcium carbonate nodules, some disseminated; clear wavy boundary

BCk $\quad 74-93 \mathrm{~cm} \quad$ light yellowish brown (2.5Y 6/4) and pale yellow (2.5Y 7/4) loam; moderate medium platy to angular blocky; very hard; $2 \%$ soft calcium carbonate nodules, 0.3 to $0.5 \mathrm{~cm}$ diameter

Test Unit (TU) N1030 E997; Site 41BX1088-Area 2

Upland surface (High); Cretaceous; $21 \mathrm{~m}$ above the modern low-water channel; calcareous throughout.

A $\quad 0-19 \mathrm{~cm} \quad$ black (10YR 2/1) clay; moderate fine subangular blocky; very hard; 6 to $8 \%$ matrixsupported pebbles, 2 to $6 \mathrm{~cm}$ diameter; clear smooth boundary

Bw $\quad 19-38 \mathrm{~cm} \quad$ black (10YR 2/1) clay; moderate medium prismatic; very hard; $5 \%$ matrix-supported pebbles, 1 to $5 \mathrm{~cm}$ diameter, subrounded; gradual smooth boundary

Bss $\quad 38-67 \mathrm{~cm} \quad$ very dark gray (10YR 3/1) clay; 8\% light olive brown (2.5Y 5/4) biocasts; moderate coarse angular blocky; very hard; common distinct slickensides; clear smooth boundary

Bssk $\quad 67-84 \mathrm{~cm} \quad$ light olive brown (2.5Y 5/4) clay; 5\% black (10YR 2/1) vertical streaks; moderate coarse angular blocky; very hard; $8 \%$ soft calcium carbonate nodules, 0.3 to $0.5 \mathrm{~cm}$ diameter; common distinct slickensides 
Upland surface (Intermediate); $18 \mathrm{~m}$ above the modern low-water channel; calcareous throughout; all pebbles have a 2 to $7 \mathrm{~mm}$ thick calcium carbonate rind; the Bkm horizon undulates.

South Wall

A1 $\quad 0-12 \mathrm{~cm} \quad$ very dark gray (10YR 3/1) clay loam; moderate fine subangular blocky; very hard; 15 to $20 \%$ matrix-supported pebbles, 0.5 to $3 \mathrm{~cm}$ diameter, poorly sorted, subrounded; clear wavy boundary

A2 $\quad 12-29 \mathrm{~cm}$ black (10YR 2/1) clay loam; moderate fine subangular blocky; 15 to $20 \%$ matrix-supported pebbles, 0.5 to $3 \mathrm{~cm}$ diameter, poorly sorted, subrounded; gradual smooth boundary

$\mathrm{Bw} \quad 29-55 \mathrm{~cm} \quad$ very dark gray (10YR 3/1) clay loam; moderate medium subangular blocky; hard; 15 to $20 \%$ matrix-supported pebbles, 0.5 to $3 \mathrm{~cm}$ diameter, poorly sorted, subrounded; gradual wavy boundary

$\mathrm{Bk} \quad 55-72 \mathrm{~cm} \quad$ very dark gray (10YR 3/1) clay loam; 15 to $20 \%$ matrix-supported pebbles, 0.5 to $3 \mathrm{~cm}$ diameter, poorly sorted, subrounded; $3 \%$ calcium carbonate filaments

North Wall

A1 $\quad 0-3 \mathrm{~cm}$

black (10YR 2/1) loam; single grained; $10 \%$ matrix-supported pebbles, 0.4 to $2 \mathrm{~cm}$ diameter, poorly sorted, subrounded; calcareous; clear wavy boundary

A2 3-14 cm black (10YR 2/1) clay loam; moderate fine subangular blocky; very hard; .5\% matrixsupported pebbles, 0.2 to $4 \mathrm{~cm}$ diameter, poorly sorted, subrounded; calcareous; clear wavy boundary

Bw 14-35 cm very dark gray (10YR 3/1) clay loam; moderate fine subangular blocky; very hard; $30 \%$ matrix-supported pebbles, 0.4 to $4 \mathrm{~cm}$ diameter, poorly sorted, subrounded; calcareous; abrupt wavy boundary

$\mathrm{Bkm} \quad 35-55 \mathrm{~cm} \quad$ indurated calcium carbonate with a $4 \mathrm{~cm}$ thick laminar cap

Test Unit (TU) N1020 E994; Site 41BX1114

Upland surface (Intermediate); $18 \mathrm{~m}$ above the modern low-water channel; very weakly calcareous throughout.

A1 $\quad 0-24 \mathrm{~cm} \quad$ black (10YR 2/1) clay loam; strong fine subangular blocky; firm; $60 \%$ matrix-supported pebbles and cobbles, $1-10 \mathrm{~cm}$ diameter, poorly sorted, subrounded; animal bone and Late Prehistoric ceramics from a depth of 10 to $20 \mathrm{~cm}$; clear wavy boundary

A2 24-47 cm very dark brown (10YR 2/2) clay loam; strong medium subangular blocky; firm; $60 \%$ matrix-supported pebbles and cobbles, $1-10 \mathrm{~cm}$ diameter, poorly sorted, subrounded; clear wavy boundary

Bt $\quad 47-55 \mathrm{~cm}$ dark reddish brown (5YR 3/3) clay 
Test Unit (TU) N980 E1000; Site 41BX1090

Upland surface (Intermediate); $14 \mathrm{~m}$ above modern low-water channel; calcareous throughout; abbreviated description.

A $\quad 0-40 \mathrm{~cm} \quad$ very dark grayish brown (10YR 3/2) clay; moderate medium angular blocky; very hard; $5 \%$ matrix-supported pebbles, 1 to $4 \mathrm{~cm}$ diameter; gradual smooth boundary

Bss $\quad 50-60 \mathrm{~cm} \quad$ very dark grayish brown (10YR 3/2) clay; some color mottling; moderate medium angular blocky; very hard; common distinct slickensides; $5 \%$ matrix-supported pebbles, 1 to $4 \mathrm{~cm}$ diameter

Bssk $\quad 60 \mathrm{~cm} \quad$ common calcium carbonate nodules and slickensides

Test Unit (TU) N1156 E1038; Site 41BX1088-Area 3

Upland surface (Low); Cretaceous; $20 \mathrm{~m}$ above the modern low-water channel; calcareous throughout.

A $\quad 0-20 \mathrm{~cm} \quad$ black (2/1) clay; moderate medium subangular blocky; very hard; 5\% matrix-supported pebbles, 1 to $8 \mathrm{~cm}$ diameter; clear wavy boundary

$\mathrm{Bw} \quad 20-40 \mathrm{~cm}$ (laterally discontinuous) black (10YR 2/1) clay; moderate medium angular blocky; very hard; $50 \%$ matrix- and grain-supported pebbles and cobbles, 1 to $8 \mathrm{~cm}$ diameter, poorly sorted, subrounded; clear wavy boundary

Bss $\quad 40-78 \mathrm{~cm} \quad$ very dark gray (2.5Y 3/1) clay; 3\% dark grayish brown (2.5Y 4/2) and black (10YR $2 /$ 1) biocasts; moderate medium angular blocky; very hard; $5 \%$ matrix-supported pebbles, 1 to $3 \mathrm{~cm}$ diameter, subrounded; many prominent slickensides; gradual wavy boundary

Bssk $\quad 78-88 \mathrm{~cm} \quad$ very dark grayish brown (2.5Y 3/2) clay; weak coarse prismatic; very hard; $2 \%$ pockets of matrix-supported pebbles, 1 to $5 \mathrm{~cm}$ diameter, subrounded; $7 \%$ calcium carbonate nodules, 0.3 to $0.5 \mathrm{~cm}$ diameter

\section{BHT 1}

Upland surface (Low); Cretaceous; $6 \mathrm{~m}$ above the modern low-water channel; calcareous throughout.

A $\quad 0-25 \mathrm{~cm} \quad$ black (10YR 2.5/1) clay; moderate medium subangular blocky; very firm; $2 \%$ matrixsupported pebbles, 0.3 to $1 \mathrm{~cm}$ diameter; gradual smooth boundary

Bssk1 25-61 cm very dark gray (2.5Y 3/1) clay; weak coarse angular blocky; extremely firm; 3 to $4 \%$ matrix-supported pebbles, 0.5 to $1.5 \mathrm{~cm}$ diameter, angular; $1 \%$ calcium carbonate nodules, $0.5 \mathrm{~cm}$ diameter; few distinct slickensides; gradual smooth boundary

Bssk2 $61-89 \mathrm{~cm} \quad$ very dark gray (2.5Y 3/1) and light olive brown (2.5Y 5/4) clay; weak coarse angular blocky; extremely firm; 1 to $2 \%$ matrix-supported pebbles, 0.3 to $0.8 \mathrm{~cm}$ diameter; $1 \%$ calcium carbonate nodules, $0.5 \mathrm{~cm}$ diameter; few distinct slickensides; gradual smooth boundary

Bssk3 89-124 cm olive (5Y 4/3) clay; 15\% light olive brown (2.5Y 5/4) and 10\% very dark gray (2.5 3/1); weak coarse angular blocky; extremely firm; few slickensides; $1 \%$ calcium carbonate nodules; abrupt smooth boundary

$\mathrm{Cr} \quad 124-146+\mathrm{cm}$ fossiliferous olive yellow and reddish brown clay loam 
BHT 2

Upland surface (Low); Cretaceous; $6 \mathrm{~m}$ above the modern low-water channel; calcareous throughout.

A $\quad 0-25 \mathrm{~cm} \quad$ very dark gray (2.5Y 3/1) clay; moderate medium subangular blocky; friable; $1 \%$ matrix-supported pebbles, 0.3 to $0.5 \mathrm{~cm}$ diameter; clear smooth boundary

C/B $\quad 25-41 \mathrm{~cm} \quad$ olive brown (2.5Y 4/4) clay with 50\% very dark grayish brown (2.5Y 3/2); $25 \%$ matrixsupported fossiliferous pebbles, 0.3 to $1 \mathrm{~cm}$ diameter; clear smooth boundary

$\mathrm{Cr} \quad 41-72 \mathrm{~cm} \quad$ olive, yellow and orange fossiliferous clay loam

BHT A; Site 41BX1070

Upland surface (Intermediate); Holocene colluvium over Cretaceous; calcareous throughout.

A1 $\quad 0-14 \mathrm{~cm}$ (colluvium); very dark grayish brown (10YR 3/2) clay loam; moderate medium subangular blocky; very hard; $5 \%$ matrix-supported pebbles, 1 to $8 \mathrm{~cm}$ diameter, subrounded, commonly on surface; clear smooth boundary

A2 14-44 cm (colluvium); very dark gray (10YR 3.5/1) clay; moderate coarse angular blocky; very hard; $2 \%$ matrix-supported pebbles, 1 to $2 \mathrm{~cm}$ diameter, subrounded; gradual smooth boundary

Bss $\quad 44-70 \mathrm{~cm} \quad$ (colluvium); very dark gray (10YR 3/1) and light olive brown (2.5Y 5/3) clay; moderate medium angular blocky; very hard; common distinct slickensides; $4 \%$ matrix-supported pebbles, 0.5 to $2 \mathrm{~cm}$ diameter, poorly sorted, subrounded; abrupt wavy boundary

C $\quad 70-108 \mathrm{~cm}$ (colluvium) very dark gray (10YR 3/1) and brown (2.5Y 5/3); 60\% grain-supported pebbles and cobbles, 0.5 to $12 \mathrm{~cm}$ diameter, poorly sorted, subrounded; abrupt wavy boundary

$\mathrm{Cr} \quad 108-112 \mathrm{~cm}$ (Cretaceous); olive (5Y 5/3) shale; massive; very hard; $2 \%$ white and soft calcium carbonate nodules

\section{BHT G; Site 41BX1114}

Upland surface (Intermediate); Holocene colluvium over Cretaceous; $15 \mathrm{~m}$ above the modern low-water channel; calcareous throughout.

A1 $\quad 0-18 \mathrm{~cm} \quad$ (colluvium); black (10YR 2/1) clay loam; strong fine subangular blocky; very hard; $20 \%$ matrix-supported pebbles, 0.5 to $4 \mathrm{~cm}$ diameter, poorly sorted, subrounded; gradual smooth boundary

A2 18-35 cm (colluvium); very dark gray (10YR 3/1) clay loam; moderate fine subangular blocky; very hard; $20 \%$ matrix-supported pebbles, 0.5 to $4 \mathrm{~cm}$ diameter, poorly sorted, subrounded; gradual clear boundary

C 35-66 cm (colluvium); olive brown (2.5Y 4/3) clay loam; weak coarse prismatic; extremely hard; $50 \%$ matrix and some grain-supported pebbles and cobbles, 0.5 to $8 \mathrm{~cm}$ diameter, poorly sorted, subrounded; some pebbles covered with calcium carbonate coats (relict), layer thins downslope; abrupt wavy

$\mathrm{Cr} \quad 66-152 \mathrm{~cm}$ (Cretaceous); light olive brown (2.5Y 5/4) clay; 10\% very dark gray (10YR 3/1) pockets; $5 \%$ distinct light olive brown (2.5Y 5/6) soft iron masses; few pockets of soft and white calcium carbonate nodules, 1 to $2 \mathrm{~cm}$ diameter 


\section{Medio Creek}

\section{BHT 3}

T0 flood plain; Unit IV; 2 to $2.5 \mathrm{~m}$ above the modern low-water channel; calcareous throughout.

Al $\quad 0-11 \mathrm{~cm} \quad$ very dark grayish brown (10YR 3/2) silty clay loam; firm; clear smooth boundary

A2 11-25 cm very dark gray (10YR 3/1) silty clay; weak medium angular blocky; very firm; gradual smooth boundary

Bw 25-55 cm dark grayish brown (2.5Y 3/2) silty clay; weak coarse prismatic; extremely firm; abrupt smooth boundary

C $\quad 55-68 \mathrm{~cm} \quad$ olive (2.5Y 5/3) and yellowish brown (10YR 5/4) clay loam; 30 to $35 \%$ grain-supported pebbles, 0.3 to $1.5 \mathrm{~cm}$ diameter, subrounded, poorly sorted; common shale clasts; abrupt smooth boundary

Ab1 $\quad 68-87 \mathrm{~cm} \quad$ very dark gray $(2.5 \mathrm{Y} 3 / 1)$ clay; weak coarse angular blocky; extremely firm; $20 \%$ grainsupported pebbles, 0.5 to $6 \mathrm{~cm}$ diameter, subrounded, poorly sorted; clear smooth boundary

Cbl 87-148 cm dark grayish brown (2.5Y 4/2) clay loam; $10 \%$ olive (5Y 5/3); 30 to $40 \%$ matrix-supported pebbles, 0.3 to $1.5 \mathrm{~cm}$ diameter, subrounded, poorly sorted; common shale clasts; clear smooth boundary

Agb2 148-168 cm dark grayish brown (2.5Y 4/2) clay with 5\% light olive brown (2.5Y 5/3) and few bluish gray (5B 6/1) redox depletions; weak coarse angular blocky; extremely firm; $1 \%$ matrixsupported pebbles, 0.5 to $1 \mathrm{~cm}$ diameter; clear smooth boundary (carbon-14 age of $1220 \pm 70$, Beta 90717)

Cgb2 168-188 cm bluish gray (5B 5/1) clay loam; common distinct light olive brown (2.5Y 5/4) soft iron masses; $20 \%$ grain-supported pebbles, 0.3 to $3 \mathrm{~cm}$ diameter, poorly sorted, subrounded; water table at $170 \mathrm{~cm}$

\section{BHT 4}

T1 flood terrace; unit $\mathrm{m} ; 4 \mathrm{~m}$ above the modern low-water channel; calcareous throughout.

A1 $\quad 0-11 \mathrm{~cm} \quad$ very dark gray (2.5Y 3/1) silty clay loam; moderate fine subangular blocky; firm; few fine matrix-supported pebbles; clear smooth boundary

A2 11-29 cm black (10YR 2/1) clay loam; moderate medium subangular; firm; 15\% matrix-supported pebbles, 0.5 to $1.5 \mathrm{~cm}$ diameter, subrounded, moderately well sorted; gradual smooth boundary

Bw 29-71 cm very dark gray (10YR 3/1) clay; weak coarse prismatic; extremely firm; $2 \%$ matrixsupported pebbles, 0.2 to $2 \mathrm{~cm}$ diameter, subrounded; abrupt smooth boundary

C $\quad 71-89 \mathrm{~cm}$ dark grayish brown (2.5Y 4/2) clay; massive; extremely firm; $15 \%$ pebbles, 0.2 to $4 \mathrm{~cm}$ diameter, poorly sorted, subrounded; abrupt smooth boundary

$\mathrm{Ab} \quad 89-102 \mathrm{~cm}$ grayish brown (2.5Y 5/2) clay loam; common distinct light yellowish brown (2.5Y 6/3) and few distinct orange soft iron concentrations; weak coarse angular blocky; extremely firm; $1 \%$ matrix-supported pebbles, 0.2 to $1 \mathrm{~cm}$ diameter; abrupt smooth boundary (carbon-14 age of $1830 \pm 70$, Beta 90718) 
$\mathrm{Bkb} \quad 102-109 \mathrm{~cm}$ light brownish gray (2.5Y 6/2) silty clay loam; few distinct dark yellowish brown (10YR 4/6) soft iron masses; $5 \%$ matrix-supported pebbles, 0.2 to $1 \mathrm{~cm}$ diameter; weak coarse angular blocky; very firm; 1 to $2 \%$ white and soft calcium carbonate nodules, $0.5 \mathrm{~cm}$ diameter; common shale fragments; abrupt smooth boundary

Clb 109-161 cm grayish brown (2.5Y 5/2), light olive brown (2.5Y 5/6), and dark yellowish brown (10YR $3 / 6$ ); $60 \%$ grain-supported pebbles, 0.5 to $3 \mathrm{~cm}$ diameter, moderately well sorted, subrounded; abrupt wavy boundary

C2b 161-295 cm pale olive (5Y 6/3) clay loam with common distinct brown soft iron masses; 15 to $20 \%$ matrix-supported pebbles, 0.2 to $1 \mathrm{~cm}$ diameter; $1 \%$ white and soft calcium carbonate nodules, $1 \mathrm{~cm}$ diameter; down to $295 \mathrm{~cm}$ cobbles increase in diameter to $10 \mathrm{~cm}$ water table at $295 \mathrm{~cm}$

\section{BHT 5}

T0 flood plain; Unit IV; $2.5 \mathrm{~m}$ above the modern low-water channel; calcareous throughout.

Al $\quad 0-20 \mathrm{~cm} \quad$ very dark gray (2.5Y 2.5/1) silty clay; moderate fine subangular blocky; firm; few fine matrix-supported pebbles; clear smooth boundary

A2 20-48 cm very dark grayish brown (10YR 3/2) clay; weak coarse angular blocky; very firm; $25 \%$ matrix-supported pebbles, 0.5 to $1.5 \mathrm{~cm}$ diameter, moderately well sorted, subrounded; clear smooth boundary

Bg $\quad 48-58 \mathrm{~cm} \quad$ grayish brown (10YR 5/2) clay; weak coarse angular blocky; very firm; 2 to $3 \%$ matrixsupported pebbles, 0.5 to $1.5 \mathrm{~cm}$ diameter, moderately well sorted, subrounded; clear smooth boundary

Bkg $\quad 58-81 \mathrm{~cm} \quad$ gray (2.5Y 6/1) clay loam; common distinct olive yellow (2.5Y 5/6) soft iron masses; moderate coarse angular blocky; very firm; $1 \%$ white and soft calcium carbonate nodules, $1 \mathrm{~cm}$ diameter; abrupt wavy boundary

$\mathrm{Ab} \quad 81-95 \mathrm{~cm}$ dark gray (2.5Y 4/1) clay loam; massive; $40 \%$ matrix-supported pebbles, 0.5 to $6 \mathrm{~cm}$ diameter, poorly sorted, subrounded; abrupt wavy boundary

Bkgb 95-120 cm gray (2.5Y 6/1) clay loam; common distinct light olive brown (2.5Y 5/6) soft iron masses; weak coarse prismatic; extremely firm; $1 \%$ white and soft calcium carbonate nodules, 1 cm diameter; common shale clasts

\section{BHT 6}

T0 flood plain; Unit IV; 2.5 to $3 \mathrm{~m}$ above the modern low-water channel; Calcareous throughout.

A1 $\quad 0-11 \mathrm{~cm} \quad$ very dark grayish brown (10YR 3/2) silty clay loam; moderate medium subangular blocky; very firm; clear smooth boundary

A2 11-30 cm very dark gray (10YR 2.5/1) silty clay; weak coarse angular blocky; extremely firm; $2 \%$ matrix-supported pebbles, 0.2 to $1 \mathrm{~cm}$ diameter; clear smooth boundary

A3 $\quad 30-52 \mathrm{~cm} \quad$ very dark gray (10YR 2.5/1) silty clay; weak coarse angular blocky; very firm; 5 to $8 \%$ matrix-supported pebbles, 0.2 to $1 \mathrm{~cm}$ diameter; clear smooth boundary

C $\quad 52-70 \mathrm{~cm}$ dark gray (2.5Y 5/1) clay loam; massive; very firm; 5 to $8 \%$ matrix-supported pebbles, 0.2 to $1.5 \mathrm{~cm}$ diameter, moderately well sorted, subrounded; abrupt smooth 
Ab1 $\quad 70-82 \mathrm{~cm}$ dark gray (2.5Y 4/2) silty clay loam; weak coarse prismatic; very firm; $2 \%$ matrixsupported pebbles, 0.2 to $1 \mathrm{~cm}$ diameter, gravel line at top; abrupt wavy boundary

Bgb1 82-115 cm light olive gray (5Y 6/2) silty clay loam; few patches of olive gray (2.5Y 4/2) and olive (5Y 5/6); weak coarse prismatic; very firm; $1 \%$ matrix-supported pebbles, 0.2 to $1 \mathrm{~cm}$ diameter; poorly sorted; common shale clasts; abrupt wavy boundary

Ab2 115-130 cm very dark grayish brown (10YR 3.5/2) silty clay loam; weak coarse prismatic; very firm; $5 \%$ matrix-supported pebbles, 0.2 to $1 \mathrm{~cm}$ diameter; poorly sorted; abrupt wavy boundary

Cb2 130-152 cm dark grayish brown (2.5Y 4/2) clay loam; 60\% grain-supported pebbles, 0.5 to $5 \mathrm{~cm}$ diameter, moderately well sorted, subrounded

\section{BHT 7}

T1 flood terrace; Unit II; 4 to $5 \mathrm{~m}$ above the modern low-water channel. Calcareous throughout.

A $\quad 0-22 \mathrm{~cm} \quad$ black (10YR 2/1) silty clay loam; moderate medium angular blocky; very firm; $2 \%$ matrix-supported pebbles, 0.5 to $1 \mathrm{~cm}$ diameter, subrounded; gradual smooth boundary

Bw $\quad 22-49 \mathrm{~cm} \quad$ very dark grayish brown (10YR 3/2) silty clay loam; weak coarse prismatic; very firm; 3 to $4 \%$ matrix-supported pebbles, 0.2 to $1 \mathrm{~cm}$ diameter; abrupt smooth boundary

Bk1 49-79 cm dark yellowish brown (10YR 4/4); 60\% grain-supported pebbles, 1 to $2 \mathrm{~cm}$ diameter, moderately well sorted; $1-2 \%$ calcium carbonate filaments on gravel bottoms; clear smooth boundary

Bk2 79-111 cm yellowish brown (10YR 5/4); 70\% grain-supported pebbles and cobbles, 0.5 to $7 \mathrm{~cm}$ diameter, poorly sorted, subrounded; $2 \%$ calcium carbonate filaments on gravel bottoms up to $3 \mathrm{~mm}$ thick; clear smooth boundary

Bk3 111-170 cm gray (10YR 5/1) and yellowish brown (10YR 5/6); 70\% grain-supported pebbles and cobbles, 0.5 to $7 \mathrm{~cm}$ diameter, poorly sorted, subrounded; nearly continuous coating of calcium carbonate pendants on gravel bottoms up to $3 \mathrm{~mm}$ thick

\section{BHT 8}

T2 terrace; Unit I; 7 to $8 \mathrm{~m}$ above the modern low-water channel.

A1 $\quad 0-10 \mathrm{~cm} \quad$ black (10YR 2/1) silty clay loam; moderate fine subangular blocky; friable; $1 \%$ matrixsupported pebbles, $1 \mathrm{~cm}$ diameter; noncalcareous; gradual smooth boundary

A2 10-18 cm black (10YR 2/1) silty clay; weak coarse angular blocky; very firm; occasional $1 \mathrm{~cm}$ diameter pebble; moderately effervescent; gradual smooth boundary

$\mathrm{AB} \quad 18-45 \mathrm{~cm} \quad$ very dark grayish brown (10YR 3/2) silty clay; weak coarse angular blocky; very firm; $2 \%$ matrix-supported pebbles, 0.2 to $1 \mathrm{~cm}$ diameter; gradual smooth; calcareous; gradual smooth boundary

Bss $\quad 45-83 \mathrm{~cm} \quad$ very dark grayish brown (10YR 3/2) silty clay; $30 \%$ infills of olive brown (2.5Y 4/3) and $30 \%$ black (10YR $2 / 1$ ) vertical streaks; 2 to $3 \%$ matrix-supported pebbles, 0.5 to 1 $\mathrm{cm}$ diameter; weak coarse angular blocky; very firm; few slickensides; calcareous; gradual smooth boundary 
Bssk 83-109 cm brown (10YR 5/3) silty clay; 30\% very dark grayish brown (10YR 3/2) vertical streaks; 2 to $3 \%$ matrix-supported pebbles, 0.5 to $1 \mathrm{~cm}$ diameter; weak coarse angular blocky; very firm; common slickensides; $1 \%$ calcium carbonate nodules, $0.5 \mathrm{~cm}$ diameter; calcareous; gradual smooth boundary

Bkl 109-130 cm brownish yellow (10YR 6/6) and olive brown (2.5Y 5/3) clay; 6 to $8 \%$ matrix-supported pebbles, 0.5 to $1 \mathrm{~cm}$ diameter; weak coarse prismatic; firm; $2 \%$ calcium carbonate nodules, $0.5 \mathrm{~cm}$ diameter; calcareous; gradual smooth boundary

Bk2 130-181 cm brownish yellow (10YR 6/6) silty clay loam; 5\% olive brown (2.5Y 5/3) and very dark grayish brown (10YR 3/2) vertical streaks; weak coarse prismatic; firm; 6 to $8 \%$ matrixsupported pebbles, 0.5 to $1 \mathrm{~cm}$ diameter; 8 to $10 \%$ brittle and white calcium carbonate nodules, 0.5 to $1 \mathrm{~cm}$ diameter; calcareous; clear smooth boundary

Bk3 181-190 cm yellowish brown (10YR 5/6) silty clay loam; weak coarse prismatic; very firm; $5 \%$ soft and white calcium carbonate nodules, 0.5 to $1 \mathrm{~cm}$ diameter; calcareous

\section{BHT 9}

T1 flood terrace; Unit III over Unit II; 4 to $5 \mathrm{~m}$ above the modern low-water channel; calcareous throughout.

A $\quad 0-21 \mathrm{~cm} \quad$ (Unit III); clay loam; moderate coarse subangular blocky; very firm; 1\% matrix-supported pebbles, 0.2 to $0.7 \mathrm{~cm}$ diameter; gradual smooth boundary

Bw 21-63 cm (Unit III); clay loam; weak coarse angular blocky; very firm; 1\% matrix-supported pebbles, 0.2 to $0.7 \mathrm{~cm}$ diameter; abrupt smooth boundary

Ck 63-106 cm (Unit III); 70\% grain-supported pebbles, 1 to $5 \mathrm{~cm}$ diameter, moderately well sorted, subrounded; $1 \%$ calcium carbonate filaments on gravel bottoms; abrupt smooth boundary

Bklb 106-149 cm (Unit II); clay; weak coarse prismatic; extremely firm; 1\% matrix-supported pebbles, $0.5 \mathrm{~cm}$ diameter; $8 \%$ white and soft calcium carbonate nodules, $0.5 \mathrm{~cm}$ diameter; clear smooth boundary (carbon-14 age of $4890 \pm 80$, Beta 90719 , from 120 to $130 \mathrm{~cm}$ )

Bk2b 149-180 cm (Unit II); clay loam; weak coarse prismatic extremely firm; 10 to 12\% white and soft calcium carbonate nodules, $1 \mathrm{~cm}$ diameter

\section{BHT 10}

T0 flood plain; Unit IV; 2 to $2.5 \mathrm{~m}$ above the modern low-water channel; calcareous throughout.

A1 $\quad 0-10 \mathrm{~cm} \quad$ black (10YR 2/1) silty clay; moderate fine subangular blocky; friable; 1 to $2 \%$ matrixsupported pebbles, $0.5 \mathrm{~cm}$ diameter; clear smooth boundary

A2 $\quad 10-30 \mathrm{~cm} \quad$ black (10YR 2.5/1) silty clay loam; moderate medium subangular blocky; friable; $30 \%$ matrix-supported pebbles, 0.5 to $2 \mathrm{~cm}$ diameter, moderately well sorted; clear wavy boundary

Bw $\quad 30-50 \mathrm{~cm} \quad$ very dark gray (10YR 3/1) silty clay; weak medium subangular blocky; friable; $60 \%$ grain-supported pebbles and cobbles, 0.5 to $8 \mathrm{~cm}$ diameter, poorly to moderately well sorted; abrupt smooth boundary 
Ab1 50-68 cm very dark grayish brown (2.5Y 3/2) clay; 5\% patches of olive brown (2.5Y 4/4); moderate coarse angular blocky; firm; $1 \%$ matrix-supported pebbles, 0.2 to $1 \mathrm{~cm}$ diameter; gradual smooth boundary

Bgb1 $68-86 \mathrm{~cm} \quad$ very dark grayish brown (2.5Y 3.5/2) clay; weak coarse angular blocky; very firm; 5 to $8 \%$ matrix-supported pebbles, 0.5 to $3 \mathrm{~cm}$ diameter; $1 \%$ calcium carbonate filaments; clear smooth boundary

Cb1 $\quad 86-99 \mathrm{~cm} \quad$ olive brown $(2.5 \mathrm{Y} 4 / 4) ; 70 \%$ grain-supported pebbles, 0.5 to $3 \mathrm{~cm}$ diameter; abrupt smooth boundary

Akb2 99-118 cm very dark grayish brown (2.5Y 3/2) clay; weak coarse angular blocky; very firm; 6 to $8 \%$ matrix-supported pebbles, $0.5 \mathrm{~cm}$ diameter; $5 \%$ white and brittle calcium carbonate nodules, 0.2 to 0.5 diameter; gradual smooth boundary (carbon-14 age of $1780 \pm 90$, Beta 90720)

Bgb2 118-162 cm gray (5Y 6/1) clay; common distinct yellowish brown (10YR 5/6) soft iron masses; weak coarse prismatic; extremely firm; gravel line in middle of horizon; abrupt wavy boundary

$\mathrm{Cb} 2162-177+\mathrm{cm}$ dark greenish gray (5GY 4/1); 60\% grain-supported pebbles and cobbles, 1 to $8 \mathrm{~cm}$ diameter

\section{BHT B; 41BX1103}

Site 41BX1103; T1 flood terrace; Unit III; gravel bar adjacent to an elongated channel depression 4.5 to $5 \mathrm{~m}$ above the modern low-water channel; calcareous throughout.

A1 $\quad 0-6 \mathrm{~cm} \quad$ very dark gray (10YR 3/1) clay loam; moderate medium subangular blocky; very hard; $5 \%$ matrix-supported pebbles, 0.5 to $4 \mathrm{~cm}$ diameter, moderately well sorted, subrounded; clear wavy boundary

A2 6-41 cm black (10YR 2/1) clay loam; moderate fine subangular blocky; very hard; 25\% matrixsupported pebbles, 0.5 to $4 \mathrm{~cm}$ diameter, moderately well sorted, subrounded; clear wavy boundary

$\mathrm{Bw} \quad 41-75 \mathrm{~cm} \quad$ very dark gray (10YR 3/1) loam; weak fine subangular blocky; very hard; $50 \%$ matrixand grain-supported pebbles and cobbles, 0.3 to $8 \mathrm{~cm}$ diameter, poorly sorted, subrounded; clear wavy boundary

Bk1 75-128 cm dark grayish brown (10YR 4/2) loam; 70\% grain-supported pebbles and cobbles, 0.5 calcium carbonate pendants on gravel bottoms, 1 to $3 \mathrm{~mm}$ diameter; abrupt wavy boundary

Bk2 128-151 cm brown (10YR 4/3) clay loam; moderate medium subangular blocky; hard; 10\% matrixsupported pebbles, 0.5 to $1 \mathrm{~cm}$ diameter, subrounded, well sorted; $8 \%$ calcium carbonate filaments; abrupt wavy boundary

C $\quad 151-178 \mathrm{~cm} \quad 80 \%$ pebbles and cobbles; Upper part: grain-supported, 0.4 to $2 \mathrm{~cm}$ diameter, well sorted, subrounded; lower part: grain-supported, 0.4 to $12 \mathrm{~cm}$ diameter, poorly sorted, subrounded 
T1 flood terrace; Unit III over Unit II; elongated channel depression 4.5 to $5 \mathrm{~m}$ above the modern low-water channel; calcareous throughout.

A1 0-9 cm (Unit III); very dark gray (10YR 3/1) clay loam; moderate fine subangular blocky; very hard; $5 \%$ matrix-supported pebbles, 0.5 to $2 \mathrm{~cm}$ diameter, moderately well sorted, subrounded; clear wavy boundary

A2 9-41 cm (Unit III); black (10YR 2/1) clay loam; moderate fine subangular blocky; very hard; $15 \%$ matrix-supported pebbles, 0.5 to $2 \mathrm{~cm}$ diameter, moderately well sorted, subrounded; clear wavy boundary

Bw 41-69 cm (Unit III); very dark gray (10YR 3/1) loam; moderate fine subangular blocky; very hard; $60 \%$ grain-supported pebbles, 0.3 to $4 \mathrm{~cm}$ diameter, poorly sorted, subrounded; clear wavy boundary

Bk1 69-108 cm (Unit III); dark grayish brown (10YR 4/2) clay loam; moderate fine subangular blocky; very hard; patchy thin calcium carbonate pendants on pebble bottoms; $60 \%$ grain-supported pebbles and cobbles, 0.3 to $4 \mathrm{~cm}$ diameter, poorly sorted, subrounded, increasing to 3 to $12 \mathrm{~cm}$ diameter in lower $20 \mathrm{~cm}$ abrupt wavy boundary

Bklb 108-152 cm (Unit II); dark grayish brown (10YR 4/2) clay loam; 3\% medium dark yellowish brown (10YR 4/6) soft iron masses, $2 \%$ medium dark reddish brown (2.5YR 3/4) soft iron masses; moderate medium prismatic; very hard; $2 \%$ matrix-supported pebbles, 0.2 to 1 $\mathrm{cm}$ diameter, well sorted, subrounded, increasing to $30 \%$ at lower boundary; $5 \%$ calcium carbonate filaments; clear wavy boundary (C-14 age of $3620 \pm 70$, Beta 96366 , from soil humate at $118-128 \mathrm{~cm}$ )

Bk2b 152-188 cm (Unit II); dark grayish brown (10YR 4/2) clay loam; 3\% dark yellowish brown (10YR 4/ 6) soft iron masses and 1\% dark brown (7.5YR 4/4) iron pore linings; moderate medium prismatic; very hard; $2 \%$ matrix-supported pebbles, 0.2 to $1 \mathrm{~cm}$ diameter, increasing slightly in size and abundance with depth; $8 \%$ calcium carbonate filaments and $2 \%$ nodules $1 \mathrm{~cm}$ diameter

\section{BHT D; Site 41BX1103}

T1 flood terrace; Unit III over Unit II; elongated channel depression $4.5 \mathrm{~m}$ above the modern low-water channel; calcareous throughout.

Al $\quad 0-7 \mathrm{~cm}$

A2 $\quad 7-35 \mathrm{~cm}$

Bw $\quad 35-55 \mathrm{~cm}$

C $\quad 55-96 \mathrm{~cm}$
(Unit III); very dark gray (10YR 3/1) silty clay loam; strong fine subangular blocky; very hard; $5 \%$ matrix-supported pebbles, 0.5 to $2 \mathrm{~cm}$ diameter, moderately well sorted, subrounded; clear wavy boundary

(Unit III); black (10YR 2/1) silty clay loam; moderate fine subangular blocky; very hard; $10 \%$ matrix-supported pebbles, 0.5 to $2 \mathrm{~cm}$ diameter, moderately well sorted, subrounded; gradual wavy boundary

(Unit III); very dark gray (10YR 3/1) silty clay loam; moderate fine subangular blocky; very hard; $20 \%$ matrix-supported pebbles, 0.5 to $2 \mathrm{~cm}$ diameter, moderately well sorted, subrounded; abrupt wavy boundary

(Unit III); very dark grayish brown (10YR 3/2); 70\% grain-supported pebbles and cobbles, 0.3 to $10 \mathrm{~cm}$ diameter, poorly sorted, subrounded; abrupt wavy boundary 
Bk1b 96-122 cm (Unit II); dark grayish brown (10YR 3.5/2) clay loam; moderate medium prismatic; very hard; $2 \%$ calcium carbonate filaments; $3 \%$ matrix-supported pebbles, 0.2 to $0.4 \mathrm{~cm}$ diameter, well sorted, subrounded; clear wavy boundary

Bk2b 122-175 cm (Unit II); dark grayish brown (10YR 4/2) clay loam; 5\% calcium carbonate filaments; $5 \%$ matrix-supported pebbles and cobbles, 1 to $10 \mathrm{~cm}$ diameter, moderately well sorted, subrounded, increasing slightly in size and abundance with depth

\section{BHT E; Site 41BX1102}

T1 flood terrace; Unit II; adjacent to the elongated channel depression identified at site 4IBX1103, $5 \mathrm{~m}$ above the modern low-water channel; calcareous throughout.

A1 $\quad 0-7 \mathrm{~cm} \quad$ very dark gray (10YR 2.5/1) silty clay loam; moderate fine subangular blocky; very hard; $5 \%$ matrix-supported pebbles, 0.5 to $1.5 \mathrm{~cm}$ diameter, subrounded, well sorted; clear smooth boundary

A2 $\quad 7-41 \mathrm{~cm} \quad$ black (10YR 2/1) silty clay loam; $2 \%$ matrix-supported pebbles, 0.5 to $1.5 \mathrm{~cm}$ diameter, subrounded, well sorted; gradual smooth boundary

Bw $\quad 41-88 \mathrm{~cm} \quad$ very dark gray (10YR 3/1) silty clay loam; $8 \%$ matrix-supported pebbles, 0.5 to $2 \mathrm{~cm}$ diameter, subrounded, well sorted; gradual smooth boundary

Bss $\quad 88-125 \mathrm{~cm}$ dark gray (10YR 4/1) silty clay loam; 3\% brown (10YR 5/3) vertical streaks; few distinct slickensides; $5 \%$ matrix-supported pebbles, 0.5 to $1 \mathrm{~cm}$ diameter, subrounded, well sorted; gradual smooth boundary

Bkg 125-165 cm light olive brown (2.5Y 5/3) silty clay loam; 5\% light gray (10YR 7/1) iron depletions; weak medium prismatic; very hard; $5 \%$ yellowish brown (10YR 5/6) soft iron masses; $3 \%$ matrix-supported pebbles, 0.2 to $0.5 \mathrm{~cm}$ diameter, subrounded, well sorted; $5 \%$ white and brittle calcium carbonate nodules, $1 \mathrm{~cm}$ diameter

\section{BHT F; Site 41BX1114}

T1 flood terrace; Unit $\mathrm{N} ; 2$ to $2.5 \mathrm{~m}$ above the modern low-water channel; calcareous throughout.

Al $\quad 0-8 \mathrm{~cm} \quad$ very dark grayish brown (10YR 3/2) clay loam; moderate medium subangular blocky; very hard; $1 \%$ matrix-supported pebbles, 0.5 to $1 \mathrm{~cm}$ diameter, subrounded; clear smooth boundary

A2 $\quad 8-27 \mathrm{~cm} \quad$ black (10YR 2/1) clay loam; moderate medium subangular blocky; hard; $1 \%$ matrixsupported pebbles, 0.5 to $1 \mathrm{~cm}$ diameter, subrounded; clear smooth boundary

$\mathrm{Bw} \quad 27-50 \mathrm{~cm} \quad$ black (10YR 2/1) clay loam; moderate medium subangular blocky; hard; 3\% matrixsupported pebbles, 0.5 to $2 \mathrm{~cm}$ diameter, subrounded; 1 to $2 \%$ calcium carbonate filaments; abrupt wavy boundary

C $\quad 50-102 \mathrm{~cm}$ dark gray (10YR 4/1) loam; 60\% grain-supported pebbles and cobbles, 0.5 to $8 \mathrm{~cm}$ diameter, poorly sorted, subrounded; abrupt wavy boundary

Bk1b 102-125 cm dark gray (2.5Y 4/1) clay loam; weak coarse prismatic; very hard; 5\% matrix-supported pebbles, 0.5 to $3 \mathrm{~cm}$ diameter, poorly sorted, angular; $2 \%$ brittle calcium carbonate nodules, 0.5 to $1 \mathrm{~cm}$ diameter; clear smooth boundary 
Bk2b 125-149 cm dark gray (2.5Y 4/1) and light olive brown (2.5Y 5/6) clay loam; weak coarse prismatic; very hard; $5 \%$ matrix-supported pebbles, 0.5 to $3 \mathrm{~cm}$ diameter, poorly sorted, angular; $2 \%$ brittle calcium carbonate nodules, 0.5 to $3 \mathrm{~cm}$ diameter; abrupt wavy boundary

$\mathrm{Cb} \quad 149-159 \mathrm{~cm}$ dark gray (2.5Y 4/1) and light olive brown (2.5Y 5/6) clay loam; 25\% matrix-supported pebbles, 1 to $5 \mathrm{~cm}$ diameter, poorly sorted, angular to subrounded

\section{BHT I; Site 41BX1102}

T1 flood terrace; Unit II; $5 \mathrm{~m}$ above the modern low-water channel; calcareous throughout; modern fill on north end of backhoe trench.

Ap $\quad 0-14 \mathrm{~cm} \quad$ very dark grayish brown (10YR 3/2) clay loam; moderate fine subangular blocky; very hard; $10 \%$ matrix-supported pebbles, 0.3 to $1 \mathrm{~cm}$ diameter, subrounded; clear smooth boundary

A $\quad 14-36 \mathrm{~cm}$ dark grayish brown (10YR 3.5/2) clay loam; moderate medium subangular blocky; very hard; $3 \%$ yellowish brown (10YR 5/3) and 2\% very dark grayish brown (10YR 3/2) biocasts; 3 to $4 \%$ matrix-supported pebbles, 0.3 to $1 \mathrm{~cm}$ diameter, subrounded; few burned rocks; gradual smooth boundary

Bw 36-62 cm brown (10YR 4/3) clay loam; moderate medium subangular blocky; very hard; 5\% light yellowish brown (10YR 6/4) biocasts; 3 to $4 \%$ matrix-supported pebbles, 0.3 to $1 \mathrm{~cm}$ diameter, subrounded; gradual smooth boundary

Bk 62-84 cm brown (10YR 5/3) and light yellowish brown (10YR 6/4) clay loam; weak medium subangular blocky; very hard; $15 \%$ matrix-supported pebbles, 0.5 to $2 \mathrm{~cm}$ diameter, subrounded; $10 \%$ calcium carbonate nodules, 0.5 to $1 \mathrm{~cm}$ diameter

Test Unit (TU) N1050 E970; Site 41BX1102

T1 flood terrace; Unit II; $5 \mathrm{~m}$ above the modern low-water channel; calcareous throughout.

A $\quad 0-15 \mathrm{~cm} \quad$ very dark grayish brown (10YR 3/2) clay loam; moderate medium subangular blocky; very hard; $5 \%$ matrix-supported pebbles, 0.2 to $0.5 \mathrm{~cm}$ diameter, subrounded; clear smooth boundary

$\mathrm{AB} \quad 15-42 \mathrm{~cm} \quad$ very dark grayish brown (10YR 3/2) clay loam; moderate medium angular blocky; very hard; $5 \%$ matrix-supported pebbles, 0.3 to $0.8 \mathrm{~cm}$ diameter, subrounded; gradual smooth boundary

$\mathrm{Bw} \quad 42-80 \mathrm{~cm} \quad$ dark grayish brown (10YR 4/2) clay loam; few black (10YR 2/1) vertical streaks; weak coarse prismatic; very hard; gradual smooth boundary

Bk $\quad 80-90 \mathrm{~cm}$ dark grayish brown (10YR 4/2) clay loam; few black (10YR 2/1) vertical streaks; weak coarse prismatic; very hard; $2 \%$ calcium carbonate nodules, $1 \mathrm{~cm}$ diameter; gradual smooth boundary 


\section{Appendix B: Artifact Analysis}

\section{David L. Nickels, Brett A. Houk, and Anne A. Fox}

\section{Introduction}

This appendix describes the methods used to catalogue and analyze the artifacts collected during Phase II testing at Medina Annex, and the results of the analysis. Approximately 29,575 artifacts were recovered from the eight sites investigated. These artifacts were subdivided into broad temporally significant categories of historic and prehistoric. The prehistoric artifacts were further subdivided into the following categories: chipped stone, ground stone and battered stone, drilled stone, and ceramics. The number of historic artifacts is small, and each object (or class of object) is described individually in this chapter.

\section{Chipped Stone}

Approximately 29,517 chipped stone artifacts were recovered during the project. During the cataloguing process, these were subdivided into the following classes: projectile points (51), bifaces (770), unifaces (622), cores $(2,292)$, and unmodified debitage $(25,784)$. After the artifacts were catalogued, each class was analyzed according to a variety of attributes. The chosen attributes provided a thorough technological and morphological characterization of the assemblage and allowed for consistent comparisons to be made between assemblages from different sites in the project area. The type and quality of raw material used in the manufacture of each chipped stone tool was also recorded, providing another variable which could then be compared across site assemblages and artifact class. Additionally, this data allowed for comparisons to the samples of raw material collected and analyzed from each site, except 41BX1070. The attributes for each artifact class are defined below. Colors described in the text are derived from a standard Munsell color chart.

\section{Projectile Points}

One of the smaller classes of chipped stone artifacts is projectile points. This class, however, is one of the more important artifact categories because it can provide chronological and cultural data when most artifacts can not. For projectile points, the following attributes were recorded: raw material type, raw material quality, burning, projectile point subgroup, projectile point type, serration, beveling, completeness, break type, maximum length, blade length, blade width, haft length, neck width, base width, maximum thickness, and weight.

Each point was classified into one of the following subgroups: arrow point, dart point, arrow point preform, dart point preform, arrow point blank, or dart point blank. In this system, blanks are usually bifacial artifacts that appear to be the proper shape and size to be made into an arrow point or dart point, but they lack any notching and therefore do not have barbs or shoulders. Preforms, on the other hand, are recognizable as a stage of arrow or dart point manufacture in that they have barbs and/or shoulders but were not completed. Therefore, any incomplete projectile point with a manufacturing break was classified as a preform rather than as a finished point.

Arrow points, dart points, and preforms were then assigned to a projectile point type based on the commonly accepted point typology developed by others for central and south Texas (cf., Turner and Hester 1993). Points which could not be assigned with confidence to a previously established type were coded as either "untyped" or "untypable." The former classification indicates that the point has measurable and identifiable dimensions and diagnostic attributes, but that it does not conform to a previously defined point type. The latter designation was generally reserved for fragmentary specimens lacking enough diagnostic attributes, such as the base or barbs, to determine their size or shape. 
If a point was incomplete, the break was coded as either use/resharpening related, manufacture, post-depositional, or indeterminate. Break type attributes are described in detail in the biface subsection below. Length and width measurements were made only for those dimensions that were complete.

\section{Arrow Points}

Seven arrow points, two arrow point preforms, and one arrow point blank were recovered from four of the eight tested sites (Table B-1). All arrow points and preforms (Table B-1) are made of fine-grained chert and do not show any indication of having been burned. One preform is complete and the other was broken in manufacture. The seven arrow point types were broken through use or resharpening.

\section{Arrow Point Blank}

The arrow point blank (Figure 5-6f, UI 9) was found on the surface in CU N1155 W1030 at 41BX1088 Area 1 . It is a small triangular biface with a slightly convex, unground base, and made from a flake blank of light gray, fine-grained chert. The unflaked portion of its ventral face is slightly darker, and not waxy suggesting the discoloration is probably due to weathering. Flakes have been removed by percussion except along both distal lateral margins where pressure flaking has occurred.

\section{Edwards}

The single representative of the Edwards point type was recovered from the surface at 41BX1088 Area 1 (Figure 5-6e, UT 4). This specimen is made on a flake of fine-grained, white to pinkish chert. Its straight, lateral edges show evidence of reworking. The distal tip and the tip of one barb were apparently broken through use. The Edwards type is common throughout south and south central Texas, and Edwards points are generally among the largest arrow points (Turner and Hester 1993:212). The Lackland specimen, however, is small when compared to the range described by Sollberger (1967) when he defined the type. In this regard, this point is similar to Edwards points recovered northwest of the project area in Bandera and Uvalde counties (Hester 1971; Houk and Lohse 1993).

\section{Perdiz}

Perdiz points are generally associated with the Toyah horizon of the Late Prehistoric period in south and central Texas (Black 1986; Collins 1995; Hester 1995). Kelley et al. (1940) described these points in the Transpecos region of Texas and, Kelley (1947) later named these points "Perdiz Pointed Stem" in his analysis of materials from Lehmann Rock Shelter. Toyah sites are typically characterized by Perdiz points, small end scrapers, beveled knives, Leon Plain pottery, and bison bone fragments (Hester 1995). The debate about whether or not these traits represent a cultural group or a technology which could have been adopted by various groups is unresolved (cf. Johnson 1994; Ricklis 1994).

The distinctive Perdiz type is represented by one proximal point fragment (UI 7, 41BX1088 Area 1) and two preforms (UI 3, 41BX1088 Area 1; UI 2, 41BX1088 Area 2). The arrow point fragment (Figure 5-6a) was recovered from the surface at $41 \mathrm{BX} 1088$ Area 1 . It was made on a flake of fine-grained, light brown chert, and was apparently broken in two separate incidents. In the first, an impact originating from the distal end of the point resulted in a longitudinal break which removed part of one edge and most of one barb. The second break which appears to be post depositional, snapped off the distal tip. After these two breaks, some minor reworking was apparently attempted on the broken barb and on the broken lateral edge before the point was discarded.

One of the two Perdiz preforms (Figure 5-6b, UI 3) is a complete specimen found on the surface at 41BX1088 Area 1. It is made on a flake of fine-grained chert that is identical in color and texture to the material used in the manufacture of the finished proximal point fragment described above. This specimen was worked into a roughly oval shape before the stem was begun. Although the preform is complete and free of obvious defects it was abandoned prior to completion. It measures $34 \mathrm{~mm}$ long, $19 \mathrm{~mm}$ wide, and $4 \mathrm{~mm}$ thick. 
Table B-1. Arrow Points, Blank, and Preforms

\begin{tabular}{|c|c|c|c|c|c|c|c|c|c|c|c|c|c|c|c|}
\hline \multicolumn{2}{|c|}{ Provenience } & \multirow{2}{*}{ UI } & \multirow{2}{*}{ Type } & \multirow[b]{2}{*}{ 䓌 } & \multirow[b]{2}{*}{$\begin{array}{l}\bar{D} \\
\vec{D} \\
\infty\end{array}$} & \multirow{2}{*}{ 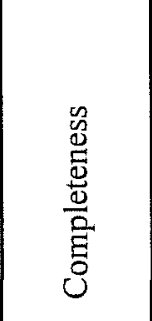 } & \multirow[b]{2}{*}{ 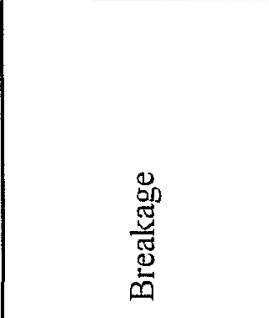 } & \multirow{2}{*}{ 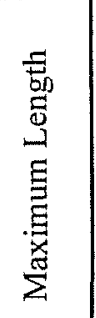 } & \multirow{2}{*}{ 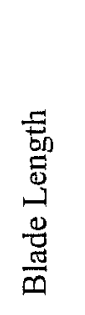 } & \multirow{2}{*}{ 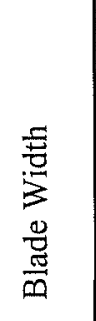 } & \multirow{2}{*}{ 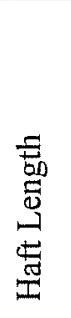 } & \multirow{2}{*}{ 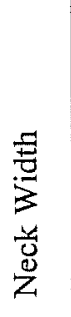 } & \multirow{2}{*}{ 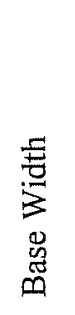 } & \multirow{2}{*}{ 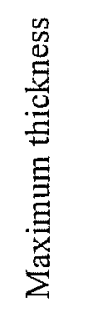 } & \multirow[b]{2}{*}{ 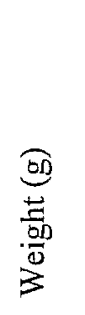 } \\
\hline Site & Area & & & & & & & & & & & & & & \\
\hline 41BX1076 & & 2 & Scallorn & none & none & proximal & use/resharpening & & & & 7 & 8 & & 4 & \\
\hline \multirow{7}{*}{ 41BX1088 } & \multirow{6}{*}{1} & 4 & Edwards & none & none & proximal & use/resharpening & & & 15 & 7 & 7 & 14 & 4 & \\
\hline & & 7 & Perdiz & none & none & proximal & use/resharpening & & & & 13 & 5 & & 3 & \\
\hline & & 14 & Scallorn & none & none & stem & use/resharpening & & & & & & & & \\
\hline & & 10 & Scallorn & none & none & proximal & use/resharpening & & & 15 & 5 & 7 & & 3 & \\
\hline & & 9 & Blank & none & none & complete & none & 29 & 29 & 17 & 3 & 17 & 13 & 4 & 1.65 \\
\hline & & 3 & Perdiz preform & none & none & complete & none & 34 & 27 & 19 & 7 & 10 & & 4 & 2.82 \\
\hline & 2 & 2 & Perdiz preform & none & none & medial & manufacture & & & & & 6 & & & \\
\hline 41BX1091 & & 2 & Scallorn & none & none & proximal & use/resharpening & & & & 7 & 7 & & 4 & \\
\hline 41BX1114 & & 4 & Scallorn & none & none & proximal & use/resharpening & & & & 6 & 6 & & 3 & \\
\hline
\end{tabular}


The unfinished stem is $7 \mathrm{~mm}$ long and $10 \mathrm{~mm}$ wide where it joins the blade of the preform.

The second preform (Figure 5-8a, UI 2) was recovered from the surface at $41 \mathrm{BX} 1088$ Area 2 . It is a medial fragment, manufactured on a dark yellowish brown, fine-grained chert flake, with pronounced rippling on the ventral surface, and break faces on the blade, the stem, and one shoulder. The break on the blade appears to be manufacture related, suggesting that the other two are post-depositional. The only complete measurement that could be made on the piece is the neck width where it joins the blade: $7 \mathrm{~mm}$.

\section{Scallorn}

Scallorn points are commonly found throughout Texas, and infrequently are associated with burials as a cause of death during the Austin Phase of the Late Prehistoric (Collins 1995; Hester 1995; Turner and Hester 1993). Scallorn points were first described by Krieger (1946) at the Harrell Site in North Texas. Kelley (1947) also discusses "Scallorn Stemmed" points without detailed descriptions in his Lehmann Rock Shelter report. More detailed descriptions were published by Suhm et al. (1954) in the first handbook. Jelks (1962) proposed a subdivision of Scallorn points into at least three varieties, however these have not been used by later archaeologists. Shafer et al. (1964) further refined Scallorn points and defined additional varieties. Five Scallorn points were recovered from four Lackland sites during the Phase II testing, four from the surface and one from below the surface.

A Scallorn-Brangus variety (Shafer et al. 1964) proximal portion (UI 4, Figure 5-52a) made from finegrained dark brown chert with light gray inclusions was found $5 \mathrm{~cm}$ bs in TU N1021 E994 at 41BX1114. Its distal tip has been broken from use and resharpening appears where one barb has been broken off. There is no evidence of burning, serration or beveling.

UI 2 (Figure 5-66a) is a proximal fragment found on the surface in CUN1000 E1000,41BX1076. It is made from white and light brownish gray, fine-grained chert. The distal tip has been broken from use. There is no evidence of resharpening, burning, serration or bev- eling. However, post depositional flaking has occurred on both lateral edges. Post depositional breaks are also evident on the ends of both barbs and on one basal corner.

UI 10 (Figure 5-6c) is a proximal fragment surface find from CU N1160 E1035, 41BX1088 Area 1. It is made from a grayish brown, fine-grained chert flake. Its distal tip has been broken from use and an impact longitudinal flake scar with pronounced rippling extends proximal to distal across its dorsal face. There is no evidence of resharpening, burning, serration or beveling.

UI 14 (Figure 5-6d) from CU N1160 E1030, 41BX1088 Area 1, is a stem fragment that was also found on the surface. It is made from grayish pink fine-grained chert. The stem appears to have snapped off from use. What little remains of this point shows no evidence of resharpening, burning, serration or beveling.

UI 2 (Figure 5-21a) is a proximal fragment made from brown, fine-grained chert recovered from the surface of CU N1000 E990 at 41BX1091. Its distal tip has been broken from use, and one basal ear is missing due to indeterminate causes. There is no evidence of resharpening, burning, serration or beveling.

\section{Dart Points}

Thirty-one dart points, two dart point preforms, and one dart point blank were recovered from six of the eight tested sites (Table B-2). They are all made of fine-grained chert. The two preforms, also of finegrained chert and not burned, are broken but complete enough to be typed as Pedernales. One of the preforms (UI 7, 41BX1102) is a barb broken during manufacture, the other (UI 4, 41BX1102) is a proximal piece with an indeterminate break. The dart point blank (UI 15 from 41BX1088 Area 1) is a biface distal end broken during post-deposition. Only a Pedernales point (UI 8, 41BX1102) shows an indication of burning. Ten dart points are either untypable or untyped. 
Table B-2. Dart Points

\begin{tabular}{|c|c|c|c|c|c|c|c|c|c|c|c|c|c|c|c|}
\hline \multicolumn{2}{|c|}{ Provenience } & UI & Type & 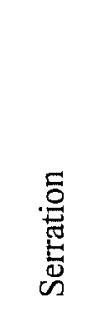 & $\begin{array}{l}\bar{\Delta} \\
\bar{\Delta}\end{array}$ & 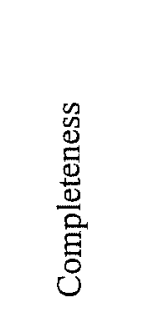 & 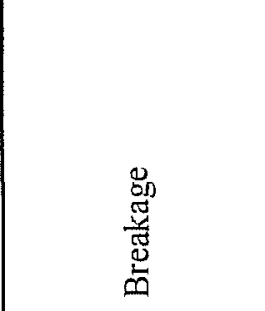 & 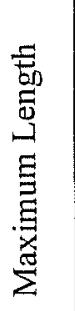 & 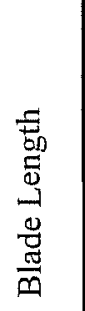 & 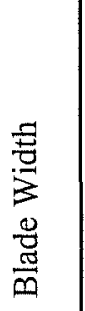 & 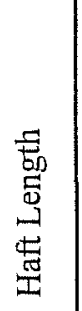 & 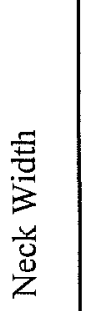 & 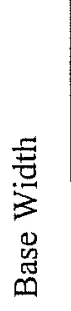 & 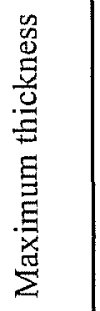 & 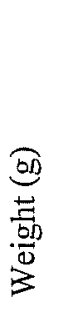 \\
\hline 41BX1076 & & 1 & Fairland & none & none & proximal & use/resharpening & & & & 10 & 18 & & 6 & \\
\hline \multirow{10}{*}{ 41BX1088 } & \multirow{9}{*}{1} & 8 & Darl & none & none & medial & indeterminate & & & 18 & 7 & 14 & & 6 & \\
\hline & & 12 & Edgewood & none & left & complete & none & 36 & 27 & 17 & 10 & 11 & 16 & 5 & 3.41 \\
\hline & & 2 & Ensor & none & none & proximal & use/resharpening & & & 16 & 11 & 11 & 13 & 5 & \\
\hline & & 6 & Frio & none & none & distal & use/resharpening & 44 & 34 & 21 & 9 & 17 & & 6 & \\
\hline & & 5 & Frio & none & right & proximal & use/resharpening & & & 33 & 10 & 17 & & 7 & \\
\hline & & 11 & Pedernales & none & none & proximal & use/resharpening & & & & 17 & 22 & & 9 & \\
\hline & & 1 & Untyped & none & none & proximal & use/resharpening & & & & 6 & 14 & & 5.5 & \\
\hline & & 13 & Untyped & none & right & proximal & indeterminate & & & 20 & 8 & 15 & 17 & 6 & \\
\hline & & 15 & Blank & none & none & distal & post-depositional & 50 & 40 & 24 & 10 & & & 8 & \\
\hline & 2 & 1 & Fairland & none & none & proximal & use/resharpening & & & & 8 & 12 & 17 & 5 & \\
\hline 41BX1091 & & 1 & Fairland & none & none & \begin{tabular}{|l|} 
proximal \\
\end{tabular} & use/resharpening & & & & 10 & 17 & & 7 & \\
\hline \multirow{12}{*}{$41 \mathrm{BX} 1102$} & & 8 & Pedernales & none & none & barb & use/resharpening & & & & 24 & 28 & & & \\
\hline & & 3 & Pedernales & none & none & medial & indeterminate & & & 36 & & 24 & & 8 & \\
\hline & & 5 & Pedernales & none & none & medial & post-depositional & & & & & 18 & & 7 & \\
\hline & & 10 & Pedernales & none & none & medial & indeterminate & & & 31 & & 23 & & 9 & \\
\hline & & 1 & Pedernales & none & none & proximal & indeterminate & & & & 20 & & 19 & 8 & \\
\hline & & 9 & Pedernales & none & none & proximal & use/resharpening & & & & 22 & 22 & 22 & 8 & \\
\hline & & 11 & Pedernales & none & none & proximal & post-depositional & & & & 17 & 22 & 20 & 8 & \\
\hline & & 12 & Untypable & none & none & barb & use/resharpening & & & & & & 17 & & \\
\hline & & 6 & Untypable & none & none & medial & post-depositional & & & & & & & 9 & \\
\hline & & 2 & Untypable & none & none & proximal & indeterminate & & & & & & & 9 & \\
\hline & & 7 & Pedernales preform & none & none & barb & manufacture & & & & & & 19 & & \\
\hline & & 4 & Pedernales preform & none & none & proximal & post-depositional & & & 28 & 24 & 27 & & 10 & \\
\hline
\end{tabular}


Table B-2. continued

\begin{tabular}{|c|c|c|c|c|c|c|c|c|c|c|c|c|c|c|c|}
\hline \multicolumn{2}{|c|}{ Provenience } & \multirow[b]{2}{*}{ UI } & \multirow[b]{2}{*}{ Type } & \multirow[b]{2}{*}{ 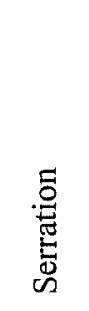 } & \multirow[b]{2}{*}{$\begin{array}{l}\vec{\Phi} \\
\vec{D} \\
m\end{array}$} & \multirow{2}{*}{ 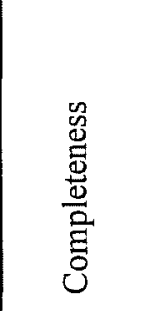 } & \multirow[b]{2}{*}{ 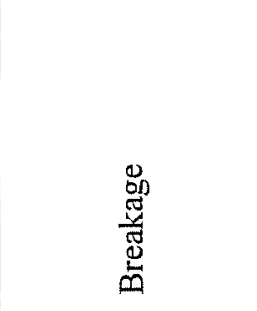 } & \multirow{2}{*}{ 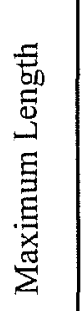 } & \multirow{2}{*}{ 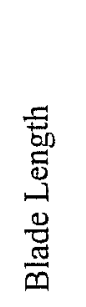 } & \multirow{2}{*}{ 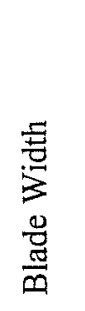 } & \multirow{2}{*}{ 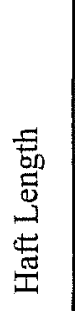 } & \multirow{2}{*}{ 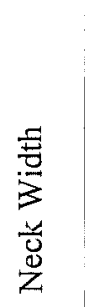 } & \multirow{2}{*}{ 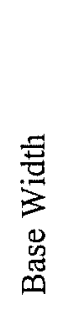 } & \multirow{2}{*}{ 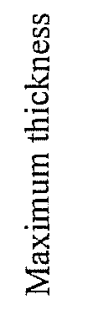 } & \multirow[b]{2}{*}{ 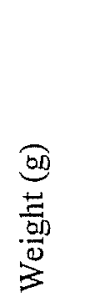 } \\
\hline Site & Area & & & & & & & & & & & & & & \\
\hline \multirow{11}{*}{ 41BX1103 } & & 8 & Edgewood & none & none & proximal & use/resharpening & & & & 11 & 15 & 21 & 6 & \\
\hline & & 6 & Ensor & none & none & proximal & indeterminate & & & 19 & 8 & 12 & & 6 & \\
\hline & & 1 & Fairland & none & none & complete & none & 41 & 29 & 20 & 12 & 18 & 23 & 5 & 4.39 \\
\hline & & 2 & Fairland & none & none & proximal & indeterminate & & & 20 & 11 & 14 & 24 & 7 & \\
\hline & & 7 & Fairland & none & none & proximal & indeterminate & & & & 12 & 15 & 19 & 5 & \\
\hline & & 9 & Frio & none & none & proximal & use/resharpening & 40 & 28 & 28 & 10 & 17 & & 8 & \\
\hline & & 4 & Marcos & none & none & proximal & indeterminate & & & & 13 & 23 & 27 & 7 & \\
\hline & & 10 & Pedernales & none & none & distal & indeterminate & & & 40 & 14 & 18 & 17 & 7 & \\
\hline & & 11 & Pedernales & none & none & proximal & use/resharpening & & & & 13 & 19 & & 7 & \\
\hline & & 3 & Untyped & none & none & proximal & use/resharpening & & & 22 & 9 & 19 & & 6 & \\
\hline & & 5 & Untyped & none & none & proximal & use/resharpening & & & & 11 & 18 & & 8 & \\
\hline \multirow{6}{*}{ 41BX1114 } & & 6 & Ensor & none & none & proximal & use/resharpening & & & 17 & 9 & 12 & & 5 & \\
\hline & & 3 & Fairland & none & none & complete & none & 37 & 24 & 19 & 17 & 13 & 16 & 8 & 4.48 \\
\hline & & 2 & Fairland & none & none & proximal & use/resharpening & & & 22 & 12 & 15 & 21 & 7 & \\
\hline & & 1 & Untypable & none & none & medial & use/resharpening & & & 26 & & & & 8 & \\
\hline & & 5 & Untyped & none & none & proximal & use/resharpening & & & 18 & 8 & 14 & & 5 & \\
\hline & & 7 & Untyped & none & none & proximal & post-depositional & & & & 16 & 17 & 17 & & \\
\hline
\end{tabular}




\section{Darl}

Darl points were first defined by Miller and Jelks (1952) at Belton Reservoir, and originally included forms now classified as Hoxie. Prewitt (1981) proposed that Darl points, as a type, should exclude Hoxie forms. Darl points are considered to be Transitional Archaic and may be commonly found in Central Texas, the Lower Pecos and some areas of the coastal plain (Turner and Hester 1993:101). One Darl point (Figure $5-7 \mathrm{a}$, UI 8) was found at one of the eight sites investigated. It is from the surface of CU N1155 E1035, 41BX1088 Area 1, and consists of a medial piece made from light brownish gray, fine-grained chert. Its distal tip is missing due to indeterminate breakage. A portion of its rectangular stem was removed by an impact break that left large impact scars on both faces. Although some Darl points show evidence of lateral edge and stem beveling, this specimen does not. Neither is there any evidence of resharpening, burning, or serration.

\section{Ensor}

Miller and Jelks (1952) also first described Ensor points at Belton Reservoir, but this form originally included projectile points that now are classified as Frio. Suhm et al. (1954) redefined Ensor points and excluded Frio forms from the definition. Like the Darl, Ensor points appear to be diagnostic to the Transitional Archaic period in Central and South Texas (Turner and Hester 1993:114). Three Ensor points were recovered during the testing project; one each from 41BX1088 Area 1, 41BX1103, and 41BX1114.

UI 2 (Figure 5-7c), from the surface of CU N1160 $\mathrm{E} 1035,41 \mathrm{BX} 1088$ Area 1, is a proximal fragment with a characteristic broad stem, shallow side notches and a generally straight base. It is made from brown, finegrained chert with occasional coarse-grained inclusions. Its distal tip has been broken from use. There is no evidence of resharpening, burning, serration or beveling. Light patination has developed equally on all damaged and undamaged surfaces.

UI 6 (Figure 5-39b), from the surface of CU N995 $\mathrm{E} 1001,41 \mathrm{BX} 1103$, is a proximal piece made from grayish brown, fine-grained chert with occasional coarse-grained inclusions. Its distal tip and one basal ear are missing due to indeterminate breakage. A proximal to distal longitudinal impact flake scar with pronounced rippling is evident on both faces. This specimen has the same generally straight base as UI 2 (Figure 5-7c), but its shoulders are broader. There is no evidence of resharpening, burning, serration or beveling.

UI 6 (Figure 5-57a), from ST C-1, 41BX1114, is a proximal end with a slightly convex base, made from brown, fine-grained chert with occasional coarsegrained inclusions. Its distal end has been broken through use, and one basal ear is missing from an unknown cause. Moderate patina evenly covers the tool's damaged and undamaged surfaces evenly. There is no evidence of resharpening, burning, serration or beveling.

\section{Frio}

Frio points from Lehmann Rock Shelter were first called "Frio Flared Stem" by Kelley (1947), but Miller and Jelks (1952) included Frio points with Ensor forms at Belton Reservoir. The type was systematically defined and the name shortened to Frio by Suhm et al. (1954). As with Darl and Ensor points, Frio points are also considered as diagnostic to the Transitional Archaic period. Their general morphological characteristics include a triangular body, concave basal indentation, and wide side-notches or corner notches. They are commonly found in central and south Texas and in the lower Pecos and the Trans-Pecos Texas regions (Turner and Hester 1993:122). Three Frio points were found: two at $41 \mathrm{BX} 1088$ Area 1 , and one at 41BX1103.

UI 5 (Figure 5-7d), from the surface of CU N1160 E1035 at 41BX1088 Area 1, is a proximal end made from dark brown, fine-grained chert. Its distal tip has been broken from use, and one basal ear has been shortened due to an indeterminate break. There is no evidence of resharpening, or serration, but some beveling is evident on one edge. Although damage from burning is not apparent, its highly glossy and slightly waxy surface suggest exposure to heat. 
A second Frio from 41BX1088 Area 1 was found on the surface in CU N1175 E1030. UI 6 (Figure 5-53e) is a distal portion made from brown, fine-grained chert. Its proximal end has been broken from use. One basal ear and one lateral edge have been damaged from an unknown cause. Light patination is present on all surfaces. There is no evidence of resharpening, burning, serration or beveling.

UI 9 (Figure 5-39f), from the surface of CU N980 E985, 41BX1103, is a proximal portion made from brown, fine-grained chert. Its maximum distal tip has been broken through use; both basal ears have been damaged in varying degree, and one shoulder is missing from unknown causes. There is no evidence of resharpening, burning, serration or beveling.

\section{Edgewood}

Edgewood points were originally defined by Suhm et al. (1954), and they are another tool associated with the Transitional Archaic period. An Edgewood can be morphologically characterized by its triangular shape, well-barbed shoulders, widely expanding stem, and concave to straight base. Edgewood points have been found in northeast, central and south Texas (Turner and Hester 1993:111). An Edgewood was found at 41BX1088 Area 1 and 41BX1103.

UI 12 (Figure 5-7b), found on the surface in CUN1175 E1025 at 41BX1088 Area 1, is a complete point with a slightly concave base, made of grayish brown, finegrained chert. Although there is unknown-caused damage to one shoulder, there is no evidence of resharpening, burning, or serration. Both lateral edges have been beveled.

UI 8 (Figure 5-39a), on the surface of CU N980 E985 at $41 \mathrm{BX} 1103$, is a proximal portion with a slightly concave base, made of brown, fine-grained chert. Its distal tip has been broken due to use, and a distal to proximal flake scar with pronounced rippling on both faces provides evidence of impact. One shoulder barb has been snapped from an unknown cause. Although there is no evidence of resharpening, burn damage, serration or beveling, a slight discoloration and gloss enveloping the undamaged surfaces suggest possible heat treating.

\section{Fairland}

These projectile points were first called "Fairland Flared Stem" in the Lehmann Rock Shelter report by Kelley (1947). Suhm et al. (1954) shorten the name to Fairland. Fairland points are also considered a Transitional Archaic diagnostic. Morphologically similar to both Edgewood and Ellis points, a Fairland is triangular with narrow shoulders, and a wide, flaring, deeply concave base extending past its shoulders. Fairland points have been found in the central, south and lower Pecos regions of Texas. Eight Fairland points were found at five of the eight sites investigated; one from 41BX1076, one from 41BX1088 Area 1, one from 41BX1091, three from 41BX1103, and two from $41 \mathrm{BX} 1114$.

UI 1 (Figure 5-66b), from the surface in CU N980 $\mathrm{E} 995,41 \mathrm{BX} 1076$, is a proximal portion with a wide base, made from dark grayish brown, fine-grained chert with occasional inclusions. Its distal tip has been broken through use and one basal ear has been removed due to an unknown cause. Slight post-depositional damage is evident on both lateral edges. There is no evidence of resharpening, burning, serration or beveling.

UI 1 (Figure 5-8b), from 41BX1088 Area 2, was found on the surface in CU N1030 E995. It is a proximal portion made from light brownish gray, fine-grained chert. Its distal tip has been broken through use and a proximal portion of one lateral edge has been damaged from apparent post-depositional processes. There is no evidence of resharpening, burning, serration or beveling.

UI 1 (Figure 5-21b) was found in level $2,23.5 \mathrm{~cm}$ below the datum of TU N1014 E990, 41BX1091. It is a proximal portion made from grayish brown, finegrained chert with common coarse-grained inclusions. Its distal tip has been broken through use. One shoulder barb has been removed and some lateral edge damage has occurred due to unknown causes. There is no 
evidence of resharpening, burning, serration or beveling.

Three Fairland points were recovered from 41BX1103. UI 1 (Figure 5-39c) is a complete point found in BHT $\mathrm{C}$ at ca. $50 \mathrm{~cm}$ bs. It is made of dark grayish brown, fine-grained chert with occasional coarse-grained inclusions. Most notable is its strongly flaring base. UI 2 (Figure 5-39d) is a proximal portion found in TU N999 E1003 at $25 \mathrm{~cm}$ bd. It is made from a pale brown, fine-grained chert. Its distal tip is missing due to indeterminate breakage, but a one-centimeter longitudinal flake scar extending from the medial area of the maximum base concavity through the center of the stem suggest an impact removal. UI 7 (Figure 520c) was found on the surface in CUN1015 E990. It is also made from a pale brown, fine-grained chert but has an occasional coarse-grained flaw in the material. Its distal tip and end of one basal ear are missing due to indeterminate breakage. None of the three points show evidence of resharpening, burning, serration, or beveling.

The two remaining Fairland points were found below the surface at 41BX1114 in TU N1039 E993. UI 3 (Figure 5-54b) was recovered from $16 \mathrm{~cm}$ bd. It is classified as a complete point made from grayish brown, fine-grained chert, however apparent postdepositional processes have removed most of one lateral edge. UI 2 (Figure 5-54a) is a proximal portion also made from pale brown, fine-grained chert and recovered from $53 \mathrm{~cm}$ bd. Its distal tip has been broken through use. Although morphologically it is undoubtedly Fairland, its deep concave base is absent of fine chipping along the edges, a normal characteristic of Fairland points. Neither of the two points show evidence of resharpening, burning, serration or beveling.

\section{Marcos}

Marcos points are found at central, south, and central coastal plain sites in Texas, and are diagnostic to the Late and Transitional Archaic periods The form was first defined by Suhm et al. (1954). The triangularshaped Marcos is generally broader than many points from the same time periods and has an expanding stem between deep corner notches and barbs (Turner and Hester 1993:147).

The only Marcos point recovered during testing at Lackland was UI 4 (Figure $5-39 \mathrm{~g}$ ) from ca $50 \mathrm{~cm}$ bd in BT-C, 41BX1103. It is a proximal portion made of light brown, fine-grained chert. Its distal tip and one barb are missing due to indeterminate breakage. However a flake scar on both faces with pronounced rippling emanating proximally from the distal break suggests significant impact has occurred. There is no evidence of resharpening, burning, serration or beveling.

\section{Pedernales}

Kelley (1947) called these distinctive points "Pedernales Indented Base," and the name was shortened by Suhm et al. (1954). Ensor and Mueller-Wille (1988) further refined the type by defining the production sequence used to make Pedernales points. Black and McGraw (1985:113) originally assigned Pedernales points to $3950-2550$ B.P., corresponding to the Clear Fork phase of the Middle Archaic. Potter and Black $(1995: 4,7)$ prefer to consider Pedernales diagnostic of the Late Archaic I, 4150-2750 B.P., roughly in accord with Johnson and Goode (1994:29, Figure 2), who date Late Archaic Period I to 4250-2550 B.P. (calibrated) and Collins (1995:384, Table 2) who postulates a Pedernales-Kinney interval, ca. 3200-2300 B.P. during the first half of the Late Archaic. Although Hester (1995:439; Turner and Hester 1993:171) continues to date the Middle Archaic in south Texas from 4450-2350 B.P. (following Hall et al. [1986]). He similarly dates Pedernales about 3950-3150 B.P. (Hester 1995). Johnson and Goode (1994:29-30) interpret the Pedernales style as part of a Bulverde-PedernalesMontell cultural continuum in the first part of the Late Archaic.

These points are often heavily reworked and therefore the body shape and size is not always uniform on all specimens. However, the distinct bifurcated stem and basal concavity distinguish a Pedernales from other point types. Sometimes longitudinal flute-like flake scars are present on one or both faces of the basal concavity. Pedernales points are commonly found at 
central Texas and lower Pecos sites, and occasionally in south Texas (Turner and Hester 1993:171-173). Ten Pedernales points and two preforms were recovered from three of the eight sites investigated at Lackland; nine of the 12 specimens came from 41BX1102, two from 41BX1103, and one from 41BX1088 Area 1.

UI 11 (Figure 5-7f), from the surface in CU N1175 E1020 at $41 \mathrm{BX} 1088$ Area 1, is a proximal point portion made from brown, fine-grained chert. Its distal end has been broken through use and both stems have been removed due to unknown causes. A single flutelike flake removal on both faces has thinned the basal concavity. There is no evidence of resharpening, burning, serration or beveling.

The predominance of Pedernales occurred at 41BX1102. Seven of the nine recovered from this site can be classified as incomplete points, and the remaining two as Pedernales point preforms. Eight of the nine recovered items were from the surface. The ninth was collected from TU N1005 E1015 at $61 \mathrm{~cm}$ bd. The assemblage consists of four proximal ends, three medial portions, and two bifurcated stems.

UI 4 (Figure 5-31h) in CU N995 E1005 at 41BX1102 is a proximal preform end made of grayish brown, fine-grained chert. A flute-like flake scar on one face has thinned what would have been the basal concavity. Its distal end and one ear of the bifurcated stem are missing due to post depositional damage. There is no evidence of resharpening, burning, serration or beveling.

UI 11 (Figure 5-31e) was found in CU N975 E1020. It is a point proximal end made of grayish brown, finegrained chert. Its distal end has been removed postdepositionally. A single flute-like flake scar is present on one face of the stem (not shown in Figure 5-31e). There is no evidence of resharpening, burning, serration or beveling.

UI 1 (Figure 5-31b) was found $61 \mathrm{~cm}$ below the datum in TUN1005 E1015. It is a proximal end made of light gray, fine-grained chert with occasional coarsegrained inclusions. The specimen has undergone extensive damage; its distal tip and both lateral edges have been broken from unknown causes. A flute-like flake scar extends from the basal concavity upwards along one face of the stem. There is no evidence of resharpening, burning, serration or beveling.

UI 9 (Figure 5-31c) in CU N990 E995 is a proximal end broken through use. It is made from dark grayish brown, fine-grained chert with occasional coarsegrained inclusions. Evidence of resharpening is present on one lateral edge. A single flute-like flake has been removed from the basal concavity upwards along both stem faces. There is no evidence of burning, serration or beveling.

UT 3 (Figure 5-31a) in CU N990 E1005 is a medial portion with its distal end and one basal ear missing from indeterminate break types. It is made of grayish brown, fine-grained chert with occasional coarsegrained inclusions. A single flute-like flake has been removed from the basal concavity upwards along both stem faces. Although no burn damage is evident, the stem shows a waxy gloss and slight darkening suggestive of heat treating. There is no evidence of serration or beveling.

UI 10 (Figure 5-31f) in CU N1010 E1015 is also a medial portion with indeterminate break types. It is made of pale brown, fine-grained chert with one coarse-grained inclusion. This specimen is absent of flute-like flake scars. There is no evidence of resharpening, burning, serration or beveling.

UI 5 (Figure 5-31d) in CU N1005 E1000 is a medial portion displaying evidence of post-depositional breakage to the distal end, one lateral edge, both shoulders, and one portion of the bifurcated stem. A light patina has formed on the undamaged surface. There is no evidence of resharpening, burning, serration or beveling.

UI 7 (Figure 5-31i) in CU N980 E1020 is a Pedernales preform bifurcated stem broken during manufacture. It is made of grayish brown fine-grained chert. No flute-like flake scar is present, and there is no evidence of resharpening, burning, serration or beveling.

UI 8 (Figure 5-31g) from CU N990 E1005 is also a bifurcated stem, but appears to have been broken through use. It is made of brown, fine-grained chert. 
A single flute-like flake scar to thin the stem is present on one surface (not shown in Figure 5-31g). There is no evidence of resharpening, burning, serration or beveling.

\section{Untyped and Untypable Dart Points}

As discussed earlier in this appendix, untyped dart points are those which have measurable and identifiable dimensions and diagnostic attributes, but they do not conform to a previously defined point type. Untypable dart points are those which are fragmentary specimens lacking enough diagnostic attributes, such as the base or barbs, to determine their size or shape.

UI 1 (Figure B-1a) is an untyped point that was found on the surface in CU N1160 E1030 at 41BX1088 Area 1 . It is nearly complete, with its distal tip missing due to use and one basal ear broken due to an indeterminate cause. This crudely made point was fashioned from a flake of brown, fine-grained chert with occasional coarse-grained inclusions. There is no evidence of serration, beveling or burning.

UI 13 (Figure B-1b) is an untyped point recovered from $6 \mathrm{~cm}$ bs in TU N1156 E1043 at 41BX1088 Area 1 . It is nearly complete, with only a tiny portion of its distal tip missing due to an indeterminate cause. It is made from dark gray, fine-grained chert. Beveling is evident on one lateral edge. There is no evidence of serration or burning.

UI 2 (Figure B-1c) is a proximal portion of an untypable point found on the surface in CUN1010 E1015 at $41 \mathrm{BX} 1102$. It is badly damaged from indeterminate causes, with only the stem and one barb remaining. It is made from grayish brown, fine-grained chert with occasional coarse-grained inclusions. There is no evidence of serration, beveling or burning.

UI 6 (Figure B-1d) is the medial portion of an untypable point recovered from the surface in CUN1000 E1015 at 41BX1102. Considerable post-depositional damage has occurred to this specimen. Both the undamaged and damaged surface exhibit a consistently moderate degree of patination. It is made from brown, fine-grained chert with occasional coarse-grained in- clusions. There is no evidence of serration, beveling or burning.

UI 12 (Figure B-1e) is the proximal base or barb of an untypable dart point recovered from the surface of CU N1000 E1015 at 41BX1102. The break appears to have been caused by use. It is made from grayish brown, fine-grained chert. There is no evidence of serration, beveling or burning.

UI 3 (Figure B-1f) is an untyped dart point surface find from CU N985 E995 at 41BX1103. This specimen is nearly complete, with only a tiny fraction of its distal tip removed due to use. It is made from yellowish brown, fine-grained chert and shows no evidence of serration, beveling or burning.

UI 5 (Figure B-1g) is an untyped dart point found on the surface in CUN1010 E990 at 41BX1103. Its distal tip and one basal ear are missing due to use. It is made of brown, fine-grained chert with common dark brown, parallel bands running lengthwise. There is no evidence of serration, beveling or burning.

UI 1 (Figure B-1h) is the proximal portion of an untypable dart point found on the surface in CU N1030 E990 at $41 \mathrm{BX} 1114$. It is made of very dark brown, fine-grained chert, and shows evidence of light patination on both its damaged and undamaged surfaces. Its stem and distal end have been snapped off during use. There is no evidence of serration, beveling or burning.

UI 5 (Figure B-1i) is a proximal portion of an untyped dart point recovered from the surface of CU N1025 E990 at $41 \mathrm{BX} 1114$. It is made from brown, finegrained chert. Its distal tip and one basal ear have been snapped off during use. There is no evidence of serration, beveling or burning.

UI 7 (Figure B-1j) is a proximal portion of an untyped dart point found on the surface in CU N1010 E1000 at 41BX1114. It is made from brown, fine-grained chert. A moderate degree of patination has enveloped its dorsal and ventral surfaces, but only slightly occurs on two proximal post-depositional damaged surfaces. There is no evidence of serration, beveling or burning. 


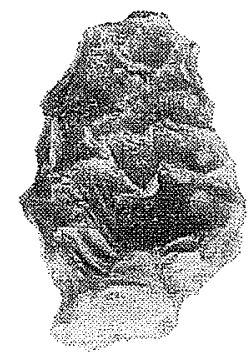

a

(UI T)

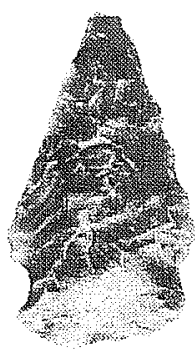

b

(UI 13)
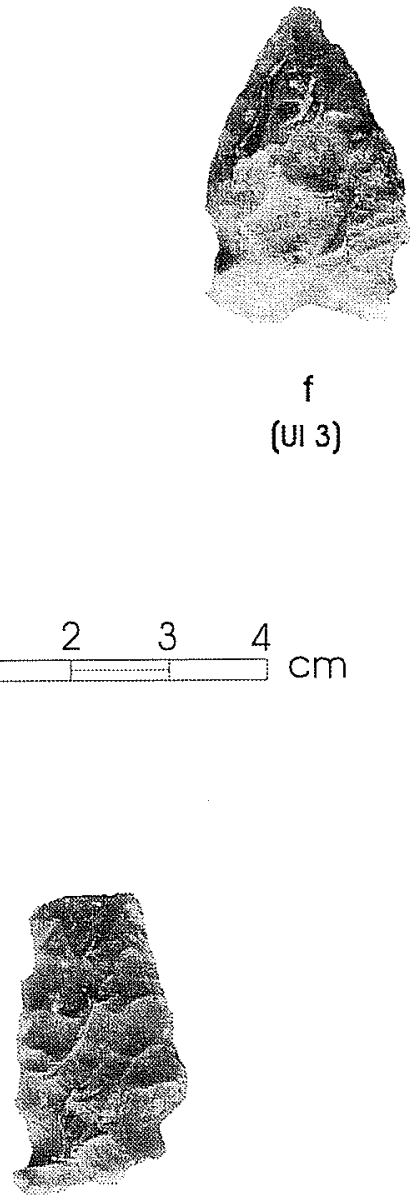

i

(UI 5)

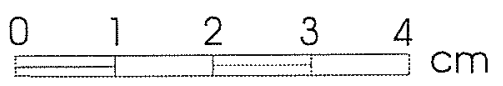

$f$

(UI 12)

(UI 3)
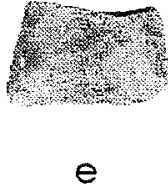

$\mathrm{cm}$

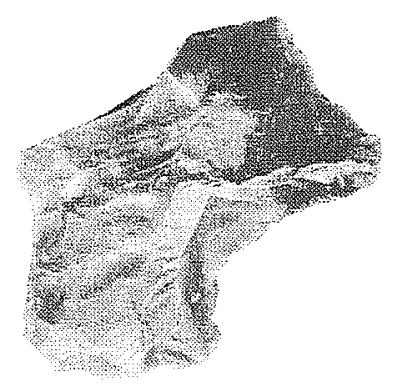

C

(UI 2)

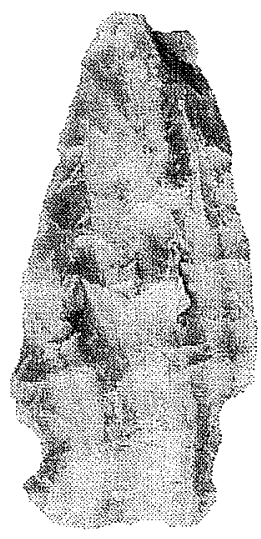

$g$

(UI 5)

(UI 6)

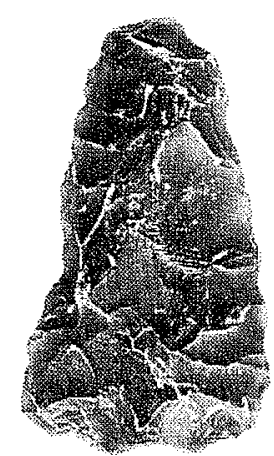

(UI 1)

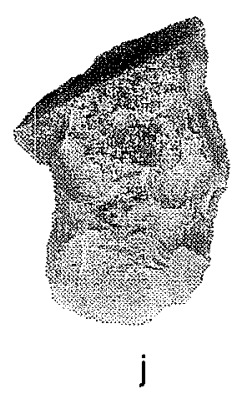

(UI 7)

Figure B-1. Untyped and untypable dart points. a: UI 1, 41BX1088, Area 1; b: UI 13, 41BX1088, Area 1; c: UI 2, 41BX1102; d: UI 6, 41BX1102; e: UI 12, 41BX1102; f: UI 3, 41BX1103; g: UI 5, 41BX1103; h: UI 1, 41BX1114; i: UI 5, 41BX1114; j: UI 7, 41BX1114. 


\section{Bifaces}

Artifacts that had been flaked on both sides of the same lateral edge are classified as bifaces. The only exception to this is bidirectional cores (discussed below). A total of 770 bifaces (excluding projectile points) was collected during the testing project. For each specimen, the following attributes were recorded: raw material type, raw material quality, burning, percentage of cortex remaining, length, width, thickness, tool completeness, blank type, stage of reduction, shape, break type, and evidence for tool recycling. The first three attributes were coded in the same manner as described above for projectile points. The other attributes are discussed below.

The percentage of cortex remaining on each biface was estimated as a percentage of the total surface area of both faces and was coded as either absent, 1-50 percent, or 51-99 percent. Length, width, and thickness were measured to the millimeter for complete dimensions only. Tool completeness was coded as either complete, proximal, medial, distal, longitudinal, wedge, or indeterminate. Longitudinal specimens are those that were broken lengthwise. Wedges are triangular fragments with one bifacially worked edge and two break faces. This type of fragment is characteristically created during biface thinning failures (Tomka 1986). If it was impossible to determine what section of a biface a fragment represented it was coded as indeterminate. Generally, this occurred on fragments which could have been classified as either proximal or distal. Blank types included flakes, nodules, and indeterminate.

The stage of reduction of a biface was a subjective category coded as either early, middle, late, or indeterminate. To insure consistency, all bifaces were coded by the same laboratory analyst. Early stage bifaces usually retain a small to large amount of cortex and have relatively few flake removals, all of which were removed by hard hammer percussion. The edges of these bifaces are generally very sinuous when viewed in profile. Middle stage reduction bifaces are typically thinner than early stage bifaces, have little or no cortex remaining, and have numerous flake scars, many of which may travel beyond the midline of the biface. The edges are less sinuous than those of early stage specimens. Late stage reduction bifaces are thin, have no cortex, and have numerous flake scars. Most of the flakes from late stage reduction are removed by billet or soft hammer percussion. Flake scars are, therefore, relatively longer and shallower than in early stage reduction. The edges of late stage bifaces are usually straight when viewed in profile. If a specimen was too fragmentary to determine its position in the reduction model, it was classified as indeterminate.

An important consideration related to stage of reduction is that functionally a biface could be used at any step in the process. For example, artifacts typically classified as "choppers" are early stage bifaces with a cortex covered proximal end and a crudely flaked distal end. Their distal ends commonly show usewear associated with one or more activity, including butchering, woodworking, and hacking (Turner and Hester 1993:245).

Biface shape, or outline, was coded as either ovate, pointed-ovate, triangular, or indeterminate. The pointed-ovate form is characterized by a rounded, or convex, base and pointed blade. A triangular biface has a pointed blade and a straight base.

One of the more important attributes coded for each incomplete biface was break type. This was classified as manufacture, use, post-depositional, burning, or indeterminate. Manufacture breaks typically result from either lateral biface thinning failures or basal thinning failures (Tomka 1986). A common break type associated with lateral biface thinning failures is known as a perverse fracture. Defined by Crabtree (1972:82) as "a helical, spiral or twisting break initiated at the edge of an objective piece," perverse fractures are easily identified by the twisting of the fracture plane on a rotational axis that corresponds to the direction of the force that initiated the fracture. Another common manufacture failure associated with bifaces is the overshot flake or outrepasse (Crabtree 1972:80). In this case, the lateral thinning blow "struck from one edge of the biface crosses the entire width of the biface and removes a portion of the opposite bifacial edge" (Tomka 1986:89). The resulting flake has a bifacial edge as a termination (Tomka 1986:89). In the cataloguing system employed during this project, overshot flakes are included in the debitage category as 
biface manufacturing flakes and not the biface category.

Basal thinning failures commonly result in transverse (lateral) snapping (Crabtree 1972:92; Johnson 1979:32) or the accidental removal of the distal portion of the biface in the same fashion as overshot or outrepasse flakes are created (Tomka 1986:91). In the latter instance, the overshot removes a large percentage of the distal end of the biface.

Use breaks commonly result from impact with a hard surface or material or from prying (Tomka 1986). End shock, resulting in a traverse fracture, is caused when the elastic limits of the material are exceeded (Crabtree 1972:60). In replication studies, Tomka (1986:94) demonstrates that end shock type breaks result from using a biface to pry something, as well as from the suspended weight of the shaft when hafted bifaces were thrown with sufficient force to penetrate wood. Impact occasionally results in the removal of burin like flakes along the lateral edge of a biface and/or crushing at the point of impact (Tomka 1986:94).

Post-depositional breaks are typically the result of force applied to the lateral surface of a biface. This results in a bulb of percussion originating not from the edge of the artifact but from its face (Tomka 1986:96). Post-depositional breaks can result from numerous activities including natural and artificial factors. At Lackland AFB, military training activities constitute an important artificial impact, especially in the Medina Annex Dog Training Area (Alternate 2).

Burning was coded as either being present or absent and was determined by the presence of crazing, heat fractures, or pot lids. Breaks resulting from burning occur as heat spalls and larger fractures. Heat fractures are the result of differential expansion and contraction of the parent material. Unlike a fracture resulting from the introduction of directed force into the material as is the case with the removal of a flake, burning fractures and pot lids lack compression rings (Crabtree 1972:84).

In some cases, it was not possible to distinguish the break type of an incomplete biface. These specimens were coded as indeterminate. If multiple breaks were present, the analyst attempted to code the fracture that resulted in the artifact being discarded, if this could be determined.

The results of the attribute analysis of the biface category are summarized for each site in Table B-3. A discussion of intersite assemblage similarities and differences is included in Chapter 6.

\section{Perforator}

One bifacial tool from 41BX1076 (UI 17) with robust morphological qualities is functionally classified as a perforator (Figure 5-60). It is a proximal end $22.3 \mathrm{~mm}$ wide and $8.6 \mathrm{~mm}$ thick, made of a chocolate brown, fine-grained chert from an indeterminate blank. Its triangular shape shows evidence of alternate beveling and late stage reduction. Its distal tip has been broken through use. Evidence for burning was not present.

\section{Guadalupe Tools}

Three Guadalupe bifaces were recovered from the surface during testing. The first two are UI 8 and UI 9 found 41BX1088 Area 3; the third is UI 3, found in CU N995 E1005 at 41BX1076. Earlier referred to as an "Attwater Adz" (Hester and Kohnitz 1975:22) or "Buffalo scraper" (Woolford 1935:5-6) the Guadalupe tool is thought to be diagnostic of the Early Archaic and used either in woodworking or hide scraping (Turner and Hester 1993:256), although they may have been either curated or manufactured for use in later periods. Black and Highley (1985:136-156) and Brown (1985) describe the manufacturing sequence and general attributes of Guadalupe tools.

UI 8, from the surface in CUN972 E985 at 41BX1088 Area 3 (Figure B-2), is made from a brown, finegrained chert with grayish, coarser-grained inclusions and is absent of cortex. Its maximum dimensions are $58 \mathrm{~mm}$ in length, $24 \mathrm{~mm}$ in width, and $17 \mathrm{~mm}$ in thickness. Its distally beveled bit angle is 53 . This specimen shows evidence of crushing and small areas of polish on its dorsal ridges, most probably as a result of hafting and pressure associated with use. Hinge fractures extending from its distal bit end along its dorsal 
Table B-3. Number of Bifaces by Attribute at Each Site

\begin{tabular}{|c|c|c|c|c|c|c|c|c|c|}
\hline & \multirow{2}{*}{ Attributes } & \multicolumn{8}{|c|}{ Site $41 B X$} \\
\hline & & 1076 & 1088 & 1090 & 1091 & 1102 & 1103 & 1114 & Total \\
\hline \multirow{3}{*}{ 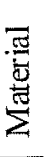 } & Chert & 104 & 338 & 10 & 25 & 78 & 116 & 98 & 769 \\
\hline & Silicified Wood & 0 & 1 & 0 & 0 & 0 & 0 & 0 & 1 \\
\hline & Total & 104 & 339 & 10 & 25 & 78 & 116 & 98 & 770 \\
\hline \multirow{5}{*}{ 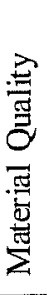 } & Fine-grained & 56 & 198 & 7 & 10 & 56 & 85 & 58 & 470 \\
\hline & Fine w/ Inclusion & 29 & 68 & 3 & 8 & 10 & 21 & 32 & 171 \\
\hline & Coarse & 19 & 66 & 0 & 7 & 12 & 10 & 8 & 122 \\
\hline & No Data & 0 & 7 & 0 & 0 & 0 & 0 & 0 & 7 \\
\hline & Total & 104 & 339 & 10 & 25 & 78 & 116 & 98 & 770 \\
\hline \multirow{8}{*}{ 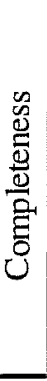 } & Complete & 77 & 219 & 9 & 23 & 33 & 42 & 65 & 468 \\
\hline & Distal & 7 & 31 & 0 & 0 & 6 & 16 & 5 & 65 \\
\hline & Proximal & 6 & 20 & 0 & 0 & 2 & 18 & 6 & 52 \\
\hline & Medial & 2 & 9 & 0 & 0 & 13 & 8 & 0 & 32 \\
\hline & Lon gitudinal & 1 & 7 & 0 & 1 & 2 & 5 & 1 & 17 \\
\hline & Wedge & 0 & 7 & 0 & 1 & 3 & 6 & 3 & 20 \\
\hline & In determinate & 11 & 46 & 1 & 0 & 19 & 21 & 18 & 116 \\
\hline & Total & 104 & 339 & 10 & 25 & 78 & 116 & 98 & 770 \\
\hline \multirow{5}{*}{ 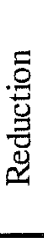 } & Early & 93 & 268 & 10 & 25 & 44 & 52 & 59 & 551 \\
\hline & Middle & 9 & 58 & 0 & 0 & 28 & 48 & 25 & 168 \\
\hline & Late & 1 & 12 & 0 & 0 & 5 & 9 & 12 & 39 \\
\hline & Indeterminate & 1 & 1 & 0 & 0 & 1 & 7 & 2 & 12 \\
\hline & Total & 104 & 339 & 10 & 25 & 78 & 116 & 98 & 770 \\
\hline \multirow{6}{*}{ 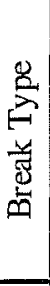 } & Manufacture & 9 & 36 & 0 & 1 & 19 & 38 & 20 & 123 \\
\hline & Use & 0 & 3 & 0 & 0 & 3 & 8 & 3 & 17 \\
\hline & Post-depositional & 14 & 67 & 0 & 0 & 8 & 8 & 3 & 100 \\
\hline & Burning & 1 & 4 & 0 & 0 & 3 & 7 & 0 & 15 \\
\hline & Indeterminate & 6 & 9 & 1 & 0 & 13 & 14 & 8 & 47 \\
\hline & Total & 30 & 19 & 1 & 1 & 46 & 75 & 34 & 306 \\
\hline \multirow{5}{*}{ 曾 } & Ovate & 16 & 22 & 1 & 3 & 5 & 3 & 12 & 62 \\
\hline & Pointed-ovate & 8 & 29 & 1 & 1 & 4 & 10 & 5 & 58 \\
\hline & Triangular & 7 & 27 & 1 & 2 & 3 & 16 & 10 & 66 \\
\hline & Indeterminate & 73 & 261 & 7 & 19 & 66 & 87 & 71 & 584 \\
\hline & Total & 104 & 339 & 10 & 25 & 78 & 116 & 98 & 770 \\
\hline \multirow{3}{*}{ 胥 } & Avg. Length $(\mathrm{mm})$ & 69.8 & 70.5 & 81.4 & 82.8 & 64.8 & 65.9 & 79.4 & 71.6 \\
\hline & Avg. Width (mm) & 47.6 & 47.0 & 63.2 & 53.1 & 45.2 & 46.3 & 49.2 & 47.7 \\
\hline & Avg. Thick. (mm) & 23.3 & 22.5 & 35.9 & 30.6 & 19.7 & 17.7 & 24.6 & 22.7 \\
\hline
\end{tabular}


surface appear to have been caused by resharpening. The bit end also shows evidence of usewear.

UI 9, from the surface of CU N960 E982 at 41BX1088 Area 3 (Figure B-2), is made of light brownish gray, fine-grained chert with approximately 25 percent dorsal cortex remaining. It is $44 \mathrm{~mm}$ long, $22 \mathrm{~mm}$ wide, and $8 \mathrm{~mm}$ thick, and has a beveled bit angle of $33^{\circ}$. Longitudinal flake scars ending in hinge fractures are evident along its dorsal ridges, while small flake scars running along its ventral surface perpendicular to its proximal lateral edges represent attempts at thinning. This specimen is morphologically similar in size and distal bit angle to UI 3 found at 41BX1076. However, unlike the other two tools described here which appear to have been made from a truncated cobble, UI 9 is made from a flake blank whose ventral side has been partially removed to form the proximal ventral face of the tool.

UI 3 (not illustrated) is a Guadalupe biface recovered from the surface in CU N995 E1005 at 41BX1076. It is made of grayish brown, fine-grained chert with no cortex remaining. It is $46 \mathrm{~mm}$ long, $20 \mathrm{~mm}$ wide, and $18 \mathrm{~mm}$ thick, with a beveled bit angle of 39 . Its proximal tip has been broken due to an indeterminate cause. Longitudinal flake scars ending in hinge fractures are evident along its dorsal ridges, while small flake scars running along its ventral surface perpendicular to its proximal lateral edges represent attempts at thinning. Morphologically, it is very similar in size and bit angle to UI 9 found at 41BX1088 Area 3.

\section{Unifaces}

Artifacts that had been flaked on one surface are classified as unifaces. The only exception to this is unidirectional cores (discussed below). A total of 622 unifaces was collected during the testing project. For each specimen, the following attributes were recorded: raw material type, raw material quality, burning, percentage of cortex remaining, maximum dimension, blank type, tool completeness, degree of retouch, location of modification, edge shape, and evidence for tool recycling (Table B-4). The first three attributes were coded in the same manner as described above for projectile points. Cortex presence or absence was
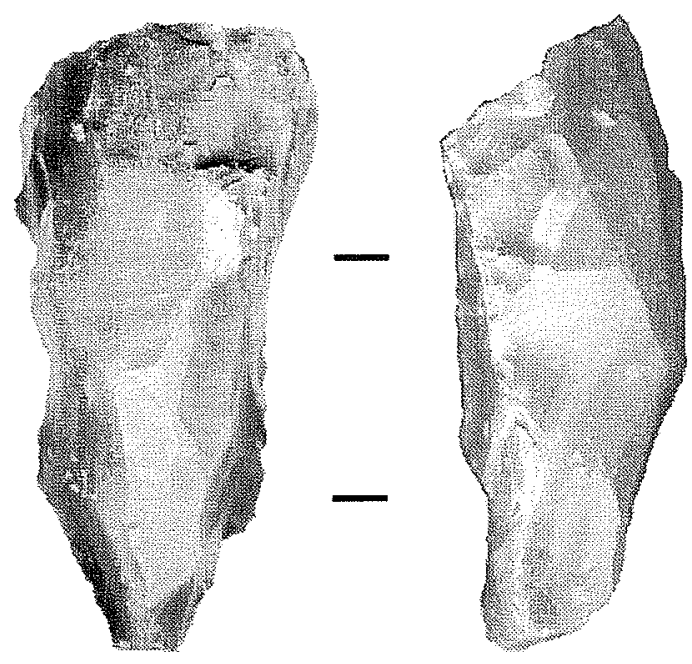

a

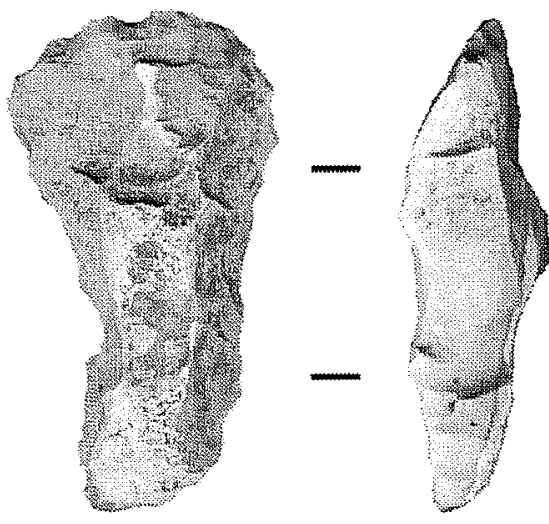

b

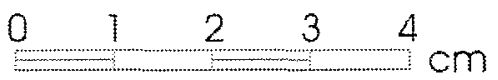

Figure B-2. Guadalupe bifaces from 41BX1088 Area 3. a: UI 8; b: UI 9.

coded in the same manner as for bifaces: absent, 1-50 percent, or 51-99 percent. The maximum dimension, if complete, of each uniface was measured to the nearest millimeter. 
Table B-4. Number of Unifaces by Attribute at Each Site

\begin{tabular}{|c|c|c|c|c|c|c|c|c|c|}
\hline & \multirow{2}{*}{ Attributes } & \multicolumn{8}{|c|}{ Site 41BX } \\
\hline & & 1076 & 1088 & 1090 & 1091 & 1102 & 1103 & 1114 & Total \\
\hline \multirow{3}{*}{ 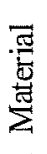 } & Chert & 60 & 132 & 5 & 19 & 49 & 172 & 182 & 619 \\
\hline & Chalcedony & 0 & 0 & 0 & 0 & 1 & 1 & 1 & 3 \\
\hline & Total & 60 & 132 & 5 & 19 & 50 & 173 & 183 & 622 \\
\hline \multirow{5}{*}{ 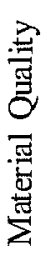 } & Fine-grained & 48 & 86 & 2 & 13 & 36 & 143 & 124 & 452 \\
\hline & Fine w/ Inclusion & 10 & 27 & 1 & 5 & 9 & 25 & 37 & 114 \\
\hline & Coarse & 1 & 19 & 2 & 1 & 5 & 5 & 22 & 55 \\
\hline & No Data & 1 & 0 & 0 & 0 & 0 & 0 & 0 & 1 \\
\hline & Total & 60 & 132 & 5 & 19 & 50 & 173 & 183 & 622 \\
\hline \multirow{8}{*}{$\frac{\frac{n}{0}}{\frac{0}{0}}$} & Complete & 39 & 86 & 5 & 16 & 28 & 97 & 135 & 406 \\
\hline & Distal & 5 & 12 & 0 & 1 & 10 & 23 & 10 & 61 \\
\hline & Proximal & 4 & 1 & 0 & 0 & 3 & 15 & 6 & 29 \\
\hline & Medial & 7 & 19 & 0 & 0 & 8 & 27 & 24 & 85 \\
\hline & Lon gitudinal & 4 & 11 & 0 & 1 & 0 & 9 & 4 & 29 \\
\hline & Wedge & 1 & 2 & 0 & 1 & 0 & 1 & 4 & 9 \\
\hline & In determinate & 0 & 1 & 0 & 0 & 1 & 1 & 0 & 3 \\
\hline & Total & 60 & 132 & 5 & 19 & 50 & 173 & 183 & 622 \\
\hline \multirow{5}{*}{$\begin{array}{l}\frac{1}{0} \\
\frac{0}{0} \\
\stackrel{2}{\Omega}\end{array}$} & Expedient & 17 & 33 & 1 & 4 & 21 & 38 & 45 & 159 \\
\hline & Minimal & 41 & 93 & 3 & 13 & 26 & 132 & 133 & 441 \\
\hline & Formal & 2 & 6 & 1 & 2 & 2 & 3 & 5 & 21 \\
\hline & In determinate & 0 & 0 & 0 & 0 & 1 & 0 & 0 & 1 \\
\hline & Total & 60 & 132 & 5 & 19 & 50 & 173 & 183 & 622 \\
\hline \multirow{4}{*}{$\begin{array}{l}\frac{x}{3} \\
0 \\
0\end{array}$} & Absent & 20 & 39 & 1 & 4 & 15 & 88 & 58 & 225 \\
\hline & $1-50 \%$ & 40 & 91 & 4 & 14 & 33 & 81 & 119 & 382 \\
\hline & $51-99 \%$ & 0 & 2 & 0 & 1 & 2 & 4 & 6 & 15 \\
\hline & Total & 60 & 132 & 5 & 19 & 50 & 173 & 183 & 622 \\
\hline \multirow{5}{*}{ 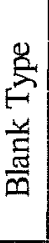 } & Flake & 57 & 124 & 5 & 15 & 43 & 167 & 163 & 574 \\
\hline & Blade & 3 & 3 & 0 & 0 & 6 & 2 & 10 & 24 \\
\hline & Other & 0 & 3 & 0 & 3 & 1 & 0 & 3 & 10 \\
\hline & Indeterminate & 0 & 2 & 0 & 1 & 0 & 4 & 7 & 14 \\
\hline & Total & 60 & 132 & 5 & 19 & 50 & 173 & 183 & 622 \\
\hline \multirow{8}{*}{ 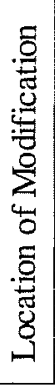 } & Proximal & 3 & 4 & 0 & 1 & 4 & 4 & 10 & 26 \\
\hline & Distal & 13 & 35 & 1 & 4 & 7 & 42 & 37 & 139 \\
\hline & Lateral (1 side) & 34 & 60 & 2 & 8 & 34 & 85 & 106 & 329 \\
\hline & Lateral (2 sides) & 5 & 18 & 0 & 4 & 2 & 11 & 12 & 52 \\
\hline & Lateral and Distal & 3 & 5 & 1 & 1 & 3 & 15 & 8 & 36 \\
\hline & Other Multiple & 0 & 9 & 1 & 0 & 0 & 12 & 7 & 29 \\
\hline & In determinate & 2 & 1 & 0 & 1 & 0 & 4 & 3 & 11 \\
\hline & Total & 60 & 132 & 5 & 19 & 50 & 173 & 183 & 622 \\
\hline
\end{tabular}


Table B-4. continued

\begin{tabular}{|c|c|c|c|c|c|c|c|c|c|}
\hline & \multirow{2}{*}{ Attributes } & \multicolumn{8}{|c|}{ Site $41 B X$} \\
\hline & & 1076 & 1088 & 1090 & 1091 & 1102 & 1103 & 1114 & Total \\
\hline \multirow{8}{*}{ 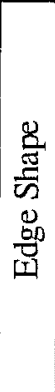 } & Straight & 12 & 24 & 2 & 3 & 11 & 29 & 40 & 121 \\
\hline & Concave & 8 & 10 & 0 & 2 & 12 & 31 & 44 & 107 \\
\hline & Convex & 31 & 82 & 3 & 11 & 21 & 64 & 58 & 270 \\
\hline & Pointed & 1 & 0 & 0 & 0 & 0 & 7 & 4 & 12 \\
\hline & Notched & 1 & 0 & 0 & 0 & 2 & 6 & 7 & 16 \\
\hline & Multiple & 2 & 6 & 0 & 3 & 2 & 25 & 21 & 59 \\
\hline & Irregular & 5 & 10 & 0 & 0 & 2 & 11 & 9 & 37 \\
\hline & Total & 60 & 132 & 5 & 19 & 50 & 173 & 183 & 622 \\
\hline$\stackrel{\mathscr{N}}{\sqrt[n]{2}}$ & $\begin{array}{l}\text { Avg. Maximum } \\
\text { Dimension }(\mathrm{mm})\end{array}$ & 53.0 & 56.4 & 65.0 & 51.8 & 53.1 & 48.0 & 56.7 & 53.8 \\
\hline
\end{tabular}

Blank type was recorded as either flake, blade (see discussion in debitage section below), other, or indeterminate. Tool completeness was coded in the same manner as for bifaces, although the wedge classification was not used. The difficulty with coding completeness for unifaces arises from the fact that a uniface may be made on an incomplete flake. In such instances, the uniface was coded as complete if it was apparent that the flake was broken before it was fashioned into a uniface.

The degree of retouch for unifaces is a somewhat subjective category. The possible classifications are expedient, minimal, formal, and indeterminate. Expedient unifaces are flakes that have been modified through use but not by intentional flaking or shaping. Minimally retouched unifaces, however, have not been drastically altered from their original form, but some flaking has been used to alter the shape of one or more edge. Formal unifaces include artifacts commonly called scrapers, gouges, or unifacial knives, inferring functional usage. One or more edge has been significantly shaped through the deliberate patterning of flake removals. The functional categories listed above were not used because no usewear studies were conducted on the assemblage.

\section{Uniface on Split Cobble}

UI 5 from 41BX1091 (Figure B-3a) is an indeterminate portion of a uniface with evidence of minimal resharpening on its slightly convex ventral surface. It is made of brown, fine-grained chert with occasional coarse-grained inclusions. Cortex covers approximately 90 percent of its ventral surface. This specimen is manufactured on a "split cobble." In split cobble technology, the cores and flakes produced have no visible bulbs of percussion and small striking platforms (Crabtree 1972:48,92). This specimen shows evidence of the missing bulb as a result of cone of force splitting it in half (see below discussion of split cobble technology).

\section{Cores}

A total of 2,292 cores and core fragments was recovered during the testing project. Of the whole cores from 41BX1076, 41BX1102, 41BX1103, and $41 \mathrm{BX} 1114,100$ percent were analyzed, while a 50 -percent sample from the remaining sites, 41BX1076, 41BX1088, 41BX1090, and 41BX1091, was examined. The number of whole cores suitable for analysis was 1,447 . For each specimen, the following attributes were recorded: raw material type, raw material quality, evidence of burning, percentage of cortex remaining, maximum dimension, number of flake scars, and flake scar direction (Table B-5). The first four attributes were coded in the same manner as described above for bifaces and unifaces. The maximum dimension was measured to the nearest centi- 


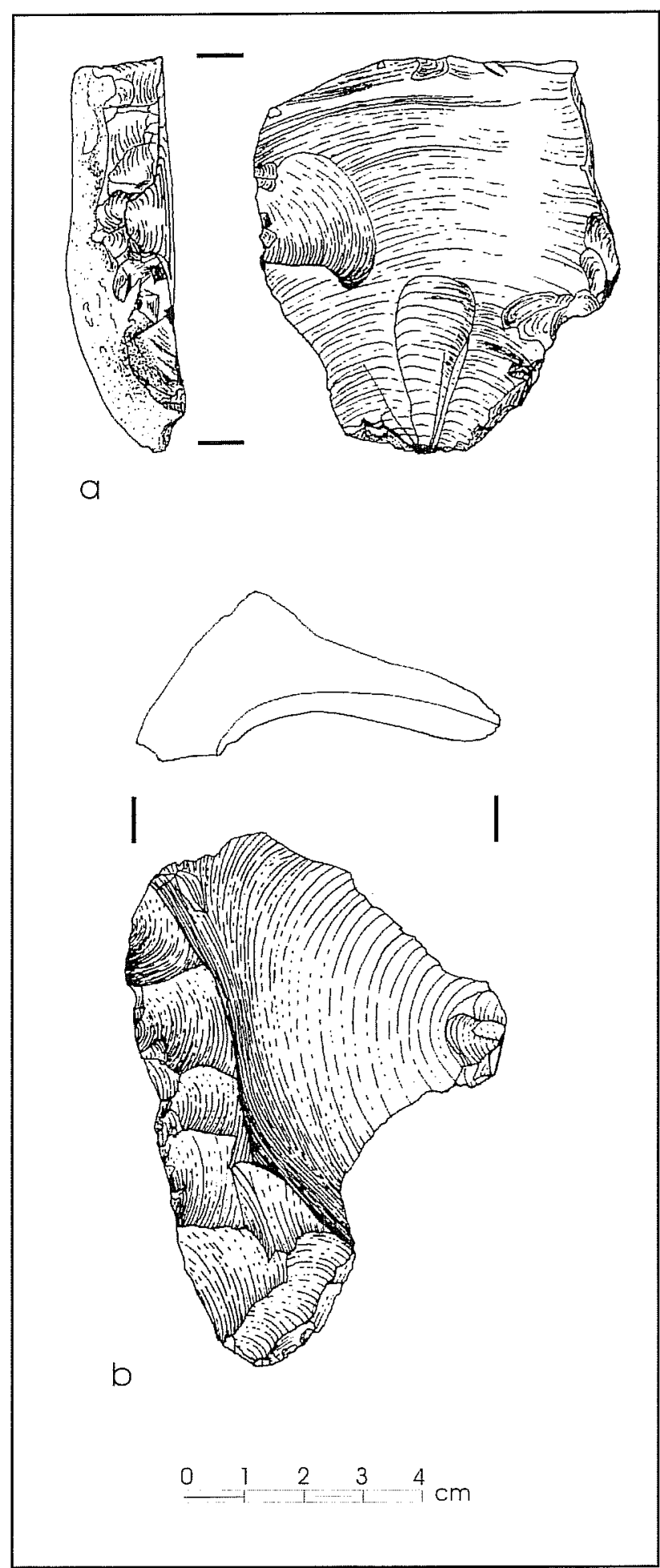

Figure B-3. Artifacts from 41BX1114. a: uniface on split cobble with uniface resharpening flake; b: overshot flake.

meter. Flake count excluded small hinge and step fractures resulting from efforts to prepare striking plat- forms. Flake direction was classified as either unidirectional, bidirectional, multiple, or indeterminate. Specimens with bifacial flaking from the same edge were counted as bifaces, not cores.

An interesting reduction technology was recognized during the attribute analysis of materials from 41BX1091 and later found to be present in collections from other sites as well. An unusual type of core and associated debitage was noted in great quantities in surface collections from 41BX1091. At first thought to be the result of machine crushing, these cores are now believed to represent a cobble splitting technology similar to what Crabtree (1972:92) describes as the "split cone technique." In this method of reduction, Crabtree (1972:34) argues that cobbles are split by smashing them on an anvil, although Steve Tomka was able to replicate these split cobbles in the CAR laboratory using a massive hammerstone without an anvil.

The successful implementation of the method results in the creation of a core and flake that have no visible bulbs of percussion and small striking platforms (Crabtree 1972:48, 92). The bulb of percussion is lacking because the cone of force is split in half by the blow from the hammerstone or against the anvil. Insufficient force or a misdirected blow can result in partially split cone of force or a shearing of the cortex around the cone of force. The resulting flakes are distinctive because they have no bulb of percussion and the proximal end appears to taper to a point with no visible striking platform. In coarse-grained material, evidence of tearing or shearing is seen along the ventral surface of the flakes. During the attribute analysis of the cores, specimens with these characteristics were noted as being "split cobbles."

\section{Unmodified Debitage}

The largest category of chipped stone recovered during the project was unmodified debitage. The goal of the analysis of this category was to reconstruct the types of reduction strategies represented in the debitage recovered at Lackland. Because of the quantity of unmodified debitage recovered during the project, the process was streamlined by analyzing only com- 
Table B-5. Number of Cores by Attribute at Each Site

\begin{tabular}{|c|c|c|c|c|c|c|c|c|c|c|}
\hline & \multirow{2}{*}{ Attributes } & \multicolumn{9}{|c|}{ Site $41 B X$} \\
\hline & & 1070 & 1076 & 1088 & 1090 & 1091 & 1102 & 1103 & 1114 & Total \\
\hline & Cores Collected & 1 & 221 & 1010 & 133 & 409 & 149 & 51 & 318 & 2292 \\
\hline & Cores Analyzed & 1 & 125 & 513 & 72 & 216 & 149 & 51 & 320 & 1447 \\
\hline \multirow{4}{*}{ 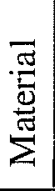 } & Chert & 1 & 125 & 509 & 72 & 214 & 149 & 51 & 318 & 1438 \\
\hline & Chalcedony & 0 & 0 & 2 & 0 & 2 & 0 & 0 & 2 & 6 \\
\hline & Other & 0 & 0 & 2 & 0 & 0 & 0 & 0 & 0 & 2 \\
\hline & Total & 1 & 125 & 513 & 72 & 216 & 149 & 51 & 320 & 1447 \\
\hline \multirow{5}{*}{ 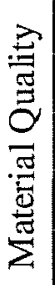 } & Fine-grained & 0 & 86 & 344 & 59 & 131 & 94 & 37 & 158 & 909 \\
\hline & Fine w/ Inclusion & 0 & 24 & 95 & 9 & 21 & 32 & 12 & 98 & 291 \\
\hline & Coarse & 1 & 15 & 74 & 4 & 64 & 23 & 2 & 64 & 247 \\
\hline & No Data & 0 & 1 & 0 & 0 & 1 & 1 & 0 & 1 & 4 \\
\hline & Total & 1 & 125 & 513 & 72 & 216 & 149 & 51 & 320 & 1447 \\
\hline \multirow{5}{*}{ 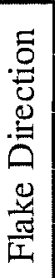 } & Unidirectional & 0 & 34 & 148 & 21 & 41 & 32 & 2 & 101 & 379 \\
\hline & Bidirectional & 1 & 15 & 75 & 18 & 34 & 27 & 7 & 68 & 245 \\
\hline & Multidirectional & 0 & 55 & 212 & 27 & 103 & 45 & 14 & 82 & 538 \\
\hline & Indeterminate & 0 & 21 & 78 & 6 & 38 & 45 & 28 & 69 & 285 \\
\hline & Total & 1 & 125 & 513 & 72 & 216 & 149 & 51 & 320 & 1447 \\
\hline \multirow{2}{*}{ 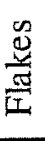 } & Cores in Sample & 1 & 104 & 435 & 66 & 179 & 105 & 22 & 249 & 1161 \\
\hline & Avg. Flake Scars & 2.00 & 5.89 & 5.25 & 3.35 & 4.07 & 6.45 & 10.18 & 5.32 & 5.23 \\
\hline \multirow[t]{2}{*}{$\stackrel{8}{\pi}$} & $\begin{array}{l}\text { Avg. Maximum } \\
\text { Dimension }(\mathrm{cm})\end{array}$ & 7.00 & 7.41 & 7.63 & 7.37 & 7.76 & 7.08 & 7.70 & 7.97 & 7.64 \\
\hline & Split Cobble Cores & 0 & 2 & 31 & 1 & 40 & 0 & 0 & 0 & 74 \\
\hline
\end{tabular}

plete flakes and by using an approach in which each is assigned to a predefined flake type. Prior to the analysis of the Lackland material a series of flake types which are defined on the basis of a list of attributes that are most characteristic of specific reduction techniques were determined. For each flake being analyzed, a limited number of measurements and attributes had to be coded. The alternative to this approach would have been to record multiple attributes for each flake and subsequently develop a flake typology. Problematic to such an approach is that it is very time consuming. The method employed during the Lackland analysis, on the other hand, results in the immediate identification of flake type. For a more detailed description of this method of analysis see Mehalchick et al. (1996).
The selection of complete flakes, defined as those with intact platforms and a measurable maximum length, reduced the sample from 25,784 pieces of debitage to 5,815 . For each complete flake the following attributes were recorded: raw material type, raw material quality, maximum dimension (rounded up to nearest centimeter), platform faceting, amount of dorsal cortex, and flake type (Table B-6). Platform faceting was characterized as either single, double, multiple $(3+)$, or corticate. The amount of dorsal cortex was quantified as either 100 percent (primary flake), less than 100 percent but greater than 0 percent (secondary flake), or 0 percent (tertiary flake) of the surface area of the dorsal side of the flake. Flake types recognized were biface manufacture, biface thinning/ resharpening, uniface manufacture/resharpening, blade, platform preparations and/or core preparation, notching, se- 
Table B-6. Number of Complete Flakes by Attribute at Each Site

\begin{tabular}{|c|c|c|c|c|c|c|c|c|c|c|}
\hline & \multirow{2}{*}{ Attributes } & \multicolumn{9}{|c|}{ Site $41 B X$} \\
\hline & & 1070 & 1076 & 1088 & 1090 & 1091 & 1102 & 1103 & 1114 & Total \\
\hline & Complete Flakes & 1 & 955 & 1708 & 75 & 287 & 359 & 1099 & 1332 & 5815 \\
\hline & In complete Flakes & 4 & 2874 & 4941 & 128 & 2101 & 1394 & 5404 & 3122 & 19969 \\
\hline & Total Debitage & 5 & 3829 & 6649 & 203 & 2388 & 1753 & 6503 & 4454 & 25784 \\
\hline \multirow{7}{*}{ 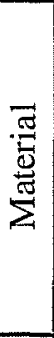 } & Chert & 1 & 937 & 1707 & 75 & 286 & 356 & 1091 & 1326 & 5778 \\
\hline & Chalcedony & 0 & 18 & 1 & 0 & 1 & 3 & 5 & 1 & 29 \\
\hline & Quartzite & 0 & 0 & 0 & 0 & 0 & 0 & 1 & 1 & 2 \\
\hline & Silicified Wood & 0 & 0 & 0 & 0 & 0 & 0 & 0 & 2 & 2 \\
\hline & A gate/Jasper & 0 & 0 & 0 & 0 & 0 & 0 & 0 & 1 & 1 \\
\hline & Other & 0 & 0 & 0 & 0 & 0 & 0 & 2 & 1 & 3 \\
\hline & Total & 1 & 955 & 1708 & 75 & 287 & 359 & 1099 & 1332 & 5815 \\
\hline \multirow{5}{*}{ 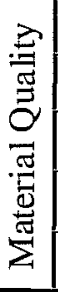 } & Fine-grained & 1 & 678 & 1208 & 53 & 198 & 255 & 886 & 932 & 5816 \\
\hline & Fine w/ Inclusion & 0 & 129 & 229 & 8 & 33 & 54 & 97 & 121 & 671 \\
\hline & Coarse & 0 & 146 & 269 & 14 & 55 & 50 & 114 & 278 & 926 \\
\hline & No Data & 0 & 2 & 2 & 0 & 1 & 0 & 2 & 1 & 8 \\
\hline & Total & 1 & 955 & 1708 & 75 & 287 & 359 & 1099 & 1332 & 5816 \\
\hline \multirow{6}{*}{ 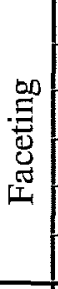 } & Single & 0 & 332 & 689 & 40 & 112 & 122 & 397 & 511 & 2203 \\
\hline & Double & 0 & 155 & 257 & 5 & 25 & 60 & 123 & 120 & 745 \\
\hline & Multiple & 1 & 275 & 411 & 10 & 73 & 123 & 489 & 427 & 1808 \\
\hline & Corticate & 0 & 193 & 3501 & 20 & 77 & 54 & 90 & 273 & 1057 \\
\hline & No Data & 0 & 0 & 1 & 0 & 0 & 0 & 0 & 1 & 2 \\
\hline & Total & 1 & 955 & 1708 & 75 & 287 & 359 & 1099 & 1332 & 5816 \\
\hline \multirow{9}{*}{$\left|\begin{array}{c}0 \\
\stackrel{0}{S} \\
0 \\
\frac{s}{J} \\
\frac{J}{I I}\end{array}\right|$} & Bif. Manufacture & 0 & 183 & 51 & 0 & 20 & 68 & 180 & 166 & 868 \\
\hline & Bif. Thin/Resharp. & 0 & 66 & 28 & 1 & 9 & 13 & 185 & 51 & 353 \\
\hline & Uniface & 0 & 18 & 13 & 0 & 3 & 2 & 47 & 8 & 91 \\
\hline & Blade & 0 & 0 & 13 & 1 & 6 & 4 & 19 & 14 & 57 \\
\hline & Core/Platform Prep. & 0 & 639 & 1310 & 65 & 206 & 246 & 519 & 1027 & 4012 \\
\hline & Sequence & 0 & 6 & 4 & 0 & 1 & 0 & 0 & 6 & 17 \\
\hline & Notch & 0 & 8 & 2 & 0 & 3 & 0 & 7 & 0 & 20 \\
\hline & Indeterminate & 1 & 35 & 87 & 8 & 39 & 26 & 142 & 60 & 398 \\
\hline & Total & 1 & 955 & 1708 & 75 & 287 & 359 & 1099 & 1332 & 5816 \\
\hline 茎 & $\begin{array}{l}\text { Avg. Maximum } \\
\text { Dimension }(\mathrm{cm})\end{array}$ & 2.0 & 4.0 & 4.3 & 5.0 & 4.2 & 4.3 & 3.5 & 4.2 & 4.1 \\
\hline
\end{tabular}

quence, channel, split cobble, or indeterminate. These are defined below.

Because the material at 41BX1103 was recovered from a gravel bar context, depositional history of the site was a primary concern. Therefore, evidence of stream damage was recorded. Stream damage was indicated by battering or crushing along the ridges of flakes, not the edges, which could have been modified through use or by post-depositional events. Evidence of stream damage was coded as either absent, present, or indeterminate. 


\section{Biface Manufacture Flakes}

These flakes are defined as primary and secondary flakes having moderate to large dorsal flake scar ridges and with minimal to considerable longitudinal curvature. The striking platforms on this type range from single to multifaceted, although single and double faceting is most common. These flakes are usually removed with a hard hammerstone or large billet, and the dorsal flake scarring is indicative of sequential flake removals and flake removals from opposite edges (Mehalchick et al. 1996). In the system employed during this analysis, overshot flakes are classified as biface manufacture flakes (Figure B-3b).

\section{Biface Thinning/Resharpening Flakes}

In other studies, biface thinning flakes have been separated from biface resharpening flakes (cf. Mehalchick et al. 1996), but because much of the distinction between the two is based on the presence of usewear, this study did not attempt any such separation. These types of flakes are generally tertiary flakes which were removed by pressure or by a soft hammerstone or billet. They are characterized by a moderate to large number of dorsal flake removal scars, but unlike biface manufacture flakes, this type has shallow flake scar ridges. Longitudinal curvature ranges from moderate to slight depending on the type of parent artifact. The striking platform is generally multifaceted and may be ground (although this was not coded), with some lipping on the ventral edge (Mehalchick et al. 1996).

\section{Uniface Manufacture/Resharpening Flakes}

As with biface thinning and resharpening flakes, the primary distinction between uniface manufacture and uniface resharpening flakes is that uniface resharpening flakes show evidence of usewear on the platforms. For the purposes of this study, the two flake types are treated as one category. These flakes are generally small to medium in size with single-faceted platforms. Often, there is a slight longitudinal curvature at the distal end of the flake, usually accompanied by a discernible ridge oriented perpendicular to the longitudinal axis of the flake. This ridge is formed by the intersection of the original dorsal surface of the blank and the subsequent flakes scars originating from the lateral edges of the blank. Other characteristics of uniface manufacture/resharpening flakes are that the dorsal surface generally is marked by a series of parallel flake scars and small step fractures, the result of use or previous manufacture activity, at the proximal end (Mehalchick et al. 1996).

A distinctive type of uniface resharpening flake that is represented in the Lackland assemblage is the result of an attempt to rework the original uniface into a bifacial tool (Figure B-3). These flakes are formed when the worn edge of the uniface is used as the striking platform to remove flakes from the ventral face of the uniface. These flakes have multifaceted platforms and a flat dorsal surface (once the ventral surface of the uniface). These flakes typically terminate in hinge fracture because of the difficulty associated with removing flakes with a near 90 degree striking platform angle (Mehalchick et al. 1996). For a more detailed discussion of uniface resharpening strategies refer to Mehalchick et al. (1996) and Shafer (1970).

\section{Blades}

Generally, a blade is defined as a flake that is twice as long as it is wide (Mehalchick et al. 1996), although in this study, the definition is restricted to flakes removed from a blade core. These flakes are characterized by single or multiple dorsal ridges that are roughly parallel to the longitudinal axis of the flake. These ridges are indicative of earlier blade removals. The longitudinal curvature of blades is slight to moderate. Striking platforms are generally single or corticate faceted, although double and multiple-faceted platforms occur as well (Mehalchick et al. 1996).

\section{Platform Preparation and/or Core Preparation Flakes}

Platform and core preparation flakes are highly variable in size, shape, amount of dorsal cortex, and platform faceting, but they all represent an attempt to prepare a platform or core for subsequent flake removals. Size and platform faceting are dependent upon 
the stage of reduction during which they were removed and the size of the parent material which may be a core or artifact. Likewise, shape is dependent on the type of core from which they were removed. The amount of dorsal cortex is also highly variable, ranging from 0 percent to 100 percent, depending on the stage of reduction (Mehalchick et al. 1996).

\section{Notching Flakes}

These small flakes are usually $5-15 \mathrm{~mm}$ long, and are removed by pressure flaking during the creation of notches on projectile points or other notched tools. They are easily recognized by their distinctive recessed, U-shaped platforms and scalloped dorsal surfaces indicative of prior notching flake removals (Mehalchick et al. 1996).

\section{Sequence Flakes}

Sequence flakes are indicative of a particular core reduction strategy in which a cobble is first split lengthwise and then flakes are removed in sequence beginning at one end of the core. Flakes removed in this fashion show "direct superposition of positive and negative bulbs of percussion on the interior and exterior flake surface respectively" (Jelinek et al. 1971). This method of flake removal may have been useful in an environment where raw material was commonly available as tubular cobbles rather than as tabular or spherical cobbles.

\section{Split Cobble Flakes}

The technique of splitting cobbles using an anvil or large hammerstone when successful creates a flake with a very small striking platform that is usually corticate, but without a bulb of percussion. Unsuccessful cobble splitting creates fractured flakes with proximal ends that taper to a point. These types of flakes were encountered in great quantities at 41BX1091 and were originally attributed to machine crushing of chert cobbles. Debitage at that site was sorted differently than at the others: the categories used were cultural complete flakes; cultural incomplete flakes, which included proximal flake fragments that were representative of one of the flake types described above: "machine flakes," which included complete and proximal specimens since the diagnostic attribute was the pointed proximal end without a bulb of percussion or obvious striking platform; and indeterminate incomplete flakes which included primarily distal flake fragments which could be attributed to either "machine" or cultural origins. Once the split cobble method of core reduction was successfully replicated in the laboratory, it was realized that the "machine flakes" were attributable to this unusual lithic technology. At several sites, split cobble flakes were used in the manufacture of unifaces.

\section{Indeterminate Flakes}

If a flake could not be assigned with certainty to one of the types described above, it was coded as indeterminate. Generally, flakes displaying attributes associated with two or more different types were included in the indeterminate category.

\section{Ground and Battered Stone}

This category includes 14 artifacts with grinding/ polish or battering (Table B-7). No pecked stone artifacts were recovered during the testing project. Each specimen was given a UI number and coded for the following attributes: raw material type and grain size; type of wear, degree of wear, location of wear, proposed functional type of artifact, and completeness. Wear type was classified as either grinding/polishing or battering. The degree of wear was subjectively determined to be minimal, moderate, or extensive. Location of wear was coded as either on an edge, on a face, on multiple edges, or on multiple faces. Functional artifact types were assigned to each specimen as either hammerstones (indicated by battering), manos (indicated by grinding or polishing), grinding slabs (inferred based on size and location of modification to distinguish from manos), or other. Actual use wear studies were not performed on these specimens. Completeness was indicated as either complete or incomplete. In no case did an artifact appear to have multiple types of wear. 
Table B-7. Ground and Battered Stone Artifacts

\begin{tabular}{|c|c|c|c|c|c|}
\hline Site & Hammerstones & Manos & Grinding Slabs & Other & Total \\
\hline $41 \mathrm{~B} \times 1076$ & 4 & 1 & 1 & 0 & 6 \\
\hline $41 \mathrm{~B} \times 1088$ & 2 & 1 & 0 & 0 & 3 \\
\hline $41 \mathrm{BX} 1090$ & 1 & 0 & 0 & 0 & 1 \\
\hline $41 \mathrm{BX} 1091$ & 0 & 0 & 0 & 1 & 1 \\
\hline $41 \mathrm{BX} 1102$ & 0 & 1 & 0 & 0 & 1 \\
\hline $41 \mathrm{BX} 1103$ & 1 & 0 & 0 & 0 & 1 \\
\hline $41 \mathrm{BX} 1114$ & 0 & 0 & 0 & 1 & 1 \\
\hline Total & 8 & 3 & 1 & 2 & 14 \\
\hline
\end{tabular}

The most common artifact type in this category is battered stone classified as hammerstones. The specific dimensions of each specimen is presented in Table B-8. The average length of hammerstones is $92 \mathrm{~mm}$. The average width is $64 \mathrm{~mm}$, and the average thickness is $55 \mathrm{~mm}$. With the exception of UI 1 from 41BX1090, all of these artifacts are fine-grained chert nodules exhibiting battering damage on one or more edge. As a practical matter, this particular category of artifact may be under-represented in the Medina Annex sample because the naturally occurring chert nodules in the area are stream battered on all surfaces. This makes it difficult to distinguish artificial battering from natural damage.
A small sample of three manos was recovered during the testing project. All three are chert cobbles exhibiting minimal to moderate amounts of wear. There are possible fibers preserved on UI 13 from 41BX1102. The average measurements for the length, width, and thickness of the manos area $94 \mathrm{~mm}, 74 \mathrm{~mm}$, and $43 \mathrm{~mm}$, respectively. The exact dimensions of each specimen are presented in Table B-9.

The one possible grinding slab is a large chert cobble that has fractured during to heating. It was recovered from Feature 1 at 41BX1076. The face with evidence of grinding was face down in the feature. The cobble is fine-grained chert, measuring $126 \mathrm{~mm}$, by $116 \mathrm{~mm}$, by $114 \mathrm{~mm}$. The smoothing on its one surface is prob-

Table B-8. Size Measurements and Degree of Wear for Hammerstones

\begin{tabular}{|c|c|c|c|c|c|c|}
\hline \multicolumn{2}{|c|}{ Provenience } & \multirow{2}{*}{ UI\# } & \multirow{2}{*}{ Wear } & \multirow{2}{*}{$\mathbb{L}(\mathbf{m m})$} & \multirow{2}{*}{$\mathrm{W}(\mathrm{mm})$} & \multirow{2}{*}{ Th $(\mathbf{m m})$} \\
\hline Site & Area & & & & & \\
\hline \multirow[t]{4}{*}{$41 \mathrm{BX} 1076$} & & 11 & Moderate & 73 & 51 & 47 \\
\hline & & 12 & Moderate & 93 & 90 & 63 \\
\hline & & 14 & Moderate & 81 & 57 & 50 \\
\hline & & 16 & Extensive & 77 & 70 & 43 \\
\hline \multirow[t]{2}{*}{$41 \mathrm{BX} 1088$} & 2 & 3 & Minimal & 66 & 46 & 53 \\
\hline & 3 & 3 & Extensive & 114 & 83 & 74 \\
\hline $41 \mathrm{BX} 1090$ & & 1 & Moderate & 122 & 57 & 31 \\
\hline $41 \mathrm{BX} 1103$ & & 12 & Moderate & 114 & 59 & 56 \\
\hline
\end{tabular}


Table B-9. Size Measurements and Degree of Wear for Manos

\begin{tabular}{|c|c|c|c|c|c|c|}
\hline \multicolumn{2}{|c|}{ Provenience } & \multirow{2}{*}{ UI\# } & \multirow{2}{*}{ Wear } & \multirow{2}{*}{$\mathbf{L}(\mathbf{m m})$} & \multirow{2}{*}{$\mathbf{W}(\mathbf{m} \mathbf{m})$} & \multirow{2}{*}{ Th $(\mathrm{mm})$} \\
\hline Site & Area & & & & & \\
\hline $41 \mathrm{BX} 1076$ & & 13 & Moderate & 67 & 58 & 52 \\
\hline $41 \mathrm{BX} 1088$ & 2 & 25 & Moderate & 89 & 67 & 41 \\
\hline $41 \mathrm{BX} 1102$ & & 13 & Moderate & 125 & 98 & 37 \\
\hline
\end{tabular}

ably the result of grinding, but could be a result of the heat to which the cobble was subjected. The degree of wear is characterized as minimal.

The other two ground stone artifacts are fine-grained chert cobbles exhibiting visible polish on one or more faces, possibly from using the artifact to smooth animal hide (Adams 1988; Webley 1990). The measurements for each specimen are presented in Table B-10.

\section{Drilled Stone}

A single drilled chert pebble artifact was found on the surface at 41BX1088 Area 2. This artifact may be a plummet (cf. Turner and Hester 1993:305) or a stone bead (Figure 5-13). It measures $27.8 \mathrm{~mm}$ long, by $20 \mathrm{~mm}$ wide, by $9.8 \mathrm{~mm}$ thick. A hole, varying in width from $4.3 \mathrm{~mm}$ in the interior of the stone to $6 \mathrm{~mm}$ at the surface of the stone, has been drilled through the artifact's cortex, slightly offset from its center. This hole exposes the chert composing the interior of the pebble. Possible functions of such artifacts include ornaments, or net weights (Turner and Hester 1993:305). This artifact, which weighs $5.2 \mathrm{~g}$, is too light to effectively have functioned as a weight, and is therefore considered to be ornamental.

\section{Ceramics}

An unexpected artifact type encountered during the Lackland testing was prehistoric ceramics. Eight sherds were recovered together at 41BX1114 and two sherds were found in close proximity to one another at 41BX1088 Area 1. All 10 sherds appear to be bonetempered plainware commonly identified as Leon Plain in Central and South Texas (Black 1986; Hester 1995; Hester and Hill 1971; Johnson 1994; Perttula et al. 1995; Suhm and Jelks 1962). The sherds from 41BX1114 appear to be from a narrow-necked jar, a common Leon Plain vessel form (Hester 1995:446; Perttula et al. 1995:196). Several of the sherds refit, as is depicted in Figure 5-52. The two sherds recovered at 41BX1088 Area 1 (Figure 5-6) are slightly different in composition in that they apparently have a bone and shell temper in a very sandy paste. One sherd, a large rim piece, is clearly from a large bowl. The other sherd is a body sherd, possibly from the same vessel. The salient attributes of each sherd are included in Table B-11.

\section{Unique Items}

Temporally diagnostic, unique, or unusual prehistoric artifacts were assigned Unique Item (UI) numbers. Table B-12 lists the unique items by site.

Table B-10. Size Measurements and Location of Wear for Other Ground-stone Artifacts

\begin{tabular}{|c|c|l|c|c|c|}
\hline Site & UI\# & Location of Wear & L (mm) & W (mm) & Th (mm) \\
\hline $41 \mathrm{BX} 1091$ & 3 & Multiple faces & 74 & 62 & 31 \\
\hline $41 \mathrm{BX} 1114$ & 8 & Single face & 68 & 65 & 56 \\
\hline
\end{tabular}


Table B-11. Attributes of Leon Plain Ceramic Sherds Recovered During Lackland Testing Project

\begin{tabular}{|c|c|c|c|c|c|c|c|c|}
\hline Site & UI & Type & $\mathbf{L}(\mathbf{m m})$ & $\mathrm{W}(\mathrm{mm})$ & Th (mm) & Paste & Temper & Vessel Form \\
\hline \multirow[t]{2}{*}{ 41BX 1088} & 16 & $\operatorname{Rim}$ & 73 & 53 & 11 & Sandy & Bone/Shell & Bow l \\
\hline & 17 & Body & 41 & 37 & 10 & Sandy & Bone/Shell & Bowl (?) \\
\hline \multirow{8}{*}{$41 \mathrm{BX} 1114$} & 9 & Body (neck) & 46 & 37 & 7 & Clay & Bone & Jar, narrow neck \\
\hline & 10 & Body (neck) & 50 & 31 & 7 & Clay & Bone & Jar, narrow neck \\
\hline & 11 & Body (neck) & 48 & 32 & 7 & Clay & Bone & Jar, narrow neck \\
\hline & 12 & Body (neck) & 37 & 33 & 7 & Clay & Bone & Jar, narrow neck \\
\hline & 13 & Body (neck) & 29 & 21 & 7 & Clay & Bone & Jar, narrow neck \\
\hline & 14 & Body (neck) & 28 & 13 & 7 & Clay & Bone & Jar, narrow neck \\
\hline & 15 & Body (neck) & 25 & 17 & 7 & Clay & Bone & Jar, narrow neck \\
\hline & 16 & Body (neck) & 23 & 15 & 8 & Clay & Bone & Jar, narrow neck \\
\hline
\end{tabular}

\section{Historic Artifacts}

The only site that contained historic artifacts was 41BX1103. The assemblage consists of seven ceramic kitchenware sherds, eleven bottle glass sherds, two window glass sherds, six machine cut nails, an iron spike, and two ceramic sewer pipe fragments. Anne Fox conducted an analysis of them and has concluded that they all appear to have been made in the nineteenth century. Modern bottle glass and metal fragments were also observed sporadically across the site surface. Given the corroborating circumstance that no evidence of a historic structure was found, the presence of modern surface trash, no patterned distribution of the nineteenth century artifacts, and the fact that with the exception of two machine cut nails, and one window glass sherd, all historic artifacts were found on the surface, it appears the site may have been used as a casual dump. Artifact classes and individual artifacts are described below.

\section{Ceramics}

The earliest ceramic sherd is a fragment of a blue edgeware plate probably made between 1840 and 1860 (Moir 1985). Two undecorated whiteware sherds collected from the surface appear to be ironstone ware most popular during the last half of the nineteenth century.

Four sherds of stoneware have a salt glaze on the outside and Albany slip on the inside. They all appear to be parts of the same crock or jar and came from adjacent surface collection units. Salt glazing was in common use during the nineteenth century, as was a dark brown Albany slip glaze (Greer 1981:180, 194).

\section{Glass}

One base and five body fragments represent a brown beer bottle possibly made by the Louisville Kentucky Glass Works about 1880 (Toulouse 1971:323). Two heavy dark green glass fragments represent an unidentifiable container. Two additional much thinner green glass fragments, judging from their patina, may have come from the same object. One clear glass fragment could be from a bottle made in the late nineteenth through the early twentieth century, or later.

\section{Construction Materials}

Two very small fragments of window glass were collected from Levels 1 and 2 of TU N998 E1003. Six 
Table B-12. Unique Items (UI) from Medina Annex Testing Project

\begin{tabular}{|c|c|c|c|c|}
\hline \multicolumn{2}{|c|}{ Provenience } & \multirow{2}{*}{ UI } & \multirow{2}{*}{ Description } & \multirow{2}{*}{ Notes } \\
\hline Site & Area & & & \\
\hline \multirow{17}{*}{$41 \mathrm{BX} 1076$} & & 1 & Fairland dart point & \\
\hline & & 2 & Scallorn arrow point & \\
\hline & & 3 & Guadalupe biface & Small and crude; with use wear \\
\hline & & 4 & Biface & Possible blood stains \\
\hline & & 5 & Quartzite flake & \\
\hline & & 6 & Biface & Possible blood stains \\
\hline & & 7 & Uniface & \\
\hline & & 8 & Split Cobble & Refit core and flake \\
\hline & & 9 & Biface & Fresh flakes on patinated surface \\
\hline & & 10 & Biface & Refit with piece collected during survey \\
\hline & & 11 & Hammerstone & \\
\hline & & 12 & Hammerstone & \\
\hline & & 13 & Chert mano (?) & \\
\hline & & 14 & Hammerstone & \\
\hline & & 15 & Grinding slab & Burned chert cobble, Feature 1 \\
\hline & & 16 & Hammerstone & \\
\hline & & 17 & Drill or perforator & Tip broken off \\
\hline \multirow{25}{*}{$41 \mathrm{BX} 1088$} & \multirow{25}{*}{1} & 1 & Untyped dart point & \\
\hline & & 2 & Ensor dart point & \\
\hline & & 3 & Perdiz preform & \\
\hline & & 4 & Edwards arrow point & \\
\hline & & 5 & Frio dart point & \\
\hline & & 6 & Frio dart point & \\
\hline & & 7 & Perdiz arrow point & \\
\hline & & 8 & Darl dart point & \\
\hline & & 9 & Arrow point blank & \\
\hline & & 10 & Scallorn arrow point & \\
\hline & & 11 & Pedernales dart point & \\
\hline & & 12 & Edgew ood dart point & \\
\hline & & 13 & Untyped dart point & \\
\hline & & 14 & Scallorn arrow point & Base only \\
\hline & & 15 & Dart point blank & \\
\hline & & 16 & Ceramic sherd & Leon Plain rim \\
\hline & & 17 & Ceramic sherd & Leon Plain body \\
\hline & & 18 & Split Cobble Core & Split cobble core/uniface \\
\hline & & 19 & Uniface & Thumbnail scraper on blade \\
\hline & & 20 & Uniface & Side scraper on blade \\
\hline & & 21 & Biface & Thin biface fragment \\
\hline & & 22 & Biface & With possible use wear polish \\
\hline & & 23 & Biface & With possible use wear polish \\
\hline & & 24 & Biface & Butted biface; chopper \\
\hline & & 25 & Ground stone & Possible chert mano \\
\hline
\end{tabular}


Table B-12. continued

\begin{tabular}{|c|c|c|c|c|}
\hline \multicolumn{2}{|c|}{ Provenience } & \multirow{2}{*}{$\mathbf{U I}$} & \multirow{2}{*}{ Description } & \multirow{2}{*}{ Notes } \\
\hline Site & Area & & & \\
\hline \multirow{13}{*}{$\begin{array}{c}41 \mathrm{BX} 1088 \\
\text { (cont.) }\end{array}$} & \multirow{4}{*}{2} & 1 & Fairland dart point & \\
\hline & & 2 & Perdiz preform & \\
\hline & & 3 & Hammerstone & \\
\hline & & 4 & Pend ant/Plummet & $27.7 \times 2.03 \times 0.95 \mathrm{~mm}$ \\
\hline & \multirow{9}{*}{3} & 1 & Flake & Possible use wear polish on one surface \\
\hline & & 2 & Chert cobble (burned) & Cobble with area of polish on one surface \\
\hline & & 3 & Hammerstone & \\
\hline & & 4 & Uniface & On split cobble flake \\
\hline & & 5 & Uniface & On split cobble flake \\
\hline & & 6 & Biface & Possible blood stains \\
\hline & & 7 & Biface & Possible blood stains \\
\hline & & 8 & Guadalupe biface & With use wear and polish \\
\hline & & 9 & Guadalupe biface & With use wear \\
\hline \multirow{3}{*}{$41 \mathrm{~B} \times 1090$} & & 1 & Hammerstone & \\
\hline & & 2 & Ground stone & Polish on chert cobble \\
\hline & & 3 & Ground stone & Polish on chert core, probably just burning \\
\hline \multirow{5}{*}{$41 \mathrm{~B} \times 1091$} & & 1 & Fairland dart point & \\
\hline & & 2 & Scallorn arrow point & \\
\hline & & 3 & Ground stone & Heavy polish on one face, hide working? \\
\hline & & 4 & Uniface & On split cobble flake \\
\hline & & 5 & Uniface & On split cobble flake, with resharpening \\
\hline \multirow{18}{*}{$41 \mathrm{~B} \times 1102$} & & 1 & Pedernales dart point & \\
\hline & & 2 & Untypable dart point & \\
\hline & & 3 & Pedernales dart point & \\
\hline & & 4 & Pedernales preform & \\
\hline & & 5 & Pedernales dart point & \\
\hline & & 6 & Unty pable dart point & \\
\hline & & 7 & Pedernales preform & \\
\hline & & 8 & Pedernales dart point & \\
\hline & & 9 & Pedernales dart point & \\
\hline & & 10 & Pedernales dart point & \\
\hline & & 11 & Pedernales dart point & \\
\hline & & 12 & Untypable dart point & \\
\hline & & 13 & Ground stone & Mano or grinding slab with possible fibers \\
\hline & & 14 & Biface & Thin, triangular biface with incipient stem \\
\hline & & 15 & Biface & Possible wed ge \\
\hline & & 16 & Biface & Possible wedge \\
\hline & & 17 & Biface & Refit broken halves \\
\hline & & 18 & Biface & Chopper-like tool \\
\hline
\end{tabular}


Table B-12. continued

\begin{tabular}{|c|c|c|c|c|}
\hline \multicolumn{2}{|c|}{ Provenience } & \multirow{2}{*}{ UI } & \multirow{2}{*}{ Description } & \multirow{2}{*}{ Notes } \\
\hline Site & Area & & & \\
\hline \multirow{18}{*}{$41 \mathrm{BX} 1103$} & & 1 & Fairland dart point & \\
\hline & & 2 & Fairland dart point & \\
\hline & & 3 & Untyped dart point & \\
\hline & & 4 & Marcos dart point & \\
\hline & & 5 & Untyped dart point & \\
\hline & & 6 & Ensor dart point & \\
\hline & & 7 & Fairland dart point & \\
\hline & & 8 & Edgew ood dart point & \\
\hline & & 9 & Frio dart point & \\
\hline & & 10 & Pedernales dart point & \\
\hline & & 11 & Pedernales dart point & \\
\hline & & 12 & Hammerstone & \\
\hline & & 13 & Uniface & Unfinished, large uniface \\
\hline & & 14 & Uniface & Uniface on large distal flake fragment \\
\hline & & 15 & Biface & Heat treated with possible use-wear \\
\hline & & 16 & Biface & Reworked uniface \\
\hline & & 17 & Uniface & End scraper \\
\hline & & 18 & Biface & Chopper \\
\hline \multirow{19}{*}{$41 \mathrm{BX} 1114$} & & 1 & Unty pable dart point & \\
\hline & & 2 & Fairland dart point & \\
\hline & & 3 & Fairland dart point & \\
\hline & & 4 & Scallom arrow point & Brangus variety \\
\hline & & 5 & Untyped dart point & \\
\hline & & 6 & Ensor dart point & \\
\hline & & 7 & Untyped dart point & Frio-like \\
\hline & & 8 & Ground stone & Possible hide working tool, polished \\
\hline & & 9 & Ceramic & Body sherd (neck) (1 of 8) \\
\hline & & 10 & Ceramic & Body sherd (neck) (2 of 8 ) \\
\hline & & 11 & Ceramic & Body sherd (neck) (3 of 8) \\
\hline & & 12 & Ceramic & Body sherd (neck) (4 of 8) \\
\hline & & 13 & Ceramic & Body sherd (neck) (5 of 8) \\
\hline & & 14 & Ceramic & Body sherd (neck) (6 of 8 ) \\
\hline & & 15 & Ceramic & Body sherd (neck) (7 of 8) \\
\hline & & 16 & Ceramic & Body sherd (neck) (8 of 8 ) \\
\hline & & 17 & Biface & heavy duty scraper \\
\hline & & 18 & Biface & Gouge preform \\
\hline & & 19 & Biface & Wedge \\
\hline
\end{tabular}

machine-cut finishing nails were recovered, four from the surface, one from Level 2 of TU N999 E1003, and one from Level 2 of TU N998 E1003. Such nails were in use throughout the nineteenth century, slowly giving way to wire nails after the 1880s (Nelson 1968).
A heavy iron spike with rounded shank and squared point was recovered from the surface. Two fragments of ceramic lead-glazed sewer tile also came from the surface. Ceramic sewer tile was being made in San Antonio by the late nineteenth century. 


\section{References Cited}

Adams, J.

1988 Use-wear Analyses on Manos and Hide-processing Stones. Journal of Anthropological Research 15:307-315.

Black, S. L.

1986 The Clemente and Herminia Hinojosa Site, 41JW8: A Toyah Horizon Campsite in Southern Texas. Special Report, No. 18. Center for Archaeological Research, The University of Texas at San Antonio.

Black, S. L., and L. Highley

1985 Distally Beveled Tools. In The Panther Springs Creek Site: Cultural Change and Continuity in the Upper Salado Creek Drainage, South-Central Texas, edited by S. L. Black and A. J. McGraw, pp. 136-156. Archaeological Survey Report, No. 100. Center for Archaeological Research, The University of Texas at San Antonio.

Black, S. L., and A. J. McGraw

1985 The Panther Springs Creek Site: Cultural Change and Continuity in the Upper Salado Creek Drainage, South-Central Texas. Archaeological Survey Report, No. 100. Center for Archaeological Research, The University of Texas at San Antonio.

Brown, K. M.

1985 Three Caches of Guadalupe Tools from South Texas. Bulletin of the Texas Archeological Society 56:75-126.

Collins, M. B.

1995 Forty Years of Archeology in Central Texas. Bulletin of the Texas Archeological Society 66:361-400.

Crabtree, D. E.

1972 An Introduction to Flintworking. Second Edition. Occasional Papers of the Idaho Museum of Natural History, Number 28. Idaho Museum of Natural History, Pocatello, Idaho.

Ensor, H. B., and C. S. Mueller-Wille

1988 Excavations at the Bull Pen Site 41BP280 Colorado River Drainage, Bastrop County, Texas. Contract Reports in Archeology, Report No. 3. Texas State Department of Highways and Public Transportation, Austin.

Greer, G. H.

1981 American Stonewares. Schiffer, Exton, Pennsylvania.

Hall, G.D., T. R. Hester, and S. L. Black

1986 The Prehistoric Sites at Choke Canyon Reservoir; Southern Texas: Results of the Phase II Archaeological Investigations. Choke Canyon Series, No. 10. Center for Archaeological Research, The University of Texas at San Antonio. 
Hester, T. R.

1971 Archeological Investigations at the La Jita Site, Uvalde County, Texas. Bulletin of the Texas Archeological Society 45:51-148.

1995 The Prehistory of South Texas. Bulletin of the Texas Archeological Society 66:427-459.

Hester, T. R., and T. C. Hill, Jr.

1971 An Initial Study of a Prehistoric Ceramic Tradition in Southern Texas. Plains Anthropologist 16(52):195-203.

Hester, T. R. and H. Kohnitz

1975 Chronological Placement of "Guadalupe" Tools. La Tierra 2(2):22-25.

Houk, B. A., and J. C. Lohse

1993 Archeological Investigations at the Mingo Site, Bandera County, Texas. Bulletin of the Texas Archeological Society 61:193-247.

Jelinek, A. J., B. Bradley, and B. Huckell

1971 The Production of Secondary Multiple Flakes. American Antiquity 36:198-200.

Jelks, E. B.

1962 The Kyle Site, a Stratified Central Texas Aspect Site in Hill County, Texas. Archeology Series, No. 5. Department of Anthropology, The University of Texas at Austin.

Johnson, J. K.

1979 Archaic Biface Manufacture: Production Failures, a Chronicle of the Misbegotten. Lithic Technology $8(2): 25-35$.

Johnson, L. , Jr.

1994 The Life and Times of Toyah-Culture Folk as Seen from the Buckhollow Encampment, Site 41KM16, of Kimble County, Texas. Office of the State Archeologist Report 38. Texas Department of Transportation and Texas Historical Commission, Austin.

Johnson, L. Jr., and G. T. Goode

1994 A New Try at Dating and Characterizing Holocene Climates, as well as Archeological Periods, on the Eastern Edwards Plateau. Bulletin of the Texas Archeological Society 65:1-51.

Kelley, J. C.

1947 The Lehmann Rock Shelter: A Stratified Site of the Toyah, Uvalde, and Round Rock Foci. Bulletin of the Texas Archeological and Paleontological Society 18:115-128.

Kelley, J. C., T. N. Campbell, and D. J. Lehmer

1940 The Association of Archaeological Materials with Geological Deposits in the Big Bend Region of Texas. West Texas Historical and Scientific Society 10:9-173.

Krieger, A.

1946 Culture Complexes and Chronology in Northern Texas. University of Texas Publications, No. 4640. The University of Texas at Austin. 
Mehalchick, G., K. Kleinbach, D. K. Boyd, S. A. Tomka, and K. W. Kibler

1996 National Register Testing of 19 Prehistoric Archeological Sites on Fort Hood, Texas: The 1995 Season. United States Army Fort Hood Archeological Resource Management Series, Research Report No. 37. Prewitt and Associates, Austin.

Miller, E. O., and E. B. Jelks

1952 Archeological Excavations at the Belton Reservoir, Coryell County, Texas. Bulletin of the Texas Archeological Society 23:168-217.

Moir, R. W.

1985 Shell-Edged Wares Ceramic Tradition, ca. 1775 to 1900. Manuscript on file, Center for Archaeological Research, The University of Texas at San Antonio.

Nelson, L. H.

1968 Nail Chronology as an Aid to Dating Old Buildings. Technical Leaflet 48. American Association for State and Local History, Nashville.

Perttula, T. K., M. R. Miller, R. A. Ricklis, D. J. Prikryl, and C. Lintz

1995 Prehistoric and Historic Aboriginal Ceramics in Texas. Bulletin of the Texas Archeological Society $66: 175-235$.

Potter, D. R., and S. L. Black

1995 Archeology Along the Wurzbach Parkway: Module 2. Initial Testing and Evaluation of Five Prehistoric Sites in the Upper Salado Watershed, Bexar County, Texas. Studies in Archeology 18. Texas Archeological Research Laboratory, The University of Texas at Austin.

Prewitt, E. R.

1981 Cultural Chronology in Central Texas. Bulletin of the Texas Archeological Society 52:65-89.

Ricklis, R. A.

1994 Toyah Components: Evidence for Occupation in the Project Area during the Latter Part of the Late Prehistoric. In Archaic and Late Prehistoric Human Ecology in the Middle Onion Creek Valley, Hays County, Texas, edited by R. A. Ricklis and M. B. Collins, pp. 207-316. Studies in Archeology 19. Texas Archeological Research Laboratory, The University of Texas at Austin.

Shafer, H. J.

1970 Notes on Uniface Retouch Technology. American Antiquity 35:480-487.

Shafer, H. J., D. A. Suhm, and J. D. Scurlock

1964 An Investigation and Appraisal of the Archaeological Resources of Belton Reservoir, Bell and Coryell Counties, Texas: 1962. Miscellaneous Papers No. 1. Texas Archeological Salvage Project. The University of Texas, Austin.

Sollberger, J. B.

1967 A New Type of Arrowpoint with Speculations as to its Origin. The Record 23(3):12-22.

Suhm, D. A., A. D. Krieger, and E. B. Jelks

1954 An Introductory Handbook of Texas Archeology. Bulletin of the Texas Archeological Society 25. 
Tomka, S. A.

1986 Biface Manufacture Failures at 41BP19. Manuscript on file. Center for Archaeological Research, The University of Texas at San Antonio.

\section{Toulouse, J. H.}

1971 Bottle Makers and Their Marks. Thomas Nelson, New York.

Turner, E. S., and T. R. Hester

1993 A Field Guide to Stone Artifacts of Texas Indians. Second Edition. Gulf, Houston.

Webley, L.

1990 The Use of Stone "Scrapers" by Semi-sedentary Pastoralist Groups in Namaqualand, South Africa. South African Archaeological Bulletin 45:28-32.

Woolford, S. W.

1935 Types of Archaeological Sites in Bexar County, Texas. Archaeological Bulletin 4. Witte Memorial Museum, San Antonio. 


\title{
Appendix C: Vertebrate Faunal Remains
}

\author{
Barbara A. Meissner
}

\section{Introduction}

One hundred twenty vertebrate faunal remains, weighing a total of $292.5 \mathrm{~g}$, were recovered during the Lackland testing project. The remains were identified to the lowest possible taxon using the comparative collection at CAR and several commonly used references (Gilbert 1990; Hillson 1986; Olsen 1964, 1968). Only three taxa could be identified to genus or species level. They are listed in Table C-1.

Most of the bone was highly fragmented, and was in fair to poor condition. The surface of most of the bone was pitted, in some cases heavily pitted. Root damage was also very common.

For each site at which bone was recovered during Phase II excavations, analysis data is presented in Table C-2. The table lists all bone by provenience, lowest possible taxa, count, and weight in grams. When possible, the element and portion of element of the specimen are noted as well as signs of butcher marks, evidence of burning, and marks from rodent or carnivore chewing. Specimens which could not be identified to the family taxonomic level are identified by class and animal size estimate (such as "UID deersized mammal") when feasible. Possibly because of the extremely fragmented nature of most of the bone, no specimen showed evidence of being from an immature animal.

Bone from this collection was described as unburned (i.e. showing no signs of heat damage); smoke-stained (i.e. showing a superficial darkening of some or all of the bone); charred (i.e. part or all of the bone is blackened, indicating that the organic component has been carbonized); or calcined (i.e. that the organic component of the bone has been carbonized and then oxidized, leaving a white or tan remainder).

All of the identified deer bone except the tooth fragment $(n=6)$ showed spiral fractures characteristic of breaks which occur while the bone is "fresh," i.e. still containing fat, water, and marrow (Lyman 1994:316, 324). In addition, two deer bones, one from $41 \mathrm{BX} 1103$ and one from 41BX1114, exhibit butchering marks, including chopping, thin superficial cut marks, and an impact fracture. The bovid humerus fragment from 41BX1114 was also broken while the bone was fresh. One large mammal bone, which is probably a cow or bison rib was chopped on its proximal end with a jagged-edged instrument. There is also a mark which may be a blunt cut mark on the same bone, but the surface is badly pitted, making the identification of this mark uncertain.

Table C-1. Taxa Identified to Genus Level

\begin{tabular}{|l|l|l|l|}
\hline \multicolumn{1}{|c|}{ Taxon } & Common Name & $\#$ & \multicolumn{1}{|c|}{ Notes } \\
\hline Odocoileus virginianus & White-tailed deer & 7 & $\begin{array}{l}1 \text { tooth fragment could only be identified as artidactyl, } \\
\text { but compares favorably with } \text { O. virginianus and is } \\
\text { included in the count. }\end{array}$ \\
\hline Sigmodon hispidus & Cotton rat & 1 & A common indigenous rat \\
\hline Sylvilagus sp. & Cottontail rabbit & 1 & $\begin{array}{l}\text { The ranges of three very similar species of Sylvilagus } \\
\text { overlap in the area, the Eastern cottontail (S. floridansis) } \\
\text { the Desert cottontail (S. audubonii), and the swamp } \\
\text { rabbit (S. aquaticus) (Davis and Schmidly 1994:86-92). }\end{array}$ \\
\hline
\end{tabular}


Table C-2. Provenienced Faunal Remains from Phase II Excavations

\begin{tabular}{|c|c|c|c|c|c|c|}
\hline \multicolumn{3}{|c|}{ Provenience } & \multirow[b]{2}{*}{ Taxon } & \multirow[b]{2}{*}{$\#$} & \multirow{2}{*}{$\begin{array}{l}\text { Wgt. } \\
(\mathrm{g})\end{array}$} & \multirow[b]{2}{*}{ Notes } \\
\hline $\begin{array}{r}\text { Site } \\
41 \mathrm{BX}\end{array}$ & Unit & $\begin{array}{l}\text { Depth } \\
(\mathbf{c m b s})\end{array}$ & & & & \\
\hline \multirow[t]{3}{*}{1088} & N963/E985 & 0 & Sylvilagus sp. & 1 & .94 & Mandible frag \\
\hline & & & Total NISP & 1 & .94 & \\
\hline & & & Site Total & 1 & .94 & \\
\hline \multirow[t]{16}{*}{1103} & $\begin{array}{l}\text { N995.1/E1005 } \\
\text { BHT B }\end{array}$ & & $\begin{array}{l}\text { Odocoileus } \\
\text { virginanus }\end{array}$ & 1 & 4.43 & $\begin{array}{l}\text { Metatarsal frag. Chopped on one end } \\
\text { with a jagged and fairly blunt } \\
\text { instrument. Broken while fresh. }\end{array}$ \\
\hline & N975/E985, ST\#1 & $60-70$ & $\begin{array}{l}\text { Odocoileus } \\
\text { virginanus }\end{array}$ & 3 & 1.49 & $\begin{array}{l}2 \text { frags of the distal end of a } 2 \text { nd } \\
\text { phalange which mend. } 1 \text { frag of } \\
\text { proximal end (does not mend to } \\
\text { others, but likely from same bone). } \\
\text { Broken while fresh. All charred. }\end{array}$ \\
\hline & N998/E1003 & $22-32$ & $\begin{array}{l}\text { Odocoileus } \\
\text { virginanus }\end{array}$ & 1 & .85 & $\begin{array}{l}\text { Frag of the distal end of a } 2 \mathrm{nd} \\
\text { phalange. Broken while fresh. } \\
\text { Charred and partially calcined. }\end{array}$ \\
\hline & N990/E1005 & 0 & $\begin{array}{l}\text { Artidactyl, cf. } \\
\text { O. virginianus }\end{array}$ & 1 & .43 & Molar frag. \\
\hline & & & NISP & 6 & 7.20 & \\
\hline & $\begin{array}{l}\text { N995. 1/ E1005, } \\
\text { BHT B }\end{array}$ & & Mammalia & 2 & 1.59 & $\begin{array}{l}\text { Long bone frags from a deer-sized } \\
\text { animal. }\end{array}$ \\
\hline & North $1 / 2$, BHT B & $0-60$ & Mammalia & 1 & 31.50 & $\begin{array}{l}\text { Long bone frag from a } \\
\text { cow/horse/bison sized-animal. } \\
\text { Carnivore (cf. canid) tooth marks on } \\
\text { one end. Broken while fresh. Surface } \\
\text { badly pitted. }\end{array}$ \\
\hline & & & Mammalia & 1 & 2.87 & $\begin{array}{l}\text { Long bone frag from a deer-sized } \\
\text { animal. There are about } 7 \text { thin cut } \\
\text { marks from a very sharp but jagged } \\
\text { edged instrument. }\end{array}$ \\
\hline & ST N90/E110 & $20-30$ & Mammalia & 1 & .42 & Charred and partially calcined. \\
\hline & ST N990/E1010 & $0-10$ & Vertebrata & 5 & .08 & Tiny frags. \\
\hline & N998/E 1003 & $22-32$ & Mammalia & 1 & 3.65 & $\begin{array}{l}\text { Long bone frag from a deer-sized } \\
\text { animal which has numerous thin cuts } \\
\text { from a sharp but jagged instrument. } \\
\text { There is also an impact scar and a } \\
\text { possible chop mark on one end. } \\
\text { Broken while fresh. }\end{array}$ \\
\hline & & & Mammalia & 8 & 1.22 & \\
\hline & N998 E1003 & $30-40$ & Mammalia & 4 & .85 & 1 is calcined \\
\hline & N1014/E990 & $25-35$ & Mammalia & 4 & 1.90 & $\begin{array}{l}1 \text { is calcined, the other three show } \\
\text { evidence of heavy weathering }\end{array}$ \\
\hline & & & $\begin{array}{r}\text { Total } \\
\text { Unidentified } \\
\end{array}$ & 27 & 44.08 & \\
\hline & & & Total For Site & 33 & 51.28 & \\
\hline
\end{tabular}


Table C-2. continued

\begin{tabular}{|c|c|c|c|c|c|c|}
\hline \multicolumn{3}{|c|}{ Provenience } & \multirow[b]{2}{*}{ Taxon } & \multirow[b]{2}{*}{$\#$} & \multirow{2}{*}{$\begin{array}{l}\text { Wgt. } \\
(\mathrm{g})\end{array}$} & \multirow[b]{2}{*}{ Notes } \\
\hline $\begin{array}{r}\text { Site } \\
41 \mathrm{BX}\end{array}$ & Unit & $\begin{array}{c}\text { Depth } \\
\text { (cmbs) }\end{array}$ & & & & \\
\hline \multirow[t]{21}{*}{1114} & Feature 1, NW Quad & & $\begin{array}{l}\text { Sigmodon } \\
\text { hispidus }\end{array}$ & 1 & .56 & All but the distal end of a femur. \\
\hline & N1019.95/E994.15 & 17 & Artidacty 1 & 1 & 4.71 & $\begin{array}{l}\text { Long bone frag of a deer-sized } \\
\text { animal. }\end{array}$ \\
\hline & N1020.05/E993.1 & 8 & Artidactyl & 3 & 5.30 & $\begin{array}{l}\text { Deer-sized. } 2 \text { of } 3 \text { pieces mend, but } \\
\text { the break is an old one. }\end{array}$ \\
\hline & N1020.2/E994.4 & 20 & Artidactyl & 1 & 6.59 & Deer-sized \\
\hline & N1020.2/E994.4 & 20 & $\begin{array}{l}\text { Odocoileus } \\
\text { virginianus }\end{array}$ & 1 & 13.14 & $\begin{array}{l}\text { Distal tibia fractured while bone was } \\
\text { fresh. Thin cut mark on anterior } \\
\text { surface near distal end. Impact scar } \\
\text { near the fracture. }\end{array}$ \\
\hline & N1020.7/E993.1 & 18 & Bovidae & 6 & 86.36 & $\begin{array}{l}\text { Frags from the distal end of the left } \\
\text { humerus. All heavily smoked, and } 1 \\
\text { partially charred. Most proximal piece } \\
\text { was broken while bone was fresh. } \\
\text { Some evidence of rodent chewing. }\end{array}$ \\
\hline & \multicolumn{3}{|r|}{ Total NISP } & 13 & 116.66 & \\
\hline & N1019.8/E994.2 & 15 & UID Mammal & 1 & 1.79 & $\begin{array}{l}\text { Deer-sized long bone frags. Heavily } \\
\text { smoke-stained, but not charred. }\end{array}$ \\
\hline & N1019.9/E993.1 & 15 & UID Mammal & 1 & 1.20 & \\
\hline & N2020/ E993, Ftr. 1 & ca. 18 & UID Mammal & 24 & 40.47 & $\begin{array}{l}\text { Frags of a single rib bone of } \\
\text { cow/horse/bison sized animal. Surface } \\
\text { is badly pitted. All breaks are recent } \\
\text { except one end on most proximal bone } \\
\text { frag, which was chopped with a } \\
\text { jagged-edged instrument on the dorsal } \\
\text { side. There is also a possible blunt cut } \\
\text { mark on the ventral side of the same } \\
\text { bone. }\end{array}$ \\
\hline & N1020.05/E993.1 & & UID Mammal & 2 & 2.89 & $\begin{array}{l}\text { One has } 2 \text { thin parallel cuts, and one } \\
\text { end smoke-stained }\end{array}$ \\
\hline & N1020.1/E993.1 & 18 & UID Mammal & 18 & 39.17 & $\begin{array}{l}\text { Cow/bison-sized. } 4 \text { are charred, } 14 \\
\text { are heavily smoke-stained }\end{array}$ \\
\hline & N1020.2/E994.4 & 20 & UID Mammal & 10 & 10.28 & Long bone frags. \\
\hline & N1020.2/E994.7 & 19 & UID Mammal & 1 & 6.99 & Deer-sized long bone frags. \\
\hline & N1020.65/E994.2 & 16 & UID Bird & 1 & 1.02 & Duck-sized \\
\hline & N1020.6/E994.25 & 17 & UID Mammal & 2 & 8.20 & Cow/bison-sized. \\
\hline & N1020.7/E993.1 & 18 & UID Mammal & 1 & 5.16 & Cow/bison-sized \\
\hline & N1020.7/E994.05 & 13 & UID Mammal & 5 & 3.76 & 3 are charred \\
\hline & N1030.1/E933.4 & 15 & UID Mammal & 7 & 2.70 & \\
\hline & \multicolumn{3}{|r|}{ Total Unidentified } & 73 & 123.62 & \\
\hline & \multicolumn{3}{|r|}{ Site Total } & 86 & 240.28 & \\
\hline
\end{tabular}




\section{Discussion}

In general, open archaeological sites in South Texas tend to contain very few faunal remains. For instance, of the 34 sites tested during Phase I of the Choke Canyon Project in Live Oak and McMullen counties, only one had more than a few faunal remains, most of which were not identifiable (see Appendix IX in Hall et al. 1982). Only 1,334 bones were recovered from the extensive Jonas Terrace excavations (Johnson 1994; Shaffer 1994:306). Tennis (1996) found only a single bovid tooth fragment and a rodent mandible among 78 features exposed during testing at a site along the upper Leon Creek drainage in northern Bexar County. Even when large numbers of faunal remains are recovered, as was the case at the Hinojosa site (41JW8; Black 1982) and at Panther Springs Creek (41BX228; Black and McGraw 1985), most of the bone is in such fragmented condition that the Number of Identified Specimens (NISP) tends to be a very low percentage of the total sample, usually less than six percent.

Both cultural and non-cultural taphonomic processes combine to cause the poor condition of bone in many South Texas sites. The following discussion is a brief summary of some of the factors which may impact bone preservation. For a more detailed discussion, the reader is referred to Lyman (1994).

Butchering practices that include smashing long bones to extract marrow, and even grinding animal bones to allow direct ingestion, were recorded by early European visitors to South Texas (Cabeza de Vaca 1542 [1966]:103). In addition, boiling bone to extract as much fat as possible is facilitated by smashing the bones of even very large animals into small pieces before cooking (Shaffer 1994:307). A third cultural factor is the burning of bone. Although bone may be burned by natural causes such as grass or forest fires, experimental studies have shown that such bone is rarely or never calcined (see discussion in Lyman 1994:388-389). In any case, the likelihood of such bone occurring in open archaeological sites (as opposed to any other area) is fairly small and will be, for the purposes of simplicity, ignored. Bone burned by humans is most likely either incidental to roasting or to the placement (either deliberately or accidentally) of bone in the fireplace. The former is likely to cause smoke-staining and some charring of bone ends, while the later is more likely to cause heavy charring and calcining of the bone. Heavily charred and calcined bone is often very brittle and easily broken due to the removal of collagen in the heating process (Lyman 1994:385), however, such burning also seems to slow chemical leaching of the bone (Shaffer 1994:307).

Twenty-one percent $(n=7)$ of the bone from site 41BX1103 showed evidence of burning, all of it charred and/or calcined. Forty-seven percent $(n=29)$ of the bone from 41BX1114 was burned, with 31 percent $(n=19)$ showing only smoke-staining and none calcined, indicating a possible difference in cooking and bone disposal practices at the two sites.

Once the bone has been deposited in or on the ground, non-cultural taphonomic processes which can effect bone preservation take place. Weathering, i.e. direct exposure to the sun and repeated wetting and rapid drying associated with exposure to air, can destroy even large bones within a matter of years. However, only three of the bones from this collection, all small fragments from 41BX1103, show the characteristic fine-line fracturing and exfoliation associated with weathering (Lyman 1994:355; Shaffer 1994:306).

Buried bone is subject to a number of other taphonomic processes. Chaplin (1971:16-18) suggests that the depositional matrix can affect bone preservation in at least four ways: $\mathrm{pH}$, aeration, water regime, and bacterial action. The inorganic component of bone is dissolved in an acid environment (Lyman 1994:422). Lyman (1994:422) notes that water will leach collagen from buried bone, depending on how much water is present, and how quickly it moves through the sediment. Both Chaplin (1971) and Lyman (1994:421) indicate that, in general, bone preservation in alkaline sediments is better than in acid sediments.

The taphonomic processes responsible for poor bone preservation in open prehistoric sites in the alkaline sediments common in South Texas are not currently understood. Shaffer (1994), in his study of the badly preserved bone collection from Jonas Terrace (41ME29), states that "carbonic acid from the surrounding limestone and root action" (Shaffer 1994:306) were responsible for the poor condition of 
the bone; however, he does not make clear how he came to this conclusion. Soil $\mathrm{pH}$ is not routinely tested in archaeological sites, but would help to provide clues for the faunal analyst to explain some aspects of bone preservation. However, destruction of collagen and subsequent leaching of the apatite fraction of bone may be due more to biological activity (i.e. bacteriological and fungal processes and/or root etching) than to sediment pH, per se (Lyman 1994:375, 395-397). In this context it should be noted that bacterial action is inhibited in acidic or strongly basic sediments (Lyman 1994:421-422).

Two factors which may play an important role in bone preservation at the Lackland sites are the highly fragmented condition of the bone and the high temperatures common during much of the year in South Texas. Von Endt and Ortner (1984) have shown that smaller pieces of bone preserve less well than larger pieces, and that collagen protein is lost more quickly at high temperatures.

\section{Conclusion}

The small sample size and poor condition of this collection does not add a great deal to our current understanding of the diet and butchering practices of prehistoric inhabitants of the region. It does, however, add to a growing body of what may be termed "negative" evidence concerning the taphonomic processes which affect bone presence and preservation in open archaeological sites in South Texas. It is becoming more and more evident that investigation of the taphonomic processes, both cultural and non-cultural, affecting bone preservation in archaeological sites which are specific to this region is important and more attention should be paid to (and fewer assumptions made about) this aspect of faunal analysis. Aside from the need to understand these phenomena in their own right, it is important because, as it now stands, there is no way to even estimate how much bone was actually deposited in prehistoric archaeological sites in the first place. Are differences in bone recovery in South Texas sites the results of differential deposition of bone or of differential preservation of the bone deposited in the sites? We cannot now even guess the answer to such questions, and we will be able to an- swer them only when we have a better understanding of the taphonomic processes affecting bone in South Texas. 


\section{References Cited}

Black, S. L.

1982 The Clemente and Herminia Hinojosa Site, 41JW8: A Toyah Horizon Campsite in Southern Texas. Special Report, No. 18. Center for Archaeological Research, The University of Texas at San Antonio.

Black, S. L, and A. J. McGraw

1985 The Panther Springs Creek Site: Cultural Change and Continuity Within the Upper Salado Creek Watershed, South-Central Texas. Archaeological Survey Report, No. 100. Center for Archaeological Research, The University of Texas at San Antonio.

Cabeza de Vaca, A.N.

1966 [1542] Relation of Alvar Nuñez Cabeza de Vaca. Microfilm reprint of 1871 edition, translated by B. Smith. Readex Microprint, New York.

Chaplin, R.E.

1971 The Study of Animal Bones from Archaeological Sites. Seminar, London.

Davis, W. B., and D. J. Schmidly

1994 The Mammals of Texas. Texas Parks and Wildlife Department, Austin.

Gilbert, B. M.

1990 Mammalian Osteology. Missouri Archaeological Society, Columbia, Missouri.

Hall, G. D., S. L. Black, and C. Graves

1982 Archaeological Investigations at Choke Canyon Reservoir; South Texas: The Phase I Findings. Choke Canyon Series, No. 5. Center for Archaeological Research, The University of Texas at San Antonio.

Hillson, S.

1986 Teeth. Cambridge University Press, Cambridge.

Johnson, L., Jr.

1994 The Life and Times of Toyah-Culture Folk as Seen from the Buckhollow Encampment, Site 41KM16, of Kimble County, Texas. Office of the State Archeologist Report 38. Texas Department of Transportation and Texas Historical Commission, Austin.

Lyman, R. L.

1994 Vertebrate Taphonomy. Cambridge University Press, Cambridge.

Olsen, S. J.

1964 Mammal Remains from Archaeological Sites Part I; Southeastern and Southwestern United States. Peabody Museum, Cambridge.

1968 Fish, Amphibian, and Reptile Remains from Archaeological Sites Part I: Southeastern and Southwestern United States. Peabody Museum, Cambridge. 
Shaffer, B. S.

1994 Analysis of Vertebrate Fauna. In Past Cultures and Climates at Jonas Terrace, 41ME29, Medina County, Texas, edited by L. J. Johnson, pp. 306-325. Report No. 40. Office of the State Archeologist, Texas Department of Transportation and Texas Historical Commission, Austin.

Tennis, C. L.

1996 Archaic Land Use of Upper Leon Creek Terraces: Archaeological Testing in Northern Bexar County, Texas. Archaeological Survey Report, No. 234. Center for Archaeological Research, The University of Texas at San Antonio.

Von Endt, D. W., and D. J. Ortner

1984 Experimental Effects of Bone Size and Temperature on Bone Digenesis. Journal of Archaeological Science 11:247-253. 


\title{
Appendix D: Documentation of A Newly Discovered Site in the Uplands, 41BX1208
}

\author{
David L. Nickels
}

\section{Introduction}

While conducting additional shovel testing and defining boundaries of sites to be investigated during the 1996 Phase II testing, CAR staff discovered a previously undocumented site in the Alternate Housing 2 areas of construction impact. Although artifacts were noted in the site area during the 1994/1995 Phase I survey, dense vegetation at the time impeded surface inspection. Arid conditions during the 1996 investigations inhibited the growth of dense grasses and therefore allowed for better visibility of surface artifacts. After properly recording the site, it was designated 41BX1208.

\section{Methodology}

Following field method protocols developed for the Phase I survey, CAR archaeologists defined site boundaries, drove a length of rebar as a site datum, developed a site map, dug a single shovel test to a depth of $50 \mathrm{~cm}$, and conducted a 100-percent inventory of surface artifacts. The shovel test was dug and results recorded in arbitrary $10-\mathrm{cm}$ levels, and all sediments were screened through $1 / 4$-inch wire mesh. A hand-held Trimble Scoutmaster Global Positioning System was used to record Universal Transverse Mercator (UTM) coordinates. A State of Texas Archaeological Site Data Form was completed and the site was assigned trinomial 41BX1208. An aluminum tag with the date, trinomial, CAR's affiliation, and the UTM coordinates was affixed to the datum. Finally, two black-and-white photographs and color slides were taken at the site. Two copies of the forms, maps, artifacts inventories, and photographs were submitted to the National Park Service (NPS), and one copy to the Texas Archaeological Research Laboratory at The University of Texas at Austin.

\section{Discussion}

41BX1208 (Figures D-1 and D-2) is a small lithic quarry measuring $25 \times 23 \mathrm{~m}$. It is set in the uplands on the northeastern portion of Medina Annex, approximately 190 m east of Medio Creek. Moderate to dense upland flora covers the area. The inventory of surface artifacts includes nine cores, seven quarry blanks, and seven exterior flakes. This collection suggests early stages of lithic reduction. Fire-cracked rock appears

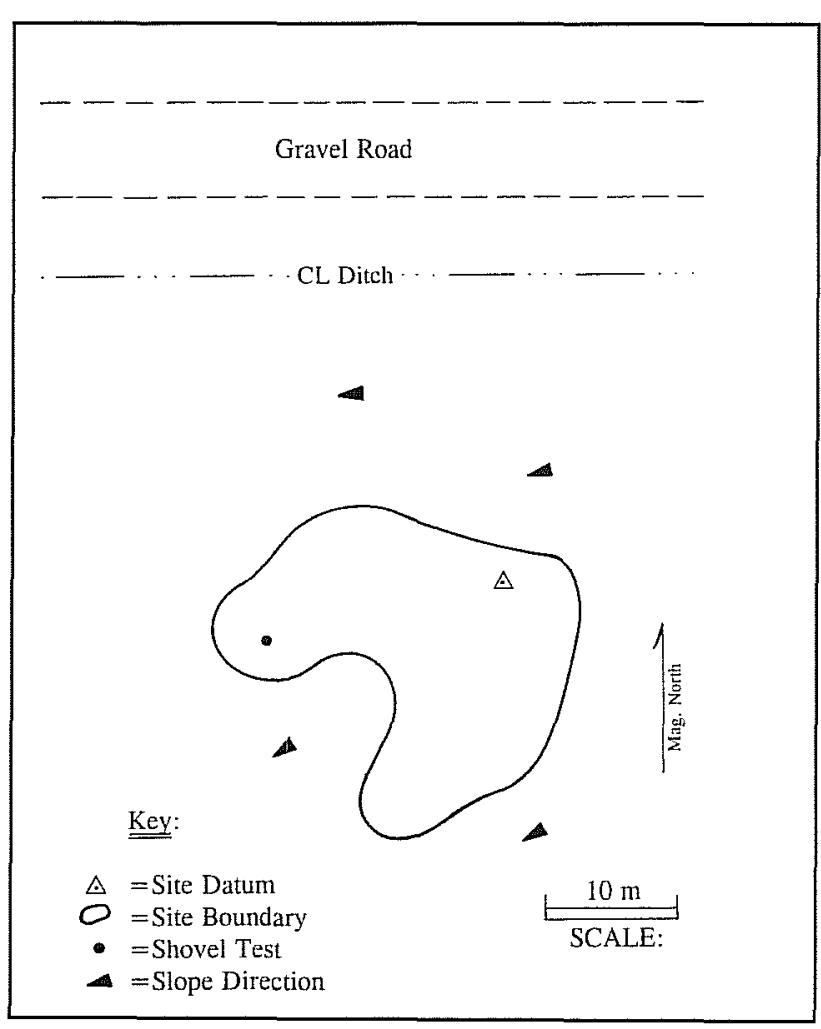

Figure D-1. Site plan, 41BX1208. 
sporadically across the surface, but no features were apparent. The shovel test revealed no cultural material. The site appears to have undergone moderate natural disturbance from erosion and bioturbation. Some surface gravels appear to be crushed, possibly as a result of bulldozing activities in a runoff ditch and gravel pit nearby.

Adhering to Phase I survey protocols, the research potential of 41BX1208 was considered minimal, and CAR advised that the site should not be considered for nomination to the National Register of Historic Places (NRHP). In a meeting held on October 15, 1996, with NPS, Air Force, and CAR personnel to discuss sites to be impacted by construction in Alternate Housing Area 2, we determined that site 41BX1208 was ineligible for NRHP nomination because it was a lowdensity lithic debris scatter lacking and integrity chronological context. As such, it was not further tested.

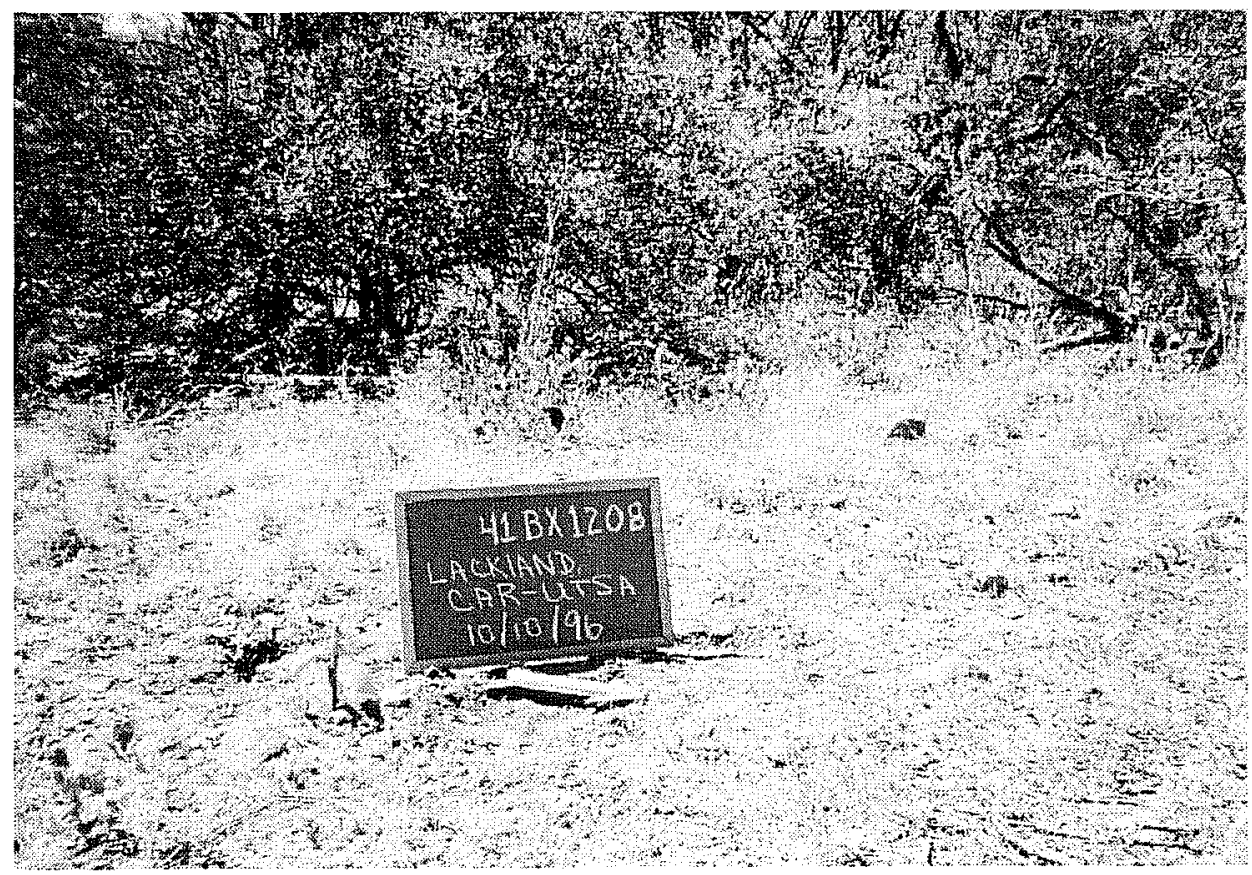

Figure D-2. Photograph of site $41 B X 1208$. 


\section{STATE OF TEXAS \\ Archeological Site Data Form \\ Trinomial 41BX1208}

Instructions: Fill in all categories unless directed otherwise. Be specific in distinguishng between "none" and "none observed" or "unknown"; use "N/A" to indicate when a section of the form is not applicable. Where categories are fo "wwed by a , simply "X" a "yes" answer; i "no," "none," "unknown," etc., enter a written response where applicable. Enter measures in metric unless directed othenvise. Use common abbreviations to shorten responses. If you are filing updated or revised information. at a minimum complete all asterisked $\left({ }^{*}\right)$ items; respond to other categories as necessary. Try to clarify possibly ambiguous responses. Attachments may be used to complete any category; at entry, write "See Attachment.." and number attachments consecutively. List all attachments at end of form. Send completed form to Texas Archeological Research Laboratory. The University of Texas at Austin, Balcones Research Center, Austin, Texas, 78712-1100. Form version: May 199

Initial Form $\square \quad$ Update/Revision* $\square$ Recorder Visited

Type of Site*: (e.g., prehistoric open campsite, lithic quarry, fort) Prehistoric Lithic Scatter

Registration*:(e.g., Nat'l Register of Hist Places, State Arch Landmark)

\section{GENERAL INFORMATION*}

Site Name(s) and \#'s (include field \# if assigned) Lackland \#64

Recorder(s) (who prepared form; do not use initials): David L. Nickels, Jeff Francis, Chris Horrell, Owen Ford

Affiliation (institution/agency/society):

Center for Archaeological Research - The University of
Texas at San Antonio (CAR-UTSA)
Date of Form: $9 / 10 / 96$
Project Name and \#: Lackland Air Force Base Survey
Project Funding Source:
US Air Force through National Park Service

Permitting Sources and \#'s:

INA

Owner/Address/Phone \# (also note if State, Federal, ...):

Federal, US Air Force

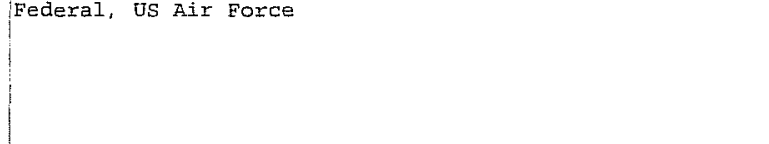

Informants/Addresses/Phone \#s:

NA. observers [who, what, when, why; begin with first known]; references and current project report, if prepared; add attachment pages as needed)

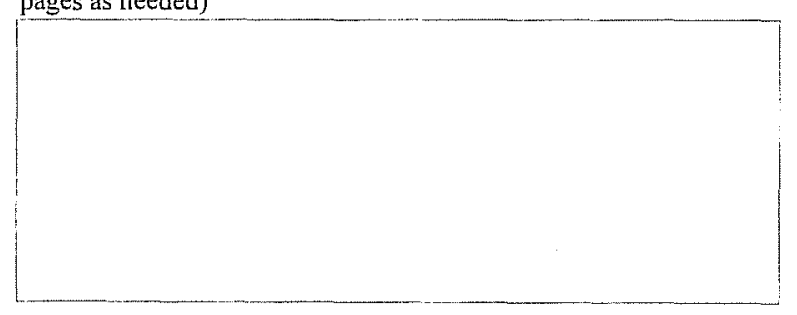

\section{Work Performed}

Observe/Record $\mathrm{Date}(\mathrm{s}): 8 / 19 / 96$

Surface Inspect/Collect $\mathrm{D} \quad$ Date(s): $8 / 19 / 96$

Techniques (e.g., controlled, non-controlled, select, random describe):

$100 \%$ surface inspection wi.th recorded inventory.

Mapping $\mathrm{Q}$ Date(s): $8 / 19 / 96$
Method: Pace and compass
Testing $\mathrm{Q}$ Test Date: $8 / 19 / 96$

Method(e.g., hand: shovel tests; machine: test trench) and Amount:

1 shovel test to $50 \mathrm{~cm}$

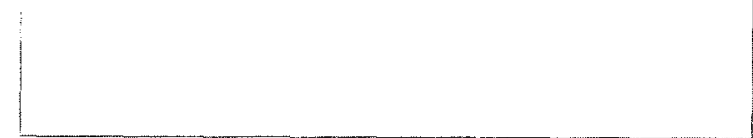

Excavation $\square \quad$ Date(s): $\square$

Method and Extent:

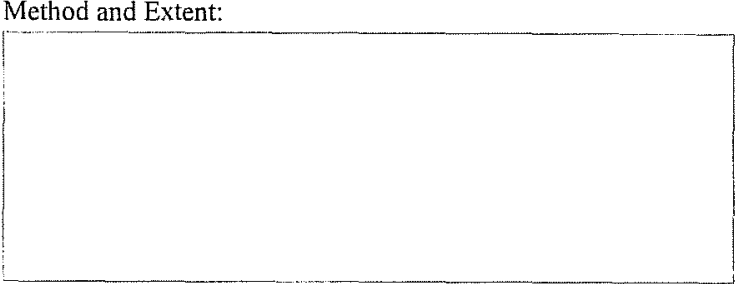

\section{Records:}

Daily Journal $\square$ Testing/Unit/Square Records $\square$

Artifact Sketches $\square$ Maps/Drawings $\triangle$ Archival Records $\square$

Field Catalog $\quad$ Lab Inventory $\square$ Analysis Notes $\square$

Photos: Slides/Log $\triangle \square$ Prints/Log $\square$ Aerials $\mathrm{Q}$

Other Records: GPS, Computer database 


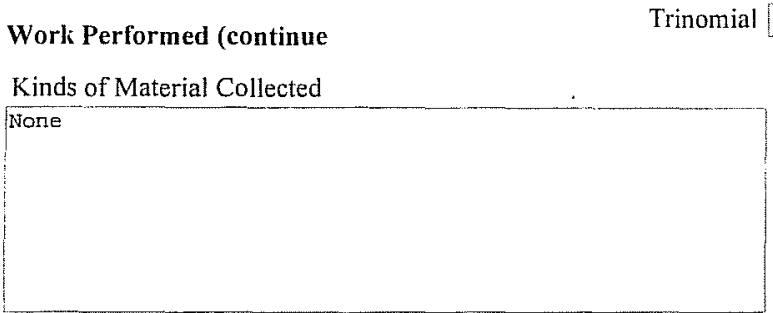

Special Samples, Collection Strategy, and Technique: (e.g., carbon, archeomagnetic; list and describe)

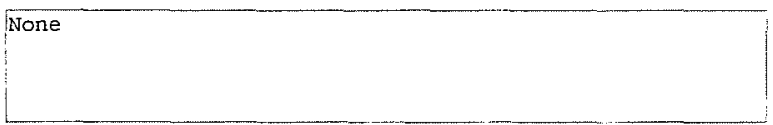

Temporary Housing (location of materials during field work and/or analysis): $\mathrm{NA}$

Permanent Housing (selected repository where materials are to be permanently curated:

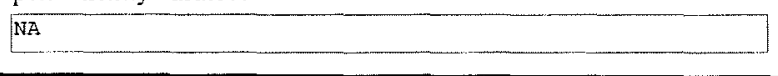

\section{Locational/Environmental Information}

County(ies)* Bexar

Site Location in County (e.g., SW, NE Southwest

USGS Map Series, Name and Quad \#* (e.g., 7.5' Austin West, 3097-231):

7.5 ' Culebra Hill, $2998-243$

Description of Location* (use either or both):

a. Triangulations from USGS Map Points to Marked Site Center/Nucleus (use numbered boundary markers, benchmarks, spillways, etc., as landmarks and note their direction to site-NNW, ESE: or

b. On-The-Ground Distances and Directions to Site (begin at major intersection or unambiguous point and choose relatively permanent map and /or field landmarks)

From Building \#471 in the northeast conner of Medina Annex, proceed east along a gravel road, and across Medio Creek. After crossing the creek there will be an open field military training area on the left (north) side of the road. Continue east on the gravel road, crossing a n-s intermittent drainage. Stop at a point in the road $180 \mathrm{~m}$ east of Medio Creek and proceed south (180 degrees) across a drainage ditch and into the brush $25 \mathrm{~m}$ to the site datum.

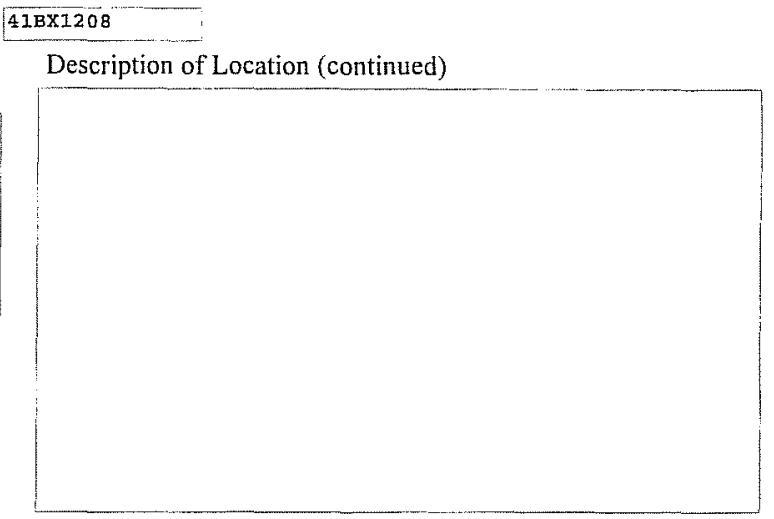

Elevation (in Ft. at Marked Site Center/Nucleus 72

Elevation Range 71.5 to $720^{\prime}$

UTM (at Marked Site Center/Nucleus)* Zone: 14_ Easting: 3250975 Northing: 533120 Latitude/Longitude (if UTM indeterminable

Lat. Long: (Note: Taken by GPS unit at site datum)

Nearest Natural Extant Water, Type, Distance and Direction (note name, if named):

Medio Creek is $180 \mathrm{~m}$ to the west.

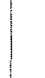

Major Creek Drainage: Medio Creek

Name of Drainage Basin and Type (River/Coastal/Playa): Medina River

SCS Soil Series Name, Mapping Unit: Houston Black gravelly clay

Genetic Type (e.g. lithosol, vertisol) vertisol

Surface Texture (e.g., sand/silt, clay loam, etc.): sandy loam sand

Source/Derivation: In Situ $\square$ Marine $\square$ Eolian $\square$
Colluvial $\square$ Alluvial $\square$ Other $\square !$
Percent surface visible*: $5 \frac{5}{6}$


Environmental/ Topographic Setting of Site( vegetation, pertinent landforms, slope, visible landmarks, etc.):

site is covered with dense brush, weeds and grasses.

Mature mesquite and persimmons form a moderate canopy.

A dormant gravel pit lies $75 \mathrm{~m}$ to the north. Site sits

on $a 3$ to 5 : slope from east to west. An east-west

gravel road and runoff ditch lies $30 \mathrm{~m}$ to the north.

Because of the dense vegetation no other landmarks are visible.

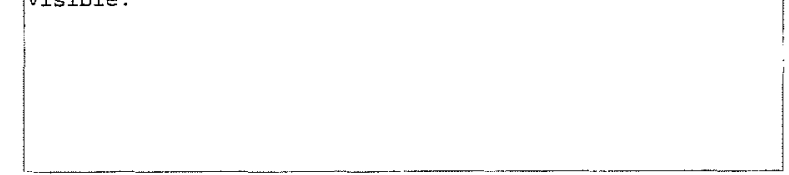

\section{Cultural Manifestations*}

Time Periods of Occupation (e.g., Early Archaic, Late Prehistoric, Republic of Texas, may be multiple): Unknown

Component (discrete occupations):
Single $\square$$\quad$ Multiple $\square \quad$ Unknown $\square$

Basis for Determination:

No diagnostic artifacts

Cultural Features (if present, do not merely list, describe; e.g., burned rock midden, hearth, pictographs, mounds, structural remains; how many are there, what is their spatial distribution, size, contents; how do they relate to components, time periods, physiography, etc.; indentify intrusive features, e.g. fence):
Approximate Site Size (length $\mathrm{x}$ width, with orientation; diameter or area; systems other than metric may be used where appropriate for historic sites):

$25 m(e-w) \times 23 m(n-s)$

Basis for Determination:

observed surface scatter

Top of Cultural Deposit below Ground Surface (Minimum Depth): surface

Basis for Determination:

observed surface scatter

Thickness Range of Cultural Deposit

Surface only

\section{Basis for Determination:}

One shovel test to $50 \mathrm{~cm}$ yielded no cultural material

Artifactual Materials Present (both reported and observed as well as collected; kinds of materials, disribution across site, relationship to features, etc.):

Exterior and interior flakes, cores, quarry blanks, tested cobbles. Sparse scatter of firecracked rock in no discernable patters.

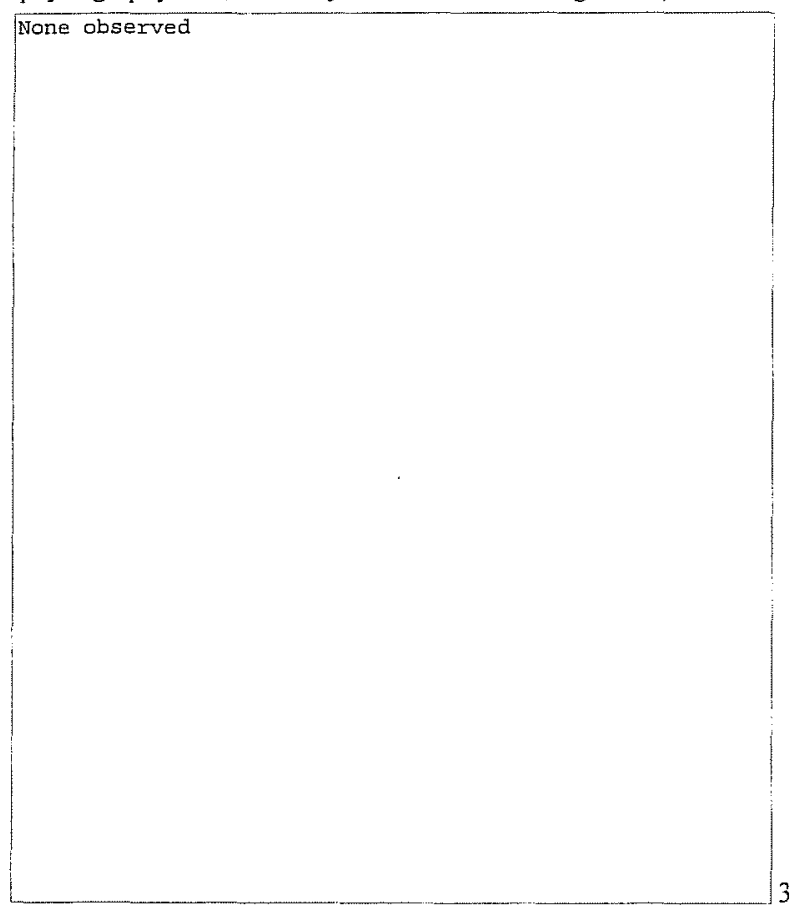

Additional comments on cultural manifestations:

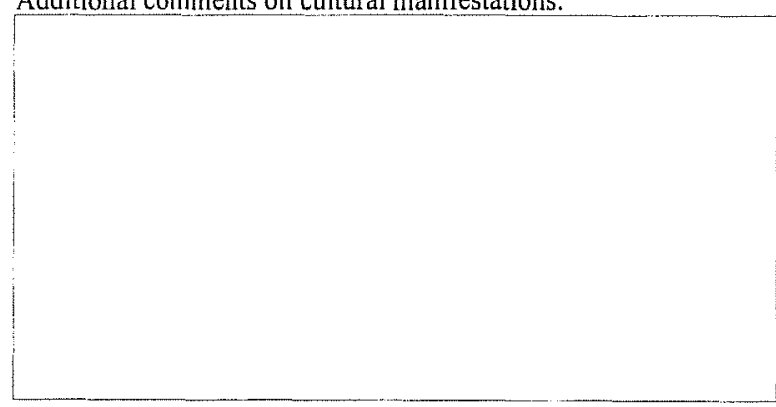




\section{Site Conditions, Recommendations, Registration Status*}

Circumstances Affecting Observations (e.g., time of day, weather conditions, could not walk over entire site, etc.; conditions affecting observation, including ground cover)

Dense leaf and grass cover inhibited surface

observation. Clear skies.

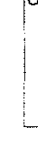

Approximate Percentage of Site Remaining Intact:

Current Land Use:

Military training.

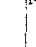

Natural Impacts:

Erosion, bioturbation.

Erosion, bioturbation.

Artificial Impacts:

Some gravels appeared crushed, posstbly as a result of a bulldozed runoff ditch and gravel pit nearby.

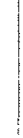

Known or Perceived Future Impacts:

$$
\text { Unknown }
$$

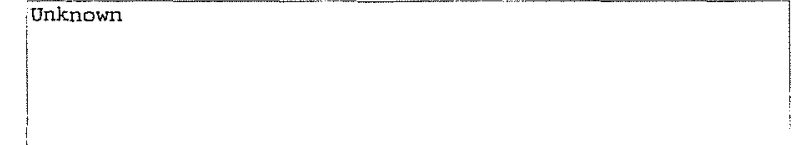

Recommended Actions (regional and project specific research, management, preservation)

Research Value of Site:

Moderate when considered in context with other upland sites recorded during this survey.

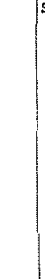

What Further Investigations and Why:

If site is to be impacted by further development, recomend further shovel testing and controlled surface collection.

$$
{ }^{\operatorname{col} 1}
$$
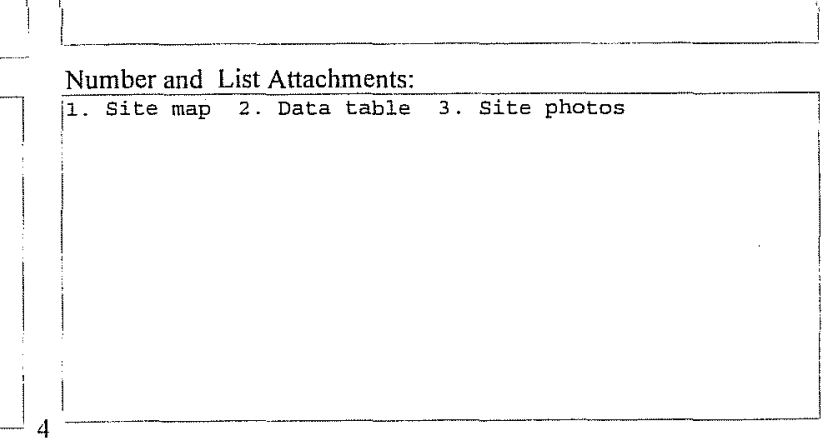

Number and List Attachments:

1. Site map 2. Data table 3. Site photo
If No Further Investigation, Why Not:

Registration Details:

$S A L=$ State Archeological Landmark

NRHP=National Register of Historic Places

$\mathrm{CE}=$ Conservation Easement

SAL NRHP CE Other

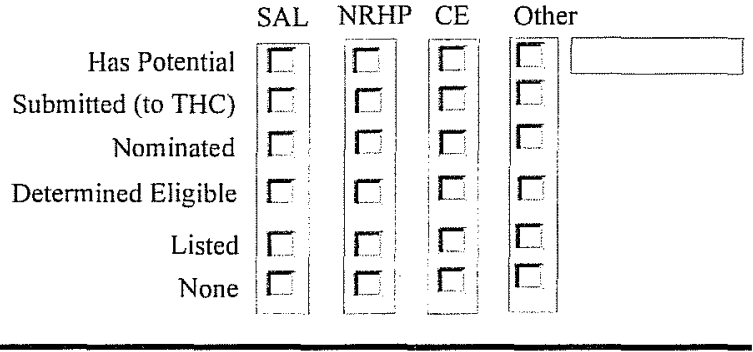

\section{Discussion of Site}

Additional comments, observations, impressions:

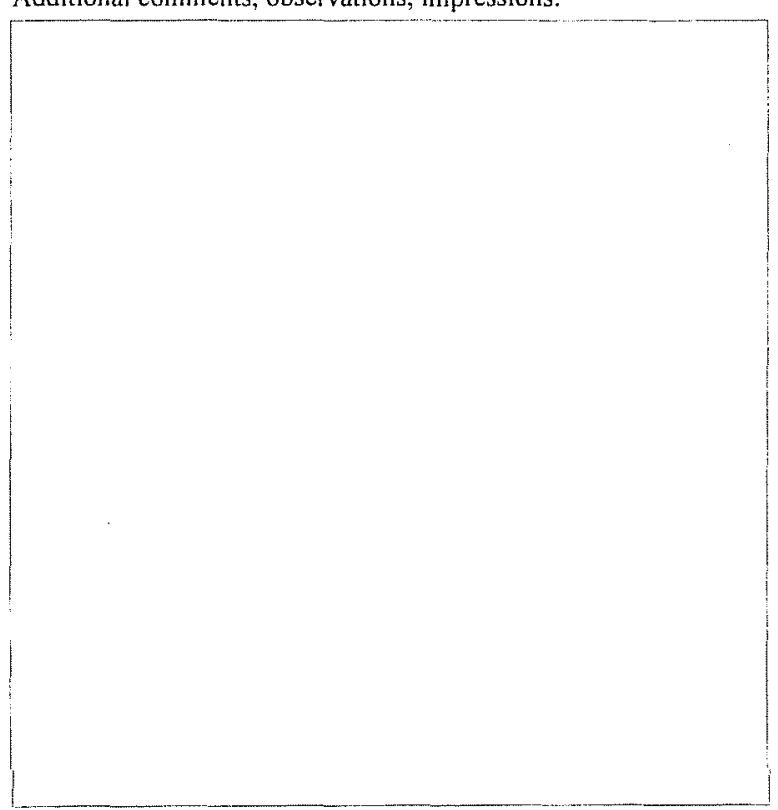




\section{Attachment 1: See Figure D-1}

Attachment 2: Site Data for 41BX1208

\begin{tabular}{|c|c|c|c|c|c|c|c|c|c|c|c|c|c|c|}
\hline \multicolumn{4}{|c|}{$\begin{array}{c}\text { Surface Artifact Counts } \\
\text { Flakes }\end{array}$} & \multicolumn{3}{|c|}{ Cores/preforms } & $\begin{array}{l}\text { Tools } \\
\text { Formal }\end{array}$ & Informal & Projectile point & Thin bifaces & $\begin{array}{c}\text { Cumulative } \\
\text { Total (chert only) }\end{array}$ & Other & Historic & Varia \\
\hline Site surface & 7 & 4 & & 9 & 7 & & & & & & 27 & & & \\
\hline Total & 7 & 4 & 0 & 9 & 7 & 0 & 0 & 0 & 0 & 0 & 27 & 0 & 0 & 0 \\
\hline \multicolumn{15}{|l|}{$\begin{array}{l}\text { Shovel Test } \\
\text { Counts }\end{array}$} \\
\hline \multicolumn{15}{|l|}{$\begin{array}{l}\text { Counts } \\
\text { ST 64-1 }\end{array}$} \\
\hline $0-10 \mathrm{~cm}$ & & & & & & & & & & & 0 & & & \\
\hline $10-20 \mathrm{~cm}$ & & & & & & & & & & & 0 & & & \\
\hline $20-30 \mathrm{~cm}$ & & & & & & & & & & & 0 & & & \\
\hline $30-40 \mathrm{~cm}$ & & & & & & & & & & & 0 & & & \\
\hline $40-50 \mathrm{~cm}$ & & & & & & & & & & & 0 & & & \\
\hline & & & & & & & & & & & 0 & & & \\
\hline Total & 0 & 0 & 0 & 0 & 0 & 0 & 0 & 0 & 0 & 0 & 0 & 0 & 0 & 0 \\
\hline Cunulative & & & & & & & & & & & & & & \\
\hline
\end{tabular}

Attachment 3: See Figure D-2 


\title{
Appendix E: Lackland Sewer Line Proposed Right-of-way
}

\author{
David L. Nickels and Andrew A. Scease
}

\section{Introduction}

On April 18, 1997, Lackland Air Force Base authorized the Center for Archaeological Research of The University of Texas at San Antonio to conduct limited shovel testing and backhoe trench monitoring on a 2,545-m sewer pipeline right-of-way running north from Range Operations through Long Hollow to an uplift station near Highway 90 at Lackland Air Force Base Medina Annex (Figure E-1). The right-of-way, which is immediately adjacent to a gravel road and in a recently scraped bar ditch, impacted the eastern lobes of $41 \mathrm{BX} 1104$. The latter is a prehistoric lithic procurement site recorded by CAR in 1995 (Nickels et al. 1997).

CAR staff archaeologists excavated 55 shovel tests and monitored trenching operations on April 21 and 22. Monitoring of construction excavations continued during the remainder of the construction project in April and May. This appendix reports on the findings of the testing and monitoring.

\section{Methodology}

\section{Shovel Testing}

Shovel testing was limited to $15-\mathrm{m}$ intervals within the known site boundary, 30-m intervals in floodplain areas outside the known boundary, and 100-m intervals outside the floodplain and site. The upper 10-20 $\mathrm{cm}$ generally appeared heavily disturbed, with a mixture of road fill and colluvial/alluvial sediments. In a few instances, either modern artifacts or apparent machine-crushed chert cobbles were present to as much as $50 \mathrm{~cm}$ below the surface.

Of the 55 shovel tests (ST) excavated, 20 contained cultural material (Table E-1). Shovel tests were num- bered from south to north along the right-of-way. STs 1-3 were not excavated because of obvious disturbance, and STs 6-7 were in a parking lot and not excavated. Shovel tests $24-30$ are in the southern lobe (Figure E-2) and STs 39-54 (Figure E-3) are in the northern lobe. Two additional shovel tests (STs 14.9 and 15.1) were added south of 41BX1104 in response to consistent, although low frequency, archaeological materials in ST 15 between $20-50 \mathrm{~cm}$. Forty-seven percent of the material was recovered in the upper 10 $\mathrm{cm}$ of the shovel tests, and probably represents surface artifacts. Other than chipped stone, an unburned animal rib fragment was recovered from ST 31 and a modern rifle cartridge from ST 24 . Fire- cracked rocks were observed sparsely and sporadically along the surface of the project area, and rarely below the surface. No features were encountered in any of the shovel tests or observed within the monitored trench. As a result of shovel testing, the previously known boundary of 41BX1104 will be extended.

\section{Monitoring Trenching Operations}

Archaeologists noted upon arrival that trenching activities had already begun without archaeological monitoring. In a brushy area south of Highway 90 , and approximately $180 \mathrm{~m}$ along a gravel road, the trench had been dug, the sewer pipe installed, and the trench backfilled. However, a pedestrian survey of these areas and backdirt inspection revealed no archaeological remains brought to the surface. In addition to the trenching operation, the side of the gravel roadway had been prepared for excavation by scraping off surface debris with a front-end loader. Little sediment was moved in this process, and a pedestrian survey of the affected areas noted only a small number of isolated finds. It is likely that these areas had been previously disturbed when the gravel road was originally constructed. 


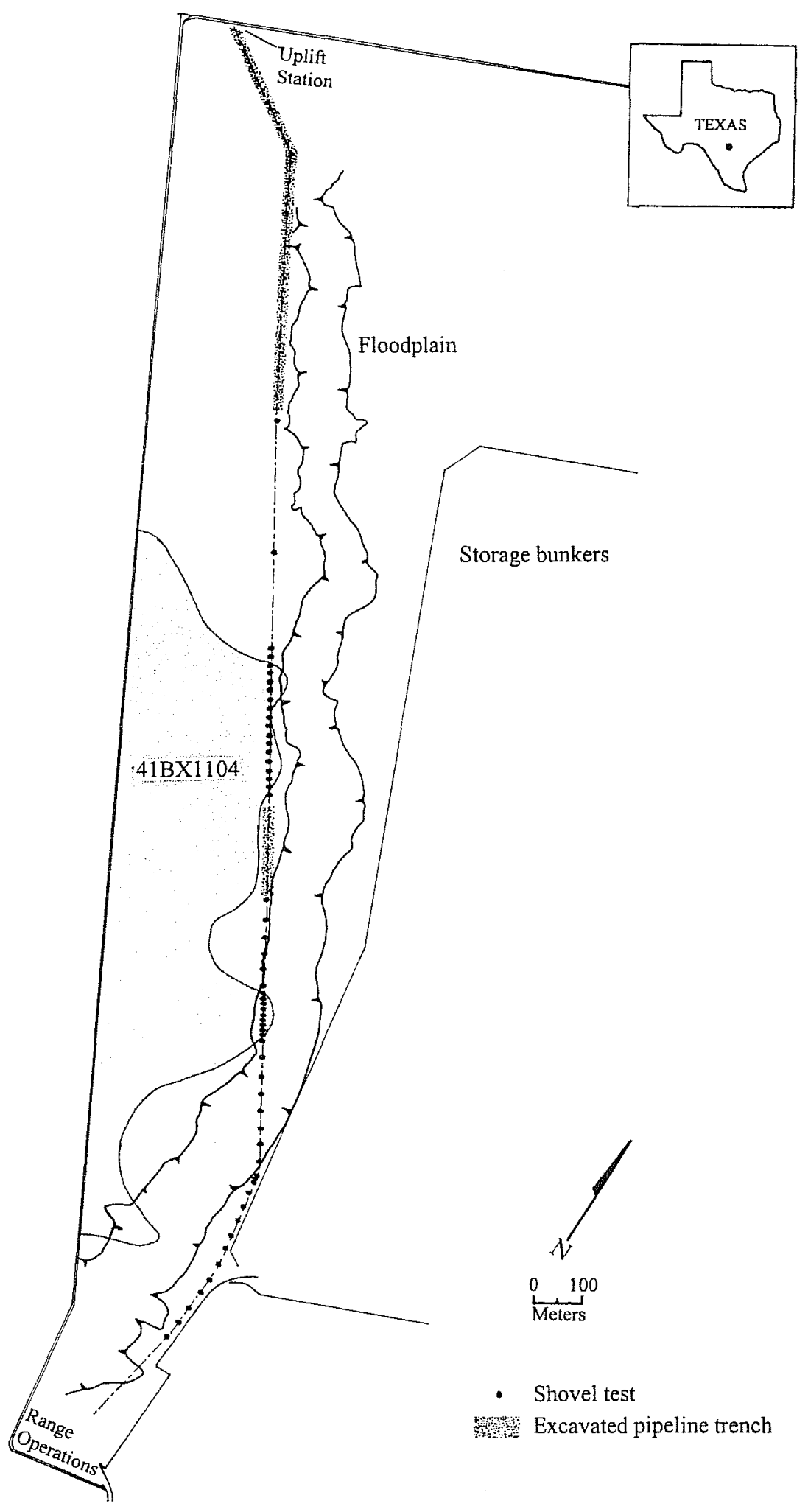

Figure E-1. Sewer pipe right-of-way on Medina Annex. 
Table E-1. Artifacts Recovered from the Sewer Right-of-way Shovel Tests

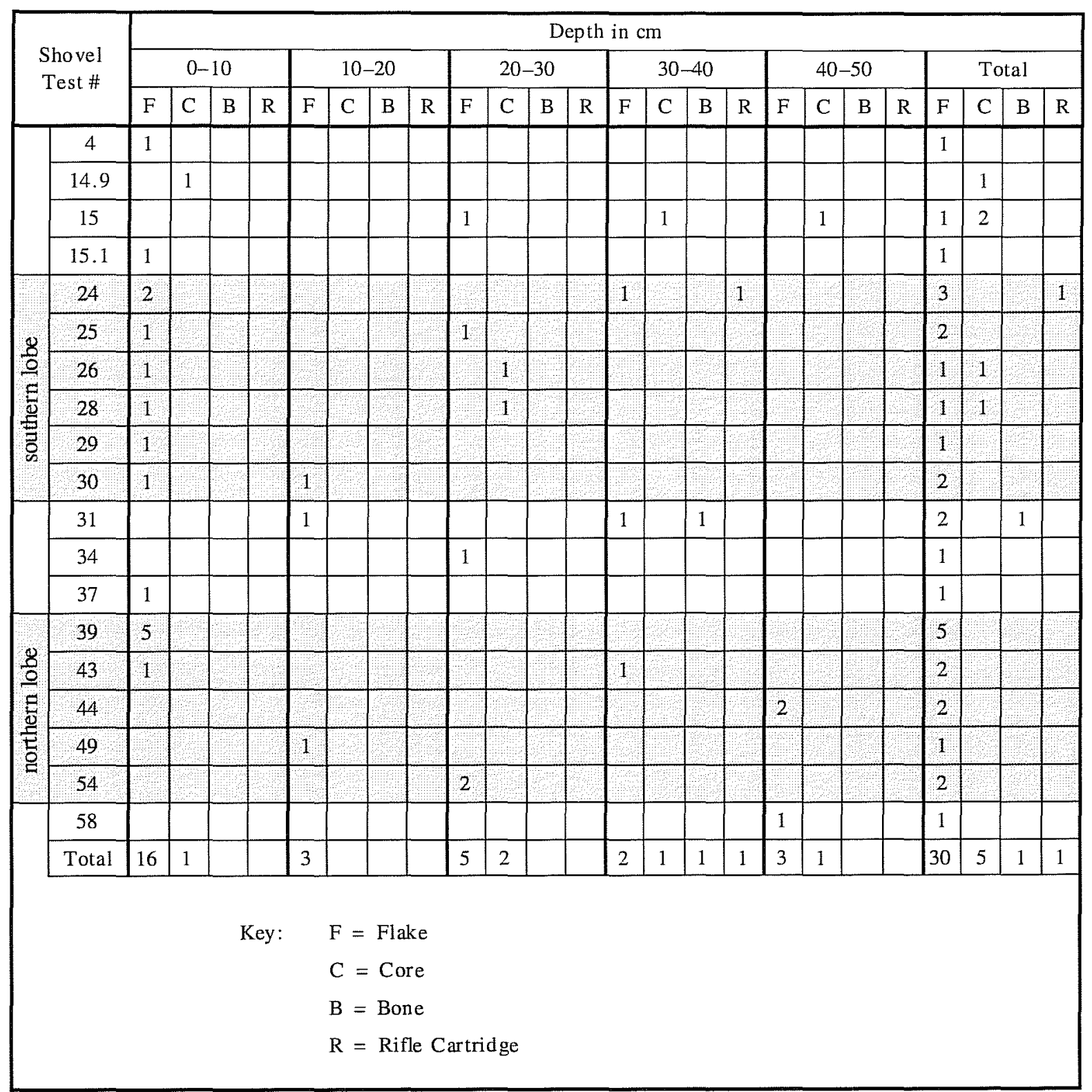

The trench for the sewer pipe was $1-1.3 \mathrm{~m}$ wide and about $1-1.3 \mathrm{~m}$ deep. In approximately the first $350 \mathrm{~m}$ from the pumping station adjacent to Highway 90 , the right-of-way was cut through an area of thick brush. The trench then traversed and followed a gravel road to its intersection with a paved roadway running south to Range Operations. At this point the trench ran across Range Operations between several buildings and under several small paved roads and parking lots, eventually ending on the southern end of the area. A 4.2- $\mathrm{m}^{2}-\mathrm{x}-4.8-\mathrm{m}$-deep ditch was excavated at this ter- minus point to accommodate a concrete manhole casement.

Most of the excavated soils consisted of heavy dark clays underlain by beds of cherty gravels. The trench crossed several small drainages as it ran alongside the gravel road. In these drainages, the clays went to the bottom of the trench. Between the drainages, the clays were only about $30 \mathrm{~cm}$ thick and the trench penetrated at least $60 \mathrm{~cm}$ into the underlying gravels. Two hundred meters north of Range Operations, dark clays were present to $90 \mathrm{~cm}$ and no gravels were noted from 


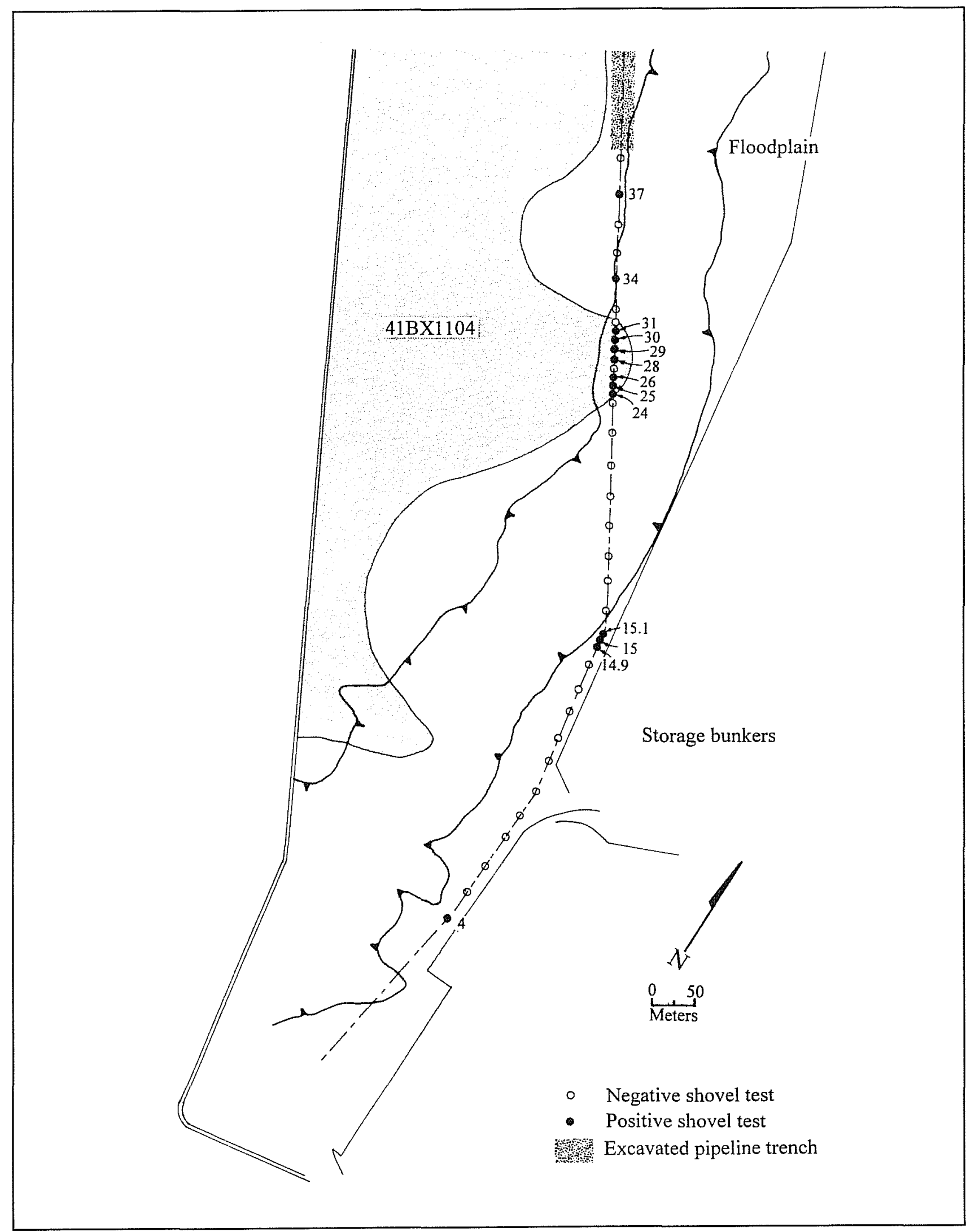

Figure E-2. Shovel tests in the southern lobe of $41 B X 1104$. 


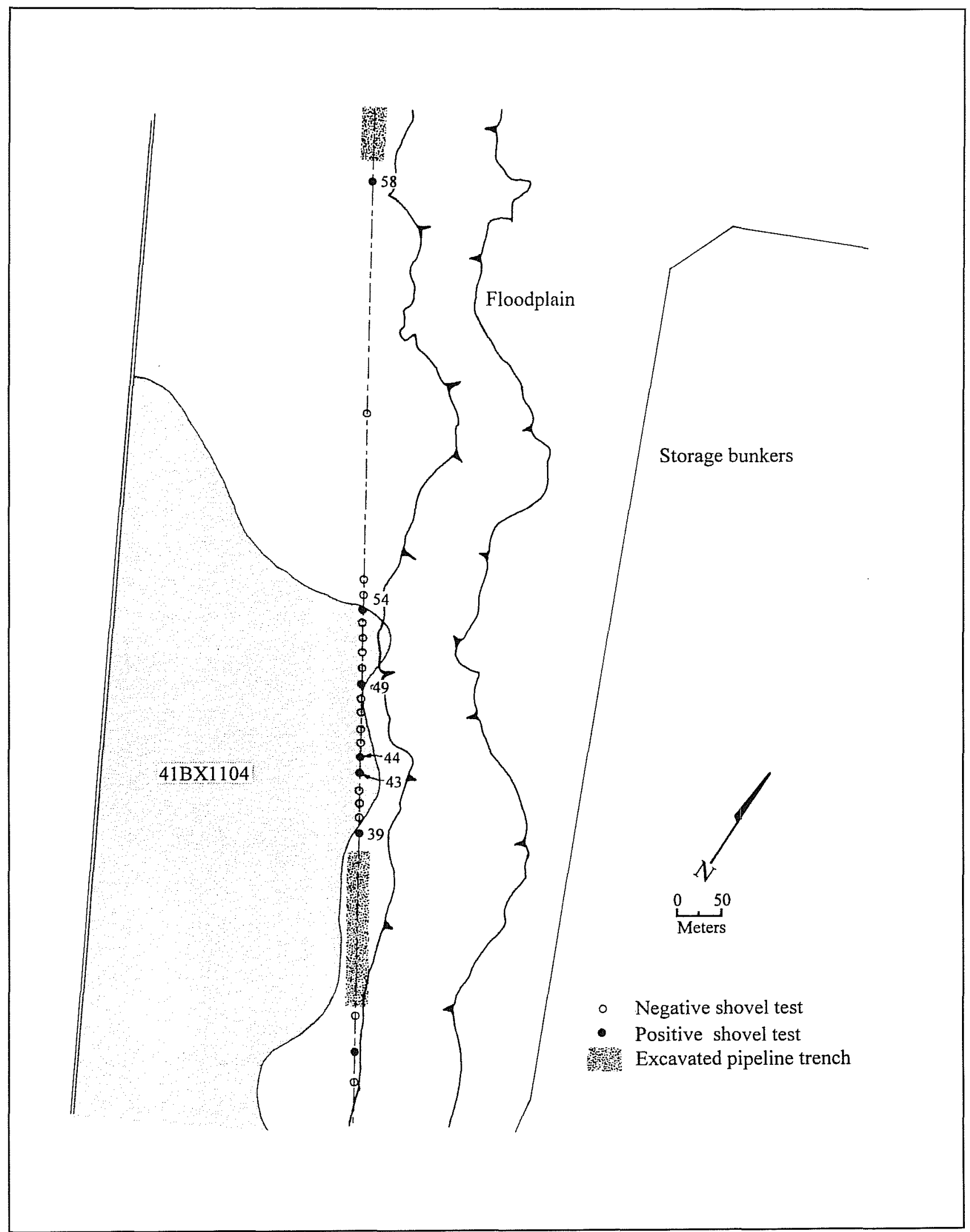

Figure E-3. Shovel tests in the northern lobe of $41 B X 1104$. 
this point to the end of the trench at the southern end of the Range Operations area.

The trench excavated for a manhole casement in the Range Operations area provided an opportunity to observe the deeper soils. Dark clays were approximately $1-1.5 \mathrm{~m}$ deep in this area. Underlying the darker clay was a yellowish tan clay that became increasingly lighter and sandier with depth. At about three meters below the surface these sandy clays became redder and nodules of a sandy shale (approximately $30 \mathrm{~cm} \mathrm{dia)} \mathrm{began} \mathrm{to} \mathrm{appear.} \mathrm{The} \mathrm{percentage} \mathrm{of} \mathrm{sandy}$ shale increased to about 30 percent at five meters.

\section{Discussion}

No intact archaeological deposits or features were noted during construction monitoring. However sparsely isolated cores and flakes were noted at or near the surface along the 2,545-m right-of-way. Although buried cultural material was recovered during the shovel testing portion of this project, the quantity and types of artifacts did not appear with sufficient concentrations to warrant additional testing given the nature of the narrow impact zone. Personnel from the National Park Service, the Texas Historical Commission, and Lackland Air Force Base were kept apprised of findings during the shovel testing and monitoring phases of the project. All parties concurred that the construction of the pipeline be allowed to proceed as scheduled. 


\section{Reference Cited}

Nickels, D. L., D. W. Pease, and C. B. Bousman

1997 Archaeological Survey of Lackland Air Force Base, Bexar County, Texas. Draft manuscript. Archaeological Survey Report, No. 248. Center for Archaeological Research, The University of Texas at San Antonio. 


\section{Appendix F: Results of Radiocarbon Analyses}

\section{Brett A. Houk}

\section{Introduction}

This appendix presents the results of the analyses of four samples submitted to Beta Analytic for radiocarbon analysis. One sample (Beta-96336) was from 41BX1103, the other three (Beta-96367, Beta-96368, and Beta-98912) were from the Feature 1 area at $41 \mathrm{BX} 1114$.

\section{Discussion}

Beta-96336 from 41BX1103 was a soil sample collected from the upper part of Unit II in BHT C. Nordt (Chapter 4, this volume) uses this sample to date the deposition of Unit II to the early to middle Holocene.

Beta-96367 and Beta-96368 were pieces of charcoal collected from the area designated Feature 1 at 41BX1114. During excavations, it was believed that this area represented an intact hearth dating to the Late Prehistoric period. The geoarchaeological assessment of the site (Chapter 4 and Chapter 5) and the results of the radiocarbon assays, however, suggest that the charcoal may postdate the cultural material at the site. Both charcoal dates fall in the nonlinear portion of the calibration curve and make an accurate age determination impossible. The third sample from Feature 1, Beta-98912, was a piece of animal bone. This sample was dated using an Accelerated Mass Spectrometer (AMS). The sample was reported to contain "bomb carbon," making it younger than 50 years old. 


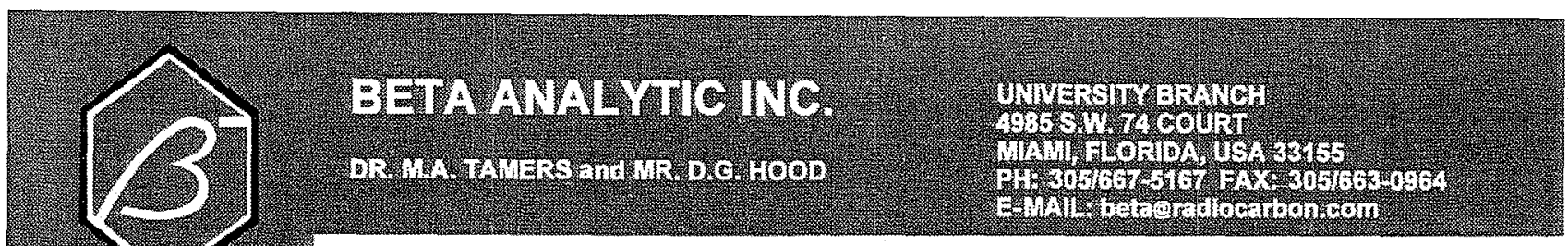

\section{REPORT OF RADIOCARBON DATING ANALYSES}

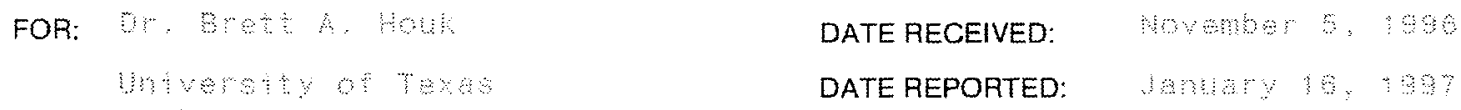

\begin{tabular}{|c|c|c|c|c|}
\hline Sman & लméta & 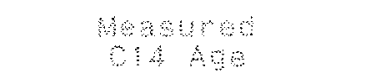 & 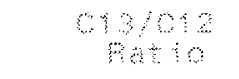 & 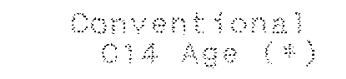 \\
\hline \multicolumn{2}{|l|}{ satams } & 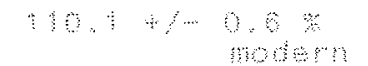 & $-\mathrm{b}=\mathrm{\beta}$ & 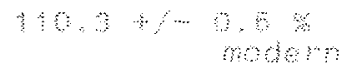 \\
\hline 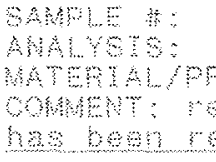 & 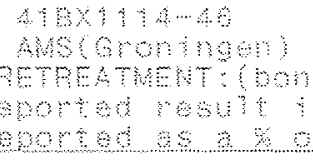 & 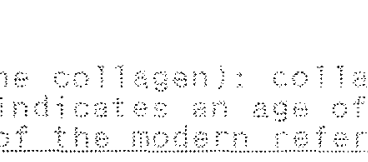 & 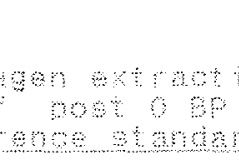 & wh \\
\hline
\end{tabular}

FOR: Mr. Brett A* Houk

DATE RECEIVED: August 26,1996

University of Texas

DATE REPORTED: October 7,1996

\begin{tabular}{|c|c|c|c|}
\hline Sample Data & $\begin{array}{l}\text { Measured } \\
\text { C14 Age }\end{array}$ & $\begin{array}{c}\text { C13/C12 } \\
\text { Ratio }\end{array}$ & $\begin{array}{l}\text { Conventional } \\
\text { C14 Age }(*)\end{array}$ \\
\hline
\end{tabular}

Beta -96366

$3530+1-70 \mathrm{BP} \quad-19.30 / 00 \quad 3620+1-70 \mathrm{BP}$

SAMPLE \#: $418 \times 1103$ - Sample \#1

ANALYSIS: radiometric-standard

MATERIAL/PRETREATMENT: (organic sediment): acid washes

COMMENT: low carbon sediment requiring special handiing

Beta-96367 $110+/-50 \mathrm{BP} \quad-24.10 / 00 \quad 120+/ 50 \mathrm{BP}$

SAMPLE \#: $418 \times 1114$ - Sample \#62

ANALYSIS: radiometric-standard

MATERIAL/PRETREATMENT : (charred material): acid/alkali/acid

Beta-96368 $\quad 180+1-50$ BP $-25.00 / 00 \quad 180+1-50 \mathrm{BP}$
SAMPLE\#: 41BX1114 - Sample \#63
ANALYSIS: radiometric-standard
MATERIAL/PRETREATMENT:(charred material): acid/alkali/acid

NOTE: It is important to read the calendar calibration information and to use the calendar calibrated results (reported separately) when interpreting these results in $\mathrm{AD} / \mathrm{BC}$ terms. 


\section{CALIBRATION OF RADIOCARBON AGE TO CALENDAR YEARS}

(Variables: $\mathrm{C} 13 / \mathrm{C} 12=-19 \cdot 3:$ lab. mult $=1$ )

Laboratory Number: Beta-96366

Conventional radiocarbon age: $\quad 3620 \pm 70 \mathrm{BP}$

Calibrated results: $\quad$ cal BC 2145 to 1760

( 2 sigma, $95 \%$ probability)

Intercept data:

Intercept of radiocarbon age

with calibration curve:

cal BC 1955

1 sigma calibrated results: $\quad$ cal BC 2035 to 1890 ( $68 \%$ probability)

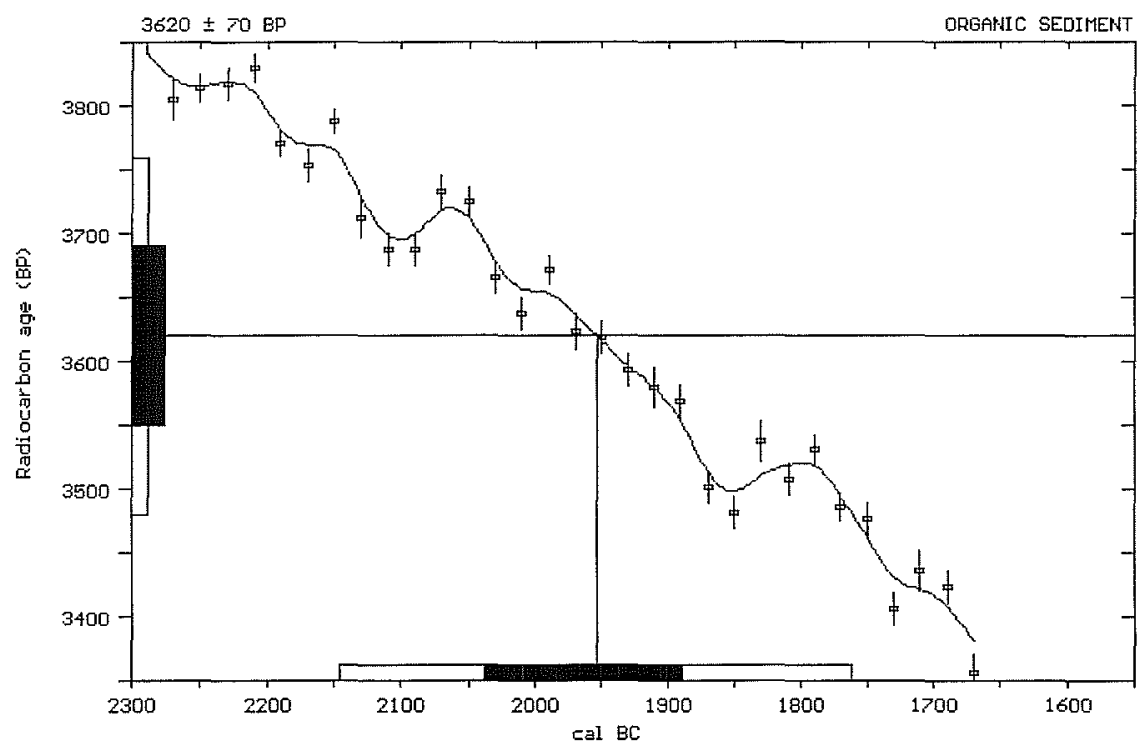

References:

Pretoria Calibration Curve for Short Lived Samples

Vogel, J. C. Fuls, A., Visser, E. and Becker, B., 1993, Radiocarbon 35(1), p73-86

A Simplified Approach to Calibrating C14 Dates

Talma, A.S. and Vogel, J. C., 1993, Radiocarbon 35(2), p317-322

Calibration - 1993

Stuver, M., Long, A., Kra, R. S. and Devine, J. M., 1993, Radiocarbon 35(l)

\section{Beta Analytic Radiocarbon Dating Laboratory}

4985 S.W. 74th Court, Miami, Florida 33155 m Tel: (305)667-5I67 a Fax: (305)663-0964 m E-mail: beta@radiocarbon.com 


\section{CALIBRATION OF RADIOCARBON AGE TO CALENDAR YEARS}

(Variables:C13/C12=-24.1:1ab mult.=1)

Laboratory Number: Beta-96367

Conventional radiocarbon age: $\quad 120 \pm 50 \mathrm{BP}$

Calibrated results:

(2 sigma, 95\% probability)

cal AD 1665 to 1950

Intercept data:

Intercepts of radiocarbon age with calibration curve:

cal $\mathrm{AD} 1700$ and cal AD 1720 and cal $A D 1820$ and cal $\mathrm{AD} 1855$ and cal $\mathrm{AD} 1860$ and cal AD 1920

1 sigma calibrated results: cal $\mathrm{AD} 1680$ to 1755 and (68\% probability) cal AD 1805 to 1940

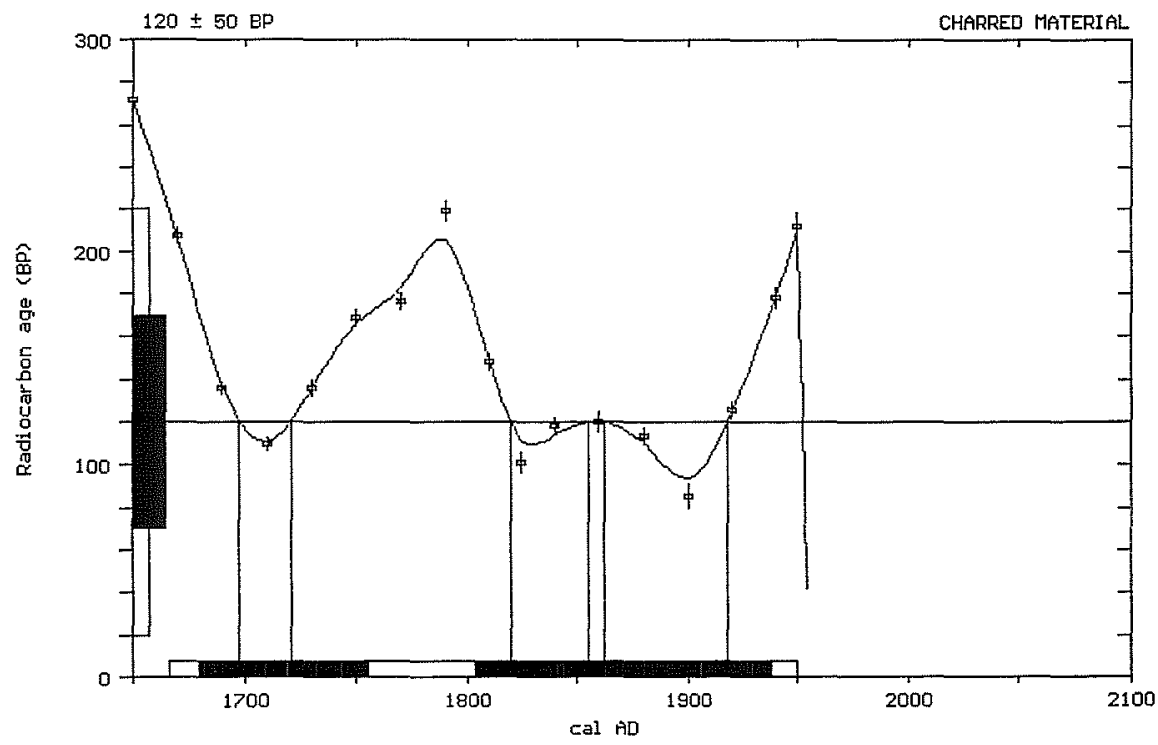

References:

Pretoria Calibration Curve for Short Lived Samples

Vogel, J. C., Fuls, A., Visser, E and Becker, B., 1993, Radiocarbon 35(I), p73-86

A Simplified Approach to Calibrating C14 Dates

Talma, A. S. and V'ogel, J. C., 1993, Radiocarbon 35(2), p317-322

Calibration - 1993

Siuver, M., Long, A., Kra, R. S. and Devine, J. M., 1993, Radiocarbon 35(I)

\section{Beta Analytic Radiocarbon Dating Laboratory}

4985 S.W.74th Court, Miami, Florida 33155 . Tel: (305)667-5167 max: (305)663-0964 E-mail: beta@radiocarbon.com 


\title{
CALIBRATION OF RADIOCARBON AGE TO CALENDAR YEARS
}

\author{
(Variables: $\mathrm{C} 13 / \mathrm{C} 12=-25: 1 \mathrm{ab}$ mult. $=1$ ) \\ Laboratory Number: Beta-96368
}

\section{Conventional radiocarbon age: $\quad \mathbf{1 8 0} \pm 50 \mathrm{BP}$}

Calibrated results: $\quad$ cal AD 1650 to 1950

(2 sigma, $95 \%$ probability)

Intercept data:

Intercepts of radiocarbon age with calibration curve:

cal $\mathrm{AD} 1675$ and cal AD 1770 and cal AD 1800 and cal AD 1940

1 sigma calibrated results:

cal $\mathrm{AD} 1665$ to 1695 and (68\% probability) cal AD 1725 to 1815 and cal AD 1920 to 1950

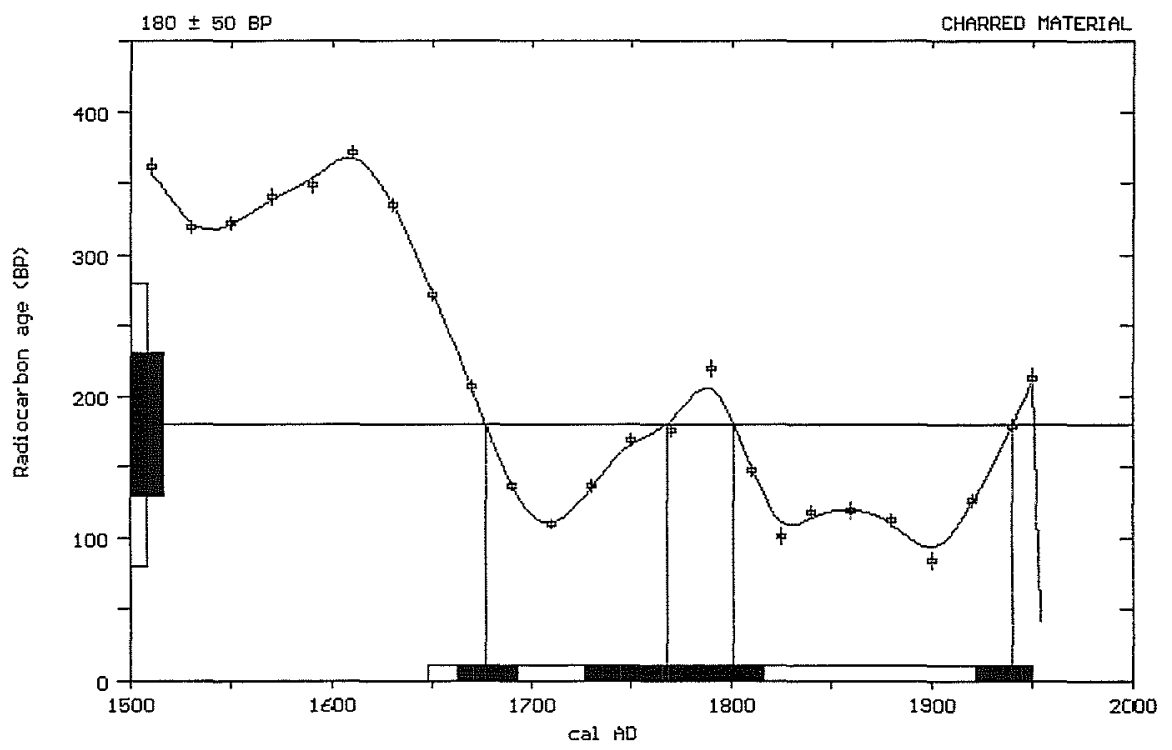

References:

Pretoria Calibration Curve for Short Lived Samples

Vogel, J. C., Fuls, A., Visser, E. and Becker, B., 1993, Radiocarbon 35(I), p73-86 A Simplified Approach to Calibrating C14 Dates

Talma, A.S. and Vogel, J. C., 1993, Radiocarbon 35(2), p317-322

Calibration - 1993

Stuiver, M., Long, A., Kra, R. S. and Devine, J. M., 1993, Radiocarbon 35(1)

\section{Beta Analytic Radiocarbon Dating Laboratory}

4985 S.W. 74th Court, Miami, Florida 33155 Tel: (305)667-5167 Fax: (305)663-0964 E-mail: beta@radiocarbon.com 


\title{
Appendix G: Evaluating Field Methods
}

\author{
Brett A. Houk
}

\section{Introduction}

The data generated by the testing project provide a useful means by which to evaluate the field methods employed, particularly as they relate to investigating upland sites. In general, a standardized methodology was employed at each of the tested sites (excluding 41BX1070): surface collecting in 5-x-5-m blocks, shovel testing to define site boundaries, and excavating $1-\mathrm{x}-1-\mathrm{m}$ test units, and backhoe trenching to assess subsurface deposits. This approach is useful because it generates comparable units of data, thereby allowing for meaningful intrasite and intersite comparisons. The methodology, however, was flexible in the sense that different combinations of these investigative techniques were employed at each site. The primary variables manipulated in different situations were unit placement relative to one another and the total number of units collected or excavated.

\section{Surface Collecting Methods}

Prior to beginning fieldwork, the project staff decided that surface collection units (CU) would be $5 \times 5 \mathrm{~m}$. The rationale behind this decision was that the spatial control of provenience data would be much greater than if $10-x-10-m$ units were used, but that the increased effort required by smaller units would not be detrimental to the project's timetable. Smaller units create additional record keeping and additional site preparation requirements. For example, a 10-x-10-m unit requires the placement of only four corner stakes and the use of one collection bag. Subdividing this unit into four $5-x-5-m$ units increases the number of corner stakes to nine and the number of bags to four. If these units were further divided into $2.5-\mathrm{x}-2.5-\mathrm{m}$ blocks, the number of stakes increases to 25 and the number of bags jumps to 16 . Preparation effort increases exponentially each time the collection unit is divided in fourth.
The resolution of the data from $5-x-5-m$ collection units has proven to be poor. In some cases, as with 41BX1091 and 41BX1114, the amount of debitage per collection unit shows concentrations within certain areas of the site. In most cases, however, no patterns are evident, and this may be due in part to the fact that a $5-x-5-m$ unit obscures small concentrations. While the project did not collect smaller units as a control with which to evaluate the difference in resolution, the block of $1-\mathrm{x}-1-\mathrm{m}$ units excavated at $41 \mathrm{BX} 1114$ can be used as a point of comparison. There is clear variation in the amount of debitage in the first excavated level of the 1-x-1-m units forming the block excavation at Feature 1 (Figure G-1). This suggests that smaller surface collection units would also demonstrate such variation and it is likely that this information would be useful for intrasite spatial analyses.

With respect to other artifact categories which typically had fewer representative specimens, the "averaging" effect created by the coarse resolution of the 5-x-5-m collection unit would completely obscure any artifact concentrations covering very small areas. The $5-x-5-m$ collections also have the potential to create artificial associations between artifact types. For example, a cluster of biface manufacturing flakes and broken bifaces concentrated in a 1- or 2- $\mathrm{m}^{2}$ area and a distinct cluster of core/platform preparation flakes located four meters away covering a similar area could all be collected in the same $5-x-5-m$ unit. The 5-x-5$m$ resolution would average the concentration of each artifact type across the $25-\mathrm{m}^{2}$ collection area, obscuring the spatial separation between clusters and creating an artificial association between the artifacts from the two clusters and any other surrounding material. The data from this hypothetical $5-x-5-m$ would still be valuable because it would indicate the types of reduction that took place in the unit, but the distinctness of the activities, and possibly their temporal association, would be lost. 


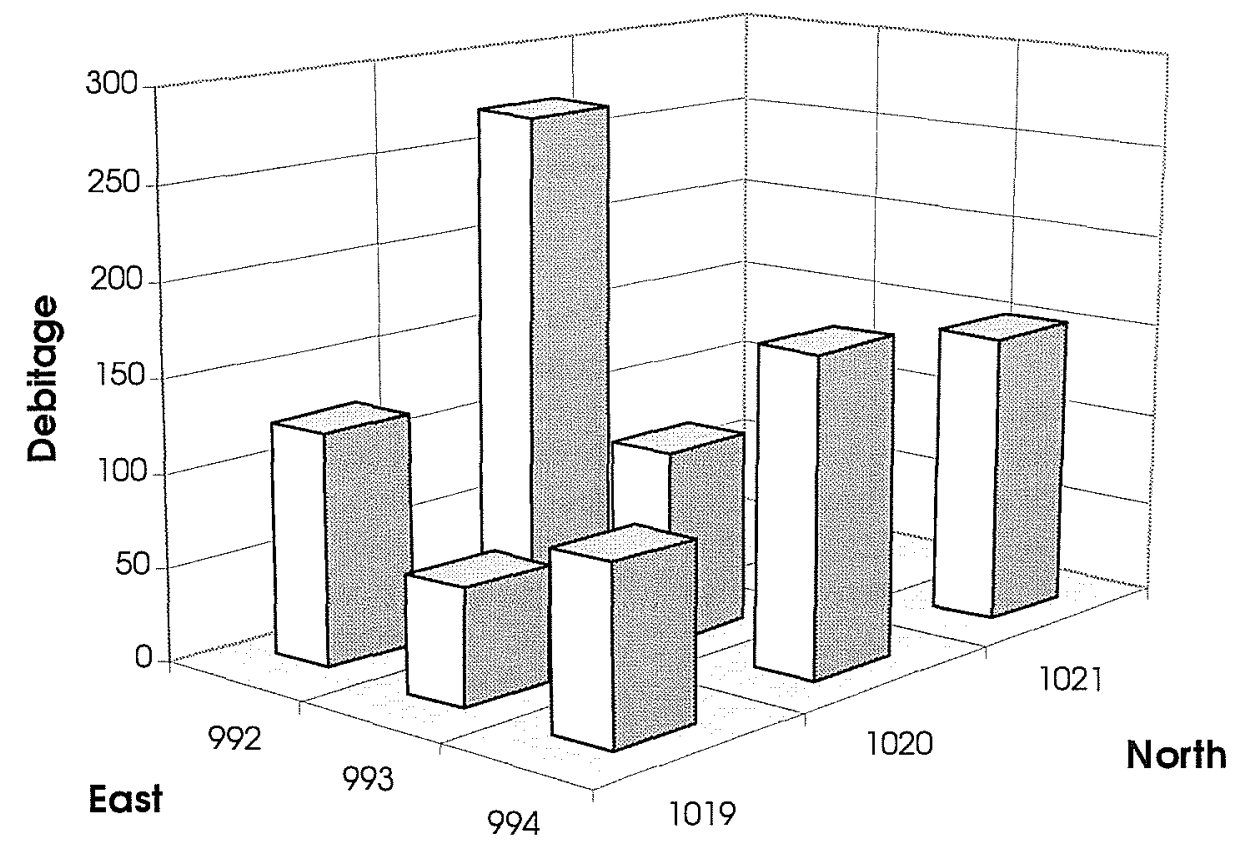

Figure G-1. Debitage counts in Level 1 of excavation block at Feature 1, 41BX1114.

Another element of the surface collection methodology which was flexible was the arrangement of the 5-x-5-m CUs with respect to one another. Every attempt was made to place units in undisturbed areas of a site. At 41BX1114, for example, the area east of the collection block was excluded because of numerous rodent burrows. At 41BX1076 and 41BX1088, units were similarly skipped because of the presumed contamination of the surface assemblage with subsurface materials displaced by rodents. The result of this approach is that at most sites, the collection area did not form a rectangular block. This limited certain data manipulation options during the analysis of the collected materials. It was not possible to easily generate artifact density maps using PC-based contouring programs because an uncollected unit was treated as having an artifact count of zero, thereby distorting the actual artifact counts in adjacent units.

\section{Shovel Testing Methods}

Shovel testing was used at 41BX1090, 41BX1091, 41BX1102, 41BX1103, and 41BX1114 to determine site boundaries. At upland sites like 41BX1114, this method proved to be time-consuming and inefficient considering the fact that the geoarchaeological assessment of the site indicates that the surface is too old to contain buried material in primary context. Simply locating the limits of the distribution of cultural material on the surface would have been a more efficient method of determining site boundaries. The same is generally true for 41BX1090 and 41BX1091 where the majority of material was confined to the surface and any subsurface material would have been in a secondary context due to the environment of deposition.

At 41BX1102 and 41BX1103, shovel testing proved to be a more effective method of establishing site boundaries. At these two sites, the depositional environment was conducive to the preservation of buried materials and the density of material on the surface was comparatively low.

\section{Backhoe Trenching Methods}

Backhoe trenches were excavated at $41 \mathrm{BX} 1070$, 41BX1102, 41BX1103, and 41BX1114. In all cases these proved to be a very effective means of evaluat- 
ing the geoarchaeology of each site. They provide deep and long profiles relatively quickly and inexpensively. Their placement can be directed by the project geomorphologist to provide the clearest picture of a site's formation history based on the visible surface topography. Archaeologically, however, they do not allow for the recovery of well-provenienced artifacts since one scoop of the bucket can slice through hundredsif not thousands - of years of stratigraphy. They do reveal features and artifacts in their profiles, however, and are therefore useful in directing excavation unit placement.

\section{Test Unit Excavation Methods}

Test units (TU) were excavated at every site except 41BX1070 to determine the depth of cultural deposits and to search for intact buried features. In most cases, units were scattered across the collection area to assess different parts of the site. At 41BX1114, seven units were clustered together in a small block to expose Feature 1, and at 41BX1103 adjacent test units were excavated as 1-x-2-m blocks to expose burned rock concentrations in the gravely deposits.

Each of the three permutations of TU placement was effective in addressing different issues. At 41BX1102 and 41BX1103, excavating isolated TUs proved to be a useful method of assessing the subsurface stratigraphy. At upland sites, however, isolated 1-x-1-m units were little more than geomorphological profiles since there was no potential for intact buried deposits. In this type of situation, the combination of 1-x-1-m units to form a small excavation block demonstrated clear variations in artifact densities horizontally and recovered large quantities of artifacts. At 41BX1103, the 1-x-2-m units formed by two adjacent TUs were effective in exposing larger surface areas of buried stratigraphic layers.

\section{Proposing a Modified Method}

The following section is based on the above evaluation of the testing methodology used at Medina Annex. These recommendations are intended to refine future testing methods at Lackland AFB and surround- ing areas. Some of the proposed recommendations are suitable for mitigation efforts.

The major conclusion evident in the above analysis is that lowland and upland sites should be investigated differently because they are structurally dissimilar. Lowland sites have the potential for stratigraphically isolable components and buried features in primary context. Upland sites have the potential for high densities of artifacts on or near the surface with equally high densities of artifacts transported from the surface to the upper $20 \mathrm{~cm}$ of underlying soil through natural processes. Lowland sites in good geological context, or in some cases even in redeposited contexts, warrant vertical investigations while upland sites (e.g., sites with clearly separated components even if in a turbated palimpsest) merit horizontal investigations. In all cases, a geoarchaeological assessment of the site prior to testing or mitigation is necessary to plan for efficient and productive archaeological investigations.

\section{Lowland Sites}

For sites like 41BX1102 and 41BX1103 situated on creek terraces at Lackland AFB, shovel testing is the best method for determining site boundaries. Backhoe trenches should be excavated concurrently with or before shovel testing to assess the depth, age, and nature of cultural deposits. Surface collecting is not recommended at lowland sites because the quality of surface data will not be as informative as subsurface data nor, in many cases, a good predictor of subsurface artifact distributions. Effort should not be expended on a task offering inferior data when other avenues of investigation are available that will produce high resolution information.

Isolated 1-x-1-m units are recommended as a useful tool for prospecting for data rich features or deposits. These should be expanded into 2-x-2-m units, excavated in 1-x-1-m quadrants, to expose more horizontal space during mitigation. Larger blocks, however, may not offer substantial gains in information, but will require greater time and effort, particularly for deep deposits. If intact features and associated artifact scatters are encountered, larger blocks may be required to 
document and sample adequately the buried deposits. The size of excavation blocks in lowland sites must be assessed for each individual site and will depend largely on the nature of the impending impacts.

\section{Upland Sites}

Upland sites are surface sites, but biological and pedogenic activities have resulted in the vertical transportation of artifacts to produce turbated palimpsests in many cases. Most material, as evidenced by testing at 41BX1114, has not been transported deeper than $20 \mathrm{~cm}$ below the surface. Shovel testing, which recovers such displaced subsurface material, does not appear to be the most efficient method of determining site boundaries. Striping vegetation and mapping the extent of the surface distribution of artifacts will accomplish the same task in less time. Surface collecting large rectangular blocks (ca. 20-x-20-m) in small units $(1-x-1-m$ or $2-x-2-m)$ will potentially provide fine enough resolution to identify specific artifact clusters and to isolate activity areas. This may be of limited value on multicomponent sites, but as the testing data indicate, some upland sites apparently demonstrate intensive use exclusively during the Transitional Archaic and Late Prehistoric, and it is not clear how much temporal overlap exists between the two periods. Complete collection of rectangular areas will make it easy to generate artifact density plots. Features, diagnostic artifacts and formal tools should be point plotted when possible. This intensive effort, however, may be reserved for mitigation.

When initiated, the surface collection should be augmented by the excavation of one or more shallow excavation blocks, subdivided into 1-x-1-m units for maximum horizontal control. Through turbation the surface of an upland site has become, in effect, stretched vertically to a depth of $20 \mathrm{~cm}$. Block size may be dependent upon time, level of investigation, and specific research questions. Such excavations do not need to go deeper than $20 \mathrm{~cm}$ based on the available data, although this should be quickly verified at each site. 

